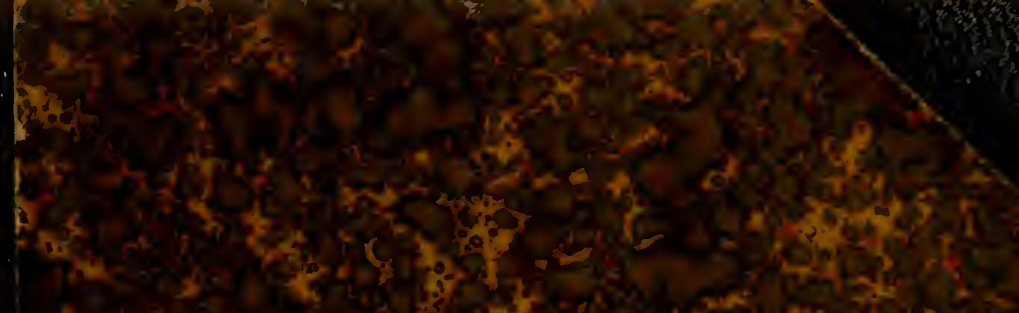

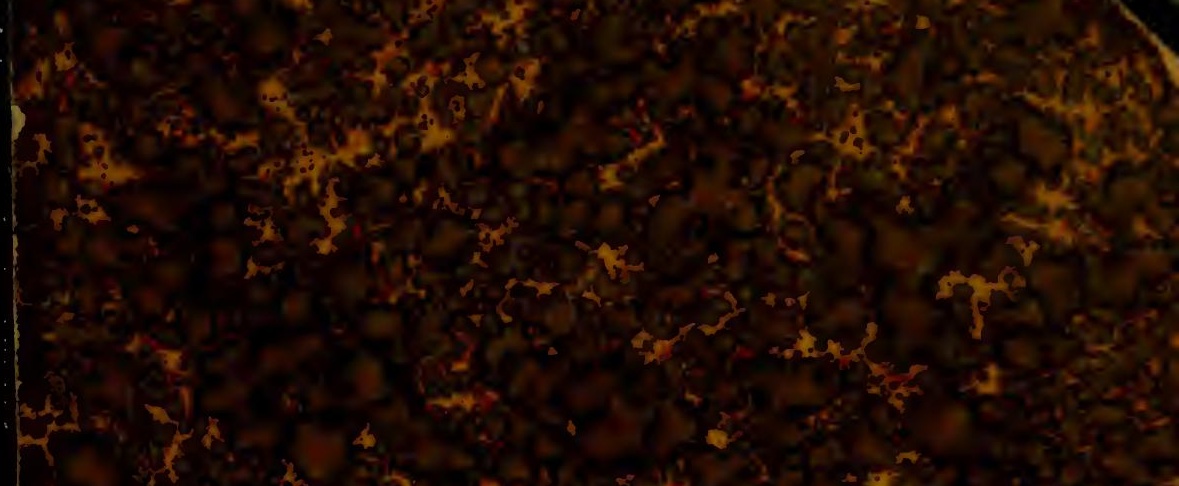

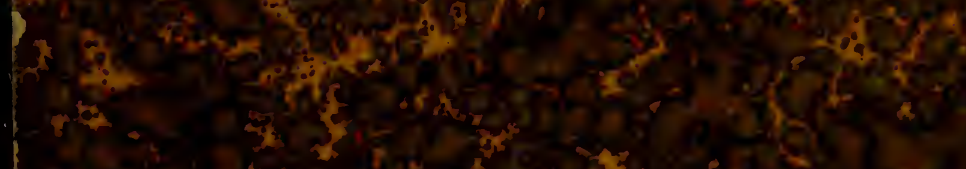

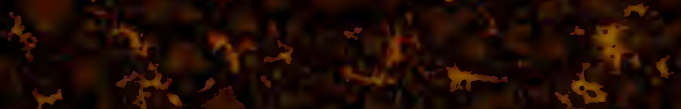

F.t.

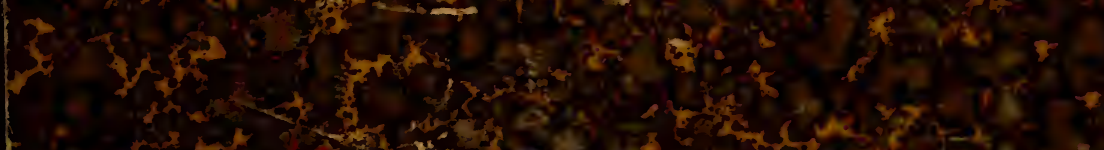

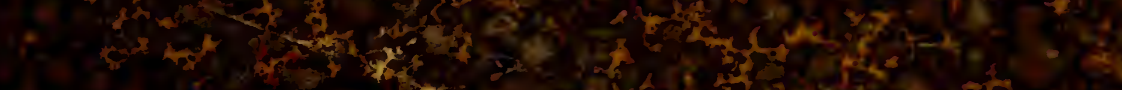

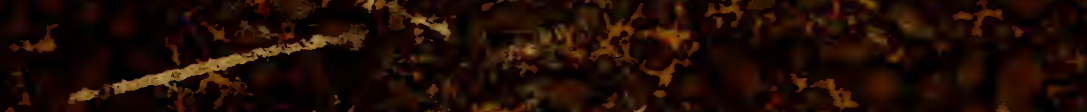

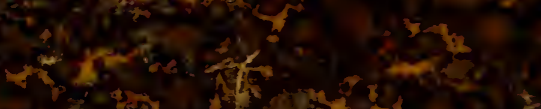

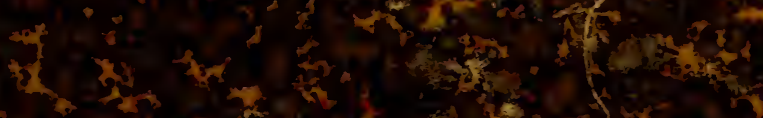

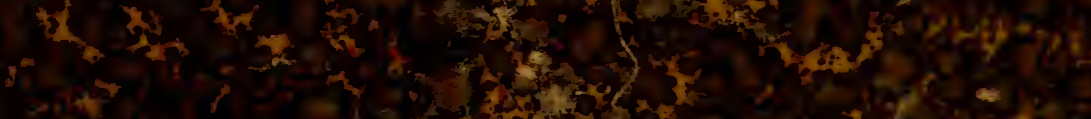

$5^{\prime}$

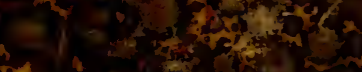

$+$

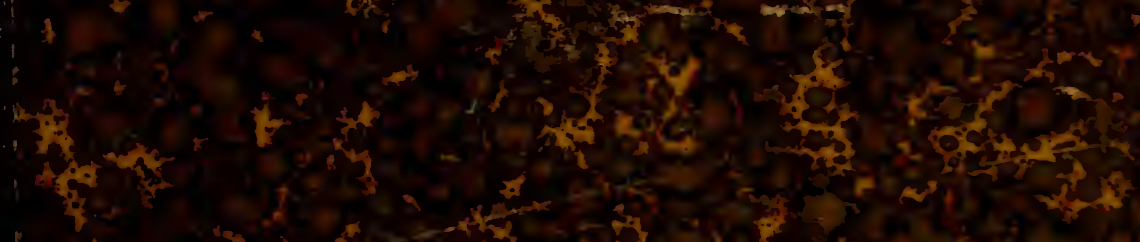

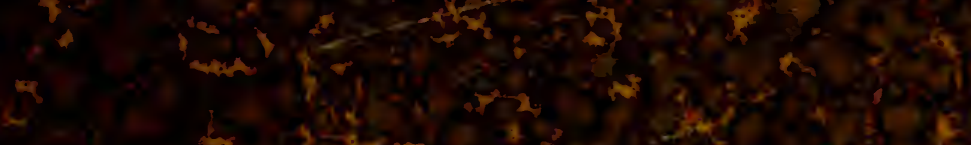

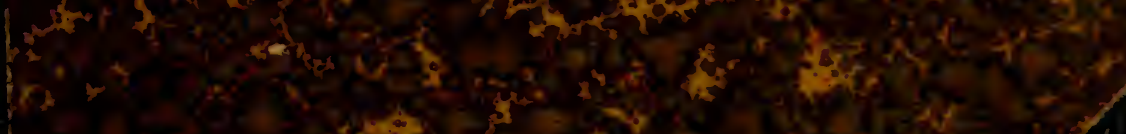

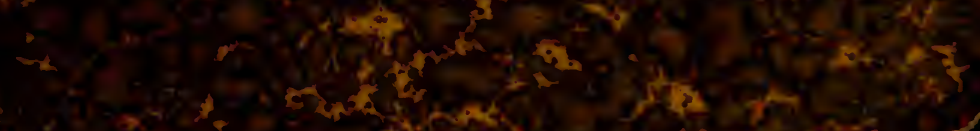




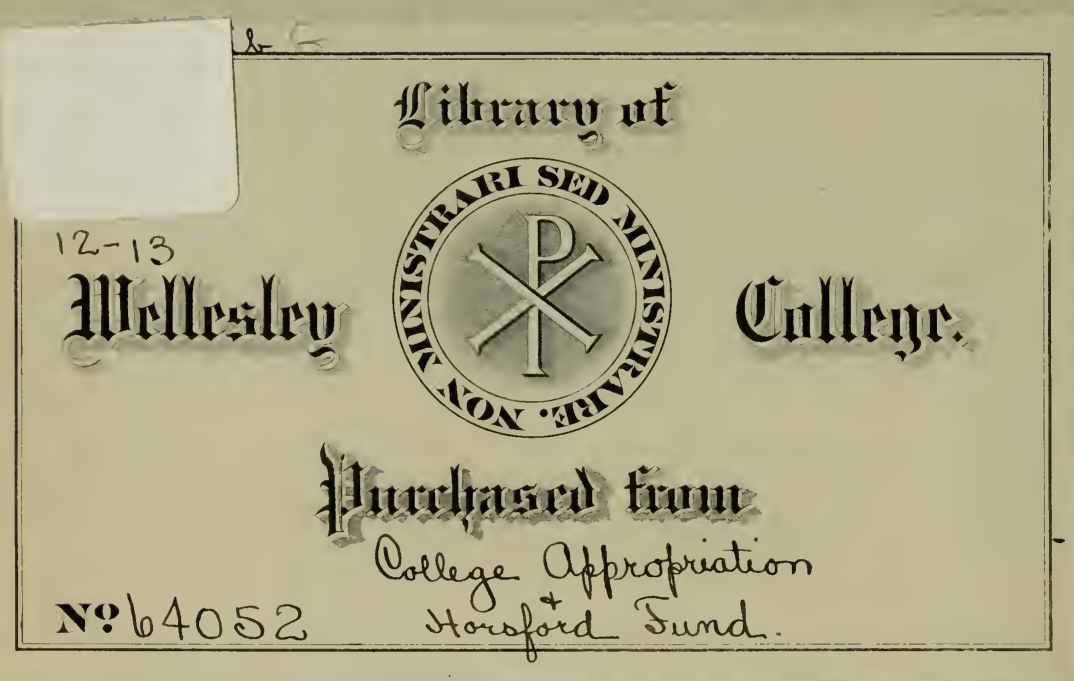




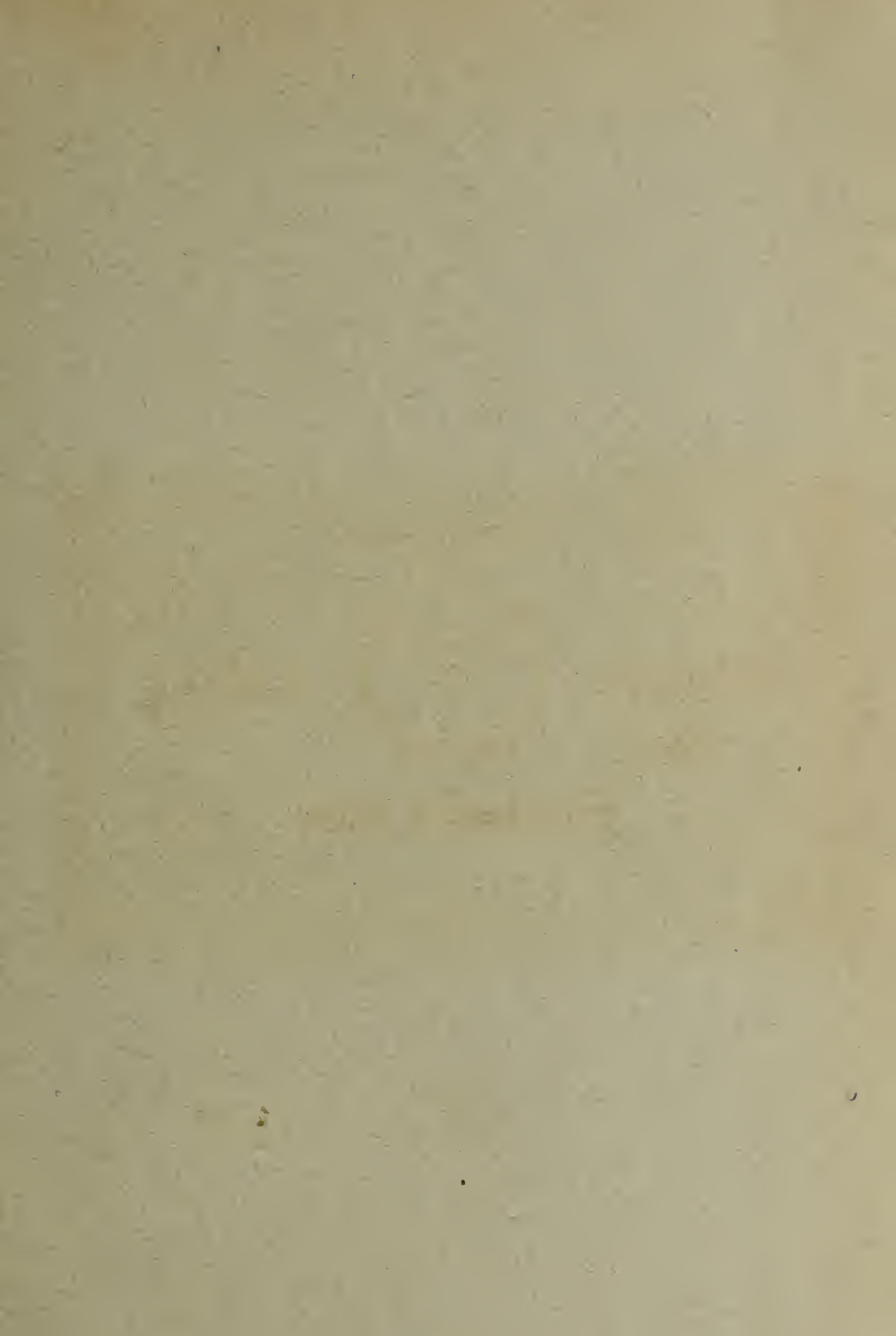





\title{
MEMOIIRS
}

OF THE

\section{Torrey Botanical Club}

\author{
VOLUME XIII
}

\section{SPECIES AND VARIATIONS \\ OF}

\section{BIOTIAN ASTERS}

WITH

DISCUSSION OF VARIABILITY IN ASTER

BY

EDWARD SANDFORD BURGESS 



\section{STUDIES IN THE 1}

HISTORY AND VARIATIONS OF ASTERS

PART II

\section{SPECIES AND VARIATIONS}

OF

\section{BIOTIAN ASTERS}

WITH

\section{DISCUSSION OF VARIABILITY IN ASTER}

BY

EDWARD SANDFORD BURGESS

ILLUSTRATED BY 108 FIGURES

New YORK

The Torrey Botanical Club 


\section{STUDIES IN THE \\ HISTORY AND VARIATIONS OF ASTERS}

\section{PARTS PUBLISHED}

Part I. History of Pre-Clusian Botany in its Relation to ASTER :

Vol. X of the Memoirs of the Torrey Botanical Club.

ISSUED 22 NOVEMBER 1902

Part II. Species and variations of Biotian Asters, with DiscusSION OF VARIABILITy in ASTER:

Vol. XiII of the Memoirs of the Torrey Botanical Club. ISSUED I 5 MARCH 1906.

The Torrey Botanical Club Columbia University, N. Y. 


\section{PREFACE}

The present volume of Aster Studies discusses the specific limits, life-history and variability of Asters, and also begins the systematic treatment of Aster species ; in fulfilment of investigations which commenced in 1886 . The descriptions comprise the Biotian section of the genus, a section confined to North America, and including 84 species ( 58 of which are here first published or characterized) * and IO subspecies; each of which is illustrated by one or more figures; in all 108 figures, I 3 of which are heliotype plates, the others being cuts in zinc. About 250 subordinate forms are also briefly characterized.

In a former volume, the History of Pre-Clusian Botany in its relation to Aster, $\uparrow I$ have traced the progress of the monotype conception of Aster from the Greeks onward through the year I600. Distinct establishment of Aster as a polytype genus came with Clusius, beginning with 1576 and culminating in $160 \mathrm{I}$. Rapid increase followed in the number of new species attributed to Aster, species which have since been assigned to Conyza, Inula, Pulicaria, etc. The next two centuries may be termed the Clusian and the Linnaean periods of Aster history; the former including, and the latter excluding, numerous yellow-rayed relatives. To dwell upon these periods is not at present pertinent, for the details of Aster history, as previously remarked, are better presented, after Clusius, group by group and species by species. The historical matter in the present volume consists instead, Ist, of a sketch of Aster as a genus with its segregations and recombinations since I 600 (pp. $5 \mathrm{I}-58$ ) ; $2 \mathrm{~d}$, a detailed historical review of the Biotian group to date, with notice of authors, early collectors, etc. (pp. 59-80); and 3d, separate historical sketches of such species as have already a history (p. IO7, etc.).

* Of the species here first characterized, two, $A$. ambiguus and A. subcymosus, represent names given to herbarium material by Bernhardi; one, $A$. viridis, is similarly credited to Nees; another, A. subinteger, similarly to Mr. E. P. Bicknell ; five were formerly described by me as the varieties $A$. divaricatus persaliens, $A$. curvescens oviformis, A. curvescens umbelliformis, A. macrophy lus excelsior and A. macrophyllus biformis; the others appear here de novo.

† Mem. Torrey Club, 10:-. 1902. 
The genus Aster has long been reputed one of most pronounced variability; and of all Asters, perhaps the most variable are those of the Biotian section ; some other groups, as Gray's Glandulosi, being quite stable in comparison. It is to their variant forms that the Asters owe their supreme interest to the student of the evolution of species; exhibiting a genus evidently engaged at this present time in the development of new lines of descent. Many of the latter show apparent stability and therefore demand recognition as species; a few seem unstable and rank merely as subspecies; and a much larger number are still too uncertain for absolute rank, and I leave them under the indefinite term form.

Since these descriptions left my hand for the press, the world has been enriched by the appearance of the monumental work of de Vries on the origin of species by mutation. I have no doubt that many if not most of the new species of Aster here described are similarly mutants proceeding from dissimilar parents. Explicit proof is not so readily attainable in Aster, however, owing to the perennial habit and the number of years before flowering. Working without the opportunities of garden-sowing but entirely from plant-colonies as established in nature, I have been forced to draw my conclusions as to specific difference rather from collateral comparisons than from a series of lineal descendants. The length of preliminary growth before blossoming, often seemingly seven years, interferes decidedly with observations on aster-seedlings of successive sowings. When the working life of a botanist passes the century mark, then perhaps such a botanist can see with his own eyes the successive generations of an Aster like the Upsalan $A$. tardiflorus of i 8 years before flowering.

Asters are further complicated by remarkable responsiveness to environment, producing an unusually wide area of variationrange on each side of a norm or center of species-character, a norm or species-type which may have been, in very many cases, of mutant origin. With closely allied and parallel types, each with wide variation-range, it is natural that many outliers belonging to allied species should overlap and should present confusing characters. If these individuals were regarded as forming such connecting links as to invalidate species, close distinction of species would in many groups of Aster become hopeless ; and it is in this sense that Aster 
species may be considered to be separated by arbitrary lines; arbitrary lines as regards a minor number of recalcitrant specimens; but natural lines nevertheless, in their broader interpretation, because doubtless representing real currents of descent, currents in an onward flow which continues as a mass to move forward, in spite of the presence of cross-currents and lateral blending.

And yet, concerning some of the new species of Aster here described, some authorities may question the title to specific rank. It is indeed seldom that there would be entire agreement between any two monographers of a long series of critical forms. But the result which is of first importance is, that these forms, being clearly distinct entities in nature, should be put on record and described. I once myself suspected that certain of these species were but forms assumed by $A$. divaricatus or $A$. macroplyyllus when under special conditions, and that they could not be relied on to show the same characters in successive offshoots of the same colony. My field studies since I 886 have been largely devoted to the determination of this subject, seeking for the limits of variation in unchanged environment, and for the beginnings of new permanent species. Many of the species here first published have been watched in their natural environment for periods varying from seven to ten years; and without change of characters. I have not spared expense or time or travel, while keeping selected plantcolonies under repeated observation, in widely separated localities, in New England, about Lake Erie, the Hudson Valley and the Potomac. I have called on each form to show its permanence while in unaltered natural conditions before according it the rank of an independent species. I have often held back some remarkable form from specific recognition (as I do still the obolarian form, p. I I 3) with the thought that it must surely be but a passing phase of the speeies, induced by the particular environment ; only as often to meet the same form again in a new and distant locality, presenting not only the same characteristics possibly due to environment, but also presenting identical additional characters apparently not connected with its environment at all. In such cases I have thought it better to describe such a type as a distinct species. How cautious I have endeavored to be may be seen from the number, some 250 , of plant-types under observation which are listed here merely as 
indeterminate forms, most of which represent not casual specimens but forms which I have followed up year after year.

My plan of treatment, practicable only in an extended monograph like the present, is to present not only a full description of each species, but also all that is known of its history and of its conditions of variation. The full descriptions given being necessarily long, I preface to each of these a brief diagnosis, distinguished by lines differently spaced, and serving to condense into few words some salient features which are instantly obvious and distinctive of the species.

A similar but still briefer characterization of each species will be found in the analytic key, pp. 89-99. The difference in the case of the key-character is that it is so drawn as to emphasize comparative features rather than the absolute; with principal reference to distinctions between closely allied species. A yet briefer single-line key with page references, for use as a first or trial clue, will be found at the end of the volume, next preceding the general index.

Where a species has been described before, in order to present its history fairly, I introduce the exact words of its original description as an integral part of its history; and to supplement this, I quote from subsequent descriptions such additional or altered characters as make any real contribution to the original description. I have been at much pains to follow out this treatment, from the feeling that a monograph should not be merely a series of references to scattered literature, but should instead bring together into one convenient series, the substance of all previous work on the subject.

Types of specimens of all the new species here described are to be found in my own herbarium ; with a few exceptions, stated under the respective species. Their locality is given with each species. The locality-list following each description consists, unless otherwise designated, of flowering specimens which I have collected at the date and place given, and usually still retained in my herbarium. In cases not of my own collecting, the name of the collector and the herbarium is added.

I desire again to acknowledge the many courtesies received from other botanists, ${ }^{*}$ and especially the continued kindnesses ex-

* See Mem. Torrey Club, ro: 3, 4 . 
tended at Cambridge by Dr. B. L. Robinson, and at home by Dr. N. L. Britton, Dr. L. M. Underwood, and Dr. J. H. Barnhart of the New York Botanical Garden.

NEW YoRK, Dec. II I 1905.

E. S. B. 


\section{ERRATA}

Page 59, line 7, read "consist of five of the six species."

Page 59, line 9, read " ten," not " eight."

Page 59, line I I, read "including," not " also."

Page 68, insert "A. nobilis, A. multiformis," after A. rosci:hus.

Page c6, no. $55^{17}$, read "Dover," not "Downy."

Page I 27, near top; the first subspecies under $A$. div'aricutus should read " Ib " not " Ia," and the four following subspecies accordingly ; reserving " Ia" for the typical form.

Page I70, line I4, read "Dr. Samuel Boykin," not “Dr. George Boykin."

Page 2 I I, near middle, before A. chlorolepis, read "29" not " 20."

Page 265, read "Fig. 60," not " Fig. 45."

Page 323 , near middle, read " $55 \mathrm{e}$ " not " 55 d." 


\section{CONTENTS}

\section{VARIATION IN ASTER.}

SPEcific Limits in Aster........................................ 3

General Distribution of Aster-species.......................... 3

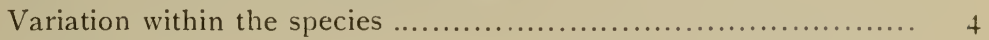

Variation between the species................................ 4

Reasons for intermediate forms ............................... ;

Specific rank.................................................. 7

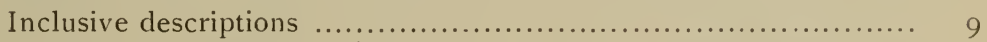

Treatment adopted for subspecies, forms, hybrids, types, sub-

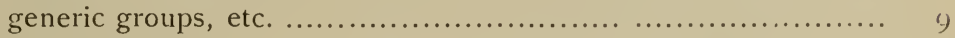

NORMAL CharaCters............................................. 12

Coincident Leaf-forms..................................... 12

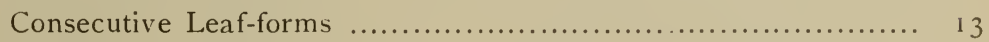

Inflorescence Stages....................................... 16

Sylvanism and other sources of change......................... 18

Variability of Aster seedlings and of root-propagated plants ....... 19

Comparative VARIABILITy OF ORgans ............................. 22

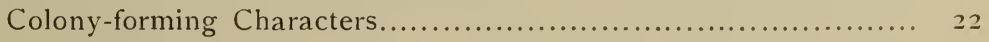

Color-characters .............................................. 24

Pubescence ............................................... 3 [

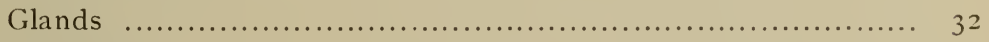

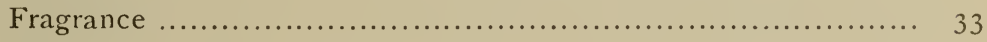

Size....................................................... 35

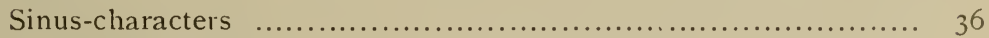

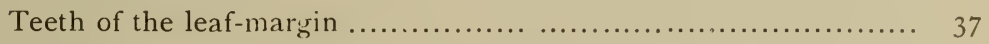

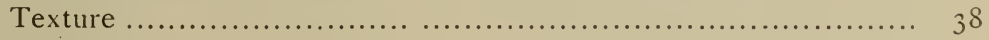

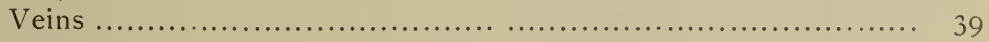

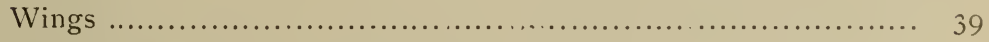

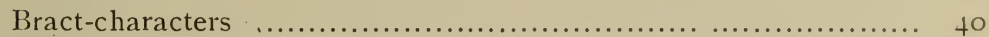

Inflorescence development and corolla characters ............... +2

Plasticity of characters........................................ +5

Primordial leaves as possible phylogenetic clues ................. +5

\section{MODERN SYSTEMATIC TREATMENT OF ASTER.}

Sketch of the Later History of Aster ........................ ; 1

Recognition of Segregate Genera ........................... ;i

Brief Bibliography for American Asters......................... 54

Table of Increase in Recognized Species ........................ 56 
History of the Biotian section of Aster...................... 59

Rank of the Biotian section.................................... 60

Comparative History of Biotian Species ........................ 62

First known collectors of Biotian Asters ......................... 69

First cultivation of Biotian Asters .............................. 72

European work upon Biotian Asters ; Nees ...................... 73

American work upon Biotian Asters ........................... 76

\section{SYSTEMATIC DESCRIPTION OF ASTERS.}

Introductory Explanations . ................................... 83

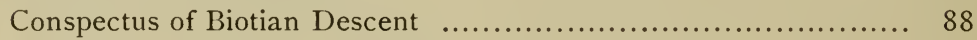

Analytic Key to Biotian Asters ................................ 89

Description of Species and Variations of Asters................. Ioo

Generic Character............................................ I00

Section Character............................................ I I I

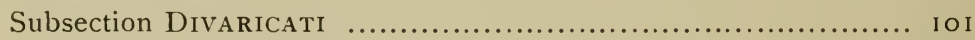

Description of $A$. divaricatus.................................. I02

History of $A$. divaricatus ................................... 107

Variants of $A$. divaricatus ...................................... I I

Subspecies of $A$. dizaricatus ............................... I 27

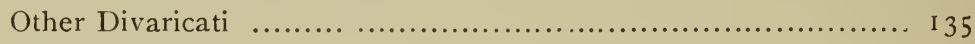

Carmesine Asters .......................................... I 73

Tenebrosian Asters ........................................... $20 \mathrm{I}$

Claytonian Asters............................................... 2 I 2

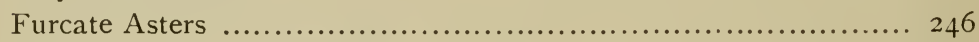

Subsection Curvescentes .................................... 249

Curvescent Asters ............................................ 249

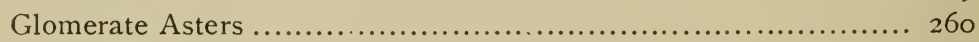

Schreberan Asters ............................................. 273

Subsection Macrophylli ..................................... 297

Lavender Macrophylli......................................... 297

Description of $A$. macrophyllus ............................... 298

History of $A$. macrophyllus................................... 306

Variants of $A$. macrophyllus ................................. 314

Its subspecies ............................................... 319

Allied species .................................................. 327

Ianthine Macrophylli.......................................... 350

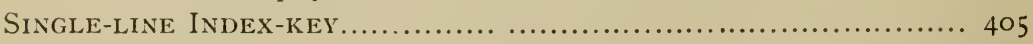

GENERAL InDEX.................................................. 4 I 3 


\section{LIST OF ILLUSTRATIONS}

(For explanations see p. 83 and under each species figured.)

Figure.

I. Leaf-margins

PAGE.

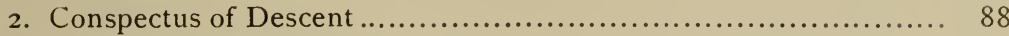

3. Plate I, A. divaricatus ..................................... 102

4. Obolarian form of A. divaricatus $\ldots \ldots \ldots \ldots \ldots \ldots \ldots \ldots \ldots \ldots \ldots \ldots \ldots \ldots \ldots \ldots$

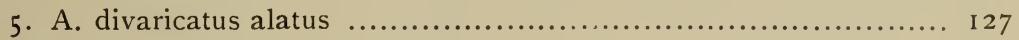

6. Plate 2, A. divaricatus cymulosus............................ I 30

7. Plate $3, \mathrm{~A}$. divaricatus curtifolius ........................... I 32

8. Plate $4 \mathrm{~B}, \mathrm{~A}$. divaricatus deltoideus $\ldots \ldots \ldots \ldots \ldots \ldots \ldots \ldots \ldots \ldots \ldots \ldots \ldots \ldots \ldots \ldots$

9. A. divaricatus fontinalis.................................. I 34

Iо. A. viridis .................................................. I 36

I I. A. a renicola .................................................. I 39

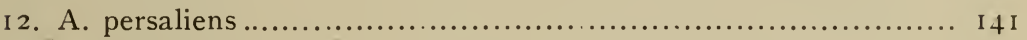

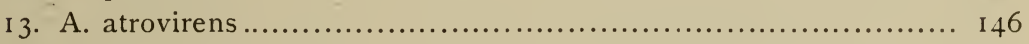

I4. Plate $4 \mathrm{~A}, \mathrm{~A}$. erectus...................................... I 33

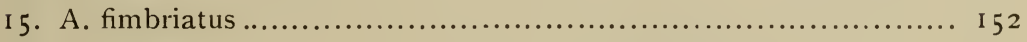

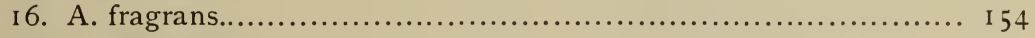

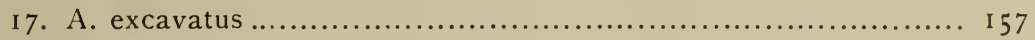

18. A. subinteger................................................ I60

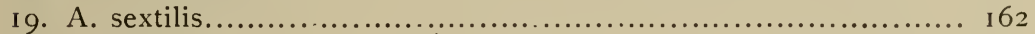

20. A. stilettiformis .......................................... I 63

2 I. A. Parthianus.............................................. I 67

22. A. camptilis ............................................. I 69

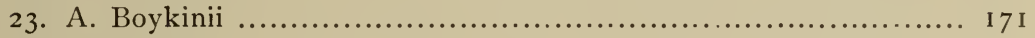

24. A. flexilis ................................................. I 72

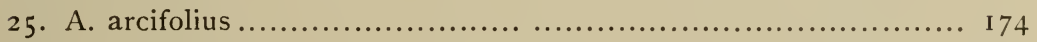

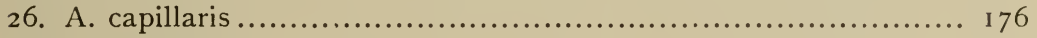

27. A. virgularis................................................... I 8

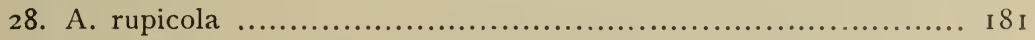

29. Some Biotian Leaf-forms - Deltoid, Scutiform, Caudate, Falcate, Angulate, Pluridentate, Biacuminate .. ...................... I 83

30. A. circularis .................................................... I 8

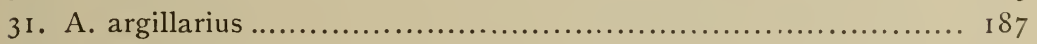

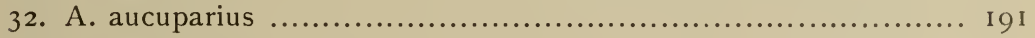

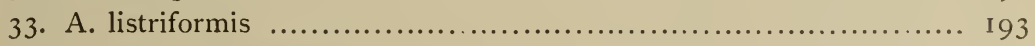

34. Plate 5, A. carmesinus ................................... I 97

35. A. castaneus.................................................. 202

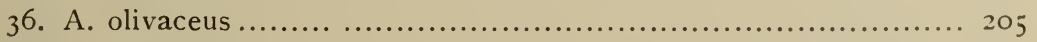

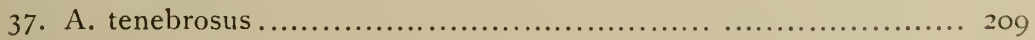




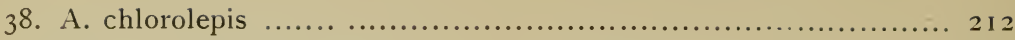

39. Plate 7, A. Claytoni.......................................... 213

40. Brown-top form of A. Claytoni............................. $2 \mathrm{I} 7$

4 I. Verticil form of A. Claytoni ................................. 20

42. Plate 8, A. Claytoni crispicans .............................. 226

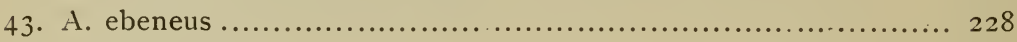

44. A. mollescens............................................... 23 I

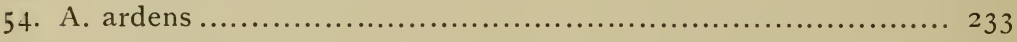

46. A. scutiformis............................................. 238

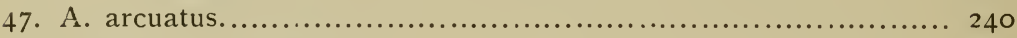

48. Plate 6, A. sociabilis ........................................ 243

49. A. ulmarius ............................................. 245

50. A. furcatus ................................................. 247

5 I. A. leptocaulis ............................................... 249

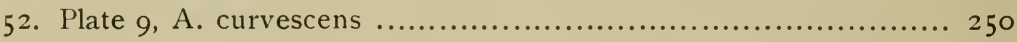

53. Plate 10, A. curvescens, radicals ; A. oviformis, two radicals..... 253

54. A. oviformis............................................. 254

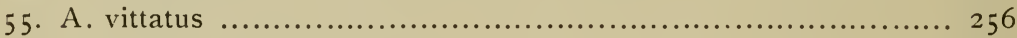

56. Plate I I, A. umbelliformis.................................. 258

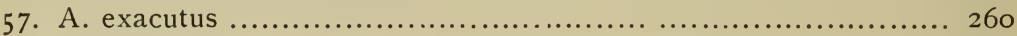

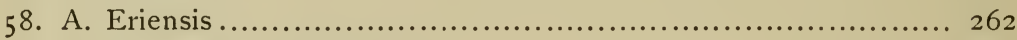

59. A. glomeratus, small state................................. 263

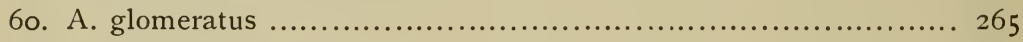

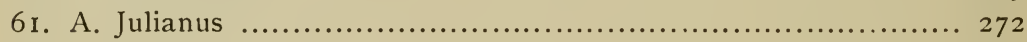

62. A. limicola ................................................ 274

63. A. Schreberi.............................................. 276

64. A. Schreberi, radicals, and all-reniform form.................. 277

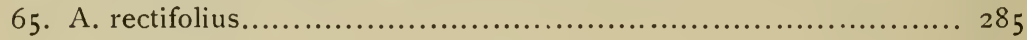

66. A. amnicola .................................................. 287

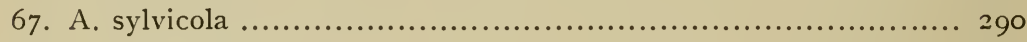

68. A. ambiguus.............................................. 292

69. A. subcymosus............................................. 296

70. A. macrophyllus ............................................ 300

71. A. macrophyllus of European gardens ........................ 302

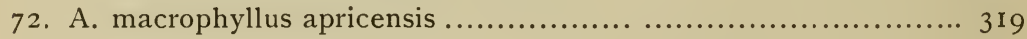

73. A. macrophyllus sejunctus.................................. 32 I

74. A. macrophyllus velutinus................................ 322

75. A. macrophyllus pinguifolius............................... 324

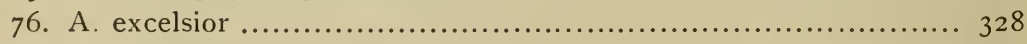

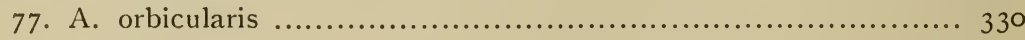

78. A. biformis............................................... 332

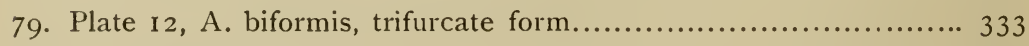

8o. A. uniformis................................................ 334

81. A. Alleghaniensis ............................................. 336

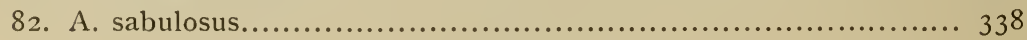




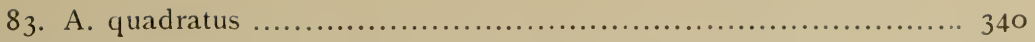

84. A. densatus .................................................... 342

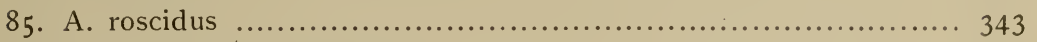

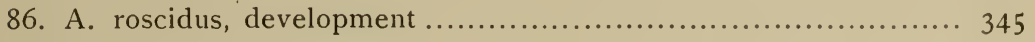

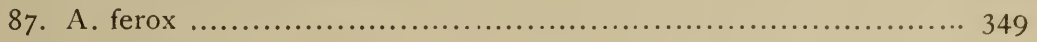

88. A. iostemma.................................................. 352

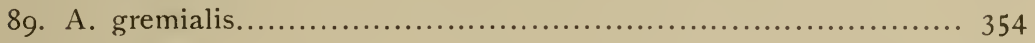

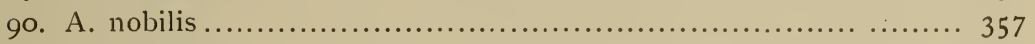

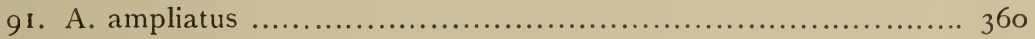

92. A. sympodialis............................................ 362

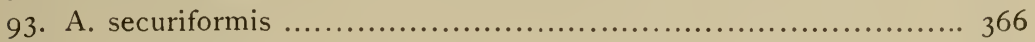

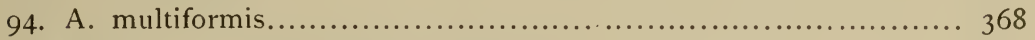

95. Plate I 3, A. multiformis, arrest-form ......................... 369

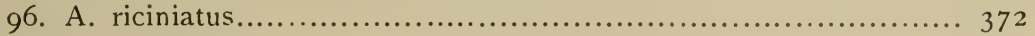

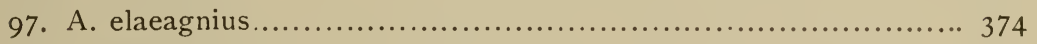

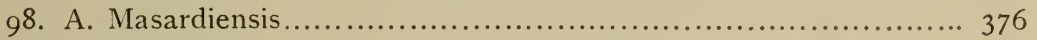

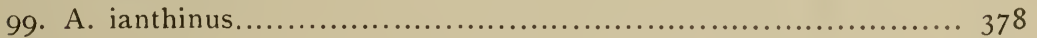

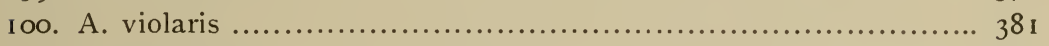

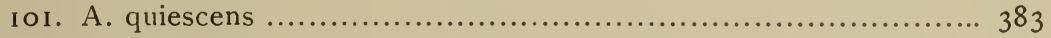

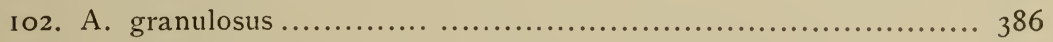

I03. A. Jussiei ................................................. 389

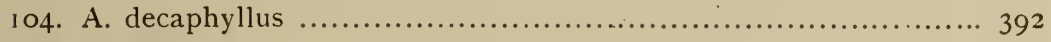

I05. A. Herveyi................................................ 394

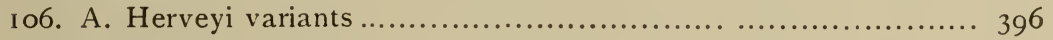

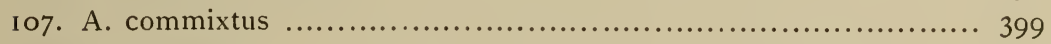

I08. A. mirabilis ................................................ 403 

VARIATION IN ASTER 



\section{SPECIFIC LIMITS IN ASTER}

Aster as now recognized forms a very large genus of over 300 species. It possesses remarkable solidarity and coherence within the United States. Here the center of its distribution lies, covering especially the eastern half of the continent, where perhaps two thirds of the known species of the genus are located. Northward its species extend through Canada into Labrador and Alaska; southward a few occur through Mexico and onward into the Chilean Andes. Southern reputed representatives in the Old World have not been able to retain their original position within the genus Aster. Those of the Cape of Good Hope, of Australia and of Tasmania, have been erected into small corollary genera. The Old World Asters as now understood are thus confined to Europe and Asia. Early species which had been described from China, Madagascar and Oahu, were separated by Nees in I 832 . Nees still retained (besides the 5 North American Asters then placed in his Eurybia) 102 species in Aster proper, a number now nearly trebled. Of his 102, all but 20 were in the United States and Canada; 6 others were from mountains of tropical America, in Mexico and in the Andes from Colombia to Chile; the remainder included I from Japan, I from Siberia, 8 from Nepâl, 2 from the Cape of Good Hope, 2 from New Zealand. Many others have since been added to the representation in Asia, including an endemic species in Formosa, others in the Kuriles and on the Amoor in Manchuria, several in Siberia, and others still in the Himalayan region.

The center of gravity of the genus however still remains in the eastern half of the United States, where Aster seems not only to exhibit its greatest number of species but also its greatest profusion of individuals, its greatest variability, its greatest size and greatest beauty, and where, if the combination of these evidences can show it, the genus is presumably not geologically an immigrant but a native.

Memoirs Torrey Botanical Club, Volume 13. 
Variation within the species. - Each species of Biotian Aster, the most variable group (and to a large degree this is true of the other groups also), is to be expected to develop quite a new aspect in any or all of the following classes of modifications :

I. Branch-forms, plants which seek to replace a lost upperstem by unusual branch-growth; involving not only a changed aspect by reason of the branching habit, but also many minor details of growth, particularly in leaf-form.

2. Sprout-forms, which spring up when the whole original stem is lost, and are usually unbranched and just the opposite from the preceding in aspect.

3. Arrest-forms, when sudden or gradual arrest of leaf-development or petiole-development, or of certain internodes or of certain leaf-types, may effectually disguise the relationship of the plant for a time.

4. Dwarf and luxuriant, condensed and expanded, smooth and pubescent forms, and their intermediates ; dependent on nutrition, shade, etc.

For all the above variations, which may be called regular irregularities, allowance must be made when in the field and when assigning value to specific characters. But I do not make allowance for these variations in keys or in descriptions of species, my plan being to describe the typical development of the species and then to add references to its variants.

The large number of coincident leaf-forms simultaneously existing on the normally developed plant must also be taken constantly into consideration. But a still greater source of misinterpretation is the remarkable series of consecutive leaf-forms (soon to be described in detail) which are assumed in different years or in different relations to light, moisture and crowding.

Variations between the species. - When the norm of a given species has been satisfactorily determined - and in order to do. this I have felt it necessary to watch a given species in several localities during several years of practically unaltered natural conditions - there still remains beyond this norm, and sometimes in every direction, a number of outstanding forms which often establish a perfectly graded connection to other neighboring species. But we will not deem a species nullified because nature has not yet extinguished all the light that could illuminate its descent. 
Aster species must usually be limited by arbitrary lines. Type specimens in Aster are often remarkably distinct from each other; one inspecting an herbarium with but few representatives of each species would gain no conception of the actual connections between the species still existing in nature, made by thousands of intermediate plants, usually capable of such arrangement in gradual sequence as to show a remarkable transition between species, with no satisfactory dividing line. Taking a single sequence from the long-established species of Gray's Synoptical Flora, A. macrophyllus is thus gradually connected with $A$. Herveyi, $A$. Herveyi with A. spectabilis, $A$. spectabilis with $A$. surculosus, both these with $A$. gracilis, and all three with $A$. radula.

In short, of the long-known northeastern species, there is hardly one which does not afford intermediate forms to some other within its own region, unless we except $A$. Nurae-Angliae, $A$. ptarmicoides, and $A$. subulatus; it happens that these are species which by certain botanists are, on other grounds, separated from Aster. Doubtless when the southern and western species which now seem more sharply defined shall have been studied equally thoroughly in the field, similar connecting forms will be found between many of those also. Continuous experience in the field over wide areas, and continued observation of the same localities through a series of years, confirm me in the conclusion that a sharply defined species of Aster is likely to remain an exception.

Intermediate forms do not invalidate species in Aster. Should we admit that they do we must accept a series of reductions which would not end till the principal bulk of the whole vast genus had been reduced to one species. For instance, among narrow-leaved species, Gray's group the Ericoidei included his A. Porteri, $A$. polyphyllus and $A$. ericoides. Because of essential similarity and multitudes of closely connecting variants, the advocate of reduction may unite all these into the one species, $A$. ericoides. If he seeks for connecting forms in Gray's next group, the Multiflori, he will find them, and he might similarly unite these into one species, A. multiflorus. But between this and $A$. ericoides numerous additional connecting forms exist, so another coalescence would follow. The next group, Gray's Divergentes, including A. dumosus, vimineus, lateriflorus, etc., by the same plausible reasoning might be 
merged into one species, and that itself shows such variants toward $A$. multiflorus and $A$. ericoides that all would be found connected. Next, the following group, Gray's Vulgares, including $A$. paniculatus, A. longifolius and A. Novi-Belgii, would prove impossible to separate. In other words, the variants preserved in my own herbarium link together all of the fourteen northeastern species recognized by Gray as forming those groups, and if connecting links were to invalidate species, would lead to such an absurdity as the reduction of the whole fourteen to one, including such diverse extremes as $A$. ericoides and $A$. Novi-Belgii. Nor would it end there, for further variants would be found when looked for, leading to $A$. foliaceus, $A$. puniceus, and other species. Similarly among the broad-leaved species, a chain of variant links connects together all of Gray's Heterophylli, and even his Patentes and Brachyphylli. A third group without definite natural demarcations is afforded by the species now to be treated, the Biotian series.

Intermediate forms ought to be expected between species of Aster, because belonging to a youthful race. Aster being apparently of recent origin considered geologically, it is natural that it should present, as it does, these characteristics of a young and vigorous race :

(a) Innate variability, or a strong tendency to vary independent of apparent assignable cause.

(b) Responsive variability, or a strong tendency, in addition, to vary in consequence of assignable cause ; $i$. $e$., great adaptiveness to environment; asters varying very promptly in response to change of nutrition, soil, sunshine, shade, or contiguity of associated plants.

As the result, a multitude of transitional forms are developed, species are difficult to limit, and there is opportunity for unusually wide divergence of opinion as to the position of the arbitrary specific lines which must be drawn.

Because apparently still occupying their region of original distribution, our asters of the northeastern United States may be expected to be prolific in intermediate forms. Like the Red Oak section of Quercus, like Lechea, like Solidago, like Viola, Aster is a genus in which multitudinous variants occur, which might have been exterminated had great alterations in climate or geographical 
form overtaken their habitat within their geological history, or had they been forced by such changes to migrate into new and remote regions. Consequently the expected dying-out of less-adapted intermediates has not been as usual or complete in Aster as in most genera even seemingly equally recent in origin. That common criterion of species, the absence of intermediate forms, fails to be of avail in this and the other genera cited.

Specific rank in Aster is indicated by continued development, while remaining in similar environment, of a body of characteristics which show a considerable degree of difference from the nearest kindred. Cases are rare in Aster where a single character alone distinguishes a species, however strong that character may be. Cases are numerous where a number of slight characters, on the other hand, mark, in their totality, a degree of difference certainly sufficient to require recognition as a species. An example is $A$. vimineus as distinguished from $A$. lateriflorus; it is rightly separated and by all recent authors; but more on account of a fairly persistent combination of slight modifications than on account of any one single character.

Theoretically, each species of Aster is a family group, descended from ancestors not very remote, and in habit and also in less obvious characters distinguishable from the descendants of some other related collateral.

We should limit the connotation of the idea of species to the existence of strong difference rather than to impress into the word species the explanation of the original difference. The word species does not itself tell us how the species has become individualized, whether by slow process of gradual modification responsive to a new kind of environment; or by gradual modification due to an innate variability acting in all directions at once, but of which variants only those best adapted to the environment have survived; or by gradual modification due to an innate variability acting only in a certain direction which constitutes the line of progressive change or evolution for that species; or by abrupt modification, a sport or mutation, coming in full vigor, though unheralded and unexplained; or, in the fifth place, by mixture of race as a fertile hybrid. It is quite conceivable that a species should originate in either of these ways, and however originated, if fairly persistent, it deserves to be called a species. 
Nor is the species-rank a measure of exact amount of difference. The species is a unit which is recognizable and is permanent within certain limits of time and environment. Given that permanent difference, and we have specific rank; whether the difference from its next surviving kindred measure five per cent. of difference or thirty. It is unreasonable to expect all the species of a genus to be each equally unlike each other; evolution progresses faster in one part of a race than in another. It is impracticable and wholly undesirable to attempt to give the word species the connotation of a certain and exact degree of difference. For instance to use the term variety for the forms in which an observer sees two per cent. of difference from each other, subspecies for those which show five per cent., species for those showing ten per cent., superspecies. for those showing twenty, etc., etc., would burden nomenclature, and would restrict and paralyze rather than enlighten. We need a short expressive binomial for each species, not a long trinomial or a phrase-name which shall locate its rank. Let its rank, that is, the amount of its difference, $i$. $c$., the degree of its relationship, be indicated by separate statement in its description.

Some of the species described in these pages are, as I believe, young and not as perfectly differentiated as they may yet become. Such closely related species may be ignored by some because, if species at all, "merely incipient species." Instead, they seem to me of utmost interest and most desirable to describe and name; to name rather than to indicate merely by number; for it is far easier for the memory to associate given characters with a significant name than to attempt to cluster them around an abstract and soulless number. In some respects such youthful species possess a greater interest than those of old established habit which have settled into a state of stable equilibrium. To capture a species in the making is indeed one of the prime rewards of research. If we are right in judging many of these new species of Aster to be of such character (as A. umbelliformis, A. fragans, $A$. camptilis, etc.), we shall find more than ordinary importance attaching to them. Therefore we shall not grumble though we find their limits uncertain, their characters sometimes baffling and failing in precision, their reversions innumerable, and the direction of their 
progress perceptible only after careful comparisons. All of this is just what might be expected of species new-born.

Thoroughly inclusive descriptions of species are impracticable in Aster, as in so many other variable genera. Aster descriptions must be descriptions of types. It is vain to attempt to make descriptions so broad as to include all variations. To attempt completely inclusive descriptions is to abandon distinctness, to sacrifice all clear results, and to lose the salient features in a general average of the inconspicuous. For instance, a typical plant of A. divaricatus will produce leaves about twice as long as broad; but some variants may have them reversed and twice as broad as long. Again its leaves typically are scarcely roughened at all, are thin, are sharply and deeply serrated, are acuminate, are alternate, are continuously cordate well up the stem; but every one of these characters is to be found occasionally reversed in plants otherwise like the type, and not to be excluded from the species in classification. The species may be described inclusively by stating that its "leaves are usually but little roughened, though sometimes very much so; leaves thin or thickish; teeth sharp or often blunt, directed outward or often forward or even backward," etc., etc. Mere citation of such a mode of description is enough to ensure its condemnation, for in losing point it loses utility. The plan I adopt is, instead, to describe the species by the characters regarded as normal to the type; afterward making separate mention of any special lines of variation that may be observed.

Treatment adopted for species and forms. - My practice is therefore as follows :

I. To class as species, those which persistently repeat a certain body of strong characters ; even though outlying forms exist connecting them with other species.

2. To class as subspecies, those which exhibit the above repetition of characters in a much diminished degree, and appear also to be frequently varying back into the type or between themselves. If there be doubt whether the plant should be classed as species or subspecies, I term it a species, rather than add another cumbrous trinomial.

3. Many subspecific groups display some character of their own caling for recognition, and yet seem too little known or too 
unstable to warrant a formal Latin name. I have numbered these by a small Arabic number following the species number; $I^{1}$ standing for the typical form of $A$. divaricatus; $\mathrm{I}^{2}$ for a variant; as $\mathrm{I}^{31}$, an All-cordate form of $A$. divaricatus, $\mathrm{I}^{32}$ a Non-cordate form of divaricatus; etc., etc. My effort has been to give each of these forms the badge of an informal descriptive English name.

4. Species or varieties (subspecies) already published I retain as such if reasonably distinct, even though the degree of distinctness vary considerably; it is not to be expected that the species of a large genus will all be equally distinct from each other. To reduce the species of a previous monographer to varieties or subspecies or vice versa, because some of them are evidently more closely related than others, is to burden synonymy without giving adequate benefit. The name is a badge, not a detailed inventory of rank. It gives a hint of rank and relative importance; but exact definition of the degree of difference involved, should be given in the original description of the species.

5. As probable hybrids I have classed a few cases that represent individual plants which unite two or more somewhat contradictory characters of their probable and near-growing parents. Such cases are usually isolated individuals. Cases of wide or abundant distribution, or of plants whose characters shade off gradually into the nearest related forms, I have classed not as probable hybrids but as intermediate forms.

6. Few single specimens in the genus Aster, especially within the Biotian group, can be so preserved as to exhibit all the typical characters : either for lack of space in the herbarium, or because of disappearance of leaves before flowering, or still more from the common habit of such asters to develop their typical characters only in part upon a single plant, neighboring plants of the same rootstock or colony supplementing these characters. It follows that herbaria can seldom show single sheets which present complete proper types of the species. The figures illustrating the species in this volume are usually made from a highly representative specimen in my own herbarium; but if, in case of new species, this specimen be called a type-specimen, it is not to imply that it is completely typical in every way, for perhaps such specimens hardly exist in Aster. 
Nor is a completely typical character to be expected of each observed specimen which I enumerate as examples of localities and dates after each species.

These examples are cited especially to give serial dates for colonies which I have kept under repeated scrutiny; and to give citations from herbaria in which I have seen examples which I should refer within the limits assigned to the species in question. Such examples when cited without special credit, were of my own observation and are preserved in my herbarium; although in a few cases, for clearness sake, my own observation or herbarium is specially indicated, and then by the abbreviation $B u$.

The descriptions are written with regard to both growing and dry states, which often differ greatly in roughness, color or aspect.

7. Instead of dividing the closely-linked chain of Aster-species into formal subgenera, I have classed them as groups or sections, informally named from a leading character or species - preferably from character.

8. I not only write my own subspecific names without separating commas and without any prefix var., but I also so print those previously published. I have given the nomenclature of subspecific Latin names the same treatment as that of species, recognizing that further evidence may at any time cause some one to elevate a subspecies or a form into a species. I have not deemed the same importance to attach to the nomenclature of subvarietal forms, and I simply label these, as already remarked, by an English name, seeking to embody in it as tersely as possible some characteristic aspect of the particular form.

9. I also endeavor in naming a new species to name it from some strongly marked characteristic, using Latin form, but by no means confined to Augustan Latin. The first object of science is not to uphold a supposedly pure Latinity, but to use the most expressive term. So I have occasionally drawn upon a source in medieval Latin; as carmesinus for crimson; and in a few cases in lack of a satisfactory and unused term existing in recorded Latin, I have constructed a Latin term from the brief and more definite Greek ; as iostemma, violet-crown, where I would not use violaceus, which had been long before published by Pursh for an Aster variety. 
No one without similar experience would imagine the difficulty of securing a new name which shall be duly expressive and which has not been already used as an Aster name, so many hundreds of synonyms already existing. Yet I have usually succeeded in naming from some characteristic, it may be in aspect, leaf-form, time of blossom, habitat, etc. It is not to be assumed, however, that the characteristics thus furnishing names are wholly restricted to the species bearing them; these are also shared by other species, but usually in less degree. Aster fragrans for instance is not the only Aster species which is apt to be fragrant in early blossom; but it is more apt to be so, and to be lastingly so, than are its relatives. So Aster fimbriatus is one of many species with a tendency to fimbriate rays: but it possesses the tendency in stronger degree than others. So Aster biformis is not alone in having a sudden reduction of leaf-type from a large, lower leafform to a small differently shaped upper leaf-type ; but this reduction, which is occasional elsewhere, seems in Aster biformis to have become a fixed habit.

\section{NORMAL CHARACTERS}

\section{CoInCident Leaf-Forms}

Aster lenf-forms normal upon a single plant.-Plants of the genus Aster are peculiarly liable to mistaken identification on account of their complex leaf-series. The principal steps in the series are commonly the eight following :

(a) Primordial leaf (so termed by Nees, I 832), usually a single leaf following a few more or less rudimentary scales. This leaf is very commonly orbicular, is very much smaller than those following, and different from them in surface and margin. It soon disappears in most cases; in $A$. roscidus, and in late shoots of other allies of $A$. macrophyllus, it is sometimes persistent to the end of the flowering season.

(b) Radical leaves; 2 or 3 on a shoot in A.macrophyllus; usually 2 in $A$. Schreberi, A. multiformis; usually 3 in $A$. ianthinus, $A$. roscidus; often 4, sometimes several more, in $A$. nobilis; often 5 or more in A. lacvis, $A$. undulatus, etc.; often $\mathrm{o}$ or more in certain allies of $A$. macroplyyllus in their plantain-leaved stages. The presence 
of few radicals, and those small, is characteristic of Gray's Heterophylli. Large radicals are often progressively different in form; as in $A$. multiformis, A. roscidus; the smaller are all quite similar, as in $A$. undulatus, A. Shortii, A. cordifolius, A. laevis, and allies.

(c) Lower cauline leaves; the most characteristic leaves usually, and usually also the predominant leaves, in so far as affecting the eye most, and giving the plant its characteristic aspect. They are apt to continue the form and size of the uppermost radical, now usually perished. These and the entire radical series may be classed together as basal leaves.

(d) Middle cauline leaves; in most species transitional in shape and other characters between the preceding and the next.

(e) Upper cauline leaves; usually much smaller and of quite a new form, often of the same form as the next but frequently not so.

$(f)$ Axile leaves; those at the base of primary inflorescence branches, i. e., subtending the primary axils. According to their diminution or enlargement they make the inflorescence seem naked or leafy.

$(g)$ Rameal leaves; on the primary inflorescence branches (peduncles); almost absent in some but in others very conspicuous.

(h) Bractlets, belonging to the pedicels (ultimate branchlets); little developed in Biotian species but very conspicuous in $A$. undulatus, A. ericoides, A. dumosus, etc.

According as one or the other of the foregoing parts of the leafseries is more strongly developed, the plant will change its aspect and may be mistaken for a new species, whereas it should not be so accredited unless the new development be persistent.

\section{Consecutive Leaf-Forms}

The normal individual aster may be expected, as a seedling or offshoot, to develop radical leaves, and to remain as a tuft of radicals for one or more seasons, then developing an erect flowering stem. I treat both the normal and the less usual stages of life-history in combination, following the order of succession of development, distinguishing by number and by letter, the normal by the letter $\mathrm{N}$, the accidental or less usual by letter $\mathrm{A}$. The normal stages are to be expected in all genuine species of Aster, but are particularly conspicuous in the Biotian group. 
$\mathrm{N}^{1}$. First normal stage, seedling stage, developing a small rootstock and usually 2 small radical leaves.

$\mathrm{N}^{2}$. Radical-tuft stage ; remaining often year after year as a tuft of radicals, storing up material, thickening and lengthening the rootstock. In some, as often in A. lateriflorus, these radical tufts may develop into flowering stems the same year. In many species the radical tufts remain commonly undeveloped but are occasionally called out by unusual conditions; as in $A$. divaricatus. In $A$. paniculatus and allies they are narrow and little conspicuous. In most other species they are broader than most subsequent leaves, at least in proportion; as in A. azureus, A. Shortii, A. undulatus, $A$. cordifolius and allies. Species in which they become large and conspicuous include A. macrophyllus, A. Schreberi, A. spectabilis, $A$. laevis and their respective allies; the continued development of their tufts soon covering the ground with the plantations which are so familiar in northern woods, sometimes becoming very extensive and in $A$. macrophyllus and $A$. spectabilis often composed of these leaves entirely exclusive of any foreign intermixture.

$\mathrm{A}^{1}$. Oval-topped stage; into this the preceding develops when the normal radicals are topped out by a few additional smaller non-cordate leaves, oval leaves often arising above cordate ones, sometimes intermixed with them. These appear as the result of vigor, occurring in strong plants, in rich soil. These noncordate radicals are smoother and thinner than the others, less uniform in shape, usually 2 or 3 times longer than broad, and with both ends nearly alike, the outline being oval, elliptical or oblong, sometimes spatulate or orbicular. Often the base is decurrent on one side of the petiole. A. macrophyllus, $A$. divaricatus, and nearly all of their allies and varieties will occasionally show this stage.

$\mathrm{A}^{2}$. Plantain-leaf stage; an extreme development of the last, the preceding non-cordate leaves becoming those now chiefly developed, growing large, broad, rough, sometimes io to a plant, and reminding one of the leaves of Plantago major. These seem to be due to access of light and nutrition, suddenly, not gradually, admitted. Favorable conditions for this development are afforded when, after the plants have become thoroughly established in deep rich soil, the trees are suddenly cut away. Examples are 
seen in $A$. roscidus; $A$. diraricatus fontinalis and $A$. viridis are similar.

$\mathrm{N}^{3}$. Cauline stage, the radical tuft sending up an erect leafy stem, usually without passing through the last two stages, and often without retaining its radical leaves, but developing three principal shapes below the branches, the lower, middle and upper caulines already described, these changing gradually into each other, but their particular form being characteristic of the particular species. But instead of taking this normal course of development, $\mathrm{N}^{3}$, the plant may enter into any of the following seven stages which I enumerate as accidental or less usual.

$\mathrm{A}^{3}$. Intercalary stage, when one or more little leaves are intercalated into the series, with much larger leaves above and below. Occasional in Biotian asters, especially in A. Schreberi, the appearance seeming like the exhibition by the plant of a rhythmic ebb and flow in its energy; possibly due to a short period of diminished nutrition.

$\mathrm{A}^{4}$. Arrested stage, when the gradually diminishing normal series of cauline leaves meets sudden arrest from which it never recovers, a succession of little leaves now continuing into the inflorescence, making the inflorescence seem raised on a long peduncle. Such an arrest is particularly apt to occur in late-developing or feebly nourished plants. It is frequent in the allies of $A$. cordifolius, of $A$. macrophyllus and $A$. Schreberi. In a few species, as $A$. multiformis, there is a marked tendency to adopt this habit of growth. I doubt, however, if there is any case in which it has become persistent enough to form by itself a valid specific character, except in $A$. biformis.

$\mathrm{A}^{5}$. Sprout-form ; due to development of a lateral bud near the ground, either on the base of a vertical stem or on the rootstock near it ; occasioned sometimes by excess of vigor in the plant as a whole, sometimes by the clogging of the main stem with age. Sprout-forms usually have the leaves somewhat different from the type, larger or smaller or very much narrowed or otherwise peculiar in shape. All species are liable to them, as also to the next, and their characters must be separately determined for each species.

$A^{6}$. Ramifolial or branch-form, when after suppression of the main stem, one or more branches rise to replace it; often due to 
cropping by cattle or to the use of the scythe or bush-knife. The newly stimulated branches differ from the normal in their angle and direction; their leaves are much larger and more numerous; but the leaf-form developed remains true to the branch-type for that particular species, and is a shape different from the cauline type, often thoroughly disguising the plant.

$A^{7}$. Bifurcation, either in leaf or stem, arising not apparently as result of accident but as a sport; occasional in species of widely remote affinity, as in $A$. macrophyllus, $A$. multiformis, $A$. nobilis, $A$. tardiflorus, $A$. cordifolius, $A$. divaricatus.

$A^{8}$. Opposite-leaf state, due to suppression of internodes, occasional in many or all species, especially frequent upon abnormal branches.

$A^{9}$. Verticil form, 3 nodes brought together; frequent in the inflorescence of Biotian species, and sometimes found in the leaves.

\section{INFLORESCENCE STAges}

$\mathrm{N}^{4}$. Normally the next stage of development of an aster after the cauline is that of aestivation or budding, when each species presents a very different aspect from that before or after, and one which often is wholly unlike what might have been expected of the plant, notably in forms of $A$. cordifolius and $A$. divaricatus.

$\mathrm{N}^{5}$. The flowering stage with pectinate heads which follows, begins with the rays normally erect, terete, or soon tubular by involution, appearing as if a pectinate fringe to the flower-head, often of a different color from that of their maturity. During its progress the appearance of the plant is apt to change greatly according as the following progressions become developed or not:

(a) Pedicels lengthen, changing sessile buds into long-pedicelled flower-heads, and changing dense bunches into loose clusters ; common in most species and occasional in all.

(b) Cymose development sets in to such extent that the outer branches become greatly prolonged and far overtop the inflorescence proper; in some this is occasional, in others it tends to become fixed and normal as in $A$. tenebrosus, A. nobilis.

(c) Rays flatten across, changing involutely-tubular rays into boat-shaped pointed rays and finally flat with rounded ends. Common to most species. 
(d) Rays change position, erect in bud, in expansion sometimes remaining upcurved for some time (A. divaricatus, $A$. erectus, $A$. nobilis), normally soon horizontal and finally decurved, very commonly at length incurved into a close coil (A. patens, etc.). A few forms tend to have the rays finally pendulous in straight lines (in $A$. divaricatus, $A$. cordifolius and allies).

(e) Rays change color with age; sometimes bleaching out from violet to white ( $A$. versicolor, $A$. macropliyllus pinguifolius, $A$. iostemma, $A$. ianthinus), sometimes by virescence passing through an olivaceous stage from white to greenish-brown, often seen in $A$. Schreberi and A. divaricatus, or sometimes by marcescence passing from the normal color to brown-white, retaining more or less horizontal position (sometimes in Biotian forms).

$(f)$ Disks regularly change color from yellow to red, reddishbrown or brown.

$(g)$ Disks in all become elevated with continuous bloom, changing from flat to dome-shaped.

(h) Pappus changes color from white to yellowish, or to dusky (A. patens) or to reddish-brown; the latter common among many Biotian forms, especially after five or ten years in the herbarium.

$A^{10}$. Enfeebled state; after close cutting down one year; when the new stems rising from the same rootstocks the next year are so different as to seem sometimes a different species, being often shorter, less vigorous, weaker, with inflorescence scanty and of a different form, the flowers often paler. A. paniculatus, $A$. violaris and $A$. nobilis are species which suffer badly in this way; $A$. roscidus and $A$. multiformis are examples which seem less affected.

$\mathrm{N}^{6}$. Resting stage, when after the flowering stem has died away, the rootstock continues year after year to develop radical leaves only. This seems to depend largely on nutrition and shade, especially the latter, sylvanism retarding growth of many colonies as woods grow denser over them.

$\mathrm{N}^{7}$. Surculous stage, when a lateral offshoot from preceding rootstock develops, usually rising within Io or even but I or 2 inches, and throwing up I or often 2 small leaves, ready with further growth to enter upon the radical-tuft stage, $\mathrm{N}^{2}$, and renew the round of life history again. Usually the connection between parent and daughter-plant dies away long before the latter has made much progress in developing large radicals. 
It will be readily seen that a species must often assume a complete disguise as it passes from one to another of these seven normal stages, and if it happen to enter into one of the accidental stages it may become still more unlike its proper self. Some species are especially prone to prolong certain stages or to accentuate them sharply. Specific distinctions are hardly to be found in the constant absence or the constant presence of any of the less usual stages, but rather in the relation which the plant bears to them when they are found, the ease with which they are induced, the shapes assumed when induced, and the speed with which they are thrown off. The character may remain latent in the species as a general thing, while circumstances have called it out in some individual. Species must usually be decided upon balance of characters or total aggregate of features; it is seldom that a single character in Aster will prove absolutely specific.

Sylvanism and other sources of change. - Many other modes of variation are occasional. Some temporary stimulation may have suddenly increased the internode lengths, so separating the leaves sufficiently to produce a new effect. Sudden influx of light or the cutting away of a neighboring tree may have induced unwonted size and number of radicals or may have changed the divergence of peduncles or pedicels. Unwonted shade may have reduced the thickness, roughness or pubescence of leaf. Such results of sylvanism may be temporary, and may even affect but part of the leaves or the inflorescence, or may not appear in the same plant the year following; yet they influence the aspect greatly, and are among the chief factors in the uncertainty often felt regarding aster species.

\section{COMPARATIVE VARIABILITY OF CHARACTERS}

\section{AMONG ASTER SPECIES}

\section{Variation of SeEdlings}

In the lack of a garden, and having need to conduct my observations in the time which could be spared from routine work of instruction within the city, I have had little opportunity to investigate the variability of aster seedlings as indicated by successive sowings. Long-continued observations of this kind are 
made difficult by the length of life of the individual aster, each plant living without flowering it may be from three to seven years, or in some cases even twenty or more. By each plant I mean not only each seedling, but also each rootstock branching from each seedling, many at least of which remain some years without further growth than the development of radical leaves. My main source of evidence as to variability of aster seedlings, as would be true in case of most other perennials, is the comparison of simultaneously-existing colonies of the same species. Such colonies can include but a slight range of generations, and many, sometimes all, belong to one. Careful comparisons of this kind may give rise, however, to inferences as correct and as convincing as any known to logic. I have made these comparisons, with this inquiry in view, during the last seventeen years, and through a region extending from the Androscoggin to the Potomac. My conclusion is that while offspring is like parent in most cases, there is relatively a very large percentage of sports in Aster; relatively large as compared with most other plants; though not absolutely a large number, for it may be only one individual among thousands.

\section{Variation of Root-propagated Plants}

My most careful direct efforts have been devoted to determining how far and in what ways the members of a single colony vary from each other. By a single colony I mean the plants descended from a seedling and still bound together by a continuous system of rootstocks or still indicating that origin by their position, although many of the connecting rootstocks have been lost by decay. Such a colony in the Macrophylli may be very large, perhaps a rod or more in diameter, and in case of similar compound colonies of $A$. quiescens I have known the ground for IoO feet radius to be practically occupied by the radicals to the exclusion of almost all other herbage. Such a colony in the Curvescentes may be of large size also, $2 \mathrm{C}$ feet or more; and among the Divaricati sometimes the same, though more often not over three or four feet. Among the other broad-leaved species colonies are smaller. Among the narrow-leaved they are with great difficulty traceable, because of the early decay of connecting rootstocks, making it 
impossible to say from how many seedlings a whole connected field full of $A$. dumosus, $A$. paniculatus or $A$. cricoides may have developed.

In attempting to determine how far the plants of a single colony may vary from each other, I have made observations on a series of widely scattered examples selected with reference to continued opportunity of access, for periods varying from 3 to 8 years, chiefly the latter, and including the following localities :

Washington, D. C., on the Potomac, along Rock Creek, at Terra Cotta, etc.

New York city, in Central Park; at Inwood; on the Palisades ; in Van Cortlandt Park; at Bryn Mawr Park; at Hillview, Mosholu, Neperhan, Grassy Sprain Lake, etc.

Western New York, in the Lake Erie region, in the Cattaraugus Indian reservation; in Silver Creek ravine; at Swift's Hill, Silver Creek; at Talcott's Woods, in Sheridan; at Point Gratiot in Dunkirk; at Fredonia ; in Niagara gorge ; etc.

White Mountain region, about the Franconia Notch, the Androscoggin and Peabody Rivers, etc.

Taconic Mountain region, Mt. Washington, Mass.

Massachusetts interior, Charles River in Weston.

Martha's Vineyard, at numerous localities.

These continued comparisons, together with less prolonged observation at many other places, give evidence that, in Aster, sports are apparently very common among seedlings, showing abrupt divergence from type; and that gradual modification on the other hand is very common among root-propagated plants, showing rapid but not very abrupt adaptations to environment and usually departing from the type rather in degree than in kind.

For example, in one large plantation composed wholly of thousands of plants of $A$. quiescens (watched for years on the Palisades but now unhappily destroyed) while perhaps nine out of ten plants conformed quite strictly to type, the following adaptive modifications occurred, producing what might at first have been taken in some cases for new species.

I. Stump-fed plants, with great increase of foliage and decrease of inflorescence where nourished from a well-rotted oakstump; the naturally large basal leaves being somewhat larger, 
the middle and upper leaves a great deal larger, the internodes longer but weaker, the inflorescence narrower and more axillary. Result of peculiar and rich nutrition; seen repeated in several separated examples.

2. Impoverished plants, with little leaves and stems.

3. Taller-stemmed plants, growing close together.

4. Low subremote plants.

5. Petiole-flowering plants, where the main stem becomes abruptly reduced, slight and short, resembling the preceding petiole, but bearing a half-dozen scale-like rudimentary leaves and a single head. Such a state occurs in similar conditions among most if not all of the Macrophylli, and seems due to late development (shaded usually by other plants of its own kind) a single head being at once developed without completing the usual intermediate stages.

6. Non-flowering plants in deep shade.

For similar details see the description of species following, especially the adaptive variants of $A$. divaricatus $\mathrm{L}$.

Variations seemingly of the nature of sports are not wholly absent from the root-propagated plants, however, though less usual. For example, a certain colony of $A$. divaricatus in Central Park, $\mathrm{N}$. Y., remained in a state of nature undisturbed for the seven years ending 1902 (the older central plants perished that winter, perhaps from old age). It consisted of as many as one hundred plants, of equal size and all alike in general as regards leaf, stem, branching and inflorescence; but differing as to the color of the rays. All the plants were normally white-rayed, but the central plants had their rays begin to turn a coppery red during early flowering or by the end of the first week, becoming completely so in another week, and fading somewhat in a week more. There were three grades of plants in this colony as to color: $a$, those remaining a dingy white throughout blossoming; $b$, the central plants, turning coppery-red ; $c$, a number of outer plants which partook of the coppercolor change to a less degree and more slowly. Throughout the seven years the same plants kept true to character, the same portion of the group remaining white each year, the same portion changing completely, and the same portion changing partially. There was no difference observable in the nutrition or other con- 
ditions of growth of the different plants; except that the reddest plants were in the greater shade, a condition usually unfavorable to developing red rays in that species, and inducing me to class these red-rayed plants as sports, or abnormal.

\section{Diagnostic Value of Structural Organs}

Diagnostic characters which prove serviceable in discriminating Aster forms include the following, being characters which often remain moderately true and distinct within one or more particular forms.

Predominant leaf-form (of large radicals and of lower caulines).

Sinus when with cordate base.

Teeth and acumination of the leaf.

Upper cauline leaf-form.

Winged petioles, as to presence, position, form.

Leaf-color, texture, roughness.

Color of rays ; of stem ; of disks after turning.

Pubescence on under leaf-surface, on upper surface, on stem, on petiole, on inflorescence.

Glandular hair, as to presence, parts affected, closeness, form, odor and viscidity.

Angle of branching.

Inflorescence-form; density at maturity; outline produced in nature, and again when flattened in drying.

Heads, as to shape and size.

Bracts, as to quincunx or triseriate maculation (green tips prominent in 3 or 4 rows out of 5 rows of bracts), apex, breadth, shape, substance, degree of taper, color, midrib, ciliation, puberulent surface.

Rays, in shape and number.

Green tips, as to form, color, margin, persistence through the head, etc.

\section{Colony-Forming Characters}

Colonies are patches due to root propagation by pale or bright smooth slender surculi which become dark thickened rootstocks gradually separating by decay. The colonies vary according to the species in density, size, permanence and freedom from intermixture. Within the species the colony habit seems little variable. 
Most of the Macrophylli and Curvescentes form conspicuous colonies with large leaves which remain throughout the season. Colonies of the Divaricati have capricious or merely vernal developments of radicals. The character of the colony depends much on the length of the rootstock, which varies with the species somewhat, and also within the species according to soil and position in rockcleft or swampy ground. A. quiescens may cover the ground with a dense colony for 200 feet; A. curvescens, A. Schreberi, A. umbelliformis, $A$. multiformis, produce strong colonies; but it is reserved for $A$. macrophyllus to cover the ground loosely with radicals for many rods together, or even for the half-mile, as among second-growth sprout-lands of the Cattaraugus Indian reservation.

Dense colonics. $-A$. sociabilis and $A$. ulmarius are remarkable for their compact bunch-like colonies or stools formed by very short rootstocks of one or one and a half inch in length.

Isolation. - I have never found $A$. viridis growing as a colony, which is remarkable considering the resemblance of its leaves to $A$. macrophyllus; this isolation of individual growth is one reason for considering $A$. viridis to be a hybrid. Similar though not such absolute isolation on the part of $A$. divaricatus fontinalis suggests a possible hybrid origin for that form also. Isolation of the individual on the part of $A$. macrophyllus sejunctus does not call for the same interpretation, however, because it is unaccompanied by any other character suggesting hybrid origin; the characteristics of sejunctus are such as are presumably assumed by certain seedlings derived from $A$. macrophyllus which have happened to start apart in grassy sward and which would, perhaps, in course of years, become assimilated in their descendants to the normal $A$. macrophyllus; hence my classification of sejunctus as but a subspecies.

Charactcristic length or shortness of rootstock seems to hold fairly constant throughout most species, as in $A$. multiformis, $A$. macrophyllus, $A$. divaricatus, where they are long and horizontal, $A$. roscidus and $A$. carmesinus, where they are much inclined to upturned or even vertical growth on account of preferred habitat among rock-clefts, $A$. sociabilis and $A$. ulmarius where they are very short but subhorizontal, $A$. undulatus, $A$. cordifolius and relatives, where they are ascending points from the crown of the 
last year's stock, and in most of the narrow-leaved species, in which they are apt to be of this latter description.

Slenderness or stoutness of rootstock seems quite constant within the species, rather more so than the length. As a general thing there is an increase in stoutness of rootstock through the succession of Biotian species in the order considered in this paper, beginning with the slender Divaricati and proceeding to the stout Macrophylli.

Succulescence of rootstock, a character which requires field observation, accompanies rapid growth and turgid stout rhizomatous condition; it seems to be always found in any species entering the plantain-leaf stage (so in $A$. divaricatus fontinalis, $A$. viridis, $A$. roscidus, $A$. decaphyllus).

Irrespective of that stage it seems to be regularly characteristic of plants of $A$. violaris and $A$. quiescens, in which case succulescence extends also to the stem and the leaves. It seems to be frequent if not regular in $A$. multiformis in the same way; not frequent in $A$. ianthinus; regular in $A$. nobilis; doubtfully present in the other Macrophylli.

Position of rootstock. - Upright or suberect position characterizes the short thick turionic rootstock of the plantain-leaf stage of any species. Biotian rootstocks otherwise are horizontal or nearly so, upcurving at the ascending end ; except where growing in crevices of rocks or among stones, when they may assume any position, and are frequently erect (as sometimes in A. carmesinus, A. Claytoni, A. mollescens).

Position of rootstock is liable to so many chance modifications from immediate environment that it is only after extensive comparisons that it can be used at all as a character.

\section{Color-ChaRActers}

Color of rays. - This is sufficiently constant to be of decided value as a character. White rays are as a rule dissociated from glands; traces of purple accompany glands in Biotian species, as in the more familiarly-known glandular species, Gray's Glandulosi, etc.

In the Divaricati and Curvescentes, if a color is present in rays, it is rose or rose-purple or crimson, or a copper-red; and not a 
violet or lavender containing blue. Such reddening is occasionally strongly marked in $A$. divaricatus, $A$. rupicola, $A$. listriformis, A. aucuparius, A. carmesinus, A. Claytoni, and A. Eriensis, and probably it is latent and may be elicited in any species of the Divaricati or Curvescentes whatever, though I have not yet observed it in a wide range of specimens of $A$. Schreberi, $A$. curvescens, $A$. Julianus, A. glomeratus and A. olivaceus.

Similar tendencies exist in many other ordinarily-white Asters, as in $A$. ericoides and relatives, $A$. vimineus and relatives, in which reddening occurs; $A$.dumosus, $A$. paniculatus, etc., in which either reddening or violaceous change occurs, but most frequently the latter; A. sagittifolius, with violaceous tinge, but its subspecies or cognate species, urophyllus, with white rays only.

Among Biotian species, certain ones, as $A$. ardens, show a stronger tendency to develop reddening than others; but no specific or varietal distinction seems to be discoverable in the more frequent occurrence of this reddening ; as indicated by the following reasons :

(a) It is frequently found throughout certain heads and not others, on the same plant; or even certain rays only, of a head.

(b) It often characterizes certain plants of a colony and not others, though otherwise similar.

(c) Its occasional increase with the progress of the season suggests an origin in such a chemical change in the cell-sap as may be possible in all though not equally frequent.

Against the supposition that it is a normal color-change in the cell-sap and associated with old age of the individual flower it is due to mention the following observations :

(d) Where the heads are partly reddened and partly not, those not reddened are often equally old.

(e) Where the reddening is only partial in a single head, all the rays are nevertheless of equal age.

Against a supposition that it is due to mere inequality of illumination is the fact that in cases $d$ and $e$ the chance of illumination has seemed on inspection to be equal and well-diffused. I'et that prolonged sunlight is a necessary factor seems indicated from the following fact: $(f)$, no reddening has been seen in the deepwoods species or in deep-woods specimens of well-diffused spe- 
cies; and is confirmed $(g)$ by occasionally finding $A$. Claytoni and $A$. ardens and perhaps other species reddened in the sun on surface of rocks while similar plants on the same rocks under bushes were not so.

It may therefore be thought that continued exposure to sun may produce more numerous reddened rays toward the end of the flowering season. While a great many of the best examples of reddening are September collections, there are a few of October dates. Those of August, as the reddened A. Eriensis, fall toward the end of the blossoming-period for the respective species.

On the whole, species of the Divaricati and Curvescentes vary greatly in their liability to reddening; in some species the tendency is certainly very much more easily excited than in others; it is not called out in deep shade; it is active in sunlight, whether the unmixed sun of the open (A. Eriensis, $A$. ardens) or the diffused broken sunlight of thin woods ( $A$. divaricatus, $A$. listriformis); it is more often observed after the height of the flowering season, but it also occurs well-developed before the middle of August; and I have found it persistent as much as seven years in certain individuals of a colony and yet not developed in the other offshoots of the same group and in the same conditions.

Full rose or pink coloration replacing white is much more common in Aster than rose-color replacing violet or purple. The latter has perhaps its most conspicuous occurrence in $A$. NovaeAngliae roseus; among others are occasional rose-red sports of $A$. undulatus, $A$. cordifolius, $A$. junceus, $A$. Novi-Belgii.

Distribution of reddening over the surface of ray is usually uniform, at least till toward the base, which is paler and remains for some time whitish in many plants, A. dumosus, A. Novi-Belgii and some Biotian species. In a very few sporadic Biotian examples the red occurs only as a narrow margin around one or both edges of the ray; in a few others it colors the whole ray except the tip.

Blue in such mixture with red and white as to make violet, is common in the rays of $A$. multiformis and relatives, and with a large proportion of white, making lavender rays, it occurs widely among these and the other Macrophylli. Nearly pure deep blue, but with a little red in it, is common in $A$. iostemma and $A$. gremialis. Deep violet turning whitish is common in the preceding and in $A$. 
zanthinus, $A$. nobilis, $A$. quiescens and kindred. Sometimes deep violet-blue and older white heads are to be found over the plant at once, as in $A$. iostemma and in $A$. versicolor; sometimes all the flowers on a plant are of nearly even development and all change together from violet to pale, often deceiving the collector as to their identity. In general, presence of violet characterizes the glandular Biotian Asters, and white rays (regular among nonglandular species) are among them the result of fading. As an exception, very little color is developed, even at the beginning, in A. violaris and in $A$. macrophyllus pinguifolius.

Many of the other cases which we have described as pale lavender might by some observers be simply termed whitish. In such cases, however, the trace of blue is still present to my eye, and is noteworthy as an indication of affinity with $A$. macrophyllus and as an accompaniment of the glandular character.

Other groups in which violet or purple rays accompany glands include $A$. grandiflorus, $A$. oblongifolius, $A$. patens, $A$. claviger, $A$. spectabilis, etc., and so with $A$. Novae-Angliae, which is royal purple. On the other hand, white rays are seldom found in the above glandular species; and the distinctively white-rayed species, as $A$. ericoides, $A$. paniculatus, etc., are non-glandular.

Some other non-glandular groups, however, as $A$. cordifolius, A. laevis, A. salicifolius and congeners, are blue or violet.

Pure blue rays are rare in Aster and do not occur in the Biotian group; forms of $A$. azureus, $A$. cordifolius and kindred approach close, however, to a pure blue.

Of the relation of glands and color, we can simply say that glands never or very rarely occur among the white-rayed asters, but do occur widely among the violet. It is yet to be proved what chemical connection, if any, exists between the development of these glandular secretions and the presence of violet color.

Yillow rays. - Their absence in Aster and presence in numerous related genera was made the ground of generic distinction for Aster by Vaillant as far back as I720. Asa Gray and many other writers have since emphasized this as a remarkable and valid character. Popular language has grown to reflect this fact, unconsciously observed, perhaps, at first, until "a yellow aster" has become recognized as a lusus naturac. 
Nature, however, which will not allow us to think herself trammeled by hard and fast lines, varies sometimes in the direction of yellow in the rays, and without actually reaching a full yellow, they become decidedly yellowish in $A$. viridis, $A$. Claytoni crispicans, and in other forms of $A$. Claytoni, $A$.erectus, and $A$. ardens. One very late-flowered plant of the second mentioned, gathered November 8 , i 896 , half way up the rock-front of the Palisades, growing on a ledge, came quite near to clear, though pale, yellow.

Virescence.-White rays often become greenish with age. All the Divaricati and Curvescentes seem subject to this, irrespective of exposure or nutrition. The degree and kind of color and the readiness with which it is assumed seems however to be, in many cases at least, a valuable distinctive character; as in the following white-rayed species :

$A$. olivaceus, rays apt to turn early to a pale olivaceous tinge.

$A$. divaricatus fontinalis, rays apt to turn cream-color and sometimes even yellowish.

A. Schreberi, rays apt to turn cream-color.

A. curvescens, rays apt to turn cream-color very early.

$A$. divaricatus, many forms, rays apt to turn cream-color.

A. sociabilis, rays cream-color and soon turning olivaceous, slightly greenish with a little brown; universal or at least common in this species.

A. tenebrosus, rays sometimes like the last, but olivaceous tinge assumed more rarely or more slowly.

$A$. castaneus, rays apt to turn cream-color.

A. axillaris, rays apt to turn cream-color.

Virescent rays are, as might be expected, rare among the Macrophylli and other species which show any trace of blue; but are produced sometimes in late-flowering stages of those which become pale or whitish, as $A$. densatus, $A$. securiformis, and $A$. violaris; also rarely, blended with purplish, in $A$. roscidus.

Color of disk-flozers: normally deep yellow turning to some shade of reddish-brown, and fading brownish. In a few varieties the disks are pale, not becoming a deep yellow. The shade of reddish-brown assumed is very characteristic and conspicuous. Brown predominates over red in many forms of $A$. divaricatus, including the typical form. Red predominates in many other 
forms, often amounting to a deep beautiful crimson. In others the disks are apt to turn a pale olivaceous color ; sometimes almost green, as in the green-disk form of A. divaricatus; and rarely to a full green. But while it is generally possible to say of a species that its disk is "usually crimson" (as A. mpicola) or "usually red-sienna" (as $A$. biformis) or "usually olivaceous brown" (as $A$. sociatilis), it is not often that any species is wholly constant to its predominant color, nor is it easy to find any cause for the exceptions. For instance, side by side, in shade or in sun, the kindred of $A$. divaricatus, though seemingly the same in leaf and habit, may have disks turning crimson and others a pale olivaceous. The heads of a whole plant however are all alike in their disks.

Color of pappus.-This is usually deepened in the herbarium, becoming somewhat ecru; sometimes deeply so, as in $A$. patens; among the Biotian species it is apt to become reddish, sometimes purplish or slaty. Species seem to differ considerably in the rapidity of this change, and in its first intensity; and perhaps there may be a difference among individuals within the species. Young half-grown heads seem to deepen much more than those which had become a little expanded before collecting; especially in $A$. nobilis and $A$. curvescens. In life the pappus is usually whitish, the same hue throughout a species from the beginning, bright in $A$. subulatus, $A$. argillarius, etc., dingy in $A$. divaricatus, or even ecru in $A$. macrophyllus. In $A$. curvescens I have seen a faint trace of reddening already during life, and it becomes beautifully red in a few years in the herbarium. In A. umbelliformis and A. Schreberi, I find it turning from ecru to a decided red in three years. The more remarkably red examples (except the above) are old specimens which have been reddening in herbaria for forty to sixty years, and which caused much wonder among collectors at their inability to duplicate them in nature until it was perceived that aster-pappus is widely subject to change of color.

Other asters of non-Biotian groups do not share this colorchange so conspicuously. But it is not absent from them, various Calliastrum species reddening decidedly (as A. conspicuus); and $A$. patens becoming a dark ecru or a well-marked brown.

Color of stem. - This is usually affected by sun or shade; the same stem may be reddened on the sunny side and greenish-brown 
on the others. Allowing for this, there often remains a color-tendency which is specific. For instance, the stem of $A$. puniceus tends to develop a deep purplish-red; that of $A$. biformis also a purplish-red; that of $A$. cbeneus, a deep red that is almost an ebony black; that of $A$. gremialis a shining green; that of $A$. ulmarius, a pale brown; etc., etc. Most of the Divaricati show a greenish stem with a little brown; $A$. macrophyllus and kindred, brown with little green.

Color of leaves. - This is quite constant throughout a species; deep dull green in A. macrophyllus; a brighter green in A. Schreberi, A. umbelliformis, etc., apple-green in $A$. macrophyllus sejunctus, pale yellowish-green in $A$. mollescens, etc. A. violaris is apt to show a deep blue-green but is sometimes pale; $A$. quiescens has a still different tone of deep blackish-green.

Autumnal leaf-color is also moderately constant; yellowish with some brown in $A$. divaricatus, $A$. Schreberi, $A$. violaris, etc., russet-brown in $A$. roscidus, and many others. Some forms tend strongly to marmorate or irregularly spotted leaves, or leaves veinstreaked with deep and lighter red; as $A$. mipicola.

Primordial leaves are apt to be strongly purpled, due to presence of sugar compounds, especially underneath; showing the tendency to red common in opening maple and ash leaves. When primordial leaves develop green color it is commonly paler than in the later and higher leaves, as is to be expected from their commonly shaded position.

Etiolated leaves occur in any species when deprived of light, as by a board or a woodman's chips fallen on them. $A$. divaricatus shows extreme examples.

Dark green species among the Biotian asters are apt to be those of deep woodlands, as if the less light the more chlorophyll were developed; as in $A$. atrovirens, $A$. tenebrosus, $A$. quiescens, $A$. roscidus, $A$. decaphyllus. The cause invites inquiry; for they seem to antagonize the other observed result of complete lack of light, etiolation.

Glaucous surfaces of leaf or stem are nearly confined to A.laevis and relatives, and among Biotian species to $A$. excelsior, which has a somewhat glaucous stem. 


\section{Pubescence}

Pubescence is increasingly developed northward, as illustrated in the Cordifolial groups, in some Biotian species, and many other plants. But in many varieties and species it seems independent of locality or exposure. About five different kinds of hairs occur; all well developed in A. macrophyllus sejunctus; distinguished as follows.

Strigose hairs or weak multicellular bristles are a common feature throughout most groups of asters; according to their length, closeness or direction they may make the surface seem velvety, downy, soft or merely hairy to the touch when in life, while the same leaf may seem when dry to be decidedly rough. Obvious hair, $i$. $e$., that which is observed by the naked eye, is much less widespread among asters than minute hair, observable only by lens.

Appressed bristles scattered over leaves, especially about one to an areola over the upper surface, form a very characteristic feature of the Macrophylli; these are usually whitish, straight and stiff and needle-like when dry, and point toward the apex of the leaf. Their number, etc., is of considerable diagnostic value.

Ciliation is the rule with the bracts of a large part of the Aster species; and in many cases with the petioles.

An aculeus tipping each serration of the leaf-margin is a common Aster character and its kind and direction is fully constant within a species.

\section{GLANDS}

Glandular hair, as regards its presence, form and extent, forms one of the most important and constant of species-characters. Absent from the Divaricati and Curvescentes, glands are always developed in the other Biotian asters, unless it be in A. mirabilis. It has been already noted that among Biotian as among other asters, glandular hair occurs with violet rays; the few species in which it may seem to accompany white rays are cases where the white is presumably a precociously-bleached violet, or where it is proven so by finding the earlier violet stages, as $A$. ferox, $A$. macrophyllus pinguifolius, and the whole group of the Ianthine species. 
Glandular hair is most developed in $A$. rosidus, where it makes the young growth, in case of vigorous plants, clammy to the touch, sometimes under the lens appearing gemmed as with little drops of dew over all surfaces of stem, leaf and bract; from the top of a plant four feet high in June completely to the ground, with exception of the older radical leaves which by that time have lost much of the secretion.

In diminishing order, the glandular secretion is also abundant in the Glandulosi, and in A. commixtus, A. spectabilis, A. Herveyi, A. ianthimus, A. uniformis; and then follow the other Macrophylli.

Perhaps a minimum of glandular development is that of $A$. gremialis and of $A$. excelsior, in which it is sometimes confined to the backs of the lower broader bracts. In $A$. multiformis, $A$. nobilis, etc., it extends over the pedicels; in $A$. securiformis over the whole inflorescence ; in $A$. biformis also over the upper part of the stem; in $A$. macrophyllus well down the stem; in $A$. decaphyllus and $A$. Herveyi nearly to the base; in $A$. violaris and $A$. ianthinus to the very base.

Similar glands may occur also on the petioles: along their outer surfaces, as in A. ianthimus; or only in their channeled upper surfaces, as in $A$. multiformis and many others; or only where that channel is continued into the midrib of the leaf, as in $A$. biformis, etc.

The glands may occur also over the lower surface of the leaves as in A. ianthinus, A. uniformis, and many of the Ianthine subsections; or over both surfaces, as in $A$. roscidus.

Where the glands occur they may be so thickly placed as to conceal the stem, as in $A$. roscidus; or may be so thinly scattered as to average one for each areola formed by the veinlets of the leaf, as often in $A$. iostemma.

Typical glandular hairs, as in A. macrophyllus, may be short, stiff hairs tipped with a large globular gland, and standing out straight, at right angles to the stem. In A. biformis and the Ianthine asters the gland is usually but little broader than its stub or stalk. In $A$. securiformis and others it is almost sessile. In most, the gland is darker than its stalk and when well developed shows the dark color to be a violet which is often almost black, and seens 
to be the same as that which is developed in the rays; as in $A$. violaris, A. iostemma, etc.; and, with less violet, in A. macrophyllus and many others. On the same plants the glands of the underside of the leaf, where they exist, are of a different and lighter color, from whitish (as A. ianthinus) to straw color (A. roscidus).

\section{FRAGRANCE}

At least six kinds of fragrance occur among Biotian asters, some of which are quite persistent through the species in which they occur.

I. Bee-bread odor, in the disks, strongest when their colorchange is about half accomplished, when a luminous warm siennabrown has succeeded the yellow preliminary to the full reddening. The pollen-masses are at this time opening, and insects arriving. The odor is rather difficult to define by parallel, but is quite similar to that of bee-bread in the cells of the common bumblebee. It appears not much developed in asters outside the Biotian group, but it is very common in Solidago, especially $S$. serotina, and S. gigantea, and in many other flowers, in early anthesis. I have observed it highly developed, among Biotian Asters, in A. biformis, $A$. roscidus, $A$. ianthinus, considerably so in $A$. violaris, A. quiescens, A. Claytoni, A. uniformis, moderately so in A. multiformis, $A$. macrophyllus; also in $A$. ardens; slightly so in $A$. divaricatus, at least in many instances.

2. Nutty odor; derived from the glands, an odor somewhat as of walnuts, especially of the glands of Juglans nigra and of Hicoria tomentosa. Many glands widely diffused through the vegetable kingdom diffuse this odor, which is subaromatic-but very different from the aromatic odor of broken magnolia leaves; equally different from the more typical aromatic odors of spices and not at all to be confused with the anisate odors of Aralia racemosa and many Umbellifers. Of this nutty odor familiar examples among asters are A. Novae-Angliae, $A$. oblongifolius, A. grandiflorus; among Biotian asters $A$. roscidus shows it in highest degree, sometimes equal to $A$. Novae-Angliac. It is perceived in those two species on approaching within a few inches of the pedicels or bracts, where the odorous glands are particularly numerous. It is faintly perceived in the same way in $A$.ianthinus, and $A$. Here' $y$ i, as 
also in $A$. spectabilis. It is increased by brushing the hand lightly across the glands, thus breaking them open; in that way it is made plain in any of the species from $A$. violaris to $A$. Herveyi inclusive, and in $A$. macrophyllus. So much odorous matter adheres to the fingers on lightly touching $A$. roscidus in this way that the fingers retain its fragrance for some time. Probably this is the "not-disagreeable odor" which Nees remarked upon, I 832, in $A$. commixtus, the only previous mention of odor in Aster which I recall in print.

3. A delicate true fragrance exhaled from the flowers of $A$. fragrans, and sometimes in $A$. tenebrosus and some other Divaricati; but not continuously found in every individual of those species. I have been unable to find evidence to prove whether every flower of $A$. tenebrosus diffuses this fragrance for some brief period and then loses it; or whether it is peculiar to special conditions; or to special individuals. Plants in which I have observed it have many flowers out at once, and these moderately close; are but just fully open; are either in the shaded positions normal to the species, or perhaps a little more inclined to peep out toward the wood border. It is not perceived until within six inches or so from the flowers. Some other Biotian species not of the Divaricati have this same fragrance, as A. uniformis. Outside of Aster, I cannot parallel the fragrance exactly, but think there is some resemblance in that of the lily-of-the-valley.

4. An attar-fragrance, faintly suggesting attar of roses, is perceptible in $A$. fragrans and in many of the Divaricati after pressing; chiefly from the dried inflorescence but also sometimes from the leaves; sometimes perceptible two feet away, but more often requiring as close a distance as an inch, when it becomes strongly perceptible to any one. It does not appear to occur during life, but is developed in drying, and in certain of the Divaricati selected to test the rapidity of its development, in plants which were tested when collected and which then did not possess this fragrance it was already well developed in three days or as soon as they were dry in the press. How long it lasts is uncertain ; certainly for three years in case of plants lying unmounted between papers.

5. An anisate odor is perceived from the fresh, broken stembases and rootstocks of $A$. roscidus, and in less degree of many 
other Biotian species. Those of Solidago species generally possess the same in a still higher degree; Aralia racemosa still more.

6. A very subtle saccharine fragrance is discernible from foliage of many individuals among the Divaricati when growing rapidly as in June, on approaching within an inch or two. The same leaves will be found slightly viscid and glistening (above; and perhaps beneath?) with a colorless exudation of saccharine sap (honey-dew). I have found no diagnostic character in this, but attribute it to conditions of individual growth. Perhaps similar conditions produce greasiness of many leaves of $A$. macrophyllus pinguifolius-which is however unaccompanied by odor or saccharine feel, and persists late, even till yellowing in October.

Size

After allowing for difference of nutrition, light and moisture, each species is found to have a somewhat uniform characteristic size. Aster nobilis and $A$. iostemma reach 5 feet; $A$. excelsior I have seen $4 \frac{1}{3}$ feet in Niagara gorge and at the time thought it the highest of its section. Each species or variety has usually quite a range of variation in this regard; $A$. excelsior averages very high, however, perhaps $3 \mathrm{t} / 2$ feet when growing undisturbed. These Biotian species are surpassed sometimes in the undulatus group, where I have measured $7 \mathrm{I} / 3$ feet; the cordifolius group, 7 feet; the paniculatus group, 6 feet; and in A. Carolinianus, which clambers over bushes in ponds for I 2 and sometimes 20 feet. These examples are of course extreme instances and an ordinary aster height, whether in the Biotian or other groups, is 2 to 3 feet.

Largest leaves measured are perhaps of A. macrophyllus pinguifolius, $12 \times 8$ inches, with about 12 -inch petioles, from Niagara gorge.

Larger heads (and fewer) characterize most glandular species as compared with the non-glandular ; reaching $\mathrm{I} / 2$ inches diameter.

Cultivation, and accidental loosening of soil in the wild state, is known to double the size of a leaf or head in a season, as in case of $A$. biformis.

Size of flower-head is also influenced by number; among the plants of a single colony of the Divaricati, an occasional plant may 
put forth a very few larger heads instead of numerous smaller ones. Sometimes the central head of one of the Divaricati shows a similar excessive size; and sometimes the terminal head of each branch, as compared with the subsequent lateral heads. Sometimes this excess of size is merely apparent and proves on examination to be merely excess in number of rays. In either case the first localization of the growth-impulse has had first and best opportunity to absorb and make over the unfabricated plant material into flowers.

\section{SinUS-CHARACTERS}

Other characters which are tolerably constant within the species, when due allowance is made for development stages, are to be drawn from the leaf-form and especially its relation to cordation.

Leaf-form, while at first seeming so variable as to be wholly baffling, proves within certain limits for each species (indicated with each description) to have great value as a distinction; and it possesses the special merit of being evident, and of giving to the plant much of its characteristic general aspect. In cultivation it does not alter as quickly as many other characters; size, for example.

Simus-character is the most important single feature of the leafform. Sinus-characters are rather constant, but require very cautious application from the transitions which a normal stem develops, as the sinus is gradually or suddenly obliterated among the upper leaves. Taking the best-developed sinus from among basal cauline and radical leaves as the type for the species, we get such results as these:

Sharp deep sinus, A. carmesinus.

Sharp shallow sinus, merely a notch, A. flexilis.

Narrow deep sinus, $A$. orbicularis.

Broad deep sinus, A. macrophyllus.

Broad shallow sinus, $A$. ianthinus.

Brace-sinus, or tricurve-sinus, such as the last but with the center decurrent a little down the petiole, the entire sinus forming the outline of a printer's brace; a very frequent type, especially characteristic of $A$. arcifolius and $A$. violaris.

Excavated sinus, one narrow at its entrance but enlarged circularly within; A. excavatus. 
Square sinus; one with rectangular corners within; A.limicola, A. Schreberi, some leaves of A. ampliatus and A. roscidus.

Securiform sinus; one with reëntrant angles within; the curvature resembling a battle-ax with broad convex, sharp-angled blade; A. securiformis.

Absence of cordation in radical or basal leaves of the Biotian species. This is frequent in sprout-forms and is usual in case of the primordial leaf. It is continuous in the plantain-leaf stage of any species, and it is therefore occasionally very conspicuous in such species as show a strong development of this plantain-leaf stage, as in A. decaphyllus or A. roscidus, A. Jussiei, A. viridis and A. divaricatus fontinalis.

Besides the above, absence of cordation occurs sporadically in various other species, or perhaps in all. In $A$. mirabilis perhaps cordation may yet be discovered; in $A$. Hervevi it is but slight and often disappears; in A. aucuparius and in $A$. castaneus it is little developed.

\section{TEeTh OF THE LeAF-MARgiN}

Teeth along the leaf-margins of the Biotian species are in general coarser and stronger in the Divaricati. In all the other species they are apt to be tipped abruptly with an aculeus; in the Divaricati each tooth is apt to be practically acuminate, the green membrane continuing nearly to the point, instead of ceasing abruptly as in A. macrophyllus. In A. mirabilis, and in slightly less degree in A. macrophyllus sejunctus, the ending is a solid, sharp, short, triangular, yellowish tubercle instead of a slender, needle-like aculeus. In estimating the characteristic form of teeth for a leaf the middle of the sides is most reliable; toward the base the form is often varied decidedly, or intermixed, crowded or greatly reduced. Almost all the leaf-borders become gradually entire before reaching the apex. Small leaves which are nearly entire throughout are not unusual, irrespective of species ; sometimes in A. macrophyllus pinguifolius and $A$. excelsior the teeth are almost obsolete, even on very large leaves.

The form of the teeth on the leaf-margin is quite characteristic usually, and among broad-leaved asters is often one of the most available single characters to be found. The middle and lower 
leaves of the stem are generally those which yield the most characteristic teeth. See figure showing forms, under Terminology.

\section{Texture}

Leaf-texture is highly characteristic usually; the variations are noted in the following descriptions; thickness and thinness may either of them be accompanied by great roughness or smoothness. The thick leaf may be, either flabby (A. macrophyllus, $A$. quiescens) or firm ( $A$. violaris) or coriaceous in substance. The thinnest large leaves are perhaps those of $A$. oviformis, about $6-7 \times 4$ inches; the thickest perhaps in $A$. macrophyllus, the most coriaceous in oval radicals of $A$. roscidus. Biotian leaves which are smooth, firm and thickish nevertheless always come short of the peculiar smooth feel of $A$. spectabilis (approaching it nearest in $A$. Herveyi) and fall still farther short of the cool smoothness of $A$. laevis (except in a few sports or hybrids).

Texture is sometimes a notable feature of the petioles also; crisp brittle subsucculent petioles occur in $A$. carmesimus; limp watery petioles (equally sticculent) in $A$. limicola; stiff straight petioles, as in forms of $A$. macrophyllus, etc.

Roughness of upper surface is usually increasingly developed in sun. It is chiefly due to increased number or greater thickening or hardening of the bristles normally present (A. macrophyllus); or may be due to development of minute hard projections, or the formation of a callus on each areola (granular roughening, in A. macrophyllus pinguifolius, etc.); or even to stout minute spines set closely over the whole upper surface ( $A$. mirabilis). It may be uniform over the leaf ( $A$. macrophyllus commonly) or confined to a marginal zone leaving the center smoothish ( $A$. Schreberi often), as noted by Nees, Gen. Ast. I 832 , and habitually designated by him as scaber ad margines.

This is a very different thing from the line of bristles or hairs which forms a marginal ciliation upon most Biotian leaves, which projects horizontally from the exact edge, lies in the plane of the leaf, and is usually much rougher than the feebler bristles of the upper surface just described.

Roughness may be developed in drying on a leaf which was smooth in life; and in $A$. macrophyllus pinguifolius, two parts 
of the same leaf in the same exposure may be smooth and rough either while living or after drying.

\section{VEINS}

Veins are much alike, but of some diagnostic importance; in $A$. carmesinus, $A$. obolarius, $A$. castaneus, $A$. axillaris, and perhaps others, they are remarkably succulent and stand out as slender ridges beneath, little confluent with the leaf-membrane; as if an aftergrowth, applied to the leaf. In $A$. castaneus they are apt to be depressed above and therefore retain dust and show as pale dusty lines over the dark green leaf. In $A$. biformis and in "pale-streak" forms of $A$. multiformis the same is true, perhaps aided by some glandular hair.

Direction of veins : in some cases diagnostic, forwardly curved like Cornus and Doellingeria infirma, in coriaceous forms of $A$. divaricatus, in $A$. castaneus, etc. ; curved directly toward the margin in the beech-twig form of $A$. divaricatus, in $A$. ulmarius, etc.; strongly outcurved in $A$. rupicola; upward-curved in most species.

Trinervate leaf-bases characterize all deeply cordate Macrophylli and Multiformes, with the sinus bordered on each side of the petiole by three veins, one primary bounding the sinus toward the petiole, its lower branch bordering the outer corner of the sinus, and a branch from that bordering the side of the sinus, at least for a short distance.

Usually there are three pairs of primary veins given off quite close together just above the leaf-base; sometimes only two; the two or more remaining pairs are quite remote.

\section{WINGS}

Winged petioles are common among many forms of the $D_{i}$ varicati as well as among the glandular species. Strap-ivings, long broad wings of uniform breadth like straps, occur often in $A$. divaricatus apricensis and are occasional elsewhere. Undulatiformwings, i. e., dilated gradually to a very broad base as in $A$. undulatus, are frequent throughout; $A$. curvescens is particularly subject to them. Half-wings, i. e., petioles winged along one side only or chiefly, form a singular prevailing feature of one form of $A$. divaricatus and are of sporadic occurrence in most species. But 
the more usual wings are irregular as in $A$. divaricatus alatus, and scarcely reducible to definite forms. Wings seldom occur on all the leaves at once, or on the lower leaves; and the chance of their occurrence is more and more probable upward. In fact the same plant of either $A$. macroplyyllus or $A$. divaricatus often shows all the transitions in petiole-formation, from a sessile to a slender petioled leaf, that are so remarkably manifested in $A$. undulatus.

\section{BRACT-CHARACTERS}

Bracts form one of the most helpful sources for discrimination of species after making due allowance for a certain range of change which is to be expected. Characters may be drawn from their number of rozus or ranks, an optical effect due to overlapping, or to such successively increased height of inner bracts as to produce the appearance of 5 ranks in A. biformis and some other Biotian species. The other extreme, a single rank of bracts, is produced when the outer, middle and inner ones are substantially alike in length, as often in $A$. puniccus, $A$. Novi-Belgii, etc.

Triseriate appearance of bracts characterizes most of the glandular Biotian species, with the outer lowermost bracts broad-based, and narrowed to an acutish but dark conspicuous point, as in $A$. macropliyllus; the tips of the second and third rows equally dark and conspicuous; those of the fourth narrow, pale and unobservable; few of the fifth now developed at all.

Quincunx pattern, with dark tips above the spaces below. The dark tips of the 3 rows may make a bright conspicuous quincunx or chequered pattern, usually among kindred of A.lacvis, A. cordifolius, $A$. undulatus, $A$. divaricatus and $A$. macrophyllus. Other kindred species may have the bract-tips so little darkened as to leave the involucre pale or nearly a monotone in color; as $A$. curvescens, $A$. olivaceus, $A$. sagittifolius.

Scarious margins, wide and shell-pink or, later, colorless, in $A$. fragrans, narrow in $A$. divaricatus, purple in $A$. biformis, and some other species, are apt to be quite persistent through a species and to be best developed on the middle bracts ; i.e., excluding the lowermost, which are seldom scarious-edged, and excluding the innermost, which are likely to be quite scarious in most species.

Ciliation of bract margins also forms a rather persistent spe- 
cific character. So does the presence of puberulence over the back, or of webby hair (A. divaricatus, A. patentissimus), or strigose hair (A. patens), or of glandular hair (the Macrophylli, etc.)

Squarrose bracts with abruptly reflexing tips are highly distinctive of A.mirabilis, A. Herveyi, A. spectabilis, A. anomalus. Such squarrose tendency seems to be stimulated in the cordifolial groups by trampling, when the heads are thrown into an unnatural prostrate condition and the bracts separate half-way down and become so divergent as to be reflexed (fide plants at High Bridge Park, N. Y.).

This phenomenon seems somewhat akin to the greater acumination and outreach of teeth and leaf-apices on the part of prostrated Divaricati when growing in much shade, and perhaps in both cases is due to the effort for light; but then why was not the leaf-direction similarly altered? An entirely different explanation must be sought for the squarrose-directed bracts of those species, like $A$. spectabilis, which produce them normally in erect growth in the open sun.

Coriaceous, succulent, all-herbaceous or part-herbaceous characters are usually quite constant for the bracts of the species which possess them. So also of the flatness or curvature of the back ; or it may be keeled along the midrib; the midrib may itself be obsolete (A. curvescens), or a faint dark line (A. oviformis), or a broad, herbaceous, green band ( $A$. vittatus).

The dark tips of the bracts, produced by a somewhat herbaceous or even pulpy expansion of the green tissue accompanying the midrib, are of very characteristic form in many species, elliptical in $A$. Novi-Belgii, rhomboid in $A$. laevis, long diamond-form, lanceolate, narrowly elliptical or of various other shapes in other species. The middle bracts are those presenting these tips in best development. Bracts with some aculeate hardening above the fleshy "green-tip" occur among the Multiflores.

In all broad-leaved asters the inner bracts are as a rule sucsessively higher, longer, narrower, and more tapering, also smoother, thinner, less colored, and less ciliate. But within these limits each species tends to have its own norm. That norm cannot be reliably established however by magnifying a single head taken at random; nor by taking any number of lateral heads with- 
out also examining some terminal or earlier heads, which sometimes present a regular difference from the less vigorous lateral ones.

Among Biotian asters large broad bracts are most conspicuo us among the Macrophylli, narrow tapering ones in $A$. curvescens and $A$. olivaceus. From the narrowed tips of the chief bracts results the conical form of the flower-bud in the Macrophylli; from their undiminished roundish tips results the subglobose or ovoid bud of the Divaricati; from the longer narrower bracts, the cylindrical bud of the Curvescentes.

\section{INFLORESCENCE-DEVELOPMENT}

This is usually quite characteristic of the species. Each branch is in certain Biotian forms so conspicuously cymose as to give a characteristic aspect to the plant; with lateral heads subsessile, yet while the central flowers are flowering on long pedicels, as sometimes in $A$. roscidus; and in allies of $A$. Schreberi perhaps representing Bernhardi's $A$. subcymosus. Each branch is somewhat so in $A$. curvescens and many other examples; so most forms of $A$. Schreberi.

On the contrary in $A$. umbelliformis, A. Eriensis, A. Julianus, A. glomeratus, $A$. biformis and many others, the tendency is for all heads on a plant to come into flower at once, and to cease at once.

And on the contrary in $A$. nobilis the outer pedicels become divaricated and greatly lengthened, at first suggesting a corymbose branch, till it is observed that the real outermost pedicels are still short and are deflexed underneath those which are older and are more horizontally prolonged.

In $A$. umbelliformis numerous pedicels radiate from the top of the peduncles. In $A$. excelsior and $A$. macrophyllus pinguifolius it is frequent to find 5 pedicels so radiating. In $A$. macrophyllus it is usual to find 3 , making the trifurcate inflorescence long ago noted by Nees.

Branching angle is apt to be rather characteristic, after making allowance for occasional slight alteration due to crowded growth.

Rameal or ramular leaves: their presence, shape, direction or closeness is often highly distinctive. In most of the Divaricati 
the branches usually have no rameals except as branchlets are produced, and are subtended by these bracteals. In the Curvescentes and in $A$. Claytoni and relatives, a very peculiar habit of growth occurs, a pair of nearly opposite bracteal leaves occurring on the exterior branches at about two-thirds the distance toward the last branchlet. In long branches sometimes several additional bracteals follow; so also in A. macrophyllus apricensis. At least a pair of such bracteals, but alternate or at least less closely opposite, occur usually in longer branches of $A$. macrophyllus, $A$. roscidus, $A$. multiformis. Other asters are apt to have a number of much reduced bracteals on a branch, not simply a pair.

Number of rays: fairly constant within narrow limits ; certain forms of $A$. divaricatus producing 5 or 6 , others $6-9$ rays; in the five-ray form largely 5 , in the Trientalis form largely 7 ; in $A$. Claytoni 6 ; in the Curvescentes about 10 ; in the Macrophylli about I 3 ; in $A$. nobilis apt to be I I ; in $A$. violaris up to $\mathrm{I} 5$ or more; the highest number produced in any frequency in a Biotian aster seems to be about 20, doubled by $A$. Novat-Angliae, and sometimes so by forms of $A$. Novi-Belgii.

Numbers of disk-flowers : less often tested, and subject certainly to somewhat wider latitude; but within those wider limits seems fairly constant. The green-disk form of $A$. divaricatus is perhaps the minimum, with 4 disk-flowers repeatedly; full disks show 20-25 (A. tenebrosus) and maximum disks 50 in A. macrophyllus, A. roscidus, etc.

Number of nerves in each ray 5 and with little variation; so of the 5 lobes of the disk flower.

Number of teeth terminating the ray 2 usually, in the Divaricati and Curvescentes, but with many exceptions, broad-ray forms being likely to have 3 , and some forms more. The number is rather characteristic within the species, but not wholly so. In the Macrophylli it is more regularly 3 ; in $A$. nobilis, none at all, and with sharp apex; in $A$. excelsior, none, with rounded spatulate apex.

Depth of disk-lobes is a moderately permanent character; the remainder of the disk-body is twice that depth in most Macrophylli, little more than equal to it in A. Jussiei, A. nobilis, $A$. decaphyllus, etc., three times the depth in A. Claytoni and perhaps four times in $A$. divaricatus. Disk-lobes divided nearly through- 
out the body of the tube I do not find, though relied on by Cassini as a marked character for his $A$. Jussiei, nor do I find unequal disk-lobes, such as he described, and I surmise that these two points in his description relate to an accidental, not a regular, condition.

Disk-flower form is very characteristic throughout a species; bell-shaped usually, narrowly so in $A$. Claytoni, moderately in $A$. divaricatus, broadly in $A$. carmesinus and $A$. mipicola; in all these the stalk of the disk-flowers is abrupt. They are funnel-form or gradually narrowed into the stalks in $A$. nobilis, $A$. Jussiei and close congeners. Disk-lobes are erect in the latter examples, but are widely spreading in most other species.

Achene variations are few among the Biotian species; usually . there is no pubescence; in certain species, as $A$. Claytoni, scanty pubescence often occurs, but almost as often does not, or is gone at maturity; in $A$. furcatus pubescence over the achenes forms a marked character.

Receptacle characters I do not find very discriminating, for the reason that through so large a number of species their receptacle remains the same, foveolate (areolate with a little firm, thin, greenish-white raised border around each areola), and fimbrillate (having this border cut into five or more lobes). When I was first delighted with the beauty presented by this character, in examining $A$. divaricatus curtifolius specimens at Washington, D. C., in I 889, I supposed it diagnostic of that particular form. Later I found it extending widely, if not continuously. Nees made much of this character. Asa Gray remarked, on the other hand, that he could make nothing of it, I think because working with herbarium material instead of living plants; and he may also have concluded that little difference is shown in different species. There is this difference, however, that seems to show occasionally, that some forms lack the fimbriae, some have but very shallow raised borders, and some have an additional central tubercle in each areola, bearing the base of the achene.

Annular thickening on the summit of the achene. Such a thickening forms a whitish ring uniting the summits of the vertical striae in many species, notably the Curvescentes. In some it is much stronger than others, and in some it is decurrent between 
the striae. In numerous examples seen such differences seem fairly constant within their species.

\section{Plasticity of Characters}

Comparative readiness of characters to change, under exposure to changed conditions, especially of sun, shade or soil, seems to rank in about this order :

Ist. Size and vigor of whole plant and of parts. First to change.

2d. Number of heads.

3d. Amount of pubescence.

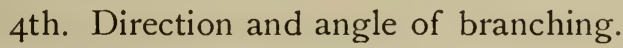

$5^{\text {th. Thickness of leaf. }}$

6th. Roughness of leaf.

7 th. Depth of color of rays.

8th. Rigidity or weakness and consequent attitude of stem.

9th. Bracts.

I oth. Glands.

I I th. Leaf-form ; last to change.

But some varieties have their idiosyncrasies respecting such changes, and transpose parts of this order; as A. macrophyllus pinguifolius, which seems to be particularly susceptible to influence as to roughness and then as to size of leaf.

\section{Primordial-leaves as clue to Ancestral Leaf-Form}

Can we read traces of the past history of Aster species in their succession of leaves? Does the growth-impulse as it develops one form of leaf after another on an uprising aster shoot, still pass through some of the ancestral stages? Do some of the numerous radical leaf-forms recapitulate for us in little the past history of their race? The radical series is quite uniformly begun by an entirely different shape from those following, entire and spatulate in narrow-leaved species, subentire and nearly circular in the broad-leaved. If we may see in this primordial leaf an evidence of the leaf-type borne by progenitors of the asters, we may conclude that the development since has been in the line of production of cordation, acumination and serration, $i$. $e$, developing the large serrate cordate acuminate leaves of the present time. If it could be proved that this primordial leaf holds true phylogenetic 
value, we might infer for Aster an ancestry with broad non-cordate, spatulate or subcircular leaves, little serrate or entire.

Granting the above, it would then become possible to explain as reversions certain curious subcircular or broad-spatulate stunted cauline leaves which occur perhaps among all asters as occasional intercalations among the normal leaves. Such is the case with an intercalary form of $A$. subcymosus where, after two or three fully developed cordate basal leaves, the stem intercalates a little roundish or oval entire leaf of the primordial type and then begins again with the modern cordate type; the nodes and the stem itself being as usual above and below. Among numerous examples of this species all apparently in the same conditions of shade and nutrition, perhaps two thirds developed this intercalary leaf.

Such an intercalary leaf is sometimes produced by the allies A. Schreberi, A. glomeratus, etc.

Very similar is the phenomenon of the interrupted-form assigned here to $A$. Jussiei, with which it grows. A little oval entire leaf appears suddenly halfway up the stem after a full series of large cordate leaves. But here the cordate series is not resumed, the oval leaf-type gradually enlarging and changing into greatly augmented axiles and producing a leafy top.

A whole series of arrest-forms follows next for comparison, forms occasional in most species and becoming typical in $A$. biformis, in which sudden arrest of the series of proper cauline leaves is followed by a continuously-small subcircular or broadspatulate series of little leaves without much increase in size upwards. Does the leaf-form assumed under this arrest of development betray a trace of the ancestral type? Does the arrested leaf stop at the stage of development from whence the modern leaftype has sprung?

But another interpretation of all these facts may be offered. The primordial leaf may owe all its characters to suppression of growth due to rapid passing of the growth-impulse into the better-illuminated higher nodes. The primordial leaf may stand in the succession of rapid and unfinished partial recapitulations of ancestral stages, but may yet fail to assume any definite or mature ancestral form; it is so brief a growth. Like the first little scalelike rudimentary leaves on the seedling aster, so the larger first 
scale-like phyllodes on the surculi, and the more-definite moremembranous primordial leaf as well, may all be held to possess no atavistic value, because too unfinished and indefinite. They may never reach the full expression of any one of their ancestral stages; like the rudimentary scales produced on the young oak seedling before the first leaves. The very crude and scalelike but already round-tipped or spatulate first primordials of $A$. ericoides, $A$. paniculatus, $A$. puniceus, etc., may be adduced to strengthen this explanation. Intercalated minute entire leaves may then be explained (though very incompletely) as failures of vigor due to temporary unfavorable conditions; and so with the arrest forms. By this explanation A. biformis becomes an example of a transmitted arrest-impulse so strong as to hold even in favorable conditions and so become measurably permanent. 

MODERN SYSTEMATIC TREATMENT OF ASTER 



\section{MODERN SYSTEMATIC TREATMENT OF ASTER}

\section{Recognition of Segregate Genera}

During the Linnaean period of Aster history, the steady enlargement of knowledge had changed the total of 30 species published by Linnaeus in 1753 to I07 listed by Nees in I818. The American representatives had increased not only numerically but proportionally, from Linnaeus' 20 to Nees' 82, the latter number being substantially anticipated by Muhlenberg, who catalogued 8 I American species in 1809 .

With the year I 8 I 8, Nees' Synopsis and its I07 species rnarked the culmination of the Linnaean period of the one cohesive genus ; and the publication by Cassini of his Eurybia* in the same year, I 8 I 8 , marked the distinct entrance upon an epoch of disintegration, which we have already called the period of Segregation, because marked by the recognition of segregates from Aster as distinct genera. Cassini had already published well-founded segregations like Agathaea, I 8 I 5, Galatella, I8 I7 ; but in I8 I8. his separation of Eurybia was the beginning of a series of temporary cleavages of certain Asters from the genus, segregations which have been repeatedly united and separated since, a characteristic of this modern period.

Cassini's segregate genera, I8 I 5-1829, established or recognized by him, were the well-known Eurybia, Galatella, Callistephus, Calimeris, Felicia, Agathaea, Munychia; also Printzia, Zyrphelis, Chiliotrichum, Polyarrhena, Henricia, Brachycome, Charieis, and Paquerina.

Lessing in his Synopsis generum Compositarum, I832, established several additional segregate genera, Gymnostephium, Leptocoma, and Rhinactina.

Nees' Genera et Species Asterearum, I 832, followed immediately, and made a larger number of segregates than any author before or since. He accepted Cassini's genera and Lessing's; he

*Cassini in Dict. des Sciences naturelles, 16. 1818 . 
added, as new genera of his own, Sericocarpus, Machaeranthera, Doellingeria, Mairia, Tetramolopium, Detridium, and Symphyotrichum; and from other sources he adopted the Boltonia of L'Heritier, Olearia of Moench, Diplostephium of Kunth, Asteromoea of Blume, and the Amellus of Linnaeus. The last genus, Amellus, was an inappropriate and high-handed transfer of the name Amellus from the classic plant, to a group of South African species; a misapplication upon which Adanson's substitution* of the name Amellus for the whole genus Aster, was but little improvement.

De Candolle's Compositae in his Prodromus, I 836, retained with modifications most of Cassini's genera, and Nees' Sericocarpus, Machaeranthera, Mairia and Calimeris ; and also separated Biotia, Heleastrum and Tripolium; as well as a number of small or less important genera of Siberian and of southern latitudes.

Rafinesque, who lfad been, as he says, "waiting to see what De Candolle would do," now hurried forth with his own disintegration of Aster, which had been begun by him in MS., as far back as I 8 I 5 , the year that Cassini begun his series of separations in Europe. Now Rafinesque proceeded to change the genus-name Aster (or what remained of the genus after Rafinesque's withdrawals) to Asteriscus (New Flora in I836); and in his Flora Telluriana, part 2, p. $4 \mathrm{I}+$, in $\mathrm{I} 836$, he published a group of ill-founded genera, all segregates from Aster, viz., Leiachenis, Diplactis, Fimbristima, Virgulus, and Venatris. In the same year, I 836, he issued two other Aster-genera, Myctanthes and Bindera, in his New Flora, p. 22 and 7 I respectively.

Nuttall, in publications I8I8-I84I, was the next American author of segregate genera, establishing Dieteria, Eucephalus, and Xylorhiza, and recognizing Tripolium.

Torrey and Gray's Flora of North America, when treating the Asters, May, I 84I, reunited most of the Astereae of the United States into the one genus Aster; including within Aster the groups Heleastrum and Tripolium, since separated by some; and including Biotia, which has since remained undisturbed in Aster; but

* Adanson adopted Amellus as his name for our genus Aster, and separating Tripolium, he nuust needs bestow the name Aster upon that. Necker also was not content without changing the name of the genus Aster, which became his genus Pinardia. 
not including Sericocarpus; in which again their judgment has been uniformly approved since.

If we ignore the whimsical and universally rejected mésalliance of Aster with Solidago and other genera by Kuntze in 189I, little alteration in the bounds of the consolidated genus Aster remains to mention, until the work begun in 1896 by E. L. Greene in his Pittonia, resulting in his separating or recognizing Doellingeria, Eucephalus, Machaeranthera, Tripolium, Heleastrum, Oreastrum, Leucosyris, Leucelene and Ionactis.

The limits for the genus Aster which my own judgment approves are those adopted in Britton and Brown's Illustrated Flora, in I898, retaining two of Greene's new genera, Leucelene and Ionactis, and recognizing Machaeranthera and Doellingeria as well as Sericocarpus and Brachyactis. My contribution of Aster-species to Small's Southeastern Flora, I903, also follows these limits. With the exception of the segregate genera named in this paragraph, Aster now includes in America nearly all the species which have ever been accredited to it; disregarding a few species which stood so near the debatable lines between Solidago, Aster and Erigeron, that they had occasionally crossed over the lines in earlier times. 


\section{BRIEF BIBLIOGRAPHY FOR AMERICAN ASTERS}

I635, Cornut, J. P. Canadensium plantarum ... historia. Paris, I635.

1640, Parkinson, J. Theatrum botanicum. London, 1640.

I680, Morison, R. Plantarum historiae ... Pars II. Oxford, I680.

I686, Ray, J. Historia plantarum. London, vol. I, I686; vol. 2, I688; vol. 3, 1704 .

I687, Hermann, P. Horti Lugduno Batavi catalogus. Leyden, I687.

I69I-6, Plukenet, L. Phytographia. London, I69I-6.

1696, Plukenet, L. Almagestum. London, I696; its Mantissa, I700.

1705, Plukenet, L. Amaltheum botanicum. London, 1705.

1698, Hermann, R. Paradisus Batavus. Leyden, 1698, edited by Wm. Sherard. 1700, Tournefort, J. P. de. Institutiones. Paris, 1700.

I 7 10, Boerhaave, H. Index plantarum quae in . . Lugduno . . Leyden, I 7 Io;

ed. 2,1720 .

1718-22, Vaillant, S. Etablissement de nouveaux caractères des . . Corymbifères... Paris, I 7 I 8-22.

1728, Martyn, J. Historia plantarum centuriae primae. London, 1728.

I731, Miller, P. Gardener's dictionary. London, ed. I, I731; ed. 2, I733; etc., to ed. 8 , I 768 , edited by Miller; ed. 9, I797-1804, edited by Thos. Martyn.

I732, Dillenius, J. J. Hortus Elthamensis. London, I732; ed. 2, Leyden, 1774. 1737, Linnaeus, C. Hortus Cliffortianus. Amsterdam, 1737.

1739, Gronovius, J. F. Flora Virginica. Leyden, Ist part, I739; 2d, I743; ed. 2, I 762 ; all containing descriptions of asters by John Clayton.

I740, Royen, A. Florae Leydensis prodromus. Leyden, I740.

I 753, Linnaeus, C. Species plantarum. Stockholm, ed. I, 1753; ed. 2, I763; Vienna, ed. 3,1764 .

I 77 I, Forster, J. R. Flora Americae Septentrionalis. L.ondon, I771.

I783, Cutler, M. Account of the vegetable productions growing in New England. Phila., 1783 .

1783, Lamarck, J. B. de. Encyclopédie méthodique, Botanique, vol. i. Faris, 1783.

I 788, Walter, T. Flora Caroliniana. London, 1788.

I 789, Aiton, W. Hortus Kewensis, London, I789, ed. I, Dryander editor ; ed. 2, I810-13, W. T. Aiton editor-in-chief, Robert Brown supplying the Asters.

1796, Cutler, M. MS. Aster descriptions, 1796-1804, etc.; in libr. Bot. Gard., Cambridge, Mass.

I803, Michaux, F. Flora Boreali-Americana. Paris, I 803.

1804, Willdenow, C. L. Linnaeus' Species Plantarum, ed. IV. Berlin, 17951830 ; vol. 3, part 2, containing the Asters, in 1804 .

I807, Eddy, C. W. Plantae Plandomensis (near Flushing, L. I.) N. Y., I807. I809, Willdenow, C. L. Enumeratio... Hort. Berol. Berlin, I809.

I 8 I I, LeConte, J. E. Plants of Manhattan Island. $N$. Y., Oct. I8I I (in Am. Med. and Philos. Register, 2 : 134-142).

I8I3, Muhlenberg, H. Catalogus plantarum Am. Sept. (completed 1809): ed. I, Lancaster, Pa. (printed Nov. I812-July I813) I813; ed. 2, Phila., 1818.

I814, Bigelow, I. Florula Bostoniensis, Boston, ed. I, 1814; ed. 2, I824; ed. 3,1840 . 
I814, Pursh, F. Flora Am. Sept. London, I8I4.

1815, Barton, W. P. C. Florae Philadelphicae prodromus, Phila., 1815; and ed. 2, or Compendium, 1818 .

I817, Eaton, Amos. Manual of Botany, N. Am. Albany, i817t, ed. 8, i84r.

I819, Torrey, John. Catalogue of Plants of N. Y. (Made public 1817 ), printed Albany, 1819 .

1818-25, Cassini, H. Dict. des sci. naturelles, vol. I6, and vol. 37.

1818, Nees, C. G. Synopsis ... Asterum. Erlanyen, I818.

1824, Elliott, S. Sketch of the botany of S. C. and Ga. Charleston; vol. I began appearing in $\mathbf{1} 816$, complete 1821 ; vol. 2, including the Asters, 1824 .

1826, Darlington, W. Florula Cestrica. West Chesler, Pa., $1826+$.

I832, Nees, C. G. Genera ... Asterearum. Brtslau, 1832; and Nuremberg, 1833 .

I833-40, Hooker, W. J. Flora Bor.-Am. London, vol. I, I833; vol. 2, I840.

1836 , De Candolle, A. P. Prodromus, vol. 5 (including the asters and kindred). Paris, 1836 .

1836, Rafinesque, C. S. New flora ... of N. Am. Phila., 1836.

1836, Rafinesque, C. S. Flora telluriana, part ii. Phila., 1836 .

I84I, Torrey \& Gray. Flora N. An. N. Y., vol. I, 1838-1840; vol. II (the Compositae), pt. I, including the asters, May, I84I ; pt. 2, Apr., I842 ; pt. 3, Feb., I 843 .

1843, Torrey, John. Flora of the State of N. Y. Albany, I 843 .

I 848, Gray, Asa. Manual of botany, No. U. S.; with many subsequent editions.

I860, Chapman, A. W. Flora of So. U. S., ed. I, $N . Y$., 1860 ; ed. $2, N . Y$., 1884 .

I873 +, Gray, Asa. Papers on Compositae, etc., publ. chiefly in Proc. of Am. Acad. of Arts \& Sci., especially the issues for $1873, \mathbf{1} 874, \mathbf{1} 879, \mathbf{1} 880, \mathbf{1} 882, \mathbf{1} 88_{3}$.

1884, Gray, Asa. Synoptical flora of No. Am.; vol. I, pt. 2, including Compositae, July, I884 ; vol. 2, pt. I, I878; 2 d edn., including the two parts and supplement, Washington, I886.

I 898, Britton \& Brown. Illustrated flora; vol. $3, N . Y$., I898; including the asters by N. L. Britton and E. S. Burgess.

I90I, Britton, N. L. Manual, N. $Y$., I90I.

1903, Small, J. K. Southeastern flora; with the asters by E. S. Burgess.

For mention of other descriptions of asters see the appropriate species; especially for the numerous references from American local floras, from state and government reports, and from periodical literature, as the Bulletin of the Torrey Botanical Club, Botanical Gazette, Pittonia, etc. 


\section{Table showing Increase in Recognized Aster Species}

It is difficult to construct a perfectly graded table for comparison of the growth of the genus Aster, because the limiting lines of the genus have varied so much at different times. Approximate uniformity is reached however, it is believed, by the plan adopted in constructing this table, which is to take as standard the Aster species of today as recorded in part in Britton and Brown and in part in the Flora Germanica. Species published by earlier authors under other genera than Aster are included* in this table if they have been included within the Aster limits recognized in the two standard authorities adopted. Biotian species, for example, are counted in under whatever name published. For Aster Amelizis L., the symbol A. A. is occasionally entered.

\begin{tabular}{|c|c|c|c|}
\hline Author & Date & Number of Aster-species & $\begin{array}{l}\text { Number of } \\
\text { ese still so } \\
\text { ecognized }\end{array}$ \\
\hline Dioscorides & .65 A. D. & $\mathbf{I}=$ Aster Amellus L. & I \\
\hline Serapion & IIIO & $\mathbf{I}=$ Eryngium & o \\
\hline Anguillara & $\cdot 1525$ & $\begin{aligned} \mathbf{I}= & \text { Pallenis spinosa }\left(\mathrm{L}_{.}\right) ; \quad(\text { and } \\
& \text { perhaps also }=\text { Tragopogon } \\
& \text { in part })\end{aligned}$ & 0 \\
\hline Valérius Cordus & . 1535 & $\mathbf{I}=$ Aster Amellus L & $\mathbf{I}$ \\
\hline Gesner & $1561+$ & $\begin{array}{l}5=\text { Pallenis, Buph:halmum, etc. } \\
\text { with A. A. }\end{array}$ & $\mathbf{I}$ \\
\hline V. Cordus, as edited & I 56 I & $3=$ Pallenis ; Anthemis ; A. A. & I \\
\hline Matthioli & I 563 & $2=$ Pallenis, A. A. & I \\
\hline Lobel & 1576 & $8=$ Pallenis, etc. & o \\
\hline Clusius & $\left\{\begin{array}{l}1576 \\
1583\end{array}\right\}$ & 8 A. A., A. alpinus L., etc. & 2 \\
\hline Dodoens & I $5^{8} 3$ & $3=$ A. A., etc. & I \\
\hline Cesalpino & I 583 & $4=$ A. A., etc. & I \\
\hline Dalechamps & $15^{87}$ & $\mathbf{I O}=$ A. A., A. alpinus, etc. & 2 \\
\hline Tabernaemontanus & I 588 & $5=$ Pallenis and Inula sp. & o \\
\hline Colonna & $1592+$ & $5=$ A. A., Inula, Helianthus, etc. & o \\
\hline Gerarde & I 597 & $\mathrm{I} \mathbf{I}=\mathrm{A} . \mathrm{A}$. , etc. & I \\
\hline C. Bauhin, Pinax, & 1623 & $\mathrm{~s}_{7}=\mathrm{A}$. A., A. alpinus, etc. & 2 \\
\hline Cornut & I 635 & 2 (2 American, A. cordifolius, etc. $)$ & .) $I$ \\
\hline Parkinson & 1640 & $\begin{array}{l}20 \text { (6 American, doubtful from } \\
\text { scanty descriptions) }\end{array}$ & ? \\
\hline J. Bauhin & 1650 & Io (none American) & 2 \\
\hline
\end{tabular}

* Excepting Aster Tripolium L., which had been a fairly uniform segregate from the first. 


\begin{tabular}{|c|c|c|c|c|}
\hline Author & Date & ber recognize & Aun & $\begin{array}{l}\text { umber } \\
\text { ierican }\end{array}$ \\
\hline Morison & 1680 & 48 & & $13 ?$ \\
\hline Ray & $\mathbf{r} 686+$ & 22 & & 4 \\
\hline Hermann, Ilort. Lugd. & 1687 & I 2 & & 4 \\
\hline " Parad. Batav. & I 698 & 3 & & 3 \\
\hline Plukenet, Phytographia & 1691 & 14 & & 5 \\
\hline "Almagestum & x 696 & 60 & & 17 \\
\hline Mantissa & I 700 & I4 more & ".Id." & 14 \\
\hline " Amalthea & 1705 & $\cdot 20 \quad 6$ & chiefly "Fla.", & 17 \\
\hline Tournefort & 1700 & 52 & & 7 \\
\hline Garidel, Plts. of Aix. & 1715 & I I & & o \\
\hline Vaillant, Corymbiferes & 1720 & 47 & & 32 \\
\hline Tilli, IIort. Pisa & 1723 & 33 & & 6 \\
\hline Boerhaave, Hort. Lugd. & 1727 & 30 & & IO \\
\hline Miller, Dict., ad ed. & I 733 & 9 & & 6 \\
\hline Linnaeus, Hort. Cliff. & I 737 & 19 & & 10 \\
\hline Clayton; Gron., Fl. Va., I & 1739 & & Va. & 10 \\
\hline " $\quad$ " $\quad$ " $\quad I I$ & 1743 & & Va. & 2 \\
\hline Linnaeus, Sp. pl.. Ist ed. & 1753 & 30 & & 20 \\
\hline Clayton; Gronovius, jr. & 1762 & & Va. & 12 \\
\hline Linnaeus, Sp. pl., $2 d e d$. & 1763 & 36 & & $2 I$ \\
\hline Miller, Diit., sth ed. & 1768 & 35 & & 25 \\
\hline Forster, Cat. $\Lambda . A m$. & 1771 & & U. S. & 35 \\
\hline Lamarck, Fncyc. & 1783 & 44 & & 3.3 \\
\hline Cutler, in Trans. Phil. Soc. & $\mathbf{I}_{7} 8_{3}$ & & Mass. & 3 \\
\hline Allioni, Fl. Ped. & 1787 & 17 & & I \\
\hline Walter, Fl. Caro. & I 788 & & Santee R. & I 4 \\
\hline Aiton, Hort. Kerv. & I 789 & 42 & & 35 \\
\hline Cutler, MS., F\%. Mass. & $1796+$ & & Mass. & 17 \\
\hline Michaux, Fl. Bor. Am. & I 803 & & U.S. & 82 \\
\hline Willdenow, Sp. $P l$. & 1804 & 103 & ( 5 Cape G. I. ) & 66 \\
\hline C. W. Eddy, Pl. Pland. & I 807 & & Flushing, I.. I. & 5 \\
\hline Muhlenberg, Cat. $I . A m$. & I 809 , publ. $18 \mathbf{I}_{3}$ & & U. S. & $8 \mathbf{I}$ \\
\hline Le Conte, Plts. of $N . Y$. & I 8 I I & & Manhattan I. & 5 \\
\hline Bigelow, Fl. Bost. & I $8 I_{4}$ & & Boston & I 4 \\
\hline Pursh, Fl. Am. Sept. & $181_{4}$ & & & $7 S$ \\
\hline Barton, Prodr. Fl. Phil. & 1815 & & Phila. & 25 \\
\hline Torrey, Cat. Plts. N. Y. & I8I 7 , publ. I8I9 & & N. Y. City & 22 \\
\hline Barton, Compendium & 1818 & & Phila. & $2 S$ \\
\hline Muhlenberg, Cat., $2 d e d$. & I 8 I 8 & & & 79 \\
\hline Nees, Sy'nopsis Ast. & I 818 & 107 & (I5 Cape G. H.) & $\mathrm{S}_{2}$ \\
\hline Elliott, Sketch & I 824 & & So Carol. & $4 I$ \\
\hline Bigelow, $\mathrm{Fl}$. Bo. $2 d \mathrm{ed}$. & I 824 & & Boston & 20 \\
\hline Darlington, Fl. Cest. & เ 826 & & & 16 \\
\hline Brereton, Fl. Columbiana & 1831 & & Washington, D. C. & $\mathbf{r}_{3}$ \\
\hline Nees, Genera Ast. & 1832 & 127 & & 107 \\
\hline
\end{tabular}

But if we include Nees' Doellingeria, Diplostephium, Eurybia, Tripolium, Machæranthera and Symphyotrichum, then Nees' totals will be 155 corresponding to the present genus Aster; American, 120. Nees' total Astereae are 230 (in 33 genera); of which the American are 127. 
Monern Treatment of Aster

\begin{tabular}{|c|c|c|c|}
\hline Author & Date & Number recognized & $\begin{array}{l}\text { Number } \\
\text { American }\end{array}$ \\
\hline Hooker, Fl. Bor. Am. & 1840 & & 50 \\
\hline De Candolle's Aster and Biotia & 1836 & I 55 & 138 \\
\hline Eaton, Manual, $7^{\text {th }}$ ed. & 1836 & & 94 \\
\hline Torrey and Gray, Flora & 1841 & & I3I \\
\hline Gray, Synoptical Flora & 1884 & & 124 \\
\hline Britton and Brown, Ill. Fl. & 1898 & & Northeastern U. S. 80 \\
\hline
\end{tabular}

Seventy-two species in Aster and eight in allied genera are included in the last.

Britton, Manual

Chapman, Sn. Flora

Chapman, 2d ed.

Small, S. E. Flora
I 901

N. E. U. S. 86

1860

I 884

I 903
S. E. U. S. 48

S. E. U. S. 49

S. E. U. S. 102 


\section{HISTORY OF BIOTIAN ASTERS}

\section{The Biotian Section}

Two species of Biotian Asters were recognized by Linnaeus and by Asa Gray; $A$. divaricatus and $A$. macrophyllus. Six were recognized by De Candolle in 1836 ; previous to my own work some 27 different names for species or varieties had appeared, I I of which represented plants now regarded as genuine Biotian species. The species described in the present monograph consist of the six known to De Candolle, two others before named by Bernhardi and one by Cassini, two species named by Asa Gray, eight which I published in Britton and Brown's Flora in I 898, one more in Britton's Manual, I90I, seven others in Small's Southeastern Flora in 1903, and about 56 in the present volume; also one now first published, A. subinteger, named by Mr. E. P. Bicknell. The number of Biotian species here admitted would be much more increased were it not for my holding back all the less distinct forms, some 60 of which I here describe under $A$. divaricatus by provisional English names. Between one and two hundred more are also listed merely as forms under the species following.

As a rule, other sections of Aster either do not equal the Biotian in their number of variant forms or have been already more fully described; no such great increase in species recognized is to be expected in most of the other groups.

Biotian Asters are like the Heteroplyylli and unlike other Asters in producing some cordate leaves. They are distinguished from the Heterophylli by their broader, thicker, more coriaceous bracts and their more corymbose and less floriferous inflorescence. From these and all other Asters the Biotian section is distinguishable by certain indefinable characteristics of aspect, including the following as frequent factors aiding to produce the complex result:

I. Larger basal leaves.

2. Greater diminution and diversity from the basal leaves up the stem.

3. Tendency to form large, leafy, sterile colonies. 
4. Tendency to harsh, or thick, or flabby texture.

5. Tendency to an inflorescence of larger well-separated heads, or if the heads be small, to a corymbosely flat-topped arrangement, rather than a panicle.

But these tendencies, though pervasive, are none of them absolute, and each finds as remarkable departures from itself within the Biotian group as without it.

I have not recognized this Biotian group as a genus, for it grades too imperceptibly into Aster species of the spectabilis group, especially in involucre, the chief character by which it had been separated.

The last to recognize this Biotic or Eurybia as a genus was Hooker, in his Flora Boreali Americana, 2 : I4 (I840), though under protest, remarking under his Eurybia, "I follow the learned Nees von Esenbeck in the adoption of this and other genera of his Astereæ, but I must confess that I think the character is much too slight, and the difference in habit by no means sufficient to warrant such a separation."

Torrey and Gray made Biotia a formal subgenus under Astir; and Hoffmann in Engler and Prantl's Pfanzenfamilien, I 894, so continued it, but as a section* rather than a formal subgenus.

I have not entitled the Biotian group as a subgenus, deeming formal subgenera of doubtful utility. If the distinction is sharp enough to require organization into a formal subgenus, why not constitute it as a genus at once as the more direct and simple treatment? It is in vain to hope to make all genera the expression of an exactly equal rank; their degrees of difference can never be exactly alike throughout a family.

Treating the Biotian Asters as an informal group or section, $i . \epsilon$., without technical name in Latin form, I retain the use, in that sense, as an appellative of the name now almost 70 years familiarly and happily associated with them, which would be compulsorily replaced if the Biotian Asters were erected into a genus, Biotia as a genus-name having been invalidated by its earlier use by Cassini.

* His second section, consisting of "A. corymbosus" and " A. macrophyllus"; preceded by his first section, Hesperastrum, consisting of a single species, Gray's Hesper. astrum Shastensis, from California. 
The name Biotia commemorates the French chemist, physician and botanist, Jean Baptiste Biot (born and died in Paris, 1774-1862), whom De Candolle had called in 1836 " clarissimus amicissimus Biot, qui ex Astrorum studio ad botanicam physiologicam feliciter migravit."

Biotia was first published as the name of a genus by Cassini (Dict. des sci. nat. 34: 308) in 1825, with one species, his Bioiza viscosa, the Madia iiscosa of subsequent botanists. In 1836 De Candolle observed that Cassini's description had been founded on a teratological form of the Pacific-American genus Madia, remarking, "Biotia Cassinii est monstruositas Madiae" (Prodr. 5: 264). Instead of dropping the name Biotia, however, De Candolle proceeded to revive it for that section of the genus Eurybia of Cassini, which is of North American habitat; retaining the name Eurybia for the Tasmanian species which Cassini had first assigned to it - species which are unlike the Biotian section in their shrubby habit, with coriaceous leaves usually tomentose beneath.

The genus Eurybia had been constituted by Cassini in 1818 * and distinguished from Aster by having " bracts perfectly straight from base to apex," as he remarks ; $\uparrow$ "instead of being more or less spreading as in Aster." This distinction, the recognition of which is ascribed to Adanson by Cassini $(l . c$.), does not hold completely when applied to certain Biotian species with recurving bract-tips, nor to numerous Heterophyllous species with straight erect bract-tips.

Cassini's Eurybia was originally meant for the Tasmanian group of shrubby species which De Candolle retained in it; species enumerated by Cassini in 1820 as Eurybia quercifolia, $E$. fulvida, E. viscosa, E. microphylla, all of which had been originally described as species of Aster by Labillardière. In I 825 Cassini added $\ddagger$ E. lirata, E. argophylla, E. Jussiei, E. macrophylla, E. corymbosa, and at this point left it. Of these 9 species only the latter 3 properly belong in Aster.

* Bull. de la Soc. Philom., Nov. I818.

$\dagger$ When repeating and enlarging his account of Eurybia in Dict. des sci. naturelles, $x 6: 46$ ( 1820$)$.

$\neq$ Dict. des sci. nat. $37: 487$. $\quad$ 1825. 
Comparative History of Biotian Species

The succession of descriptions of Biotian Asters tabulated below presents a synopsis of the different modes of presentation of these species. For sake of comparison, a few brief descriptions are quoted entire, in italic. Equivalence is given as recognized in the present monograph.

Vaillant, Mémoires de l'Académie Royale des Sciences de Paris, I $720^{2}$ : 3 I I. I 722.

Aster Canadensis foliis imis amplioribus cordatis et serratis $=$ A. macrophyllus $\mathrm{L}$.

Linnaeus, Sp. Pl. $2: 873 . \quad$ I 753.

Aster divaricatus L. (confused with Doellingeria infirma, to which belongs Linnaeus' description but not the specimens) $=A$. divaricatus $\mathrm{L}$.

Clayton, original description written I 759 ?, printed i 762 , following the next citation.

Aster serotinus, floribus in umbellula...., etc., no. $767=A$. Claytoni $\mathrm{Bu}$.

Gronovius, Flora Virginica, ed. 2. I $25 . \quad$ I 762.

Aster foliis cordatis, . . . etc. $=$ A. Claytoni $\mathrm{Bu}$.

Linnaeus, Sp. P1. ed. 2. 2 : I $226 . \quad$ I 763.

Aster divaricatus L.

Aster macrophyllus L.

Forster, Catal. Plants No. Am. 5I, 52. I 77 I.

Aster divaricatus L.

Aster macrophyllus L.

Houttuyn, Linnaeus' Pfl. Syst. 9: 377, 391. 1783.

Aster macrophyllus L.

Aster divaricatus L.

LAMARck, Enc. Méth. I : 307. I 783.

Aster macrophyllus L.

Aiton, Hort. Kew. 3: 207. I 789.

Aster corymbosus Aiton $=A$. divaricatus $\mathrm{L}$.

Aster macrophyllus L.

Succeeding writers who merely repeated Aiton's names of I 789 are omitted from this catalog except as introduced for other reasons. 
Michaux, Fl. Bor. Am. I 803.

Aster macrophyllus L.

Aster cordifolius L. (perhaps included A. divaricatus L., at least fide herbarium).

Willdenow, Sp. Pl. $3^{3}: 2036$. 1801 .

Aster corymbosus.

Aster macrophyllus.

(.. A. corolla radio caruleo $=A$. macrophyllus $\mathrm{L}$.

3. A. corollce radio albo $=A$. Schreberi Nees.

Muhlenberg, Cat. Plantarum Am. Sept., written i 809, printed Nov. I 8 I 2-July I 8 I 3 ; enumerates as blooming in July in Pennsylvania,

Aster corymbosus $=A$. divaricatus L., with blending, fide her-

barium, of $A$. umbelliformis $\mathrm{Bu}$.

Aster macrophyllus.

Bertero, * in his "Specimen," I8II ; or in MS. before I83I, Aster elatus $\dagger$ Bertero $=A$. divaricatus $\mathrm{L}$.

Aiton, Wm. Townsend, Hort. Kew. ed. 2. 5: 57 . I 8 I 3. Aster corymbosus.

a. caule purpureo. Purple-stalked corymbed starwort [may have been a transient state of the next].

$\beta$. caule viridi. Green-stalked corymbed starwort $=A$. divaricatus $\mathrm{L}$., which in typical development has a green stem, or greenish brown; but is sometimes purplish. Aster macrophyllus L.

o. foliis radicalibus oblongis cordatis, Large-leaved white starwort $=A$. Schreberi $\beta$ Nees; probably.

$\beta$. foliis radicalibus ovatis cordatis, Large-leaved blue starwort $=$ A. macrophyllus L.

Pursh, Flora N. Am. 2: 552 . I 8 I 4.

Aster corymbosus Ait.

In shady woods, Canada to Florida. 24. Aug.-Nov. v. v.;

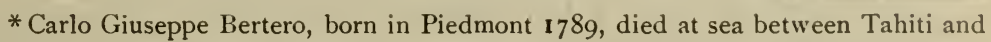
Chile, 1831; was author of "Specimen . . . indigenas stirpes continens exoticis succedaneas," Turin, 1811 ; 36 p. He was also author of a catalog of plants he observed in visits to Chile, of which a translation appeared in the American Journal of Science. volumes 19 and 20 ; in this however no Aster appears.

† Fide Steudel, Nom. ed. 2. I54. 1841 . 
a. s. in Herb. Banks et Lambert. A foot or two high; flowers white, larger than the preceding $[A$. cordifolius $\mathrm{L}.]=A$. divaricatus $\mathrm{L}$.

Aster macrophyllus $\mathrm{L}$.

In shady woods about rocks; Canada to Virginia. 24. Scpt.-Nov. v. v.; v. s. in Herh. Banks et Lambert. A foot or two high; flowers above the middle size, rays white, and somctimes blue. $=A$. Schreberi Nees, and A. macrophyllus L.

Bigelow, Florula Bostoniensis, ed. I. I 8 I 4. Astcr corymbosus Ait.

Barton, Wm. P. C., Prodromus Fl. Phil. I 8 I 5 ; and Compend. I 8 I 8.

Aster corymbosus $\mathrm{Ait} .=A$. divaricatus $\mathrm{L}$.

var. alatus Barton $=A$. divaricatus alatus (Barton) $\mathrm{Bu}$. Aster macrophyllus $\mathrm{L} .=A$. macrophyllus $\mathrm{L}$.

Torrey, Cat. Plants within 30 miles of N. Y. I 8 I 7, publ. I 8 I 9. Aster corymbosus Ait. In woods. Aug.-Sept., white. Aster macrophyllus Ait. Rocky, shady zvoods. Bloomingdale, Aug., white or pale blue.

Nuttall, Genera N. Am. Plants. I 8 i 8. Aster corymbosus Ait. Aster macrophyllus L.

NeEs, Synopsis Asterum, I8 8 ; repeated by Sprengel, Syst. Veg. $3: 532$. I 826.

Aster corymbosus Ait. Aster macrophyllus L. Aster Schreberi n. sp.

Bernhardi, as cited from his letters, herbarium, Nees, Ast. I 832 , or DC., etc. (lived I774-I850; wrote I799-1834). Astcr glomeratus, in litt. ad Nees; who so edited it $1832=$ A. glomeratus (Bernh.) Nees.

Aster subcymosus, in hb. Günther; an ally of $A$. Schrcbiri Nees; printed as its synonym by Nees, $1832=A$. subcymosus Bernh.

Aster ambiguns, in Hort. Vratisl. ex Hort. Erfurt. A redstemmed ally of $A$. Schreberi, fide Nees' plant in hb. 
Gray. Printed as synonym by Nees $1832=A$. ambiguus Bernh.

Aster glutinosus (where published ? in the Thuringische Gartenzcitung or the Allgemeines deutsches Gartenmagazin? which Bernhardi edited, I 8 I 5-1824. Known by its enumeration, DC. Prodr. 5: 250, (as a synonym of Biotia glomerati DC. ; but incorrectly so ? for Bernhardi's species glomeratus seems wholly non-glandular) see infra.

Elliotr, Sketch, Bot. of S. C. and Ga. I 82 I-4. Aster corymbosus Ait. $=A$. riciniatus Bu.?

Bigelow, Florula Bostoniensis, ed. 2. 1824 . Aster corymbosus Ait. $=A$. divaricatus $\mathrm{L}$. Aster macrophyllus L. $=A$. macrophyllus L. and $A$. ianthinus $\mathrm{Bu}$.

Torrey, Fl. Northern and Middle States, I 824 ; also in his Compendium, I 826 .

Aster corymbosus Ait.

Aster macrophyllus L.

Cassini, Dict. Sci. Nat. 37: 437. 1825.

Eurybia corymbosa (Ait.) $=A$. divaricatus $\mathrm{L}$.

Eurybia macrophylla (L.) $=$ A. macrophyllus L.

Eurybia Jussiei n. sp. $=A$. Jussiei.

Desfontaines, Catalogus Plant. Horti Regii Parisiensis, ed. 3. I 829.

Aster corymbosus Ait.

Aster macrophyllus L.

Aster latifolius Desf. name only, without description $=A$. macrophyllus pinguifolius.

NeEs, Genera Ast. I 832.

Eurybia Schreberi.

$\alpha$, reniformis cordatis, etc., typical ; $=A$. Schreberi Nees, I 8 I 8 , and so accepted here.

$\beta$, oratis cordatis, etc., included forms of our $A$. Schrcberi or allies, early known as $A$. latifolius, $A$. discolor, $A$. subcymosus, $A$. ambiguus, etc.

Eurybia glomerata $=A$. glomeratus Bernhardi in Nees.

Eurybia macrophylla $=$ A. macrophyllus $\mathrm{L}$. 
\%, all-cordate form.

$\beta$, sessile leaf form.

$\gamma$, Cove Valley form, from Penn.

Eurybia commixta $=A$. commixtus (Nees) Kuntze.

Eurybia corymbosa $=A$. divaricatus $\mathrm{L}$.

De Candolle, Prodromus, 5: 264-265. I 836 .

Biotia Schreberi $=$ A. Schreberi « Nees.

Biotia latifolia $=A$. macrophyllus pinguifolius $\mathrm{Bu}$.

Biotia glomerata $=A$. glomeratus Bernhardi in Nees.

Biotia macrophylla $=A$. macrophyllus $\mathrm{L}$.

Biotia macrophylla divaricata $*=A$. divaricatus $\mathrm{L}$.

Biotia commixta $=A$. commistus (Nees) Kuntze.

Biotia corymbosa $=A$. divaricatus $\mathrm{L}$.

Biotia corymbosa alata $=A$. divaricatus alatus (Barton) Bu.

Since De Candolle's Frodromus, Biotia has not been recognized as a genus, the foregoing plants being relegated to Aster; but three other species have at various times been temporarily enrolled as species of Biotia, as follows:

Biotia crenata Steudel, Nom. ed. 2. I 54. I $84 \mathrm{I}=$ Mairia

crenata. This was the Aster crenatus of Lessing, Syn.

Comp. I66. I 832.

Biotia discolor Maximovicz, Primitiæ Fl. Amurensis, I46. I $859=$ Aster scaber, Thunberg (Fl. Japon. 316. I 784) = Doellingeria scabra Nees, I832. Some would still separate $B$. discolor of the Amoor from typical $D$. scabra of Japan. The representatives of Maximovicz's Biotia discolor in American herbaria are certainly very different from American Biotian Asters, and this plant does not appear to belong within Aster as now understood.

Biotia? Japonica Miquel, Prolusiones Florae Japonicae, IO2. I866-7. Not the same with Aster Japonicus Lessing ex Nees, Gen. Ast. 33, 34. I 832 ; which is Inula dubia Thunb. Fl. Jap. 3I8. Miquel was very doubtful when writing his description in the Prolusiones as to the proper

* A variety founded by De Candolle upon a misconception regarding such specimens of $A$. divaricatus $\mathrm{L}$. as have a leafy inflorescence. Such were classed correctly by Linnaeus under $A$. divaricatus, but by Nees were assigned to $A$. macrophyllus L., which led De Candolle to constitute them a variety of the latter species. 
place of this species, finally publishing it as "Biotia?" with the remark: "Perhaps a new genus; but it agrees in many characteristics with Biotia discolor," e. i., with Doellingeria scabra Nees. That Miquel's plant was not a Biotian aster seems indicated by its outer involucral scales, described as but little shorter than the inner ones. Probably this species and the preceding when fully studied will be found not members of Aster at all.

Torrey and Gray, Fl. N. Am. 2 : 103-105. May, i 84I.

$A$. corymbosus Aiton $=A$. divaricatus $\mathrm{L}$.

A. macrophyllus L., . . . rays white or purplish. The "purplish" plants $=A$. macrophyllus L. proper; the "white" ones were probably in part the same in older bleaching condition; and in part were rougher larger-leaved forms of $A$. Schreberi Nees.

3. stem and leaves nearly smooth and glabrous; heads usually smaller; A. Schreberi Nees. = A. Schreberi Nees in smoother states; and $A$. umbelliformis $\mathrm{Bu}$. and perhaps other smoothish allies.

$\gamma$. exterior scales . . . broadly ovate or roundish oval" instead of acute. This seems the same with a rare round-bracted form or ally of $A$. macrophyllus L.; see infra.

"Varies with the heads somewhat glomerate on short pedicels and the rays shorter; an accidental state, Eurybia glomerata Bernhardi in Nees Ast. Biotia glomerata, DC. Biotia Schreberi, glomerata, and latifolia, seem to be merely slight forms of this species. Biotia (Eurybia Nees) commixta DC., is of doubtful origin, but perhaps it is only a form of this species," T. \& G.

A. mirabilis $\mathrm{T}$. \& $\mathrm{G}$.

Torrey, Fl. N. Y. State. I 843.

A. corymbosus Aiton.

A. macrophyllus $\mathrm{L}$.

Provancher, Flore Canadienne, I : 305. Quebec, I 862.

A. corymbiforme, A. corymbosus, Ait. Aout.

A. ì grandes feuilles, A. macrophyllus, L. Petouane, Sept. At St. Joachim, where Provancher collected both species, he 
thus records this name Petouane or Little Tobacco for this plant, from its radicals.

Gray, Syn. Fl. N. Am. I 884.

A. corymbosus Ait.

A macrophyllus $\mathrm{L}$.

A. mirabilis $\mathrm{T}$. \& $\mathrm{G}$.

A. Herieyi Gray (first described in his Manual, i 867).

Peck, N. Y. St. Mus. Nat. Hist. Annual Repts. $46: 45$. 1893.

A. Herveyi intermedia $=A$. macrophyllus $\mathrm{L}$.

Burgess in Britton and Brown, Illustr. Fl. 3: 356-36I. 1898.

A. carmesinus $\mathrm{n}$. $\mathrm{sp}$.

A. tenebrosus n. sp.

A. divaricatus L., with varieties cymulosus, deltoideus, curtifólius, fontinalis; also persaliens, now made a species, infra.

A. furcatus n. sp.

A. Claytoni n. sp., with variety crispicans.

A. macrophyllus L., with varieties pinguifolius, sejunctus, velutimus; also biformis, and excelsior, here made species, infra.

A. roscidus $\mathrm{n}$. $\mathrm{sp}$.

A. ianthinus n. sp.

A. violaris $\mathrm{n} . \mathrm{sp}$.

A. curvescens $\mathrm{n}$. sp., with varieties oviformis and umbelliformis, here made species, infra.

A. Schreberi Nees.

A. glomeratus Bernhardi in Nees.

A. Herveyi Gray.

Burgess in Britton's Manual; I90I. The preceding species and A. leptocaulis n. sp.

Burgess in Small's Southeastern Flora, I 2 IO-I 2 I 3. 1903.

A. divaricatus $\mathrm{L}$.

$A$. tencbrosus $\mathrm{Bu}$.

A. stilettiformis n. sp.

A. excavatus n. sp.

A. castaneus $\mathrm{n}, \mathrm{sp}$.

A. chlorolepis n. sp.

A. Boykinii n. sp.

A. Alexilis n. sp. 
A. multiformis $\mathrm{Bu}$.

A. riciniatus $\mathrm{n}$. $\mathrm{sp}$.

A. macrophyllus $\mathrm{L}$.

A. commixtus (Nees) Kuntze.

A. mirabilis T. \& $\mathrm{G}$.

\section{First Known Collectors of Biotian Asters}

I. Sagard. Father Gabriel Sagard, a French missionary to the Hurons, a Recollet or reformed Franciscan monk, who went from Paris to Canada in 1624 and spent two years in the country of the Hurons, publishing his Grand Voyage du Pays des Hurons and his Huron vocabulary, in 1632 , and enlarging these in 1636 to the "Histoire du Canada et Voyages que les Freres Mineurs recollets $y$ ont taits pour la conversion des Infideles," in four books, of which the third treats of natural history. Tuckerman, in Archaeologia Americana, 4: I I9, remarked that he thought Sagard to have been the first collector of a number of Sarrasin's plants; $i$. e. of species which Sarrasin,.nearly a century later, described or sent to France. Certainly, Sagard, from the region where he traveled and the acute observation he displayed, must have become familiar with Aster macrophyllus in Canada, and he is perhaps the earliest writer of natural history who saw the plant. In fact, his descriptions * of flowers seen by him in the Huron country includes one which suggests a violet Aster macrophyllus; for he says it is "of a violet color, of the form of a star, and size of a small narcissus" ; all of which might be said more appropriately of one of the Macrophylli than of almost any other plant in his region. He also remarks that its leaf is "very like our Muguet," a name then $†$ and now used in France for our lily-of-the-valley, Convallaria; making it probable that the leaves of Sagard's Huron plant were those of Clintonia, abundant there, and extremely suggestive of Convallaria. With leaves of Clintonia he may perhaps have confused the flowers of an Aster. Possibly his reference was based on a memory of autumn, with broad leaves of Clintonia and of Aster macrophyllus covering the ground, and with

* In my copy of Chevalier's reprint of Sagard's Grand Voyage (Paris, r 865 ), on page 234 ; in the original of 1632 , page 332 .

$\dagger$ Muguet $=$ Convallaria, fide Lobel, in 1576 . 
no flowers then but the violet-colored star-like Aster blossoms. Curiously enough, even his comparison of leaves to "Muguet" has a glimpse of Aster in it; for at the time of Sagard's life the standard French name for the Aster of Europe, Aster Atticus, was Petit Muguet.*

Perhaps his Huron Muguet is wholly based + on a Clintonia; but possibly it is based for the leaves on Clintonia, and for the flowers on an Aster macrophyllus, ianthimus or multiformis.

Later botanists record the name for Aster macrophyllus among the French in Canada of "Petouane," or "Petune," $\ddagger$ or Little Tobacco, from a custom of using its leaves as substitute for the tobacco leaf. Such uses were commonly learned from the Indians. Sagard in his Huron vocabulary, 1632, gives Testenc and other names as the Huron for Petun or tobacco, and Satéya and Ataya as the equivalent for Petune. If he used Petun and Petune with the same distinction that is now maintained, it follows that his Huron Indians called Aster macrophyllus Ataya, or with prefix, Satéya ; signifying, apparently, Tobacco-smoke-plant = "what we smoke."

2. Sarrasin. Dr. Michel Sarrasin of Quebec, born and died in France I659-1734, was while living at Quebec, a member of the superior council of the French colony; contributed many scientific papers to the society memoirs of the day, including descriptions of the beaver (1704) and muskrat, and the plant Sarracenia on which Tournefort bestowed his name. The historian Charlevoix on arriving in Canada expressed surprise at "finding so learned a man in the colony," says Tuckerman.

To Vaillant in Paris, Sarrasin sent, before 1720 , many of the Canadian Compositae, including $A$. macrophyllus L. (Vaillant's no. 28) 3 other asters (Vaillant's nos. 3 I, 38, 46) and as many goldenrods, with Artemisia Canadensis and related species.

Later Sarrasin returned to Paris and was there honored as

* Petit Mugnet $=\Lambda$ ster Atticus, fide Fuchs, I55I, and Jean Bauhin's Historia plantarum, 1650 .

† Sagard's reference is as follows : Le Muguet qu'ils ont en leur pays a bien fueille du tout semblable au nostre, mais la fleur on est toute austre ; car outre qu'elle est de couleur tirant sur le violet, elle est faicte en façon d'Estoille grande et large comme petit Narcis." Sagard, page 332, of original edition of 1632 .

$\ddagger$ Provancher, Flore Canadienne. 
physician to the king, Louis XV; was keeper of the king's seal, and a member of the Académie Royale des Sciences.

He has been ascribed to the distinguished race of physicians which produced Jean Antoine Sarrasin, or Saracenus, Antwerp, editor of Dioscorides, whose father, Philibert, the physician at Lyons, espousing the Reformed faith, sought refuge in Geneva in 1550. Jean's sister, Louise, famous as a linguist, was twice married to a physician. Jean's two sons were physicians, one of them, Jacques Sarrasin, I 594-1663, being physician to Louis XIV. Should it be proved that our Michel Sarrasin at Quebec was of the kindred of Philibert Sarrasin, he will be found to have merely maintained the family traditions when he became Médecin du Roi to Louis XV in $1733-4$.

The name Sarrasin is still occasional in France, due originally, it is claimed, to the appellative of one who, as Crusader or otherwise, had returned from Saracen lands.

A sketch of "Sarrasin à Québcc" is recorded as published in French at Quebec, by L'Abbé Bois, in 1856, forming a pamphlet of i 2 pages.

3. Clayton collected Aster Claytoni, his Aster . . cum umbcllula, in mountains of Virginia, along the tributaries of the upper James or Rappahannock, probably in or before 1754. See infra, under A. Claytoni.

4. Manasseh Cutler was searching for A. macrophyllus L., in Essex Co., Mass., in or before 1796 , as is indicated by his MSS., but does not appear to have found it then, his plants proving to belong to A. undulatus. Bigelow and Oakes, a few years later, were more fortunate in that county, obtaining there $A$. macrophyllus and also A. divaricatus. The latter Cutler must have seen also (at Chebacco Pond, for instance, where I find it abundant, and where he mentions obtaining other asters), though I do not find it mentioned among his surviving memoranda.

5. Collections of A. macrophyllus L. and A. divaricatus L. were made soon after I800, by Michaux, Pursh, Rafinesque, Muhlenberg and Barton, the exact localities for which are, however, unrecorded. After this the species became common in botanical collections. Of other early collectors, Elliott and Gibbes in South Carolina, Oakes and Boott in Massachusetts, Shuttleworth in Penn- 
sylvania and Lapham in Wisconsin, were among those whose field work added something to our knowledge of Biotian Asters.

6. There were other collectors early in the nineteenth century who furnished Biotian species from New York, New Jersey and Pennsylvania, to European herbaria, especially to that of Bernhardi and to Günther's Flora Pennsylvanica at Breslau. The most active of these collectors was Eduard Friedrich Pöppig, who collected in Pennsylvania in I824. He was born in I 797 at Playen, in Saxony, made botanical collections in Cuba, in I822; Pennsylvania, I824; Chile and Peru, I826-1832; became Professor of Zoölogy at Leipsic in I833; was author, with Endlicher, of "Nova Genera" of Chilean and Peruvian plants, and died I 868.

Pöppig sailed from Matanzas for Philadelphia on April 24, I824, and then collected plants through Pennsylvania all that summer and fall. At Connellsburg, in southwestern Pennsyl. vania - or "Conelsburgh," as Pöppig calls it - he spent the winter of 1824-5; he was for some time at Baltimore, into the next fall apparently; while in this summer, of 1825 , he sent over his collection of I 2,000 Cuban and North American plant specimens to his friend, Dr. Radius, * of Leipsic.

Pöppig seems to have been the source of the Aster specimens from "Cove Valley, Penn.," which Nees received and cited in I832; including Nees' Aster macrophyllus $\gamma$, founded on a specimen from Cove Valley in Günther's Flora Pennsylvanica. See that plant, infra.

After leaving Baltimore, Pöppig was in 1826 in Valparaiso, there beginning his distinguished career as South American traveller and botanist.

\section{First Cultivation of Biotian Asters}

Aster macrophyllus $\mathrm{L}$. is referred to in cultivation as follows :

I 739, Kew; under name $A$. macrophyllus, fide Philip Miller's Gardener's Dictionary, ed. 3, vol. 2, no. 23, pub. I739; probably introduced into Kew after I 733, when Miller's second edition was published without mentioning it.

I 750 ? Paris; about the middle of this century or later, $A$.

* Justus W. M. Radius, born 1797 in Leipsic, professor there 1825 , physician to the Georgenspital 1832-53; died 1884. - Allyemeine Deutsche Biographie, $26: 422$. 
macroplyyllus was cultivated in the Paris garden as A. Acadiensis, fide Lamarck in 1783 .

I 809, Berlin; Willdenow enumerates Aster macrophyllus as cultivated in the Berlin garden, in his Enum. Hort. Berol. 2: 882 ; probably some white-flowered plants of $A$. Schreberi Nees were mingled with it, as in Willdenow's description of I 804 .

I 8 I 9, Hort. Hafniensis, Copenhagen.

A. macrophyllus pinguifolius seems to have been cultivated under the name $A$. latifolius in the Paris garden, fide specimens, I $814+$, and fide Desfontaine's Catalogue, I 829.

Other allied but uncertain forms were early in the gardens of Paris, Berlin, Erfurt, Erlangen, Breslau, Hamburg and Bonn, and were so mentioned by Nees, I 832 ; including $A$. subcymosus, A. ambiguus, and others.

Aster Schreberi seems to have been cultivated in the Leyden garden between I 762 and I 766 ; at Paris before I 783 ?; at Berlin before I 804; at Erlangen, whence Nees described his type, before I 810 ; at Turin before I82I ; an allied form was the $A$. discolor of the Hamburg garden, as cited by Nees, 1832 .

Aster divaricatus was cultivated near London by Peter Collinson in 1765 ; in Hort. Jenensis before 1792 , by the name of A. divaricatus (fide Nees, Gen. 142); at Berlin before 1809, under name $A$. corymbosus.

See the respective species for details.

\section{European work upon Biotian Asters: Nees}

Nees, in his monograph on the Asters states expressly that he gives more detailed treatment to the species since known as Biotian, because some doubted their validity. This fullness of detail included extended description, attention bestowed on the quickperishing primordial leaves, and care in distinguishing varieties. Consequently the sketch of Biotian history is the appropriate place for some notice of Nees, the great European student of the Asters.

There were two brothers Nees, botanists, natives of Reichenberg near Enbach in the Hessian Odenwald; the younger was the short-lived professor at Bonn, Theodor F. L. Nees von Esenbeck, 1 787-1837, mourned in I 838 "by his friends" in a pamphlet of 40 pages, issued at Breslau, doubtless through the means of his 
brother already located there. Theodor Nees wrote especially on medical plants, was early at the botanical garden of Leyden, and in I 833 on becoming director of that at Bonn, began the publication of his valuable illustrated "Genera" of Germany, which was continued by other hands till i 860 .

The elder brother was the monographer of the Asters, Christian Gottfried Nees von Esenbeck, born 1776, who died at Breslau, I 858 , aged 82 . His productive period was I 8 I4-I84I, writing on a great variety of botanical subjects; beginning with freshwater algae, fungi, mosses and hepatics; with monographs on grasses and Lauraceae besides Asters among higher plants. He was also a writer on entomology and philosophy. Nees was president of the Leopold Academy, professor i 8 I 8 of natural history at Erlangen, I 8 I 9 at Bonn, I 830 at Breslau. His first work on Asters, Synopsis Asterum, * was published during his brief period at Erlangen, I 8 I 8 , and sketched the outlines of the species then known to him and for which he was planning a more extensive treatment. During his eleven years at Bonn, although publishing many other dissimilar works meanwhile, he continued the work on the Asters, and its completion followed closely upon his beginning his career at Breslau, being printed there I 832 under title Genera et species Astcrearum, $\dagger$ an octavo of 323 pages. He continued twenty-two years in his Breslau professorship, when he was removed in 1852 for political reasons, and lived but six years longer; the last we hear of him is his giving certain aster-specimens to Schultz Bipontinus in I 856 , which found their way into the hands of Dr. Asa Gray at Harvard. As to disposition made of Nees' herbarium in which further representatives of his Asters should be sought, Gray made unavailing inquiry. Quite a considerable part afterward appeared in the Herb. Cosson, Paris, and in the Herb. Klatt, an herbarium recently. added to the collections of the Cambridge Botanical Garden, from which numerous asters given by Nees to Schultz Bipontinus had

* Synopsis specierum . . Asterum, a thin quarto of 32 pages (Erlangen, 1818); rare in America; copies are in the libraries of the Gray Herbarium and of Dr. J. H. Barnhart.

† Genera èt species Asterearum, Breslau, Gruson, 18.32 ; reissued, Nuremberg, Schrag, 1833 ; its preface is signed by Nees, Breslau, Jan. 1832 . To the reissue belong the early American copies, that of William Boott, given to Gray, and two of Dr. Torrey; besides others like mine obtained later. 
already been secured by Dr. Gray. Many other specimens from among Nees' asters which went to Schultz have latterly been added to the British Museum collections.

Nees obtained part of his material from his own and other botanical gardens and a part from native pressed specimens sent or submitted to him by friends, especially by Bernhardi, director of the botanical garden at Erfurt (see infra). Among those aiding him were Link and Schlechtendal; Meyer and Besser; Nestler and Mougeot at Strasburg; Chamisso at Berlin; Lehmann at Hamburg; Günther, "medical assessor" in the medical college of Breslau; Kunz at Leipsic; Doellinger at Munich, and Steudel at Esslingen. All of these, together with Beilschmied, whom he styles his "friend," supplied abundant material from their herbaria. Living rootstocks from such as were cultivated in their botanical gardens were also sent by Hooker from Glasgow, Heller from Würzburg, Otto from Berlin, Wiegmann from Brunswick, and Zeyher from Baden.

Nees' Astereae included 33 genera, some of which, as Olearia and Felicia, have received great enlargement since; one, Symply'otrichum, was apparently ill-founded; this and five others were Nees' own creation, including the now well-established genera Sericocarpus, Machaeranthera, and Doellingeria. A few are not now recognized as so closely allied to Aster, as Boltonia, Brachycome, Paquerina. Erigeron was not included by Nees. Nees distinguished his Astereae from the Baccharideae by possession of rays; from Solidagineae by absence of yellow rays; from true Bellideae by absence of scapiferous habit. Nees' Astcreae or Asterinae is in the main the Astcrinae rather than the Astercae of Engler and Prantl, I894, in which Hoffmann's treatment makes 39 genera of Asterinae, of which I 3 were formed later than Nees'. Of Nees' 32 Astereae, 24 survive, under the same name or incorporated in Hoffmann's Asterinae; Hoffmann's additional genera are mainly small or monotypic.

Nees' Astereae included in their 33 genera, some 230 species, of which 127 were American. In his genus Aster were I 27 species, I07 American. Within the limits assigned to Aster by Gray, Nees had I 55 species, of which I 20 were American. 


\section{AMERican wORK UPON Biotian Asters}

Biotian Asters were rather slow to make their appearance in writings about American plants. Their region of principal growth, and the scope of the work accomplished, made it less remarkable that they failed to appear in the work of Thevet, I 558, on French America; or in that of Monardes, I 596, on Spanish America; or in the works of Catesby, I73 I+, and the less extensive ones of Brickell, 1737 , and Walter, I 788 , on the Carolinas.

But it was remarkable that Cornut, 1635 , writing of the plants of Canada, made no mention of them; they would not have been left unmentioned surely, had he himself visited America. That Josselyn, in his New England Rarities, 1672, said nothing of them, does not perhaps indicate that he did not observe them; for he had a keener interest in plants of unfamiliar shape, like the Impatiens, which he took pains to figure. That Cadwallader Colden, in his Plants of New York, 1743-1750, did not mention then, was due to his total failure to complete his catalog, as it extends but through the first i 2 Linnaean classes. Meanwhile plants of $A$. macrophyllus had been noticed and had been sent abroad to France and to England not far from the same time by Sarrasin from Quebec to Vaillant at Paris shortly before 1720 , and by some one in the British colonies to Philip Miller, I733-I739. Aster Claytoni followed early, perhaps in I 754, from Clayton's collections in mountains of Virginia ; and a little earlier, from Collinson or some other source, specimens of $A$. divaricatus reached Linnaeus, to receive their well-known mingling with Doellingeria infirma in his description of 1753 .

With that century's close Manasseh Cutler, who must have been familiar with several Biotian forms abundant in northeastern Massachusetts, seems to have been endeavoring in vain to fit European descriptions to them. Others succeeded little better; as Michaux, who was mingling together the heart-leaved $A$. cordifolius and $A$. divaricatus.

Rafinesque, in 1807 , had begun, he remarks, "to reform" * the Asters, saying that "Solidago, with Erigeron, Inula and Aster, were in utter confusion, the determination of species hardly attain-

* Rafinesque, Flora Telluriana, 2: 41. 1836. 
able " ; but he did not publish till I 836 , "waiting," with unusual reticence, " to see what De Candolle and Torrey will do." * When, in 1836 , he published his long-delayed remarks on Aster and Solidago, he observed (New Flora, 7) that "many species of Aster and Solidago are found chiefly in October, and therefore had escaped the attention of our botanists, who chiefly botanize or travel in the summer." But even this year, in revising the Compositae, Rafinesque states that he is "leaving most of the Asters for further inquiries" ; which explains why this genus is not more complicated by synonyms of his introduction. As it is, he had determined on the separation from Aster (his Asteriscus) of several new genera. One of these was to contain the Biotian Asters; he called it Leiachenis, characterizing it by having smooth achenes and simple pappus. Under this in a subgenus Dodecalis he proposed to class the species with appressed bracts and about I 2 rays ; which was to include the Biotian plants, "A. corymbosus," as he says, etc.; but was also to include such dissimilar species as A. dumosus, and illustrates, the danger of relying on a single character.

At about the same time with Rafinesque's beginnings, or by I 809, Muhlenberg, with his usual careful observation, had collected the plants of southeastern Pennsylvania, and seems to have been the earliest to take notice of $A$. umbelliformis, which the fragments of his herbarium include as one of his unnamed forms of " $A$. corymbosus."

Barton, who in addition to $A$. macrophyllus and $A$. divaricatus, had made known his variety alatus of the latter as early as I 815, seems to have been the first recorded as watching an Aster colony for several years to determine its normal range of variation. It was in that way that he satisfied himself that his variety alatus was genuine.

Slightly later, some new forms appear in American descriptions; $A$. riciniatus may have been what Elliott described as $A$. corymbosus, about I824; . ianthinus that which Bigelow, also I 824, described as $A$. macrophyllus; $A$. orbicularis and securiformis seem to have been collected under the latter name by

* Rafinesque, New Flora, part 4, page $69 . \quad$ I $8{ }_{3} 6$. 
Oakes in the same region; $A$. mirabilis, ${ }^{*}$ since not rediscovered, was collected by Professor L. R. Gibbes in 1835 , near Columbia, S. C.

One of the zealous seekers for the Asters in this period was Wm. Boott, $\dagger$ an acute student of the flora of eastern Massachusetts, who was so fortunate as to secure a copy of Nees' Genera Asterearum, later passing as a part of Boott's botanical library, to the library of the Gray Herbarium. As the result of these studies, plants still exist in the Torrey herbarium, which had been referred by Dr. Torrey to Mr. Boott for identification, and bear the names given by him, 1836 or later, after receiving De Candolle's modification of Nees' Asters ; including his Biotia macrophylla and his Biotia Schreberi, which seem to be the plants Nees intended; and his Biotia glomerata, which was a less successful venture, the specimen being a young and therefore subsessile plant of $A$. macroplyyllus, which would not have remained glomerate at maturity, and which presented longer and differently-shaped leaves from those Nees' description called for.

Later than the effort of Wm. Boott no other serious attempt to identify all the European descriptions of Biotian Asters is known to me, prior to my undertaking it at Washington in 1886.

The interval was broken by the active collecting by Shuttleworth in Pennsylvania; and by the discovery by E. W. Hervey in Massachusetts of the species named for him by Gray.

Perhaps many other Biotian forms would have been recorded during the half century, I 836-1886, had it not been for the extraordinary dictum of Torrey and Gray's Flora, in 1843 , that " there are certainly but two species of Biotia indigenous to the United States." Although giving in most respects an excellent descrip-

* On the doubtful line between the Biotian and Spectabilis groups.

†William Boott, 1805-1888; born in Boston, lived later in Medford, Mass.; studied at Exeter Academy and at Harvard; studied medicine at Dublin and Paris; soon returning to America, turned to botany, doing special work on Isoetes, the Grasses, and certain tribes of the Cyperaceæ. His only written work was "a short Caricological paper"' written in assistance of his brother.-Asa Gray in Am. Jour. Sci. III. $35: 262$. Wm. Boott was youngest brother of the well-known specialist on Carex,

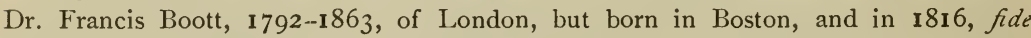
Tuckerman, an explorer of Mt. Washington and its flora, the southeastern arm of that mountain, Boott's Spur, bearing his name. Their cousin, Francis Boott the composer, of Cambridge, Mass., continued the family name in America till his death, 1904, at the advanced age of $9 \mathbf{1} .-D r . B$. L. Robinson. 
tion of $A$. macrophyllus and $A$. divaricatus, the Flora of i 843 had added to the difficulty of disentangling $A$. macrophyllus by emphasizing white as its prevailing color. Willdenow, who first distinguished the "blue" and "white" elements in the Linnaean $A$. macrophyllus, made the blue (i. e., pale violet) his leading form. But Torrey and Gray's color phrase "white or purplish," gave the white forms (A. Schreberi, curvescens, etc.) the precedence, and it might be inferred that the species would ordinarily produce white rays. Torrey's Flora of N. Y. said of it expressly " rays white, sometimes pale blue"; and white flowers continued to be the first color-character for $A$. macrophyllus, including the Synoptical Flora, I 884, and the description of $A$. macrophyllus to accompany an illustration in Garden and Forest, ${ }^{*}$ in I 891 . This tendency to esteem the rays white was increased by the necessity under which so many labored, of working from herbarium material, in which condition much of the blue or lavender has left the flowers. As a result, white-flowered plants came so far to monopolize the $A$. macroplyylius of American botanists that presently the occurrence of a purplish or violet $A$. macrophyllus form occasioned much surprise and an attempt to bestow it under $A$. Herveyi.

Keen observers, however, had begun to query if $A$. macrophyllus had not been made to include too much. Dr. Vasey and Prof. L. F. Ward had noted the unlikeness of the white-flowered forms ( $A$. curvescens, etc.) ascribed to it about Washington. To Dr. Vasey I brought Washington plants of $A$. curvescens, as a peculiar glomerate-flowered macrophyllus form in I887. I found that he had himself distinguished this form mentally for years, because of its smaller heads and different bracts from the northern macrophyllus. But the latter to him was still a whiteflowered plant.

Observations next appeared in the Hudson River region, Mr. E. P. Bicknell collecting variants about New York City (A. Schreberi chiefly) and Professor C. H. Peck about Albany, etc. ( $A$. Schreberi and $A$. glomeratus), both remarking their "intermediate position " toward " $A$. corymbosus."

On the other hand, the latter observers noted another opposite tendency in their collections toward the highly glandular and

* Gard. \& For. $4: 88,89 . \quad$ I 89 I. 
deeply violet $A$. Horveyi. A series of such specimens from the Adirondack region was actually separated and published as a variety intermedia under $A$. Herveyi by Professor Peck in 1893, but was soon remanded by him to $A$. macrophyllus, where I think they belong.

At last, after multitudinous comparisons, I established the general law for Biotian Asters, that when a blue element (producing violet, which often speedily changes to white) is present in the rays, it is accompanied by glandular surfaces. It was only on full recognition of this law that separation and classification of the tangle of macrophyllus forms became possible. Glands had been observed in certain of the species in German gardens by Nees before I 832 , and perhaps earlier by Bernhardi in his $A$. glutinosus; but without reaching the perception of their absence from the whole white-flowered complex of species formerly assigned to $A$. macrophyllus. 


\section{SYSTEMATIC DESCRIPTION OF ASTERS}





\section{INTRODUCTORY EXPLANATIONS}

\section{FigURES}

A number of plants are illustrated by full-page plates (thirteen in number, showing fourteen species or varieties, from drawings by Mrs. C. D. Henline), exhibiting the whole plant reduced, with separate representation of a single head, series of bracts, a diskflower and a rayflower.

Most species are illustrated by smaller figures, 92 in number, representing drawings from the specimens, by Miss Evelyn G. Flynn, and Miss Else H. Seringhaus, and by the author. These figures are intended to indicate characteristic leaf-form and bract; also characteristic habit. No adequate representation of the rays is attempted; and in certain species they have been wholly omitted. The rays would require drawing in the field to bring out their slight but interesting differences satisfactorily; and the rays are of little importance in distinguishing species in the herbarium. The uniform lettering adopted for these figures includes :

(a) Whole plant or large portion of it, to show habit.

(b) Characteristic leaf-form ; with comparative reduction added, as $\frac{1}{1}$ if represented natural size, or $\frac{1}{2}, \frac{2}{3}$, etc. Usually the position of this leaf on the stem may be seen from figure $a$.

(c) Characteristic bract; usually not a lowermost nor an innermost bract.

Any other letters occurring are explained with the particular species.

\section{Terminology}

Genus. An assemblage of somewhat closely-related species; but itself of somewhat varying degrees of difference from other similar groups or genera.

Subgenus. Not used.

Section. A less definite subdivision of a genus, informal and permitting English name; used to express a certain degree of natural affinity, or to combine miscellaneous species for convenience.

Species. A group of individuals indicating their common 
ancestry by continued development, while remaining in similar environment, of a body of characteristics which show a considerable difference from their nearest allies. A distinct group which continues its kind; either observed not to revert quickly to a diverse parent form, or sustaining such a comparison with other better known species as to make non-reversion probable.

Subspecies. More easily or frequently passing back into its parent form than does the species.

Variety. Not used; better referred to horticultural use.

Form. Indefinite group-term not predicating rank; and thus applicable to species, subspecies or subordinate form.

State. Useful occasionally when speaking of less separable groups which seem so plastic as to be of doubtful permanence, their characters seeming assignable to the immediate environment. Can be used of a slight variation without implying that it is not to be classed under the typical form.

Condition. Useful occasionally in speaking of a temporary stage of growth or activity during part of an individual life-history as "a prostrated or an impoverished or a floriferous condition of an axilliferous state of Aster divaricatus."

\section{Limitation of other Terms}

Pedicels, the ultimate branchlets, each supporting a single head of flowers.

Bractlets, leaves on pedicels, whether minute or not.

Bracteals, any leaves closely investing or subtending the inflorescence or a part of it, whether they are homologous with bractlets, rameals or axiles.

Bracts, the involucral bracts or scales.

Tips, the dark portion of the bracts just within the apex, usually thickened with green cellular tissue.

Apices, the apices of the bracts. Chanfer or bevel-tip bracts, those with apex cut off at the sides, $i . e_{\text {, }}$ terminated by a broad low triangle.

Bases, the bases of the leaves.

Wings, the wing-like dilation of certain petioles.

Primordials, early-developed and soon-perishing little leaves on radical shoots, preceding the genuine radicals and usually succeeding a few transient phyllodes. 
Radicals, leaves on radical shoots or tufted about the base of the stem.

Caulines, stem-leaves.

Axilcs, leaves at the base or axil of primary branches.

Rameals, leaves on primary branches.

Leaves, as in ordinary language; the blade or lamina as distinguished from the petiole.

\section{Terms Used For Leaf-Margins}

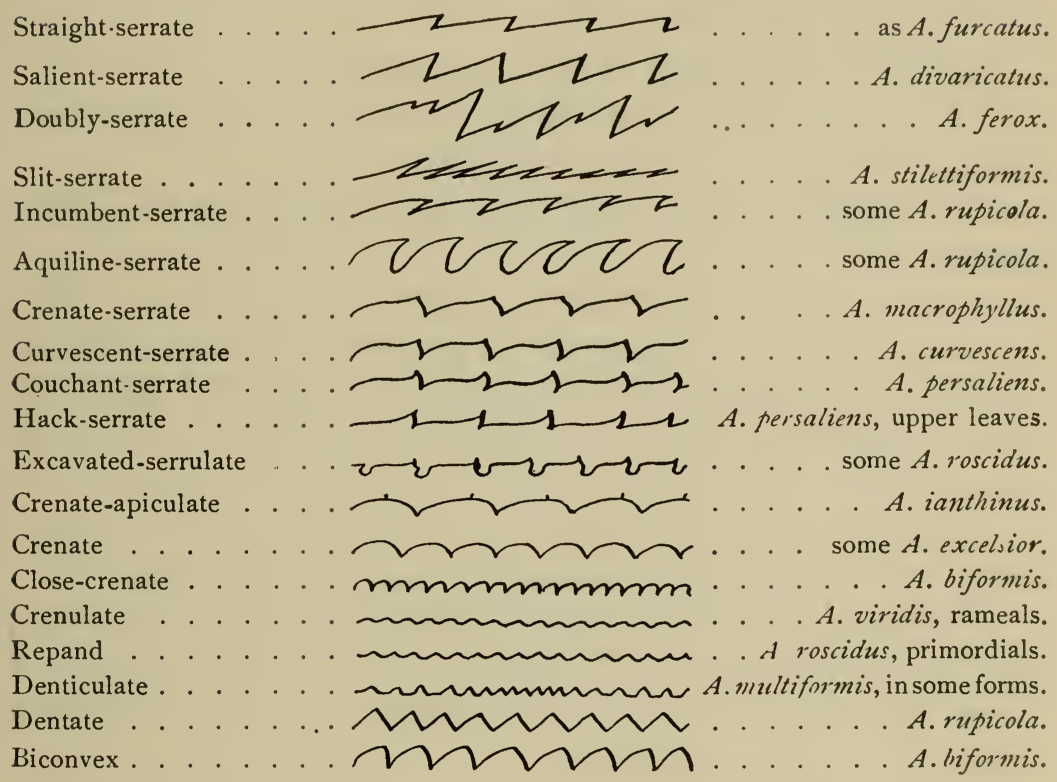

Crispicant, with teeth alternately or irregularly directed upward and downward, or with one tooth horizontal and the next tilted up; as in many thistles ; and in A. Claytoni crispicans and in occasional specimens of many species.

Strap wings, the dilation of uniform breadth.

Undulatiform wings, the dilation greatly enlarged below, as in $A$. undulatus, and narrowing toward the leaf-base.

Cuneate wings, somewhat straight-sided, widening toward the leaf-base. 
Abbreviations Used in Locating Plants.

N. Y. vic., for localities near or within New York City.

$W . N . Y$., Western New York; as, near Lake Erie.

N. $Y$., elsewhere in New York state.

$D$. C., implies occurrence in adjoining parts of $\mathrm{Md}$. and Va., as well as in the District of Columbia.

M. V., Marthas Vineyard, Mass.

L. I., Long Island, N. Y.

S. I., Staten Island, N. Y.

Hort. $=$ Hortus ; so used of European botanical gardens.

hb. = herbarium.

hb. Colu. = herbarium of Columbia University.

$B u .=$ collected by E. S. Burgess and represented in his herbarium.

$B i .=$ collected by E. P. Bicknell and represented in his herbarium.

\section{COLOR-TERMS AS HERE USED}

Lilac. - Like lilac-blossoms; a pale reddish purple; such as produced by color-disks $\frac{1}{2}$ ultramarine, $\frac{1}{6}$ vermillion, $\frac{1}{3}$ white; as in $A$. macrophyllus often, and with more red, and more luminosity, in $A$. concolor.

Lavender. - The preceding but still paler, the vermillion reduced to $\frac{1}{16}$ by replacing with white; as in $A$. violaris rays.

Violet. - A blue that is placed under increased illumination; or with a trace of red; as the bluest petals of Viola cucullata; as $V$.odorata; as $A$. iostemma, $A$. ianthinus and young $A$. multiformis.

Blue $=$ Some $A$. cordifolius.

Purple. - Between violet and crimson; the red being $\frac{1}{3}, \frac{1}{2}$ or even $\frac{2}{3}$; as $A$. Novae-Angliae.

\section{Other AbBreviations}

Special words and special phrases which must recur constantly in treating of Asters are sometimes abbreviated as a gain in space and in clearness of effect; as the following will indicate:

early = early flowering.

flrs. $=$ flowers.

lvs. = leaves.

infl. $=$ inflorescence.

ben. = beneath. 
res. $=$ resemble.

hds. $=$ heads.

obvious, used of hair, etc., when readily seen to be present without magnifying.

Comparative degree refers to preceding statement of the same rank, whether description or conspectus-heading, without continued repetition of the correlative.

Phrases such as "continuously," or "persistently petioled." Here, where the adverb is not liable to mistaken application to time, I use it to indicate that the tendency to develop a petiole is not only characteristic of the base of the stem (as in most species), but continues above, the production of petioles persisting well up to the top of the main stem (as in few).

$A u$. Se. Oc., used for the chief months of Aster-flowering, instead of the longer abbreviations, because constantly recurring.

Dimensions stated as " $5 \times 3$ " " are to be read "Leaves reaching 5 inches long by 3 broad" ; and "stems $2^{\circ}$ " $=2 \mathrm{ft}$. high.

Measurement equivalences : approximately,

$$
\begin{aligned}
& \text { I metre }=39.37 \text { inches }=3 \text { feet } 3.37 \text { inches. } \\
& \text { I decimetre }=3.94 \text { inches. } \\
& \text { I centimetre }=\frac{2}{5} \text { inch }=43 / 4 \text { lines. } \\
& \text { I millimetre }=\frac{1}{25} \text { inch }=1 / 2 \text { line. }
\end{aligned}
$$

$$
\begin{aligned}
& \text { I inch }=25 \text { millimetres }=2 \mathrm{I} / 2 \text { centimetres. } \\
& \text { I oot }=30 \text { centimetres }=3 \text { decimetres. }
\end{aligned}
$$




\section{CONSPECTUS}

OF THE HYPOTHE'TICAL, DESCENT OF GROUPS OF BIOTIAN ASTERS

Antecedent undifferentiated mass of ancestor Subsections $\mid$ Groups, and number of species

Divaricate A Aters - 1-16

DIVARICATI

Canmesine A $17-25$

Species $1-39 \therefore$ Tenebrosian $A_{\text {26-29 }}$

Claytonian $A$ 30-37

Funcate $A \therefore$ - 38-39

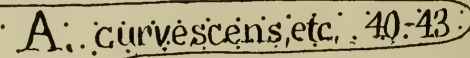

CuRVESCENTES

A: glomeratus etci $44: 47$.

$40 \div 54$

Schreberan A: $48 \div 54$

Lavender Macrophylli $55-65$

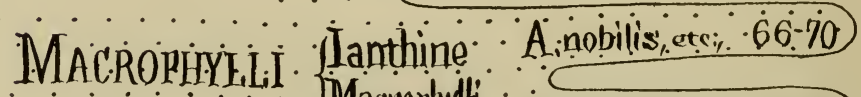
$55 \div 84$

A:multiformis, its: $71-79$

A. Herveỹi etce 80-83.

Aimirabilis . 84 


\section{ANALYTIC KEY * TO THE BIOTIAN ASTERS}

\section{Genus Aster}

\section{Section i, BIOTIAN ASTERS}

Broad cordate leaves present $\dagger$; upper cauline if cordate are petioled (not clasping as in A. undulatus and other Diversifolial Asters); dilated petiole-bases occasional only, and then not conspicuously clasping (unlike $A$. undulatus); coriaceous bracts present $\ddagger$; radical leaves more strongly developed than in other Asters; phases of life-history more strongly accentuated than in other Asters; variability at its height.

Inclucles the non-fruticose portion of the genus Eurybia of Cassini, I8 8 , and of Nees, I 832, which portion became the Biotia of De Candolle, i 836 .

SubSeCtions IMIVARICATI AND CURVESCENTES. White rays; noglands; involucre not large, usually $\frac{1}{4}$ in. high or less; rays usually under 12, chiefly bidentate; thin soft smooth leaves prevalent; rootstocks chiefly rather slender; low plants, in shade.

DIVARICATI. Radicals few and inconspicuous, seldom produced; involucre broadly cylindrical ; ramification somewhat furcate (subpinnate in $30,31,32$ ); flower-buds ovoid; chief bracts apt to remain broad to or toward the apex. Sp. $1-39$.

CURVESCENTES. Radicals usual, numerous and large; involucre narrowly cylindrical; flower-buds cylindrical ; chief bracts apt to be narrow ; leaves often large and thickish. Sp. 40-54.

Subsection MACROPHYLLI. Violet rays, and glands, present. Sp. 55-84.

\section{DIVARICATI}

DIVISION A. DIVARICATE ASTERS proper. Thin smoothish prolonged membranous leaves, in polymorphous series on the stem. Disks turning dull reddish-brown or full-brown. Teeth sharp, salient. Bracts subtruncate or chanfer-obtuse. Stem chiefly green.

* Compare, also, the single-line key placed for reference-use at end of volume.

† There are species in which cordation, however, is rare and slight, as in $A$. aucuparius, $A$. Herveyi, and $A$. commixtus; it is perhaps still more so in $A$. mirabilis. Most of the other species will occasionally produce a non-cordate shoot.

$\ddagger$ Like the other broad-leaved asters; which have usually narrower bracts, however. 
Subdivision A. STEM assurgent, repeatedly flexuous, brittle.

a. Chief leaves prolonged ovate-lanceolate, incurved-acuminate.

I. A DIVARICATUS : coarse teeth; moderately broad and deep sinus; pedicels and petioles slender, divergent or divaricate ; rays 6-9; outermost bracts truncate, middle ones chanfer-obtuse ( $i$.e., bevel-tipped), inner ones rounded, all very ciliate.

I $^{1-1}$. A. DIVARICATUS variants (of doubtful stability, and not recognized here by Latin

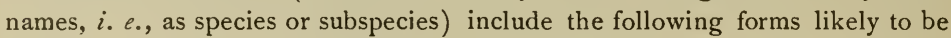
sought in this key. For other less-marked forms, in this and other species, see descriptions.

Tuherous form : stem bases conspicuously thickened.

Mitchellian form: conspicuous small rameals, oval-obtuse and subentire; like leaves of Mitchella repens.

Tobyhanna form : strict stems and branches.

Flabellate form : deeply branched.

Green-disk form : disk pale-yellow turning greenish.

Circaean form : dwarf communities, few-flowered, Circaea-like.

b. Leaves highly diverse, much shorter (except the last two forms).

Mixed-leaf form : some upper cauline leaves half-size and paraboloid.

Obolarian form : some upper cauline leaves quarter-size and subcircular.

Russet-tuft forms : shorter ovate leaves, dull-green, turning russet.

Cupreous form : dull ovate leaves; much ciliation; rays turn copper-red.

Prune-stem form : taper-lanceolate leaves; stem prune-color.

Stellarian form : dark oblong-lanceolate leaves; disk very pale; flower-heads star-like.

Ib. A. DIVARICATUS ALATUS : large sirongly-cut leares; ivinged petioles; broad slight sinus; bracts paler; only the outer ones obtuse.

Ic. A. DIVAR. CYMUlosus : smaller incurved-acuminate leaves; crowded heads; short rays; small, sharp teeth.

Id. A. DIVAR. CURTIFolius : small rounded leaves, obtuse or acute; close sharp little teeth.

Ie. A. DIVAR. DELTOIDEUS: small triangular-ovate leaves, acute; small remotish teeth.

If. A. DIVAR. Fontinalis : tufts of large thin radicals, oval-acute, chiefly; bracts blunt-tapered.

2. A. VIRIDIS : inflorescence as of $A$. divar.; but heavy thick radicals as of $A$. macrophyllus; large oval-rhomboid rameals.

3. A. ARENICOLA: leaves oblon; ovate, acuminate, pale, small, low-serrulate; sinus rather narrow ; disk reddish-brown; bracts pale, narrow-oblong; rays about $\mathbf{I I}$.

c. Leaves prolonged, and attenuate, but unlike $A$. divaricatus.

* Bracts obtuse or chanfer, linear; teeth very sharp, outflung; sinus broad; rays dingy-white. Virgate.

4. A. PERSAliens; leaves chiefly lanceolate, tuper-bused; many remote couchant teeth; some heads with acute bracts.

$4^{6}$. Rounded-base form : most leaves broad-based : teeth less pronounced.

$4^{7}$. Jagged-leaf for $\mathrm{m}$ : most leaves truncale-based; teeth stronger, crowded.

5. A. ATROVIRENS: dark; leaves triangular-acuminate; long close slender teeth; many leaves with deep broad sinus; heads small, close, leafy-subtended. 
6. A. ERECTUS : leaves ovate or lanceolate, incurved-acuminate; many couchant teeth; sinus broad, shallow; bracts narrow ; rays thickish, remaining a long time suberect; heads rather large, close.

7. A. FIMBRIATUS : leaves longer; large couchant teeth; broad-brace sinus; broader bracts; many slit rays.

** Bracts truncate and rounded, broadly scarious-edged; teeth small, sharp.

8. A. FRAGRANS : leaves lanceolate from a broad base, very thin; sinus shallow; heads loosely massed, delicately fragrant; pedicels long; bract-margins white or pinkish.

9. A. EXCAVAtus: leaves oblong-lanceolate; sinus narroze, deep and enlarged within; most bracts thin and pale.

*** Bracts more uniform, with dark broad rounded tips; teeth few or shallow on the upper leaves.

IO. A. SUbINTEger : dark and slender; leaves lance-triangular; heads few, divergent.

**** Bracts triangular-acutish ; teeth of slit-serrate type.

II. A. SEXTILIS : low, early; leaves oblong-lanceolate, closely slit-serrate, often caudate; sinus slight; heads small.

Subdivision B. STEM weak or decumbent.

12. A. S'TILETTIFORMIS : leaves long, narrow, linear-oblong, straight-acuminate; close straight-backed teeth; but little sinus or petiole; lingual bracts.

123. Dentifolial form : leaves delicate, more oblong and cuneate-based.

1 24. Jag-edge form : ieaves heavier; teeth irregular, some of them reflexed.

13. A. Parthianus : leaves ovate-lanceolate, incurve-acuminate, serrulate; many deflexed; little sinus; short narrow petioles; bracts narrow, many obtuse.

14. A. CAMPTILIs : leaves oblong-acuminate, serratc; winged petioles common; bracts uniform, subacute; inflorescence flattish.

15. A. BovKINII : leaves oblong-or ovate-acuminate, strongly serrate; narrow petioles common; bracts multiform; inflorescence lax and axillary.

I6. A. FLEXILIS : leaves ovate-acute, subcrenate; short narrow petioles common; sinus narrow ; bracts uniform, narrow, obtuse.

Division B. CARMESINE ASTERS. Thinnish firmer leaves of shorter types.

Disks turning soon to a more definite red or finally to a deep crimson.

Stem erect, stiff, or wandlike.

SUbDIVISION A. LOWER BRACTS acutish.

17. A. ARCIFOLIUS : wide-branching; leaves short-ovate, acutish; with brace-base sinus, very open and shallow.

18. A. CAPILLARIS : high-branching; leaves ovate- or oval-acute; sinus moderate; pedicels long and capillary; rays long; erect upon rocky slopes.

SUBDIVISION B. CHIEF BRACTS obtuse or chanfer, diverse.

19. A. VIRGULARIS : little wands; leaves ovate-acuminate to oblong-acuminate; sinus sharp; close sharp outflung teeth.

192. Tangle-tuft form : teeth coarser, fewer; long entangled pedicels.

193. Linear-oblong form: teeth slight, remote; many upper leaves deflexed, narrow oblong.

194. Crimson-tassel form: leaves verging toward $A$. divaricatus; rays short; disks high, deep crimson.

195. Turbine-wheel form : leaves triangular-lanceolate; rays twisted near the base.

20. A. RUPICOLA : leaves small, firm, rough when dry, broadly ovate-acuminate, spiketoothed; sinus large, broad; veins prominent, upcurved. 
204. Angulate form : leaves irregularly abruptly angulate.

20'. Pluriden'a'e form : subcircular part of the leaves increased; buzz-saze teeth; larger heads.

206. Rock-dwarf form : leaves more ovate, thickened, serrate.

2I. A. CIRCULARIS : leaves smaller, firm, and with a broad sinus, but more circularacute, the close-teeth curve-backed; veins obscure, more outcurved.

Subdivision C. BRACTS lingual, rounded at tip, nearly all alike in shape, nearly all-over green.

22. A. ARGILlaRIUS : leaves very small, ovate-acute, with but little sinus, and with two or more short teeth, all petioled, firm, rough when dry ; plants almost dwarf; inflorescence obconical.

224. Pale-disk form : leaves more cordated, more acuminate; teeth often obsolescent.

225. Linnaea-leaved form : leaves very small, thickish, roundish, crenate.

226. Pinnated form: leafy pinnately-corymbose inflorescence.

227. Rock-seam form: leaves darker, thinner, larger.

23. A. AUCUPARIUS: leaves oval-acuminate, with rounded or subtapering base, all petioled or upper with cuneate sessile base; a few lower leaves with a slight sharp sinus; inflorescence convex. Virgate.

232. Truncate-base form: leaves shuttle-shaped.

24. A. LISTRIFORMIS : leaves oval-obtuse, crenate, spade-like, cuneate-winged; axiles larger, prolonged, ovate-triangular, acuminate ; branches long or whiplike, lax and foliose.

24. Helioscopian form : bracteals suborbicular, in threes.

$24^{3}$. Refracted form : bracteals chiefly ovate-triangular.

24. Virescent form: bracteals limp, oval, enlarged.

$24^{5}$. Trowel-leaf form : leaves chiefly ovate-triangular.

$24^{6}$. Round-leaf form : many lower leaves roundish, enlarged.

$24^{7}$. Little-spade form : many small subentire listriform leaves.

24. Shuttle form : most leaves shuttle-shaped, obtuse.

25. A. CARMESINUS: leaves oval-acute, crenate-serrate, crisp, all with short slender petioles; sinus deep, narrow; inflorescence shallow, widely divergent, segregated.

25. Parchment-leaf form : leaves firmer, granular-roughened.

$25^{7}$. Syncopated form : heads subsessile, in leafy-subtended clusters.

25. Green-awl form : rays crowded, open-filiform, erect, virescent.

Division C. TENEBROSIAN ASTERS. Thinnest smoothest leaves. Disks with less red or none.

SUBDIVISION A. BRACTS obtuse, very narrow.

26. A. Castaneus: leaves ovate-lanceolate, slit-serrate, dark, dull, roughish when dry, zuithout sinus, a few smaller lower leaves ovate-acute with small sinus; disk soon dull yellowish-brown then sienna or chestnut-colored; inflorescence of deeply separated loose convex cymules; bracts linear, truncate-obtuse; rays linear, about 8-10.

27. A. OLIVACEUS: leaves ovate-acuminate, coarse-serrate, with strong broad sinus, smooth when dry, pale-green; disks greenish, then brown; cymules deeply separated, compact; inner bracts many, scarious and very taper: rays narrowly linear, about 7-9.

SUBDIVISION B. BRACTS acute, very broad-triangular; the inner oblong, obtusish.

28. A. TENEBRosus : leaves oblong-ovate, incurved-acuminate, large, coarsely acumi- 
nately serrate; sinus very large and broad; axiles long, lanceolate, subentire; inflorescence proliferously overtopped; rays long, narrow, usually 10-1 2.

SubDivision C. BRACTS rounded, short and broad, scale-like, all alike.

29. A. CHLOROLEPIS: leaves large, resembling $A$. tenebrosus, but with sharp, deep sinus; rays long; bracts with little hair; bracteals moderately serrate; disk verging to deep red.

Division D. CLAYTONIAN ASTERS. Thickened firmer leaves, roughish when dry, chiefly ovate-acuminate in type, not large, nor very narrow, nor very long; petioles short, not rapidly lengthened below. Disks high, very fragrant of bee-bread, golden-yellow, soon becoming a warm rich brown. Petioles short, not rapidly lengthened below.

SUBDIVISION A. BRACTS narrow, oblong; leaves chiefly smooth in life; veins cord-like beneath, pale.

30. A. Claytoni : leaves ovate-incurved, short-acuminate, coarse-serrate, with broad strong sinus; axiles sessile-truncate, triangular-acute; bracts green ; the lowermost acutish, the rest nearly alike, tapered slightly to an obtusish apex; rays short, chiefly 8 ; disks turning sienna; inforescence with strong central stem, not quickly deliquescent, as in typical $A$. divaricatus, when pressed pinnate, with lons-stalked, convex, umbellulate cymules.

$30^{7}$. Branchy-base form : widely branched from the base; heads large.

308. Brush-top form : profusely upwardly branched above; heads small.

$30^{9}$. Bright-eye form : small dissolved inflorescence; disk glowing.

$30^{10}$. Brown-top form : bushy-branched; chief leaves taper-based, brownish, oblong or spatulate; heads many, small.

3011. Catskill form : cinereous, high-cordate, dense-topped.

3012. Cliff-clinging form : clusters dense, remote, making an ovoid-oblong outline.

$3^{14}$. Flagelliform form : heads subsessile and dense on long swaying branches.

$30^{15}$. Rock-cleft form : very dark green; leaf-bases broad.

$30^{17}$. Verticillate form : much-branched inflorescence, with many nodes bearing 2 or even 3 leaves.

3ob. A. Claytoni cristicans: leaves ovate-incurved, caudate; teeth close, smaller, acuminate, crispicant (alternately elevated and depressed); axiles subpetiolate ; more of the bracts acutish.

Subdivision B. BRACTS lingual (except 34); leaves thicker, rougher; or subsucculent $(32,33)$; veins cord-like; involucre very small and narrow ; plants less massed in loose groups.

31. A. EbENEUS: leaves oblong-acute to ovate-obtuse, thicker, rougher, crenate-serrate, dark-green; stem deep-red or black if in the sun; heads small, profuse; branches very numerous, rather short ; sinus a broad brace, or in lowest leaves narrow; disks soon brown.

32. A. MOLLESCENS : leaves ozate, subsucculent, little serrate, pale-green; stem pale; heads small and crowded, from many axiles; sinus shallow ; disks pale-yellow, finally pale-brown; bracts narrow-lingual.

32 $2^{3}$. Reniform form : many upper leaves broad-reniform.

33. A. ARDENS: leaves triangular-ovate, acuminate, sharp-dentate; stem red, smooth, shining, rigid and brittle, paniculately decompound; bracts pale, broad-lingual, uniform; disks yellow, becoming a glowing reddish.brown or soon crimson, quickly fading brown.

$33^{2}$. Broad-bush form : luxuriant, flaccid; rough when dry. 


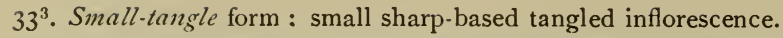

34. A. SCUTIFORMIS : lower leaves scutiform (somewhat cordate-acuminate, with very shallow, broad, tricurve sinus), serrate; upper leaves oblong-lanceolate, shortpetioled or wing-based; stem reddish-brown; veins strongly cornaceous ; bracts chanfer and attenuate; disks dull reddish-brown.

34ㄹ. Sessilifolial form : leaves thicker, denser, whiter beneath.

SubDivision C. BRACTS broad : leaves of dense, firm texture : plants in stools.

35. A. ARCUATUS: leaves broad and short, low-serrate, deep-green and rough, with broad deep subtruncate sinus; stem brittle, decurved from radiating tufts; bracts rounded or truncate; disks chiefly maroon.

36. A. SOCIABILIS: leaves ovate-acuminate, close salient-ser-rate, short-petioled, with deep strong sinus; stems erect, close-cespitose, chiefly green; bracts broad; disks soon brown.

37. A. Ulmarius: leaves oblong-ovate, crenate-serrate, dark-green and dull, with narrow sinus; stems erect, close-cespitose ; bracts broad; disks soon purplishbrown.

Division E. FURCATE ASTERS. Bracts acute or acutish, large, flattish. Snall scattered plants about $\mathbf{I} \mathrm{ft}$. high.

38. A. FURCATUS: leaves ovate-triangular, straight-acuminate, the upper ellipticoblong and sessile; a few basal are ovate with small deep sinus ; all hispidulous both sides when dry ; teeth long, straight, forward-directed; bracts triangularelongate; heads large and few, remote, on stout prolonged forking pedicels, turbinate; disks purplish-brown.

39. A. LEPTOCAULIS : leaves oblong-acute or ovate-lanceolate, little roughened, densepubescent beneath; bracts verging to the obtuse; stem green, smooth and shining.

\section{CURVESCENTES}

Radicals usual, numerous and large, forming conspicuous colonies; involucre narrowly cylindrical or terete, and the flower-buds cylindrical; rays white, sometimes turning rose-color but not violet; disks turning brown or sienna, not crimson; pedicels not tomentulous all over as in $A$. divaricatus and kindred, but bearing its pubescence in lines; no glandular hair present; inflorescence subpinnately ramified rather than furcate.

DIVISION A. CURVESCENT ASTERS proper. Bracts chiefly scarious and pale, very narrow and attenuate, tapering-obtuse. Leaves large, thin. Rays narrow.

SUBDIVISION A. INNER BRACTS very thin, without obvious midrib, color, or hair.

40. A. CURVESCENS : leaves orbicular-cordate, curvescent-serrate; inflorescence small, convex-topped, domed when pressed, its pedicels radiating outward and upward; rays 8 , very narrow, long-linear.

SUBDIVISION B. INNER BRACTS with obvious midrib.

4I. A. OVIFORMIS : leaves oviform or oval-acute with sharp sinus, close-crenate, large but excessively thin; inflorescence more irregular, flattish-topped ; rays linearoblong; bracts broader, obtuse.

42. A. VITTATUS: leaves ovate-acuminate, closely acuminate-serrate, the lowest with broad shallow sinus ; inflorescence a loose dome ; most bracts very long-attenuate, obtuse, with green medial band and whitish edges, 
43. A. UMBELLIFORMIS : leaves orbiculiv-ovate with deep sinus, crenate-servatc, smooth, becoming thickened in the fall and the lowest ones roughish when dry ; inflorescence decompound, each branch subumbellate; lower and middle bracts with green tips, the lowest subcoriaceous.

Division B. GLOMERATE AND SCHREBERAN ASTERS. Bracts highly coriaceous, chiefly pale and obtuse, with green tip and midrib.

Subdivision A. GLOMERATE ASTERS. Inflorescence rather dense, quite regular, not very large; radical colonies not very conspicuous.

* Bracts glabrate, but little ciliate, acutish or attenuate-obtuse; teeth close, sharp, outflung; leaves almost glabrate.

44. A. EXACUTUS: lonver large leaves few, acuminately-serrate, triangular or with rounded base; other leaves numerous, long, sessile, serrulate, elliptic-oblong; heads snıall, 1/4 inch high; inflorescence-branches slenderly fastigiate.

45. A. ERIENSIS : leaves oval-acute, very firm, slit-scrrate; axiles conspicuous; rays longer than in the next, often reddening; inflorescence convex, close; lower bracts acutish.

** Bracts ciliate; teeth of crenate-serrate type; heads in a domed mass, compact; texture coarse and heavy.

46. A. GLOMERATUS : leaves orbicular-acute, firm, rough, closely crenate-serrate, with broad deep sinus, pilose beneath; rays short; heads short, often subsessile; bracts obtuse; low plants, branching at a wide angle.

*** Bracts ciliate; teeth of crenate-serrate type; heads pressing into a high-convex or cylindric mass; texture coarse and thin.

47. A. Julianus: leaves ovate-acute, crenate-serrate, with broad deep sinus and scanty hair, drying smooth or roughish; bracts obtuse, the inner narrow ; tall plants, branching at an acute angle.

SUbDivison B. SCHREBERAN ASTERS. Inflorescence looser, more irregular; rather flattish-topped; texture firm; radical colonies usually very conspicuous; plants larger.

* Radical leaves large, in extensive colonies, thin, very broadly cordate.

$\dagger$ Narrow petioles (of radicals) long, ciliate; middle petioles winged; upper caulines broadly sessile; radical leaves ovate-orbicular, extremely large and thin, crenate, apple-green.

48. A. Limicola : cauline leaves chiefly ovate, middle ones without sinus, with zuinged petioles; heads small, $1 / 4$ in. high; inflorescence-branches short, spreading.

482. Lilacifolial form : leaves small, dark, broadly ovate-deltoid.

$\dagger \uparrow$ Narrow petioles continuous up nearly or quite to the branches.

|| Radical leaves reniform, or deltoid-orbicular, large, thick, roughish.

49. A. SCHREBeri : most cauline leaves broadest near the base, curvescent-serrate; bracts thick, obtuse; heads large, about $1 / 2$ in. high.

492. All-reniform form : all leaves broadly reniform.

||| Radical leaves oblong-cordate, moderately large ; stem tall, robust.

50. A. RECTIFOLIUS : most lower cauline leaves somewhat straight-sided, crenate, acute, with deep broad sinus; axiles winged; leaves thicker; heads smaller, about $\frac{6}{16}$ in. high; rays about 10 ; bracts oblong-acutish, pale and rigid.

51. A. AMnicolaA: leaves oblong-acute, slant-sided, somewhat triangular-elongate and falcate, curvescent-toothed, with narrow sinus, soft and thinnish, webby be. neath; rays about 14 , very long, often olivaceous; heads about $\frac{5}{16} \mathrm{in}$. high ; bracts acute, the inner attenuate and scarious, much as in $A$.curvescens. 
** Radical leaves ovate-cordate, smaller, thin but firm, dark-green.

52. A. SYLVICOLA : leaves small, cordate with square sinus, acute, very dark, firmer and subentire, villous beneath; stem slender; rays about 10, short; bracts shallow-chanfer.

53. A. AmbiguUS : leaves small, broad-cordate with broad and rather shallow sinus, light-green, glabrous or nearly so; bracts shallow-chanfer or acutish; lateral buds late-developed; heads $\frac{4}{16}$ in. high.

54. A. subcymosus : leaves broader in the middle, very firm and thin and smooth, with sharp curvescent or aquiline teeth, cordate-ovate, suddenly slender-acuminate; heads $\frac{5}{16}$ in. high.

\section{MACROPHYLLI}

Violet present in the rays. Glandular hair present. Involucre larger and thicker, $\frac{3}{8}$ to $\frac{4}{8}$ in. high; rays usually about 13 , tridentate at apex; plants larger than in the preceding (excepting some Curvescentes) in rootstock, stem and leaf; colonies of radicals extensive; texture often very thick, very rough or very rigid; crenate teeth often predominant; bracts less ciliate; tomentum of pedicels less crispate than in the Divaricati, not in lines as in the Curvescentes, often entirely replaced by glandular stubs; disks soon purplish-red or maroon; inflorescence tending more often to trifurcate than to subpinnate pedicels.

DIVISION A. LAVENDER MACROPHYLLI. Lilac rays slowly turning lavender, finally becoming pale, dull and whitish; at length brown. (Division $\mathrm{B}$ as a rule develops more strictly violet heads, changing to purer white ; the color of the rays contains more blue in Division $B$, more red in Division A; though occasionally, plants of Division A will produce an equally deep-violet head.) Radicals heavier and shorter-stalked than in $\mathrm{B}$, often less numerous, chiefly 3 , but usually forming larger colonies.

Subdivision A. LEAVES thick, heavy, not firm in life, but flabby. Teeth broad, crenate-serrate; glandular hair chiefly confined to pedicels and bracts and upper part of stem.

* Plants stout, rather tall, often $3 \mathrm{ft}$., with sprangle-top inflorescence ; bracts polymorphous.

55. A. MACROPHYLlUs : leaves cordately oblong-ovate, acute, harsh but only sparingly hairy; sinus broad, deep, irregular, unequally overlapping ; upper leaves broadly oblong-acuminate, taper-based or winged; bracts thick, the lower triangularacute, others oblong, obtuse ; green tips conspicuous. Stem rough-hairy in most typical forms.

$55^{10}$. Glabrate form : leaves more serrulate, rough; stem glabrate.

$55^{11}$. Kid-finish form: leaves smoother, thinner, firmer; roughish when dry.

$55^{12}$. Hetchel form : leaves very rough and irregular.

$55^{13}$. Triangle-hetchel form : leaves triangular-cordate; apt to show 5 -forked pedicels and violet rays.

55 $5^{14}$. Tall-top form: lateral branches later and shorter; apt to be 5 -forked, but lilac. 55 $5^{15}$. Aculeated form : radicals blackish-green, triangular-cordate, aculeate-serrate.

$55^{16}$. Bunch-top form : glabrate; heads small, dense, livid.

$55^{17}$. Downy form: downy, serrulate, flat-topped, little-leaved.

$55^{18}$. Denticulate form : dark-green, subrepand, with pale veins.

55 $5^{19}$. Kound-bract form : serrate; heads dense, round-bracted.

55b. A. MACR. APRICENSIS: leaves oval-acute, with strap-zvings, very flabby, few with 
sinus; inflorescence deep-branched, floriferous; roughness extreme, but hair scanty ; plants in sunny clearings.

55c. A. MACR. SEJUNCTUS: leaves soft, more hairy, both sides rough and bristly when dry ; the lower cordate-ovate; stem hairy; plants subsolitary, in grass.

55d. A. MACR. VEluTinus: leaves smaller, firmer, closely short-pubescent beneath, subtriangular, short-acuminate.

55e. A. MACR. PINGUIFolius : leaves broad-cordate, greasy, often very large and suborbicular; hair almost absent; inflorescence wide-branched; heads larger, paler.

** Plants taller, smonth and glabrous, with convex or diffuse inflorescence ; bracts lingual, acutish.

56. A. EXCELSIOR : leaz'es large, many cordate-oblong, smooth; sinus deep, broad; hair almost absent; stem purple-red or glaucescent, tall.

*** Plants smaller, with compact bunch-top inflorescence; bracts lingual, obtusish.

57. A. ORBICULARIS : leaves small and numerous, cordate-suborbicular to oval-oblong ; sinus strong and deep, often narroiv; veins pale, strongly rectangular; plant apt to be rough-pubescent and leaves strongly apiculate.

58. A. BIFORMIS : leaves few and small, cordate-oval, acutish, close-crenate; sinus deep, narrow; plant glabrate. Little leaves of a new type abruptly succeed the few lower characteristic leaves.

SUBdivision B. LEAVES firmer and less polymorphous than in A ; strongserrate, but the teeth not very deep; stem strong but slender, with some strigose hair; plants usually glandular all over when young.

* Plants not tall, with convex inflorescence; chief bracts acutish; heads lavender.

59. A. UNIFORMIS : leaves thinnish, broad, of deltiform type, abruptly short-acuminate, the middle ones long-acuminate; heads lavender, paling soon, with a delicate fragrance; plant often downy.

6o. A. Alleghaniensis : leaves thicker, less broad, of ovate type, broad-based, few cordated, greatly reduced upivard; plant strict, low ; heads lavender and pink, densely narrow-bunched.

61. A. SABUlosus: leaves thicker, ovate acuminate with cuneate wing, few cordated, all small but not greatly reduced upivard; plant stiff, low; leaves erectish; heads densely shallow-bunched.

62. A. QUADRATUS: leaves thickish, of quadrate type, with slight broad sinus; the radical suborbicular and ovate, with deep sinus; plant strict, low ; heads lavender or when dry of a leaden-blue.

** Pants tall, with dense convex inflorescence (63) or soon becoming diffuse (64); chief bracts lingual, rounded at apex.

63. A. DENSATUS: leaves thinnish, firm, of orbicular type, slowly changing upward in size and shape; plant rough-pubescent, with intermixed capitate glands all over.

64. A. Roscidus: leaves thickish, firm, of quadrate type, with sudden broad obtuse apiculation; much smaller and round-oval above; plants densely covered with viscid capitate glands all over, at least while young; more glandular and less pubescent than the last; rays more lilac.

SUBdivision C. LEAVES thinner, saragely doubly-serrate; plant low, with strigose hair.

65. A. FEROX : radical leaves very large and asymmetrical; caulines small, chiefly slender and petioled; from doubly-serrate below to entire above; heads pale, diffuse. 
Division B. IANTHINE MACROPHYLLI. Violet rays turning pale or white. Radicals apt to be smoother and longer-stalked than in $55^{-65}$; or very numerous and short-stalked; colonies apt to be smaller (except in $A$. quiescens). Leaves seldom of extremely rough or of flabby type, chiefly moderately rough and firm; usually not very thick in comparison with $A$. macrophyllus and $A$. roscidus. Glandular hairs mostly of stub-form, less broadly capitate than in preceding Macrophylli, more abundant than in $A$. macrophyllus, less than in $A$. roscidus.

SUbDIVISION A. PLANTS tall and robust, often $4 \mathrm{ft}$. or more; radicals large, 8 in. or less; glandular and strigose hair little developed below the inflorescence.

* Inflorescence somewhat deeply-branched, rather regular and convextopped.

$\dagger$ Violet of the rays often almost blue but quickly becoming white.

66. A. Iоsтемма: characteristic leaves ovate-acuminate, with taper-zving hase, crenate-serrate; rough; radicals about 4, cordate-oblong, finally incurvedacuminate; stem brownish.

67. A. GREMIALIS : characteristic leaves (middle, upper and axile) oblong-lanceolate, elongate, with taper-wing; radicals about 5, cordate-orbicular; plant very smooth; stem green and shining; rays narrow, long, deep blue-violet; margins crenulate or subentire, or the radicals acutely serrate.

$67^{2}$. Fedian form : upper leaves short, oblong-oval, entire.

$\dagger+$ Violet and subsequent white of the rays usually less pronounced.

68. A. NoBILIS : characteristic upper and axile leaves oblong-lanceolate, soon broadbased and sessile, often acutely serrate; radicals about 4 , cordate-ovate, acute or short-acuminate, low-serrate or crenate; stem smooth, green; leaves rough.

69. A. Ampliatus: middle and upper leaves zarious, broad or asymmetrical ; radicals about 4 , chiefly cordate-oblong with gradually dilated pendulous basal lobes; margins dentate, crenulate or subentire; leaves thinnish.

** Inflorescence sympodially proliferous, very irregular, deep and narrow, violet of the rays moderate or pale.

70. A. SYMPODIALIS : middle and upper leaves ovate-oblong with strap-wing or with taper-base; radicals about 3 , broadly cordate-ovate; margins low-crenate; leaves thicker.

Subdivision B. PLANTS smaller, chiefly 2 feet or less; radicals fewer or smaller, chiefly 3 , chiefly 5 inches or less.

* Inflorescence with flattish top; hair usually little developed; glands minute, less widely distributed ; leaves firm, thinnish.

$\dagger$ Inflorescence deeply V-shaped, high-branched.

71. A. SECURIFORMIS: middle and upper leaves cordate and petioled, reduced; radicals cordate-acuminate; teeth close, sharp, forwardly directed; sinus broad and deep, sharply recurved (securiform).

†† Inflorescence shallow V-shaped, wide-spreading; plants low.

72. A. MULTIFORMis : cauline leaves of multiform types, cordate, deltiform, oval, elliptic, ovate, oblong, and lanceolate ; radicals about 2, cordate-oblong, shortacuminate, lozv-serrate, rough, full green; stem purpled; inflorescence small, regular.

73. A. RICINIATUS: caulines fewer and quickly diminished; radicals about 2, cordatetriangular, acute, smaller, dentate; plants lowe, glabrate, pale; bracts narrow, reddened. 
** Inflorescence more irregular or diffuse.

$\dagger$ Leaves thicker, rougher; hair often downy, or when dry, bristly.

74. A. ELAEAGNiUs : radicals about 2 , orbicular-ovate, acutish, with slight sinus; caulines multiform, characteristic middle ones deltiform-acute; leaves very dark green, harsh, crenate-serrate, gray beneath.

75. A. MASARDIENSIS : characteristic leaves elliptical, elongate, the ends abruptly and somerwhat equally acuminate; other leaves with rounded base; teeth strong, curvesient and aquiline; plant light green, downy, its lines and branches in sweeping curves; outer and inmost bracts acute, middle ones rounded.

76. A. IANTHINUS: radicals about 3 , suborbicular, firm or thick, low-serrate with broad sinus; characteristic middle leaves oval-orbicular vitín strap-zings; bracts oblong, with rounded apex; violet of the rays often particularly full and clear, soon fading utterly to a dingy-white.

†† Leaves thickish, with peculiar roughened surface, but with little hair.

77. A. VIOLARIS : radicals small and broad, often numerous, reniform-apiculate, sharp-serrate, with broad shallow sinus and long slender petioles; characteristic middle leaves oblong-oval, acuminate, slender-petioled; inflorescence apt to be deep and narrow, short-branched, with oblong-lanceolate bracteals; bract-tips rounded ; rays pale-violet to dingy white.

78. A. QUIESCENS : radicals ozal-acute, irregular, heavy, dark green, crenate, with deep sharp sinus, often with pendant dilated lobes; inflorescence irregular and often rather scanty; bracts acute; rays pale violet or lavender, or dingy white.

79. A. GRANULOSUS: radicals ovate-oblon;, with deep sinus; others chiefly ovateacuminate with truncate base and slender petiole; all leaves small, intensely granular-roughened; most bracts bevel-tipped; the inmost linear-acuminate.

Subdivision C. PL.ANTS of moderate height, often $3 \mathrm{ft}$; radicals moderate, 5 in. or less; many non-cordate radicals and caulines; glands abundant nearly all over; leaves not extremely rough nor very thick; disk-flowers deep-slit, funnel-form; violet of the rays deep.

80. A. JUSSIEI : radicals multiform, some radicals and lower caulines oblong-lanceolate with narrow sinus, serrate, and acuminate; inflorescence deep-branched, irregular, proliferous; stem smooth, green; leaves rough ; rays narrow, tapered.

81. A. DECAPHYllus : characteristic leaves cordate-ovate, incurve-acuminate, subcrenate or serrulate; often with many (often 10) oval radicals, smooth and firm; caulines chiefly taper-zvinged, oval-acuminate; stem smooth, low and pale, or robust and red-brown or ebony ; bracts acute, with narrow white edges ; bracteals lance-oblong, sessile; heads very numerous in flat-lop inflorescence.

82. A. HERVEYI: leaves ovate, thinnish, high-petioled, the radical large, lowcrenate, about 4; heads subremote, reaching various levels; outer bracts loose, often with broad squarrose dilation; chief bracts erect, appressed, obtuse or bevel-tipped or mucronulate.

Subnivision D. PLANTS smaller, $\mathbf{I} \frac{1}{2}$ or $2 \mathrm{ft}$; lower leaves 3 in. or less; cordation almost absent; bracts squarrose; leaves thick, very rough.

* Glands abundant; bracts narrow, acute.

83. A. Commixtus : leaves oblong-acute or ovate; a few, lower and soon-perishing. have a sharp sinus; inner bracts subuiate, with the apex squarrose-recuried, ** Glands nearly or quite absent; bracts broad, subtruncate.

84. A. mirabilis : leaves oval, crenate, spinulosely hispid aboz', and minutely so beneath, when dry ; the lowest short-petioled, others sessile by a rounded base ; heads loosely subremote; bracts very abruptly squarrose. 


\section{SPECIES AND VARIATIONS OF ASTER}

\section{Aster L.}

Perennial, branching, glabrous or pubescent herbs, various in habit, but only in a few species annual, unbranched, shrubby or spinescent. Leaves alternate; pinnately veined, broad or narrow, often cordate at the base of the leaf-blade or clasping at that of the petiole, non-dissected, chiefly serrate, but sometimes entire. Rootstock usually strong and horizontal, sometimes short and erect, usually bearing for several years a subterminal tuft of leaves (radicals); these are often smaller, often larger than the somewhat dissimilar leaves (basal leaves) which finally clothe the base of the rising stem. Lower, middle and upper cauline leaves polymorphous, often gradually transitional to each other in form, often of sharply dissimilar types. At the axils of the branches the subtending leaves (axiles) are gradually reduced from the upper leafform of the stem, but on the branches themselves the leaves (rameals or bracteals) are usually profoundly modified or are abruptly of a new type.

Heads with both tubular and radiate flowers, either corymbed, racemed or panicled, and borne on erect, spreading or secund ultimate branchlets (pedicels), rarely solitary. Involucre campanulate, turbinate, cylindric or hemispheric; its components (bracts) imbricated in several series; the outer sometimes enlarged and foliaceous, but usually smaller and shorter than the inner, and somewhat herbaceous or otherwise much modified at or toward the apex (this modified portion constituting the green tip), which is itself either erect, spreading or squarrose. Receptacles flat or convex, alveolate or foveolate and often delicately fimbrillate. Ray-flowers pistillate, with white, pink, purple, blue or violet ligules (rays). Disk-flowers perfect, numerous, consisting of a tubular base (the tube) swollen above into the shape of an erect bell, urn or funnel (the $b c l l$ ), bearing a short, five-lobed spreading or erect border; disks typically yellow, usually changing to red, brown or purple. Anthers obtuse and entire at the base. Stigmas flattened, their appendages subulate, lanceolate or ovate, acute. Achenes com- 
pressed or fusiform, sometimes terete, either glabrous or slightly pubescent. Pappus typically composed of one series of numerous, uniform, slender, straight, white bristles, capillary and minutely roughened, the inner tips sometimes thickened.

\section{Section I. Biotian Asters}

Cordated strongly surculose colony-forming Asters with broad firm coriaceous close-imbricated bracts and non-floriferous corymbose inflorescence, chiefly with white or lavender ray's and reddened disks.

Cordate-leaved Asters with greatly developed rootstocks of strong and persistent vitality, producing large subterraneously connected colonies; unlike the other heart-leaved Asters (the Heterophyllous and Diversifolial sections), among which the rootstocks are diminished in size, robustness and duration of life. Rays either white, reddened, purple, violet, or almost blue, sometimes greenish or yellowish with age, chiefly 6-I 3, finally drooping ; seldom circinately inrolled as in many other groups. Diskflowers usually 20-30, yellow, soon turning reddish-brown or even maroon or crimson, becoming brown in age or sometimes yellowish-green or greenish-brown. Involucre somewhat cylindric, compactly imbricated in 3-5 rows. Bracts coriaceous (or even scarious) close-appressed, short-ovate to linear-acuminate, green or pale; with the margins similar (or even white, purpled or yellowish), chiefly ciliate, on the back either puberulent, glandular or glabrous, not herbaceous at the tip, but usually with a small soft green subterminal thickening (the green tip of botanists), the apex either rounded, truncate, obtuse or acute; the back planoconvex, or sometimes even cymbiform, sometimes even flat.

Leaves broad, at least the lower and radical, predominantly of cordate-ovate type, membranous, smoothish or harsh, pubescent or glabrous, persistently petioled, with conspicuous spreading veins.

Heads numerous or few; plants seldom very floriferous, not producing heads by the hundreds as in the Heterophylli.

Inflorescence of corymbose aspect, cymose in development, chiefly produced by the formation of a terminal arrest on each stem or branch, this arrest-region consisting of two or three nodes, each with its leaf and bud, these buds developing into pedicels or branches which are at first so little separated as to simulate verticillate branching during early growth; later separating slightly or considerably, but usually retaining a repeatedly trifurcate aspect. As in allied Compositae, though the central or terminal head of each stem or branch develops first, the central disk-flowers develop last, being long preceded by the rays and by the outer disk-flow- 
ers in successively blooming circles. But great variety exists with regard to the degree of difference in development, and in some species or varieties the heads are all in flower at once, and even all the disk-flowers in a head at once.

Pappus white or dingy, often reddening in the herbarium.

Achenes subfusiform to terete, slightly compressed or not at all, finely striate, generally glabrous at maturity, but sometimes with fine upward bristles on the striae ; the bristles, if present, are often early deciduous.

Radical leaves more strongly developed than in other Asters; phases of life-history also more strongly accentuated; variability at its height.

\section{Subsection $A$. Divaricati}

Low white-rayed plants with globose or ovoid buds, ciliate broadtipped bracts, salient teeth, and tomentulose pedicels; typically without glands, radicals, or violet color.

Rays white, under I 2 ; if colored, the color is reddish, pink, rose or coppery; not violet, purple or bluish. Glands absent. Buds ovoid, or at first globose. Bracts ciliate, chiefly rounded or truncate. Leaves thinnish, membranous, typically smoothish and sharply-toothed, not very harsh nor rigid, not radiately veined at the base. Crenate teeth rare; salient teeth common. Pedicels loosely covered all over with minute curly-crisped tomentum; not hairy in lines as in the Curvescentes nor covered with capitate glands as in the Macrophylli. Radicals few, inconspicuous, seldom produced.

\section{Division A. DIVARICATE ASTERS PROPER Species I-I 6}

Thin smoothish prolonged membranous leaves, polymorphous on the single plant. Teeth sharp and salient. Stem chiefly green. Disks turning dull reddish-brown or brown. Bracts subtruncate or bevel-tipped.

Subdivision $A$. Stem assurgent, repeatedly flexuous, brittle. Sp. I-I I.

Species I,* Aster divaricatus L. White Wood-Aster.

Low assurgent Aster filling thin northeastern woodlands; with slender divergent pedicels, 6 to 9 rays, truncate and bevelled

* This species deserves to be placed first because it is a generalized form. Species which appear to form varying radiations from this, are to follow successively until with species $40, A$. curvescens, another generalized form of equal rank is reached, to be followed in turn by variants, etc., etc. It is obvious that the linear order imposed upon descriptions of variants does not represent the actual irregularly radial order of their real relationship. 


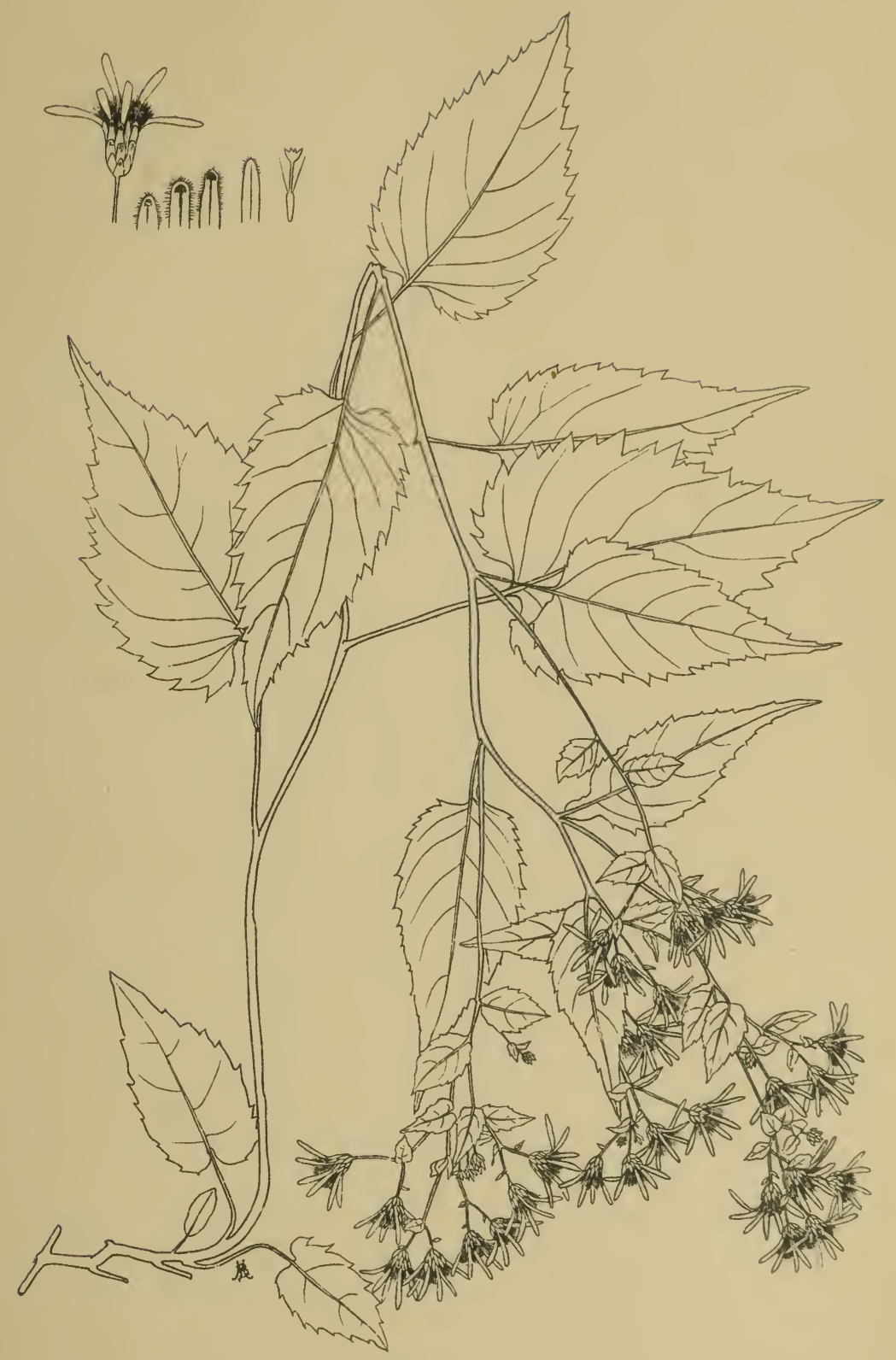

ASTER DIVARICATUS

THE HELIOTYPE PRINTING CO.. BOSTON. 

strong-ciliate bracts, and long thin smoothish ovate-lanceolate coarse-serrate leaves, chiefly slender-petioled, about one third of them cordated.

Name, L., appropriate to the widely divergent branching and pedicels; and especially to the squarrose spreading upper axiles, two or three of which usually make a prominent divaricate group (or even a whorl) in the center of the inflorescence.

Fig. 3 (= Plate I), from a N. Y. plant in hb. Bu., with 4 bracts, of the outer and three inner types, the $2 \mathrm{~d}$ representing the normal truncate form, and the $3 \mathrm{~d}$ the chanfer- or bevel-tipped type.

Aster divaricatus L. Sp. pl. 873. 1753; excluding synonyms from (ironovius and Plukenet, which are of Doellingeria infirma (Michaux) Greene.

Not $A$. divaricatus Lam. Dict. I : 305. I783, which, fide hb. Jussieu, is $A$. acuminatus Michaux (so Gray, S. Fl. 199).

Not $A$. divaricatus Poiret, Enc. méth. Suppl. I : 498, n. 82 . I 8 1o which is Docllingeria infirma.

Not A. divuricatus Sprengel, S. Veg. 3: 529. 1826, which Nees deemed to be his Doellingeria amygdalina.

Not $A$. divaricatus T. \& G., Fl. N. Am. 2: 163. I84I (the Tripolium divaricatum of Nuttall), which is $A$. exilis Ell.

Not $A$. divaricatus Raf. ex DC. Prodr. 5: 24I. I836, which is $A$. divergens Aiton. Gray.

Not $A$. divaricatus Kuntze, Rev. Gen. 318. $189 \mathbf{1}=$ Aplopappus diraricatus A.

But = Biotia macrophylla divaricata DC., Prodr. $5: 265$.

and $=A$. divaricatus L., Bot. Club Check List, N. Am., 323. 1894.

and $=A$. divaricatus L., Br. \& Br. Ill. Fl. $3: 357$. I 898 and works following.

Also $=A$. cordifolizes Michaux, Fl. $2:$ I I 4. 1803 in part fide herb.

$=A$. corymbosus Dryander in Aiton, H. Kew, 3: 207. I789; followed by Willdenow, Nees (1818), Poiret, Sprengel ; and in America by Bigelow (1814), Pursh, Torrey and Gray, and American authors generally till I894. Not $A$. corymbosus Moench, Meth. Suppl. 250. I802, which is Inula germanica.

$=$ Eurybia corymbosa Cassini, Dict. des sci. nat. $37: 487$. 1825; followed by Nees, Syn. Ast. 143. 1832 ; Lindley, Bot. Reg. pl., 1532. 1832 ; Hooker, Fl. Bor. Am., 2 : 14. I840; Darlington, Fl. Cestrica, 469. 1837.

= Biotia corymbosa DC., Prodr. 5 : 265. 1836 .

Plants low, assurgent, irregularly and acutely flexuous, brittle, $\mathrm{I} \frac{1}{2}$ to $2 \frac{1}{2} \mathrm{ft}$. high, glabrate at maturity, nearly smooth to the touch, loosely cespitose. Rootstocks slender, the small delicate radical leaves rather seldom produced, coarsely serrate, I in. long or less, oval-acute. Stem terete, usually green, occasionally purplishtinged or brownish, soon glabrous. Leaves thin, smoothish, incurved-acuminate, ovate-lanceolate, full green, fading yellowish, $4 \times 2$ in. or less, regularly diminished upwards. Lower caulines with a broad deep sinus, so continuing for about $\frac{1}{3}$ of the stem, passing into rounded leaf bases and finally into a few sessile ones. Petioles slender, or sometimes a few upper ones broad-winged, of 
moderate length, neither very short nor very long, chiefly i to $\frac{1}{2}$ in., usually shorter than the leaf-breadth. Teeth sharp, coarsely salient, nearly even, projecting outward $\frac{1}{8}$ in. or more.

Leaves of the inflorescence small, short, ovate-acute to orbicular, subentire. Inflorescence a broad corymb, flattish, and repeatedly forking, the slender peduncles and pedicels long and broadly divergent, several chief peduncles contiguous and with conspicuous divaricate axile leaves. It is to these peduncles and especially their axiles that the specific name is most appropriate.

Heads about $\frac{3}{4}$ in. broad, sometimes more. Rays chiefly 6 to 9 , especially 6 , linear-oblong, white, at first erect and involuteterete, soon horizontal, minutely bidentate, toward night deflexed, finally often deflexed by day, at last withering brown. Disks yellow, changing to a dull reddish-brown.

Bracts broad, oblong, coriaceous but thin, obtuse, truncated or chanfer-obtuse at the greenish erect slightly-thickened appressed tip, highly ciliate, especially at the tip. Inner bracts linear, obtuse, thinner, tapering slightly, with a narrow white scarious margin. A few outermost bracts are sometimes broadly and very slightly pointed, involucre $\frac{1}{4}$ in. high or less, changing from turbinate to somewhat narrow-bell-shaped during flowering. Achenes light brown, finely multistriate, glabrous, little if at all compressed, clavate-terete, slightly constricted at top.

- In open woodlands and thickets, in rather dry soil, Canada and Manitoba to Georgia and Tennessee. Sept. chiefly; a few in Aug. and in Oct.; with stragglers in Nov. about the Potomac and the Hudson.

Very abundant in Piedmont and hilly districts of the Middle States. Absent from the eastern Laurencian region? "Occurs from the western part of Quebec to the Kawinistiquia R., west of L. Superior," Macoun, 1883. Absent from wide stretches of the Adirondack plateau and of the White Mts.; as also from the coastal plain in New Jersey, and southward, to which it descends along the great rivers, as toward Washington along the rocky banks of the Potomac wherever covered with deciduous trees. Nearly or quite absent however from many ravines where it should be sought; as the Niagara gorge. Macoun remarks that in Canada it is much less abundant than is $A$. macroplyyllus.

Extends south along the Appalachians, as at

N. C., Highlands, Se. 9, '97, coll. Biltmore hb., and Biltmore, open woods, Au. '98, no. 34 , in hb. N. Y. Bot. Gar.; Biltmore, ' 96 , no. 283663 in hb. U. S. Natl. Mu.

N. C., Salem, Schweinitz (who d. I834) in hb. Phila. Acad. Sci.

Ky., Cumberland R., Bell Co., Se. I893, T. H. Kearney, Jr., no. 535, in N. Y. Bot. Gar. 
Ky., "moist low grounds and hillsides of Licking R., fl. Se.; no. 7, C. IV. Short," in hi. I'hila. Acad. Sci.

Ga., Tallulah Fulls, in the canyon, Se. 2, '94, Small in hb. N. Y. Bot. Gar.

Ala., Clay Co., Se. 29, '97, F. S. Earle in hb. N. Y. Bot. Gar.

Older Herbaria include these representatives :

Herb. Linnaeus, in London, a leafy inflorescence of $A$. divaricatus.

Herb. Nees, fide specimen of Nees's certification, cultivated in Hort. Breslau ; given by Nees to Schultz Bipontinus, and in $\mathbf{I} 885$ by Klatt to A. Gray ; now in hb. Cambridge Bot. Gar. Other specimens from hb. Nees represent vars. cymulosus and deltoideus.

Further remarks. Rootstocks pale, subterete, often $2 \frac{1}{2}$ in. long by June, by September $6-8$ in. long and $\frac{1}{16}$ in. thick, slightly knotted in drying at the nodes, which are about $\frac{1}{2} \mathrm{in}$. apart. Often 3 or 4 such surculi start in different directions from near the base of the one plant, all purplish at their ascending tips.

Puberulence moderate on midribs and principal veins beneath, increased to a minute tomentum over the pedicels, but little developed over the involucre. Strigose hairs very slightly developed on the upper surfaces, most prominent as a ciliation upon bractmargins. Puberulence sometimes viscid when fast-growing in early summer; but no true glandular or capitate hairs present.

Radicals usually not developed except as small transient ovatelanceolate basal leaves with much purple beneath, soon perishing. Walking daily for ten years in Central Park among thousands of plants more or less closely typical, no persistent radicals were seen. When developed these are usually few, small and inconspicuous, hardly raised into the light, glabrate, purplish-tinged, orbicularacute, finely serrulate. More strongly developed persistent radicals have been observed in dry rock-clefts, in dry woods, among dead leaves of beeches (Ct. ; vic. N. Y.; and W. N. Y.), and also under hemlocks, a less usual habitat. They suggest the resource of slow growth, holding over in spite of unfavorable conditions. They are very thin, glabrate, cordate-oval, acutish or sometimes obtuse, $2 \times \mathrm{I} \frac{1}{2}$ in., or rarely more, with broad, open sinus, about $5-7$ coarse sharp teeth on each side which project forward and are commonly crenate or at least dorsally convex and elongated, much as in $A$. macrophyllus, and unlike the subsequent cauline leaves of $A$. divaricatus. They suggest that the common original for the two species had a strong crenate tendency. When most developed (beechen hills of W. N. Y.) such radicals form a rosette of 6-9 dark nearly prostrate uniform leaves with very slender glabrous petioles of nearly their own length.

Corymb commonly about 6 in. broad and 6 in. high; but sometimes twice this. Pedicels often $\frac{1}{2}$ in. high.

Heads round-topped in bud, on account of the obtuse bracts ; those of A. macrophyllus are sharp-conical on account of acute bracts: 
Rays linear, slightly narrowed at the ends, about $\frac{1}{4}$ in. long, often $\frac{1}{6}$ as broad.

Disk-flowers often about 25 , their lobes cut about halfway down the body, which is broad funnel-form, tapering into a stout, pale greenish tube. The tube expands slightly at its base, and is about $\frac{3}{5}$ the length of the disk-flower.

Pappus yellowish-white in bud, then white, becoming dingy after flowering and slightly tawny in the herbarium within a year, often reddening finally; seen a fine salmon-red in Io years, and still deeper in 20 .

Receptacles convex, alveolate, the socket of each flower stellated with a sharply 5-pointed membrane. Each alveolus rises in its center into a hollow conical tubercle or foveolus on which the achene stands.

Involucre usually but faintly triseriate-chequered from the green tips.

Bracts with their sides whitish (in the middle and inner bracts) the narrow midrib distinctly precurrent, greenish or brownish, and slightly clustered, inner bracts often without any green.

Internodes lengthen greatly during flowering, changing the aspect totally. The inflorescence is prominently bracteate in the bud, the subglobose young buds often remaining for some time in sessile clusters among their triangular-ovate bracteals, suggesting little Carpinus bracts (July I I-25, in W. N. Y., etc.).

Development; as noted about Washington, D. C., I in. high, 3 leaves unfolded, Apr. I7; on May I 7, I 5 in. high, 7 leaves full grown, one of them already dead; on July 17, near Dunkirk, $\mathrm{N}$. Y., same height and number of leaves but with the flower-buds becoming distinct.

In full flower, Dunkirk, N. Y., at $500 \mathrm{ft}$. elevation, and Taconic Mts. at I,600 ft., last week of Aug. and first week of Sept. ; vic. N. Y., Sept., into first week of Oct.; Washington, D. C., last week of Aug. through Oct.

Some flowers remain till frost, especially from sprouts; late flowers collected about N. Y., Nov. 3, 5, 8 ; about D. C., Nov. 8.

Young radicals about $\mathrm{N}$. Y. have been found to reach $\frac{2}{3} \mathrm{in}$. long by Apr. 1 2, $2 \frac{1}{2}$ in. by Apr. 25. 


\title{
HISTORY OF THE DESCRIPTIONS OF ASTER
}

\section{DIVARICATUS L.}

\author{
First description, Linnaeus, Sp. pl. ed. I, $2: 873$. \\ I 753 .
}

"Aster ramis divaricatis, foliis ovatis serratis, floralibus integerrimis."

This brief and indecisive character may have been drawn from a plant coming to Linnaeus directly or indirectly from some one of his American correspondents, as Cadwallader Colden in N. Y., John Clayton in Va., John Bartram in Pa., all of whom sent plants to Collinson at London, which found their way to Linnaeus. If this supposed specimen was that which became incorporated with the Linnaean herbarium and which still remains there as type of $A$. divaricatus, it was, fide Gray, I882, "the upper part of a specimen of $A$. corymbosus Aiton, wanting the cordate petioled leaves, and with open inflorescence unusually foliolose." But however unlike his specimen may have been, Linnaeus ("who did not well know his Asters," said Gray), confused this plant of Aster divaricatus with our Doellingeria infirma, specimens of which had been sent by Clayton as his No. I 43 to Gronovius. Linnaeus himself was at Leyden in 1738 assisting Gronovius on Clayton's plants, and doubtless handled the infirma specimens. At all events, Linnaeus in his $S p$. pl. of 1753 adopted the Virginian infirma plants of Clayton and their description by Gronovius of I 739 (as Astcr caule infirmo, etc.) as equivalent of his own Aster divaricatus, and also adopted Gronovius' synonym from Plukenet's Almagestum.

Linnaeus' originai presentation of his $A$. divaricatus in 1753 consisted therefore of the brief description I have cited, followed by citation as synonyms, of Gronovius' and Plukenet's descriptions of Docllingeria infirma. Because of its composite character Gray decided, I882, that the Linnaean name divaricatus "should subside." Its reinstatement was not till I 894 , in the Botanical Club's Check List, in deference to the Linnaean specimen.

Linnaeus' original description was retained by him in his Systima Naturae, Ioth edn., I 759. In I 763, in his Species plantarum, ed. 
2, 2 : I 226, he added to it the words (applying to the foliis floralibus) obtusiusculis amplexicaulibus; an afterthought doubtless due to noticing the foliose inflorescence. In this strengthened form the Linnaean description long remained, as in Sp. pl. ed. 3, in I 764, and in Syst. vegetabilium, ed. I4, in I 784 . Houyttuyn's German translation of 1783 , Pf. Syst. 9: 377 added the German translation-name Ausgebreitete Sternblume.

Aiton's Description, Dryander in Ait. Hortus Kervensis, 3: 207. I 789 .

"Aster corymbosus. Aster foliis cordatis glabris acuminatis omnibus argute serratis petiolatis, petiolis simplicibus, ramis fastigiatis, caule glabro."

Willdenow's DEscription, Sp. pl. $3^{3}: 2036$. I 804. Arranged as character and description, as follows :

"Aster corymbosus. Aster foliis ovatis argute serratis acuminatis, inferioribus cordatis petiolatis nudis, caule superne corymboso-fastigiato, ramis pilosis, calycibus oblongis imbricatis, squamis arcte adpressis."

"Doldentraubige Sternblume.

" Habitat in America boreali, perennis (v. v.).

"Caulis glaber purpureus aut viridis superne ramosus, ramis corymboso-fastigiatis pilosis. Folia inferiora cordata petiolata serrata glabra, quandoque ad venas pilis raris obsita, petiolis nudis, superiora acute argute serrata petiolata, summa ovate acuminata subpetiolata et subserrata. Calyx oblongus imbricatus, squamis lanceolatis obtusis arcte adpressis. Corollae radii albae.

To the above, Schulze, editing Willdenow, added, p. I 28.? Folia nostri pilosa.

Bigelow, Florula Bostoniensis, ed. i, 202. I 8 I 4 ; and ed. ii, 3 I 4 . I 824.

"Aster corymbosus Ait. Corymbed Aster [Willdenow's character is quoted, with the following remarks]: A pretty large white-flowering plant, stem smooth, frequently of a dark reddish color. Lower leaves heart-shaped, petioled, smooth, toothed; upper ones ovate, acuminate, subsessile. Flowers white in a large flat-topped corymb, the branches of which are slightly pubescent. Woods and shades, Roxbury, Brookline. - Aug. - Perennial.",

Barton, Wu. P. C. Prodromus Florae Philadelphicae, 8I. ISI 5 ; and Compendium Pl. Phil. 2: I I 4. I 8 I 8.

" 15. Aster corymbosus Ait. Corymbous-flowered Aster. From 14 in. to $2 \mathrm{ft}$. high. Flowers white, in a large corymb. On the shaded rocks bordering the Schuylkill ; in shaded woods and thickets, everywhere common. Perennial. July." [For the variety alatus which he adds, see infra.] 


\section{Nees, Genera Astereanum, I43. 1832.}

“Eurybia corymbosa, Cass.

E. foliis ovatis, inferioribus cordatis, serratis petiolatis, caule dichotomo-corymboso, periclinii foliolis imbricatis obtusis, exterioribus ovatis.

Crescit in sylvis umbrosis a Canada usque ad Virginiam. Floret ab Augusto in

Novembrem; apud nos in Septembre ineunte. 2 . V. v. c. et sicc. spont.

"Habitu quodam proprio inter reliquas distincta. Caulis gracilis, angulatus, purpureus, nitens, glaber, apicem versus ramosus; rami apice corymbiflori ; superiores ipsi saltem corymboso-fastigiati. Folia primordialia minora, subtus purpurea, cordato-ovata ; reliqua cordata sinu rotundato nervo marginali cincto (trinervata), acuminata, inaequaliter grosse patenti-serrata, ut in urtica; quorum inferiora utrinque, superiora in facie superiori praesertim setuloso-scabra. Petioli longi, canaliculati; inferiores sparse ciliati, basi purpurei. Inflorescentia arcuato-dichotoma, foliosa, ramis trichotomis, basi nudis, apice bi-trifloris, inferioribus superiores plerumque excedentibus. Calathia mediocris magnitudinis. Perıclinium ovatum, arctissime imbricatum, foliolis, obtusis, quorum exteriora ovata, media oblonga, interiora lineari-lanceolata, intima lineari, perangusta, haec quidem tota membranacea, omnia autem pallida, nervo viridi, sursum nıdice dilatato divisa, longe ciliata. Radius periclinii longitudine, pauciflorusa albus; ligulis lanceolato-linearibus. Discus periclinium excedens, e flavo purpuras, cens. Alveolorum clinanthii dentes parvi, subulati. Achaenia lineari-cuneata, glabraecostata. Pappus scaber, inaequalis, rufescens.

"Adnot. varietatem caule humili, vix folia, quae pleraque sunt radicalia, superante, ex horto Parisiensi, in herb. cl. Mougeot vidi. [Probably a sprout from a tuft of radicals.]

\section{L.INDLEY in Botanical Register, pl. 1532.0 I 832.}

A good representation of typical Aster divaricatus, the plate drawn by Drake, engraved by Watts, and published by Pickering. Lindley furnished two pages of accompanying text, consisting chiefly of Nees' description of 1832 , with the following remarks :

"Very common in [botanical] gardens, I-2 ft. high, Aug. to Sept. ; from shady woods, Canada to Virginia; wild it bears only 6-10 heads [in fact often 40] but numerous heads when cultivated, as shown in the figure [which has about 30 heads $3 / 4$ in. broad].

"By favor of M. Achille Richard we possess a specimen from the herbarium of Michaux from which we have ascertained that this $A$. corymbosus is his $A$. cordifolius. We have received it under the same name $[A$. cordifolius $)$ frorn Dr. Torrey; and it is probably that of other American botanists, not however of Nuttall, who evidently, by combining it [A. cordifolius] with $A$. heterophyllus, was aware of the true [relationship of] A. cordifolius." ' J. L.

\section{De Candolle, Prodr. $5: 256 . \quad 1836$.}

“Biotia corymbosa, caule glabro gracili apice laxè corymboso, foliis petiolatis serratis acuminatis subtus secus nervos subsetosis, infer. petiolatis cordatis, mediis ovatis, sup. alato-petiolatis aut subsessilibus, capitulis pedicellatis, invol. squamis imbricatis obtusis, exter. ovatis, ligulis 6-8 invol. duplò longioribus. 2 . In sylvis montanis à Canada ad Virginiam. B. alata (Bart. Fl. Phil. 2: II 4 ) petiolis latius et frequentius alatis. Varietas ex cl. auct. permanens.'" 
Torrey and Gray, Fl. N. Am. 2 : i 04. My i 84 I.

Aster corymbosus (Ait.): Stem slender, often flexuous, terete ; leaves membranaceous, coarsely or incisely and unequally serrate with sharp spreading teeth, conspicuously acuminate, all but the uppermost cordate and on slender naked petioles, ovate or ovate-lanceolate; heads loosely corymbose; involucre shorter than the disk; the ex. terior scales roundish-ovate; rays (white) 6-9. [Repeated in Torrey's Fl. N. Y. I : 335. I 843.]

Dry woodlands, Canada and Northern States! To the middle country or mountains of the Southern States! July-Aug. Stem I-2 ft. high, glabrous, or pubescent towards the summit, where it branches into a loose (often somewhat leafy) corymb. Leaves very thin and membranaceous, 2-4 or 5 inches long, strongly serrate with sharp and spreading rather distant and irregular teeth, which are tipped with conspicuous mucronate-acuminate points, glabrous or sparsely-hairy above, and often hairy on the midrib and veins beneath, as also the slender petioles, varying from broadly ovate to ovate-lanceolate, but all except the uppermost cordate; the upper rarely with margined petioles; the uppermost sessile and sparingly serrate. Heads smaller than in the following species, the outer scales of the involucre (smooth, except the ciliate-pubescent margin) rounder and less rigid. Pappus tawny. Achenia neatly glabrous when mature. [Repeated, condensed, in Torrey's Fl. N. Y. I : 335.] Lindley cites the Aster cordifolius of Michaux as a synonym of this species, on the authority of a specimen communicated by A. Richard; but if we mistake not, the chief specimens of his proper herbarium accord with the Linnaean A. cordifolius."

\section{Chapman, Southern Flora, ed. i, ig8. i 860 ; and ed. ii, I98. I 883.}

"Aster corymbosus, Ait. Stem slender, smooth ; leaves on slender petioles, thin, coarsely serrate, acuminate; the lower ones cordate, the upper oblong; involucre shorter than the disk, the scales obtuse; rays 6-9, white. Shady woods in the upper districts, Georgia and northward. Sept. and Oct. Stem I-2 ft. high, leaves 2 to 4 n. long, corymbs loose.

$$
\text { Gray, Sy'u. Fl. N.Am. I' : I 74. I } 884 .
$$

"Aster corymbosus, Ait. Stem slender, 2 ft. high, sometimes flexuous, terete; leaves membranaceous, much longer than wide, gradually or very prominently acuminate and acuminately serrate; involucre only one fourth inch high, little surpassing the rather broadly compressed fusiform akenes: rays 6 to 9, white. - Woodlands, Canada to upper part of Georgia."

I888, Oct.-Dec. My preliminary survey of the Aster divaricatus forms about Washington, D. C., written at this time, distinguished 50 forms ; but instead of publishing, was held for verification in the field, and was so tested during i 889-1894, while still residing at Washington. The result was that perhaps half of the forms were determined to be no more than forms; about 12 were held over to be tested further (one of these appearing as species in the present work for the first time, A. cbeneus; and one in Small's Southeastern Flora, I903, A. stilettiformis). The other 13 were published as species or varieties, in the Illus- 
trated Flora, 1898 , including the new $A$. curvescens and varieties oviformis and umbelliformis, A. Claytoni, A. dizaricatus cymulosus, curtifolius, deltoidens, persaliens, and fontinalis, A. macrophylins pinguifolius, and the revival of the $A$. Schreberi and $A$. viridis of Nees.

\section{898. BRItTON AND Burgess in Britton and Brown's Illustrated Flora, 3: 357.}

"Aster divaricatus L. White Wood Aster. Figure 3,737 [showing top of small typical plant, and a lower leaf].

"Stems tufted, assurgent, flexuous, brittle, terete, $11 / 2-2 \mathrm{ft}$. high, glabrate at maturity. Leaves thin, smoothish, slender petioled, ovate-lanceolate, closely dentate with sharp teeth, or the basal ones coarsely serrate, acute to acuminate, the basal sinus moderate; leaves of the inflorescence small, short, ovate and acute to orbicular, subentire ; corymb broad, flattish, repeatedly forked, the slender branches long, divergent ; heads 9 to 12 lines broad; rays chiefly 6-9, linear, white, disk turning brown; bracts of the involucre broad, ciliate, the rounded tip with an inconspicuous green spot.

In open woodlands and thickets, in rather dry soil, Canada to Manitoba, Georgia and Tennessee. Variable ; rays rarely rose-purple. Sept.-Oct."

[With 5 new varieties, cymulosus, curtifolius, deltoidens, persaliens, fontinalis, and with notice of $A$. viridis Nees; for all of which see infra.]

\section{Variants of Aster divaricatus}

As an extreme case of the variability possessed by Asters, I describe the 60 following forms in special detail. The first 8 or 9 are transient states; the others may be more or less permanent forms, but have not yet given sufficient evidence of permanence to warrant their present recognition as species. Using the Arabic numerals consecutively for species and I for $A$. divaricatus, I number these variants as $\mathrm{I}^{2}, \mathrm{I}^{3}, \mathrm{I}^{4}$, etc., reserving the form $\mathrm{I} a$, I $b$, I $c$, etc., for subspecies.

\section{* Transient States}

$I^{2}$ Rosette state, an adaption with tufts of radicals for holding over in unfavorable shaded conditions; see description, supra.

$\mathrm{I}^{3}$ Sprout-Forms; these tend to have more leafy inflorescence; stem shorter, more reddened; lower leaves small, with subtruncate base; the next leaves are the more conspicuous, ovate or narrower, rougher, shorter, and more bulky than in the type, also less serrate, and often sessile ; upper leaves (axiles) lanceolate Collections (in vic. N. Y., Sept. 29-Nov. I), were seemingly due to either of these conditions :

$a$, loss or injury of the main stem ;

$b$, new stimulus late in the season, after the work of the main stem is done; as the stimulus of new drainage, new supply of nutrition, or newly loosened or comminuted soil ; 
$c$, simple continuance of late sunshine and warmth.

$I^{*}$ BRANCH-FORMS, or ramified state, where cropping of the top of the main stem has caused an upgrowth of prolonged flowering branches from the upper or even lower axils, producing on the branches leaves of the rameal type, narrow oblong-lanceolate, sessile with a narrowed base, rather elongated toward the acute apex, and but little serrulate. Examples :

N. Y. vic., Bryn Mawr Park, Oc. I, '98, etc., shaded rocks.

W. N. Y., Siiver Creek, Au.''98, etc.

I $^{5}$ TUBerous-Form, with tuber-like thickenings of the base of stem due apparently to cropping just above ; from which swellings short upright stems rise a foot or less, with small concentrated inflorescence. Pedicels short, suberect and stretching up into the light. Bracts scarious-edged, bevel-tipped, with very definite dark-green tip.- Many plants, in clearing on mountain road, Hunter Mtn., Catskills, Se. 6, I 899.

\section{**Arrested States}

$I^{6}$ Pedunculate state; appearance as of whole inflorescence raised on a peduncle, above the proper leaf-series and below the lower branches; due to partial suppression of the upper leaves. Occasional; example, N. Y. vic., Oc. 2, '98, Bi.

$I^{7}$ Syncopated state; pedicels suppressed or nearly so, the somewhat prominent bracteals closely investing the subsessile flower-clusters; most peculiar in appearance, but due apparently to some non-hereditary cause producing arrest only in the individuals directly affected. Examples :

N. Y. vic., Bryn Mawr Park, Se. I3, '97, shaded roadside; and Se. I7, '98, in mud.bottom of dried pool ; Caryl, Se. 29, '98, shaded roadside, Bu.; Woodlawn woods, Se. $2 \mathrm{I}$, '98, Bi.

Penn., Phocnixville, W. K. Fisher in hb. Bu., Au. 26, '96, from " rather moist place in edge of young bushes."

$I^{8}$ BUNCH-LEAF state, an arrest or suppression of lower or middle internodes causing an abnormal centering of large leaves together :

N. Y. vic., Pelham, Se. 20, '98, woodland.

W. N. Y., Silver Cr. glen, Au. I I, '98.

$\mathrm{I}^{9}$ Mixed-Leaf states. Very singular states; some leaves, mixed in among the others, sustain an arrest of the terminal half or third, the apex becoming obtuse or rounded (or sometimes remaining acutish); the general leaf-type being lanceovate-acuminate. The arrest-leaves are short-oblong or variously suboval, mingled irregularly among the normal leaves, chiefly among the 
upper ones, sometimes alternating with them, sometimes replacing them for two or three nodes in succession. Such arrest sometimes appears on several of the stems from one clump, but seldom from all of a colony. The arrest-leaves are often smaller than the normal in all dimensions, but are still more often unchanged in breadth. I have sought with little success for evidence of similar arrestleaves from the same rootstocks during successive years; but have found them produced continuous seasons from the same colony within a few feet at least of the previous years' examples (under chestnuts by Palmer Av. and paths, Bryn Mawr Park).

Compared with arrestleaves in the Curvescentes and the Macrophylli there is this great difference, that in those the arrest-leaves are chiefly repetitions of the normal form in dwarf size; but in the mixed leaf states of $A$. divaricatus here intended, the change is not simple dwarfing but includes malformation of the upper half of the leaf No insect-sting nor indication of fungi is apparent.

Observed very often in Aug. and Sept. about N. Y. City, in W. N. Y., near Boston, Mass., etc., etc., various years. - As observed in Central Park, N. $\mathrm{Y}$. City, this form is late to start in the spring, and its broad, roundish and irregular leaves reach $\mathrm{t} / 2$ and $2 / 3$ in. long by Apr. 20, when those of typical $A$. divaricatus reach 2 in.

I $^{10}$ ObOlarian form.

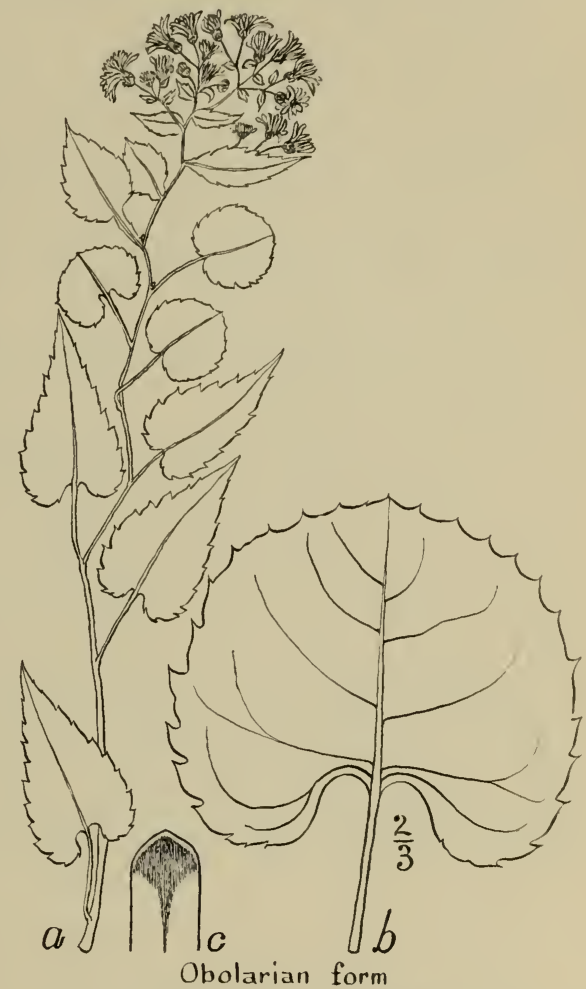

Fig. 4, from plant of Bryn Mawr Park, N. Y. vic., Se. '96, in hb. Bu. with typical leaf and bract.

Very peculiar in aspect, with normal ovate-acuminate and lanceolate leaves intermixed upwards with reniform, orbicular and cordate-rotund leaves.

Small, thin, smooth, delicate green-stemmed plants, I to I I/2 $\mathrm{ft}$. high, differing from $A$. divaricatus $\mathrm{L}$. especially in their subcircular upper leaves, which suggest the form of a penny or of a 
Greek obol. In the preceding mixed-leaf states only a minor part of the caulines manifest arrest ; in many plants of the present form all or nearly all of the leaves do so from the middle of the stem upward, the leaf-succession changing abruptly from the ovateacuminate serrate lower leaves $3 \frac{1}{2} \times 2$ in., to the small subcircular upper leaves, about $\mathrm{I} / 4 \mathrm{in}$. long and broad, in parts repand denticulate or entire. Occasionally one of these leaves escapes the arrest-tendency and becomes long like the lower leaves. On the other hand, sometimes some of these small leaves become reniform and more than twice as broad as long.

Petioles narrow, very slender; the lower petioles longer than the leaf-breadth, the upper ones becoming shorter and often narrowly cuneate-winged. Inflorescence rather small and close, the heads and bracts nearly as the type.

Nothing else suffers arrest except the upper leaves. The same cluster of some 40 plants has been watched for Io years without change in character except that during the last four years vitality has seemed low, the stems shorter, and the whole group of rootstocks dying out.

I do not describe it as a species because it seems uncertain if it perpetuates itself.

For any indication of an external cause of arrest we look in vain ; it is not due to local conditions of soil, shade or crowding, as a half-dozen other divaricatus-forms grow with this under the same chestnut tree without showing the same arrest-tendency.

The bright, smooth surface, and clear green of the arrestleaves has year after year indicated their own healthy condition, quite equal to that of the non-arrested plants in their company.

To the inquirer as to the cause of the arrest which terminates a stem by the development of a flower, this obolarian form is of great interest, both cases being equally inherent.

Examples: N. Y. vic., Bryn Mawr Park at Palmer Av., chestnut, typical ocality (see FIGURE 4), I 896-1 905 ; brook-bank, Se. 17, ' 98 ; under Split Rocks, Se. 25, '97, '98; Park Hill, Oc. 10, '98; Mosholu, 8 in. high, Jun. 26, 1905.

\section{$* * *$ SPORTS}

Individual plants displaying some remarkable and unexplained peculiarity ; perhaps different examples are to be interpreted as

$a$, reversion to an ancestral character ; or,

$b$, saltatory variation, involving points of new departure from the type; due to unusually intense action of the tendency to variation [written in I 897 , before mutations had become so well accredited as now]; or, to

$c$, hybridization ;

$d$, alteration due to insect-puncture ; 
$\ell$, alteration due to fungal attack; or,

$f$, alteration due to some other unobserved local condition affecting the individual but not its neighbors. Such sports are the rare cases with one or more leaves bilobed; or opposite; or three at a node, etc.

Individual sports are not however the subject of the following enumeration of forms, which consist instead of numerous examples.

$* * * *$ LuXURIANt STATES, developed in rich or loosened soil ; marked by characters as follows :

I $^{11}$ Large leaves, even to $6 \times 31 / 2$ in. ; occasional.

I $^{12}$ Floriferous branches.

$I^{13}$ Great branches, long or straggling.

$I^{14}$ Great heads and narrow rays.

$I^{15}$ Great heads and broad rays (growing among plants with moderate heads). amples.

${ }^{16}$ Leafy inflorescence; otherwise normal; occasional ex-

I $^{17}$ Broad-wing petioles; the upper, or even all of them; the wing irregular and asymmetrical, or sometimes undulatiform; occasional everywhere.

Examples: Mass. (Middlesex Fells, Au., '98; Tashmoo Spr., Au. II, '90); N. Y. vic., and W. N. Y., '95, etc.; D. C. (Oc. 24, '9I).

$$
* * * * * \text { Diminished states due to exposure }
$$

I $^{18}$ SEA-SwePT state, exposed on dry hills to sun and swept by the sea-wind.

M. V., Harlock's pond slopes, rising but one inch from the ground, with about 6 short broad leaves $I \times 2 / 3$ in., and with about 4 heads nearly normal, but subsessile and with narrower bracts. Strigose hairs broader than in the type. Au. 10, '92.

I $^{19}$ Sunburnt state; erect plants, roughened and thickened, with longer leaves and bracteals, and increased puberulence. Roadsides, etc., common with the type.

$* * * * * *$ Diminished STATES, IMPOVERISHed, and due apparently to poor soil or imperfect nutrition

$\mathrm{I}^{20}$ Little-leaf state, occasional; whole succession of leaves nearly alike, sometimes reduced to $2 \times \mathrm{I}$ in., but otherwise typical ; foliage unlike $A$. argillarius, in which the little leaves are generally still smaller, are broader than in the type and are differently toothed. Examples :

N. Y. vic., S. I., New Dorp, Britton in hb. Colu.

D. C., Broad Branch road, Oc. I3, '89, Bu.

$I^{21}$ Little-head state, otherwise typical, but with small inflor- 
escence of heads $1 / 4 \mathrm{in}$. high, $5 / 8 \mathrm{in}$. broad; the involucre $1 / 8 \mathrm{in}$. high or but little more, deep-green chequered. Examples:

N. Y. vic., 1830 ? Torrey in hb. Colu.; N. Y. vic., Se. 14 , ' $98, B u$.

$\mathrm{I}^{22}$ Dwarf long-leaf state, plants otherwise typical ; occasional.

${ }^{23}$ Dwarf broad-leaf state; plants 6-9 in., high, with acute leaves I I $/ 2 \times$ I in., obtuse radicals, purple disks and stems, and large heads $\mathrm{I}$ in., across, with rather narrow bracts. Examples:

N. Y. vic., Inzoood, Se. 27, '97, halfway up the north slope of Dyckman Av. rock.

\section{$* * * * * * *$ Dininished STATES CHOKED by growth in dense masses}

$I^{2+}$ Slender state otherwise typical, occasional.

I $^{25}$ Pauciflore state, of wet woods, in excessive shade ; growing tall and narrow, though not always in dense masses; flowers of full size or more with about 8 rays: disks turn purple; stem very slender, greenish, highly zigzag; leaves well separated, normal below, soon greatly diminished and lanceolate, subentire and subsessile.

N. Y. vic , Mosholu zoood's, Se. 30, '96; so continuing '97, '98, etc., and 1905.

S. I., Princes Bay', Oc. Iо, '96.

D. C., Pierce's Mill Brook, Oc. I6, '91.

$\mathrm{I}^{26}$ Monocephalous state, a modification of the last and often growing with it, with more flexuous stems, tall and persistently leafy with little diminution to the single head; in dense patches in rich dark wet woods: plainly the result of mutual interference; the virgate stems ascending I 5 in. toward the light to bear a single flower-head; or varying to a single little cluster seated among the long terminal leaves. Examples:

N. Y. vic., Mosholu, Se. 30, '96; Woodlazen woods, Se. 16, '98.

W. N. Y., Pt. Gratiot, Au. '97, '98, etc. ; Fredonia, at Marsh's woods, Au. '97, and Wiley's brook, Au. 9, '98.

\section{$* * * * * * * *$ Explicable miscellaneous states, assign- able to definite cause, but not greatly increased or diminished in size}

$I^{27}$ Slant-stem state; plants leaning forward into the sunlight from growth about the base of bushes or about fence rails; angle about $30^{\circ}$ from the vertical. Common along roadsides, especially W. N. Y., where it usually shows an increase of hair and roughness, giving it a dusty appearance due in fact less to roadside dust than to puberulence - sometimes all the plants filling thin woodlands will assume a uniform slant at this angle of $30^{\circ}$, apparently in consequence of a prevailing wind. 
I $^{28}$ Etiolated state; with pallid leaves and disks, long weak assurgent or decumbent protracted stems and capillary pedicels; plants under wooden steps, etc., seeking light.

I $^{29}$ Subscandent state; tall, narrow but not virgate; leaves thin, smooth, apple-green, of normal form or some lanceolate.

N. Y. vic., Inwood, Se. 24, '96, etc. ; numerous plants growing out of cracks in perpendicular faced gneiss and growing straight up along the rock wall, with remote inflorescences along the stem from the middle and lower axils; in sun.

I $^{30}$ Depressed state; prostrate, decumbent or geniculate, due to growth after trampling, in pastures; and in clearings, after the work of axmen.

W. N. Y., Fredonia, Au. '97 ; Silver Cr., Hanover Centre, etc.

N. Y. vic., New Rochelle, etc.

$* * * * * * * * *$ UNEXPLAINED FORMS of Aster divaricatus L., of uncertain permanence, inexplicable by the preceding explanations, and evidently due in part at least to a tendency to

vary independently of the immediate environment;

the plants not being individual sports but of numerous examples. To be classed as

Leaf-variants, Stem-variants and Inflorescence-variants

- Leaf-variants ; forms varying in many ways, but in which the variation in the leaves is particularly conspicuous.

$I^{31}$ All-Cordate form; leaves cordated to the small inflorescence; otherwise normal.

N. Y. vic., Mile-Square road, spring, Oc. 26, '87.

I $^{32}$ NoN-CORDATE form; leafy and floriferous; stem purpleblack, $2 \mathrm{ft}$. high ; leaves somewhat ovate, acuminate, coarsely and remotely slit-toothed, and nearly as much so to the cuneately attenuate base; bracts greener, mostly acutish, little ciliate; heads larger, pressing into a large dense dome.

N. Y. vic., Gunther Park, on rock-pile by roadside, Midland Av. corner of Mile-Square road.

I $^{33}$ Oblong-LEAF form; slender long-leaved irregular plants, apt to produce a few flowers and leaves in the lower axils. Leaves oblong-acuminate, often $4 \times 1 \mathrm{I} / 2$ in., straight-serrate or sharpserrulate, dark green, slender-petioled. Axiles $3 \times 3 / 4$ in. or less, lance-acuminate, tapering straight from near the short-winged or sessile base. Almost all bracts bevel-tipped.

N. Y. vic., Tarrytown, opposite Sleepy Hollow cemetery, numerous and straggling among bushes, Se. 24, '98. 
$1^{34}$ Oblong-ovate form; thinnish firm oblong-ovate leaves, finally oblong-lanceolate, nearly uniform in size and shape to the small bunchy inflorescence. Leaves $5 \times 2 \frac{1}{2}$ in.; or $3 \times I$ in. on smaller plants; not deeply toothed, not much acuminate; all nearly sessile by short broad wings at the rounded base; or only the upper ones so, and the others with increasingly long slender petioles, or sometimes with a narrow strap-wing 2 in. long. Heads well-pedicelled. Sinus well-developed, or at least vestigial at the base of the stem. - Scattered plants, in woods.

N. Y. vic., Washington Heights, '97; Yonkers, n. w. corner of Palmer Av. Rocks, Se. I6, '97; S. I., Grant City flatwoods, Oc. 17, '96.

W. N. Y., Laona, springy bank, Au. 22, '96.

I $^{35}$ Conduplicate form. Narrow-leaved slender subpinnate plants with slit-toothed attenuate conduplicate axiles. Slender plants, about $2 \mathrm{ft}$. high. Leaves peculiar, all small and nearly alike, $2 \times 3 / 4$ in., oblong-acuminate with brace-base and shortslender petiole; a few above lose the cordation, having an abruptly rounded base, with short broad wing. Axiles similar, numerous, linear, acuminate, $2 \times 1 /+$ in., or finally shorter, not quite sessile, remarkable for their continuous conduplicate tendency, clasping and concealing the peduncle. Margins persistently and finely slittoothed, or in some very lowest leaves more irregularly serrulate. Inflorescence somewhat pinnate, with prolonged axis from which the long lower branches rise into a broad convex cyme. Bracts narrow, with little color, polymorphous, the apex truncate, rounded, bevelled, acute, or tapering.

M. V., Gayhead at Blackwater Knob, Se. 6, '98, among huckleberry bushes in pure sand over clay.

$I^{36}$ Russet-Tuft form. A short-leaved much-branched form, dull-green turning russet, forming masses in thin woods on gneissic rocks, with brown or pale stems, long flagellate and leafy ascending branches, short ovate leaves, and widely divaricate small dull heads.

Stem 2 or $2 \mathrm{I} / 2 \mathrm{ft}$. high, pale or brownish, ascending, seldom strictly erect. Branches irregularly flexuous-ascending, sometimes as many as 20 and bearing in all as many as I 50 heads; often half a dozen branches are 6 to 10 in. long - before their own branchlets begin. Sometimes 400 heads have been found on a single plant.

Leaves not large nor long, ovate, short-acuminate, but little incurved, the lower 6 or so with slender petioles and moderate cordate base with prominent sinus. Middle and upper caulines ovate without sinus, their petioles short and broadly winged. Axiles similar to the last, even in size; but sessile, $3 \times 1 \frac{1}{2} \mathrm{in}$. or less. 
Rameals broadly sessile, ovate-triangular, acute, $11 / 2 \times 3 / 4$ in. or less, very conspicuous and numerous. Ramulars inconspicuous, ovate to suborbicular, small and subentire, clustered closely together at the base of long subultimate branches.

Teeth conspicuous on all but the last, acutely salient, chiefly aquiline, rather close-set.

Leaf-substance firm, sometimes slightly roughish, color dull brownish-green; the autumnal change to russet or to dull brown occurs all over the leaf or in patches. Radical leaves thin, short or roundish, cordated, strongly toothed, $2 \mathrm{I} / 2 \times 2 \mathrm{I} / 4 \mathrm{in}$. or less.

Bracts not truncate, chiefly narrow-lingual, pale, little ciliate, smooth-backed, the green tips slight and indefinite. Lower bracts broad, rounded, a very few acute, innermost bracts prolonged, narrow, obtusish, hardly attenuate.

Heads small, $\frac{6}{8}$ to $\frac{7}{8}$ in. broad, $\frac{5}{16}$ in. high. Pedicels long, slender, distinct, $\frac{1}{4}$ in. to $\frac{1}{2}$ in. long. Rays thickish, dull white, becoming dingy. Disks turning reddish-brown and soon fully brown.

-Low, broad-branched plants of dull brownish-green aspect, rather late flowering and conspicuous in October; partial to thim soil over gneiss, under moderate shade of high or thin trees, tending there to form patches occupying the ground to the exclusion of anything else; also scattered in clefts of gneiss boulders, and upon sandy spots among rocks and quarries. Rootstocks pale; young spring-growth deep purple, as the under side of the ovateacute radicals long remains. Most typically developed on the Potomac banks, as to russet-changes, roundness and non-ciliation of bracts ; and abundance of large rameals. Intermediate in many respects between $A$. divaricatus, $A$. arcifolius, and $A$. ardens. Examples :

N. Y. vic., Central Park, Se. '95-I903; Inwood, Se. 22, '98; Ft. IV'ashington, Se. 30, '98. Yonkers, Hillview rocks, Se. I5, '97; Dunwoody, culvert brook, Se. 13, '96-1903, sometimes showing great' ${ }_{i}$ masses of beautiful dull white in profuse bloom; Tarrytown, opposite Kuykuit; and along the Bedford road near the Law place, Se. 24, ' 98 .

N. J., Undercliff, Se. I2, '98.

Va., Potomac bank, Oc. 20, '88; opposite Analostan I., Oc. I5, 'SS, in patches, my original locality ; Windy Gap road, Oc. 2, '88; Spout Run, Oc. 2, ' 88 , Oc. 29 , ' 88 , Oc. 9 , '9I.

$I^{37}$ STALK-LEAF form; plants of moderate size and inflorescence, their leaves continuously petioled well up to the inflorescence or within it.

N. Y., Catskills, Hunter, Se. '99.

$I^{38}$ Attenuate form, all parts long and attenuate, plants weak and wandlike or decumbent, internodes as well as leaves greatly lengthened.

N. Y. vic., Sleepy Hollow road, opposite cemetery, Se. 24, '9S. 
I $^{39}$ Long-Leaved straight-Tooth form. Numerous long narrow sage-green leaves, narrowly ovate-lanceolate, incurved-longacuminate ; sinus slight and short ; slender petioles persistent ; teeth long, straight-backed, forward-directed, almost continuous from sinus to apex. Heads very many and small ; bracts rather narrow.

N. Y. vic., Bryn Mazur Park, Se. 19, '99.

I $^{40}$ ShORT-LEAF BROAD-SInUS form, intermediate to $A$. arcifolius. Numerous dark short and small leaves of cordate-ovate type; apt to be asymmetrical, and with short decisive acumination; sinus broad and excavated, then brace-bases succeed, sometimes with a few narrow sinuses; upper caulines rounded or truncate at base; petioles short, persistent; narrow wings frequent; texture a little thickish; inflorescence small, with early arrest of main axis; bracts rather narrow.

N. J., Palisades, numerous; Undercliff, Se. I4, '99.

$I^{41}$ BROAD-HEART form. Leaves dark dull green, of broad short cordate type, merely acute or in less distinct plants slightly caudate; sinus deep, broad, rounded or almost rectangular; texture thickish; upper caulines lanceolate with short wing; inflorescence small, dense; heads small; rays 8 or more, even to I 3 , short, $1 / 4$ in. long; disks soon brown; bracts very stiff and with no scarious margin.

N. Y. vic., Bryn Mawur Park, Se. 16, '99-1903, on Palmer Av. Rock, a dense little patch now almost destroyed (Se. I g04); Inwood, Oc. I3, '99.

IV. N. Y., Fredonia at Cascade Brook, '98.

I $^{4}$ BURNISH-LEAF form: plants more slender and wirystemmed than typical $A$. divaricatus, with rather large, smooth, bright green, long-acuminate leaves of very thin firm texture and hard shining surface.

Va., Potomac, Spout Run, etc., Oc., ' 88.

I $^{43}$ SleEK-leaf form; weak-stemmed or decumbent plants with dark green oblong-acute leaves of peculiar soft smooth cool texture.

N. Y. vic., McLean Av., near Caryl, Se., 98.

I $^{44}$ Limp-LeAF form; small assurgent plants with brownishgreen coarsely forward serrate leaves which are flaccid when fresh, with brace-sinus (except some lance leaves), long incurved acumination; and with remotish clusters of subsessile heads, in which it resembles $A$. divaricatus cymulosus.

N. Y., Phoenicia, thicket on Esopus Cr., Se. 9, '98.

$* * * * * * * * * *$ UNEXPLAINED STEM VARIANT FORMS in which some character of stem or habit is conspicuous

I.5 Circaean form. Small thickly congregated plants, resembling Circaea alpina in size, leaves, habit and habitat, in mucky 
soil under trees. Leaves pale green, often approximate, very thin. Very little hair. Disks pale yellow turning brown. Rays about 6.

W. N. Y., Chautauqua Co., Pawpaw grove in Sheridan, Au. 15, '96, '97, '98, etc., type locality, with hundreds of gregarious plants 6-9 in. high, each with 3 or 4 little long-pedicelled heads or sometimes a close cluster, and 3 or 4 long-petioled large leaves $4 \times 21 / 2$ in. or less. Not seedlings, but closely cespitose on account of the shortness of the rootstocks, which rise into the erect plant after a growth of 4 or 5 nodes in little over an inch.

W. N. Y., Hanover, Rosebrook woods, Au. I900; Dunkirk, I't. Gratiot, Au. II and 21, '97.

N. Y., Schenectady Co., Niskayuna woods, Se. I1, ' 89 ; Catskills, Askin's Mt. near Hunter, Se. 9, '99. Ithaca, '84, Coville, no. 296231 in U. S. Nat. Hb.

N. Y. vic., I'an Cortlandt Pk., Se. 1903.

N. J., Palisades, Undercliff, Oc. 5, '99, 1900.

$I^{16}$ BEECH-Twig form. Small plants with stiff zigzag brown stems (about I ft.), and firm broadly ovate leaves, with winged petioles above, the lower leaves with deep sinus. Teeth shallow, remote, directed forward. Heads small, obconic, in a few small axillary and terminal clusters. Hair nearly absent. Bracts few, nearly uniform, pale, thick, the lower acute. Bracteals of the discule type, $i$. $e$, reduced to little flat or crisped circular disc-like bractlets, about $\frac{1}{16}$ in. diameter, obtuse or acute, about twice as numerous as the heads, subtending many empty nodes. Leaves turning russetbrown, their veins darker, general effect much like a beech-twig; to which effect the shape and uniformity of leaf, denticulate form of teeth, and an occasionally conduplicate leaf, all contribute; as well as the narrow straightish veins, prominent on the upper side, and not so strongly curved as in most congeners. A sport? or a depauperate and temporary condition?

D. C., Rock Cr., deep woods above Blagden's Mill, Oc. I 2, '88.

I ${ }^{47}$ Prune-stem. form. Small wandlike scattered or clustered I lants of middle September, with small domed long-pedicelled inflorescence, taper-lanceolate high-petioled leaves, and swaying flexuous prune-colored stem. Leaves very pale beneath, the upper distant, narrow, long-tapering, obtusely serrulate. Inflorescence small, rather close, with convex top and small heads. Bracts obtuse, the inner narrow and often purple-edged, the back moderately puberulent; the tip indefinite, pale, slightly developed or often none.

Differs from typical $A$. divaricatus in its prune stem, its wand effect, its small close inflorescence, its tendency to long pedicels, its less suddenly acuminate leaves, its smaller and closer teeth.

Differs from $A$. divaricatus cymulosus especially in its long pedicels and its longer narrower more taper leaves. Resembles the last, to which it is intermediate, in its small and somewhat close single-tuft inflorescence. 
Resembles $A$. olivaceus in its tendency to purpled scarious inner bracts of long narrow form. Differs in having long pedicels, obtuse roundish-topped outer bracts, triangular-lanceolate leafform, and single-dome inflorescence-form.

This Prune-stem form may include the native original of $A$. corymbosus $\%$ Aiton, Hort. Kew., ed. 2, 5: 57. I8I3, there characterized simply as "caule purpureo. Purple-stalked corymbed Starwort," in distinction from his var. $\beta$, "caule viridi," which probably represents typical $A$. divaricatus. (See supra, 65.)

The types of both $\alpha$ and $\beta$ are preserved in Herb. Brit. Mus. (Nat. Hist.), and Mr. Edmund G. Baker, in litt. I 898, remarks of \% that "Clayton's $767[A$. Claytoni $]$ resembles $\alpha$ in that it has a purple stem, but the heads of flowers are slighty larger and the character of the inflorescence is different. In A. corymbosus Aiton $\alpha$, the capitula are nearly all turned upward, while in the Clayton plant they, or some of them, turn downward."

The above characters, purple stem, smaller heads and nearly all turned upward, are strongly characteristic of the Prune-stem plants.

Examples (chiefly in woodland borders and paths):

Ct., East Windsor Hill, 1878 , Rosa B. Watson in hb. Bu.

N. Y. Cy., Washington Heights, Oc. Io, '98; June 26, '97, one foot high, in leaf.

N. Y., Catskills, Kaaterskill Junction, in numbers, Se. 7, '99.

W. N. Y., Silver Cr., frequent, '97-1903.

N. J., Palisades, ridge, abundant, Se. I5, '97.

$I^{48}$ Flabellate form. Main stem weak and deliquescent, rapidly diminished from node to node after giving off about 4 branches. Branches erect, ascending, longer than their parent-stem, slender and of quite uniform length. The whole inflorescence presses into a convex top with deep acute base. Stems smooth, sometimes shining, purplish-red. Leaves broad-based, somewhat ovate, with little cordation, rather small, their teeth very uniform and rather slight. Slender petioles continue into the inflorescence. Upper axiles and rameals oblong-lanceolate, sessile: ramulars oblongelliptic or oblong-acute, with long low minute teeth; some axiles develop short broad wings. Leaf-texture firm, nearly smooth to touch.

N. Y. vic., Bryn Mazur Park, at Split Rocks, Se. I 7, '98, unstimulated plants in hard thin soil, I to $1 \mathrm{I} / 2 \mathrm{ft}$. high, with subremote heads. Stimulated plants, Oc. $2 \mathrm{I}$, ' 98 , in loosened gravel by a newbuilt house, close to the preceding plants, showed interesting effects in their greater inflorescence and more profuse rameals. These plants were not traceable distinctly the next season or afterward and were probably trampled out. Virescence was strong by Oc. $2 \mathbf{I}$; their rays light greenish-yellow and 
their disks were fading brownish from olivaceous; many rameals were without flowerheads and were of short oblong-acute form, with about 3 low teeth on each side. In other plants which made a later start, the same quick suppression of axis was observed, but the short branches growing each only about twice the length of its axile leaf, the effect became pinnate rather than flabellate : producing a long narrow inflorescence, of 8 or 9 suberect axillary clusters each about 4 in. high.

Comparing the stimulated plants with those in hard thin unloosened soil: the stimulated show greater size and vigor, much more prolongation of branches and internodes, more redness of stem, more smoothness, and closer teeth. Both show the leafy convex inflorescence with early suppression of axis.

Other forms of $A$. divaricatus may occasionally produce flabellate plants, where the fan-like branching is due to accidental suppression of the main axis, and to the rise of several branches in its stead. Flabellate branching in these plants is the exception and suppression of the axis an accident; but in the flabellate form both seem the rule. The virescent rays were probably a late autumn result which might not have become conspicuous in a succeeding autumn of different weáther.

${ }^{49}$ Axilliferous form. Small subsessile or loose inflorescences in the axils, descending well down the stem; terminal inflorescence much larger and earlier, the others seeming like a downward retreat of the impulse to flower : nearly normal otherwise. - Examples :

Palmer Av.

N. Y. vic., Bryn Mazur Park, Se. I 7, '98, Oc. I, '98, '99- I903 near

W. N. Y., Pt. Gratiol, Au. 29, '96.

$\mathrm{I}^{50}$ Toвyнansa form. Plants with prolonged slenderness of the strict stems, branches and pedicels, small crowded heads in a flattish or irregular corymb, and lingual bracts with definite and conspicuous green tips. Unlike $A$. divaricatus $\mathrm{L}$., in often showing a flatter top, a high angle, for branches of $70^{\circ}$ or $80^{\circ}$, and in its more uniform bracts. Involucre often quincunx-chequered. Stem often purplish, $2 \mathrm{ft}$. or less, smooth. Leaves small, serrulate, glabrate, with narrow short-petiole which is soon obsolescent among the branches. Caulines broad cordate-oblong to lanceoblong, the base with a small sinus or becoming subtruncate. Branches and pedicels attenuate, heads approximate, small, $1 / 4 \mathrm{in}$. high and $7 / 8$ in. broad or less. Rays 8 or less, linear-oblong. Disks turning brown. Pappus ecru at first, and I 6 years later, in I 897 , had become ferruginous. Bracts glabrate, pale brown with large definite dark green tips, these constituting an important distinction between this form and its congener the Prune-stem form.

Penn., Tobyhanna Falls, Monroe Co., Au. 22, $188 \mathbf{1}$, T. C. Purter in hb. Penn., hb. Colu., hb. Bu., etc., - at first as $A$. corymbosus gracilis, n. var., later changing grasilis to strictus (a name already bestowed on an Aster in $18_{74}$ by Pursh) and later again to altior. In $\mathbf{I} 900$ Prof. Porter remarked that he no longer thought the form to deserve rank as a variety. 
$* * * * * * * * * * *$ UNEXPLAINED INFLORESCENCE-VARIANTS;

forms not due to immediate environment, and having some strong peculiarity in the inflorescence.

$I^{51}$ BROAD-RAY form. Plants with broad, short, dark, coarsetoothed leaves, broadly divaricate inflorescence, and broad heads with unusually broad rays and bract-tips, the latter mostly abruptly truncate. Rays about 7 , over $1 / 8$ in. broad.

N. Y. vic., Bryn Mazur, Se. 6, '99, on Palmer Rocks.

$I^{52}$ ThreE-RAY form. Peculiar plants with few large thin smooth dark-green leaves, an attenuately forked inflorescence with many large lanceolate bracteals; and very imperfect heads occasionally of 6 rays but usually with about 3 long rays and the others wholly or partly abortive. Leaf-form oblong-cordate, incurved-acuminate, with very large broad brace-base, the upper truncate, the axiles lance-oblong, tapering almost equally to the sessile base. Otherwise the petioles are very long and slender.

N. Y., Kaatersksll Min., Se. 7, '99, in shade.

I $^{53}$ FIVE-RAY form; a small little-leaved form with small heads chiefly 5-rayed; the first head of each branchlet bears 6 , the one or two lateral heads 5 . Plants cespitose, I I $/ 2 \mathrm{ft}$. high, glabrate. Leaves thin, apt to be continuously petioled. Rays oblong, blunt at the minutely three-toothed apex.

Ms., Taconics at Sky Farm, Se. 5, 1903.

I $^{54}$ Canaliculate form. Rays horizontal, linear-canaliculate, their sides being early and continuously upcurved. Leaves thin, sinus and petiole continuing well up to the loose inflorescence. Bracteals rather large, ovate-acute. Bracts very abruptly truncate or bevel-topped, broad and short, thin along the pale edges, thickened along the middle and the short dark tip. Stem apt to be pale green, $2 \mathrm{ft}$. or less, and zigzag.

N. Y. vic.,"Bryn Mawr Park, common in rich shade, forming loose patches; Sè. 16,'99, 1900, 1901, etc. ; increasing, 1904.

- Many other forms of the Divaricati and Macroplyylli occasionally lose the flatness of the rays with age, the margins becoming upraised; but in this present form the canaliculate stage is the principal one, the rays remaining flat for scarce any time, perhaps from greater delicacy of their thin texture.

$I^{55}$ Cupreous form. Rays persistently change from dull-white to coppery-red year after year. Stem strong, greenish, highly zigzag, about $2 \mathrm{ft}$; ; branches stiff, wide spreading; bracts highly ciliate, mostly truncated obtuse, as in $A$. divaricatus type. Leaves (except in larger size, earlier growth and deeper color) like those of the Russet-tuft form, with which it grows and from which it 
may be a derivative. Disks deep red-brown in nature, deep crimson in drying. Copper-color in the rays appears in about a week after expanding, and remains two or three weeks, when the rays become marcescent; and even in this shrivelled state they retain much of the copper-red color. - For color comparison, see also pp. 24-27.

N. Y. City, Central Park Ramble, throughout September, 1897-1903. Development; Apr. 6 (1900, and so I899), basal leaves I in. long, very dark copperymaroon beneath, somewhat so above; much darker and more lustrous beneath than ad. joining similarly shaped leaves of the Russet-tuft form, and of typical $A$. divaricatus. In 20 days, Apr. 26 , the red had faded entirely from these leaves above and was disappearing beneath; the leaves were now full grown, 2 and $21 / 2$ in. long, with broad excavated sinus. For seven years that this group was under observation it maintained its characters exactly, standing out year after year with copper-colored heads though surrounded with white ones. After blooming in 1903 most of the colony died, especially the central cupreous plants; only one or two sprouts from the cupreous form came up in 1904 (and again 1905), bearing feeble and faintly cupreous inflorescence.

I $^{56}$ White-DISK form, with disks whitish or after drying pale cream-color. Stem very dark plum-color, flexed, slender, i 2 to I 5 in. Leaves long, dull dark green, firm, dense, opaque, smoothish. Leaf-form oblong-lanceolate, the 4 or 5 lower ones so, abruptly rounding into a broad shallow sinus, the small close teeth continuing upon the long acumination. Other leaves oblongelliptic or lance-elliptic. Narrow petioles continue into the inflorescence, quickly diminishing, the lowest ones I inch long, most others only $\frac{1}{4}$ or $\frac{1}{5}$ in. Leaves serrulate, subrugose beneath while fresh, not so when dry. Inflorescence small, few-flowered, about IO divaricated heads on capillary pedicels $\frac{1}{2}$ to $\frac{2}{3}$ in. long, with linear bractlets. Heads very small, $\frac{1}{4}$ in. high, $\frac{3}{4}$ in. broad or less ; disks finally turn a dingy pale brown. Rays 6 , sometimes 7 , oblong, milk-white; pappus very white. Bracts uniform, smoothbacked, rounded at apex, white-ciliate all around, with a dark definite crescentic tip; the inner ones pale, scarious, without green tip.

N. Y. vic., Bryn Marur Park, Summit Rock, Se. 16, '99, many plants. Ms., Taconics, Bashbish stream, Se., Ig03.

I $^{57}$ GREen-Disk form. Small plants with pale yellow disks turning pale greenish or olivaceous ; pedicels capillary, long and wellseparated; stems often green ; heads a little above medium size.

N. Y. vic., Bryn Mawr Park, Se. 25, '97, with Doellingeria infirma; Mosholu, Oc. 2, '97 ; Central Park Ramble, Se. 18, '97, small flowered plants with disks persistently 4 -flowered.

I $^{58}$ Stellarian form; scattered white star-like flowers on a dark background of close broad deep-green leaves, suggesting a 
star the more because the small and pale whitish-yellow disks do not change to purple and blend in color with the rays. Leaves uniform, short, roughish, dull deep green, with broad brace-bases ; veins much darker than the leaf. Inflorescence of few scattered heads ; or of more ; diffuse, and on long filiform pedicels often $3 / 4$ in. long. Bracts narrow, long, obtuse, chiefly with broad white scarious-frilled margins; ciliation and tip moderate. Surculi yellow or almost orange.

N. Y. Cy., Ft. Washington, Oc. 16, '98, Bi.

Ms., Taconics, near Bashbish R., glen below Parnassia meadow, Se. 5, 1903 ; alt. I, $500 \mathrm{ft}$.

${ }^{59}$ PURPle-Pappus state; pappus purplish or deep vinouspurple (in herbarium) instead of ferruginous or salmon-red, as is usual. Leaves very smooth and thin; otherwise nearly normal.

N. Y., L. George, '95, Mrs. Watrous in hb. Colu. ; Catskills, '8o, C. H. Peck in N. Y. St. herb. ; Catskills, Balsam L., Au. '86, Mrs. C. Van Brunt, in hb. Colu.

Va., Potomac R., east of Holtzman's Landing, Oc. 29, '88 (then deemed a hybrid with $A$. curvescens; from its smoothness, etc.).

$I^{60}$ LOOSE-FLowered form; plants in sunlight, where any explanation of the diffuse pedicels as due to reaching after light is disproved by the presence of close-flowered plants in the same patch amid the same conditions and equally mature.

N. Y. vic., Ravensdale road, Oc. 19, '96.

S. I., Clove L., Oc. I7, '96.

D. C., Piney Branch, Se. 22, '88, the "intermediate form A" of my preliminary study of ' 88 .

$I^{61}$ Mitchellian form; similar in other respects to typical $A$. divaricatus L., but with conspicuous growth of Mitchellian bracteals, i. e., bracteals resembling leaves of Mitchella repens in size and shape, $i$. $e$., the normally ovate-acute bracteals fail to develop their apical portion, about one third of the leaf, and become oval with obtuse or rounded apex, and remain subentire. Occasionally plants with both kinds of bracteals are found; but generally only one kind is produced on a plant and all plants from the same rootstocks are alike, while plants otherwise similar and growing within a foot or two produce the normal bracteals. Similar Mitchellian bracteals are occasionally developed in other varieties, and in beautiful profusion by $A$. divaricatus deltoideus. They are commonly darker, firmer and of richer tissue than the normal acute bracteals, and more conspicuous though hardly half the size. I have not been able however to prove them developed a second year from the same rootstock. It is doubtful if they are properly cases of arrested development. They seem never to occur on plants of the Mixed- 
leaf states, on which they would be expected if due to similar arrest. Widely distributed ; examples :

S. I., Grant City, Oc. 17, ' 96.

W. N. Y., Silver $C r$., Au. '96-1903.

Va., Potomac, east of Holtzman's, Oc. 29, '88; 'Spout Run, Oc. 9, '9r.

\section{I $a$. Aster divaricatus alatus (Barton) Burgess}

\section{BARTON's Aster}

Deep-cut wing-leaf plants with narrow bracts, the large leaves soon taper-based and sessile.

Name, L., from the frequent winged leaf-bases.

FIG. 5, plant from near Yonkers, N. Y., Se. 23, '99, in hb. Bu.; b, its characteristic cauline form, $d$, a frequent modification.

A. corymbosus alatus Barton, in Wm. P. C. Barton's Prodromus Florae Philadelphicae, 8I. I8I 5, repeated in his Compendium Florae Philadelphicae, 2: I14. I8I8.

Biotia corymbosa alata DC. Prodr. 5: $265 . \quad 1836$.

Plants 2-3 feet high, apt to be dark green and rather closely cespitose. Leaves large, often $5 \times$ $3 \mathrm{r} / 2$ in., thin, the lower often roughish, their margins coarsely gashed with strong sharp broad teeth, each tooth bearing the usual aculeus of the Biotian species. Sinus broad, soon lost, the middle caulines at least being without it, their bases tapering into a conspicuous irregular wing. Leaf-form cordate-ovate acuminate, then oval-acuminate, soon oblong-acuminate, finally oblong-lanceolate and sessile.

Inflorescence branched at a wide angle, with many little oval or ovaloblong rameals. Bracts chiefly pale, long, narrow and acutish; only

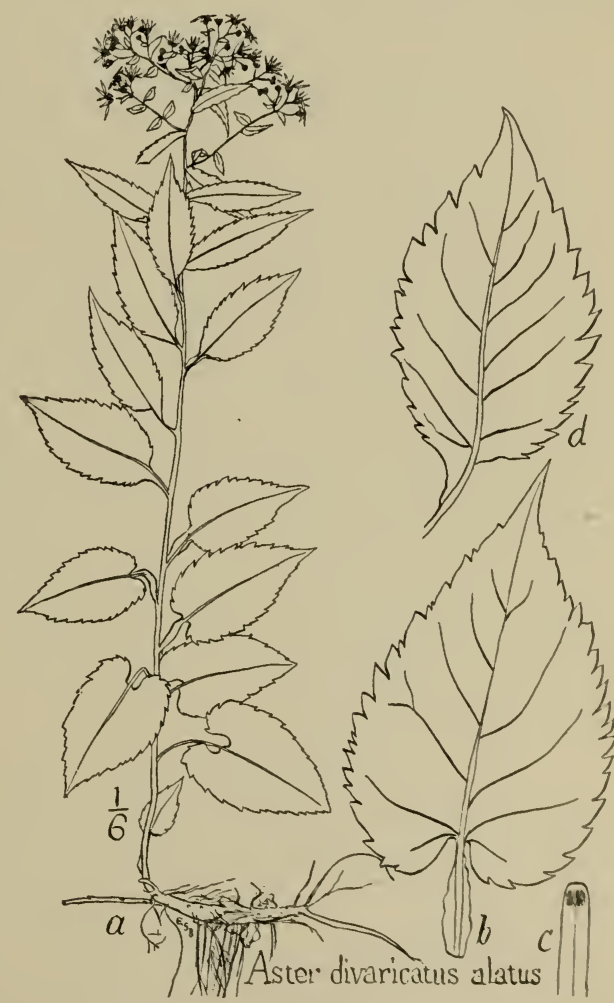

FIG. 5 . 
the outer bracts according with the type for $A$. divaricatus $\mathrm{L}$.; these outer bracts obtuse, and with conspicuously dark tips; the tips soon become small and often reduced to a medial line. Rays about 8 , dull white. Disks soon purplish brown. Hair little developed. Heads small, I in. or less broad, apt to be quite closely clustered, their pedicels not long, usually exceeded by the head.

Differs from typical $A$. divaricatus $\mathrm{L}$. in its narrower and pale bracts, its broad wings and its slight cordation. Winged forms of $A$. divaricatus $\mathrm{L}$. having broad bracts, connect the two.

Forms rather dense clumps, by stone walls or in rather damp half-shade. L. Erie and the Taconics to Philadelphia, and probably to be found accompanying the type through a wider range. Examples :

Ms., Mt. Washington, near Bashbish R., Se. 1903.

N. Y. vic., Washington Heights, '97; Vault Hill, I905. S. I., Grant City, Oc. I7, '96. Yonkers, Stony Lonesome on Summit Rock, Oc. 23, '99; Champenois Brook, stone wall, Oc. I 2, I 901 ; Hillview, I902.

W. N. Y., Laona, springy bank on Canadaway Cr., Au. 22, '96.

Penn., Phila., Barton, fide his Prodromus and Compendium, and fide specimen (top of a plant) preserved with Barton's label (reading "B. alatus mihi") in his Herb., deposited with the Phila. Acad. of Sci., as examined by me Nov. 1898 .

Va., Potomac opp. Washington, Se. '87.

I $a^{2}$ Gash-ivinged form of alatus; tall plants $3 \mathrm{ft}$. high, or weak and effuse; with many broad short gash-toothed wings along most of the petioles. Rays 5 (less often 6) narrow and elongated; unlike the broad short rays of the Five-ray form of $A$. divaricatus recorded p. I 24. The numerous thin leaves reach $5 \times 3$ in., the large size continuing well up into the inflorescence. The inflorescence itself is sometimes very large and the bract-tips very green. Examples :

N. Y. vic., Vault Hill, Oc. 18, '96, Bi.-Yonkers, Palmer Av. rocks, Se. 26, '96; Mott woodroad, Se. 26 , '96; and twin tree near the last, Se. 17, '98; Stony Lonesome, Se. 23, '99.

Va., Potomac, Roslyn at Aqueduct Br., Se. '87.

\section{History of A. Divaricatus alatus.}

The naturalist Benjamin S. Barton (I766-I8I5), does not seem to have recognized this form, though he collected the type, A. divaricatus L. on the Blue Ridge in Penn., in $\mathrm{I} 802$; his herbarium (deposited with the Phila. Acad. of Sci.) containing a specimen of the latter, labelled by him "A. corymbosus, North Mountain, I 802," fide Krout. 
His nephew, Wm. P. C. Barton (1786-1856) seems to have observed the plant alatus for some years before 18 I 5 , near Philadelphia, and the specimen in his herbarium (Phila. Acad. Sci.), bears the printed label :

"var. $\beta$ alatus [mihi], alb., foliis profunde et acuminate serratis, longe acuminatis, petiolis alatis ; Septembri."

The same words also formed his description in his Prodromus Florae Philadelphicae, I 8 I 5. In I 8 I 8, in his Compendium Florae Philadelphicae, 2: I 4 , his description appears in English, as follows :

" $\beta$ alatus. Leaves deeply and sharply serrated, long acuminate; petioles with broad wings, B.* $-A$. corymbosus $\beta$ alatus, Bart. Prodr. Fl. Ph. This is a permanent variety of the preceding, which I have constantly observed, not only in this vicinity but in other parts of the U. S. Grows with No. 15.† July."

The next appearance of the variety in print was in 1836 , in DeCandolle's Prodromus, 5: 265, as follows :

" $\beta$ alata (Bartl. [sic] fl. phil. 2, p. Ir4) petiolis latius et frequentius alatis. Varietas ex cl. auct. permanens."

With the above reference of DeCandolle the variety seems to have disappeared from notice. That its name alatus had not been already used between I 753 and I 8 I 5 is perhaps remarkable; the nearest approach to it before I 753 seems that of Cornuti, I 635 , who described Helenium autumnale as Aster luteus alatus.

It is to be noted that in I 8 I 5 and earlier, Barton regarded his variety (as well as the type) as a September bloomer; as indeed we still find it. In 1818 he changed his original date of September to July. He had probably discovered some July-blooming relative and thought it the same as his original September blooming plants. Very likely the July-flowering species was our present A. umbelliformis, which was already collected in that part of Pennsylvania, occurring as it does in Muhlenberg's herbarium, and labelled by Muhlenberg as " $A$. corymbosus."

That Barton's original alatus of I 8 I 5 was not founded on one of the slightly toothed July-and August-blooming curicscintes is indicated by his own character of 18 I 5 ,

"profunde et acuminate serratis,"

* B. was appended by Barton to his original descriptions.

$\dagger A$. divaricatus $\mathrm{L}$. 
and also by his flowering-time, "Septembri." It is confirmed by the specimen in Barton's herbarium so far as it goes. The specimen is an inconclusive fragment, some eight inches of the top of a small plant, unlike the curvescentes in the little oval rameals borne on its short branches. These, together with its other characters, agree with the occasional widely distributed narrowbracted wing-petioled form of $A$. divaricatus $\mathrm{L}$. with which it is here identified.

\section{ib. Aster divaricatus cymulosus Burgess}

Small plants with dense heads, short broad rays, and shorter less acuminate leaves.

Fig. 6 (= PLATE 2), a small N. Y. specimen in hb. Bu., with some lower leaves lacking, as usual at flowering time. follows :

A. divaricatus cymulosus Burgess in Br. \& Br. Ill. Fl. $3: 357$. I898; as

"Smaller, bearing a single dense corymb about 4 in. broad, or several smaller ones; the branches short, suberect; acumination of the leaves, sinus and teeth conspicuous; upper leaves much reduced; rays short, broad, chiefly $3^{\prime \prime}-4^{\prime \prime}$ long, sometimes laciniate. In grassy openings in woods, often in dense patches, N. E. and N. Y., to Va."

Stem erect or flexuously assurgent, about I or $\mathrm{I} / 2 \mathrm{ft}$. high. Leaves serrulate; or when sharply serrate, the teeth are few, coarse and rather straight, not upflung nor couchant. Sinus moderate or narrow. Inflorescence crowded into a single dense mass ; or less frequently compound, its well-separated cymules then brought nearly to a level. Bracts with long white terminal ciliation. Sept.-Oct.

Differs from typical $A$. divaricatus $\mathrm{I}$. and from the other varieties of that species, in its smaller and more dense-clustered heads and shorter broader rays.

Differs from vars. deltoideus and curtifolius in its longer leafform, with more incurved-acuminate apex; differs also from var. alatus in its smaller leaves and less frequent wings; and from var. fontinalis in habitat and lack of radicals as well as the foregoing characters.

History. The earliest known specimen seems to be that cultivated by Nees in his botanical garden at Breslau, and preserved before 1856 , in his herbarium, whence it eventually passed to the 


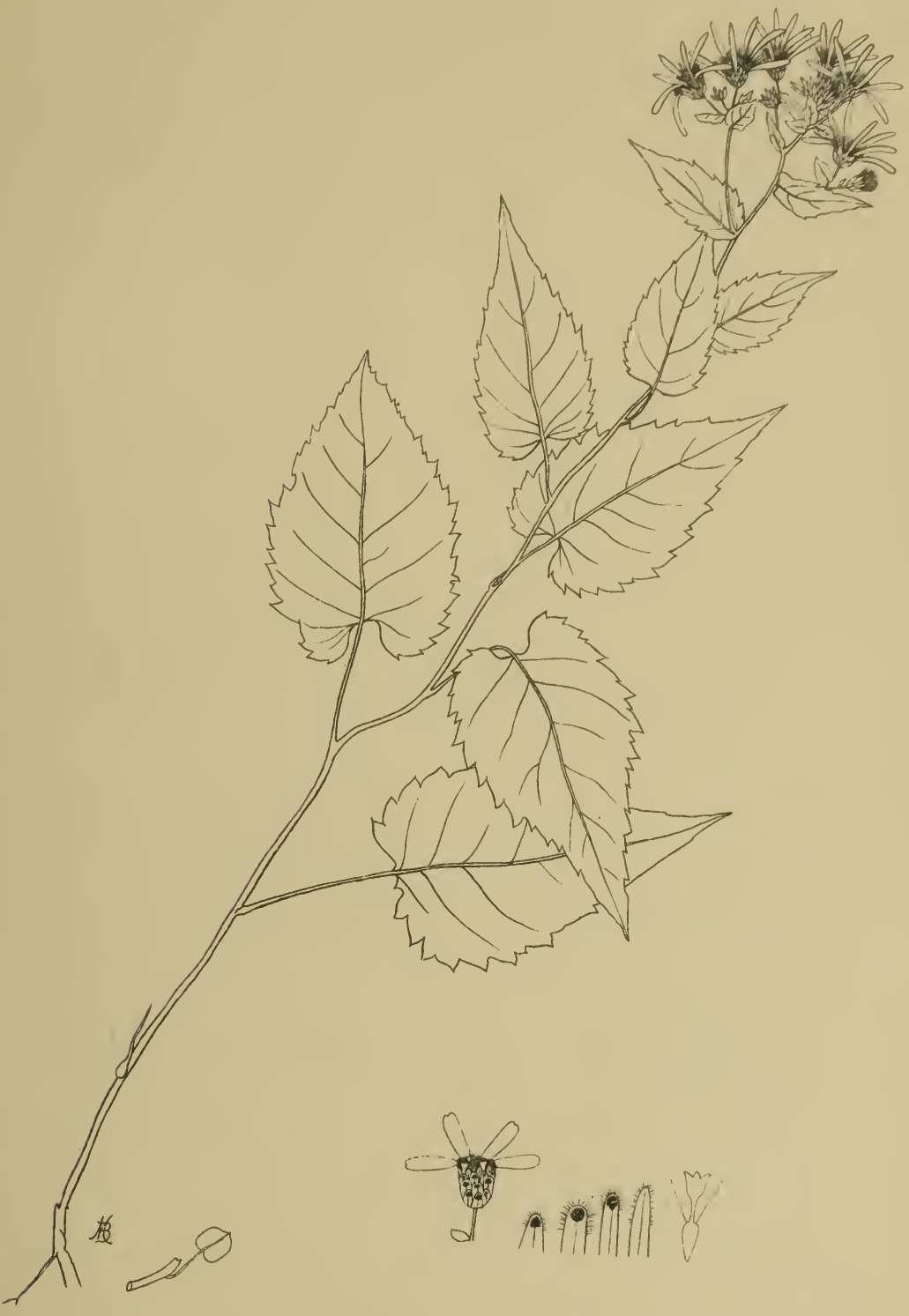

ASTER DIVARICATUS CYMULOSUS 

Gray Herbarium, Cambridge. This specimen formed a part of Nees' Eurybia corymbosa, being probably regarded by Nees as a small and unusually regular form of his typical corymbosa.

When I first distinguished plants of this variety in MS. in I 888 , I supposed them the A. glomeratus of Nees, because of the condensed inflorescence. Later I observed that their bracts, slender petioles, thin leaves, etc., could not be reconciled with Nees' description of $A$. glomeratus.

This variety seems next to have been distinguished by Prof. C. H. Peck, in I 890, fide specimen in N. Y. State Herb., of which he wrote in N. Y. St. Mus. Nat. Hist., 34th Report, 54 (publ. Oc. I 893$)$ :

"In the Catskills there is common with the type of $A$. corymbosus, a small form in open grassy places which has a dense corymb of small heads with short broad close rays sometimes exceeding 9."

Range. Probably accompanying the type throughout ; failures in reports of collectors may be from its being passed by with the impression that it is merely a poorly developed state of the type. I have collected it from Maine to Va., most abundant near N. Y. and Washington. Examples:

Me., Gilead, Se. I902.

N. H., Shelburne and Gorham, Se. I902.

Vt., Proctor, Se. 16, '99, E. Brainerd.

Ms., New Bedford, Clark's Neck, near the original glen locality for $A$. Herveyi, Se. I I, '97. Middlesex Fells, Au. I900. Taconics, to I,600 ft., Au. I90I, I903.

Ct., Salisbury, 1903. Lakeville, Au. I8, 1903. Stratford, Se. I3, '71, W. DeF. Day in hb. Canby.

N. Y. vic., Foot of I 7oth St., Oc. 6, '98; Mosholu, Furtherwoods, Se. 23, '98, Bi. ; Song Sparrow Hill, Oc. 22, '98. Yonkers, Dunwoody Seminary wall, Se. 26, I900; Hillview wall, Se. I3, '98; Stony Lonesome, Oc. 31, '97, Nov. I, '98. Bry'n Mazur Park by Fimbriatus-tree, Se. I4, '98, Se. '99, Se. 15, I900, Se. I901, 1902, I903; Stonewort Hill, Se. I 5, I900; Violaris-path, Se. 22, I900; brook-bank, Se. I7, '98; Split Rocks house, Oc. 21, '98; Bu.; woods, Se. 4, '98, Bi. L. I., Richmond Hill, Se. 27, '99.

N. Y., Catskills, Kaaterskill Junction, Se. 7, '99; Phoenicia, Se: 9, '99 ; Shokan, Se. '9o, C. H. Peck. Tarrytorm, Sleepy Hollow, Se. 24, '9S. Catskills, Sand L., and Dresden, Au., C. H. Peck in hb. N. Y. St.

IV. N. Y., Silver Cr., Au. 23, '99, Au. I903; Little Indian bank, Au. 24, '97 ; Little Indian Falls, Au. I3, '98; Brace Bay, Au. 15, '96; Sheridan, '96; Fredonia, '96-1903; Pt. Gratiot, '97, etc.

N. J., Guttenberg, brook, Se. 12, '98. 
Pa., Phoenixville, '96, W. K. Fisher; Susquehanna, '97, Jas. A. Graves. Md., Sugarloaf Mt., Se. 23, '93.

D. C., Rock Cr., Se. 29, '90, Oc. 26, '88.

Va., Potomac bank opposite Analostan I., original type locality, Oc. 20, '88; east of Holtzman's, Oc. 29, '88; above Chain Br., Oc. 9, '88. Carlin Spr., Se. I8. '93; Rhododendron Run, Se. I2, '86, H. W. Henshaw.

Va., Stony Man Mt., Se. 2, I901, E. S. Steele in N. Y. Bot. Gar. hb.

Hort. Breslau, I856, ex hb. Nees, in hb. Gray.

Hort. Berol., 1839, in hb. A. Gray.

N. Y., Bethlehem, Albany Co., Se. '99, C. H. Peck in hb. N. Y. St.

\section{ic. Aster divaricatus curtifolius Burgess}

Roundish-leaved blunt-dentate plants with strong erect red stems and larger heads.

Fig. 7 (= Plate 3), a plant quite typical, though less robust and erect and hardly as blunt leaved as in many specimens. follows :

A. divaricatus curtifolius Burgess in Br. \& Br. Ill. Fl. $3: 357$. I 898, as

"Stem erect, reddish, smooth, sometimes glaucous; leaves small, dull green, firm, ovate and orbicular to reniform, the sinus broad, rounded, the apex obtuse or apiculate ; inflorescence loose, flattish; disks turning purple; rays about 5 lines long; green tips of the involucral bracts conspicuous. In moist woods, N. Y. to Va."

Leaves smoothish or but slightly roughish, very pale beneath, blunt-dentate, the small apex often early withering or altogether obsolete (whence the name, L. curtus, cut oft), often $\mathrm{I} J / 2 \times \mathrm{I}$ in., their petioles short and slender. Axiles ovate, tapering to a narrow sessile base. Rameals oblong-acute from a broad sessile base. Ramulars apt to be very greatly reduced, suborbicular, often only $\frac{1}{10}$ in. across, close beneath the flower heads. Heads large, loosely borne; disks bright yellow, turning reddish purple; bracts very obtuse or truncate; receptacle finely fimbrillate; achenes smooth, faintly striate.

For differences from other short-leaved allies of $A$. divaricatus L., see $A$. circularis, $A$. mpicola, $A$. argillarius; also the Obolarian form of $A$. divaricatus, p. I I 3 .

Development. Young plants seen May I 3 ('99), had all leaves still subsucculent and one little reniform primordial remaining.

Examples :

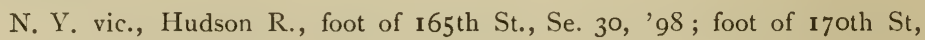
Oc. 6, ' 98 ; below Inwoud, Oc. I6, ' 98, Bi., Yonkers, Bryn Mawr woods, Se. 4, '98, $B i$., Park Hill, Oc. Iо, '99.

N. J., Palisades, above Undercliff, Se. 29, ' 97 ; one with 5 radicals, nearly circular, about $2 \mathrm{~cm}$. long; and 3 secondary leaves, oval-acute, with narrow sinus, $I \frac{1}{4} \times \mathbf{I}$ in. 


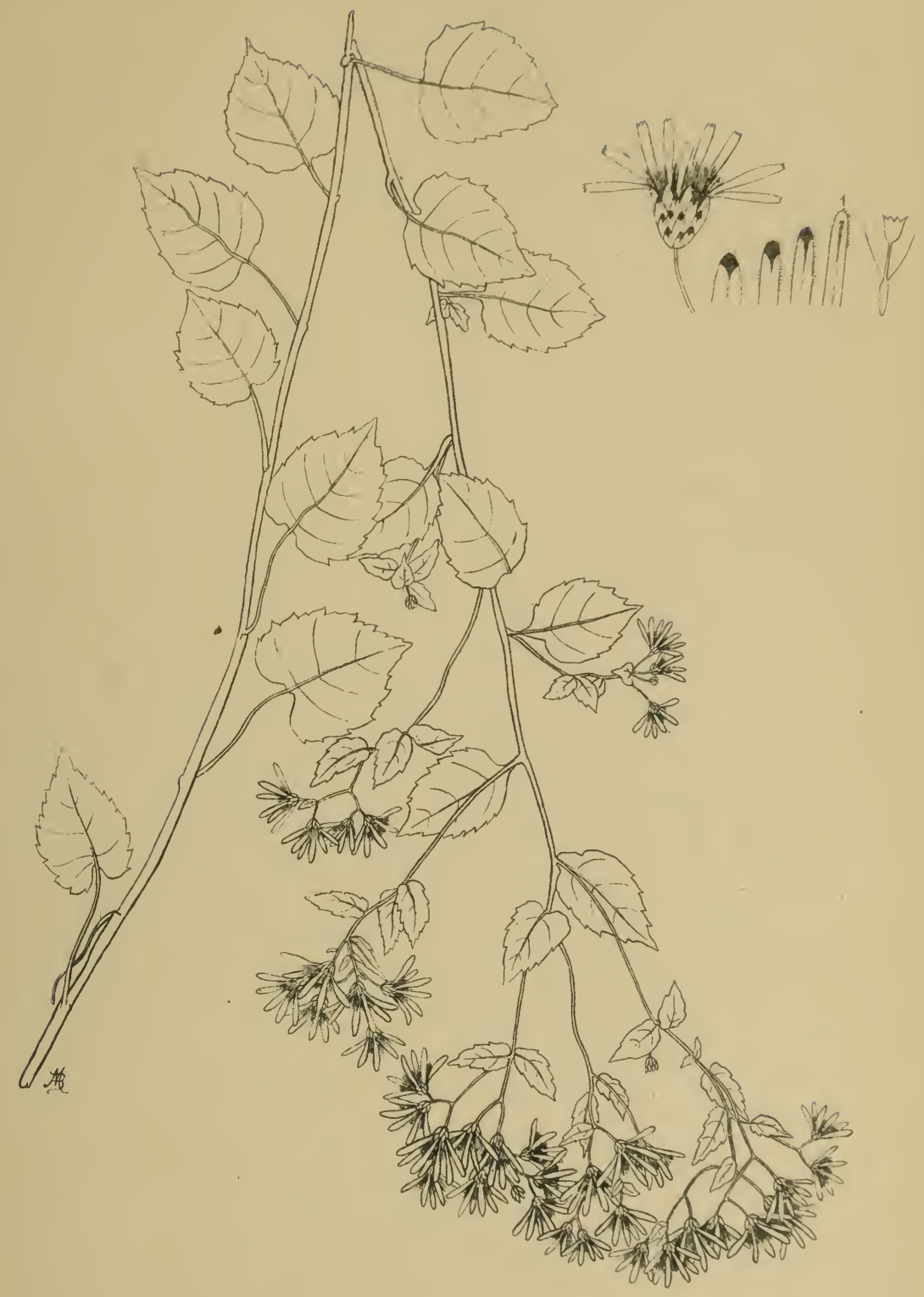

ASTER DIVARICATUS CURTIFOLIUS 


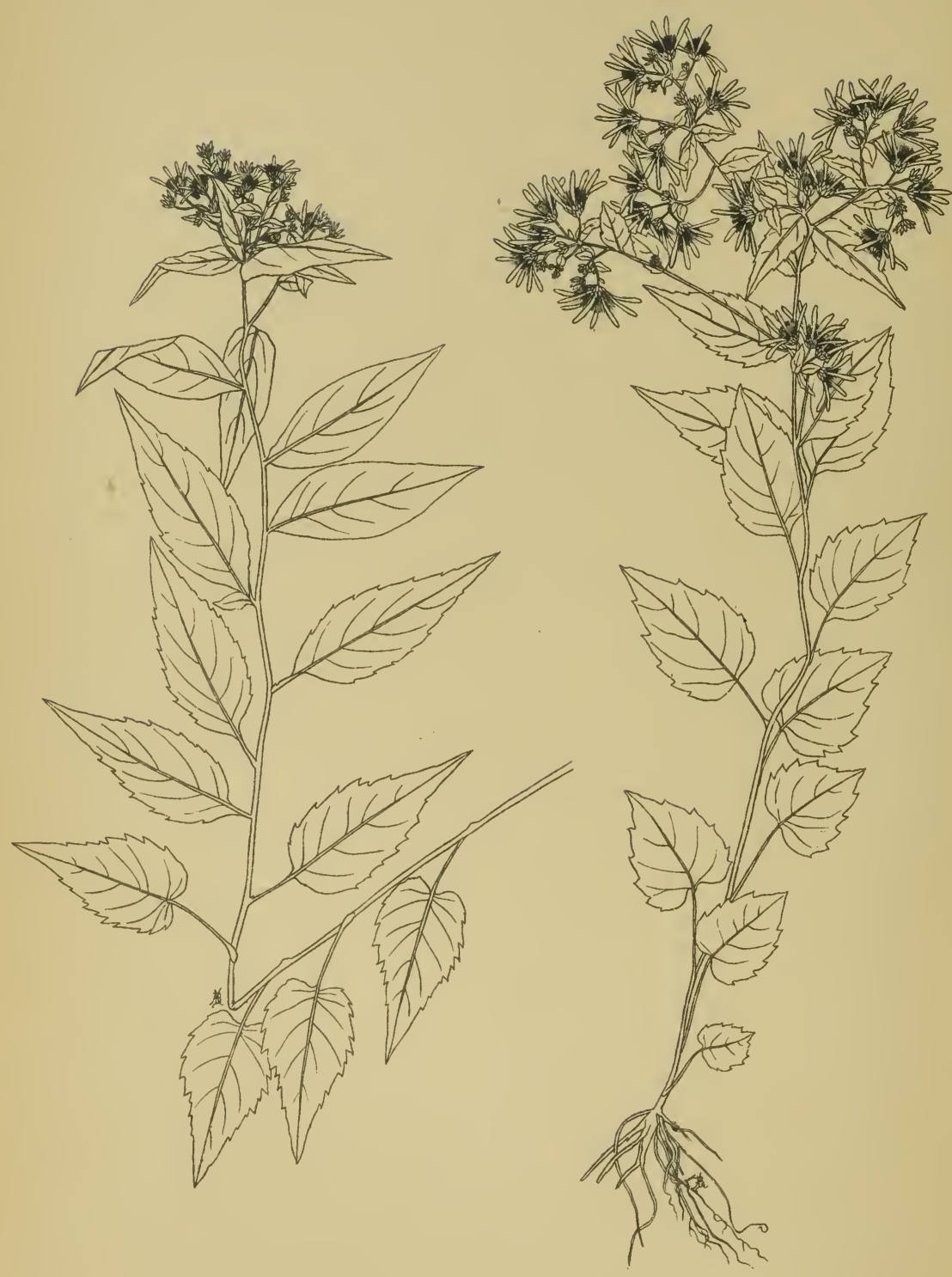
W. N. Y., Pt. Gratiot, Jul. 21, '96, in bud, unusually large robust plants, with purple glaucous stem, leaves large, $3 \frac{1}{2} \times 3$ in.; Au. 21 , '96, with rays broad, 8 or I0.

Va., Potomac, at Spout Run, Oc. 2, '88, type in hb. Bu. ; among bushes near the river-bank; also east of Holtzman's Oc. 29 , ' 88 , leaves to $3 \times 21 / 2$ in., and opposite Analostan I., Oc. 15, '88, in thicket.

\section{id. Aster divaricatus Deltoideus Burgess}

Fragile dark green plants with subdeltoid leaves and sharp remote teeth.

Fig. 8 (= Plate 4, B) showing plant from Mosholu, N. Y., in hb. Bu.

Aster divaricatus deltoideus Burgess in Br. \& Br., Ill. Fl. 3 : 357. 1898; as follows :

"Delicate, I I $/ 2 \mathrm{ft}$. high or less ; lower leaves triangular-cordate with a broad sinus or subtruncate; the apex incurved-acuminate; the teeth large, sharp; petioles often all filiform; veins directed forward; heads nearly as in the preceding variety [curtifolius]. In moist shady places, N. E. to N. Y., Va. and Tenn."

Typical subdeltoid leaves $\mathrm{I} / 2 \times \mathrm{I}$ in. ; sinus centrally recurved; veins delicate but conspicuous, in the longer leaves suggesting Cormus in curvature.

Unlike acute-leaved plants of var. curtifolius in its leaves with deeper remoter teeth and incurved-acuminate apex.

An early-flowering variety of cool brooksides, and moist shade, becoming much larger and more profuse-flowering southward, often represented in herbaria. Probably occurs with typical $A$. divaricatus throughout its range; its range in N. Y. State extending from L. Erie and L. Champlain to Long Island; specimens seen from N. H., Ms., Ct., N. Y., Pa., Del., Md., D. C., Va., Ky., Tenn.

Formed a part of the $A$. corymbosus as known to Nees and was so cultivated early in Hort. Bonn, fide specimen in hb. Gray ex hb. Nees.

\section{Examples :}

Ms., M. V., W. Tisbury Troutpond, Se. 4, '97; Mark's Valley, Se. 6, '97; Tea Lane, Se. 6, '97.

N. Y. vic., Mosholu station, Se. 30, '96 (type, figured), Se. 21, '98, Bi. ; Yonkers, Dunwoody culvert, Se. I3, '97, Se. I6, '98; Hillview, Oc. I 9, '97; Park Hill, Se. I4, '96: Bryn Mawr, Se. 23, '99.

Pa., Phoenixville, Bucks Co., Au. 26, '96, IV. E. P.

D. C., Woodley Bridge, Se. 21, '88; Oc. 22, '88; Mt. Pleasant brook, Se. 22, '88; Rock Cove, Au. 20, '89, S. Hartstall.

Va., Potomac, thickets opposite Analostan I., Se. 27, '88.

Hort. Bonn, fide specimen in hb. Gray given to Schultz Bipontinus by Nees as Eurybia corymiosa. 


\section{i $\ell$. Aster divaricatus fontinalis Burgess}

Solitary plants of moist places with large thin tissuey radicals, sharp teeth, and narrow smoothish bracts.

Name, L., from its frequent occurrence in springy places. istic radical.

Fig. 9, plant from Rock Cr., D. C., Oc. 5, '87, in hb. Bu.; 6, its characterlows :

A. divaricatus fontinalis Burgess in Br. \& Br. Ill. Fl. 3 : 357 . 1898, as fol-

"Plants solitary; basal leaves often numerous, tufted, thin, smoothish, sharply serrate or dentate, $6 \times 4 \mathrm{~T} / 2$ in., or smaller, broadly oval, acute, the base subcordate or rounded : inflorescence

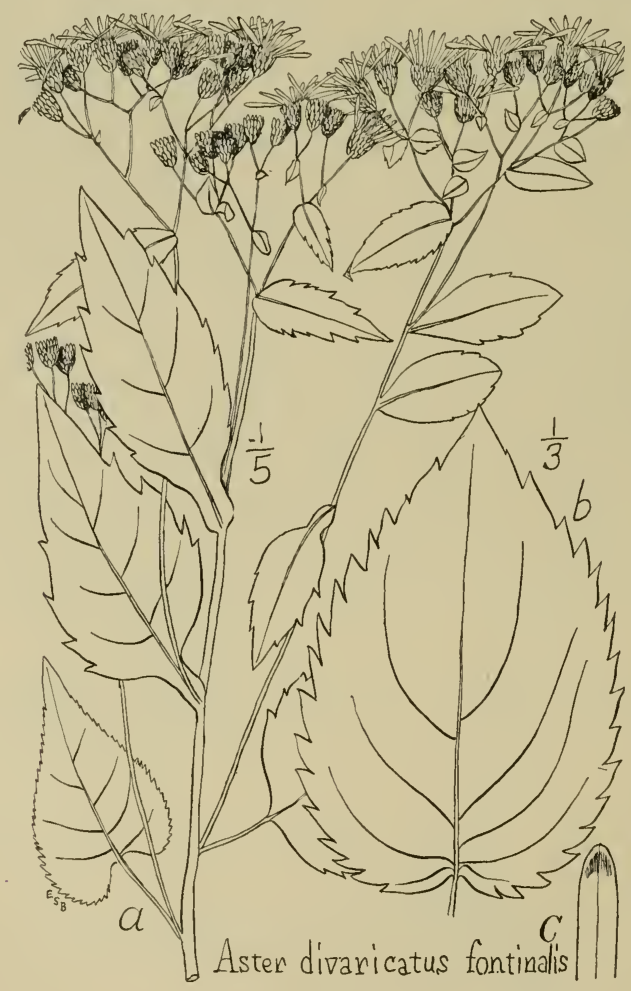

FIG. 9.

usually ample, the long virgate branches with numerous small oval-oblong leaves; involucre turbinate; its bracts with definite green tips. In springy places, and grassy ditches in open sunny situations, N. E. and N. Y. to Va." 
Radicals, while very thin and of a tender tissue-like texture, are occasionally roughened with scattered bristles on the back. Their teeth are close and mostly outflung or couchant, but sometimes straight-acuminate; each vein is forward-dissected and at length incurved; unlike the somewhat similar late sprouts of $A$. umbelliformis and $A$. curvescens, in which the radicals are of a thicker denser texture, their veins more straight and outward bent, their teeth more remote, curvescent or even crenate. In either case an additional cluster resembling radicals is sometimes borne high above the ground.

Caulines little developed, mostly as the radicals, or a few cordate in outline with strong sinus and teeth. Rameals ovate-oblong or triangular-oblong, often quite large.

Bracts of coriaceous texture, narrow, rather uniform; unlike those of late sprout-forms of $A$. umbelliformis in having a little vestigial ciliation, the back curved (not flat), and strongly lined by the narrow midrib, and a blunt-tapered apex (not sharp and straight-tapered). They have much less color at the green tip, and are so stiff as to be always erect.

Perhaps all specimens of fontinalis owe their large radicals to hybridizing with $A$. umbelliformis which sometimes grows with them. If such a hybrid, $A$. divaricatus must be strongly prepotent in it. Other possible hybrids between $A$. divaricatus and $A$. umbelliformis also occur, both at my Connecticut locality and also on the Potomac; but this second set of hybrids shows a greater likeness to $A$. umbelliformis than to $A$. divaricatus and will be referred to under the former species.

\section{Examples :}

Conn., Mianus R. at Riverside, grassy ditch by r. r., Oc. 15 , '96.

N. Y. vic., Inwood, grassy bank of Hudson R., Oc. 16, '98, Bi., Oc. 13, '99, Bu. Yonkers, Hillview, Oc. 26, '97, Oc. 22, 1900. S. I., Clove L. bank, Oc. 17 , '96. Glenpark, damp stony roadside, edge of woods, Se. 25 , ' $98, B i$.; " with heads I 2 to 6 lines across."

N. Y., Catskills, Onteora Mt., Se. 18, '9I, A. M. Vail in hb. N. Y. Bot. Gar.; Hunter, Se. 7 , '98, Bu.

Md., Potomac, at Kirk-Gold mine, above Great Falls, by a brook, Oc. I I, '9o.

D. C., Rock Cr., parapet, near Pierce's Mill, Oc. 5, '\$7.

\section{Aster viridis Nees in herb.}

Plants resembling $A$. divaricatus in inflorescence-characters, stem and stem-leaves, but bearing many large coarse rough radicals like $A$. macrophyllus and usually with numerous large ovalrhomboid rameals like neither species. 
Name, L., probably from the conspicuous green radicals.

FIG. IO, from plant of Lobelia Run, D. C., Oc. 22, '88, in hb. $B u$.; a, b, c, d, e, from Alexander, Pa., 1849, T. C. Porter in hb. Bu.; b, characteristic radical, etc., from Nees' type in hb. Gray.

A. viridis Nees ; in his hb., sheet now in hb. Gray.

Radicals forming a dense tuft, mostly $6 \times 3$ in., or even Io $\times 5$ in., strongly asymmetrical at base, usually falcate above, irregularly oblong-ovate in outline, very coarse, harsh and dense in texture, usually thick and with some scattered strigose hair.

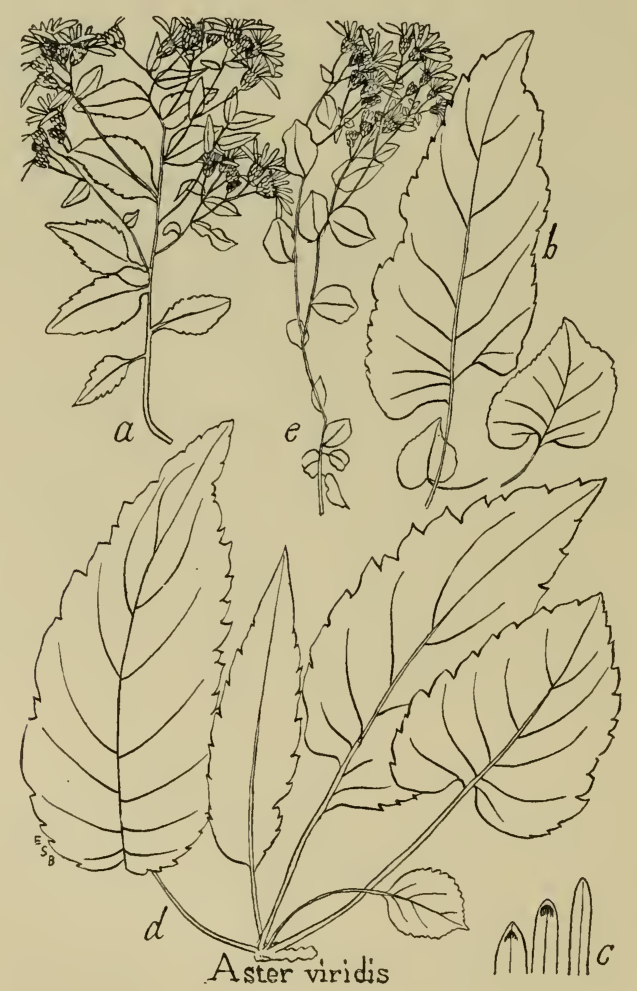

FIG, Io.

Margins very coarsely and irregularly crenate-serrate or on smaller leaves deeply aquiline-serrate. Veins pale, often conspicuously so. Leaf-form prominently acute, little or not at all incurved below the apex. Sinus deep and broad, usually highly asymmetrical; seeming narrow in pressed specimens, due to overlapping. Petiole about the length of the leaf-breadth, strong and thick, without margins. Sometimes a few smaller radicals are 
nearly orbicular, I to $2 \mathrm{in}$. in diameter.-All the above characters seem derived from $A$. macrophyllus.

Stems I or $\mathrm{I} / 2 \mathrm{ft}$. high, brownish, smooth and glabrous, slightly flexuous, brittle, forking above into a wide loose inflorescence with slender divergent branches and irregularly corymbose top, the whole often 8 in. broad and 6 in. deep. Caulines small, 8 or so occurring below the similar axiles, about $2 \times$ I in., ovatetriangular, low-serrate, acute with narrow sinus and short slender petiole. Upper axiles soon show short wings and then become abruptly sessile.-Characters allied to $A$. divaricatus.

Rameals of two types, oblong-acute and serrulate, derivable from the norm of $A$. divaricatus; and oblong-rhomboid, obtuse and crenate, derivable by prolongation from the oval Mitchellian rameals also produced on $A$. divaricatus. Both types may exist together on the same plants, either one being predominant and the other reduced to a few examples.

Head I in. broad or slightly less, resembling $A$. divaricatus except that most bracts are thinner, narrower and sharper; but thicker than in $A$. Schreberi; and many bracts are as rigid and as blunt and almost as ciliate as in $A$. divaricatus.

Differs from $A$. divaricatus fontinalis especially in its rameals, bracts, its larger coarser radicals and in the presence of many grotesque flowing teeth.

First printed, Burgess in Br. \& Br. Ill. Fl. $3: 357$. I 898, in the remark

" $A$. viridis Nees, remarkable for its coarse, rough basal leaves, and large oval rhomboid rameal ones, occasional from N. Y. and $\mathrm{Pa}$. to Va., may prove to be a hybrid between the preceding $\mid A$. divaricatus L.] and $A$. macrophyllus L." - Lack of success in finding other examples since writing the above, leaves the probability of its hybrid origin unchanged.

Habitat, especially in sandy and gravelly roadsides in deep loose soil toward ditches, in full sun, forming small scattered clumps.

Examples :

N. J., West Orange, grassy brookside, in deep sandy soil, in open sun below Orange Mt., Oc. 24, '96.

Pa., Alexandria, Huntingdon Co., 1844, T. C. Porter as "A. cory'mbosus no. 2," in hb. Bu.

D. C., Lobelia Run, sunny roadside in sand, Oc. 22, ' 88 , several plants.

Gray hb., ex hb. Nees, from a cultivated plant probably in Hort. Breslau, which seems to have been labelled $A$. viridis first in Nees' herbarium and then labelled $A$. viridis again in the handwriting of Klatt.

Nees' plant has tufted long-pedicelled turbinate heads, large bracts with blackened tips, the outer ones acute, the middle 
rounded and finally lingual. The leaves are smooth, not extremely thick, but very heavy and coarse in texture. Some cauline leaves are broadly, short-cordate. No glands are present. The rays are large and white, chiefly 8 .

That the foregoing are merely luxuriant states of $A$. macrophyllus consequent upon stimulating soil seems disproved by the totally dissimilar inflorescence. The plants have a strong suggestion of hybrid origin despite their wide distribution. They are, however, very different from many other intermediate forms presumably hybrids of similar parentage, and they are most conveniently referred to by having a name of their own. I therefore retain for them Nees' herbarium name, $A$. viridis, a name appropriate to an aster which derives its great distinction from its luxuriance of vegetation. I think them more conveniently enumerated as a species than otherwise; and who shall disallow a species because it is of mixed blood or shall say how many crosses may not have occurred in the past in the ancestry of some of our most familiar and most accredited species?

The foregoing $A$. viridis and the preceding $A$. divaricatus fontinalis are, however, the only presumable hybrids which I have enumerated as species or variety, and these because already so named. Other presumable hybrids I have described without name, under the indication of their supposed parents, as $A$. umbelliformis $\times A$. divaricatus, infra.

\section{Aster arenicola sp. nov.}

Small delicate plants in sheltered bushy places near streams, in sands near the coast; with narrow bracts and small oblongovate acuminate leaves, low-serrulate and pale.

Name, L., = sand-dweller.

FIG. II, plant from West Tisbury, M. V., Au. ' 96 , in hb. Bu., with characteristic leaf and bract.

Stem chiefly green and about Io in. high, inflorescence 4 in. or often only 2 in. across. Puberulence present slightly over the stem and the serrulate leaves. Coarse teeth few. Flower buds globular, profusely webbed by the long ciliation of the bracts.

Differs from typical $A$. divaricatus L., with which it often grows, as follows: its long leaves are not so long, and are serrulate, not coarse-serrate; its teeth are not so sharp nor large, are 
more numerous and closer; bracts narrow, often without green tips, more uniform throughout a head; heads fewer, smaller, closer, on more ascending pedicels; rays more numerous, about I I ; maximum-sized plants, I I/2 ft. high, increase the tendency of the species to narrowness of bracts, the principal ones becoming more attenuated. Their small close and even teeth have a projection mostly of about $\frac{1}{16}$ in. instead of $\frac{3}{16}$. Perhaps the pappus

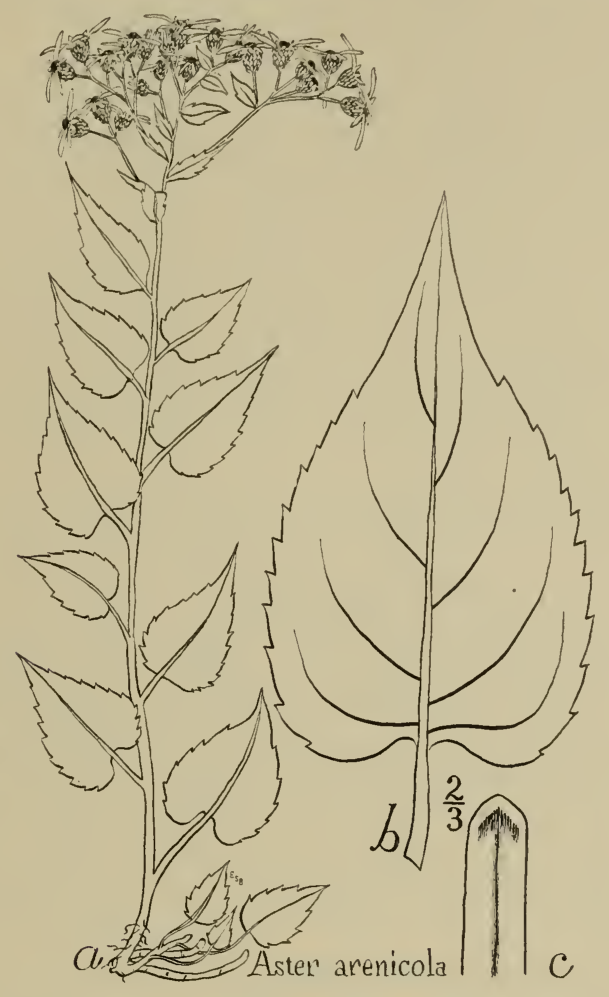

FIG. II.

reddens more slowly also; being still whitish tawny in plants four years in the herbarium, slight salmon-colored only, in plants of I 5 years, full red only in an Albany specimen of about 60 years.

Somewhat resembles $A$. divaricatus deltoideus; differs as follows : smaller in all parts; teeth not remote; leaves not dark but light green; heads not large; leaf-bases not so truncate but bicurved; sinus narrower, more pointed inward.

Varies toward $A$. argillarius; differs in its much larger leaves, diminished upwards and more acuminate, its narrower bracts with chanfer-obtuse tip, its shallower inflorescence, etc. 
Becomes the prevailing form of the Divaricati in many sandy localities on approaching the sea. The stem-leaves curl involutely in continued dry weather, and the plants almost disappear entirely in prolonged drought.

September, first week. Mass. to Va. Examples :

Ms., Middlesex Fells, Au. '98; Norumbega tower on Charles R., and in Weston near by, Au. '98, '99, I 900 ; Chebacco Pond, Au. '98 ; Brockton, Au. '87, etc. Provincetown, Se. 2, 1901, A. Hollick, in hb. N. Y. Bot. Gar.

M. V., Davistown, Se. ' 98 ; West Tishury, Trout Pond, fish-way, Se. '96, '97, '98, I900; Mark's Valley, Liab's Hill bridge, abundant, Se. '95, '96, '97, '98; not to be found during the drought of 1900 ; west of gristmill-site, abundant, ' 97, ' 98 , not found I900; Gay Head, Blackwater Knob, numerous, Se. '98, not found I 900.

Ct., East Windsor Hill, Au. 82, Roda B. Watson.

N. Y., Albany, before 1840 ? G. M. Tracy in hb. Torrey, and Dr. L. C. Beck in hb. Torrey; endorsed ( fide Dr. John Torrey) by Dr. Boott, "If this is Biotia corymbosa $[A$. divaricatus L. $]$ it is a remarkable state. An sp. nov. ?" These plants while nearest to the typical $A$. arenicola still verge toward normal $A$. divaricatus L., as probably do all examples growing so far inland as Albany.

N. Y. vic., Washington Heights, '97 ; Ravensdale Road, Oc. I9, '96 ; S. I., Clove L., Oc. 17, '96.

D. C., Piney Br., Se. 88.

Va., Potomac bank, Se. '86, '88, etc., Carlin Spr., Se. I8, '93.

\section{Aster persaliens sp. nov.}

Virgate small-flowered plants of deep shade, with thin taperbased lance-like hack-edged leaves, stiff bevel-tipped bracts (acuter on central heads), maroon disks and flat-bunch inflorescence; the couchant teeth very sharp and salient (whence the name).

FIG. I2, plant from Bryn Mawr Park, vic. N. Y., Se. 26, '96, in hb. Bu., with one of the obtuse linear inner bracts, and one of the lower leaves with unusually multifarious teeth.

Aster divaricatus persaliens Burgess in Br. and Br. Ill. Fl. 3 : 357. I898, with description :

"Stems virgate, $21 / 2 \mathrm{ft}$. high, or less; leaves extremely thin, firm, chiefly lanceolate-acuminate, long and narrow, the teeth very slender, salient or recurved; the lowest [i. e., the primordial leaves] ovate with a small narrow sinus; disk maroon. In deep shades, N. E. and N. Y. to Va. and Ky." *

Stem erect, very slender, green or brownish, $2 \mathrm{r} / 2 \mathrm{ft}$. or less, wholly straight or with continuous slight flexuosities.

* My first observed specimens of this very distinct Aster, D. C., ' 87 and ' 88 , were from Rock Cr., and in Va. opposite, then recorded as "Lance-elliptic form," with variants as " $A$. corymbosus, intermediate form A," and $A$. corymbosus $\times \mathrm{A}$.-." Further scrutiny so impresses me with the distinctness and permanence of $A$. persaliens that $I$ feel it misleading to continue it as a subspecies. 
Leaves extremely thin but firm and tough, without obvious hair, very smooth to the touch during growth, on the upper surface minutely granular-roughened when dry.

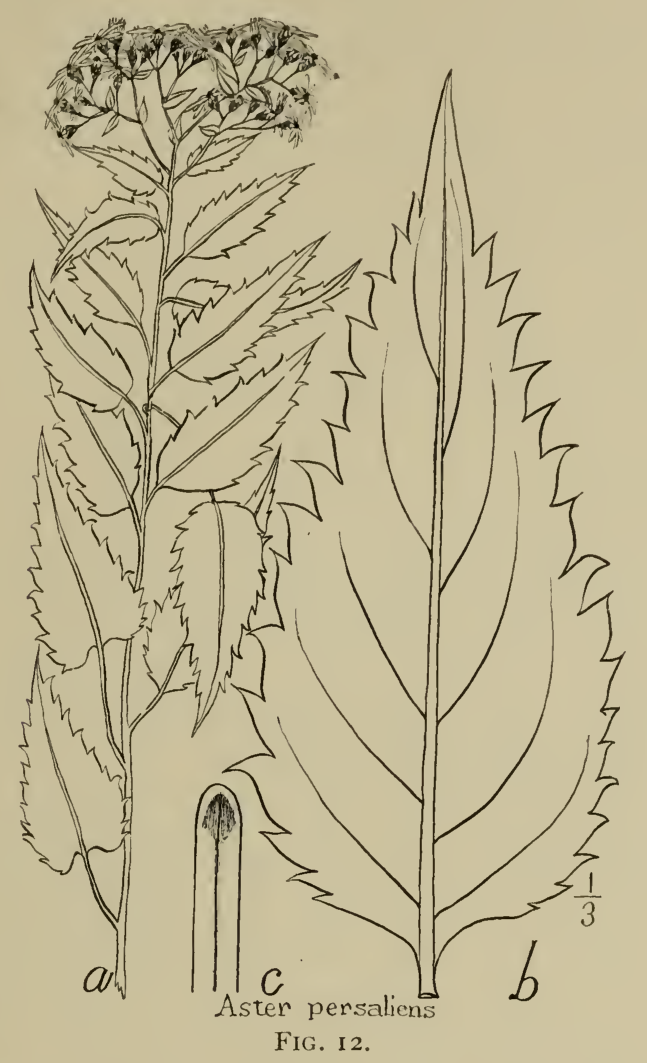

Leaf-form lanceolate, attenuately elongate and taper-based, quickly or cuneately contracted into a short slender petiole; the prolonged straight or falcate apex entire for an inch or more. Margins elsewhere sharply toothed, as if hacked by a knife, the teeth very salient and slender, occasionally close and straightbacked, but usually long, remote, and rising from a gentle curve into a sudden upflung backivard-curved (i. e., couchant) tooth, suggesting the couchant position with head thrown up, familar in coat-armor.

Sinus lacking entirely in the predominant and characteristic leaves, broad shallow and recurvate in the few lowest caulines, or small and narrow in the soon-vanishing ovate and oblong-ovate primordial leaves. Leaf-form of the basal caulines (succeeding 
the primordial) cordate-ovate, acuminate ; those next above, ovateacuminate with rounded base, $4 \times 2 \mathrm{I} / 2$ in. or more ; then oblonglanceolate, long-acuminate, with rounded base, $5 \times 2$ in. often. Predominant typical leaves follow, being the middle and upper caulines, sometimes including also lower caulines and axiles. These show the characteristic leaf-form, and are $5 \times 1 \mathrm{I} / 2$ in. or $4 \times \mathrm{I}$ in. or smaller ; upper axiles becoming sometimes still $2 \times \mathrm{I} / 2$ in., the upper leaves becoming sessile by a sharp cuneate base ; or at last, directly sessile.

Rameals lance-linear, sessile, slightly tapered at the rounding base, $3 / 4 \times 1 / 4$ in., or less ; or minutely petioled. Ramulars tiny, ovate or circular; even these are often minutely petioled; sometimes they replace the preceding, $i$. e., occur along primary as well as secondary branches. Radicals seldom seen; those observed are triangular-cordate, acute, with both straight and couchant teeth, $3 \frac{1}{2} \times 2$ in., or less ; apparently preceded by a small circular crenated form.

Inflorescence flattish-convex, usually a single branch, moderately close, its pedicels $\frac{1}{2}$ in. or less, the small heads nearly simultaneous in bloom, $\frac{5}{16}$ in. high, $\frac{12}{16}$ in. broad, or little more. Rays dull white or soon becoming so, oblong, irregularly crisped in drying, chiefly numbering 9 or 7 ; rarely, fimbriated. Disks rather high and narrow, soon reddish-brown with a vinous-purple tendency, usually deepening to maroon.

Bracts multiform, coriaceous, convex-backed, moderately ciliate, gradually darkened upward into a broad deep green tip. They are chiefly chanfer-obtuse, $i$. e., bevel-topped without becoming definitely acute. With these are many acute basal bracts, and the middle bracts are often also acute on the central or earlier heads at each inflorescence-branch. Inmost bracts linear, obtuse, with narrow green back and pale scarious margin, which is generally faintly or minutely present in the other bracts.

The scarious margin of these bracts is not as white or broad as in $A$. fragrans, nor does it occur through so large a part of the involucre; but is more nearly the seme as in $A$. divaricatus $\mathrm{L}$. The involucre of $A$. persaliens as a whole resembles that of $A$. divaricatus more than most other species do, but its acute bracts are more numerous, its truncate bracts are fewer, and all have rather less color, ciliation, and puberulence.

In young rapid growth (as Jun. I9, '97) the middle cauline leaves and those immediately below, have a soft subglutinous surface. When closely smelled they prove to have a faint delicate fragrance. A shining thin viscid exudation over the whole upper surface may be felt and is visible by a lens. A. divaricatus and allied species seems to develop a similar exudation occasionally, 
but I have not observed its presence to the same degree. - A bee-bread fragrance is exhaled from the young disk-flowers, as from many Biotian species.

Plants of considerable shade, usually in deep woods, growing commonly in small loose clusters, either on slopes or flat lands or in thin soil upon gneissic rocks.

Latter half of September. Widely diffused through the Appalachian region, N. H., to Va. and Ky. Specimens seen include N. H., Ms., Ct., N. Y., N. J., Pa., Md., D. C., Va., Ky., especially :

M. V., Davisturun, woods, Se. 4, '97.

N. Y., Albany, Loudonville, in Hughson's Glen, Se. II, '89. Catskills, Kaaterskill Mt., Se. 7, '99, near summit; Hunter Mt., Se. 5, 99, flat rock near Mossy Brook.

N. Y. vic., Ft. George, Se. 24, '96; Inwood, Se. 22, '98; Mosholu woods, Se. 26, '98, Bi.; Kingsbridge, rich woods, Oc. 9, '98, Bi., as $A$. divaricatus var. Yonkers, early plants in rich woods west of Grassy Sprain L., Se. 17, '98, Bi., as "Aster — ?" Bryn Mawr Park, Se. 17, '98', Bu., just unfolding; Se. 26, '96, Se. r 8, '97, Se. 16, 99, Se. 15 and 28, 1900, Se. 1901, 1902, 1903.

Pa., "Easton, Oc. r, '86, in deep shade of woods, late-flowering, leaves thin," T. C. Porter, in hb. Colu.

D. C., Rock Cr., above Blagden's Mill, Oc. I2, '88, Oc. 5, '90; Mintwood Bank, Oc. 22, '88; Mintwood Brook, Oc. 22, '88; Lanier Heights Brook, Se. 24, '88, Oc. 6, '87; Woodley Bridge, Se. 21, '88. Lobelia Run, Se. 7, '86, H. W. Henshaw in hb. W. Deane.

Va., Potomac, near Spout Run, Oc. 29, '88, Rhododendron Run, Se. 5, '86, H. W. Henshaw in hb. W. Deane.

“N. C. mtns., A. macrophyllus," Ashe, in hb. U. S. N. Mu., No. 327,642. Ky., Licking R., C. W. Short in hb. Torrey.

Pa., Susquehanna, '97, Jas. A. Graves.

$4^{2}$ BRAnCh Forms develop small suborbicular and rhomboid leaves enlarging upward, usually with three slight teeth toward the front, otherwise entire.

Variant forms of $A$. persaliens include:

$4^{3}$ Axilliferous form; bearing nearly as much inflorescence in each of the 6-8 upper axils as at the summit; several different localities in woodlands near Bryn Mawr Park, N. Y. (esp. Palmer Av. rocks).

Se. 25 , '97; Oc. 1, '98, Se. 16, '99, etc.

$4^{4}$ Long-Pedicelled form ; differs from the type in its larger heads loosely borne on longer pedicels over $1 / 2$ in. long, sometimes nearly I in. 
N. Y. vic., Bryn Mawr Park, Se. 26, '96, Se. 18, '97, etc. ; Mosholu Av., Oc. 2, '97; Mosholu Sta., Se. 30, '96.

Va., Potomac at Spout Run, Oc. 9, '9r.

$4^{5}$ Feiw-Flowered form; low clustered foliaceous plants having great breadth of leaf; heads few, large, close-clustered, often exceeding I in. broad; rays milk-white, linear-oblong; upper series of leaves little developed, but usually showing one or more leaves of the characteristic form of the species; from which, however, further observation may yet indicate this form to be distinct.

N. Y. vic., Mosholu Av., Oc. 2, '97 ; S. I., Grant City, Oc. 17 , '96.

Va., Potomac, Aqueduct Br., Oc. 3, '9r.

$4^{6}$ Rounded-Base form; most leaves broad-based, but taperacuminate, the middle and upper ones abruptly rounded at the base, not taper-based as in the type; teeth also less typical, small and less pronounced. Intermediate to $A$. divaricatus L., and widely distributed.

N. I. vic., Bryn Mawr Park, Se. 26, '96, Se. 18 , '97, Se. 17 , '98, Se. 16 , '99, to I904.

IV. N. Y., Fredonia, '95-1904. Sheridan, Clear Spring, July 17, '96, plants then $\mathrm{I} 6 \mathrm{in}$. high and beginning to form flower heads. Silver Cr., '95-1904.

Va., Potomac, Windy Gap, Oc. 1, '89.

$4^{7}$ JAGGED-LEAF form; leaves broad and truncate at base; the shallow broad sinus, typical for lower leaves, here continues well up the stem; teeth closer, stronger, slenderly bristle-tipped, toward the base of the leaf much crowded.

N. I. vic., "rich woods, Kingsbridge, Oc. 9, '98, A. divar. var." Bi., Bryn Mawr Park, Se. r6, '99, Bu.

Va., Potomac, Windy Gap, Oc. '86, Bu., abundant and highly developed; the "Dentate form" as then recorded.

\section{Possible HyBrids include :}

$4^{8} A$. persaliens $\times A$. excavatus. Teeth greatly developed, irregularly crowded, projecting in all directions, and including couchant, curvescent, aquiline, and also straight-backed forms. Sinus deep and narrow, occurring in almost all leaves to the axils. Inflorescence small, with bracts nearly as in $A$. excavatus. Unites in the leaf the sinus of $A$. excavatus with the teeth of $A$. persaliens; the leaf-form is more that of A. excavatus, but less slender than in either probable parent.

N. Y. vic., Tarrytozon, opposite Sleepy Hollow cemetery, Se. 24, '98, Bu. Woodlazun Woods, Se. 25, '98, Bi.

$4^{9} A$. persaliens $\times A$. umbelliformis. Leaf-form of $A$. persaliens; teeth remaining sharp and conspicuous, but more forward- 
projecting, often incurved, narrowly elongate and falcate or concavo-convex. With these occur also, couchant and curvescent teeth as in $A$. persaliens. Winged petioles frequent, even through the middle of the stem. Like $A$. umbelliformis, its leaf-substance is thickened, and curvescent teeth are common. Inflorescenceform particularly like that of $A$. umbelliformis, each long flagelliform branch bearing a convex or dome-topped subumbelliform long-pedicelled cluster. Bracts resemble those of $A$. persaliens. Rays become olivaceous, and disks purplish.

N. Y. vic., Yonkers, Tuckahoe road, two large tall plants, 3 and $2 \frac{1}{2} \mathrm{ft}$. high, with inflorescence 9 and 8 in. across, Se. 19, ' 96 . Pelham, west of r. r. sta., $21 / 2$ ft. high, Se. 22, ' 98 .

D. C., plants 2 and $\mathrm{I} \mathrm{ft}$., Oc. ' 88 , then deemed " $A$. corymbosus $\times A$. macrophyllus.",

\section{Aster atrovirens sp. nov.}

Long-leaved tall wand-like plants of moist woods, the margins closely slashed with long slender teeth, the small heads crowded in a small leafy-based convex inflorescence often continued down several axils, new heads long continuing to develop; plants of weedy aspect and deep green (whence the name, L., blackishgreen).

FIG. I3, from plant of Jerome Av., vic. N. Y., Oc. 2, 1901, in hb. Bu.; with bract of the extremest obtuse type ; and characteristic leaf from low down the stem.

Stem green or brownish-green, $2 \mathrm{r} / 2 \mathrm{ft}$. or less high, very leafy, nearly straight, erect or assurgent.

Leaves very dark green, paler beneath, thin but rather firm, smoothish: petioles chiefly rather short and slender, not equalling the leaf-breadth. Leaf-form somewhat triangular and ovateacuminate, sloping below into narrow lobes, with a broad moderate sinus, the teeth close, long, sharp and slender, their bracts straightish or at least not so continuously and strongly curved as in $A$. persaliens. Lower caulines cordate-ovate, acuminate, $5 \times 3$ in., their coarse teeth often $\frac{3}{16}$ in. deep and $1 / 2$ in. long; their broad sinus rather shallow, recurvate in the middle. Middle caulines ovate-acuminate, $5 \times 2$ in., or $31 / 2 \times$ I $1 / 2$, the slender petiole $\mathrm{I} i n$. or less. Upper caulines lance-acuminate, $3 \mathrm{I} / 2 \times \mathrm{I} / 4 / 4$ in. with short broad wing base, and long entire acumination. Axiles like the last, usually retaining the short broad wing; commonly becoming triangular-linear, finally only I $1 / 2 \times 1 / 2$ in. at an inch or so from the top of the stem. Rameals few or remote, ovate, entire, or nearly so, $3 / 8 \mathrm{in.} \mathrm{long.}$

Heads small, leafy-subtended, closely branched or subsessile, 
in a convex or narrow inflorescence; pedicels $1 / 4$ in. long or only $\frac{1}{16}$; heads $5 / 8 \mathrm{in}$. broad, $\frac{2}{8}$ high, very dissimilar in develop-

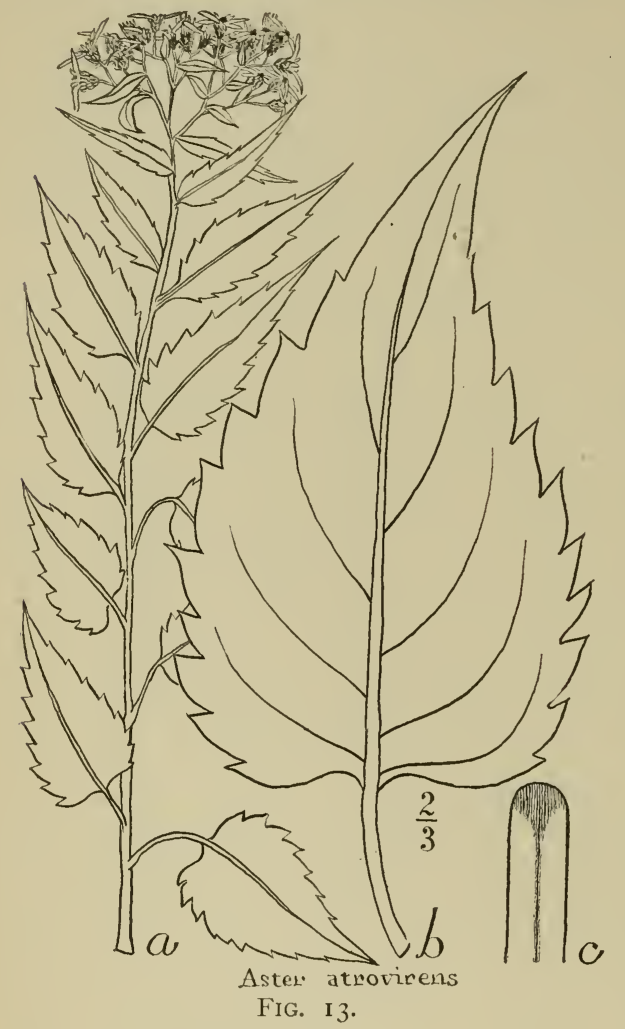

ment, many new heads developing a mong and below those already opened, many developing but partially, and still more blasting altogether.

Bracts straight-sided, obtusish, not so diverse on the same involucre as in $A$. persaliens; the green tip short, not dark nor definite, shading off gradually downward. Some lowest bracts are triangular-acutish, and many middle ones are chanfer-topped.

Rays narrow, about 7 , at first suberect, slowly flattening, finally involute-filiform or twisted; their color dull white, not clear, often becoming virescent. Disks funnelform, tapering insensibly into a slender threadlike stalk; the lobes spreading, shorter than the bell below, which itself is but about $1 / 3$ as long as the stalk. Pappus very fine and soft, reaching to the base of the lobes.

- Dark or damp woods, often filling extensive levels of thin clayey soil, growing not in close clumps or stools but rather uniformly diffused. Chiefly observed near New York City, throughout September, especially the latter part of the month.

- When its inflorescence continues well down the stem, it may resemble $A$. Claytoni, but unlike $A$. Claytoni, the axiles are petioled, not sessile, and with rounded, not truncate, bases. Its leaves are also thinner, smoother, longer and much larger.

- Passes into $A$. erectus, which is usually lower, has smaller leaves, and develops couchant teeth and larger heads with the rays quite persistently erect. Passes also into $A$. persaliens, which has 
fewer sinuses, much more taper bases to the middle and upper caulines, and more naked inflorescence more thoroughly simultaneous in blossom (though not so completely simultaneous as in A. fragrans).

From the other principal long-leaved congener of deep woods, A. tenebrosus, $A$. atrovirens is distinguished, among numerous other characters, partly by its smaller denser heads, lack of proliferation and of large acute bracts, and by its different leaf-form and inflorescence.

- Fimbriation sometimes occurs ; split rays were found in all the plants of one community at Hudson Heights, N. J., Se. I2, ' 98 ; these were unusually vigorous large-leaved plants, otherwise typical, and with the usual seedy condensed-dome inflorescence.

Examples:

N. Y. vic., Inwood, Se. 27, '97, Se. 22, '98, Bu., Kingsbridge, rich woods, Oc. 4 and 9, '98, Bi., Spuyten Duyvil, wooded bank, Se. 22, '98, Bu., Mosholu, Oc. 2, '97, Bu., Oc. 21, '98, Bi., Indianfield, Se. 2, 1900, Bu., Golf-links woods, Van Cortlandt Park, Au. 24 and 28, '98, Bi. Jerome Av., near Lincoln Park, filling dark woodlands by the million, Oc. 2, I900, I901, 1902, Bu. Mosholu Av., near Jerome Av., in dark murky thicket, Se. 22, '99, Bu. Pelham, Se. 20, '98. Yonkers, Lincoln Park, Se., '98, Belmont, Se., '99. Bryn Mawr Park ; buds beginning to be visible July 28, '99. Mile Sq. Road, Se. 25, '97.

N. J., Palisades, Hudson Heights, Se. I 2, '98.

Ohio, "Pomeroy, Meigs Co., Oc. 16, '98, W. A. Kellerman, Aster - ?" (seems to be a late-flowering plant of this species).

Md., Cumberland, '96, Howard Shriver in hb. Colu.

\section{Aster erectus sp. nov.}

Small dark-green plants, with short ovate-acute leaves, moderate teeth, broad pale-margined obtuse bracts, filiform pedicels, crimson disks, and suberect rays crowded in a tangled single-bunch inflorescence.

Name, L., because the rays are apt to remain for a long time suberect.

FIG. 8 (= Plate 4, A), from plant of Bryn Mawr Park, vic. N. Y., Oc. 2, '96 ; a plant of common slender form; but extreme forms have broader leaf-form, stronger teeth, and more numerous heads, more densely packed together and with more conspicuous and longer rays.

Stem low, I $1 / 2$ feet usually, green or blackish-green, erect. Rootstocks yellowish, uniformly about $\frac{3}{3 \cdot 2}$ in. thick, some 7 inches in length still remaining undersized. Plant without obvious hair.

Leaves broad, rather short, ovate-acute or short-acuminate, 
firm, slightly roughened, at least when dry, dark green, pale beneath, yellowish in autumn. Sinus moderate, soon shallow, followed by truncate bases along the middle stem, and above by rounded bases. Teeth not conspicuous, chiefly low-curvescent, irregular, with short and long and occasional straight-backed teeth intermixed. Petioles slender, short, shorter than the leafbreadth; some upper or axile petioles are often narrowly winged. Axiles few, oblong-linear, acuminate, usually sessile by a rounded base. Rameals minute, discoid. Radicals subcircular, low-crenate, I $1 / 8 \times$ I in., with a broad shallow sinus.

Characteristic leaves (lower caulines) usually $4 \times 21 / 2$ or 3 in.; lowest leaves smaller, $21 / 4 \times 2$, etc., less toothed or even entire; primordial leaves below these usually deciduous early, sometimes 3 , subentire, cordate-acute and oval-acute, $3 / 4$ in. broad and long, etc. Upper caulines lance-acuminate, either incurved or straightsided, $2 \mathrm{I} / 2 \times \mathrm{I}$ in. or less.

Inflorescence small, crowded, convex; typical pedicels filiform, $1 / 2$ in. long or more, erect and tangled together in a confused mass.

Rays remaining erect or suberect long after opening, usually about 7 , remote, thicker in substance than in many allied species, flat and dull white while erect, their form oblong but often a little broader toward the tip. The rays presently become deeply canaliculate and long remain so ; finally completely involute and olivaceous, by this time usually horizontal and but $\frac{1}{5}$ their original breadth. Virescence and involution are sometimes strongly developed while still erect. Rays when but little involute measure after drying $\frac{7}{16}$ in. long, $\frac{1}{16}$ broad, or more.

Disks early turning crimson or maroon (while the rays are yet erect), and often very dark. Stigmas at first whitish, becoming purplish-crimson.

Bracts rather broad, thin, broadly white-scarious margined, truncate or rounded at the apex, toward which the sides taper somewhat; a few lowest are acutish ; the inmost, attenuate-linear, obtuse, with but a narrow green midrib; the rest all with a broad green medial stripe, expanded abruptly into a very short and broad green tip.

Earlier heads on strong plants have very often IO, sometimes I 3 , rays, and with increased breadth toward the apex.

- Erect position of rays perhaps is associated in part with their thicker texture. In the Divaricati, as a rule, the rays are erect in daylight only while terete or tubular-involute, before the disk flowers begin opening; and by the time of flattening the rays have not only become flat transversely but are horizontal. In A.crectus 
the suberect position is not due simply to dense crowding of heads, or if so it has since become fixed as a character, for the position still holds in the many diffuse variants in which the inflorescence is no longer crowded enough to cause any erecting of the rays.

- Other closely allied species often show occasional similar examples of erect but flattened rays; observed in $A$. persaliens, $A$. fragrans, $A$. stilettiformis, $A$. excavatus, and $A$. atrovirens. In these cases most of the rays on a plant may be suberect, and all the plants of one cluster alike; but still these cases are exceptional in their species; unless in $A$. atrovirens, where it is quite common; but in $A$. erectus it is the rule.

- Species unlike others in its dense single-bunch inflorescence; except $A$. divaricatus cymulosus, into which it perhaps passes, but which $A$. erectus is commonly unlike in its longer rays, suberect rays, redder disks, and broader, thinner, whiter bracts. It is also akin to $A$. fimbriatus in leaf-form, etc., and often grows with it, but is unlike it in its less sharply-toothed margins, its seldom fimbriation of rays, etc. Its bracts are perhaps nearest akin to those of A. fragrans, which is usually a larger plant, with larger more sharp-serrate leaves, longer narrower thinner rays, etc. It is perhaps closest to $A$. atroiirens, which however usually has longer leaves, more sharp-serrate, and smaller more segregated heads with different bracts. From its other near allies, $A$. stilettiformis, $A$. excavatus, and $A$. persaliens, it is readily distinguished by leafform and serration.

- Scattered through moist rich woodlands near New York City; usually in small clusters; sometimes massed upon rockshelves, in rich soil upon gneiss. Middle of September or earlier ; reaches its prime one or two weeks earlier than $A$. divaricatus cymulosus and $A$. fimbriatus when they grow beside it.

Examples:

N. Y. vic., Inwoot; May 22, '97, then 6 and 8 in. high, with 4 or 6 leaves well developed; in late flower, Se. 27, '97, Se. 1903; Bedford Park, Se. 1903 ; Jerome Av., Se. 26, 1900, Oc. 2, I900; Mosholu Av., Oc. 2, '97; Yonkers, Bryn Mawr Park, in this woods by thousands, until strangled by the aggressive spread of Amphicarpaea monoica; in flower Se. 26 , '96, Oc. 2, '96, Se. 13, '97, Se. I8, '97, Se. 25 , '97, Se. I4, '99, Se. I6, '99, Se. 15, 1900; mainly dispossessed, Se. I90 I, 1902, but with survivors, Se. I4, I903, Se. I904.

$6^{1}$ Divaricated form; connecting $A$. erectus with A. divaricatus 
L. ; differs from $A$. ercctus type in its divergent pedicels, producing loose flattish or convex inflorescence with well-separated heads ; but their flattened rays remain still erect or suberect, although with abundant room for taking horizontal position. With the preceding.

N. Y. vic., Inwood, Se. 25, '97 ; Jerome Av., Oc. 2, 1900; Mosholu Av., Oc. 2, '97 ; Bryn Mazur Park, Se. '96, '97, '98, '99, 1900, 1903.

\section{Aster fimbriatus sp. nov.}

Small scattered woodland plants with long incurved-acuminate leaves, laterally-ciliate rounding bracts, large couchant teeth, broad-brace sinus, and a small loose inflorescence with some or many rays terminally fimbriate or even slit to the base (whence the name).

FIG. I5, a plant from Bryn Mawr Park, vic. N. Y., Se.' 97, in hb. Bu., with characteristic leaf and bract; $d$, face-view of an unusually fimbriate head; as drawn in the field, fimbriae surviving collection but a few minutes.

Stems slender, about I ft. high, in swamp muck or in damp shade; exceptional stems approach $2 \mathrm{ft}$. Leaf-type rather long, ovate-incurved-attenuate. Teeth sharp, the larger strongly outflung, often of couchant form.

Veins very inconspicuous, subcircular in section. Pedicels long, loose, forming a small few-flowered open inflorescence, commonly of ro-30 heads, flattish-convex, and almost without bractlets. Disks turn deep vinous-purple.

Bracts thin-coriaceous, slender, mostly with broad truncaterounded apex, laterally ciliate, with large spatulate deep green tips, rather definite, on paler involucres becoming short-triangular or crescentic. Lowermost bracts triangular-acutish. Green tips obsolescent in the inner bracts. Most bracts have narrow scarious and incurved edges.

Rays pure white, oblong; in many heads some or all of the rays are fimbriated at the tip, or even slit once or twice to the base.

In moist rich, shade, especially about standing water; or among tangles of plants along swamp borders, near Yonkers, N. Y., Sept., chiefly the $2 \mathrm{~d}$ and $3 \mathrm{~d}$ weeks.

- Differs from $A$. divar. cymulosus in having usually longer, more incurved.acuminate leaves, sharper narrower outflung teeth, long loose pedicels, no dense-bunched inflorescence, darker green thinner leaves, and broad open very shallow sinus. 
Differs from $A$. erectus in lacking the dense-bunched inflorescence of that species.

- Occasional fimbriation of rays probably may occur in any ally of $A$. dizaricatus $\mathrm{L}$., and I have actually observed it in the following, though in none is the tendency to its development strong or continuous :

A. divaricatus L. typical; obolarian form; mixed-leaf form; prune-stem form ; axilliferous form; and in many inconclusive variant forms. A. divaricatus cymulosus, a few plants.

A. persaliens, jagged-leaf form, in many plants.

$A$. erectus, more often.

A. fragrans, often.

A. tenebrosus, a few plants.

In the above, fimbriation seems to occur sporadically; in $A$. fimbriatus as a settled habit. The first plants of $A$. fimbriatus noticed, grew around the edge of a temporary pond which dries away every year in July and leaves a black-muck bottom. Some of the next plants observed grew about the margin of another similar adjoining pond. At first it seemed that there might be some connection between fimbriation and growth along standing water; especially in view of a tendency to slit-margins among leaves on depressed stems of related species ( $A$. tenebrosus, $A$. gremialis, $A$. nobilis) when sometimes growing in mucky pockets holding standing water. Subsequently I discovered scores of plants of $A$. fimbriatus growing, not closely adjoining water, but on piles of stones or wooded slopes. I was forced to abandon the hypothesis of a habitat necessarily located at the edge of standing water. The conclusion which remains applicable to all specimens is that they show a marked preference for moist rich shade.

I searched in vain to find indications of abnormal conditions which might promote fimbriation, or any insect- or fungus-attack, or any unhealthiness of the plant.

Heads of $A$. fimbriatus are apt to be all in flower at once. But in the few heads in which it could be determined, fimbriation had already begun in the bud; and I have found rays slit to the very base while yet in the bud, $i$. $\iota$., while involutely involved and erect.

Comparing the same group of plants year after year, I have found the fimbriation and the leaf-characters repeated without intermission for nine years 1896-1904. Fimbriation increased 


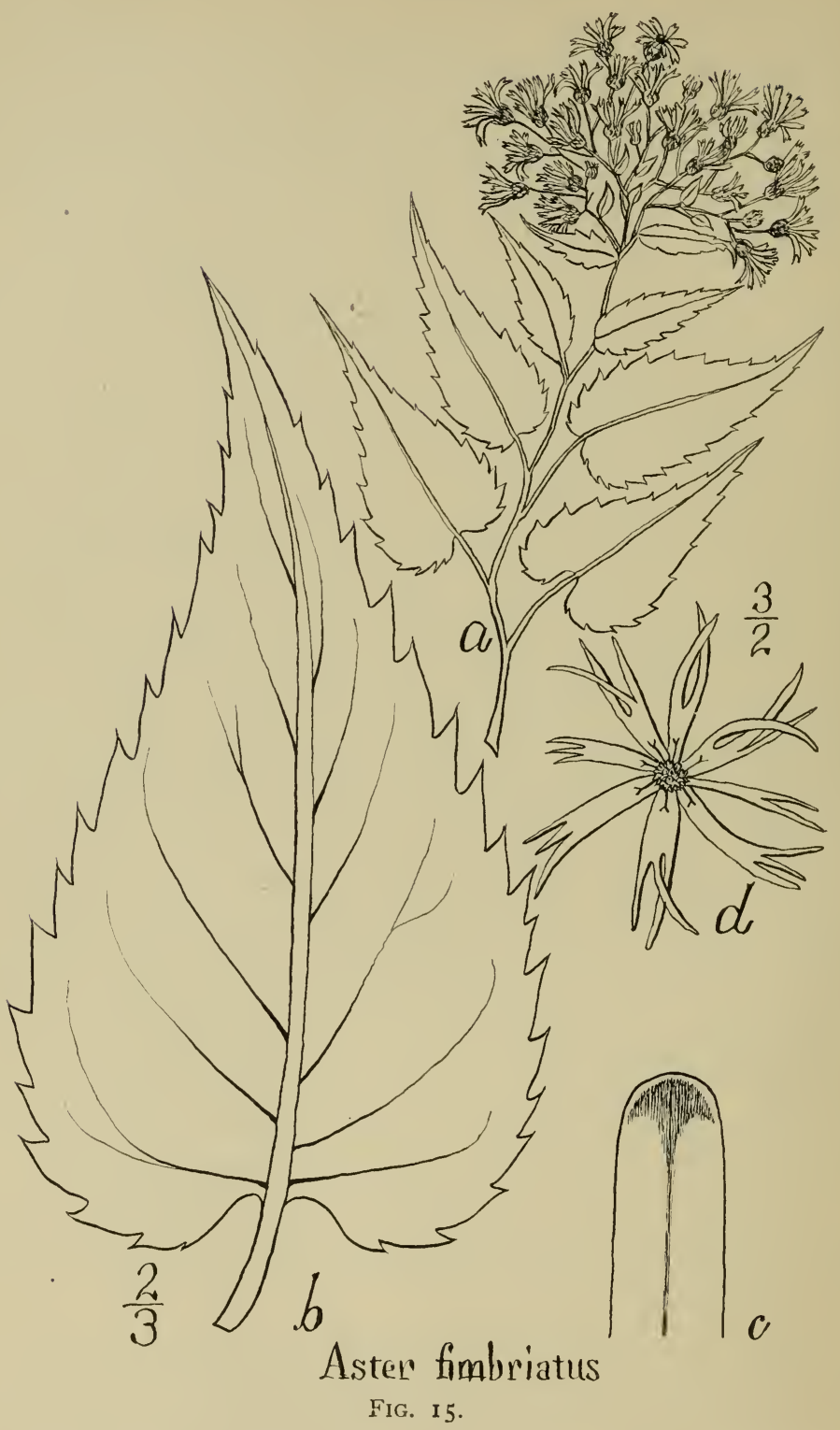

I 897 and I 898 ; the only plant seen on which the fimbriation extended to every head was a plant of 1898 . Heads in which every ray is not merely fimbriate but even slit to the base into three capillary rays, are rare but do occur occasionally. More often, some one 
or more ays will retain the usual bidentate apex. Unfortunately, pasturage and invasion by Amphicarpaea monoica have latterly interfered with the typical locality; and in Sept. 1903, plants were few owing to submergence.

- Cases of fimbriate rays also occur among plants less closely connected with $A$. fimbriatus:

Solidago bicolor; so seen $\mathbf{1 8 9 6 - 8}$ at Bryn Mawr Park, N. Y. Aster lateriflorus; Taconics, Mt. Ethel, moist meadow along wood-edge but the plants in the sun, Se. I 903 , at I, $600 \mathrm{ft}$.

\section{Aster fragrans sp. nov.}

Green-stemmed weak glabrate scattered or loosely cespitose plants with dark broad-based long-acuminate leaves, salient teeth, and a loosely-massed uniform inflorescence with prolonged pedicels and rays, lance-ovate bracteals, pink or white-margined narrow and highly scarious bracts, and much fragrance both living and dry.

FIG. 16, a plant of Bryn Mawr Park, vic. N. Y., Se. 15, '96, in hb. Bu., with characteristic leaf and bract.

Stem smooth, terete, obscurely flexuous, $1 \mathrm{x} / 2 \mathrm{ft}$. or sometimes $2 \mathrm{ft}$. high, almost wholly without hair, not very strong, sometimes partially decumbent.

Leaves thin, firm, smooth to touch, deep green. Sinus present nearly to the first branch or above, broad and deep in lower leaves (these leaves usually soon perishing), broad and shallow in middle leaves, or reduced in most into a truncate brace-base. Petioles slender, I in. long or more; the axiles suddenly tapering at the rounded base into a short cuneate-winged petiole $3 / 8 \mathrm{in}$. long.

Leaf-form triangular-cordate or oblong-ovate, suddenly longacuminate, $3 \mathrm{I} / 2 \times 2 \mathrm{r} / 2$ in. or more, quickly changing upward in diffuse plants into lance-acuminate axiles $3 \times \mathrm{I}$ in. and elliptic-ovate rameals of about I in. length. Teeth sharply outwardly salient, rather large and conspicuous, curvescent or couchant; or often closer and their backs with but a single curve. Radicals seldom seen ; those observed are short, suboval with truncate brace-base, crenate-serrate; produced in rather dry situations.

Inflorescence loose, irregularly subglobose or convex ; or, by repeated lateral proliferation, becoming extremely lax and often one-sided, especially on subdecumbent plants. Heads nearly all in bloom at the same time (unlike its ally $A$. atrovirens) I in. to I $\frac{1}{4}$ broad, $\frac{5}{16}$ in. high, well-separated by their prolonged divergent capillary pedicels, $\frac{1}{2}$ to $\mathrm{I}$ in. long. Involucre small, pale, the 
heads really small, their apparent magnitude due to the great length of the rays, each ray $\frac{1}{2}$ or $\frac{5}{8}$ in. long.

Bracts pale, uniformly narrow and long, with conspicuous thin

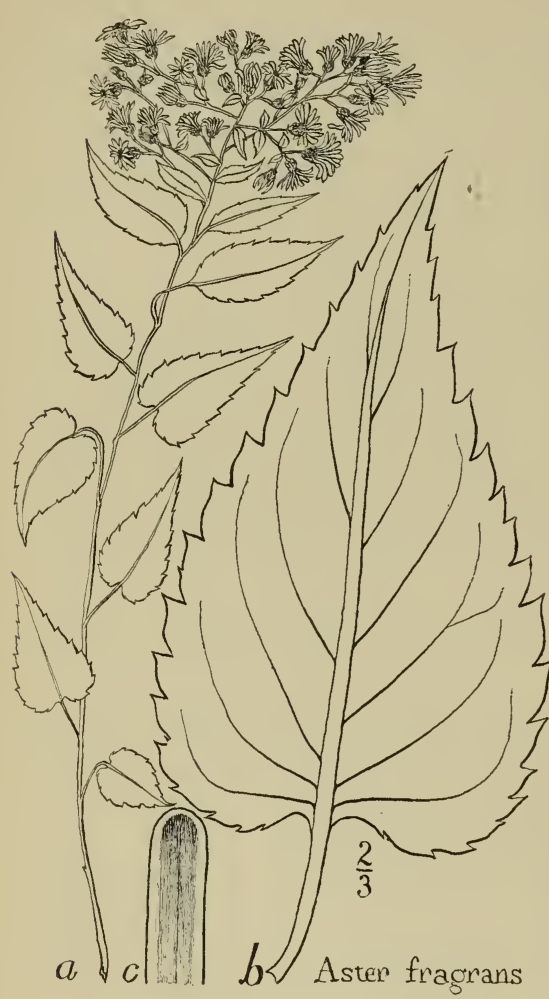

FiG. I6. shining scarious white margins (often pink at first), with palegreen narrow smoothish back and obscure hair-line midrib, the apex obtuse, the green tip only slightly enlarged and thickened, the margins tangled-ciliate, and the scarious edges commonly crinkled in drying. A few broader lower bracts, however, are thicker and sometimes acutish.

Rays about 9, minutely 3-toothed, rather broad on opening, soon conduplicate, and so seeming narrow, then becoming toward the apex involute and needle-pointed, drying capillary and $\frac{1}{32}$ to $\frac{1}{16}$ in. broad, often pendulous with age. Disks soon red or vinous-red or at least reddish, sometimes crimson, finally brown, narrow, deep-lobed, tapering into the thread-like stalk.

Flowers often of a delicate and delicious fragrance when fully open, changing as soon as dry to the different fragrance of sandalwood, still perceptible even after 3 years in the herbarium. Neither of these fragrances is wholly peculiar however to this species ; the sandalwood fragrance is nearly as well marked in many of the Divaricati, and the former, the fragrance in flower, seems sporadic in several species, as occasional $A$. divaricatus, A. tenebrosus, $A$. sociabilis and perhaps others. A somewhat different fragrance is that of the opening disk-flowers in $A$. Claytoni, $A$. ardens, etc., present also in many of the Macrophylli. The aromatic odor so widespread in the Macrophylli is wholly different again, and is due to the glands. See also p. 33 .

Distinguished, among other characters, from A. dizaricatus $\mathrm{L}$. by bracts with broader and whiter scarious margins; inflorescence less divaricated, more a single mass; leaf-bases more abrupt, truncate, chiefly with but shallow recurvate sinus. 
Similar to $A$. fragrans in their long narrow rays are $A$. tenebrosus and A. capillaris; but they differ in lacking its white bract-margins. A. tenebrosus is also readily distinguished by its predominantly acute bracts. A. capillaris has much longer and more divaricated peduncles, and longer, darker, deep-crimson diskflowers. Long-leaved variants of $A$. fragrans verge toward $A$. persalicns, which still differs from them in its bracts and its shorter pedicels, smaller heads and shorter rays. Irregularly developed inflorescences of $A$. fragrans sometimes verge toward $A$. atroirirns, which is usually more ragged in inflorescence, longer-leaved and smaller-flowered. From all allied species A. fragrans is distinguished, when typically developed, by its albo-marginate scarious bracts, and loose-massed inflorescence. The tendency to fragrance it shares with others but possesses in greater degree. Pale scarious margins it shares with $A$. divaricatus, $A$. atrovirens, $A$. olivaceus, etc., but those of $A$. fragrans are broader, more numerous and whiter at maturity.

Habitat, scattered along wood borders in grassy places or in turf on rocks, the Taconics and L. Erie to Virginia and Ohio. Middle of September, late developments lasting a month later.

\section{Examples :}

Ms., Taconics, Mt. Ethel, in bud Au. I I, in full flower Se. 8, 1903. Sky Farm, Au. 3I, 1903, Merchant's Bridge on Bashbish R., Se. 1903. Two weeks later than $A$. tenebrosus which grew with it.

Brook.

Ct., Salisbury, Au. I8, I903; especially abundant near Wochocastinook

N. Y., Round Lake, Se. '99, C. H. Peck in hb. N. Y. St.

N. Y. vic., Inwood, Se. 27, '97 ; Van Cortlandt Park, Oc. 2, '98; Indianfield, Se. 25, 1900, Oc. 2, I900; Spuyten Duyvil Cr., wooded bank, Se. 22, '98; Jerome Av. near Lincoln Park, Oc. 2, Ig0o ; Pelham, Se. 20, '98; Eastchester, Seton Falls, Se. 24, I900; NIt. Vernon Glen, Se. I4, '97; Yonkers, Kimball Av., Se. I4, '97; Dunwoody grove, Se. 26, I90o; Bryn Mawr Park, Se. 16, '96; Se. 26, '96, Se. I8, '97, Se. 17, '98, Se. 16, '99, Se. I9, '99, Se. 15, I9oo, etc.

N. J., Palisades, Se. I4, 1900.

W. N. Y., Silver Cr., Swift's Hill, '98; Hanover Centtr, Aster-bank, Au. 17, '96; Sheridan, Talcott's woods, Au. 15, '98.

Bot. Gard.

Penn., Phila. vic., Au. 30, $1869, J$. H. Redfeld as $A$. cordifolius in hb. Mo.

Ohio, Oreton, Vinton Co., Se. 30, I $\$ 95, W . A$. Kellerman as $A$. divaricatus.

D. C., Piney Branch, Se. 22, ' $8 S, B u$., as " $A$. cory'mbosus, intermediate form A.; heads nearly as large as $A$. macrophyllus."

Md., Great Falls at Kirk Mine, Oc. II, I 89 I, Bu., as ".4. corymbosus X A. macrophyllus."

VARIANT FORMS of $A$. fragrans include:

$S^{1}$ Sunburnt form; leaves thickened, lengthened; more hair ; bracts less scarious; rays olivaceous with age. 
N. Y. vic., Inwood, Se. 27, '97. Yonkers, Grassy Sprain road, corner of Tuckahoe road, Se. 19, '96.

N. J., Palisades, halfway up at Undercliff, Se. I4, '99.

$8^{2}$ Short-leaf form; more widely and closely branched; more bracteate ; leaves shorter, less long-acuminate ; with crenate roundish-acute radicals.

N. Y. vic., Ravensdale, Oc. 8 , '98, bank of the Hudson, Bi., as A. divari. catus var. $x$.

$8^{3}$ Scorpioid form; inflorescence continuously proliferous upon one side; rays and disk olivaceous with age, the disk finally umber.

N. Y. vic., Van Cortlandt Park, Oc. 2, '97.

$8^{4}$ Axilliferous form; inflorescence descending irregularly far down the axils, chiefly one-sided; this and the warm shining disks and thickish leaves suggest that it is hybrid with $A$. Claytoni, which grew near; teeth closer, less salient.

N. Y. vic., Inzvood, Se. 27, '97.

$8^{5}$ White-saucer form. Strong-stemmed erect plants with large broad rays persistently upcurved at the apex, giving to the head, for a considerable time, the form of a shallow saucer; especially when, as often, the rays are very broad and close, overlapping at the base. Finally the head at full expansion resembles a flat circular plate. Leaves sharply serrate, the broad base strongly curved into a prominent sinus. Inflorescence passing from singlebunch form in early state to that of a diffused panicled corymb in occasional large and vigorous plants. Disks broad, chiefly brickred. Sept., frequent in rich rocky woods near N. Y.

N. Y. vic., Yonkers, Bryn Mawr Park, about Se. 20, '96, '97, ' $9 \delta$; then chiefly destroyed by clearing and strangled by the greatly stimulated growth of Amphicarpaea ; but many plants were again flowering Se. 14, 1903. Stony Lonesome, Se. I900; colony uprooted by a tornado I90I; a few surviving, I903.

\section{Aster excavatus Burgess}

Slender apple green plants with long uniform smooth leaves, numerous small sharp teeth, persistent narrow sinus, and somewhat segregated inflorescence with thin, pale, acute and obtuse smoothish bracts.

Name from sinus, seeming as if cut out from the oval leaf-base as if by afterthought; L. excavatus, hollowed out.

FIG. I 7, plant from Bryn Mawr Park, vic. N. Y., Se. 16, '99, in hb. $B u$.; with more triangular leaves than usual; or rather, many plants bear many oblong-lanceolate leaves above the triangular ones.

A. excavatus Burgess in Small's Southeastern Flora (1903); with original description : 
"Stems as in $A$. divaricatus L. ; leaf-blades thin, smooth, all nearly alike, oblong-lanceolate, with rounded base abruptly excavated into a deep narrow sinus; their margins continuously lowserrate with curvescent teeth; petioles very short and slender, shorter than the leaf-breadth, replaced by short broad wings at the principal axils; the upper axils often clasped by divaricate triangular-linear bracteals. Heads forming convex clusters borne on long suberect branches or reduced to a few distant enlarged heads. Bracts ciliate, smooth - backed, pale and thin, short-oblong and obtuse on some subsolitary heads, narrow and acutish on the similar clustered heads, the inner attenuate and without green tips. Rays white, or sometimes reddened; disk broad, turning usually purplish-crimson.-Resembes $A$. divaricatus L., but the narrower less attenuate more uniform leaves differ in outline, sinus and teeth. - In mountain or hillside woods, N. Y. to N. Car. and Ga. - Early fall. - Type, Yonkers, N. Y., Se. 16, '99, Burgess in hb. Bu."

Rootstocks seen are pale yellowish brown, short

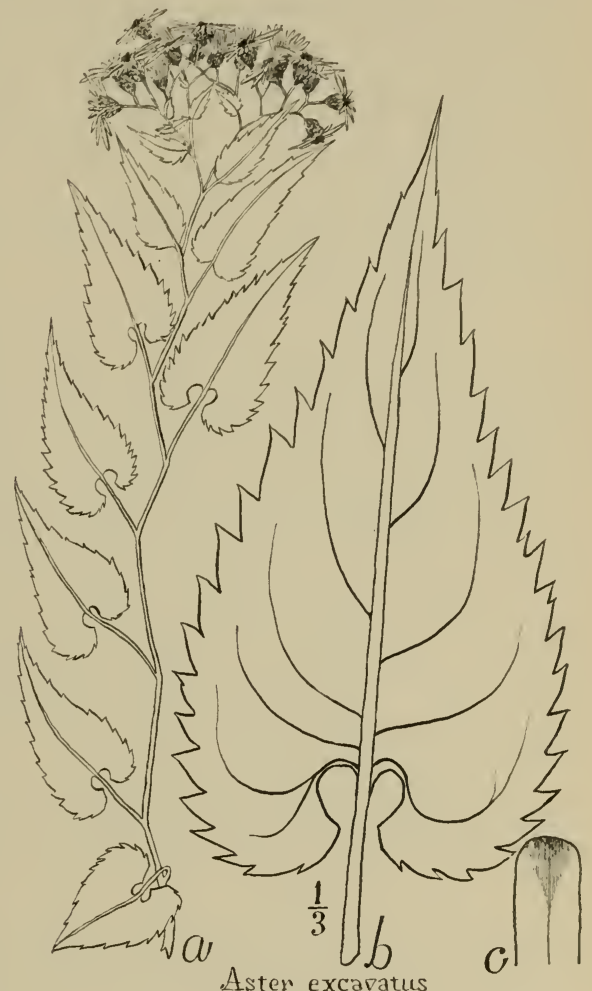

Aster excavatus

FIG. 17. and thick. Stems chiefly pale, suberect, growing in close clumps of few or sometimes of many stems.

Leaves thin, apple-green or paler, somewhat paler beneath. Leaf-form narrowly oblong-lanceolate, acuminate, broadest an inch or so above the base, then contracting into two narrowly rounded basal lobes which often overlap across the deep narrow sinus; size chiefly $3 \times \mathrm{I}$ in., sometimes $7 \times 3$. Teeth close and continuous, even into the sinus in many leaves, sharp but not greatly projected, chiefly curvescent ; toward the leaf bases, falcate, aquiline, crenate-serrate and straight-backed teeth intermingle. Sinus sometimes an inch deep, generally conspicuously excavated within. 
Petioles very slender, very short, and very persistent; still slightly present in the lanceolate rameals. No obvious hair ; but abundant, by lens, over the pedicels, though scanty elsewhere. Bracteals often triangular-linear, with clasping base, sharply serrulate.

Inflorescence irregularly convex, of somewhat separated clusters, borne on rather long suberect branches at a high angle. Heads rather large, I in. broad, $\frac{6}{16}$ in. high, or less. Bracts rather broad, with pale scarious borders of moderate breadth and brownish or yellowish tinge, their midrib a narrow elevated line, their green tips rather dark and deltoid.

Rays oblong, rather broad, $\frac{5}{16}$ in. long when dry, about 9 in number, sometimes 7 or 6 . Disks full and broad, sometimes virescent before reddening.

- Resembles $A$. persaliens, and sometimes accompanies it; like it in its long narrow leaves; unlike it in their less attenuate acumination, their broader base, their narrow sinus persistent well up the stem; and in their greatly reduced teeth.

- Resembles $A$. fragrans somewhat more, in its bracts; but its leaves differ in almost every respect.

Habitat in half shade or wood-borders, Catskills to the Great Smoky mountains, descending to $300 \mathrm{ft}$., when approaching New York City. Chiefly in the first half of Sept.

Specimens include:

N. Y., L. George, '95, Mrs. Watrous in hb. Colu.

N. Y., Catskills; Kaaterskill Mt., Se. I7, '99; Hunter, wood-fringes of Colonel's Chair Mt., Se. 6, '99; higher, and lower, on Mossy Brook, Se. 5, '99 ; to $2500^{\circ}$.

N. Y. vic., Yonkers ; Stony Lonesome, "rich high woods tuward Grassy Sprain L., Se. 17, '98, Aster — ? ' Bi., many plants; Se. 22, '99, Bu., chiefly out of flower. Vermilye's Ridge, Bu., Se. 23, '99. Bryn Mawr Woods, Se. 4, '98, Bi. ; Palmer Av., Se. 16, '99, Bu., typical locality ; also Se. 16, 1900. McLean Av., west of Caryl, Bu., Se. '99; Dunwoody, “woods north of St. Joseph's Seminary, Oc. 2, '98,' Bi.

N. J., Palisades, at Alpine, Se. I4, '99.

Va., Salt Pond Mt., Au. 25, '99, Pollard and Maxon in hb. U. S. N. Mu., No. $357, \mathbf{1} 27$.

N. Car., Highlands, 1888, G. H. Boynton, No. 18,950 in U. S. Natl. Herb.

Ga., Whitefield Co., rich shady woods east of Dalton, on Oostanaula shale (Cambrian), alt. $720 \mathrm{ft}$., Se. 7 , I90r, R. M. Harper, no. 1, 286, in hb. N. Y. Bot. Gar.

N. C., Andrezes' Bald, Swain Co., Au. '91, alt. 6,00o ft., Beardsley and Kofoid, and Long Knob, Heller; both in Gray hb.

$9^{1}$ Branch-forms have small short-oval and narrow biacuminate subsessile leaves. 
$9^{2}$ Sprout-form (or perhaps a hybrid of $A$. excavatus with $A$. tenebrosus, which grows in its region). Unites the narrow sinus and short rounded golden-brown bracts common in $A$. excavatus, with the large teeth and long rays of $A$. tenebrosus. Bracts nearly oval, with but very slight ciliation, thin and finely wrinkled when dry. Leaves all cordated, not large, ovate to oblong lanceolate. Rays few, remote, very narrow; tapering to both base and apex, partly perhaps due to imperfect unrolling. Heads large, I $1 / 4$ in. broad, or less, remote, a few also on long straggling pedicels in several upper axils. Rameals oval-acute. Some broken stimulated branches show enlarged branch-form leaves, oblong-lanceolate with long remote prominent coarse straight-backed low teeth and short broad cuneate wing-base.

Collected by II. C. Peardslee and C. A. Kofoid at 6,00o ft., on Andrews' Bald, Swain Co., N. C., Au. r891 ; in hb. Mo. Bot. Gard.

$9^{3}-$ Tubular form. Expanded heads still retain many tubular but horizontal rays, mingled with others which are canaliculate and some which are flattened. No obvious hair; but peculiar hair is visible under a lens, on petioles and pedicels, the hairs numerous, stiff, ascending, somewhat flattened and broadened toward the tips, often with dark tubercle-bases.

N. Y. vic., Yonkers, “N. E. of St. Joseph's Seminary, Oc. 2, '98," Bi., on a steep wooded bank sloping to a pond, in deep shade, 3 plants together.

\section{Aster subinteger Bicknell, sp. nov.}

Dark slender allies of $A$. atrovirens, with lance-triangular leaves, greatly reduced serration and cordation, and small divergent inflorescence.

Name, L., from the nearly entire upper leaves.

FIG. 18, plant from Yonkers, Se. 25, '98, in hb. Bu.

Stem slender, brown and green, slightly flexuous above, curving at the ground into a tough brown short thickish horizontal rootstock, at the top of which a short purplish surculus rises upward at an acute angle, within a half inch of its base bearing $\mathrm{I}$ or 2 oval primordial leaves.

Primordial leaves $1 / 2 \mathrm{in}$. long or only half as long, nearly equally broad, with 3 or 4 shallow teeth along each side; base suddenly tapering without cordation into a slender petiole of the length of the leaf; apex either truncate or slightly acute.

Lower cauline leaves somewhat cordate-lanceolate, with broad shallow bract-sinus, giving the base of the leaf a subtruncate aspect; teeth moderately sharp, slender-tipped (rarely couchant), becoming rather salient and close toward the middle of the leaf 
and then quickly ceasing, the leaf incurving into a long narrow entire acumination. Such leaves are $21 / 2 \times 1 \mathrm{I} / 4$ in., with slender petioles $I$ in. or less long, I 2 such or less, about $I 1 / 2$ in. apart.

Upper cauline leaves are the most characteristic, and give the plant its subentire aspect; 8 such or fewer, $3 \times \mathrm{I}$ in. or less, slenderly lanceolate with rounded or very slightly tapering base,

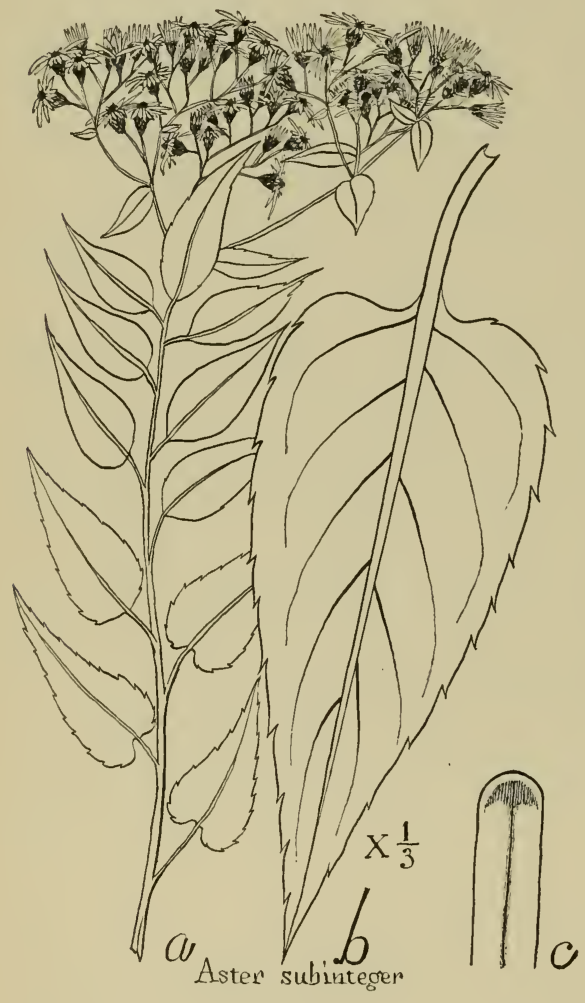

FIG. I8. sometimes wholly entire, often lined their whole length with long low shallow incurving teeth, $1 / 3$ to $1 / 2$ in. long, these teeth quite peculiar, with excavated notches, often slightly convex-backed, the green aculeus rising without preliminary basal swelling.

Middle caulines few, transitional, truncate-based. All leaves deep green above, pale beneath. Axiles few, similar to the upper caulines, entire, lanceolate, sessile, $2 \mathrm{I} / 2 \times 1$ in. or less. Rameals sometimes inconspicuous, sometimes very numerous and $I \times I / 2$ in. or less, ovate, acute. Ramulars similar, only half or a third as long.

Inflorescence small; heads $7 / 8$ in. broad, sometimes $\mathrm{I}$ in., $3 / 8$ in. high, or only $1 / 4$ in early flower, the small involucre itself hardly more than half this. Pedicels and peduncles show hair in lines, though none remains at maturity below. Pedicels widely forking, usually $1 / 2$ or $1 / 3$ in. long, very slender, bearing at the middle a minute straight linear bractlet which sometimes becomes obovate. Rays about IO, rather blunt, sometimes with even as many as 4 teeth. Disks turning brown with a little light purple cast. Bracts in 4 or even 5 rows, quite uniform, with dark broad rounded tips.

-Occasional in wet stony levels of shady woods, near N. Y. City. Examples : 
N. Y. vic., Inwood, bank of the Hudson to the south, Oc. I6, '98, Bi. Yonkers, Glen Park woods, Se. 25, '98, Bi. Mayflower Valley, Se. 17, '98, Bu.

N. J., Palisiades, Undercliff, Oc. 17, '98, Bu.; one of these plants on the talus below, in deep shade, showed repeated fasciation and crowded internodes, 27 leaves of size $2 \times 2 / 3$ inches, occurring within 3 inches of stem.

\section{I. Aster sextilis sp. nov.}

Low smoothish early-flowering plants with oblong-lanceolate closely slit-serrate leaves, pale acutish subciliate bracts, small heads and slight sinus, tending to growth in the axils, to contracted caudate acumination, to pale short-petioled stiffly-directed leaves and reddened stems.

Name, L. sextilis, of August ; from its early blossoming, chiefly mid-August.

FIG. 19, plant of Woodlawn Woods, N. Y. vic., July 31, '98, in hb. Bu., coll. by E. P. Bicknell ; $b$, its characteristic leaf; $d$, broader-based more spear-pointed leaf-form, frequent on more scattered plants, Au. I I, ' 98 .

Plant narrow, often so closely clustered as to produce elongated branchless stems, soon leafless below, but foliose or floriferous in the upper axils. Radicals not seen. Stem smooth, slender, continuously slightly flexed, terete and reddened.

Leaves thin, usually apple-green or yellowish green, mostly stiffly directed, their petioles very short and slender, or sometimes winged above.

Leaf form oblong-acuminate from a broad base, incurved or sometimes straight-tapering, usually produced into an entire caudate extension, sometimes almost a bristle. Teeth slender-acuminate, very close, forward-directed. Sinus sharp and slight, or in a few middle caulines broad, shallow and brace-based. Veins rather closely pinnate. Rameals usually sessile, inconspicuous because so narrow, but often an inch long. Lower caulines early lost, cordate-ovate, short and broad compared with those seen at flowering time.

Heads persistently close-clustered or finally divergently separated, very small, often but $1 / 2$ in. broad. Rays apt to be short and few, 5 or 6 . Disks dull yellowish, soon turning brownish. Bracts resembling those of $A$. divaricatus $\mathrm{L}$. in being thick, coriaceous and oblong, but paler, tangled-ciliate, with little green at tip, nearly smooth-backed, and chiefly acutish, the lower sharply triangularacute, the second broad, the others prolonged-triangular. In young globose buds the bract-margins are white from their ciliation, with a slight purple margin within.

In grassy wood-borders or half-green spots. Taconics to Lake Erie, chiefly in August or even in July. 


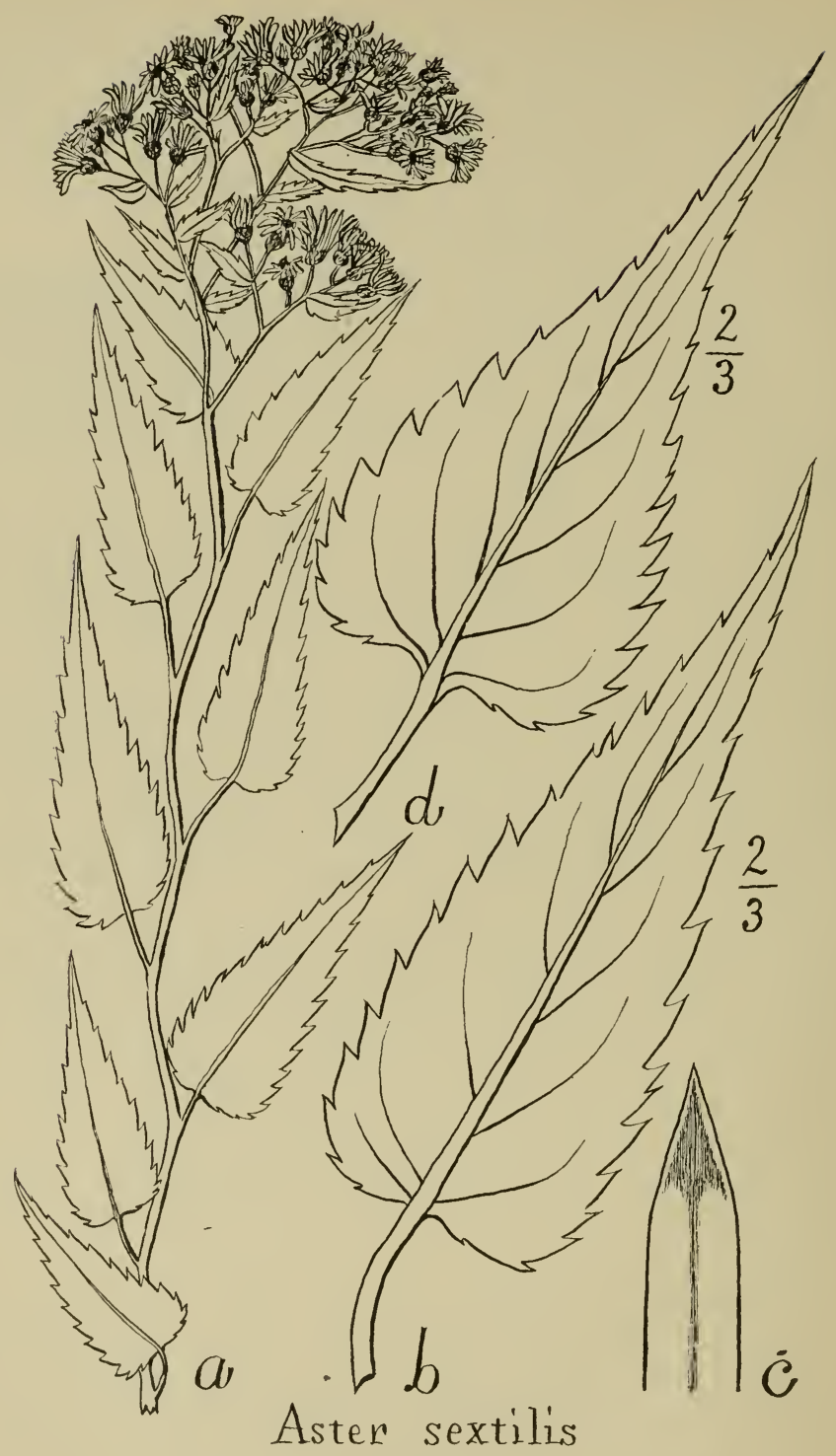

FIG. I 9 .

Ms., Taconics, Bashbish R. above Merchant's Br. last of Au. I903.

N. Y. vic., Woodlazen woods, July 31, '98, Bi, "lower leaves fallen away; no basal tufts; a close cluster, in cleared woodland."

W. N. Y., Silver Cr., Swift's Hill, Au. 15, '96, close clump grown tall and virgate, stump-fed; Au. II, 98, grassy woodborder; Au. 31, '99, Au. I903, etc. Hanover, Tompkins' woods, Au. 28, '99; Little-Indian bank, Au. 24, '97. Perrys- 
burg, Dawley woods, borders and roadsides, abundant, Au. 19, '96. Sherdan, Talcott woods, Au. 15, '96, Au. '97, '98, '99.

I I $^{2}$ Pigmy-head form. Peculiar little plants in close clumps with aspect of Acalypha, - partly due to dull gray-green coloring and partly to foliose growth in axils. Heads a dozen or less, close-crowded, about $\frac{3}{10}$ in. high and but twice as broad. Stems chiefly green and 6 to 8 in. high. Leaves serrulate, oblong-ovate, strongly caudate, chiefly with abrupt truncate base; sometimes slightly cordated, or auriculate by extension of basal lobes at the outer angle; some upper leaves lanceolate; all caudate and slender-petioled. Disks soon brownish. - Very strange plants, perhaps owing some of their peculiarity to growth as choked seedlings.

W. N. Y., Fredonia, Marsh's woods, Au. 20, '96; edge of cave, Wintergreen Gulf, Au. 13, '97; west branch of Canadaway Cr., Au. 14, '97; Cascade Brook, Au. '97; Pt. Gratiot wood-edge, Au. '97.

\section{Subdivision B of Divaricate Asters.}

Stems weak or decumbent. - Sp. 12-I 6

\section{2. Aster stilettiformis Burgess}

Much-branched plants with slender green or brownish-green often decumbent stems, long narrow linear-oblong leaves, straightbacked, sharp, close conspicuous teeth, lingual bracts, rather large flowers, and little development of sinus or petiole.

Name from the straight-pointed upper leaves and axiles.

Fig. 20, plant from Hunter, N. Y., Se. 7, '99, in hb. Bu.

Aster stilettiformis Burgess in Small's S. E. Hlora, I 211 . I903; with original description :

"Stem greenish, slender, weak and often decumbent. Predominant leaf-blades deep green, often roughened above, linearoblong and long-acuminate, with subtruncate base and short petiole, and closely set with conspicuous sharp straight-backed teeth; some lower leaves broader, ovate-acuminate with moderate sinus and with double-curved or couchant teeth; axile leaves divaricate, straight-tapered from a sessile truncate base, everywhere closely slit-toothed, suggesting a barbed stiletto. Inflorescence remotely diffused, but with short pedicels ; bracts lingual, nearly uniform, green or mostly so ; rays often 7 , sometimes reddening at the tips; disks turning brownish-red. Differs from $A$. divaricatus L., especially in leaf-form, bracts and stem.-On shaded banks, Ms. to S. C. and Tenn. - Fall. Type, Hunter, N. Y., Bu., Se. 7, '99, in hb. Bu." 
Occasional strong plants grow erect. Few leaves have any sinus. The leaf-form is best seen in the upper caulines, which are hardly to be duplicated among related species ; these and the lower leaves are often deflexed in case of bankside plants. Veins often very strong, depressed above, projecting beneath. Rays often

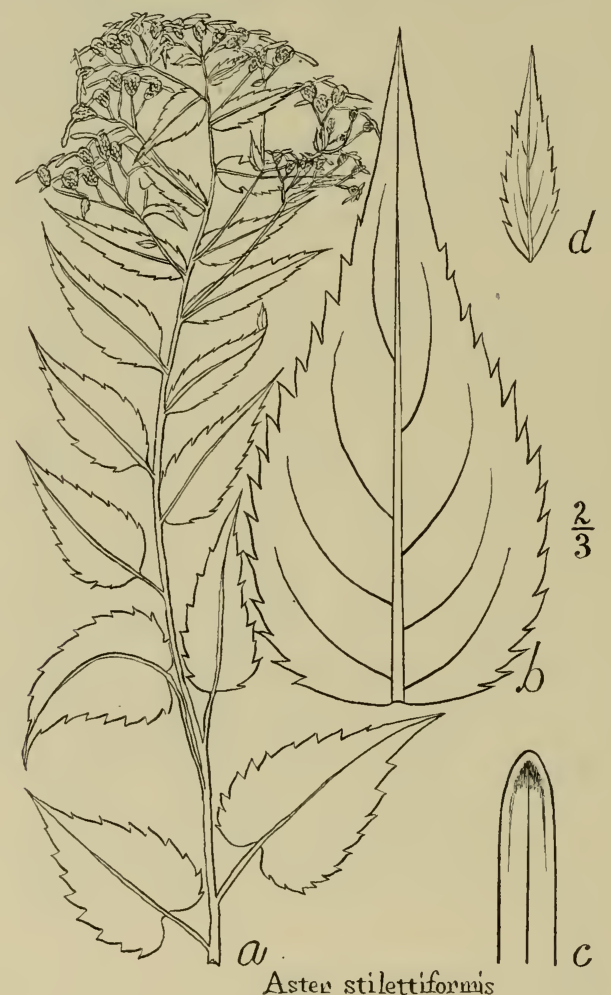

FIG. 20 .

become acuminate by conduplication. Disks become brownishred or crimson, sometimes Venetian-red, or wine-color.

- Perhaps a recent derivative from $A$. persaliens, as suggested by its lowest cauline leaves. Resembles $A$. persaliens in general appearance; differs from it in having very much narrower upper leaves, with straighter sides ; in its truncate-based long sharp sessile axiles; in its slit-toothed margins, the teeth chiefly with straight backs and rarely couchant; in its round-tipped green bracts with but few of the inner ones narrowed. It tends also to the development of a weaker stem and broader more diffuse inflorescence. 
From $A$. virgularius, which its smaller form resembles, it differs in its broader, rounder, greener bracts, in its truncate-based sessile axiles, and its far more salient teeth. It is usually a much larger plant, and its typical leaves are narrower.

It resembles buth these species in the prominence of its teeth, and $A$. virgularius in their form. It differs from both in its slittoothed straighter-sided leaves, its bracts nearly without white or scarious margins, and its axiles nearly without petioles, with truncate base and long closely-slit straight sides, suggesting a stiletto.

Habitat, scattered in loamy half-shade, often on steep banks, in little clusters or solitary. Mass. to S. C. and Tenn. Examples :

Ms., Middlesex Fells, Cascade, Fells Sta., Au. 27, ' 98.

M. V., Davistorun, woods, Se. 4, '97.

Ct., Shuttle Meadow, Se. 7, '89, Jas. Shepard in hb. Bu.

N. Y. vic., Inzwood, Se. 24, '96; Mosholu, Se. 30, '96, on steep clay banks; Indianfield, Se. 18, '98, with crimson rays; Pelham Manor, Se. 20, '98; Yonkers, Hillview, stepping stones, Se. 15, '98; Park Hill, Se. 14, '96; Bryn Mawr Park, Black Pool, Se. 20, '96, Se. 14, 1903; roadside, Se. 14, 1903; Palmer Av. rocks, Se. 26, '96, Se. 18, '97; Violaris path, Se. 14, '98, with crimson rays; on its rocks, Se. 18, '97; lanthine rocks, Se. I4, '97, crimson rays; Split rocks, Se. 18, '97, Se. 25, '98, Se. 15, 1903.

N. J., Palisades, Undercliff, tip, Oc. I7, '98.

W. N. Y., Fredonia, spring-bank toward Laona, plants with navicula-like rays, Au. 22, '96; Sheridan, Pawpaw grove, Au. 13, '95, in bud and in first flower; Hanover, Little Indian Falls, Au. 31, '99.

N. Y., Catskills, Hunter, Se. 7, '99.

D. C., Mt . Pleasant, brook, Se. 22, '88; Lanier Hts., brook, Se. 24, '88; Rock Cr., above Bladgen's Mill, Oc. 12, '88; Mintwood Bank, Oc. 22, '88, Oc. 3 , '89, a principal locality, now destroyed.

Va., Potomac bank, opposite Analostan I., Se. 27, '88; east of Holtzman's, Oc. 29, ' 88 ; above Chain Br., Oc. 9, ' 88 ; Spout Run, Oc. 2, '88; Carlin Spr., Se. I 8 , '93.

S. C., "Table Rock, Se. 30," Gibbes in hb. N. Y. Bot. Gar.

VARIANTS. I $2^{2}$ Branch-forms of $A$. stilettiformis have shown a tendency to large elliptic-acuminate rameals, often opposite by non-development of internodes, both $\mathrm{N}$. Y. and Va.

I $2^{3}$ Sprout-forms; those seen are small and but little differentiated.

I $2^{4}$ Dentifolial form. Slenderer plants with many cuneate leafbases. Leaves delicate, small for the plant, oblong-acuminate, short-petioled, few furnished with sinus, pedicels long, loose, capillary, ascending. Internodes irregular, some of them longer than the leaves. With $A$. divaricatus and $A$. arenicola, in Marthas Vineyard, and of probable occurrence elsewhere on the coast. 
M. V., Davistozon, rich woods, Au. 21, '89. West Tisbury, fishway, Au. '96, '97, in bud, Au. 10, 1900. Chilmark, Mark's Valley, in bud Au. 24, 1900, delayed by drought; in flower Au. '97, '98. Gayhead, Blackwater Knoll, Se. 6, '98 ; in bud Au. 26, 1900, delayed by drought.

I $2^{5} \mathrm{Jag}$-edge form. Teeth very close, irregular, some of them reflexed. Leaves of heavier, firm texture, more of them oblongacuminate. Late flowering. The most abundant form of the species observed in the Potomac region, including plants collected Oc. I-I 5, I 888, as " $A$. corymbosus, dentate or jagged-leaf form."

\section{Aster Parthianus sp. nov.}

Small geniculate plants of rock-faces and clay-banks, with thin ovate-lanceolate serrulate deflexed leaves, dark-tipped obtuse strongly-ciliate chief bracts, and small terminal inflorescence.

Name from the sharp back-flung leaves, suggesting Parthian arrows.

FIG. 21, plant from Silver Cr., N. Y., Au. I7, '96, in hb. Bu.

Plants growing outward and then bending upward, or sometimes suberect; some or many of the leaves stiffly deflexed or directed backward; such leaves mostly ovate-lanceolate, strongly incurved-acuminate, many of them becoming caudate, finely serrulate, with rounded base and short slender petiole. Axiles similar, few, gradually reduced. Lower leaves broader, not much longer, with rather close sharply acuminate teeth, and with broad open sinus. Radicals seen are chiefly elliptic.

Inflorescence a small and irregular loose cluster. Heads small or of medium size; bracts various, in some broad, short and truncate, highly ciliate (derivatives direct from typical $A$. divaricatus?), in many others pale, smoothish, more uniform and moderately acute (derivatives from $A$. divaricatus much further differentiated, or perhaps blended with other strains of descent. In some otherwise similar plants the leaf-form suggests blending with $A$. persaliens, $A$. stilettiformis, and $A$. rupicola. Apparently conditions of growth, especially those involved in reaching out for light and air from crevices of rocks, have caused descendants from a number of allied sources to converge into one composite group from which many of the differences and traces of descent have already disappeared. Most typical plants show the following characteristics :

Stems slender, strong, brownish, flexuous and usually abruptly geniculate once or twice at nearly a right angle. Rootstock short, thick, curving, its nodes excessively shortened, and long continuing enwrapped with petiolar expansions. The whole root- 
stock is often but I in. long, while including $\mathrm{I} 2$ to 20 nodes and $1 / 8$ in. thick or more.

Leaves numbering about $8-12$, within as many inches; all

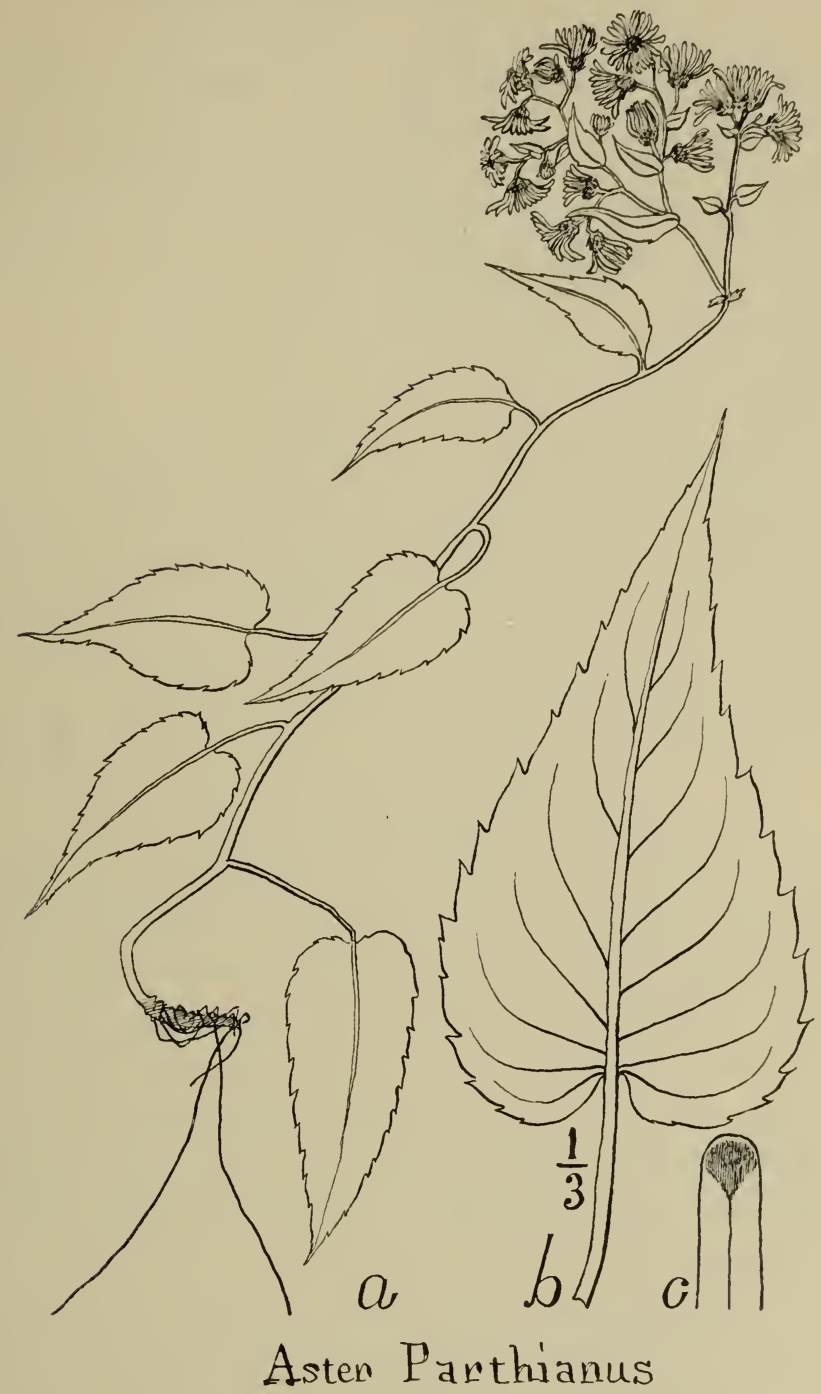

FIG. 2 I .

deflexed, or more often in part deflexed, in part divaricate and a few ascending; their petioles slender. Leaf-bases broad, the prominent sinus deep and narrow, or moderately so. Leaf-form ovate-acuminate, soon narrowing to lance-acuminate; margins 
subentire, serrulate, or serrate, the teeth straight or couchant. Axiles soon cuneate at their sessile base, lance-acuminate. Leaves rough or very slightly so. Puberulence not obvious, but abundant over whole stem and petioles as well as leaves.

Inflorescence loose, irregular. Heads medium in size, about I in. broad. Bracts triseriate, with much deep green from the acutish or apiculate tip half way down, darkest at the tip and margins. Rays narrow, about 9, their apex narrowed and entire. Sometimes the tendency to twist manifests itself in spiral rays of many turns. Disks turn purplish-brown. Achenes dark brown, smooth, clavate-terete.

Habitat, banks and cliffs, Mass. and L. Erie to Va.

M. V., Tea Lane, Au. 29, '93.

N. Y. vic., Spuyten Duyvil Cr., Cock Hill, Se. 22, '98. Inwood, Dyckman rock, Se. 24, '96. Indianfield, Se. 16, '98. Mosholu, clay bank, Se. 30, '96. Woodlawn Heights swamp, Se. 16, '98. Bryn Mazur Park, Palmer Av. Pool, Se. I 7, '98. Palmer Av. Rocks, Se. 26, '96, Se. 18, '97, Se. I7, '98; the latter with spiralled rays; a branch had fallen on it below the flowers, causing a huddled growth of inflorescence followed by long pedicels. Hillvierw, Se. 19, '97. Fordham, rocks north of, Se. 1903 .

W. N. Y., Silver Cr. glen, High Br., Au. 17, '96, type; Au. 10, '98. Little Indian Falls, on rock wall, Au. 13, '98. Pt. Gratiot, Au. 29, '96.

D. C., Mintroood Bank, Oc. 22, '88.

\section{I4. Aster camptilis sp. nov.}

Arcuate weak-stemmed smoothish small-flowered plants of wooded banks, with thin oblong-acuminate serrate leaves, slight sinus, lanceolate axiles, and uniform pale subacute bracts.

Name, L. camptilis, bent, from the bent or decurved stems.

FIG. 22, plant from Silver Cr., N. Y., Au. 17, '96, in hb. Bu.

Stem green or brownish, terete, irregularly and slightly flexuous, toward the top gradually recurved or strongly bent downward. Occasional stems however become stronger and nearly erect; but in other kindred species growing with it on shaded slopes, the erect stem is the rule, not the exception.

Leaves quite uniform, $3 \times \mathrm{I} / 2 \mathrm{in}$. or less, very thin, rather dark green, pale beneath, oblong-acuminate in type, the lowest ones ovate-acute and much shorter, the axiles sessile but still prolonged and lance-acuminate, the rameals the same or oblongacute, very much shorter but much broader in proportion. Petioles short, slenderer, cuneately winged above. Teeth moderate, continuous, of serrate type, with some curvescent and dentate ones intermixed. 
Inflorescencewith axis strongly decurved, but the heads upturned and small, often $2 / 3$ in. broad, $1 / 4$ high. Bracts quite uniform, pale with distinct green tips, sublingual or oblong-linear, rounded above into a slightly acutish apex, minutely ciliolate, suggesting those of A. divaricatus L., but less broad and ciliate, not truncate, and a little less rigid.

Habitat on banks or leaning out from rocks, growing with other related Asters of the Divaricati which do not lean. Occasionally it is to be found hanging over slight depressions in moist flat ground in woods where other related Asters are growing erect. - Aug. and Sept.

- Among species characteristically arcuate, $A$. camptilis has an oblong-acuminate leaf-form with slight sinus; A. Parthiamus ovatelanceolate and more cordate, with rounded base in the principal leaves; $A$. arcuatus broad-cordate, abrupt

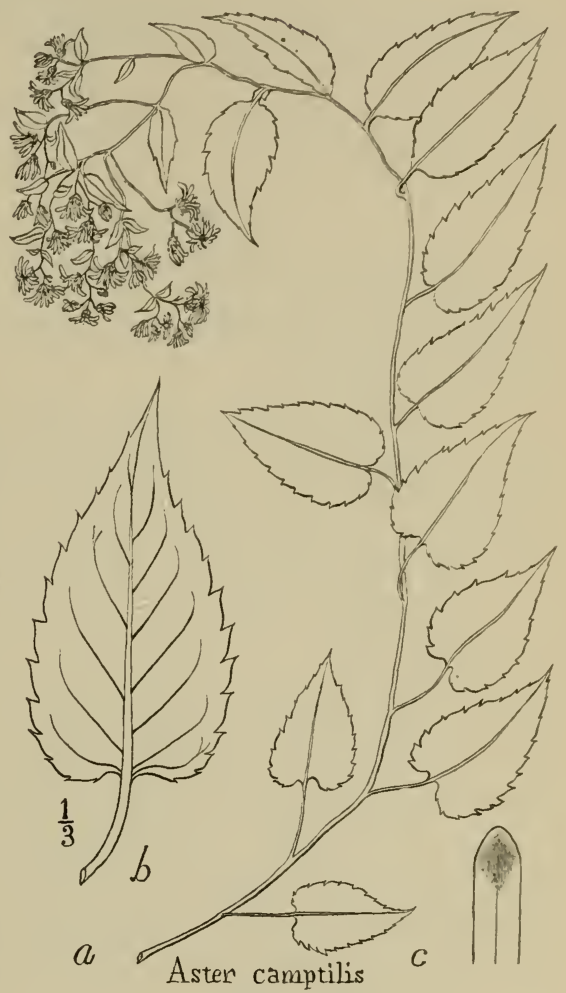

FIG. 22. and short, with large deep square sinus. In all these, the arcuate tendency seems connected with inherent weakness of stem as compared with rigid plants of $A$. divaricatus, $A$. ulmarius, etc., growing side by side.

Range, observed Mass. to L. Erie. Examples :

Ms., Taconics, Mt. Ethel, hanging down into depressed woodpaths, Se. 10, 1903 ; Bashbish, hanging over the border of small ravine at Parnassus meadow, Au. 1903.

N. Y. vic., Inzwood, Se. 23, 1903. Indianfield, Se. 25, 1900. Fordham, rocks to north, Se. 1903. Yonkers, Bryn Mawr Park, Se. 19, '99, 13-rayed; hanging out from the base of Split Rocks, Se. 18, '99, Se. 18, 1903; valley edge, Se. 15, 1903; summit rock, Se. I6, I900, stimulated to overplus rays, I0, II, and even I3, by growth in rich decaying stump; not the same with a 13 -rayed form or ally of $A$. divaricatus L., which grew near, but which has persistently broader shorter leaves and broad 
rounded bracts, and grows in dense clumps while $A$. camptilis grows few and scattered or loosely.

N. J., Palisades, Se. '98.

N. Y., L. Minnerwaska, C. H. Peck, Se. 1, '99, in hb. N. Y. St., " in low place in woods, surrounded by rocks; with long weak slim stem arcuate by nature, and could not have been trodden on ; with long limp branches, many of them Io in. long," C. H. P.

IV. N. Y., Silver. Cr., gorge, Aster-bank, Au. 17, '96, Rosebrook woods, Au., I900, I901, 1902.

\section{Aster Boykinil Burgess}

Slender and weak axil-flowered, all green plants of irregular straggling aspect, their leaves oblong-acuminate with enlarged sinus and strong teeth.

Name from Dr. Geo. Boykin of Milledgeville, Ga., its early collector of about I 840 , "pioneer botanist " in Georgia, a correspondent of Torrey and Gray, and source of many of their southern specimens (as Aster purpuratus, etc.) ; commemorated in Nuttall's genus Boykinia, ally of Saxifraga, from the North Carolina mountains.

FIG. 23, plant from Ga., I840? Boykin in hb. Colu.

A. Boykinii, Burgess in Small's Southeastern Flora, I2II (1903); with original description :

"Stems slender, greenish and glabrate, much flexed; leafblades ovate to oblong-acuminate, with broad enlarged sinus, set with strong and somewhat outflung teeth; petioles slender; inflorescence lax and irregular, composed of short branches given off at a wide angle, often continued in clusters among the lower axils; the upper axils often conspicuous with ovate or subcircular sessile bracteals ; disks turning reddish-brown; rays shorter than in its ally, $A$. divaricatus L., from which it differs especially in its more straggling habit, narrow irregular inflorescence and less coarsely toothed, less prolonged leaves. - In the mountains, Georgia. - Summer. Type, Ga., Boykin, Au. 1840, in Herb. C. U."

Stem often decumbent, I $1 / 2$ or $2 \mathrm{ft}$. high. Leaves thin and rather variable. Small oval low-serrate radicals are sometimes produced.

Inflorescence often as well-developed in the lower axils as at the tip. Bracts with thin wrinkling margins, oblong. Disks turn brownish-red. Achenes smooth, not enlarged upward, fusiform, rather strongly striate-ridged.

Unlike the next species, A. flexilis (with which it sometimes grows), in its brighter green, its thinner, longer leaves, broader sinus, more numerous and lax heads with longer pedicels, and its thin-edged acuter bracts. The teeth are much larger, longer and more outflung than in $A$. flexilis, though less so than in A. divari- 


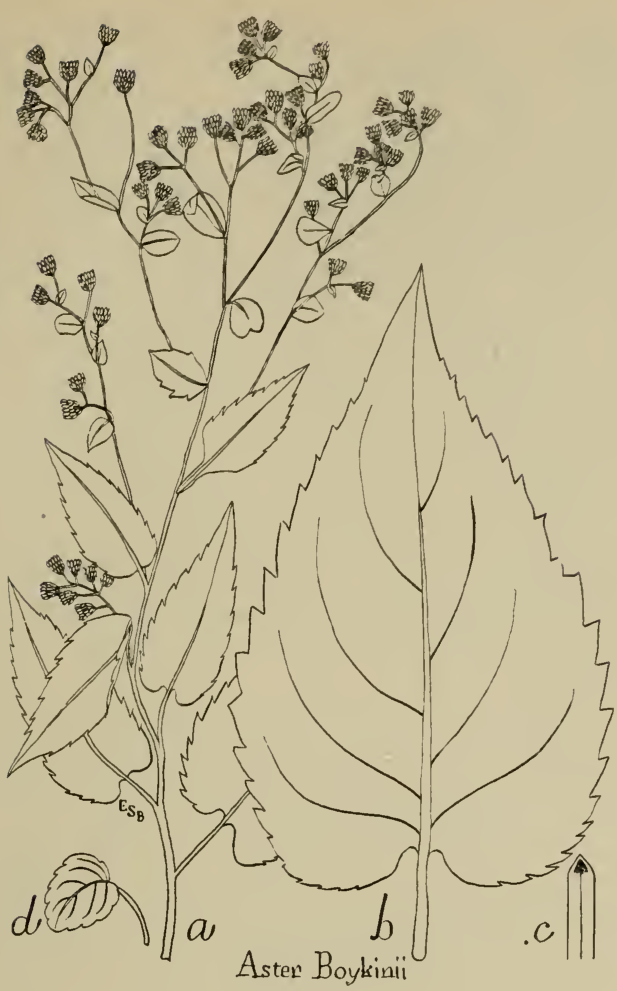

FIG. 23.

catus. In inflorescence and leaf-form it is intermediate between the two species.

\section{Examples :}

Ga., "A. corymbosus (the Southern loose form), Geo. Boykin," Gray scr., about 1840 , in Torr. hb.

Ga., "mtns. of Ga., Aug., I 84 r," S. B. Buckley scr., in Torr. hb. ; to which Gray added, "appears to be an outlandish form of $A$. corymbosus. The leaves not so coarsely toothed; as also other Southern specimens. I have not mentioned it " (on old label of T. and G. Fl. N. A.)

Ga., Chickamauga Cr., near Ringgold, Catoosa Co. ; alt. $800-900 \mathrm{ft}$. Au. 6-12, I895" J. K. Small in hb. Colu.

Tenn., K'nox Co., Au. 8, '9o, T. H. Kearney in herb. U. S. Natl. Mu., no. 306,972 .

\section{I6. Aster flexilis Burgess}

Small slender dull-green plants with little ovate-acute leaves, sharp narrow sinus, short petioles, subcrenate margins, narrow obtuse bracts, and scanty inflorescence. 


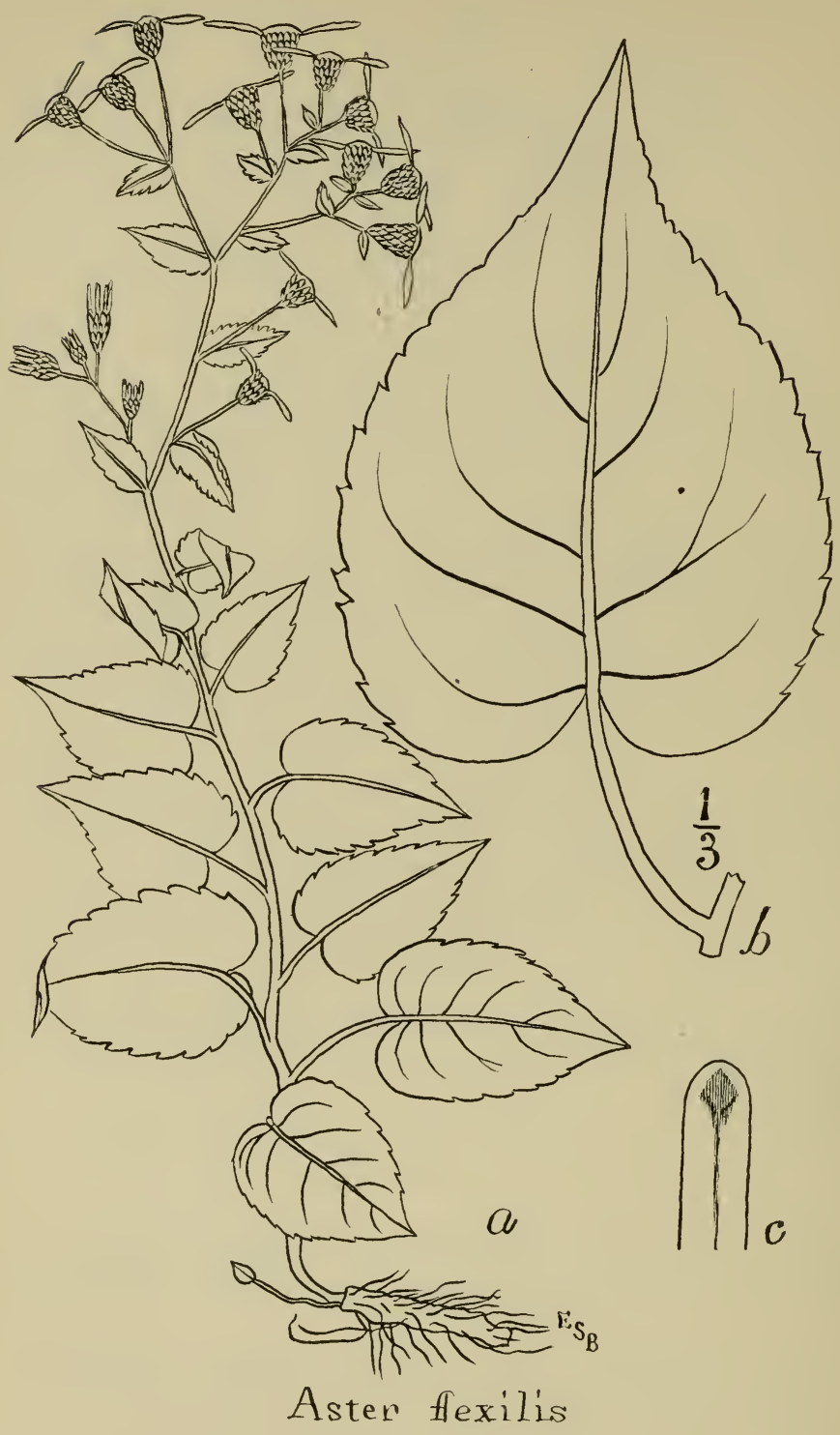

FIG. 24.

Name, L., from the flexed or subdecumbent stem.

FIG. 24, plant from Ga., about 1840, Buckley in hb. Torrey.

A. flexilis, Burgess in Small's Southeastern Flora, I212. 1903; with original description : 
"Stem low, slender, smooth and virgate: leaf-blades small, short, thin, dull, dark green, ovate-acute with the broad double rounded base bisected by a deep sharp sinus; margins crenateserrate with low obscure teeth; petioles short; inflorescence scanty, tuftlike, or of a few slim-peduncled heads : bracts narrowly linear, obtuse, quite uniform ; plant almost destitute of hair (under lens); otherwise nearly as $A$. divaricatus $\mathrm{L}$. Differs from $A$. Boykinii (with which it grows) especially in its smaller shorter dull leaves, the sharp sinus, crenate margins, and obtuse bracts. - In the mountains, eastern Tennessee, Georgia, and Alabama. - Late summer and fall. Type, Buckley, I 840, in Herb. C. U." Further remarks. Tends to small size, flexed and unbranched, with small sinus continuously developed. Axiles oval or shortoblong, leaves finely rugulose, with dark impressed veinlets. Teeth shallow, close and uniform. Bracts highly coriaceous, shortciliate, finely puberulent over the back; a few lower ones acutish.

Examples :

Ga., "a starveling $A$. corymbosus, Mts. of Georgia, in a parcel from Buckley, Feb. I, I841," Gray scr., in herb. Torr.

Ga., "A. corymbosus," Mts. of Georgia, Chapman in herb. Colu.

Ga., Ringgold, Catoosa Co., Au. 6-1 2, 1895, alt. 800-900 ft., J. K. Small in hb. N. Y. Bot. Gard.

Ga., Whitfield C'o., along brook in rich woods at east base of Taylor's ridge, alt. 975 ft., July 27, 1900, Roland M. Harper in hb. N. Y. Bot. Gard.

Ga., Walker Co., among rocks, east slope of Pigeon Mt., Au. I, 1900, alt. 1,550 ft., Percy Wilson, in hb. N. Y. Bot. Gard.

Ala., Cullman Co., Sept. 9, '97, H. Eggert; with little crenate penny-like radicals. Herb. N. Y. Bot. Gard.

Bot. Gard.

Tenn., Knoxillle, bluffs of Tennessee R., Se. '98, Albert Ruth, in hb. N. Y.

\section{Division B. CARMESINE ASTERS.}

Thinnish firmer leaves of shorter types. Disks turning soon to a more definite red or finally to a deep crimson. Stem erect, stiff or wand-like.

Subdivision A. LOWER BRACTS ACUTISH. Species 17 and IS.

\section{I7. Aster arcifolius sp. nov.}

Stiff purple-stemmed brace-based short-leaf plants, of triangular-ovate leaf form and firm texture, with about $S$ rays and these often crimson, the bracts chiefly lingual and uniform, slightly ciliate, obtuse or acutish. 
Name, L., arcus, a bow, from the brace-base character of the leaves, a double curve, suggesting a bow.

FIG. 25, plant from Hunter, N. Y., Se. 8, '99, in hb. Bu.

Growth cespitose, forming loose patches sometimes extending a rod without intermixture. Pale brown rootstocks occur with internodes about I in. long, much thickened and shortened toward

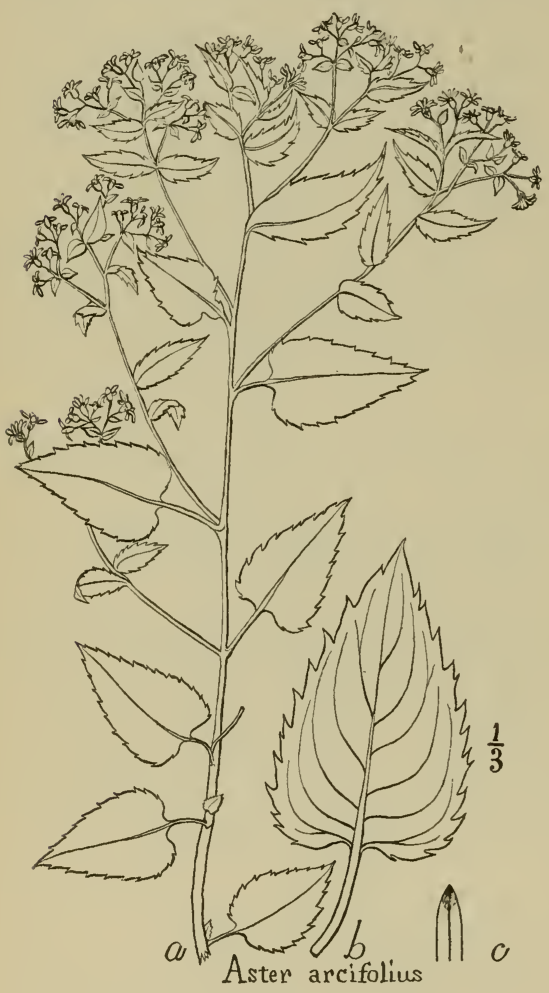

FIG. 25 . the ascending stem. Stems usually $\mathrm{I} / 2 \mathrm{ft}$. high, chiefly of a purplish wine-color (except in case of occasional exterior plants) ; usually appearing the more slender and tapering on account of the gradual reduction in size of the upper stem-leaves. Radicals seldom developed; those seen are small, orbicular-ovate, slender-petioled and serrulate.

Leaf-type triangularovate, not long nor large, broadest at or near the bracelike base, irregularly and doubly serrate, firm, roughish when dry, dark green, slender-petioled, about $2 \mathrm{r} / 2$ $\times 2$ in. in size.

Lower caulines slightly incurved-acuminate; midtle and upper caulines and axiles often taper straight from the base ; wing-bases occur with the first axiles; upper axiles sessile. Teeth of very great variety, couchant, curvescent, aquiline, straight-serrate, etc., mingled. Veins slender, pale, strongly upcurved toward the apex, chiefly external, as if laid on or applied beneath.

Sinus very broad, open and shallow, continuously developed, nearly or quite to the axiles. Sometimes a deeper sinus occurs below or a narrow one intermixed above.

Inflorescence usually a small and rather close convex cyme; or with several branches, each bearing such a cyme; after- long flowering, each becomes diffuse and widely forking. Axis semipercurrent only or obsolete. Typical heads small, $3 / 4$ in. across, 
or only $1 / 2$ in., with 6 to 8 short broad rays which are often crimson-tinged, sometimes quite deeply so. Disks becoming brownish, but usually previously crimson. Pedicels $1 / 2$ in. long or usually as long as the head, inflorescence small and often peduncular when growing in close communities, wide-spreading and forming a loose convex mass when growing in loose patches.

Bracts chiefly lingual, obtusish or acutish, all much alike, but including some acute, obtuse, truncate, bevelled or rounded tips. The oblong type with lingual-acutish tip seems most common, including a third or more of each head, the inner third being usually linear and tapering-obtuse. Green tips but moderately developed; bracts otherwise mostly pale and thin-coriaceous, their central green line very slender. Ciliation moderate, whitish, chiefly upward.

Impoverished plants show 6 broad rays repeatedly, and narrower lance-triangular leaves; they resemble small plants of $A$. divaricatus L. closely. Shaded plants show less crimson or none, and often develop quite conspicuous bracteals. Better-nourished plants of the same cluster show broader looser branching, 8 rays repeatedly and in some heads II, occasional heads I in. broad, and sometimes a leaf $4 \times 2$ in. or even $7 \times 23 / 4$ in.

Habitat, grassy open levels, in rather moist soil; especially low grounds near brooks and swamps; sometimes in slight shade; L. Erie to the Taconics at I,600 $\mathrm{ft}$.

\section{Examples :}

Ms., Taconics, on Mt. Ethel, Se. 8, 1903.

N. Y. vic., Ft. Washington, Oc. 16, '98, Bi. Indianfield, Se. 16, '98; Se:on Falls, Se. 24, I900, the flowers fragrant on collecting and while drying.

N. J., Palisades, Undercliff, Oc. I 7, '98.

N. Y., Catskills, Fernside Brook at Hunter, Se. 8, '90, type ; shanty in ShantyHollow, Colonel's Chair Mt., Se. 6, '99; Pyrola rock, Mossy Brook, Se. 6, '99. L. Minnervaska, Se. '99. C. H. Peck in hb. N. Y. St.

W. N. Y., Sheridan, Brace's Bay, Au. I5, '96; Hanover, Gardner's Brook, Au. I9, '96; Perrysburg, Au. I9, '96.

- Aster arcifolius resembles $A$. divaricatus deltoideus in its leaves; but its leaves are more acuminate, more finely serrate, the teeth more outflung, and the bracts more acutish, not strongly obtuse. Resembles $A$. Claytoni in a slight tendency to a permanent axis, but much less so and only seeming so when young, the axis becoming lost or much overtopped at complete flowering. Resembles $A$. Claytoni and the Curvescontes in its frequent development of two contiguous sessile ovate-serrulate rameals at two-thirds distance upward on each otherwise-naked branch ; but these appear only on highly developed individuals. 
All specimens when dried, of one year or several years, possess a fragrance reminding one of sandalwood though more delicate. It has been likened also to the "straw-mahogany" of cigar boxes. It seems also somewhat attar-like. The odor seems independent of poisoning by immersion in alcoholic solution of corrosive sublimate, occurring in plants with or without poisoning. I doubt however if it ever survives gluing in mounting. It is particularly wen developed in A. fragrans, and many others of the rorthern Divaricati possess the same in moderate or slight degree ; as well as more distantly connected composites. All others to whom I have submitted examples of it have agreed with me regarding this delicate but doubtful fragrance, one pronouncing it "exquisite and one of which I could never tire."

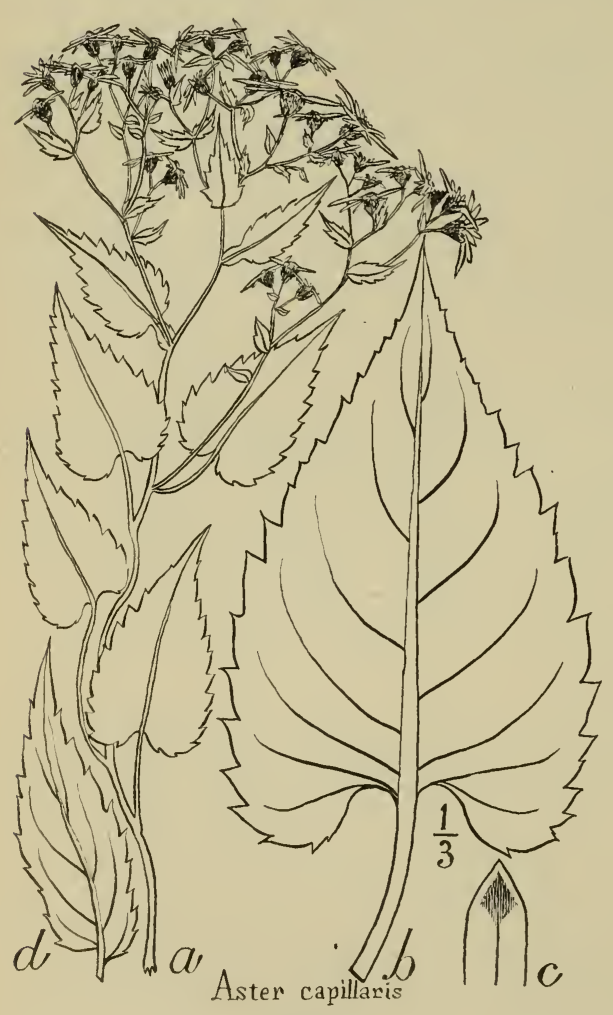

FIG. 26.

\section{8. Aster capillaris}

sp. nov.

Small stiff slender plants with ovate-acute leaves ; long low or curvescent teeth, moderate persistent sinus, crimson disks, long narrow rays, and bracts rather uniformly somewhat thin andacutish.

Name from the slender rays.

FIG. 26, plant from Silver Cr., N. Y., Au. 17, '96.

Stem terete, somewhat flexuous, deeply forked at an acute angle (about 35 degrees), brownish or reddish. Somewhat like $A$. divaricatus, in its moderately flexuous terete brownish stem; like $A$. persaliens in its many curvescent teeth some of

which become couchant; its long narrow rays; its bunched or 
widely-separated inflorescence (according to age); its crimson disks; and the leaf-form of its axiles. Like $A$. glomeratus in the numerous strigose hairs of the stem, and of the veins beneath; in the convex-topped dense young inflorescence; the ovate-acute cauline leaf-form, the dry and crumbling leaf-texture, and winged axiles. Like $A$. oviformis in form and thinness of radicals; and somewhat so in cauline leaf-form.

Possibly this is a hybrid of $A$. oviformis and $A$.persaliens; but I do not find evidence enough to warrant describing it as such, for it is unlike both those species in the remarkable deep-forked tendency of the inflorescence, with branches chiefly about $35^{\circ}$ in angle. It is also unlike both in its large size of heads, and the thinner texture of the chiefly acutish bracts.

W. N. Y., Silver Cr. ravine; growing out of the shale-wall of the gorge, near its base, with radicals $4 \times 11 / 2$ in. or less, Au. 17 , ' 96 . A. oviformis was then growing within a rod, and $A$. persaliens may have been near, certainly various allied $D i$ varicati were so.

Subdivision B. Chief Bracts obtuse or Chanfer, Diverse Species I 9-2 I.

\section{Aster virgularis sp. nov.}

Small wand-like plants with little taper acuminate leaves of elegantly bicurve base, moderate or sharp sinus, closely serrulate or minutely slit-toothed margin, pale narrow bracts and reddish disks.

Name, from L. virgula, a little wand.

Fig. 27, plant from Bryn Mawr Park, vic. N. Y., Se. 25, '97, in hb. $B u$,; $b$, characteristic lower leaf ; $d$, characteristic upper leaf.

Stem slender, chiefly about I ft. high, wandlike, erect and reddened; growing in loose clusters.

Leaves somewhat ovate-acuminate in type, incurving into a long acuminate termination from a broad base abruptly rounded into the moderate sinus.

Radicals and lower caulines broad-scutiform, the latter suddenly long acuminate, small, I I $2 \times$ I in. chiefly, elegantly curved in broadly sweeping bicurve base to a small brace or incurved sinus. Large leaves scarce, but sometimes reaching $2 \mathrm{r} / 2 \times \mathrm{I}_{3} / 4 \mathrm{in}$.

Middle caulines narrow-scutiform, with straightish or slightly incurved sides, and also with elegant bicurve brace, but the sinus sharp.

Upper caulines and axiles narrow, triangular-lanceolate, with straightish sides from a single-curve round base, the sinus having 
vanished. Upper axiles caudate-triangular, very attenuate, inconspicuous but numerous.

All leaves but the last have very short filiform petioles; followed sometimes by 2 or 3 short broad-wing petioles. Direction often erect, with some deflexed and some horizontal. Leaves

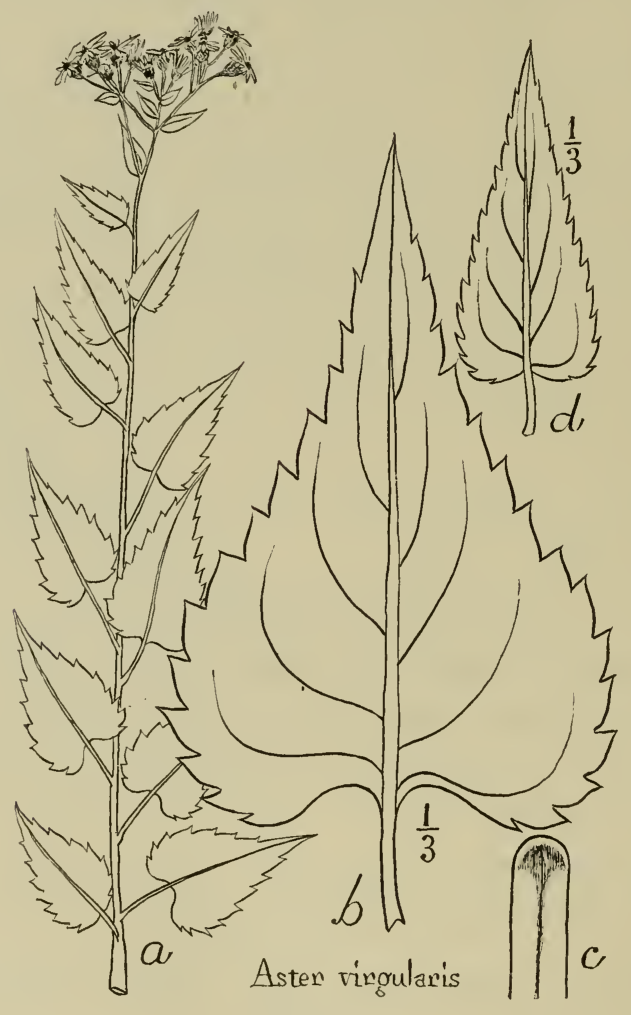

FIG. 27.

very rough and firm though thin ; their teeth minute, close, sharp, of serrulate type below in larger growths, chiefly finely slittoothed, especially above.

Inflorescence small, tuft-like, but not dense, nor very shortpedicelled. Heads small. Disks turn reddish.

Bracts rigid, somewhat oblong, narrow, the inner very taper, and becoming convex-backed; the basal broad-oblong, almost all roundish at apex and broadly white-margined, or with pale brownish margins and little green. Bracts less truncate than in $A$. divaricatus, and with but few chanfer-tips.

- Differs from A. scutiformis in having fewer scutiform leaves, 
and in its smaller more delicate plants and leaves, and in lacking the tendency to produce decurrent leaves which is common in $A$. scutiformis.

Differs from $A$. stilettiformis (which it approaches in its narrow slit-toothed upper leaves) in the less prolonged lower leaves, the closer teeth, and the more universal persistency of the petiolebase.

Resembles $A$. rupicola and $A$. scutiformis in its basal scutiform leaves but above these leaves it differs in almost all respects. Stem more rigidly erect than $A$. mpicola and inflorescence more stiff, less separated.

Habitat, rocks and rocky hills, Lower Hudson valley, Tarrytown to Manhattan ; the type locality, Bryn Mawr Park at Split Rocks, Se. 1896-' 97 , '98, destroyed by building. Rediscovered nearby, Se. 14, 1903; Se. 1904.

I $9^{2}$ Tangle-tuft form of $A$. virgularis. Teeth coarser, fewer. Flowers loosely borne in a small tuft in which the long pedicels are entangled; the tuft often centrally depressed, $i$. e., with shorter central pedicels.

Tarrytown, N. Y., Sleepy Hollow, Se. 24, '98.

I $9^{3}$ Linear-oblong form of $A$. virgularis. Teeth less developed, more remote, chiefly forward-directed, of low slit-serrulate type, and straight-backed. Leaves less curved, the upper less rapidly diminished, more of them deflexed, their type narrowly oblong with somewhat tapered base.

Grassy slopes under half-shade on gneissic rocks, in small loose patches, Lower Hudson valley; Manhattan I. at Inwood; Yonkers at Dunwoody and Bryn Mawr Park.

I $9^{4}$ Crimson-tassel form; verging toward $A$. divaricatus in leaf form, especially in larger plants; bracts narrowed to slender but obtuse apex, with very little hair or ciliation; heads small, rays short; disks very conspicuous, deep crimson. Develops some couchant teeth, like $A$. persaliens, but its leaves are much broaderbased.

In Yonkers, N. Y., at Bryn Mawr Park, Se. 26, '96, then abundant, but locality soon after destroyed.

I $9^{5}$ Turbine-zuhe el form. Delicate wiry plants with loose irregular inflorescence. Leaves between those of $A$. divaricatus and A. virgularis, bright apple-green, very soft and smooth when fresh, roughened when dry, but without obvious hair. Leaves chiefly triangular-lanceolate with broad brace-base, the lower triangular-ovate with narrower sinus, the axiles stilettiform or lance-linear and long-acuminate, the latter $2 \times 2 / 3$ in. or less. Tecth sharp and close. Heads widely separated on capillary 
pedicels, very remarkable for their twisted rays; the rays all horizontal in general position, the rays flat at base and then all turned one way, as if following the hands of a clock; the twisted part of each ray standing nearly vertical ; producing the effect of a turbine wheel. Rays $6, \frac{1}{2}$ in. long, $\frac{1}{16}$ in. wide ; or in many heads 5 ; in a few larger heads 7 , and $\frac{9}{16}$ in. long. Disks turning pale-purple. Bracts narrow, chiefly bevelled, and scarious-edged, sparingly ciliate.

A dozen such plants grew in a row, all alike, at Split Rocks, near Yonkers, along the rock base at corner nearest new dwelling house, Se. 16, '99. Similar plants without torsion grew near, apparently in exactly the same conditions; but in this particular row all the heads on all the plants exhibited this peculiar twist. No plants showing such torsion were noticed there at other years, $1896-1903$, although the spot was under careful scrutiny. The plants might be thought to represent a colony through whicb the torsion-character passed as a temporary wave, affecting a single year; but more probably the colony disappeared through the building operations near. - A few less distinctive plants, at two or three localities near, Se. 1904; also, Stony Lonesome and Mile Square Road, I 904.

\section{Aster rupicola sp. nov.}

Small wiry rock-loving plants, with crimson disks, thin firm rough spike-toothed broad little leaves, big broad sinus and up-curved veins.

Name, L., " a rockdweller," from the habitat.

FIG. 28, plant from Indianfield, N. Y. City, Se. I5, '98, in hb. $B u$.

Stems wiry and swaying; not stiffly erect, as in A. virgularis; usually red or ebony-red, chiefly $\mathrm{I} f \mathrm{ft}$., seldom $\mathrm{I} / 2 \mathrm{ft}$. high. Radicals seldom produced, cordate-oval, rough, $2 \frac{1}{2} \times 2$ in. or more, irregularly oval, closely crenate-serrate. Leafy shoots of 4 to 6 inches high produced in numbers, arcuate, with broad scutiform leaves as in $A$. scutiformis.

Leaves small, thin, firm, roughish in growth and finely granular-roughened when dry, full green, pale beneath, and glabrate. Veins numerous, close, slender, strongly upcurved, slightly darker than the leaf-tissue, often reddening earlier than the surrounding tissue in autumn and forming guiding-lines for the red and yellowish-green mottling which often beautifies this species.

Leaf-type broad and rounded, suborbicular; acuminate with the sinus deep, broad and disproportionately large. Sinus in the lower leaves much excavated, becoming shallow above the middle of the stem, and finally forming two slight notches at the wingbase of some upper caulines; beyond which are usually a few rounded bases without cordation. Leaf-form quite persistent upward, finally passing in upper caulines into an ovate-acuminate 
type, or narrower. Acumination abrupt, entire, narrow, proportionately long, as $1 / 2$ inch in a leaf of size $2 \times \mathrm{I} 1 / 2$.

Teeth very sharp, close, outflung, large for the leaf; projection $1 / 8$ inch or more, the back slightly curved, the front nearly straight or reëntrant; producing a buzz-saw effect. Toward the apex the teeth become more forward-projecting, and such are all the teeth

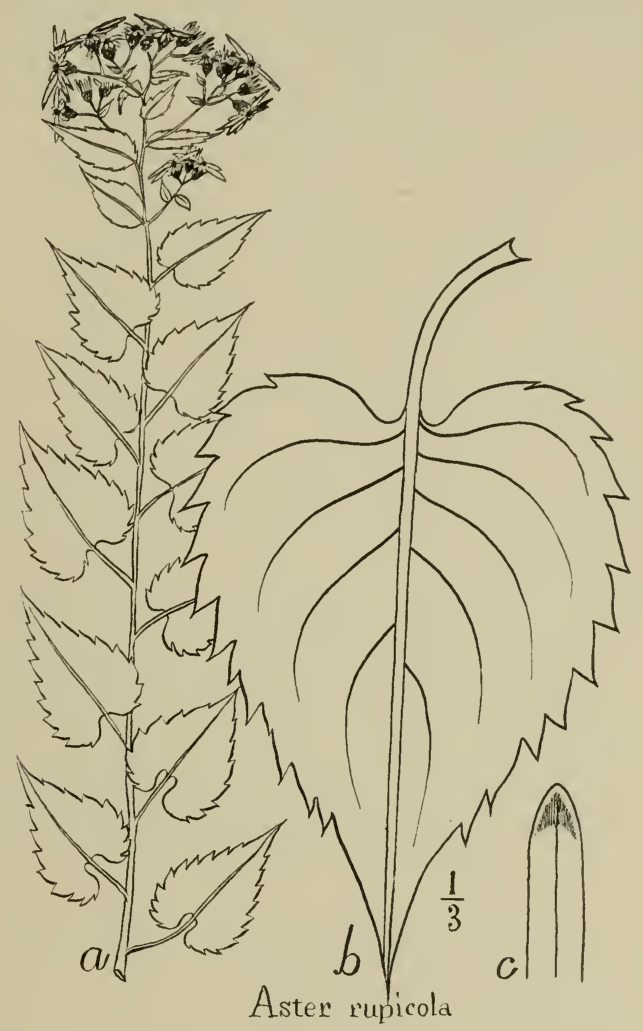

FIG. 28.

upon the upper caulines. Toward the sinus or even into it they continue much further than is usual even among strongly-toothed Divaricati.

Hair not obvious, and very slightly developed, scanty under a lens on midrib and veins beneath, most developed on the inflorescence-branches.

Inflorescence small, convex-tufted, the small heads wellseparated, their capillary pedicels often $2 / 3 \mathrm{in}$. long. Bracteals inconspicuous, ovate or oval, to.linear, $1 / 3$ in. long, or less. Heads about $7 / 8$ in. broad, $1 / 4$ in. high. 
Bracts thin, obtuse-chanfer, and oblong or almost lingual and roundish at apex, with rather strong ciliation and thin whitish scarious margins. Green tip thin and broad or absent.

Rays rather narrow, about IO or I 2 , linear-oblong, with the sharp or truncate apex nearly equally divided into 2 or 3 small blunt teeth. Disk flowers numerous, soon deep crimson, with broad bell, deep narrow widespread lobes, and slender threadlike stalk, the stalk sometimes three times the bell in length, sometimes but just equal. Achenes slender, fusiform, the minute hair generally absent from the striae at maturity.

- The foregoing typical form is very distinct from other species; than carmesinus and argiliarius and other small species it is much sharper-toothed: than virgularis, stilettiformis and other sharp-toothed species, its leaves are much rounder.

Habitat, forming loose patches, either in half-grassy or nearly bare situations, in thin soil, over gneissic or slaty rocks or among stones derived from them. Mass. to Va.

Ms., Nonquit, coll. E. L. Sturtevant, Au. 16, '89; in hb. Bu.

M. V., West Tisbury, Troutpond dam, Se. 3, '97 ; Davistown, Constant-Luce woods, Se. 4 , '97, in quantity.

Ct., Mianus, stones and wall near Coscob, Oc. 15, '96.

N. Y. vic., Indianfield, Se. 16, '98; Inwood, Dyckman Rock, Se. 27, '97, to 1904, up the n. w. slope in thin grass, many plants 8 or only 4 in. high, those flowering chiefly 10 in. ; rays chiefly 8 . Yonkers, Park Hill, Oc. 10, '98; Hillview, Se. I5, ' 97 ; rocky woods north of St. Joseph's Seminary, Oc. 2, '98, Bi. ; Bryn Mazur Park, Palmer Ave. Rocks, on top, Se. 20, '96, Se. 26, '96, Se. 18, '97; near Diller Rocks, in quantity, Se. 18, '97. Tarrytown, Sleepy Hollow cemetery, Se. 24, '98.

N. J., Palisades, Undercliff, top, Se. 29 and Oc. 23, '97; pond to north, Oc. 23, '98.

N. Y., Catskills, Phoenicia, along Esopus Cr., Se. 9, '99.

W. N. Y., Dunkirk, Pt. Gratiot, Au. 15, '96; Silver Cr., Lighthouse Pt., L. Erie bluff-edge in grass under Ostrya, Au. ' 96.

D. C., Rock Cr., Oc. '94.

Va., Potomac bank above Chain Br., Oc. '94.

$2 \mathrm{O}^{2}$ Branch-forms. Developing branches chiefly, these bearing a new type of leaf, chiefly ovate-acuminate, less sharp-toothed, mostly forward-serrulate: as,

N. J., Pulisades, Oc. 13, ' 98 .

$20^{3}$ Sprout-forms. Late; inflorescence more widely branched; chief leaves oval and ovate, slightly serrate, becoming longer upward and finally lanceolate and close-serrulate. Disks deep, crimson or sometimes purplish-red.

N. J. vic., Hillviere, Oc. 26, '97. 
The preceding examples are plants otherwise nearly or quite normal. Variants are also common, in which the leaf-form, bractform, and habit are all surprisingly modified, though seeming to belong here by balance of characters; including the following forms :

$20^{4}$ Angulate form. Leaves usually a little longer in proportion, their teeth more narrowly acuminate, the outline not a continuous series of curves as in the type, but disturbed by irregular

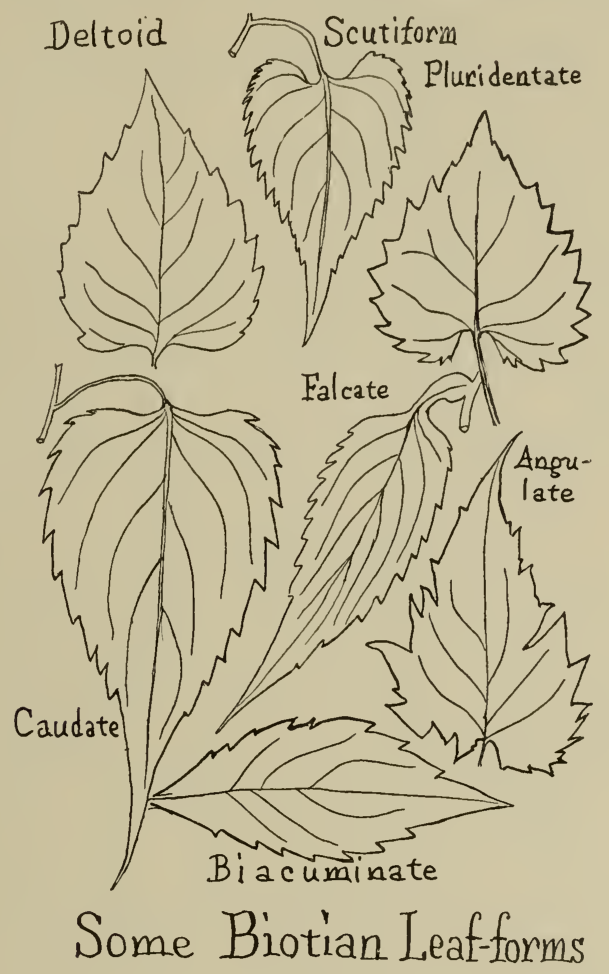

FII. 29.

and abrupt projections. Intermediate to $A$. divaricatus L. For a typical leaf of this form see FIG. 29.

\section{Examples :}

M. V., Tashmoo spring, Au. I I, '9o ; WVest Tisbury, Trout pond, Se. 4, '97 ; Davistorun, woods, Se. 4, '97.

N. J., Palisades, Undercliff, Se. 30, '97 ; full height again, June 15, '9S.

N. Y. vic., Bryn Mazur Park, central rocks, Se. '9\$, '99.

$20^{5}$ Pluridentate form. (FIG. 29 shows its characteristic leaf- 
form.) Middle and lower leaves broad, subcircular or oval, then suddenly incurved into a long straight or falcate acumination, doubly and very sharply toothed; the teeth very salient, slender and bristle-pointed, either couchant, aquiline or straight-backed, continued well into the sinus. Upper leaves and axiles nearly typical for $A$. stilettiformis. Heads often larger, with conspicuous milk-white rays, a single bunch or segregated in long-stalked clusters. Bracts often a little acutish.

Mis., Nonquit, E. L. Sturtevant, in hb. Bu., Au. 16, '89.

M. V., Tea Lane Brook, Se. 6, '97.

N. Y. vic., Inzvood, Se. 27,'97; Mosholu, hill, Oc. 22,'98; Bryn Mawr Park, Se. 26, '96; Se. 14, ' 98 ; Se. '99; Black Pool, under Fimbriate tree, Se. 15, I900; Ianthinus rocks, Se. 15, I900, Se. 15, 1903.

W. N. Y., Gowanda, Forty Hollow, Au. 29, '96.

D. C., Rock Cr., Oc. 5, '9o.

$20^{6}$ Rock-dwarf form. Intermediate to $A$. divaricatus $\mathrm{L}$., with more ovate leaf-type, forward serrate, and heavy thick rough leaves paler beneath; in rock crevices and the little leaves browned in the sun, I in. long or less; plants chiefly 7 in. high; sometimes twice that.

N. Y., vic., Inwood, Se. 24 , '96 ; rocks foot of 165 th St., Se. 30, '98; Ft. George, Se. 24, '96; Yonkers, rocks at Caryl, Se..29, '98.

\section{Aster circularis sp. nov.}

Small delicate wand-like plants with little firm subcircular acute leaves, broad sinus, close short sharp curvescent-serrate teeth, few close heads, and pale chanfer and obtusish bracts.

Name from the leaf-form.

FIG. 30, plant from Tarrytown, N. Y.; Se. 24 , '98, in hb. $B u$.; $b$, characteristic leaf-form; $d$, occasional lower leaf.

Stem terete, very slender, stiff, usually reddened, I 6 in. high, or less.

Leaf-form circular-acute with very abrupt and short acumination, very broad conspicuous sinus, and notably close sharp short teeth with curving back. Leaves mostly $\mathrm{I} 1 / 2 \times$ I in., with delicate petiole shorter than the leaf-breadth but continuously developed well into the inflorescence. Sinus also continuing far up the stem. Some occasional lower cauline leaves are larger and longer, and show the ovate-acuminate type from which this species was doubtless derived. Such leaves have longer shallower teeth and are intermediate to $A$. excavatus.

Inflorescence small, irregular, very short-branched though not compact. Bracteals ovate, small and inconspicuous. Heads small, $3 / 8$ in. high, short-rayed, little over $3 / 4$ in. broad. 


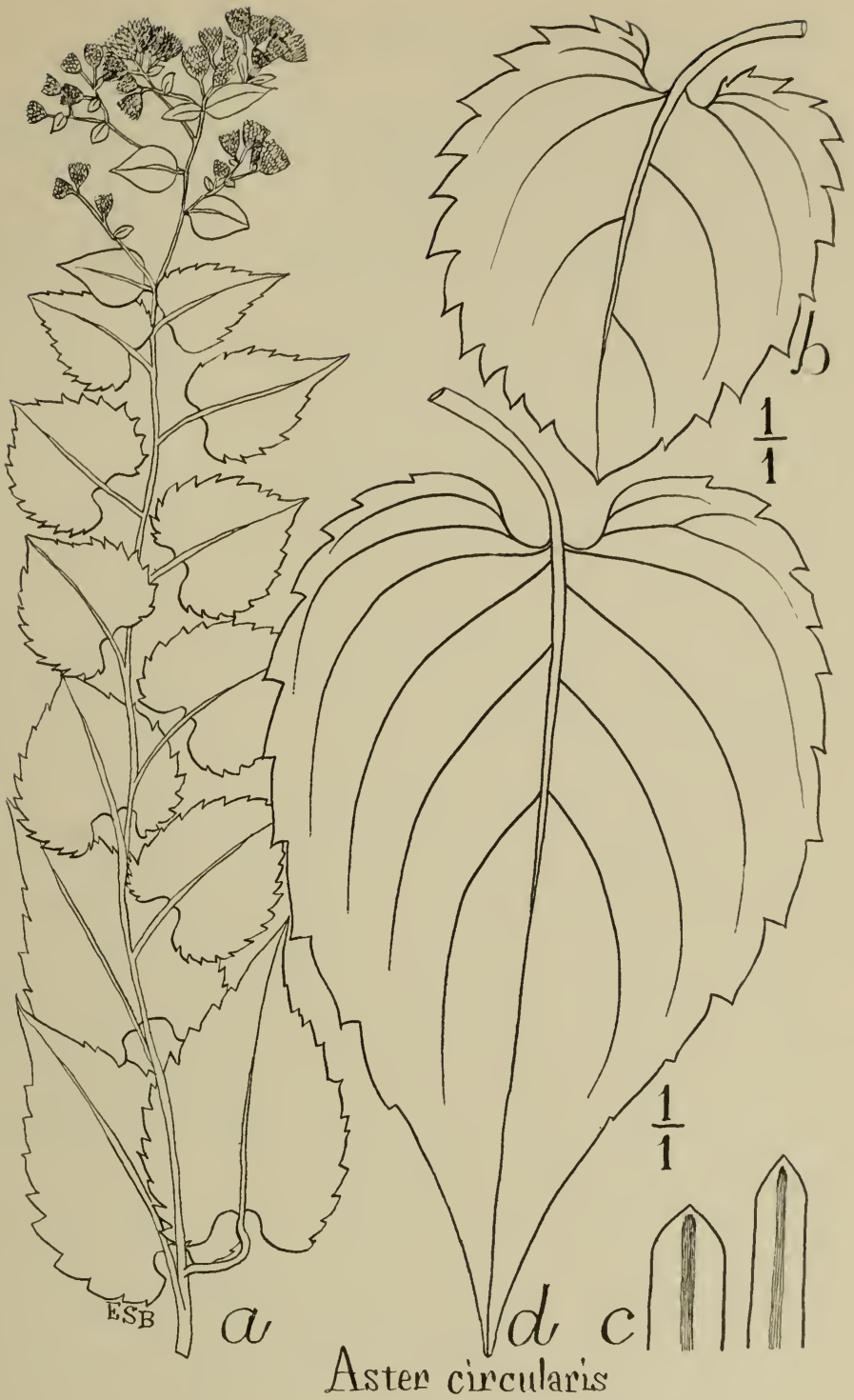

FIG. 30 .

Bracts pale, narrow or linear, somewhat obtuse, usually chanfer, the green tip slight.

Grows in loose patches, on rocky slopes, under thin shade or among bushes; lower Hudson valley. Sept. Examples: 
N. Y. vic., Tarrytozun, Sleepy Hollow, summit, Se. 24, '98. Yonkers, Bryn Mawr Park, Se. '96-'99. Mosholu, at full height June 26, 1905.

N. J., Palisades, Se. '97, '98.

A. circularis differs from obolarian plants of $A$. divaricatus in its closer, sharper teeth, firmer texture, and deeper and more persistent sinus.

From $A$. divaricatus curtifolius it differs in its thinner, smaller leaves, narrow bracts, and more continuous sinus, short rays and smaller, fewer heads.

From $A$. rupicola it differs in its smaller shorter leaves and more delicate curve-back teeth.

From $A$. argillarius it differs in its more slender leaves, more outflung teeth, and paler bevel-tip bracts.

All the above species make an approach to a subcircular leafform, but $A$. circularis approximates to it most closely.

$A$. circularis is also unlike the others in having all leaves cordate.

\section{Subivision C}

Bracts lingual, rounded at tip, nearly all alike in shape, nearly all-over green. Sp. 22-25.

\section{Aster argillarius sp. nov.}

Small, stiff, brittle, close-clustered plants, with little ovateacute subuniform leaves, little hair, almost no sinus, short petioles, obconic inflorescence, and lingual rounding-tipped bracts.

Name from its partiality to clayey soil, L., argilla, clay.

Fig. 31, plant from J'alisades, N. J., Se. 29, '97, in hb. Bu. ; e, characteristic leaf ; $f$, a lower-leaf form ; $d$, an upper-leaf form ; $g$, radicals.

Stem browned in half-sun, green in shade, slightly and repeatedly flexed, erect, stiff and brittle, very slender and delicate in aspect, chiefly I $\mathrm{ft}$. high, sometimes I $1 / 2$.

Leaves (the cauline), very small, nearly uniform, I $\times 3 / 4$ in. or sometimes $\mathrm{I} / 2 \times$ I in., ovate-acute, or slightly incurve-acuminate, thin, firm, of peculiar silken texture when fresh, rough when dry, full green, serrate with moderate straight-backed teeth, or with some curvescent or aquiline teeth intermixed. Sinus slight, rather sharp in a few lower caulines, quite open in the lowest. Petioles all short and slender, continuing to the first axils.

Radical leaves when developed often form quite conspicuous little tufts, 3 or 4 inches removed from the stem from which their rootstock springs. These radicals are often 5 to Io together, in size $I \frac{1}{2} \times$ I in., oval-oblong, with small sharp sinus, with a shorter filiform petiole, rather dark-green, their apex acute (not acuminate), their teeth crenate-serrate. 


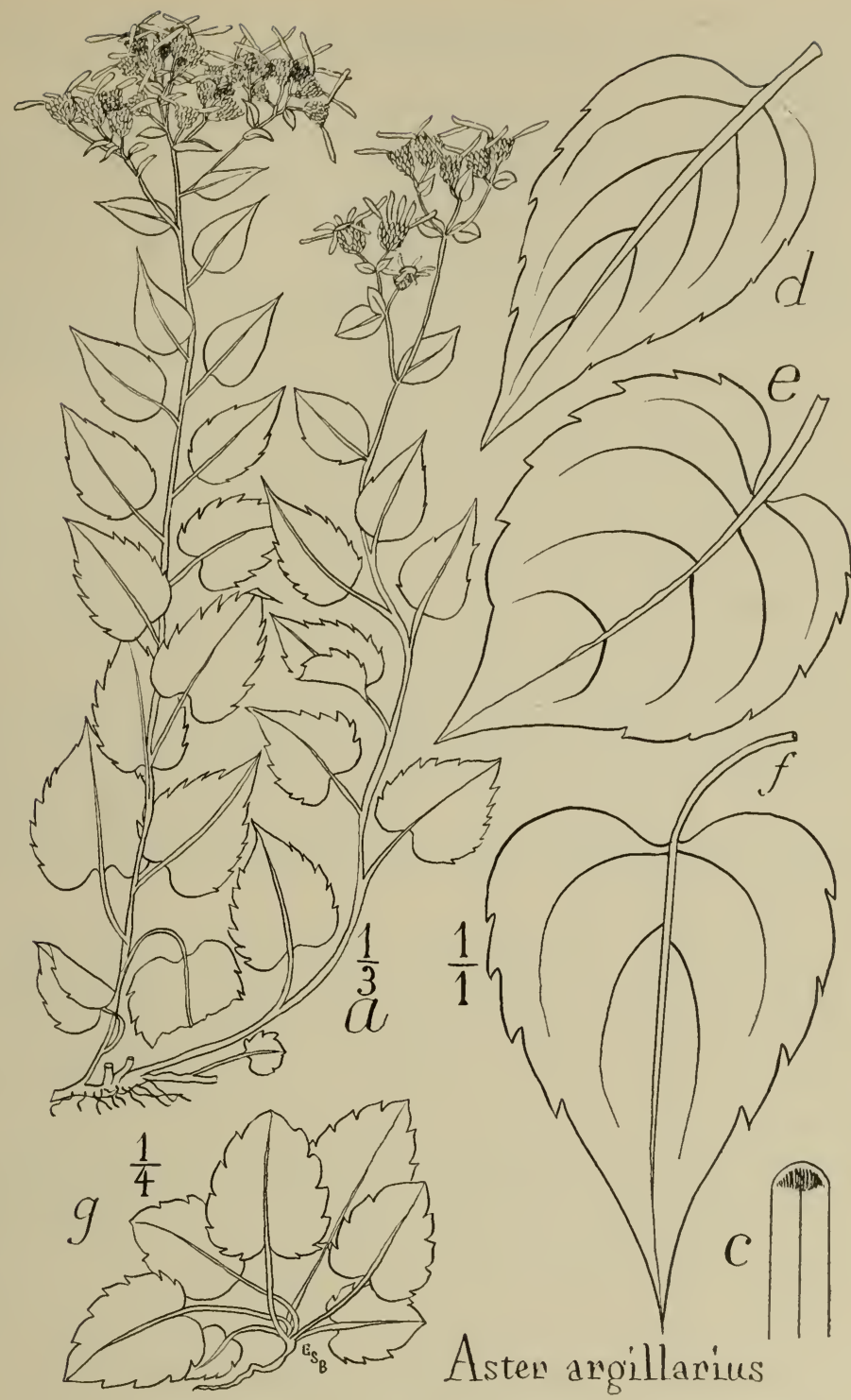

FIG. 3I.

Axiles ovate-acute or narrower, sessile by a rounded base or the lower ones slightly petioled, sharp-serrulate.

Rameals gradually smaller and blunter in apex and teeth, often mostly oval-oblong, obtuse and crenulate, sometimes all subcircular. 
Hair not obvious, but under lens it is seen minutely present on leaves beneath and on some pedicels and petioles, and slightly on bract-margins.

Inflorescence with straight stiff filiform branches, loose and convex-topped; on pressing forming a distinctly obconic deep sharp-based figure. In smaller plants rather close and broad, in large plants it becomes a foot broad and equally deep, or three times the usual measure for the species.

Heads small, $3 / 4$ in. broad, $1 / 4$ in. high, half of which is involucre. Involucre rather straight-sided and sharp-based, cylindrical in life, nearly obconic when pressed, pale and smoothish.

Bracts lingual, abruptly rounded at the broad pale apex, with broad scarious thin golden-brown and paler margins, and a narrow obscure greenish median stripe, the ciliation irregular, scanty and tangled. A few lowest bracts are often acutish and elongatedtriangular. A few innermost are wholly pale, much narrowed and prolonged, but still obtuse. Green tips on the predominant bracts are sometimes developed and are then broad, convex above and fading out and indefinite below.

Rays 6 to 9, short, thinnish, with slightly curved sides, and 2 or 3 minute teeth at the roundish apex. Disks turning brownishcrimson, with sharp wide-spaced lobes; the bell short, $1 / 3$ or $1 / 4$ the length of the filiform stalk. Achenes narrow, smooth, with contracted base. Pappus soon tawny, within one year; hardly more so after three years.

- Development : Radicals just starting, $3 / 8$ in. long, Apr. I 8, '99; a few I I $/ 4 \times 3 / 4$ in. by May I0, '99. About 3 such radicals, preceded by 3 or even 4 tiny reddened primordials, only $1 / 3 \times 1 / 3$ in. or less. All leaves thin and without obvious hair. Plants 8 in. by July 9 .

- Delicate close-clustered plants of clayey levels or banks, in half shade, growing especially in company with Liquidambar sprouts or young chestnuts (about N. Y.); also occurring on clay knolls of sandy admixture, among Gaylussacia bushes (E. Mass. and M. V.) ; and extending into crevices of gneissic rocks. Near the coast, Maine to New Jersey. Sept. and early Oct.

Me., S. Berwick, York Co., dry open woods, Se. 26, '97. M. L. Fiernald in hb. Fernald and hb. Bu.

Ms., N. Bedford, Clark's Pt., Se. I I, '97, Bu.

M. V., Gay Head, Blackwater Knoll, Se. 6, '98, obliterated and locality overgrown with smilax, Se. 1900. Tea Lane, Mark's Valley bridge, Se. 6, '97; failed on account of drought, I900. Davistown, woods, Se. 4, '97.

N. Y. vic., Indianfield, rock by Fern-swamp quarry, Se. 25, 1900. Bathgate 
woods, rock by Jerome Av., near 2d brook, Oc. 2, Igoo. Yonkers, Park Hill, wet sandy clay, Oc. 10, '98. Bryn Mawr Park, Se. 14, 1903.

N. J., Palisades, Cliffside Park, Se. 12,'98. Undercliff, in clay, typical locality, Se. 29, '97, Oc. '97, Se. and Oc. 7 , '98, Se. 14 and Oc. 7 , '99; few surviving Se. I4, I900 and none 1902, trodden out in building Supt.'s house. - Also, Palisade Av. at Hottonia brook, in clay-bank, Se. 14, I900, destroyed by turfing park. - Also, woodland between the last two stations, Se. 14, '99.

$22^{2}$ Branch-forms. Inflorescence more irregular; rameals enlarged, taper-based, subentire or obscurely crenulate. Heads somewhat larger than in the type - as often occurs in other branch-forms.

Observed chiefly at the Palisades, Oc. 7, '98, etc.

$22^{3}$ Sprout-forms, occasional, with the preceding. Short winged petioles frequent; confused series of various leaf-types developed in rapid succession, orbicular, cordate, oval-oblong, elliptic, lanceolate, etc., within the space of 5 inches, ascending the stem in the order cited.

N. Y. vic., Larchmont, Oct. 28, '98.

$22^{4}$ Pale-disk form, verging toward $A$. divaricatus $\mathrm{L}$. Red in the disks less developed; leaves more cordated and more acuminate; inflorescence more irregular, teeth often obsolescent; all parts still small.

N. J., Palisades, Se. 14, and Oc. 7, '99, hundreds of plants forming a loose mass under half shade; disks pale and leaves rough in growth ; some surviving parking, Se. $14,1900$.

$22^{5}$ Linnaea-leaved form. Very delicate plants with a long succession of very small roundish crenate leaves, resembling those of Linnaea, chiefly $3 / 4$ in. long, or even all of them only $1 / 2$ in., with the filiform petiole half the leaf-length. Leaves thickish, acute, with acute sinus or soon with rounded base. Axiles peculiar, oblong, abruptly acuminate, suddenly contracted into a sessile base, the margins slit-serrate ; verging toward the cauline leaf-type of the Dentifolial form of $A$. stilctiformis - which also grows (but some ten miles distant from this Linnaea-leaved form), on Martha's Vineyard. Inflorescence irregular, few-flowered, 10-20 heads or less.

M. V., Davistozen, woods, Se. 4, '97.

N. J., Palisades, Undercliff, at type locality for A. argillarius; Oc. 7, '9S, Se. 14, '99; survivors trampled out by builders, Au. I goo.

$22^{6}$ Pinnated form, verging toward $A$. Claytoni. Branches continued from the middle axils, producing a pinnately corymbose effect in herbarium; inflorescence $4 \mathrm{in}$. across at the rather full rounded summit, 6 to 10 in. deep, straight-sided and sharp-based as in the type, but more leafy, each branch bearing several little 
oblong subentire rameals and dividing only at the summit to produce heads, thus suggesting the inflorescence-form of $A$. Claytoni, which species the leaves occasionally equal in roughness. Retains the bracts and other characters of $A$. argillarius, and seldom exceeds it in size.

M. V., Gay Head, Blackwater Knoll, Se. 6, '98; not developed Se. 1900.

$22^{7}$ Rock-seam form, growing in lines in narrow crevices of gneissic rocks, and spreading to adjoining slopes. Differs from type in having less brown on stem and bracts, more curvature and irregularity in inflorescence, and darker thinner leaves, chiefly $\mathrm{I} \mathrm{I} / 2 \times \mathrm{I}$ in. In deep shade.

N. Y. Cy., Indianfield, near quarry, Se. 25, I900. Bathgate woods, near Jerome Ave., Oc. 2, I900.

\section{Aster aucuparius sp. nov.}

Wand-like dull green plants, with small, short, ovate-oblong, thickish leaves; with sharp, remotish notchy teeth, slight sinus, wide-forked slender branches, broad coriaceous dark-tipped bracts, and a leaf-type suggesting a leaflet of Pyrus aucuparia (whence the name).

FIG. 32, plant from Palisades, N. J., Se. 29, '97, in hb. Bu. ; b, characteristic leaf ; $d$, frequent upper leaf; $f$, little leaf occasionally replacing $d$, and otherwise often present at base of stem.

Stem erect, stiff, slender, wandlike, terete and smooth, slightly and repeatedly zigzag, pale, brownish or slightly reddened, 2 or $2 \mathrm{r} / 2 \mathrm{ft}$. high.

Leaf-type ovate-oblong, acute or short-acuminate, with rounded base and short slender half-inch petiole, regularly notched with rather remote, long, sharp, forward-projecting teeth. Teeth mainly straight-backed, sometimes curvescent, extending into the basal curve well toward the petiole. Such leaves constitute the middle caulines or the upper also, and sometimes extend into the inflorescence. They measure often $2 \mathrm{I} / 2 \times \mathrm{I} \mathrm{I} / 4$ or $2 \mathrm{I} / 2 \times \mathrm{I} / 2 \mathrm{in}$., sometimes $3 \times \mathrm{I} \mathrm{I} / 2$.

Lower caulines short, cordate-ovate, very short acuminate, with moderate sinus or few with any, $3 \times 2$, or sometimes $4 \times 3$ in., serrate. Axiles, and sometimes the upper caulines, oblonglanceolate, sessile by a rounded base.

Texture firm, dense, not as crisp as in its ally $A$. carmesinus, soft, while fresh, except as it is roughened with scattered hair above; in most leaves granular-roughened also, when dry.

Radicals seldom produced, very small, cordate-acute, sub- 
entire, $1 / 2$ in. long, nearly as broad; or broader and reniform; becoming yellow and perishing often in July.

Leaf-color dull opaque green, brownish green when dry; autumn color becoming soon deep umber. Leaves pale beneath, their veins obscure. Petioles usually narrow, but sometimes developing a cuneate wing, $1 / 4$ or $1 / 2$ in. long, and then resembling

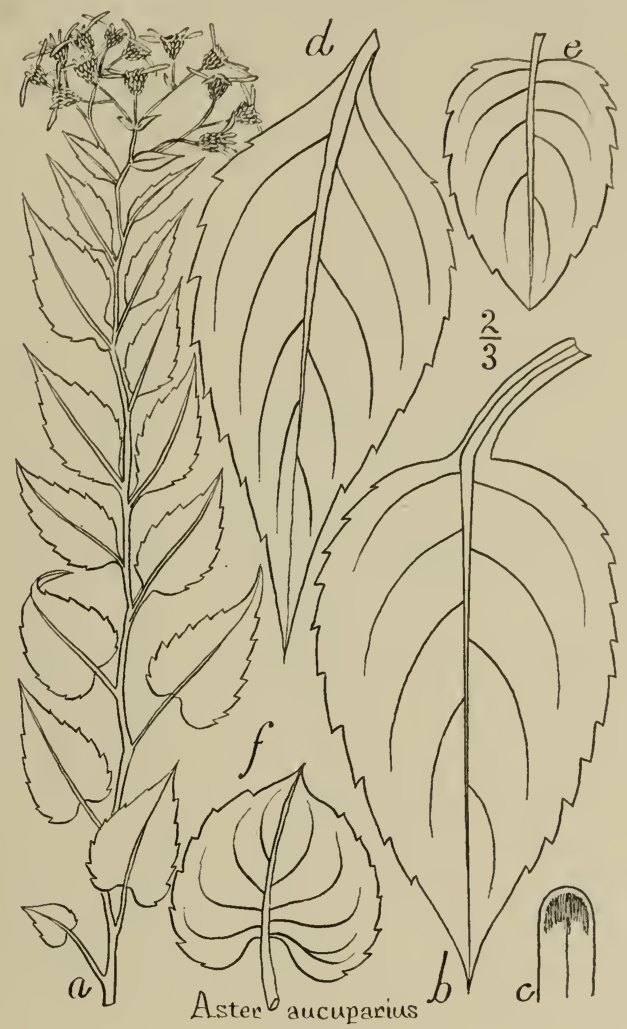

FIG. 32.

its ally $A$. listriformis. Rameals not very prominent or characteristic, ovate, often minute.

Inflorescence loose, flabellately forked in well-developed or mature growth, with irregularly convex top from a deep sharp base, with long internodes; peduncles leafless and often 4 or 5 in. long; pedicels often $\mathrm{I}$ in. or more, and diverging widely at end of flowering though short and tufted closely at first opening. Angle of chief peduncles 25 to $30^{\circ}$ from the vertical. Heads $5 / 8 \mathrm{in}$. broad or less and $3 / 8 \mathrm{in}$. high, of which the involucre is half. Involucrc pale, rather sharp-based, obconic in pressing. 
Bracts broad, heavy and coriaceous, nearly uniform, rounding to a truncate or acutish ciliate apex, smooth-backed, and little ciliate elsewhere. Green tips short, abrupt, broad and blunt, soon disappearing inward with a brief change into a few longer spatulate paler tips. Bracts otherwise pale, of a slightly brownish tinge, or on some plants greenish brown. Lowermost bracts very few, triangular-acute, green, their acutish tips sometimes continued well up the series; but often none such are developed at all. Inmost bracts inconspicuous, narrowed, pale and taperobtuse, with some scarious and purple edges.

Rays white, sometimes crimson, chiefly IO, I I or I2, rather broad, rounded at the minutely bidentate apex, very thin and quickly withering. Fimbriation sometimes occurs, some rays becoming deeply bifid while yet erect and involutely terete. The whole plant presents sometimes a similarly bifid aspect, as if cleft almost to the ground into two long parallel ascending stems. Disks maroon or dull crimson, the sharp lobes about equal to the narrow bell, and about $1 / 3$ the length of the short thickish stalk. Achenes smooth.

- Scattered plants, or in little clumps, in half or three-fourths shade, in rich soil near rocks. Albany and the Hudson valley to the Potomac.

Well-developed plants are highly unlike other Divaricati, sometimes almost without a cordate leaf, and usually with few or none at flowering. They are also readily distinguished by their ovate-oblong leaf-form from their congeners $A$. carmesinus and $A$. listriformis, both of which are also of thinner texture.

$A$. aucuparius seems nearest of kin to the shuttle-form of $A$. listriformis, and sometimes develops a single truncate-based nontapered leaf of the sad-iron type, among those of its own.

Examples :

N. Y., Albany, in Hughson's Glen near Ludlowville, Se. I I, '89.

N. Y. vic., Ft. Washington, foot of I 7oth St., Oc. 6, '98. Indianfield, swampborder, Se. 16, '98. Bryn Mazur Park, Se. 26, '96; Nov. 3, '96; under chestnut tree opposite first house, Se. I8, '97, Se. I4, I903.

N. J., Palisades, Undercliff; at Violaris-corner, most extremely developed plants, Se. 29, '97, etc.; with well-grown plants 18 in. high. July 9, 1900, but trampled out in Aug. by builders; one surviving, Se. 14, 1900, was chiefly in bud. No further traces till Oc. I904, when several plants occurred near.

Pa., near Philadelphia, as " $A$. corlifolius, - Phila.," in hb. Bernhardi, now in hb. Mo. Bot. Gard.

Va., Potomac R., on Conn I., above Great Falls, Oc. I I, 'go.

$23^{2}$ Truncate-base form; verging toward $A$. virgularis. Leaf- 
angles especially the basal, more cornered, less rounded, shuttleshaped. See Fig. 32.

N. Y. vic., Inzwood, Se. 27, '97; Ft. George, sunburnt dwarf on rocks, Se. 24, '96. Staten I., Princes Bay, Oc. 10, '96. Yonkers, Yonkers ave. swamp, chief form growing about Stanford Spr., Se. 22, '99.

\section{Aster listriformis sp. nov.}

Red-stemmed diffuse plants of shaded rock-crevices, with listriform or spade-like winged and truncate crenated caulines, long triangular sharp serrate axiles, rich maroon disks and rounded lingual bracts.

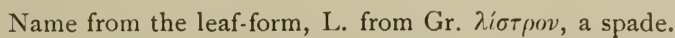

FIG. 33, plant from Bryn Mawr Park, vic. N. Y., Se. 25, '97, in hb. Bu.; b, characteristic leaf-form; $d$, typical lower leaf-form.

Stem strong but brittle, slender, terete, smooth, nearly straight, deep red or almost ebony (but in some less vigorous plants greenish or brownish). Rootstocks occur with long tough yellow surculi.

Characteristic leaf-type spade-like or listriform, being the truncated half of an ellipse, with acute or obtuse apex, and with cuneate conspicuous wing which is $1 / 2$ or $3 / 4$ in. long, and tapers decidedly to the stem. These leaves are the principal caulines remaining at blossomingtime, and usually cease abruptly with the first axil. They are closely and evenly crenate-serrate, or with some straight-backed teeth, or often with nearly all the teeth aquiline. $\mathrm{Di}$ mensions often $2 \mathrm{I} / 4 \times \mathrm{I} 3 / 4$ in. Sometimes a few

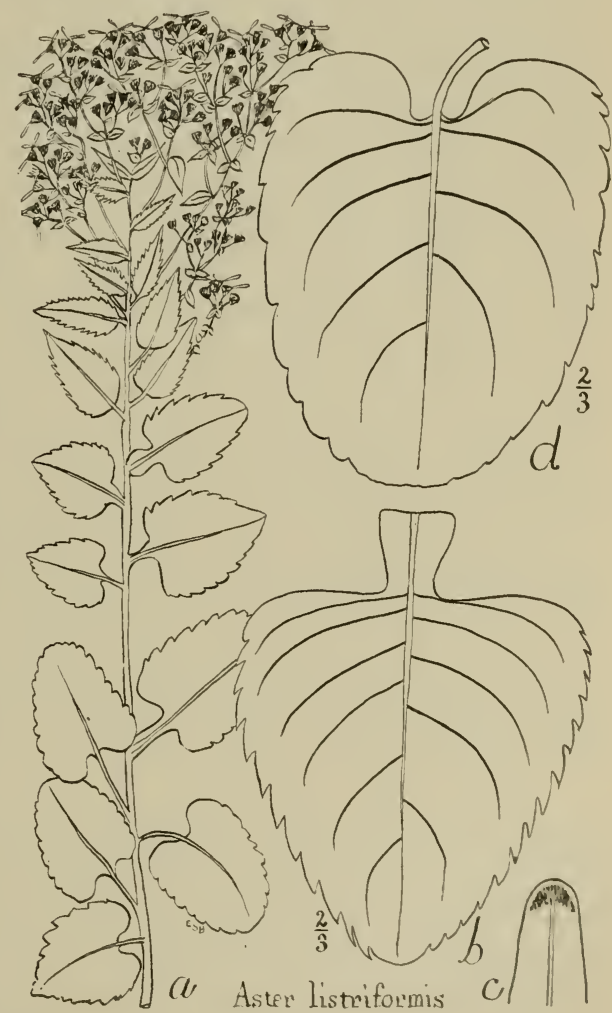

FIG. 33 . wings are oval with constriction above and below; and some petioles remain slender and unwinged. 
Lower caulines early deciduous, less toothed, the teeth couchant or straightish; the form varying, often ovate-lanceolate or ovate-triangular, with truncate brace-base and narrow slender petiole.

Lowest caulines sometimes like the last, but often of a new type, paraboloid with rounded apex, rounded swelling basal lobes, and broad rounded or bicurve sinus.

Axiles very long, truelliform or trowel-shaped, $i$. e., lance-triangular with straight sides and rounded truncate-base, acuminate, sharply slit-toothed, witlı short broad cuneate wing or sessile; often much longer and larger than the caulines, and in original type about $3 \times \mathrm{I} 1 / 4$. Rameals or the lower ones, lance-oblong, acute, obscurely slit-serrulate. Ramulars soon suborbicular, $1 / 2$ in. broad or all much smaller, entire or nearly so, often approximate in threes, giving, especially in much refracted inflorescences, a suggestion of verticillate development.

Leaf-texture very peculiar, firm, thinnish, very smooth to the touch during growth; minutely roughened above when dry, with short scattered close-appressed hair. Leaves apple-green, much paler beneath, turning fawn-color and yellowish in Sept. or Oct.

Hair almost absent; under a lens the stem commonly shows none, the petioles merely a few ciliations; beneath, the narrow imposed veins bear scattering hairs; on the pedicels some puberulence, and a little ciliation on the bracts.

Inflorescence diffuse, in well-grown plants very copious, $2 \mathrm{ft}$. or more broad, neat and clean in habit, semi-nude, repeatedly suborbicularly tribracteate, with long straight filiform pedicels and peduncles, which are widely divergent or often highly refracted. Pedicels sometimes $\mathrm{I} / 2$ in. long, but more of them $1 / 2$ inch.

Bracts lingual, coriaceous, with broad and deep dark green tip, otherwise pale green; all nearly alike, often with a minute acute point at the otherwise abruptly rounded apex

Rays clear white, eight or sometimes more, soon reflexed and pendant, often quickly becoming deep rose-purple. Disks warm honey-yellow, soon deep maroon or rose-brown or rich crimson.

- The type, combining in one all the above characters, was abundant beneath the south end of Split Rocks, near Yonkers, I 897 , but was nearly exterminated by trampling and clearing in I900, though a number of plants were reasserting themselves, Se. 1903 and I 904 .

More commonly, examples by omitting some one or two of its peculiar leaf-forms and by enlarging others, assume widely variant aspects, giving rise to some of the forms enumerated below ; many such occurring near the type, I897-1903. 
- Springing out of rich crevices in gneissic cliffs under deep shade, or in rich soil of banks or glens, near N. Y. City in N. Y. and N. J., in late September. Profuse-blooming plants sometimes produce from 100 to 200 heads, all simultaneously in flower.

N. Y. vic., Eastchester, Seton Falls, Se. 24, 1900. Bryn Mazur Park, wooded summit, '98, '99, I900, I903. Split Rocks, south end, Se. 25, '97, etc., bankside, north end, Se. 15, 1903, Hillviezv, Se. 22, 1900. Vault Hill, nearly full height, June 26, 1905 .

N. J., Palisades, Undercliff, Violaris-corner, Se. 29, '97, Se. I2, '98, young patch of very many plants, destroyed by mowing soon after.

$24^{2}$ Helioscopian form, with inflorescence (in parts or in whole) continuously sympodial and repeatedly suborbicularly tribracteate, suggesting in effect the inflorescence of Euphorbia Helioscopia. The most extreme form of the species, highly refracted, and usually with the listriform leaves numerous. The sympodial inflorescence sometimes follows upon accidental loss of the main stem but more often consists of continuous arrest of the growth-impulse, apparently independent of any external influence. Repeated growth of this kind causes many inflorescences when pressed to resemble Mollugo verticillata. Stimulus of light from above acting on a plant, growing at the base of a cliff, between the cliff and trees, accounts for this only in part, as it did not similarly affect numerous other examples of the Divaricati growing in company with this.

With slender stems, 2 feet high, near Yonkers, N. Y., beneath Split Rocks, Se. 25 , '97, Se. 15,1903 .

$24^{3}$ Refracted form. Peduncles and pedicels excessively widespread, refracted as in the preceding, the inflorescence in one plant (springing from rich soil lodged in a stump) becoming $2 \mathrm{ft}$. broad and $2 \mathrm{ft}$. high. Branching often quite largely sympodial. Unlike the preceding in developing few listriform leaves or subcircular bractlets.

N. Y. vic., Bryn Mazur Park, at several places; beneath Split Rocks, south end, Se. 25, '97; middle, Se. 28, 1900; north end, Se. 15, 1900; Slab-stump, Se. I9, '99. Hillview, Se. 15, '97.

$24^{4}$ Virescent form. Dark green, with green stem, and leafy inflorescence : result of overfeeding or of loosened soil, producing numerous enlarged limp suboval rameals, some of which occasionally develop into the axile leaf-form, - except that the base continues rounded or somewhat tapering. Late-flowering plants, and, perhaps in consequence of this, apt to lack crimson in rays and disks, and developing some green in the rays instead.

N. Y. vic., Yonkers, Park Hill, Oc. Io, ' $9 \$$; Bryn Mawr Park, Oc. 2I, 'cS. 
$24^{5}$ Trowel-leaf form. Often dark green; the axile type of the typical form here becomes the predominant cauline leaf-form ; lower caulines ovate-triangular with deeper sinus. With the type at all localities, and persisting longer, the type seeming to turn to this when depauperate.

N. Y. vic., Eastchester, Seton Falls, Se. 24, 1900. Yonkers, Hillview, Se. 19, '97 ; Bryn Mawr Park, Oc. 21, '98, Se. 28, 1900, Se. 15, 1903.

$24^{6}$ Round-leaf form. 'Verging toward A. divaricatus curtifolius: teeth less developed; many lower caulines suborbicular and quite large, $31 / 4 \times 3$ in., with deep broad sinus and apiculate base.

Beneath Split Rocks, Se. 25, 97, not found the three following years.

$24^{7}$ Little-spade form. More slender plants with reduction of leaf-size, serration and color, and with perhaps still less hair than in the type. Lower leaves ovate-acute, low-serrate, with rather deep broad square sinus, soon becoming shallow. Listriform leaves suddenly follow (or sometimes gradually), with truncate brace-base or sometimes a notched base; they are subentire and thin, very minutely crenulate or denticulate; obtuse or rounded at apex; and usually a pale yellowish-green. A few are acute and a few are entire; sometimes they are quadrate and crenate with pronounced pendant basal lobes. These leaves often numerous, but occasionally only I or 2 on a plant, and are usually $3 / 4$ in. long, rarely $\mathrm{I}$ in. Slender, undulatiform, orbicular and cuneate petioles, all occur. The axiles are less prolonged than in the type, often I $1 / 4 \times 3 / 4$ in., ovate-acute, moderately straight-serrate ; the inflorescence small, shallow, often more condensed, and shortpedicelled, 2 to 4 in. broad, with some rounded and some chanfertipped bracts.

N. Y. vic., at the localities for the type, also at Tarrytown; at Inwood and Ft. Washington on Manhattan I.; and probably widely diffused.

Seems collaterally descended with the type $A$. listriformis, from the same source with $A$. carmesinus, and $A$. divuricatus, and apparently not attaining such stable equipoise as to transmit very definite characters : a fluctuation-variant perhaps rather than a species.

$24^{8}$ Shuttle form. Middle and upper caulines not typically listriform but longer in proportion, resembling a shape seen in many shuttles; $i$. e., somewhat oblong with straight parallel sides, truncate square-cornered base, and at the end abruptly sloped into an obtuse or very slightly acute apex. Such leaves are about $\mathrm{I} I / 2 \times I$ in., and have less rounded corners than the listriform type, besides being much more tardily narrowed toward the apex. Lowest caulines and the axiles nearly as in A. divaricatus in form, the lower leaves $2 \mathrm{I} / 2 \times \mathrm{I} I / 2$ in. or less, the axiles $\mathrm{I} 1 / 2 \times 3 / 4$ in. or 



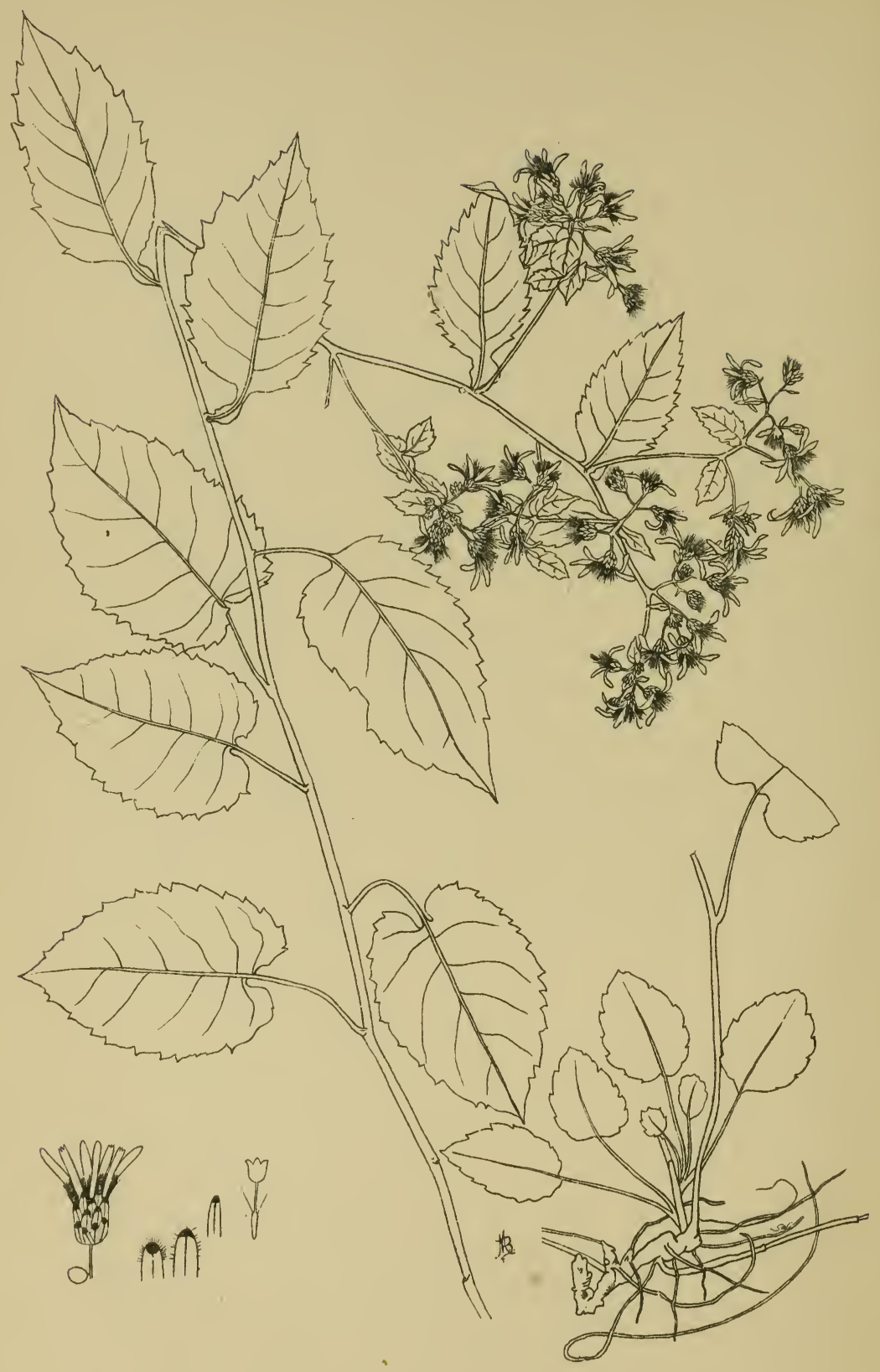

ASTER CARMESINUS 
less, the latter lanceolate, serrulate, less truncate-based than in typical $A$. listriformis. Leaves in general thickish, apple-green, straight-serrate, some of them often subentire. Bracts more varied, narrower, sometimes acutish. - Widely distributed, in scattered individuals or small clumps, in rich soil near rocks, in little shade, $\mathrm{N}$. Y. to Va. - Unlike $A$. aucuparius in lacking acuminate leaves. Unlike $A$. carmesinus in having few cordated leaves. Unlike $A$. divaricatus curtifolius, toward which it verges, in its straight-sided leaves, more wand-like aspect, etc. Unlike any in its characteristic leaf-form, which may however be a peculiar modification of that of $A$. listriformis.

Examples of this shuttle-form :

N. Y. vic., Inwood, on Dyckman Rock, Se. 27, '97; Se. '98; Se. 23, 1903. Ft. Washington, Se. 30, '98. Ft. George, Se. 24, '96. Yonkers, Bryn Mawr Park, Se. 1900, Se. 15, 1903; Split Rocks, Oc. '97. Staten I., Princes Bay, Oc. 10, '96.

N. J., Palisades, above undercliff, Se. 29 , '97.

Va., Potomac R. banks, Spout Run, Oc. 2, '88.

\section{Aster carmesinus Burgess}

Small rock-loving plants with crenate-serrate crisp leaves, persistent short slender petioles and small deep narrow sinus, widely divergent peduncles and shallow inflorescence of segregated cymules with deep crimson disks (whence the name, Late Lat. carmesinus, crimson).

Fig. 34 (= Plate 5) ; plant from Bryn Mawr Park, Se. 29, '96, in hb. Bu.; with radical group of Se. 23 , '99; characteristic leaf-form is seen in the lowest leaf of the larger stem.

A. carmesinus Burgess in Britt. \& Br. Ill. Flora, 3: 356. f. 3.735. I 898 . Original description :

"Stems erect, delicate, closely tufted, I or $2 \mathrm{ft}$. high, glabrous, reddish brown, terete. Leaves all petioled, glabrate, very thin but firm and crisp, the lower and basal ones oval, rounded or with a small deep and rounded sinus at the base, bluntly acute or shortacuminate at the apex, crenate-serrate, the upper ones sometimes ovate-lanceolate, the uppermost short-elliptic. Petioles slender, the uppermost sometimes winged. Inflorescence 5 in. broad, or less, usually of about 5 convex glomerules, each often of Io to I 5 short-peduncled heads, its branches spreading, 3 in. long or less.

"Rays chiefly 6, white; disk at first golden-yellow, finally deep purplish-crimson; florets broadly bell-shaped. Outer bracts obtuse, ciliate, pale with a green tip. Achenes glabrous.-On shaded rocks, near Yonkers, N. Y. Peculiar in its dense glomerules subtended by large short-elliptic leaves [this character proves to 
belong not to the typical form of the species but to the less usual syncopated form]. September."

Leaf-form cordate-oval, acute or short-acuminate, crenateserrate or curvescent-serrate, with small but rather deep and narrow sinus, best developed in the lower half or two thirds of the stem.

Radical leaves dark green, small, an inch long or less, cordateoval, obtuse or acutish, a few still smaller ones sometimes suborbicular. Their crenations are long, shallow, about 6 to the side of a larger leaf $2 \times \mathrm{I} / 2 \mathrm{in}$. Sudden access of light, accompanied by loosening of soil, produces very much enlarged and multiplied radical clusters, with coarser more serrate and more oblong leaves sometimes $4 \times 2 \mathrm{~T} / 4$ in. Elevated rosettes of large oval radicals each 2 in. long or more, are sometimes raised on an erect turionic rootstock 4 or 5 in. high (or from the side of the stem at the same distance above the proper base) when upward growth in a cranny has denied room for radicals below. Rootstocks not in crevices are yellowish-brown and short, about 3 in. length.

Lowermost caulines hardly show the typical leaf-form, a few or I or 2 nodes bearing smaller shorter broader more quickly acuminate leaves with broader sinus.

Lower and middle caulines typical, apple-green, about $3 \times 21 / 2$ in., smooth to the touch when growing, nearly so when dry, their petioles very slender, I in. or less long.

Upper caulines ovate-acuminate or lanceolate, still with short slender petioles or with moderate wings, continuing as muchdiminished sessile axiles.

Inflorescence shallow, broad, usually small, 4 to 7 in. broad, consisting of rather widely separated cymules or divisions segregated by their long wide-spreading peduncles. Pedicels slender, not much elongated, a half-inch long, sometimes an inch. Heads small, usually $\frac{7}{8}$ in. broad or less, about $\frac{3}{8}$ in. high. Rays moderately truncate or at least blunt, broad, $\frac{5}{16} \mathrm{in}$. or more in length. Disks soon deep crimson, with broad short bell abruptly contracted into a slender stalk.

Bracts very broad, short, uniform, rounded at the apex. Green tip hatchet-like, broad and short. A few bracts may vary; some lower ones may be triangular-acute; some of those following are sometimes chanfer-oblong with slight acutish tip, decurrent into midrib; some inner ones are narrowed and without green tips, having only a green midrib with pale nearly white margins. Bracts of 5 ranks, of which about 3 are of the predominant form, palegreen, subscarious, nearly smoothish, with ciliation very long, soft, tangled and pale. Achenes smooth.

- In the lower Hudson region, in thin woods on high ridges, 
rising from crevices among gneissic rocks when filled with rich black leaf-mold; or straying slightly into neighboring loose micaceous soil. Stems clustered rather closely, under half-shade, as of chestnut trees, forming a loose mass which sometimes covers a whole rock to exclusion of other forms. Rootstocks best developed in the wood-earth of rock-crevices, there becoming thick and heavy and contorted, blackish or dark brown, with very close and prominently ridged nodes, a length of about $3-4$ in. rernaining sound and often $\mathrm{T} / \mathrm{i}$ in. thick, sometimes with short stubby branches, sometimes with a few branches nearly as long as itself. One old rootstock of 1899 had on it the scars or the bud-points for the growth of I 894-I903, or the epitome or possibility of 9 years of connected growth.

Old rootstocks seem about twice as thick and corrugated and closely stoloniferous as in case of $A$. divaricatus or $A$. rupicola or subspecies cymulosus, when these by growing in similar rockcrevices have become specially contorted and thickened. Young surculi in such situations are short, yellowish-brown, uprising into new radical tufts within about a half-inch of the main plant. In neighboring loose soil surrounding rocks, they become somewhat more slender, and longer.

\section{Examples :}

N. Y. vic., Inwood, Dyckman Rock, Se. 27, '97. Indiınfield, rocks near quarry, Se. 25, I900. Yonkers, Bryn Mawr Park, Split Rocks, Se. 26, '96, Se. '97, Se. 98 ; locality destroyed by building; Diller Rocks, Se. 25, '97. Stony Lonesome, above St. Mary's Cem., Se. 23, '99, Oc. 6, I900, Oc. I901, Se. I902, Se. 22, I903, Se. I904. Grassy Sprain, reservoir rockwall, Se. 23, '99. Mile Square road, I900; Bu. Rocky woods n. e. of St. Joseph's Sem., Oc. 2, '98, Bi. Tarrytozun, Sleepy Hollow Cem., Se. 24, '98, many plants having crimson rays.

N. J., Palisades, Undercliff, Se. 29, '97, with rose rays.

Pa., Bethlehem ? Schweinitz in hb. Phila. Acad. Sci., labelled Aster thyrsiflorus by Schweinitz; and by Nuttall, perhaps about I810-1819, Biotia thrysifora; apparently from the somewhat dense cymules. Later labelled " $A$. cormybosus" on incorporation of the hb. Schweinitz with that of the Phila. Acad. Sci. - Schweinitz did not indicate locality; his own herbarium is however understood to represent his collections about Bethlehem, Pa., and Salem, N. C.

Allies. Similarly deep crimson disks occur in $A$. rupicola, $A$. listriformis and $A$. virgularis; and to a less degree, in $A$. fragrans $A$. aucuparius, $A$. argillarius, $A$. stilettiformis, $A$. camptilis; also sometimes in $A$. divaricatus when the plant is otherwise nearly typical.

Plants intermediate between $A$. carmesinus and $A$. diz'aricatus 
occur over a wide range, observed from $\mathrm{L}$. Erie to Connecticut and the Potomac. But these seem to be variations in the direction of $A$. carmesimus which still do not quite reach it, except in the Hudson region. Other intermediates of $A$. carmesimus occur in the Hudson region also, notably toward $A$. rupicula, $A$. listriformis, $A$. aucuparius and probably others.

Variants. $25^{2}$ Branch-forms bear little oval or oval-oblong subentire leaves gradually increased into long low-serrate acuminate upper leaves. Rameals suborbicular, well separated, following abruptly upon the long upper caulines and axiles.

$25^{3}$ Sprout-forms occur with all the leaves very small, noncordate, oval and suborbicular to lanceolate.

$25^{4}$ All-cordate form, all leaves or almost all, cordate to the inflorescence, shorter than in the type ; still acute, but nearly cordateorbicular. Thin, green-stemmed, with narrow bracts, little ciliate, more apt to be bevel-tipped.

N. Y. vic., Ft. Washington, Se. 30, '98; Inwood, Dyckman rock, Se. 27, '97. Spuyten Duyvil Cr., rocks of Cock Hill, Se. 22, '98. Yonkers, Bryn Mawr Park, Se. 26, '97. “Rocky woods north of St. Joseph's Sem., A. carmesinus? Oc. 2, '98,', Bi.

$25^{5}$ Broad-ray form: much larger plants, with green stem; heads a full inch broad, the rays broad, about $1 / 2$ in. long. Cauline or axile leaves enlarged; disks still crimson but bracts greener.

N. Y. vic., Bryn Mawr Park, Palmer Ave. Rocks, Se. 26, '96.

$25^{6}$ Parchment-leaf form, sunburnt, in open gravelly places, leaves firm, thickened, in drying having a fine granular roughness ; crimson of the disks intense.

Ct., Mianus R., ditch, Oc. 15, '96.

$25^{7}$ Syncopated form, peculiar and rare extreme state, with subsessile heads in involucrate clusters, owing to syncopation of pedicels and development of unusually large subelliptic rameals. Bracts broader, rounder, paler. Crenation more appressed.

N. Y. vic., Split Rocks, Se. 26, '96, about 15 plants; locality destroyed summer of '97, by building; others seen on Stony Lonesome, Se., 1903.

$25^{8}$ Green-awl form; virescent plants with small crowded heads, scarcely involucrate, peculiar in their greenish awl-shaped open-filiform erect rays; filiform by involution, erect on account of crowding. Teeth often sharper, but bracts and crimson disks usually remain normal. In small clusters, in half-shade.

N. Y. vic., Stony Lonesome, with the type, Se. 27, '99; absent, Oc. 2, 1900. Inwood, pavilion, Oc. 13, '99. 


\section{Division C. TENEBROSIAN ASTERS.}

Thinnest smoothest leaves. Disks with less red or none.

Subdivision $A$. Bracts obtuse, VERY NARRow.

Sp. 26, 27 ; A. castaneus and A. olivaceus.

\section{Aster Castaneus Burgess.}

Wand-like swaying dull-green plants with many ovate-lanceolate caulines and rameals, minutely roughened texture, inflorescence of fastigiated arch-top branches, the pedicels prolonged, filiform and upcurved, the rays quickly pendulous, long remaining snowywhite, the disks dull rose-brown becoming chestnut-color (whence the name, L. castanea, the chestnut-tree).

FIG. 35, plant from Hillview, N. Y. vic., Se. I5, '97, in hb. Bu. ; b, characteristic leaf-form; $d$, occasional lower leaf.

$A$. castaneus Burgess in Small's S. E. Flora, I2II. 1903, with original description :

"Stem glabrate, terete, graceful and wand-like, reddish-brown or greenish, with about twelve delicate straight darker striae, and becoming sinuous in the inflorescence. Predominant leaf-blades remote, very thin, of a dense and hard texture, minutely granularroughened when dry, ovate-lanceolate, closely slit-serrate, often unequally decurrent upon the short slender petiole; the lowest leaves much shorter, ovate-acuminate, coarsely serrate, and with a moderate sinus; rameal leaves lanceolate-acuminate or often all crescent-like and decurved, sessile by a short cuneate base. Inflorescence nearly naked, narrow, composed of several upcurved slender unequal branches bearing close convex clusters, all in flower at once and very short-lived. Pedicels long, filiform, upcurved, sometimes bearing small circular bracteals or discules. Bracts narrow, linear-obtuse, pale, with bright-green tips. Rays often 9, linear, snow-white, excessively thin and soon pendulous. Disks soon turning to rose-brown, sienna or chestnut-color. Resembles $A$. divaricatus L.; differs in all the above characters, especially in form of inflorescence, bracts and leaves. - In clayey spots amid swamps, near N. Y. City, also Conn. and L. Erie to No. Car. Early fall. - Type, Hillview, N. Y., Se. I 5, '97, Bu. in hb. Bu."

Supplementary remarks. Stem 2-3 ft. high, often decumbent, normally forming swaying masses where each stem supports the other. Rootstocks short, deep, pulling up with difficulty.

Leaf-form characteristically ovate-lanceolate with rounded 
base, without sinus, closely slit-serrate but with entire acumination. Such are most caulines and the first axiles; about $3 \times 1 \mathrm{x} / 4$ in., or $2 \times \mathrm{I}$. Lowest caulines on large plants sometimes $21 / 2 \times 21 / 4$ in ; the first ones apt to be remarkably small and broad, $\mathrm{I} / 4 \times \mathrm{I}$ in. or less.

Teeth sharp, conspicuous, rather close, but not large, chiefly of slit-serrate type, everywhere continuous except on the acumination

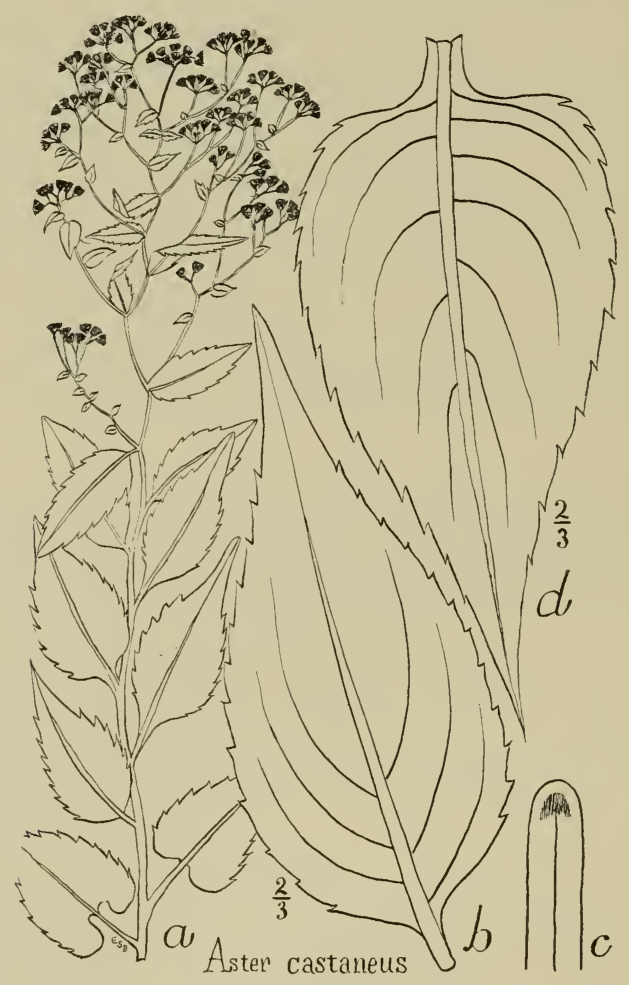

FIG. 35 .

and sometimes on the ultimate rameals; becoming in the inflorescence mostly remotely low-serrate, and in the lowest broader cordated leaves becoming coarser and outflung.

Leaves very apt to be decurrent down their petioles on one side; even the rameals are so occasionally; some plants choked under tall tangles of blackberry and smilax show still stronger decurrence into long cuneate wings, $\mathrm{I} / \mathrm{t}$ in. long or more.

Inflorescence deep and narrow, very peculiar when characteristically developed, pressing into a convex or flattish top of separated branches each of which repeats the general structure, the 
whole suggesting a series of white arch-segments thrown up loosely to outline a larger arch. Heads $\frac{3}{4}$ in. broad, $\frac{5}{16}$ high.

Bracts truncate-obtuse, a few of the inner ones much attenuate, or of the basal ones acutish. Green tips spatulate or irregular. Involucre narrow, very short, sharp-based.

Rays not large, excessively thin, apt to be 9 on vigorous heads, 7 in many, and 5 on impoverished heads or on whole plants.

Obvious hair lacking; under a lens some white ciliation shows on bracts, a little on pedicels, and minute puberulence on pedicels.

- Drier clayey spots in sivamps or near water, or in clayey pockets about stumps of trees; especially struggling upward through tangles of smilax, blackberry and other thickety growth; about Se. IO-20.

In a season of prolonged drought it becomes greatly altered, the pedicels shorter, stouter, less curved, the inflorescence much more contracted, often but a single bunch.

In the sun, fewer ovate leaves and more numerous cordate leaves seem to be produced.

In case of interruption to its accustomed conditions, with dryingout of swamp lands (draining or clearing, or laying out streets), shorter leaves are developed which are of stunted little acuminate form with many cuneate wings.

- Grows in company with $A$. ardens and $A$. Claytoni; from the source of these it is apparently a recent offshoot. When typically developed, it has less percurrent axis, fewer cordations, thinner and larger leaves, than $A$. Claytoni, with narrower inflorescence, and leaves and more forward-directed teeth than either that or $A$. ardens.

Specimens include :

Ct., Riverside, Mianus R., Oc. I 5, '97.

N. Y. vic., Inwood, Se. 27, '97; Van Cortlandt, golf links, Oc. 2, '97. Yonkers, Hillview swamp, Se. 15, '97, Se. '98, Se. '99, Se. 22, 1900; type locality, but obliterated by building, I90I. Bank beneath Split Rocks, Se. I7, '9S ; Stony Lonesome, with $A$. carmesinus, Se. 1903.

W. N. Y., Silver Cr., glen, Se. 8, '96.

N. C., Biltmore, coll. Herb. Biltmore, no. 34, "Aster -," in hb. N. I. Bot. Gar., etc.

Pa., Bethlehem, in hb. Schweinitz; two non-cordate fragments which seem to be of this species, and if so, the earliest specimens perhaps preserved; Schweinitz wrote on his label, "A. - ?" and later, in a blacker ink added "A. bruchintus Ly." A later hand substituted " $A$. corymbosus."

$26^{2}$ Branch-forms; similar, with shorter leaves. 
$26^{3}$ Sprout-forms; similar with ovate fewer-toothed leaves, and with some ovate radicals; in flower as late as Oc. 26 near N. Y.

$26^{4}$ Alternately decurrent form. Leaves long, narrow, to $5 \times 1 \mathrm{I} / 2 \mathrm{in}$. ; the short petioles $\mathrm{I}$ in. or less; all of the middle and upper ones margined, but on one side only or chiefly; the rounded base of the leaf also singularly decurrent down the petiole on one side, overpassing the other side by $1 / 4$ or $1 / 3 \mathrm{in}$. The leaf which is decurrent on the right side is followed by one decurrent on the left, and so forth; this being true of all the plants from a group of rootstocks.

N Y. vic., Bryn Mazur Park, Se. 17, '98, rich shaded brook-bank, with numerous non-decurrent forms of $A$. divaricatus L. growing everywhere near.

\section{Aster olivaceus sp. nov.}

Tall pale wand-like plants with thin tissue-like ovate acuminate leaves, strong teeth and sinus, narrow rays and long tapering inner bracts, slender upcurved naked branches, widely separated dense-flowered involucrate cymules, and disks finally brown but for a long time light greenish yellow or olivaceous (whence the name).

FIG. 36, plant from Dunkirk, N. Y., Au. 21,96 , in hb. Bu. ; $d$, younger cymules in bud; of same date.

Stem tall, very slender, somewhat wand-like but not rigid, 2 or $2 \mathrm{r} / 2 \mathrm{ft}$. high, erect and nearly straight, pale and olivaceous or light purplish or vinous-brown.

Leaves very thin, of delicate tissue-like texture, light-green or yellow-green, smoothish above in growth, finely roughened when dry, and quite downy beneath. Leaf-form nearly as in $A$. divaricatus L., but more triangular-ovate, coarse-serrate, commonly not large, $2 \mathrm{I} / 2 \times 1 \mathrm{I} / 2$ in., but sometimes $5 \times 2 \mathrm{I} / 2$ in. Sinus deep, broad and strong, continued well up the stem unlike $A$. castaneus. Teeth strong, either curvescent, couchant or of low-serrate type. Incurved acumination little-developed. Petioles slender, persistent into the inflorescence ; winged petioles occur seldom, but sometimes slightly among lower axiles.

Axiles few, lanceolate, with short acumination and short petiole or sometimes a little wing-base, only slightly serrulate; somewhat like those of $A$. tenebrosus, but light or full green, not dark and not nearly so long or so entire. Bracteals similar, gradually shorter and sessile, chiefly conduplicate around their branches, especially the secondary branches, often $\mathrm{I} \times \frac{5}{16}$ in. Radicals resemble the lower caulines, being ovate-acuminate, but smaller and less serrate. 
Internodes of the stem long and continuing for a long time to lengthen; those of the long pale-sienna slender rootstock are very short and close.

Stem generally forking into about 3 main branches, near its top, which rise at an acute angle into an upward curve and become erect or nearly so; their own branches are given off at a wide angle, bearing well-separated cymules which remain for a long

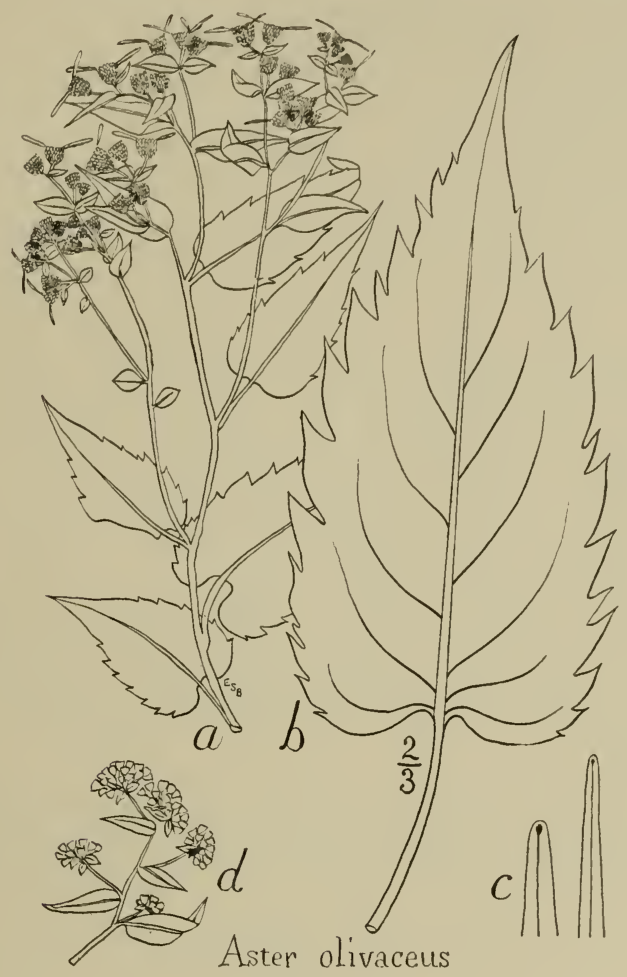

FiG. 36.

time dense with IO-I 2 crowded heads in an irregularly convextopped cluster, which is involucrate and for some time enclosed by $\mathrm{I}-3$ broad ovate-lanceolate partly conduplicate bracteals.

Pedicels tardily developed, white tomentulose and often but $\frac{1}{3} \frac{1}{2}$ in. long when the rays are already beginning to flatten, finally filiform and often $1 / 2$ in. long at length. Great time-difference also exists between central and lateral blossoming, buds continuing to push out centrifugally while older heads are in pappus ; unlike the somewhat similarly upcurved branches of $A$. castancus, which are all completely in flower at once. 
Heads of all sizes at once, but chiefly moderate, some a little over I in., but many on the same plant never reaching nearly that breadth. Involucre rather sharp at base.

Outer bracts rather pale, puberulent all over, of about 3 rows, with narrow midrib forming a green line, oblong or shuttleshaped with the sides nearly straight, obtusely pointed or the lowest acutish and more ovate.

Inner bracts very much longer, much narrower or attenuate but hardly acute, smoothish, often purpled all over or on the margins, of about 2 rows, the pale greenish tip disappearing with the innermost row.

Rays milk-white or dull white, often olivaceous-tinged, repeatedly 8 , but sometimes I I, long and narrow, widest near the middle, curving to a narrow acuminate end, with persistently upcurved sides, the apex entire or but very obscurely toothed. During blossom the rays long remain caudate, or filiform-acicular at these tips, and in drying they quickly become involute-acicular. When flattened they show no channels, but 4 fine firmer lines.

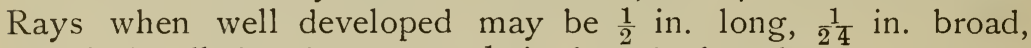
usually inrolled and not over $\frac{1}{40}$ in. broad when dry.

Disks pale or but moderately yellow, soon olivaceous or greenish brown, finally dingy brown, seldom passing through any decidedly reddish brown stage.

In damp hollows in beech woods, etc., best developed on clayey soil of Lake Erie bluffs; also observed near Boston and N. Y. City; apt to form small rather loose clumps.

Examples:

Ms., Weston, near Charles R., Au. 28, '98 ; radicals and young stems of 6 in., May 7, '99; radicals still remaining, stems now 20 in., but lacking 2 weeks of blossom, though about 2 weeks earlier than neighboring $A$. tenebrosus and $A$. divaricatus, Au. 8,1900 .

N. Y. vic., Bryn Mawr Purk, brookbank, Se. 17, '98. Pelham Manor, in loosened gravel, Se. 20, '98.

W. N. Y., Dunkirk, Pt. Gratiot, Au. 29, '96, Au. 21, '97, Au. 19, '98, Se. 2, '99, Au., 1900, 1901, I902, I903, 1904. Fredonia, Marsh's woods, Au.,'97. Sheridan, Brace's woods, Au. 15, '96. Hanover, Aster-bank in Silver Cr. gorge, Au. I7, '96. Silver Cr., Talcott's woods, Au. 23, '99; Swift's hill, Se. I, '99, Au., I900. Cattaraugus reservation, Little Indian banks, in tussocks among cattails, Au. 20, '96, and Au. 24. '97; Tompkins woods, Au. 28, '99, on mound in low bushes; Skidway clearing, Au. 31, '99.

- A. olivaceus is distinguished from $A$. divaricatus especially by its inflorescence, not freely diffused but of few remotish cymules which long retain a dense contracted habit. Its bracts are less truncate and ciliate, more puberulent, the inner ones more taper- 
ing, more purple-tinged. Its leaves are paler, shorter, less longacuminate. The sinus is broader. The cymules in case of small plants are all in one mass, but in most they become separated on pale bare slender upcurved branches. A. divaricatus occasionally has its disks turn olivaceous without preliminary reddening, but not with the predominant regularity of $A$. olivaceus.

$A$. olivaccus resembles $A$. divaricatus cymulosus in having segregated cymules, but differs in many of the just mentioned particulars and in its whole habit, taller, slenderer stem, etc. The rays of cymulosus are notably shorter, broader, dense, more apt to be tridentate, its disks are reddened, its sinus not so broad and shallow, its cymules little involucrate. Both $A$. divaricatus and its variety cymulosus, when growing with $A$. olizaceus, are chiefly in blossom two weeks later or more.

$A$. olivaceus is distinguished from $A$. tenebrosus by its rougher leaves, much narrower inner bracts, fewer and less developed rays, paler color, etc. My supposition at first sight that it was an immature or a drought-condensed stage of $A$. tenebrosus was disproved on watching its development the ensuing eight years. Like A. tenebrosus, its leaves are extremely thin; but are not so sleek; they are broad-based and salient-toothed, but not so much so, nor so large; the outer bracts paler, the inner ones of different shape, and the subsessile heads are much more segregated.

$A$. olivaceus is distinguished from $A$. fragrans, which has very thin leaves of somewhat similar shape, by its subsessile heads, greenish disks, pale leaves, and very different inflorescence.

Subdivision B. Bracts acute, very broadly triangular; the inner ones oblong-obtusish. Sp. 28.

\section{Aster tenebrosus Burgess}

Tall wide-branched dark-green plants of deep shade, with large thin sleek leaves, strong teeth, acumination and sinus, loosely forked inflorescence with numerous long rays and axiles, and acute green bracts.

Name from its home in the shadowed edges of thick woods; L., = accompanied by shadows.

Fig. 37, plant from Dunkirk, N. Y., Au. 29, 96, in hb. Bu.; showing small inflorescence-branch, a lower cauline leaf (not nearly so large in proportion to the 
others as is common) an upper cauline leaf, and an axile leaf of occasional but less typical form.

A. tenebrosus $\mathrm{Bu}$. in $\mathrm{Br}$. and $\mathrm{Br}$. Ill. Fl. 3 : $357 \cdot$ f. 3736 . $\mathrm{I} 898$, with original description :

"Stems solitary or scattered, glabrate, striate, about $3 \mathrm{ft}$. high. Leaves very thin and smooth, slender-petioled, broadly oblong, coarsely toothed with remote acuminate teeth, abruptly longacuminate at the apex, the basal sinus broad, rounded, shallow, except in the lowest ones; leaves of the inflorescence lanceolate, subentire, sessile, sometimes 4 in. long. Inflorescence broadly corymbose; heads about 4 lines high, often $\mathrm{I} / 4$ broad, rays usually 9 to 12 ; disk pale yellow, becoming purplish brown, the florets funnel-form with a long slender tube; outer bracts chiefly elongated-triangular, acute, green; the others linear, obtusish, the green tips lance-linear; achenes generally glabrous. - In moist dark woodlands, New York to Virginia. Peculiar in its large dark leaves with coarser teeth than in the next species $[A$. divaricatus]. Aug.-Sept."

Supplementary remarks. Stems green, or greenish brown, erect but easily made decumbent, and often repeatedly geniculate. Leaves rather pale beneath, the larger ones often 6 in. long, and 2 or 3 in. broad, or sometimes even 4 in., very thin and tissuelike, usually smooth when dry, and in growth having a smooth surface like dressed kid.

Sinus, where best developed, in a few lower caulines, broad, deep, somewhat rectangular. Most leaves have a brace-base with double curve and almost truncate.

Leaf-form oblong-ovate with strongly incurved and entire acumination. Teeth chiefly coarse, strongly outflung, mostly between curvescent and couchant in form, with occasional typical examples of both, and with aquiline teeth appearing toward the rounding base, or sometimes all along the margins.

Petioles slender, distinct but not long in proportion to the leaf, being commonly less than half the leaf-breadth. They continue well into the inflorescence.

Axiles and rameals low-serrate, ovate-lanceolate to lanceolate, their petioles often becoming winged. Finally the bracteals become sessile and sometimes wholly entire, while still remaining long, conspicuous and streamer-like; 30 such on a large inflorescence being seen, about $2 \mathrm{x} / 2$ in. long, and $1 / 2$ in. or more broad.

Inflorescence subject to early arrest at main stem and subsequently at main branches, each soon overtopped irregularly by proliferous branches, the whole sometimes 16 in. broad and high. Smaller inflorescences and those of only a few heads, often, however, remain level or convex-topped. 


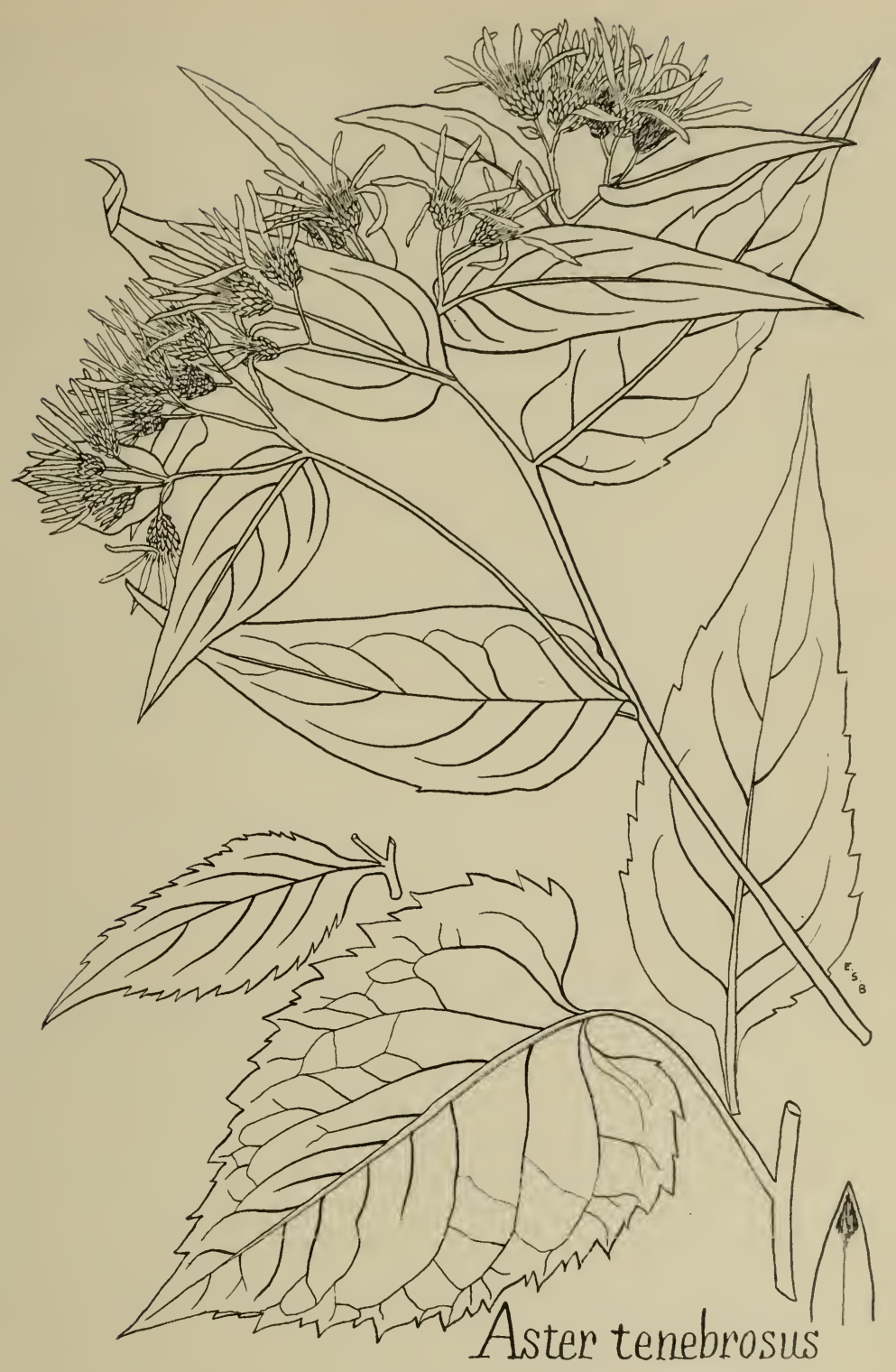

FIG. 37 .

Bracts chiefly very acute, the green tip very dark and large, broad-based, triangular-elongate. Middle bracts becoming oblong, diminishing in breadth above their middle, then chanfer-acute or acutish, chiefly pale, with slender brown marginal lines and midrib. 
Inner bracts pale, linear, tapering at the end to a rather obtuse point. Ciliation rather strong on the outermost bracts; their backs smooth or with some scattered tangled hair.

Rays long and narrow, their white often dull or slightly virescent, very variable in number, sometimes only 6 , but often $\mathrm{I} 2$.

Heads terminating each main branch. Form at first a small dense glomerule, usually soon widely and unequally separated by development of simple or branching pedicels.

In deeper shade than $A$. divaricatus, Mass. and L. Erie to North Carolina. Late in August. Specimens include:

M. V., Mark's-valley Road, on side-hill in bushes, Se. 7, '98; leaves much smaller in sea-air and sand than leaves of inland correlatives, but larger than in the prevailing $A$. divaricatus of that sea-coast. '97, Bu.

N. Y. vic., Bryn Mawr Park, Se. 4, '98, Bi. Mile-Square road, Se. 25,

N. Y., Catskills, Kaaterskill Mt., Se. 7, '99.

W. N. Y., Dunkirk, Pt. Gratiot Park, Au. 21, '96, Au. 29, '96 (maximum bloom), Au. 3 and II, '97 (young buds), Au. 19, '98, Au. 22, '99, Se. 2, '99; July I 9, I 900 (young buds); nearly trampled out, I90I-I903. Fredonia, Se. I, '96, Se. I I, '96, etc. Sheridan, Au. 15, '96. Silver C'r., Au. 15, '96, to '97, '98, '99, 19001903. Hanover, near High Br., Au. I7, '96; near Little Indian Falls, Au. 31, '99. Cattaraugus, Indian reservation at "Isaac's-place," Perrysburg, Au. I9, '96.

Gard.

Pa., Phila. vic., Au. 30, '69, G. H. R. as "A cordifolius," in hb. Mo. Bot.

Va., Potomac bank, above Washington; Spout Run, '88.

N. C., "Sruain Co., alt. 5,000 ft., Au. 20, '91, H. C. Beardslee, A. corymbosus,' ' in Hb. U. S. N. Mu., as no. 18,948 .

N. C., Andrew's Bald, alt. 6,000 ft., '9r, Beardslee, as A. cory'mbosus, in hb. Mo. Bot. ('ard.

$28^{2}$ Sprout-forms show broader rays, smaller leaves, and many leaves of ovate shape with non-truncate rounding bases; inflorescence still proliferous but small, segregated, the little cymules less readily becoming diffuse. Such persist in clearings and often flourish well although prostrated by trampling.

$28^{3}$ Condensed forms, either in sun or shade, resulting two successive seasons, ' 99 and I 900 , from unusual prolonged drought. They showed the effect chiefly in the inflorescence, only their main branches developing and their heads remaining subsessile or but little separated in their remotish cymules.

Au. 23, '99, Se. 2, '99, Au. 1900, in W. N. Y.

$28^{4}$ Bushy form, with bronzed leaves, stout erect stem, and increase of leaf-substance making them membranous rather than tissuey, and roughish in drying. More in sun. Disks purpled or maroon ; intermediate to $A$. divaricatus alatus.

IV. N. Y., Hanover, Au. I7, '96. 
$28^{5}$ Hybrid? A. tencbrosus $\times A$. glomeratus? Grew with both species, Au. I0, '97, Darby Switch on Canadaway Cr. near Cassadaga, W. N. Y. Pale yellowish-green, hoary with pubescence ; bracts narrower. Like $A$. tenebrosus, it shows acute bracts, long narrow rays, long lanceolate axiles, long flexile branches, and lower leaves somewhat typical also. Like $A$. glomeratus, it shows much obvious hair on bracts, leaves and stem, yellowish green color, rough surface, membranous texture, and especially a less diffused convex-topped inflorescence with each branch bearing a dense glomerule at its summit. In moderate sun.

Subdivision C. Bracts rounded, short and broad, scale-like, all alike. Sp. 29.

\section{Aster Chlorolepis Burgess}

Dark large-leaved, long-rayed plants resembling $A$. tenebrosus, but having a sharp deep sinus, crimson disk, moderate serrate bracteals, and rounded bracts.

Name from the prominent green scale-like bracts. Gr. $\chi \lambda \omega_{\rho} \tilde{j}_{5}$, greenish, $\lambda \varepsilon \pi i$, a scale.

FIG. 38, plant from Grandfather Mtn., N. C., H ller, no. I290, in hb. Colu.

A. chlorolepis Burgess in Small's S. E. Fl. I2II. I903, with original description :

"Stem strong, glabrate, brownish, terete below, angulatestriate above. Leaf-blades large, smooth, very thin, brownish green, pale beneath, ovate-acute, very coarsely serrate with outflung teeth; sinus deep and sharp; petioles short, slender; axile leaves also large, oblong lanceolate, serrate with long forwarddirected teeth, the upper ones sessile. Inflorescence loose and irregular; heads large, long-peduncled, inclined to be widely separated; rays nearly twice the length of the involucre; bracts quite uniform, thick, broad, short and scale-like, with very little ciliation or hair, chiefly golden-brown with a short, broad, dark green rounded tip; disks turning crimson. Resembles A. tencbrosus in its large heads, leaves, teeth and bracts; differs especially in having the sinus sharp, and bracts rounded, and in the absence of greatly prolonged entire bracteals. - In the mountains, N. Y., W. Va., and N. C., reaching altitudes respectively of 300 , I,000 and I, 850 meters. Fall. - Type, Grandfather Mt., N. C.. Hcller, no. I 290, in hb. C."

Also, W. Va., Aurora, 3,00o ft., Au. 26, E. S. Steele in hb. N. Y. Bot. Gard. 


\section{Division D. CLAYTONIAN ASTERS.}

Thickened firmer leaves, rough when dry, ovate-acuminate in principal form or broader; not large nor very narrow nor very long. Disks high, very fragrant of bee-bread, golden-yellow, soon becoming a warm rich brown (exc. nos. 33-35.) Petioles short, not rapidly lengthened below.

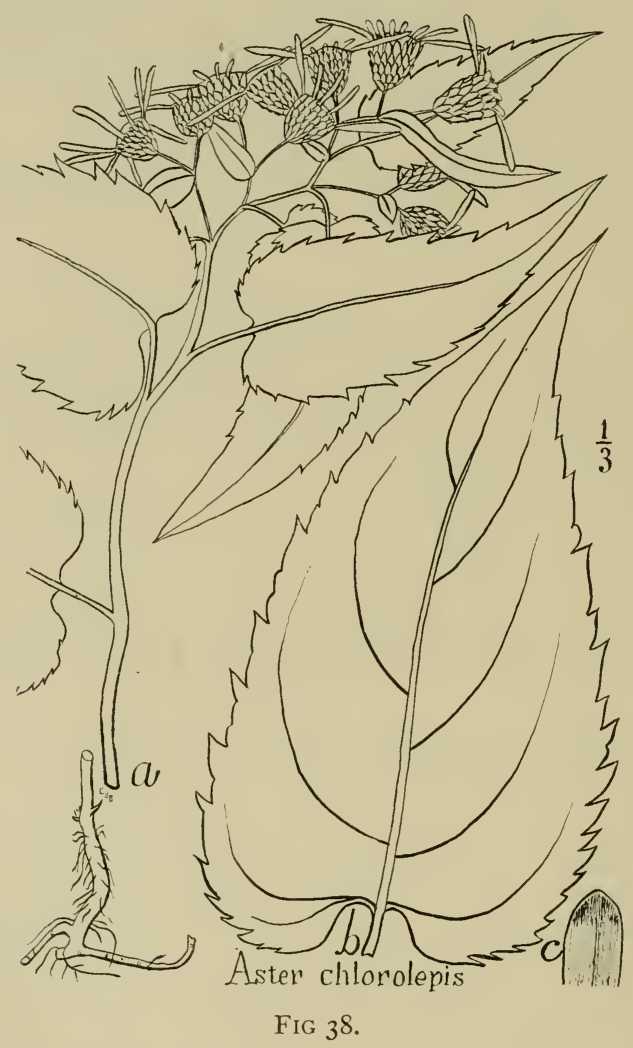

Subdivision $A$. Bracts NARRow, oblong.

Leaves chiefly smooth when fresh. Veins cord-like beneath, pale. Sp. 30.

30. Aster Claytoni Burgess. Clayton's Aster.

Pinnately percurrent 6-rayed plant, with sharp teeth and sinus, roughening leaves, broad-based axiles, long suberect peduncles, small, subumbellate heads, attenuate inner and beveled outer bracts, and glowing sienna disks. 



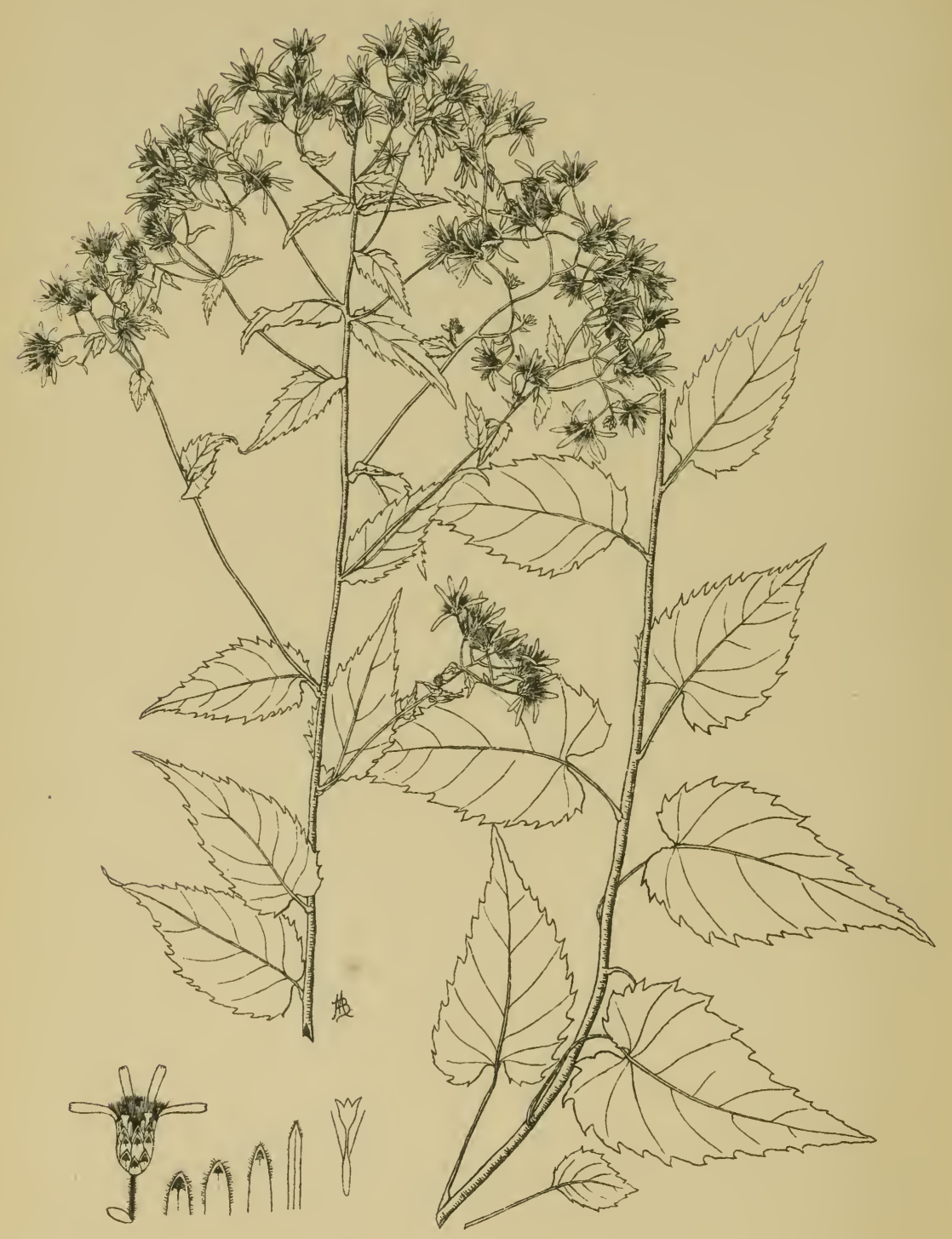

ASTER CLAYTONI. 
Name from John Clayton, of Virginia, its first observer, 1755 or earlier.

Fig. 39 (- I'LATE 7) ; plant from Inwood, N. Y. City, Se. 24, '96, in hb. Buu.

Aster serotinus, floribus in umbellula . . , no. 767. Clayton in Fl. Virg., ed. 2, 125. 1762; so written by Clayton 1755 or earlier ; see p. 221 ; fide Clayton's type specimen in hb. Br. Mus. (Nat. Hist.) see p. 225.

Aster foliis cordatis . . caule subfruticoso, Gronovius, Fl. Virg., ed. 2, 125. I 762 .

A. Claytoni Burgess in Br. and Br. I1l. Fl. $3: 358$. f. 3,740. 1 \&99, with original description.

"Similar to $A$. dir'aricatus, stems red, tough.

"Leaves chiefly ovate-lanceolate, not large, rough, thick, slender-petioled, coarsely serrate, pale, or dull, the apex incurvedacuminate, the upper spreading or deflexed, sessile by a broad base, lanceolate-triangular, serrulated. Inflorescence high, with percurrent axis, the long suberect branches each bearing a small umbelliform cluster of heads; peduncles filiform, as long as the heads, $3^{\prime \prime}-4^{\prime \prime}$ long; bracts pale; rays short, narrow, chiefly 6 , snow-white; disks at first golden-yellow, finally sienna-brown; florets about 20 ; achenes [when young; sometimes when mature] densely short-hairy.

"In sunny or slightly shaded rocky places, New York to the mountains of Virginia. September."

Supplementary remarks. Stem usually about $2 \mathrm{ft}$., without obvious hair, dull red or reddish-brown, tough, terete, erect but slightly sinuous above.

Leaves about $3 \mathrm{I} / 2 \times 2$ in. or smaller, rather uniform, very slowly diminished upward; often all are about $2 \times \mathrm{I}$ in.

Leaf-texture thick or thickish, compared with $A$. divaricatus L., strongly roughened when dry; often roughish when fresh, but as often smooth, even sometimes so when in the sun.

Leaf-form ovate-acute to ovate-lanceolate. Petioles short, slender, mostly less than half the leaf-breadth, finally forming a short concave wing, and usually disappearing with the axiles.

Sinus strong, quite persistent, chiefly sharp; broad and deep in one or more lowest leaves, broad and shallow sometimes in one or more upper ones, and then replaced by truncate or finally rounded bases. Teeth sharp, moderate in size, curvescent or with back of a single-curve, irregularly spaced. Apex incurved-acute or short acuminate.

Axiles lanceolate-triangular, broad based, sessile or almost so, deflexed or spreading sharp-serrulate. Rameal similar but suddenly and greatly reduced. Ramulars form little discules, $\frac{1}{16}$ in. broad or less often none.

Veins inconspicuous above, very slender and cord-like below, forward-curved, chiefly 6 pairs, sparingly strigose-hairy. 
Leaf-color dull apple-green, very pale beneath, fawn-color on their autumnal turning, by end of September.

Inflorescence high and convex-topped, with percurrent axis, and long slender suberect peduncles each bearing small convex umbelliform cluster of small heads, $\frac{5}{16}$ in. high or less, borne on filiform pedicels of similar length.

Rays snow white, chiefly 8 and 6 , oblong, short, rounded at the apex, often reddening with age.

Disks full, broad and high, of about 20 florets, on expanding of a warm golden yellow and exhaling a bee-bread fragrance, soon turning a glowing sienna-color, and on withering a dull brown. Usually scarce any red is developed, but sometimes it occurs, replacing the sienna-color.

Achenes clavately fusiform, sometimes at maturity retaining close short hairs along the numerous fine striations, but often losing them early and becoming smooth before maturity.

Pappus ecru and after drying becoming faint fawn or slightly tawny after 4 years.

Radicals very rarely produced, perhaps 3 clusters in the many hundreds of plants observed; a group found Se. I 5, '97, showed 6 similar cordate-orbicular leaves, usually $3 \times 2 \frac{1}{4}$ in., with sharp crenate teeth.

Habitat. Rock-loving plants in sunny or slightly shaded places; N. Y., to the mountains of Virginia, about the middle of September.

Stems loosely scattered, usually several together from one rootstock-cluster; occasionally these clusters are near enough to each other to fill rocky spaces or slopes. The plant seems to be partial to dry rock slopes covered with thin soil and also to the drier places in rocky swamps, where tufts of the plant grow just above wet clayey mud; as Clayton indicated in his original description, in saxosis aut lutosis.

Allies. For distinctions from $A$. mollescens see that species. From $A$. divaricatus into which it passes, typical $A$. Claytoni is distinguished readily by its shorter smaller rough coarse leaves, sessile truncated axiles, and pinnated inflorescence of subumbellate clusters borne along a percurrent axis. It is usually paler, has less red in its disks, and has smaller heads. From $A$. ardens, one of its near allies, it is distinguished partly by smaller size, narrower and tapered bracts, and very different inflorescence. $A$. ardens has also usually an intensely bright deep-red stem and deepcrimson disks. 
A. ebeneus, another near ally, has usually thicker blunter less sharp-toothed leaves, axiles taper-based not truncate, and darker stem, apt to be more percurrent and more numerously branched.

Examples of $A$. Claytoni include :

Ms., Taconics, Sky Farm.

N. Y., Albany Co., at Menands, Se. '99, C. II. Peck in N. Y. St. Herb. Catskills, Hunter, Se. 5, '99, Bu.

N. Y. vic., Inwood, Dyckman Av. rock, Se. 24, '96, Se. 24 and 27, '97, Se. 22, '98, Se. 14, '99, Se. 1900, 1901, 1902, 1903, 1904; by pavilion, ()c. 13, '99, late-blooming and virescent. Bank of the Hudson below Inwood, Oc. 16, '98, Bi. Ft. Washington, Oc. 16, '98, Bi.; 165th St. rock, Se. 30, '98, Bu.; foot of 17 oth St. Oc. 6, '98, Bu. Mosholu, Se. 30, '96. Ft. George, rocks, Se. 24, '95. Indianfield, Se. 18, '98. Yonkers, Hillview swamp, among rocks, Se. 15, '97, Se. 13, '98, Se. '99, Se. 23, 1900; nearly obliterated, Se. 190I-1905; late-blooming, Oc. 26, '97. Park Hill, rocks, Se. 14, '96. Bryn Mawr Park, Se. '99; Split Rocks, Se. 25, '97, Se. 17, '98, Se. 16, '99, Se. 1900, Se. 1903. Woods n. e. of St. Joseph's Seminary, Oc. 2, '97, Bi. Bronx R. or near, Fordham and Woodlawn, Se. 1903. Tarrytown, Se. 24, '98.

N. J., Palisades, Woodcliff, Se. 12, '98 ; Ft. Lee, Oc. 17, '99; Undercliff, top, Se. 14, '99, Se. 14, 1900, Oc. 17, '99; in bud, Au. 8, '99; halfway up, Se. 14, '99.

W. N. Y., Hanover, High Br., clearing, young buds, Au. I7, '96. Fredonia, Marsh's woods, Se. I, '96 ; Canadaway Cr., rocky bank, Au. 22, '96, just opening.

Va., Potomac R., Spout Run, Oc. 2, '88, Bu. Blue Ridge region, before 1755, Clayton, no. 767 , now in hb. Br. Mu. Nat. Hist.

\section{Variants include :}

$30^{2}$ Branch-forms. More irregularity of leaf-form, even with oboval and triangular-lanceolate upper leaves, and sometimes with many leaves opposite by disturbance of the regular position of nodes. Large cuneate-based elliptic rameals are sometimes developed.

N. Y. vic., Inwood, Dyckman Av. rock, Se. 24, '97, '98, '99.

$30^{3}$ Sprout-form (seldom developed?) shows less regular inflorescence and less symmetrical leaves; rameals oval to oblongovate.

N. Y. vic., Hillvierw, Oc. 26, '97, etc.

$30^{4}$ Arrest-stem form; upper part of stem not developed; inflorescence seeming as if seated in leaves; plants small; inflorescence brushy, widely and repeatedly branched, and full of little oval leaves.

N. Y. vic., Inwood, pavilion, Oc. 13, '99.

W. N. Y., Hanover, High Br., Au. 17, '96.

$30^{5}$ Arrest-leaf form. Sudden arrest or reduction in size affects all the leaves above the first few ; plant consists of a small single-bunch inflorescence raised on a pedunculate axis which is 
clothed with little ovate leaves following upon a few much larger basal ovate leaves. The same effect is produced regularly by $A$. biformis, and in occasional plants by other allies of $A$. macropliyllus, but is infrequent in the Divaricati.

N. J., Palisades, Ft. Lee, Oc. 17, '99; lake to south, Oc. 17, '99.

$30^{6}$ Axilliferous form, differing from the type in having shorter peduncles and such extending well down the stem. With the type. 17, ' 98 .

N. Y. vic., Inwooa', Se. 22, '98; Indianfield, Se. 18, '98; Split K'ocks, Se.

$30^{7}$ Branchy-base form; plants repeatedly branching widely and divaricately near the base and upward; often within 3 in. of the ground; sometimes with branches lying on the ground though stiff and strong; plants becoming in this way sometimes about $2 \mathrm{ft}$. broad and $1 \mathrm{I} / 2 \mathrm{ft}$. high. Unlike the proper branch forms of the species, this seems not the result of cropping, but develops its main axis in full. Proper truncate-based sessile upper leaves of the species first appear in this form on the secondary branches, instead of simply subtending the base of the primary. The cauline leaves are all, or nearly all, axiles, and with a strong broad deep sinus. Rameals ovate, elliptic or lanceolate. Ramulars truncateovate, sessile.

N. Y. vic., Inwood, shallow grassy ditch by roadside below Dyckman Ave. Rock, Se. 24, '96, Se. 24, '97, Se. 22, '98, Se. 14, '99, Se. 1900.

N. J., Palisades, Se. 27, '97, Se. 14, '99.

$30^{8}$ Brush-top form. Very proliferous profuse inflorescence of small heads, from long ascending peduncles, overlapping into a dense pinnate or corymbose mass, with rather long suberect pedicels. Cordate bases few and slight; upper caulines ovate, rather large, wing-based; rameals often large and numerous, oblong, sessile, passing from taper-based to truncate-based; bevel bracts common. Late, with the type ; seems sometimes to be produced as an abnormal growth from the type by strangulation with Amplicarpaca, by overcrowding, entangling with other plants, etc.

N. Y. vic., Ft. Washington, Oc. 6, '99; Woodlawn Heights, Se. 25, 1900; Hillview, ditch border, Se. 22, 1900.

N. J., Palisades, Ft. Lee, Oc. I7, '99.

$30^{9}$ Bright-eye form. Differs from type in smaller size, and dissolved inflorescence, which is not so remotely pinnate, and is intermediate to $A$. ardens. Each branch bears not an umbel-like corymb with upper internodes syncopated, as in typical $A$. Claytoni, but a stiffly divaricate corymb of remotish spreading branchlets, each of these bearing an umbellule or instead a miniature corymb. Leaves smooth and soft in life, rough when dry. With 
particularly bright glowing golden disks. - In half sun, in thin grassy turf on rocks. Frequent near N. Y. City, with the type; examples :

N. Y. vic., Inwood, Dyckman Ave. Rock, Se. 27, '97, etc. Ft. Washington, foot of 17 oth St., Oc. 6, '98.

N. Y., P'alisades, Woodcliff, Se. 12, '98. Ft. Lee, Oc. 17, '99. Undercliff, Se. $16, ' 99$.

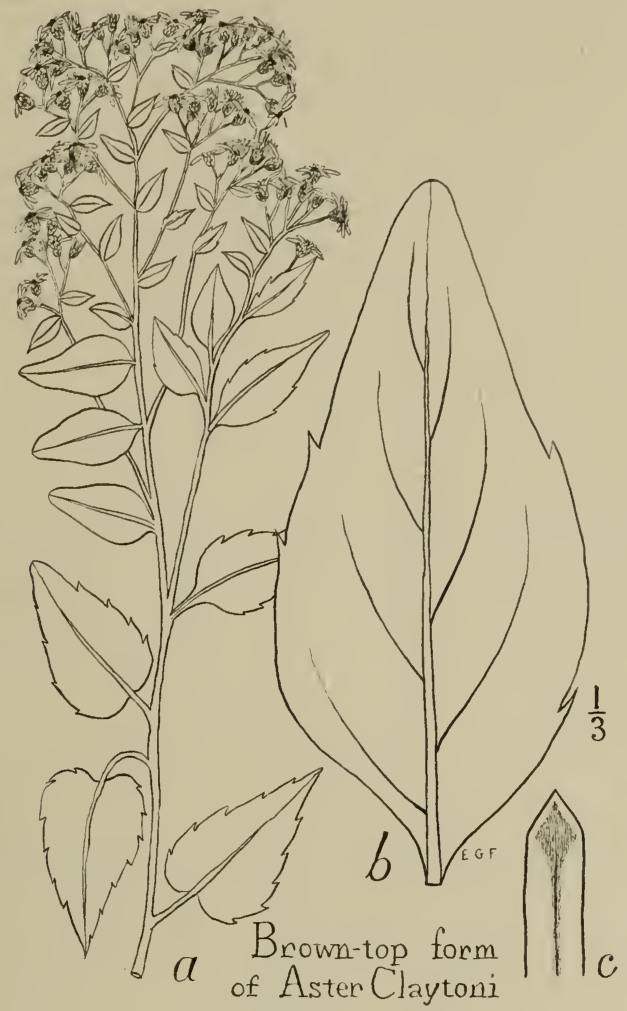

FIG. 40.

$30^{10}$ Brown-top form.

Fig. 40, from plant of Orange Mt., N. J., Oc. 24, ' 96 , in hb. Bu.

Low, bushy-branched, small-flowered, floriferous brownish plants with very numerous large oblong or spatulate taper-based rameals. Stem green or brownish, often beginning to branch almost at the ground. Branches green, numerous, long and ascending, sometimes I $2-20$ on a plant and each $8-\mathrm{I} 2 \mathrm{in}$. long, themselves soon similarly and repeatedly ramified.

Leaves brownish green, much blotched with deeper brown in autumn, their veins often paler and whitish beneath. Caulines 
and lower axiles few or none at flowering time, cordate-ovate, rather small, $23 / 4 \times$ I $3 / 4$ in., with coarse and rather remote teeth which are irregularly couchant; the sinus shallow, and petioles slender or the upper winged.

Upper axiles and rameals peculiar, sessile, obtuse, elliptical spatulate or oblong, strongly tapered toward the base : $21 / 2 \times 1 \mathrm{I} / 2$ in. when elliptical, or if spatulate-oblong narrowed to $21 / 4 \times 3 / 4 \mathrm{in}$.

Inflorescence often 6 to 10 in. across, sometimes 16 in. Heads very small and numerous; large ones $\frac{6}{8}$ in. broad, $\frac{6}{16}$ in. high ; on more floriferous plants $\frac{5}{8}$ in. broad, $\frac{4}{16}$ in. high, with hundreds such on the plants. Rays dull white. Disks soon brown, becoming a conspicuous dark umber in many extreme plants, occasionally with some red. Bracts indefinitely green-tipped, not very ciliate, apt to be truncate-obtuse with a slight central point.

Late-flowering plants of gravelly spots or crevices of rocks.

N. Y. vic., Bedford Park, Se. Io, 1903. Yonkers, McLean Av., Se. 29, '98.

N. J., West Orange, Eagle Rock, Oc. 24, '96.

Va., Potomac bank above Aqueduct Br., Oc. 15, '87.

D. C., Washington, Vasey, ' 87 , nos. I8,955 and 18,956 in U. S. Natl. Hb.

$30^{11}$ Catskill. form, intermediate toward $A$. divaricatus $\mathrm{L}$. Early-flowering high-cordate dense-topped cinereous plants with small close sharp teeth, and thickish leaves. Bracts all of a uniform stiff brown coriaceous texture, with medial line and short tip darker, slanted to a rounded or obtuse apex, oblong or the lower somewhat triangular. Stems closely cespitose, dark prune-color, much bent and sinuous, chiefly I ft. high.

5 ,'99.

On sunny banks, above Schoharie Cr., at Hunter, Greene Co., N. Y., Se.

$30^{12}$ Cliff-clinging form. Growing out of narrow ledges or crevices well up the side of cliffs, and rising almost vertically instead of divergently outward as in many plants in similar situations, or instead of curving upward as in $A$. Parthianus or curving downward as in $A$. arcuatus. Inflorescence of about 6-8 wellseparated clusters which flatten as a whole into an ovoid-oblong outline from the failure of the lower peduncles to elongate far, the axis continuing high; a direct result of situation and access of light; the kindred typical plants of $A$. Claytoni on the top of the same rock display a much broader-topped inflorescence. Clusters denser than in type, and more convex.

On side of rocks crowned with the type above, at Inwood and Ft. George on Manhattan I., at Split Rocks near Yonkers, on the Palisades, and also in Chautauqua Co., N. Y., at Fredonia.

$30^{13}$ Etiolate form, blanched by growth under new building, soft, smooth, decumbent and elongate, with capillary tendril-like whitish 
pedicels I and almost 2 in. long; no kinship to $A$. Claytoni would be guessed from these, but from the same rootstock grew a short erect rough condensed plant nearly typical for $A$. Claytoni, retaining its characters because happening to project into the sun.

Mosholu, N. Y., Se. 30, '96.

$30^{14}$ Flagelliform form. Very remarkable in appearance from its many long swaying flagelliform branches, each bearing a little dense cluster of heads, with syncopated pedicels.

N. Y. vic., Tarrytowen, Se. 24 , '97.

N. J., Palisades, face of the rock, above Undercliff, Se. 14, '99.

$30^{15}$ Rock-cleft form. Very dark green, but leaves wholly different from other dark green Divaricati, and in shape agreeing with $A$. Claytoni; roughish a little on account of scattered hair in life, more so when dry; disks reddish brown; rays about I2, sometimes I 3. Partial to clefts of rock, where it grows in lines or scattered clusters; also in loose stony soil in their vicinity.

N. Y. vic., Park Hill, Se. 14, '96.

N. J., Palisades, Undercliff, Se. I4, 1900.

$30^{16}$ Thin-leaf form. Verges toward $A$. divaricatus, the leaves not very rough when dry; but quite firm and of a dense texture.

N. Y. vic., Yonkers, Hillview rocks, Se. 15, '97; near woodborder, Se. '97 ; Park Hill, Se. 14, '96.

\section{$30^{17}$ Verticil form.}

Fig. 41, top of plant of Bryn Mawr Park, N. Y., Oc. 21, '98, in hb. Bu.

Strong much-branched rigid plants with many strongly divaricate verticils each with 3 (or sometimes only 2 ) leaves and branches. Rigid ; stem greenish, angulate ; leaves cordate-ovate, short, small, dark green, with broad base. Inflorescence profusely branched, greatly divaricated, many of the upper nodes giving off the characteristic verticillate or opposite leaves and branches. These cases are unlike the normal inflorescence of the Divaricati in retaining an early suppression of internodes, which in others becomes partially obscured by slight separation during development. Examples :

N. Y. vic., Pelham, Se. '99. Bryn Mawr Park, in loosened soil, Oc. 21 , ' 98 , some plants with as many as $\mathbf{1} 2$ 2-3-leaved verticils; their rays chiefly virescent.

- Extreme plants of this form are exceedingly distinct, so much so as to seem in habit to indicate distinct generic position. Yet I have not felt warranted in assigning even specific rank, for the following reasons: Ist, variants grew with it connecting with typical $A$. Claytoni; as also with $A$. divaricatus and its flabellate form. I would deem this but a slight argument against specific 
rank in Aster, if it stood alone; but it is here reinforced, 2d, by the failure to observe other similar specimens, though searched for in the original locality, I 899 to 1905 ; and $3 \mathrm{~d}$, by the nature. of the building-operations by its side, leading to the conclusion that it was a stimulated form, altered by a sudden loosening of its soil and by rich accession of material ; the spot being abandoned by builders, luxuriant growth set in.

The tendency to verticillate development seems a freak; no fungus or insect-swellings appear associated ; and the possible ex-

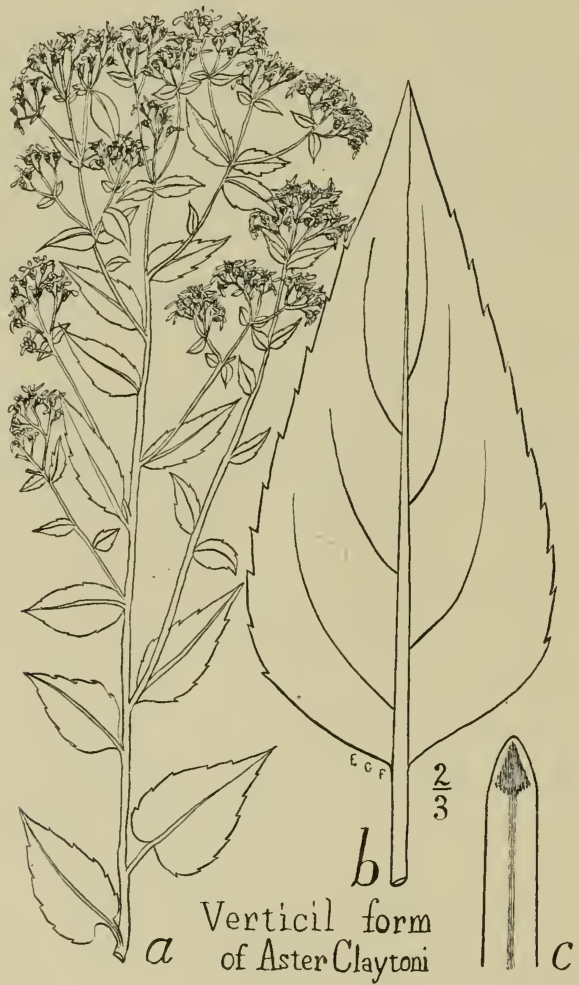

FIG. 4I.

planation of suppression of upper internodes because of a supposed drought seems unsatisfactory, because, Ist, other neighboring plants of $A$. divaricatus were not so affected, and $2 \mathrm{~d}$, because the presence of at least 3 successive verticils would on that hypothesis call for the improbable alternation of as many periods of drought and moisture.

The smoothness of the leaves points to $A$. divaricatus, but their shape and the form of the inflorescence-clusters indicate a nearer affinity to $A$. Claytoni. 
Intermediate forms or perhaps hybrids of $A$. Claytoni with other species include :

$30^{18} \mathrm{~A} . \mathrm{Cl} .>A$. divaricatus; inflorescence and leaf-form verging toward the latter, bracts nearly all broad like the former and sublingual. Palisades, Se. 14, '99, etc.

$30^{19} \mathrm{~A} . \mathrm{Cl} .>$ A. mpicola; some lower leaves like the latter in leaf-form and with broad shallow curving sinus; upper part of the plant resembling the former. Palisades, Se. I4, '99.

$3 \mathrm{O}^{20} \mathrm{~A}$. Cl. $>$ A. argillarius; little leaves resembling the latter; bracts as in the former. Palisades, Se. 14, '99, etc., numerous.

$30^{21} \mathrm{~A} . \mathrm{Cl} .>\mathrm{A}$. mollescens; with habit, yellow rootstock and narrowed inflorescence, of latter species; but sharp sinus, and non-succulent leaves of the former. Split Rocks, Se. 18, '97, Se. 27 , '97, Se. '98, '99, I 900 ; formerly abundant; July 3, I 900, showing I I leaves on stem 9 inches high; and primordial leaves, $\frac{3}{16}$ in. high, oval-orbicular; with later radicals oval, $\mathrm{I} \times 3 / 4 \mathrm{in}$.

$3 \mathrm{O}^{22} \mathrm{~A}$. Cl. $>\mathrm{A}$. ardens; profuse diffused habit ; large plants, about midway between the two types; Bryn Mawr Park, grassy ledge, Se. 25, '97; at another rock, Se. 16, '99; Split Rocks, Se. 25, '97.

$30^{23} \mathrm{~A} . \mathrm{Cl} .>A$. atrovirens; all peduncles abbreviated; but rough as any $A$. Claytoni. At Ft. Washington, Oc. 6, '98.

$3 \mathrm{O}^{24} \mathrm{~A}$. Cl. $>$ A. ebeneus; leaves like the latter, but with the narrow sinus of $A$. Claytoni; with both. Ft. Washington, Oc. 6, ' 98.

$30^{25} \mathrm{~A} . \mathrm{Cl} .>A$. divaricatus deltoideus; leaves dark green, with more truncate base than normal to $A$. Claytoni; occasionally $N$. Y. vic.

$30^{26}$ A. Claytoni $\times A$. lateriflorus; probable hybrid. Late plant of Nov. 4, '96, on Palisade rock-face, near the top; with long oblanceolate sharp dentate radicals resembling $A$. lateriflorus; and heads, bracts and branching somewhat of A. Claytomi rays yellowish, by virescence.

\section{Histoky of Aster Claytoni}

I 755. It was apparently in this year that the type specimen of A. Claytoni was forwarded as "no. 767 ," with description, by Clayton to Gronovius at Leyden, resulting in its inclusion, I 762, by the younger Gronovius in the $2 \mathrm{~d}$ edition of the Flora Virginica. Clayton seems to have failed, on account of his locality, near the sea, to discover this or any very near ally in time for publication in the Flora Virginica, Part I, I739, or in 
Part II, I 743, which contained respectively I 2 and 2 species described as Aster. After that publication the elder Gronovius is said by his son Theodor (Fl. Virg., ed. 2, preface) to have awaited arrival of "another not less abundant instalment .. . from Virginia" for "almost I6 years," when " at last there came a small bundle." Probably the type specimen $A$. Claytoni was in this bundle. It is fortunate that it was not in that large collection sent by Clayton soon after, which "perished," says Theodor Gronovius, "at the hand of truculent pirates, who would not spare even our studies." Apparently the I6 years before the arrival of the "small bundle," were counted by the son from his father's first publishing, in I 739, making the date of arrival 1755 . Within the next two years, or during $175 \%$, the elder Gronovius seems to have finished working up the species in this bundle, for the son, writing I Jan. 1762 , says in his preface to the $2 \mathrm{~d}$ edn. of Flora Virginica, that "now four years have passed" since his father prepared this "Part $3 \mathrm{~d}$."

Clayton, the correspondent not only of Gronovius but of Jinnaeus and Collinson, and rightly styled by the latter "the greatest botanist of America," was John Clayton, Jr.; born at Fulham, London, I686, who came with his father I 705 to Virginia, where the father became attorney-general and the son was for 5 I years clerk of Gloucester Co., dying I 773, aged about 87, just in time to be spared the grief of seeing his botanical MSS. and his herbarium destroyed in the burning of the New Kent County courthouse in the Revolution.

Clayton had sent to Gronovius a map of Virginia to show his botanical journeys; probably in 1755 , as it was published in the I 762 edition. Clayton stated in label-description, that he obtained this particular plant no. 767 , among the mountains ; which might have been, judging from his journey on the map, in the Blue Ridge region, among the tributaries of the James or the Rappahannock, both of which he followed into the mountains.

I 762. Original description, Gron. Fl. Virg. ed. 2, I 25. I 762.

ASTER foliis cordatis acutis serratis petiolatis, summis ovatis amplexicaulibus : caule subfruticoso. [Written by Jan Frederik Gronovius, apparently I756-7.]

Aster serotinus, floribus $[i$. e., of a single branch] in umbellula tenui laxa flavis [i.e., yellowish in general appearance ; on account of the more conspicuous disks] : semiflosculis in radio niveis acuminatis [probably young and acuminate because not yet fully 
expanded] : foliis inferioribus acute cordatis [in outline; corlatis here describing not simply the base but the general shape] serratis petiolatis alternis, supremis minoribus amplexicaulibus [so the truncate-based sessile axiles seem in growth, investing the stem somewhat conduplicately], caule ramoso subligneo fusco. Crescit saxosis lutosis et umbrosis, plagis occidentalibus montosis solummodo inveniendus. Initio Septembris floret. Clayt. n. 767." [Written by John Clayton, apparently in or before I755.]

This description may have been meant by Clayton to cover forms which would now be classed as $A$. divaricatus $\mathrm{L}$., in addition to A. Claytoni for which alone it is exact and accurate. But the type specimen points to the latter species.

For a long time this no. 767 remained unidentified by modern botanists. Perhaps some would have referred it to A. divaricatus L., but for the fact that Clayton's no. I 43 (which is Doellingeria infirma Greene) had been by Linnaeus (Sp. pl. ed. I. 873. 1753) confused with his own $A$. divaricatus and cited by him as its synonym.

Perhaps Clayton's description of the stem by the adjective subligneo may have helped to defer the identification. It seems to have led Gronovius into the mistake of calling the species suffruticose. But for what stems does Clayton use the term ligneus? We find him writing caule ligneo of Aster rigidus [i.e., single head plants of Ionactis linariifolius (L.) Greene] and of Artemisia campestris $\mathrm{L}$. These stems are slightly more woody than in A. Claytoni, and $A$. Claytoni is slightly more so than many other Asters. In short, Clayton did not apparently mean "suffruticose" but "containing obvious woody tissue," which is not inappropriate to this very brittled-stemmed Aster. In a similar way Clayton describes (ed. 2, p. I 26) Helenium autumnale as "frutescens annua."

Features in Clayton's description which are especially appropriate to the plant $A$. Claytoni include the following:

I. "Floribus in umbellula temui laxa." This is graphic for the characteristic habit of each branch of the plant, as distinguished from the more corymbose and more divaricate heads on any similar branch of $A$. divaricatus $\mathrm{L}$.; assuming as $\mathrm{I}$ do that Clayton's meaning was, "Heads borne in loose and somewhat umbelliform little clusters, on slender pedicels." - Some might object that Clayton may mean here by floribus "disk-flowers," in opposition to his following semiflosculis, "ray-flowers." But Clayton's descriptions of Asters use flore's to mean heads, as is proved by his descriptions no. 74I and no. 9, both with flore unico or "a single head." When he wanted to mention disk-flowers, 
he wrote "flosculi in mcdio" or " in disco."- Others may object that Clayton meant to say that all the heads on the plant constitute one little umbel. But to construe him in this way, applying the same method to his A. grandiflorus, would make him say of that species, "It bears a single handsome head," whereas it is evident that he meant by his flore specioso, "with handsome heads." So of our common thoroughwort, Clayton wrote "flore albo," and thus to put the singular for the plural was with him a frequent elegance.

2. Semiflosculis ... niveis describes well the snow-white rays of $A$. Clavtoni as distinguished from the dull white of $A$. ericoides or A. multiflorus for which Clayton uses simply albus.

3. Amplexicaulibus is used of the axiles, from their truncate and at first conduplicate bases which seem when young to be clasping.

4. Caule ramoso subligneo fusco; because the stem of $A$. Claytoni branches deeper down than most of its allies, is less often green, and is tougher, $i$. e., a little more woody.

5. Crescit saxosis lutosis ct umbrosis; for $A$. Claytoni seems to require three essentials in its habitat, rock, clay and (moderate) shade.

6. Initio Septembris floret. On the other hand, $A$. divaricatus flowers more in October than in September in the Potomac and Rappahannock latitudes.

I 77 I. Here occurred the first identification of Clayton's plant no. 767 ; and the only identification which I find in print prior to mine of I 898. - This occurs in Johann Reinhold Forster's Florae Americae Septentrionalis - or a catalogue of the plants of North America, printed in his translation of Bossu's Travels, London, I 77 I, where, p. 5I-53, he enumerates 2 I Asters, first of which he names $A$. divaricatus apparently intending the name as Linnaeus used it, and including both $A$. diraricatus $\mathrm{L}$. and Doellingeria infirma. Lastly he mentions $A$. macroplyyllus, adding as a reference "Gron. A. Virg., p. I 25? A. foliis cordatis, acutis serratis, petiolatis, summis ovatis, etc." ; i. e., suggesting that Clayton's no. 767 may be $A$. macrophyllus. This identification we could not admit for Clayton's description required snow-white rays. Forster was no doubt led to his reference of 767 to macrophyllus by the following considerations: ( I) No other Claytonian species could be referred to $A$. macrophyllus. But Clayton may never have seen A. macrophyllus at all; or if he secured it in his trips to the Blue Ridge, it may have been one of the plants in his last ill-fated col- 
lection destroyed at sea and so never published by Gronovius. $A$. divaricatus $\mathrm{L}$., is a reference Forster might have thought of for 767 , but that species was not yet disentangled from Doellingeria infirma, a non-cordate plant evidently remote from the cordate no. 767 sought.

I $83 \mathrm{I}+$. A specimen, apparently of $A$. Claytoni, collected near Pittsburg, Pa., by Voltz, I $83 \mathrm{I}$, and now in the hb. Br. Mu. (Nat. Hist.), was made the type by Shuttleworth of his new MS. species Biotia stricta; fide Mr. Edmund G. Baker, who remarks in litt. " it must approach this Clayton plant [no. 767] very closely," and who cites its similar inflorescence and its scabrid serrate leaves. Shuttleworth's name seems not to have been published, and had been long antedated by an Aster strictus of Pursh and by three or four others.

1897. My identification of my plants of $A$. Claytoni with Clayton's type specimen for his no. 767 rests upon comparisons kindly made for me by Mr. Edmund G. Baker, of the Natural History section of the British Museum, in I897, with Clayton's type specimen there preserved in the Gronovian herbarium. I sent to him five native forms which in one way or another suggested Clayton's description 767. Of these, two were forms of $A$. Schreberi and two of A. umbelliformis. The fifth was a plant of $A$. Claytoni growing on Dyckman Ave. Rock, Inwood, Manhattan I., and concerning it Mr. Baker wrote, Aug. I0, I 897, " no. 5 seems to match the Virginia Clayton plant much the best, and must be very close to it if not absolutely identical." Mr. Baker further remarked that the otherwise similar pappus in the Virginia plant was darker and now rustcolored (the normal effect of age, as he himself queried); and that " we had provisionally referred Clayton's no. 767 to Aster corymbosus Ait. in our herbarium." At the time when he wrote, I 897 , A. corymbosus Ait. was certainly the nearest published species to which to refer any plant of $A$. Claytoni.

\section{0b. Aster Claytoni crispicans Burgess}

Plants unlike $A$. Claytoni in having sharper-bevel bracts, more attenuate acumination, more petioled axiles, more rounded bases, more shallow sinuses, closer narrower kerf-edge teeth.

Name, L., crispicans = rising up and down like successive waves; in allu- 
sion to the frequent alternation of assurgent and deflected teeth along the margins; constituting a kerf-edge, or such as in setting the teeth of a saw will cut a wide " kerf."

Fig. 42 (= Plate 8), plant from Silver Cr., N. Y., Au. 27, '96, in hb. Bu. A. Claytoni crispicans Burgess in Br. and Br. Ill. Fl. $3: 358$. 1898, with fig. and original description :

"Basal leaves often not cordate, deeply incised; those of the stem long-acuminate or even caudate, sharply serrate with large acute close teeth, some of which are suberect; chief bracts of the involucre acute. - On rocky banks, solitary or in small clusters, Maine to N. Y. and N. J.'"

Radicals rare; those seen are variable, sometimes suboval and crenate-serrate, sometimes oblong, sharp serrate and without sinus.

Hair more developed than on most A. Claytoni, on bract edges and pedicels, and on leaves beneath.

Leaves quite uniform in size, often about $2 \mathrm{I} / 2 \times \mathrm{I} / 4 \mathrm{in}$; or all narrower, as $3 \mathrm{I} / 2 \times \mathrm{I} / \mathrm{t}$ in.

Rays short, oblong, clear white, remaining for some time acute at the strongly flattening apex.

Bracts bevelled, few lingual, some of them tapering and acutish.

Resembles typical $A$. Claytoni in leaf-texture, smoothish, fresh, highly roughened when dry, with cord-like veins obscure above; and in lower leaf-bases, with strong sinus. Upper ones or axiles less truncate, more petioled; truncate axiles are finally reached high up the inflorescence. Unlike $A$. Claytoni, the shallow sinus form of leaf-base is here predominant, or at least throughout the middle stem. Like $A$. Claytoni in the fragrance of its glowing golden-yellow just-opened disk-flowers; which quickly become light sienna-brown.

- Grows in close masses occasionaily, along roads, in sun, or in thin woods; but is most characteristically developed when in little solitary clusters, projecting from rocky slopes or even from nearly vertical cliffs. Seems to take the place of $A$. Claytoni more and more toward the north, as about L. Erie. Collected in flower, Au. Io to Se. IO, W. N. Y. to N. Y. City; in prime the last ten days of August. All the W. N. Y. plants grew on shale, those from near N. Y. City on gneiss, schist or basalt. Examples :

Me., York Harbor, " dry bank by roadside and wall ; rough puberulent stem, leaves and panicle" while fresh, Au. 20, '96, Bi.

Ms., Taconics, Guilder Hollow, Au. 22, 1903.

N. Y. vic., Washington Heights, Bryn Mawr Park and Palisades, Bu., also Woodlawn woods, Au. 7, '98, West Woodlawn, Se. 5, '98, and Jerome Av. near Gunhill road, Se. 10, '98; $B i$.

W. N. Y. Silver Cr., gorge at Crenated Falls, Au. I 7, '96; Hanover, Rose- 


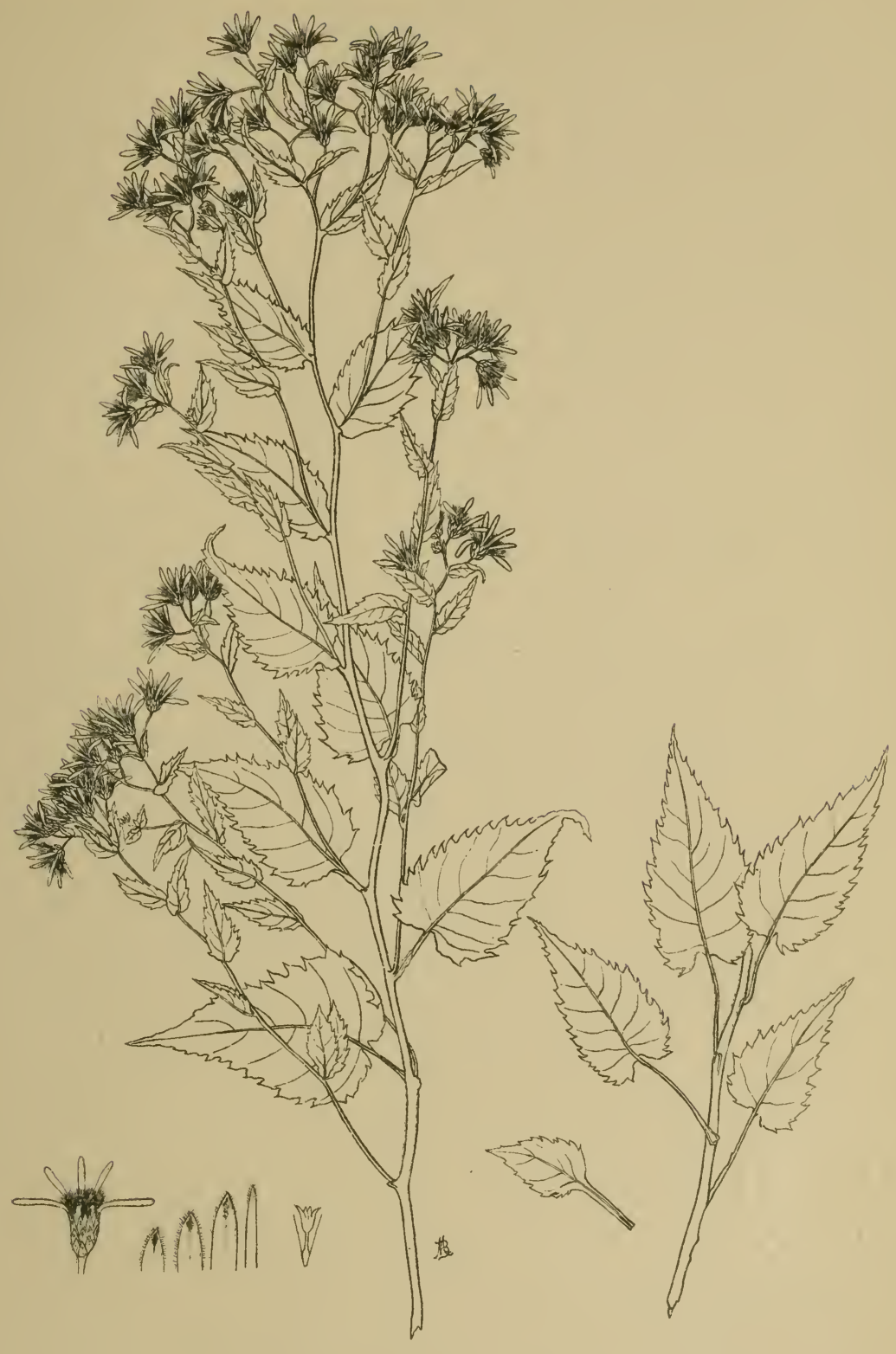



brook wood, Au. 3, '97, already budded; Cattaraugus reservation, Little Indian Cr., Au. 20, '96; Au. I3, '98, budded; Big Indian Cr., Au. 3, '97, budded; Indian-line road, Au. 28, '98; Campanula Valley, Au. 19, '96 ; Fillmore's orchard, Au. I 9, '96 ; Burning Spr., Au. 13, '96. Perrysburg, Dawley woods, Au. 19, '96. Sheridan, Herrick's woods, Au. 12, '96, Dunkirk, Pt. Gratiot, Au. 29, '96. Fredonia, Marsh's woods, Se. I, '96; Dunn's Mill, on shale cliff, Au. 22, '96.

$30 b^{2}$ Rose-ray form; numerous plants with their rays roseate; Fredonia, N. Y., several places, '96.

$30 b^{3} A$. Cl. crispicans $\times A$. glomeratus. Probable hybrid, in general like the former parent, but with heavier leaf-texture, rougher and with more hair, shorter leaves and shorter pedicels; dense glomerate clusters; as if derived from A. glomeratus.

W. N. Y., Pomfret, Canadaway ravine at Darby switch, Au. Io, '96.

Subdivision $B$. BRACTS LINGUAL OR WITH BEVEL-TOP (except no. 34$)$.

Leaves thicker, rougher or subsucculent. Veins cord-like. Involucre very small and narrow. Plants loosely cespitose. Sp. $31-34$.

\section{I. Aster ebeneus sp. nov.}

Stout dark-green plants with ebony-red stem, with thick oblongovate leaves, short-petioled bases, sharply crenate-serrate margin, and harsh rough crumbling texture (when dry); with deep profuse subpanicled inflorescence of small heads.

Name, L., from the color of stem.

FIG. 43, plant from Ft. Washington, N. Y. City, Oc. 8, '98, in hb. Bu.; $b$, characteristic leaf-form; $d, e$, occasional additional forms.

Stem of a red so dark as to seern almost black; or greenish brown at the base; stout, brittle, about $2 \mathrm{ft}$. high, or sometimes $3 \mathrm{ft}$., and even then nearly wholly inflorescence; continuously slight-sinuous, but erect, with no obvious hair.

Leaves thick, soft and with some appressed hair when fresh, rough when dry, becoming excessively harsh, and of a brittle crumbling texture, hispid with scattered appressed bristles above, and hispidulous beneath; the cord-like veins bearing weaker but more numerous hairs. Sometimes the leaves are almost velvety in growth and hardly rough when dry.

Leaf-form ovate-obtuse to oblong-acute, sometimes more acuminate and becoming oblong-lanceolate, with brace-base and short slender petioles, quite uniform, persisting with little change of size and shape into the lower axils, then becoming broad-ovate and finally triangular-elongate, with broad truncate base. Lower leaves with deep narrow sinus; and in some cases this persists far up the stem; in others it is soon replaced by a broad shallow 
sinus of very gentle curves. Petiole usually less than half the leaf-breadth.

Leaves very dark green, with still darker veins, finely areolate under a lens with blackish veinlets, the under surface paler and apple-green.

Rameals oblong, triangular, serrulate, sessile.

Radicals suborbicular, crenate, with brace-base.

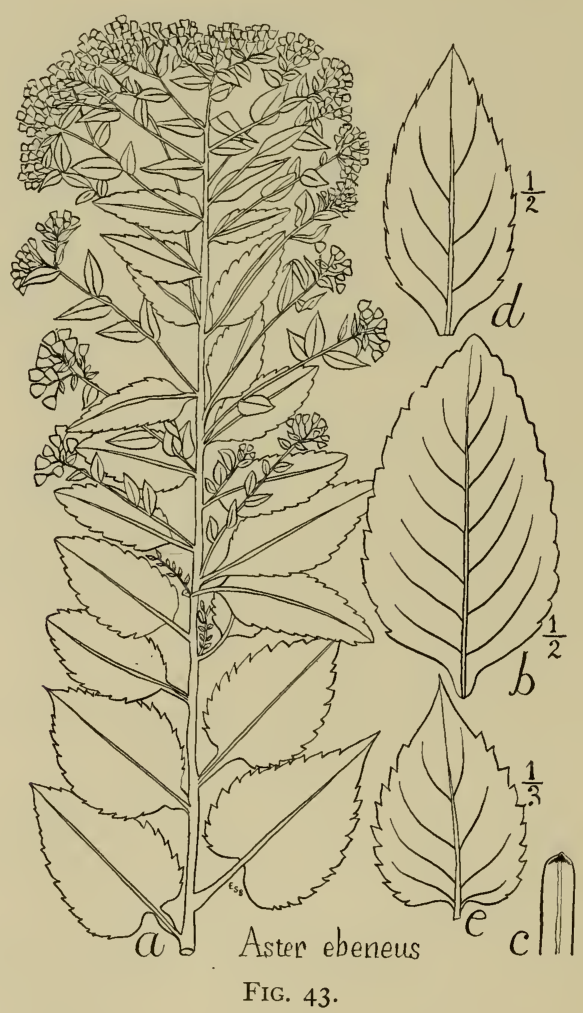

Inflorescence profuse and very floriferous, its numerous closely ascending branches rising at a high angle from near the base, or in smaller plants from near the middle of the stem. Large inflorescences are sometimes $2 \mathrm{ft}$. high and I ft. broad; more usual ones, I ft. by 7 in.

Heads small, about $2 / 3$ in. broad, about $1 / 4$ in. high, loosely borne on rather long filiform divergent corymbose pedicels, the branches leaving the stem like those of $A$. Claytoni, but closer and more numerous, more repeatedly divided above, and not umbelliferous in aspect but corymbose-paniculate. Rays white, 
about 8 , oblong. Disks turning brown with little red, the short disk-flowers borne on very long slender stalks. Achenes smooth at maturity.

Bracts oblong, straight-sided, broad to the bevelled apex, pale with slight or short and broad dark tips. Inner bracts a little tapered, acutish.

Habitat, on rocks and ledges and especially on sloping banks immediately beneath large rocks, especially on Manhattan Island, also on the Potomac in Virginia; late Sept. and first week of Oct.

Examples :

N. Y. vic., Ft. Washington, r65th St., rock, Se. 30, ' 98 , numerous; foot of I 7oth St., Oc. 8, '98, abundant; also Se. '05. Yonkers, Park Hill, rocks, Oc. Io, '98.

N. J., Palisades, Woodcliff, Se. I2, '98, in bud. Undercliff, top and also on the rockface, 8-rayed, Se. 14 , '99, abundant; also Oc. 23 , '97, when some were $3 \mathrm{ft}$. tall. divaricatus.

Va., Potomac R. bank, Spout Run, Oc. 2, '88, then deemed a hybrid of $A$.

\section{Aster mollescens sp. nov.}

Small yellowish-green erect plants growing in lines from fissures in gneissoid rocks, with thickish ovate subsucculent leaves, very shallow sinus, very slight serration, pale yellow and brownish disks, pale narrow-lingual uniform bracts, and small crowded heads from many axils.

Name, L., from the flaccid subsucculent leaves.

FIG. 44, top of plant of Split Rocks, N. Y., Se. 25, '97, in hb. Bu., 2/3 natl. size; $b$, characteristic leaf-form; $d$, axile form.

Stem stiff and erect, short, often I I/2 ft., not straight but irregularly slight-sinuous, terete, green, or brownish in the sun, with no obvious hair.

Leaves thickish, smooth when fresh and subsucculent, flaccid and often drooping, slightly rough when dry, nearly uniform. A subtruncate base and very broad and shallow sinus continues well up the stem.

Leaf-form ovate-acute; all small, $3 \times \mathrm{I}_{3} 3 / 4$ in. or less; teeth low and remotish, very little developed, but of serrate type; veins cord-like, very slender. Petioles short, slender, tough.

Plants predominantly pale, as to stem, leaves, bracts and disks ; the leaves yellowish-green; disks at first whitish, soon pale yellow, then pale brown. Leaves becoming pale brown in autumn. Yellow color prevails in the young surculi; old rootstocks become pale brown.

Axiles elongated oblong, somewhat tapered at base and apex, $2 \mathrm{I} / 2 \times \mathrm{I}$ in. or less, with short slender petiole or cuneate-wing. 
Axillary inflorescences dense, irregularly convex, continuing throughout or half down; in shorter little-developed plants, merely terminally clustered; and borne on short stiff peduncles which do not much exceed the subtending leaves; pedicels of quite irregular lengths, chiefly $\frac{3}{16}$ in. or less, with sessile buds intermixed. Branches given off at a high angle.

Heads small, about $3 / 4$ in. broad, $1 / 4$ in. high. Rays chiefly 6 , sometimes 8 , oblong, the breadth $1 / 4$ the length.

Bracts quite uniform, narrow-lingual; an acutish lowermost bract or an attenuate innermost bract being seldom developed; their ciliation moderate; color confined to the narrow green midrib which expands but slightly at the tip.

- Growing in long lines out of narrow fissures in gneiss, in part shade, and spreading to neighboring rock-ledges and to meadow-borders, near N. Y. City, last half of September.

\section{Examples :}

N. Y. vic., Inwood, Se. 27, '97 ; Se. 22, '98, Se., I903, Se. '04, '05. Indianfield, Se. 16, '98. Central Park, Ramble, Se. 27, '98. Yonkers, Park Hill, Oc. Iо, '98. Bryn Mawr Park, esp., Split Rocks, Se. 25, '97, Se. 17, '98, Oc. 21, '98 (late survivors with rays turning crimson but disks still inconspicuous), Se. 16, '99, Se. 28 , I900; no survivors could be found, I90I-I 905 .

Variants include :

$32^{2}$ Syncopate form; pedicels almost suppressed and heads very densely crowded. With type, Split Rocks, Se. I7, '98, Se. I6, '99, Se. 28, I 900 ; locality replaced by a garden, I90 I.

$32^{3}$ Reniform form, derived from $32^{2}$ evidently, and growing with it, but extremely dissimilar, many or most of the upper leaves being broadly reniform, $\mathrm{I} I / 2$ in. broad, $3 / 4$ in. long or less, with broad shallow sinus, and with convex front, with or without a minutely apiculate midrib.-Split Rocks, Se. I7, '98, Oc. 2 I, '98, etc.

Affinity. The descent or relationship of variant forms in $A$. mollescens seems very plainly traceable in the Split Rocks plants, or was for 4 years until building interfered. The typical form is there the most abundant form, and originally formed several narrow lines of plants in fissures at top of a partially shaded cliff; with many other allied Asters near, but less numerous. Surrounding these rocks, $A$. mollescens was still the prevailing species in ' 97 and '98, but its characters becoming less distinct with distance and presently verging toward $A$. Claytoni into which remote individuals seemed finally to pass. Some of the rows in the typical locality had become modified into what I have called the Sy'ncopate form 
by syncopation of pedicels; this was not a dry-weather shortening of some single season, but was shown by the plants from the same rootstocks successively in ' 98 , '99, and 1900 . Some of the Syncopate form had become still further modified into the Reniform form, the tendency to shortening now affecting the leaves as well as again increasing in the inflorescence, and producing as

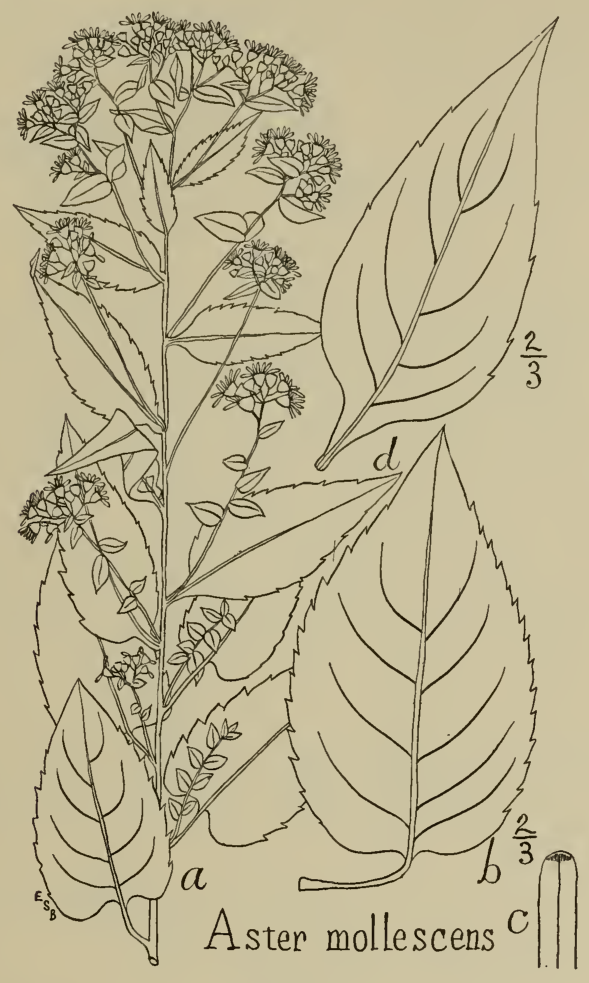

FIG. 44.

distinctly reniform leaves as are to be found in any North American aster.

The balance of characters, and its limited occurrence so far as yet observed, suggest that $A$. mollescens is a specialized branch derived from the prolific stem of $A$. Claytoni in not a very remote past. Weakening of vitality seems to have attended (or caused ?) its own derivatives, the Syncopate and Reniform variants, and I should have expected them to die out, irrespective of building operations which have hurried them toward extinction in their original locality. 
Distinctions between $A$. mollescens and its ally $A$. Claytoni are as follows: Sinus in $A$. mollescens broad, shallow and slight; not narrow, deep and strong as in $A$. Claytoni, which may have shallow and slight sinuses among the higher leaves only. Bracts in $A$. mollescens narrow-lingual, uniform, but little tapered; but in $A$. Claytoni diverse, chanfer- or taper-obtuse, the inner very much narrowed. Axiles, again, are chiefly petioled, elongated-oblong, with non-truncate rounded or taper base; not, as in A. Claytoni, sessile, elongated-triangular, with broad truncate base. Differs also from $A$. Claytoni in its paler leaves and disks, more limp succulent texture, slighter teeth.

\section{Aster ardens sp. nov.}

Stout floriferous paniculately decompound plants with smooth shining red stem, sharp-clentate oft subsucculent leaves, triangularovate-acuminate leaf-form, multiform sinus, broad lingual uniform scale-like rounded bracts, diffuse prolonged pedicels, and warm luminous crimson or reddish-brown disks.

Name, L., ardens, glowing, from the transient glow of the disks.

FIG. 45, plant from Bryn Mawr Park, N. Y. vic., Se. 25, '97, in hb. Bu.; $b$, characteristic leaf-form; $d$, frequent upper leaf or lower axile; $e$, frequent upper axile.

Stem rigid, brittle, usually $2 \mathrm{ft}$, , sometimes over $3 \mathrm{ft}$., moderately percurrent throughout the much-branched inflorescence; terete, smooth and bright red, dull and somewhat angulate when dry ; about I4-striate.

Leaves full-green, chiefly yellow in autumn, of a dense firm texture, smooth and often subsucculent while growing, roughish both above and beneath when dry.

Leaf-form (seen in most caulines and lower axiles) triangularovate-acuminate with base suddenly rounding into a short wingpetiole.

Lowest caulines (and in some plants, all leaves) broad and short, rounded-ovate, acute, with deep narrow sinus; rather small, $3 \times 2 \mathrm{I} / 4$ in. or less.

Succeeding lower caulines larger, $4 \frac{1}{2} \times 3$ in. or less, slenderpetioled, scutiform with broad brace-base, and strongly cornaceous veins, which extend far forward in parallel sweeping curves; the leaf-outline triangular-oblong with strong incurved acumination. In some plants these leaves predominate over the preceding form, and over the next. 
Predominant caulines however in strong vigorous plants are triangular-ovate-acuminate with winged base, already mentioned as typical ; $4 \times 2 \mathrm{y} / 4$ or less.

Axiles oblong-lanceolate, incurved into a sessile or a shortwing base, often developing a peculiar subcircular dilated wing, separated from leaf and stem by an abrupt contraction. Axiles remain large, $3 \mathrm{I} / 2 \times 2$ in. or less.

Rameals similar, smaller from the first, $13 / 4 \times 3 / 4$ in., persistently the same in size, sometimes 8 or 9 such on each of a dozen

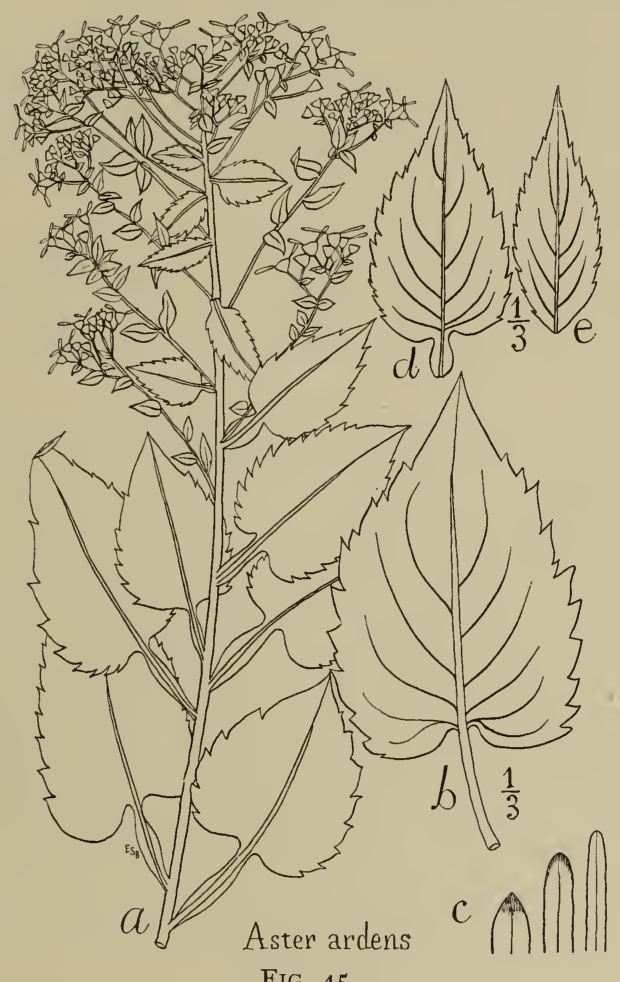

FIG. 45 .

long ascending branches, the upper ones sessile by a broad base.

Ramulars at once smaller, triangular-elongate with a broad sessile base, resembling the upper axiles of $A$. Claytoni; or many of them ovate; a half-inch long or less, and subentire.

Teeth sharp, dentate or repand on lowest leaves, the points becoming more and more forward-directed and acuminated as the leaves ascend, the principal axiles and rameals being slit-serrate. Little curvature appears, but a few curvescent teeth occur on middle caulines. 
Petioles usually shorter than half the leaf-breadth. Veins slender, cord-like beneath, impressed above or slightly elevated when dry. Obvious hair absent, and but little to be found by lens except on pedicels.

Branches numerous, long, rigid, ascending in straight or irregularly slight sinuous lines, each branch very loosely corymbose or in larger plants pinnately branched with corymbs on the branchlets only.

Inflorescence in well-developed plants paniculately decompound, very profuse, strongly pinnate in effect on pressing; the panicle often somewhat urceolate by outcurve at the base of uprising branches. Still stronger plants rise higher, the inflorescence forming $2 / 3$ of the plant or more; and assuming an elliptic or oblong form, more than $2 \times \mathrm{I} \mathrm{ft}$. long; of its dozen branches several becoming as much as 20 in. long.

Pedicels (ultimate branchlets) filiform, stiff, I in. or $1 / 2$ in. long, either with subtending linear or discule bractlets, and divaricate widely or slightly according to number, their bases usually corymbosely separated, not umbelliform or subradiate as often in A. Claytoni.

Heads very small, about $5 / 8$ in. broad, $1 / 4$ in. high, the involucre when dry being $1 / 8$; or in less floriferous plants all heads may be larger, $3 / 8$ in. high, $3 / 4$ in. broad, etc.

Involucre narrowly urceolate, contracted above during early flower, appearing as if pinched together just before the expanding summit, as also to some degree in $A$. Claytoni.

Bracts in general character lingual, very broad, rounded and scale-like, very uniform, with little herbaceous or green growth, reddened, especially at the edges, or straw-color throughout, with but slight ciliation, otherwise smooth; the pale green midrib abruptly terminated by a broad shallow inconspicuous crescentic green tip, absent from the inner half of the series; or the green tip subdeltoid and with no green color decurrent into the midrib. A few lowest bracts are sometimes slightly acutish; a few inmost are slightly tapered to an obtuse apex.

Rays dull white, sometimes reddened, persistently 8, oblong, tapered somewhat to both ends, obscurely tridentate at the apex; Some vigorous plants produce Io rays; more often some rays are missing.

Heads very subject to malformation, many of them blasted in small plants, or with only a few rays and half the disk developed. Disks rather full, glowing, 20 -flowered, the lobes very acute. Achenes often copiously hairy when young, seldom so at maturity; Pappus soon slightly reddened in the herbarium, decidedly so within 3 years. 
- Rich rocky woods, filling cleared or half-open spaces, forming dense tangles; reaching greatest development when growing more separately out of deep rich rock crevices; near N. Y. City, on gneissic rocks, at its prime Se. I5, two weeks earlier than most $A$. divaricatus plants close by; and often forming circles around rocks and stumps. Examples:

N. Y. vic., Inzwood, Se. 27, '97; Yonkers, Bryn Mawr Park, summit rocks and Split rocks, Se. 26, '96, Se. 25, '97, Se. 14 and 17 , '98, Se. 16, '99, Se. 15, 1900. Se. I4, I903, Se. '04,'05; with late plants Oc. 26 , '98, Nov. 3 , '96, etc. ; development, $\mathbf{I} 6$ in. high on July $\mathbf{I} 3$, with $\mathbf{I} 2$ leaves, besides half as many already gone. Also, "Bryn Mawr Park, woods, high rocky spot, Se. 4, '98," Bi., as "A. Claytoni var.?"; fence, Se. 12, '98, Bi. ; Glen Park, woods, Se. 20, '98, Bi. ; Cheilanthes rock, Oc. I6, '98, Bi. Hillview swamp, Se. 15, '97, in drier rocky spots and thicket-covered clay banks along ditches; so Se. 13, '98, Se. '99, Se. 22, 1900; then destroyed by clearing.

Allies. From $A$. divaricatus, $A$. ardens is in part distinguished by its pinnated floriferous inflorescence, its leaves, which if similarly strong in sinus are short, if similarly long are scutiform and brace-based, if winged are apt to have the wing semi-circular and margins slit-serrate. Its broad rounded bracts, red stem, and little pinched-urn heads, are other differences.

From $A$. listriformis, with which it grows, $A$. ardens is distinguished by absence of listriform leaves, by stronger coarser texture and habit, brighter red stem, less red in rays and disks, etc.

Compared with $A$. Claytoni; both have warm glowing golden disks, but in $A$. Claytoni they develop little red, and turn siennabrown ; in $A$. ardens the sienna is soon developed into red or crimson. Both show red on the stem, strengthened sometimes into ebony ; in $A$. Claytoni dull, in $A$. ardens very bright during growth, and of a more purplish cast ; in the similarly dark $A$. ebeneus there is less red, more brown or black. All three species have a pinnated inflorescence branching deeply down the stem, each branch somewhat radiately and briefly divided at its summit in A. Claytoni, corymbosely and very loosely compound in $A$. ardens, very densely in $A$. ebeneus. All may be smoothish to touch during growth; A. ebeneus is much rougher when dry than $A$. Claytoni and that more than $A$. ardens.

Another congener, $A$. stilettiformis, is suggested by the slitserrate upper axiles of $A$. ardens and by its broad bracts. The two grow together, and perhaps pass into each other - as what 
Asters do not? - but the similar axiles are broader and more curving in $A$. ardens, and less often truncate-based. Their cauline leaves are quite unlike in detail.

From $A$. scutiformis, which $A$. ardens resembles in sometimes developing scutiform leaves, it is distinguished by their usually fewer number with very different habit and inflorescence surmounting, with broader more obtuse bracts, etc.

From $A$. castaneus, $A$. ardens differs in its broader bracts, thicker less persistently ovate leaves, different inflorescence, etc.

$A$. ardens seems as yet in a state of original polymorphism as to leaf-bases, developing often on a single stem all of the types which have separately become more fixed and continuous in its various congeners. It develops vast numbers of intermediate plants in lines of variation tending toward each of the foregoing species. Unfortunately the three best localities for it, Hillview Swamp, Bryn Mawr Summit Rocks and Split Rocks, have all been invaded by the progress of suburban improvement, cutting short my notes on its development, though not till eight years' observations had been rescued from oblivion.

Variants include : $33^{2}$ Sprout-forms show narrower taper-based elliptic leaves, low-serrate and often asymmetrical, similar crenated ones being developed also as radicals; collected as late as Nov. 3.

$33^{3}$ Broad-bush form, an altered condition where the plant is assuming the attitude of a weed in cultivated ground, and around house walls, especially under the eaves. Leaves chiefly of the oblong-acuminate wing-based type; few cordate leaves produced; brancling beginning near the ground, profusely ramified and producing a hemispherical or almost spherical plant of about $2 \mathrm{ft}$. diameter, with many small imperfect heads and still more numerous blasted ones. Leaves flaccid when fresh, quite rough when dry, surprisingly altered then from their sleek growing condition. Abundant near Split Rocks, N. Y., Oc. I, '98, '99, I 900 ; a few survivors remaining Se. 1903 and $1904-5$, though nearly run out by stronger weeds.

$33^{4}$ Small-tangle forms; filling woodland clearings on rocky hills ; inflorescence small, sharp-based, forming a somewhat convex cyme, usually very irregular and patchy; but glowing beautifully in the sun when the golden disks are first opened. Branches given off at a very high angle; when much entangled among bushes they become prolonged and bracteose. Usually with all leaves small, short-acute, with uniform aquiline teeth; rays 6 , rarely 8 ; heads but $2 / 3$ in. broad; disks turning chiefly to a pale brown; many narrower bracts produced. With the type, Bryn Mawr Park and Hillview swamp. 
$33^{5}$ Refracted form, with copious inflorescence subdichotomously divaricate and refracted; highly disculiferous, $i$. $e_{\text {., with }}$ most of the ramulars reduced to minute subsessile discs $\frac{1}{16} \mathrm{in}$. broad. With the type, Inwood and Bryn Mawr Park.

$36^{6} A$. ardens $\times A$. axillaris; a probable hybrid with succulent leaves, most of them still smooth when dry; deliciously fragrant; its short axillary inflorescences from the latter parent? its short broad leaves and very deep golden prominent disks from the former parent?

Bryn Mawr Park, down Maple Av., Se. I6, '99.

$33^{7} A$. ardens $\times A$. roscidus; a probable hybrid with heads, rays and involucre resembling the former; in most other characters resembling the latter, including the following: Leaves small, broad cordate, with the narrow or winged petioles thick, spongy when dry, crenate-serrate, the upper ones and rameals oval to orbicular. Branching resembles chiefly the former parent. Hair scanty, occasional strigose hairs blackening and thickening at the tip, as if inheriting from the glandular hairs of $A$. roscidus which grew near. Rays 6, in larger flowers 7 , milk white; heads larger than in $A$. ardens, $7 / 8$ in. across when fresh. Two plants, Bryn Mawr Park, Se. I6, '99.

\section{Aster scutiformis sp. nov.}

Cespitose slender plants along old stone walls or rock-slopes, with reddish-brown stems, serrate often decurrent-based leaves pale beneath, strong cornaceous cord-like veins, single-bunch or pinnately-segregated inflorescence, chanfer and attenuate bracts, and scutiform lower leaves with broad tricurve base.

Name L., scutiformis, shield-shaped.

FIG. 46, plant from Mianus R., Ct., Oc. 15, '96, in hb. $B u$.

Stem reddish-brown, smooth, nearly erect, only moderately straight, terete, chiefly I I/2 ft. high, cespitose, sometimes filling extensive spaces.

Leaves soft and smooth in earlier growth; becoming harsh and when dry minutely roughened, spongy-thickened and very firm; deep green above, beneath a little whitened; its pale cast suggesting a fine tomentum but proving by lens to be nearly without hair and due to reflection from the minute areolae. Lower leaves scutiform, $i$. $e$, escutcheon-shaped, somewhat cordate-acuminate, with very shallow and broad tricurve sinus; the sides too much curved to be oblong; the greatest breadth a little above the base. Upper leaves oblong-lanceolate, short-petioled 
or wing-based. Teeth strong and sharp, aquiline or at least curving -backed; but with straighter-backed teeth intermingled.

Inflorescence usually small, dense or tangled, irregularly convex, with wide-spread repeatedly-divaricate short branches, the ultimate pedicels short, $1 / 4$ in. long or so. In occasional larger plants the inflorescence becomes pinnately segregated; in other colonies, hundreds of plants will show but scanty rudiments of heads.

Heads always rather small, $3 / 4$ in. broad, and with about 7

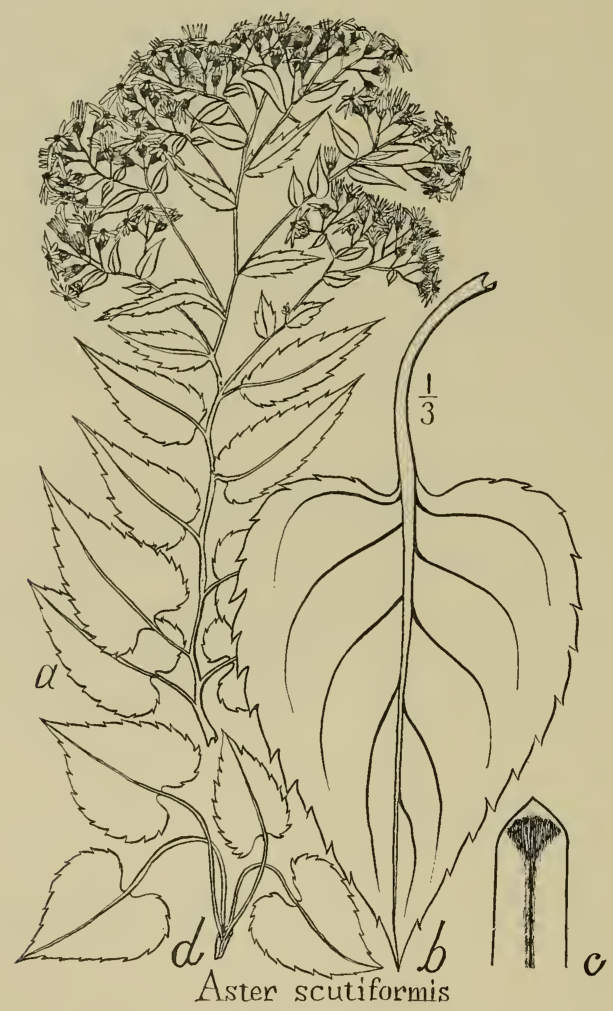

FIG. 46.

dull-white rays. Disks turning reddish-brown. Achenes fusiform, often retaining some minute bristles.

Bracts rather pale, narrow-oblong, chanfer-obtuse or even truncate; rather suddenly changing to very attenuate and numerous inner bracts which form about one half of the whole series.

Leaves in autumn (middle of October, N. Y. City) uniformly suffused with soft reddish-brown, or at first pink-veined or soon purpled all over. 
Cespitose, in half-shade or slight-shade, on ravine banks or rock-slopes or along stone walls; sometimes with stems close and half-supporting each other. Near N. Y. City; first half of Sept. Examples: Oc. $15, ' 96$.

Ct., Mianus R., near Riverside Sta., along a stone wall in slight shade,

N. Y. vic., Inwood, in quantity, Se. 23, '03; '05; Yonkers, Belmont ridge, Se. 15, '97 ; Hillview ditch, Se. 15, '97 ; Bryn Mawr Park, Se. 26, '96; Split Rocks, brook bank, Se., ' 98 ; McLean's Pond, stone wall in slight shade, Oc. 22, 1900; a few still flowering there, Nov. 3, Ig00; Gunther Park, Se. 14, 1905; Hastings, Oc. 17,1905 .

N. Y., Shokan, Ulster Co., Se., '98, C. H. Peck in hb. N. Y. St.

N. J., Palisades, Pleasant Valley Brook, top of cliff, Se. 14 , '99.

Allics. Species with which $A$. scutiformis is most likely to be confounded are $A$. virgularis and $A$. castaneus, possessing as it does lower leaves somewhat like those of the former and upper leaves like the latter. From A. castaneus it is distinguishable by its thicker, larger leaves, different denser more-tangled inflorescence, etc., as well as the entire series of lower leaves. From $A$. virgularis it differs also in its spongy-thickened leaves with the lower surface more whitened and with more cord-like veins. Comparing typical plants of $A$. scutiformis and of $A$. virgularis, $A$. scutiformis has an inflorescence which is more a dense bunch, with short pedicels, not a loose tassel with long pedicels; has tricurve bases, not bicurve; has more reduced and curving teeth, not so sharp and slit-serrate; has more sessile upper caulines; and has more difference toward the tips of the veins between the veins and veinlets.

A. micola when its leaves approach this species has sharper and closer outflung teeth; it is also a smaller plant and more delicate.

\section{Variants.}

$34^{2}$ Sessilifolial form; intensifies the typical characters of thick leaves, dense texture, whitened under surfaces, projecting narrow cord-like veins. Scutiform leaves less fully developed. Upper leaves and axiles sessile by narrow or semi-truncate base.

With the type, near Yonkers, at Hillview, Se. 15, '97; Seminary Corner, Se. I4, I905; and especially studied at Split Rocks, Se. 18, '97, Oc. 20, '98, Se. 16, '99, Se. 15,1903 , Se. 16,1905 .

Subdivision C. Bracts broad. Leaves of Dense firm texture. Plants in stools.

Species 35-37. 


\section{Aster arcuatus sp. nov.}

Small rock-loving deep-green tufted plants with short broad leaves, moderate serration, broad deep subtruncate sinus, small heads, broad rounded and truncate bracts, about 8 rays, and brittle half-reddened arcuate stems.

\section{Name, L., arched over.}

FIG. 47, plant from Palisades, N. Y., Se. 14, '99, in hb. Bu., the arcuate stem but little more closely bent than in nature.

Stems several or many in a cluster, about $2 \mathrm{ft}$. in length, variously arching by sweeping curves, or geniculate at the base

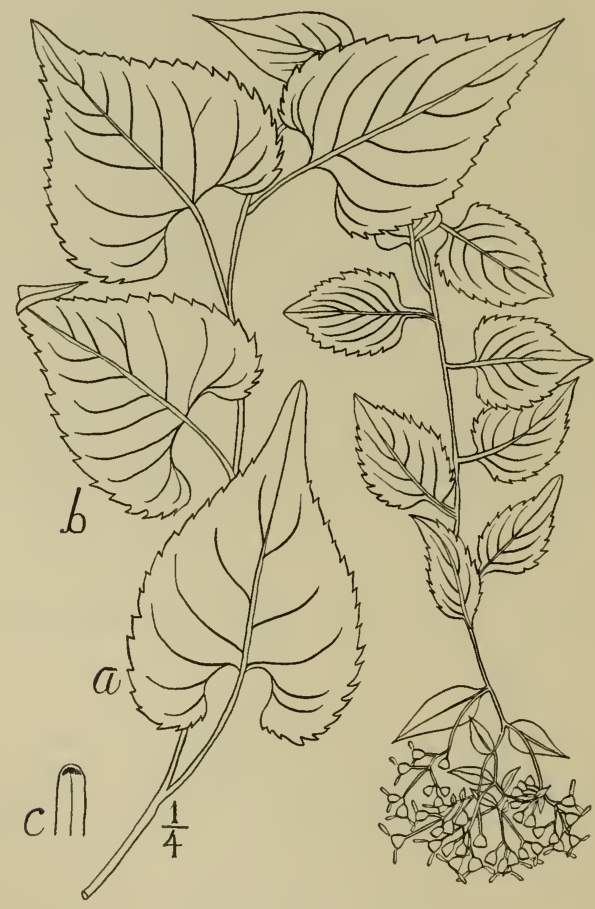

Aster ancuatus

FIG. 47.

and then ascending, or continuously flexed and finally drooping from the face of rocks. Stems partly reddened, generally greenish toward the summit; without obvious hair, slender, brittle, terete, rather leafy. 
Leaves deep-green, thickish, roughened when dry; veins inconspicuous; teeth of serrate type, of moderate size, extending well around the basal lobes, reduced to slight serrulations on a few lowest leaves and on numerous small upper caulines.

Leaf-form orbicular-acuminate or broadly ovate-acuminate; with deep broad sinus often truncate-based within; always strongly incurved before the short sharp acumination. Such leaves are the lower caulines, about 3 or 4 to a stem, larger than the others and giving the leaf-series its characteristic appearance; about $2 \times 1 \frac{3}{4}$ in. upon sun-reached plants, $4 \times 2 \frac{1}{2}$ in. heavily-shaded plants, then thinner and usually not rough till dry.

Lowest caulines longer in proportion and less remarkably broad, more like those of $A$. divaricatus $\mathrm{L}$., smaller, $\mathrm{I} \frac{3}{4} \times \mathrm{I}$ in. in sun, $4 \times 2$ in. in shade, subentire, with sinus not so large.

Middle caulines broadly ovate-acuminate, little reduced from the characteristic lower caulines in size but much reduced in sinus, which has now become shallow and broad and then slight and sharp; 3 or 4 such leaves are usual.

Upper caulines numerous, quickly or abruptly much reduced, ovate-acuminate with truncate or chiefly with rounded base, $\mathrm{I} \times \frac{1}{2}$ in. or less, finally tapered into a short-wing base.

Axiles sessile, similar to the preceding in shape and size.

Bracteals few and inconspicuous, ovate, oval, subcircular or reduced to discules.

Petioles slender, very various in length, in the lowest leaves longer than the leaf-breadth, in the next lower leaves longer than half the leaf-breadth, in the remaining, shorter, disappearing halfway up the upper caulines, where short wing-petioles continue for 3 or 4 more little leaves.

Inflorescence small, rather compact and tangled, irregularly convex, with widely divergent slender pedicels about $\frac{2}{3}$ in. long.

Heads very small, $\frac{5}{8}$ in. broad, $\frac{5}{16}$ in. high, chiefly with 6 rays. Remoter heads become $\frac{7}{8}$ in. broad, $\frac{3}{8}$ in high, with 8 rays. Rays small, straight-sided, and oblong with slightly tapered apex, deep opaque white, soon becoming dull white, finally often virescent.

Disks reddening, and finally maroon; or with little red in the shade, where many change directly to brown, which in some is a pale raw umber, in others of the same clump, a deep maroon umber.

Bracts broad, rounded or truncate at the darker apex but green almost all over, thinnish, moderately ciliate. Inner bracts narrower, somewhat tapered but still obtuse, without green tips.

- Remarkable for its very broad lower leaves, and their broad deep sinus; for its numerous much-reduced upper leaves, and for 
its arcuate stems. On the flat summits of granitic and basaltic rocks, or more commonly springing from cracks and ledges in the face of such rocks; in which case a few stems are assurgent, but most spread downward and radially outward from the face of the rock. Their neighboring outliers on the top of the same rock show all the same directions and also produce many erect but weak stems.

Apparently modified from weak-stemmed plants of $A$. Claytoni by place of growth, but seems to have now acquired the arcuate habit so thoroughly as to reproduce it often where unnecessary or even prejudicial; and seems to retain the weakness of stem persistently.

Range. White Mountains to the Palisades, and probably elsewhere ; first half of September.

Examples:

N. H., Franconia, Flume, Au. 30, '98, and Sc. 7, I9oo.

N. Y. vic., Yonkers, Stony Lonesome, Se. 23, '99; Bryn Mawr Park, Se. '99; Split Rocks, Se. 28, 1900, Se., I 901 , Se., 1902, Se. 15, 1903, Se. 16, 1905; Seminary Corner, Se. 14, 1905.

N. J., Palisades, above Undercliff, Se. 29, '97, Se., '98, Se. 14 , '99, Oc. 7, '99, Se. 14, 1900.

Allies. Comparing other arcuate congeners, $A$. camptilis has a more oblong and narrower leaf-type, and very much narrower slender bracts ; and so far as observed, is partial to banks and soil above shale.

A. stilettiformis is sometimes almost equally decumbent, but is then easily distinguished by its very conspicuously slit-serrate axiles. A. Parthianus lacks the breadth of leaf, sinus and bract which distinguish $A$. arcuatus.

Variants.

$35^{2} A$. arcuatus $\times A$. aucuparius, a probable hybrid; orbicular tendency strong below as if from the former parent, oval-oblong tendency strong above, as if from the latter; but all leaves very small, I6 or more being only I $1 / 2$ or $1 \mathrm{I} / 4$ in. long; stems over 2 ft. ; inflorescence increased and more branched. - With both supposed parents, Palisades, Se. 29, '97.

\section{Aster sociabilis sp. nov.}

Rigid-stemmed erect plants with small roughened ovate-acuminate leaves, short petioles, salient teeth, deep strong sinus, broad lingual and diverse bracts, small high-angle or all-axillary 


$$
\text { - }
$$




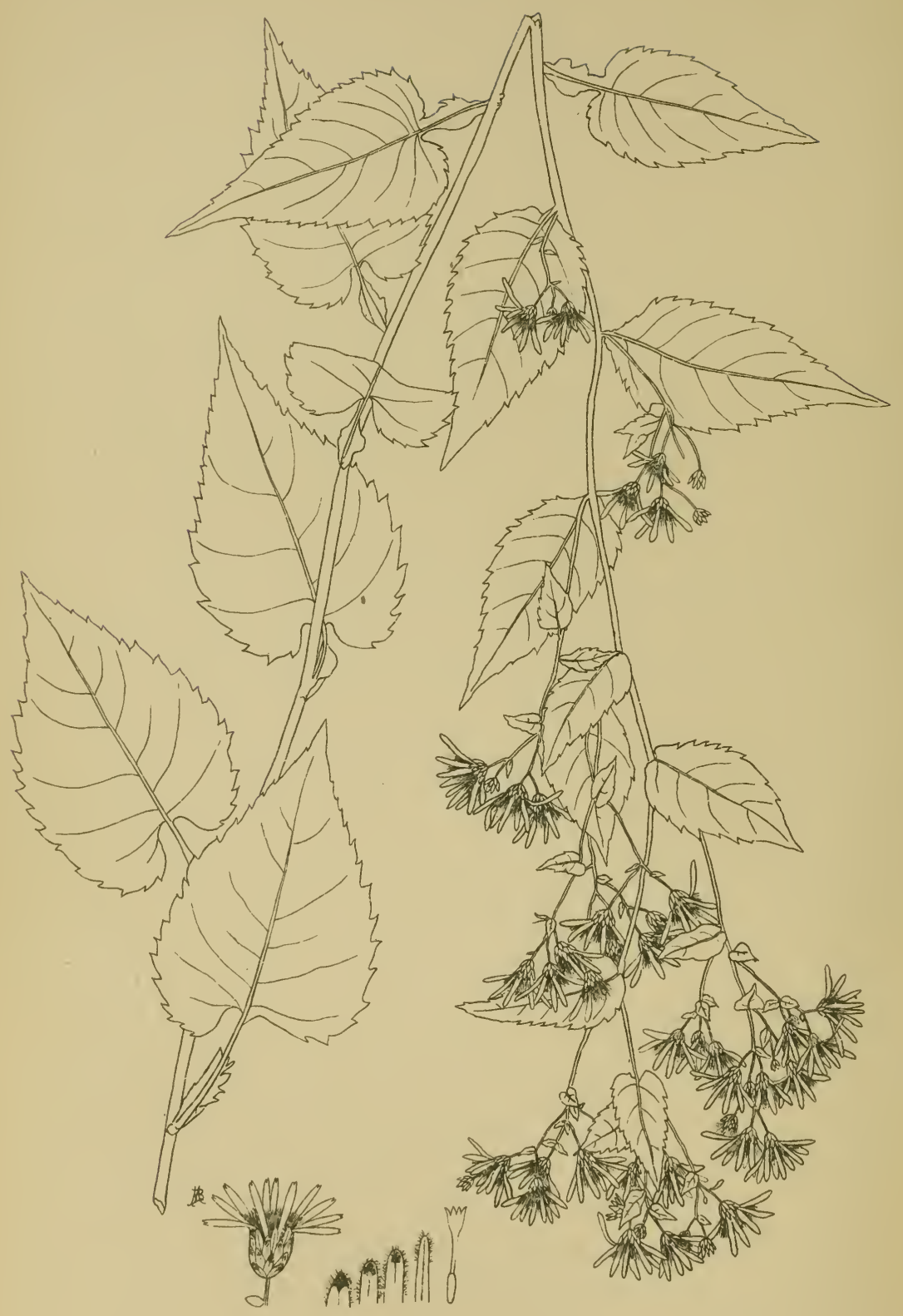

ASTER SOCIABILIS

THE HELIOTYPE PRINTING CO., BOBTON. 
inflorescence, and short-branched rootstocks, from which the numerous stems sprout up closely, and make dense stools.

Name, L., "close-connected in companionship."

Fig. 48, plate 6; plant from Palisades, N. J., Se. 12, '98, in hb. $B u$.

Stems slender, but strong, continuously slightly flexed but erect, greenish-brown, about $2 \mathrm{ft}$. high or even $31 / 2 \mathrm{ft}$. in thickets.

Rootstocks dark brown, intertwisted into a complex mass, sprouting so closely that stems stand but an inch apart.

Leaves dark, thickish, rough dry, and somewhat so occasionally when growing, rather small, all much alike, continuing on short and narrow petioles well into the inflorescence.

Leaf-form ovate, incurved-acuminate, about $3 \mathrm{~T} / 2 \times 2 \mathrm{I} / 4$, with deep conspicuous sinus. Leaf-substance firm or harsh. Petioles slender, and chiefly sharply ascending, slightly or strongly erected. Teeth rather close, the back a single curve or less often somewhat couchant. Sinus deep and conspicuous, continuing well up or almost to the inflorescence.

Inflorescence small, loosely convex-topped or few-flowered, with smaller clusters on short axillary branches 2 in. long or diminished to subsessile heads ; entire inflorescence 4 in. broad and 6 in. high when pressed, or in most-narrowed plants 2 in. broad and 8 in. high. Heads (except when remote or solitary) with short broad-based involucre.

Bracts rather few, rather broad, lingual and obtusish in predominant effect, diverse and presenting 3 or more types, the inner ones taper-obtuse with green medial stripe and pale thin scarious edges, the inmost narrow and acutish. Some lower bracts are usually very short and broad, rounding at the apex. Often some truncate and some broadly bevelled acutish middle bracts also occur. Green tips very irregular, sometimes either slight or broad and conspicuous in the same row of bracts.

Rays rather short, broad, $\frac{1}{16}$ in. broad and $3 / 8$ in. long, when dry (or larger in solitary heads), about 8 or in some colonies chiefly 5 or 6 , rounded or but slightly diminished at the apex, the curve of which is entire or contains I or 2 minute notches. Rays often virescent, especially late in the season.

Disks turning purplish or themselves sometimes also virescent, the lobes deep, the bell narrow, with abrupt base and borne on a very slender thread.

Achenes fusiform, pale and smooth; the narrow annulus deep red, a peculiarity which seems also to be shared by $A$. Claytoni occasionally, and perhaps by other species.

- Grows in dense stools a foot or two through, or even $3 \mathrm{ft}$, 
the young colonies forming merely a tuft of a few stems, older ones showing 20-100 or more; the stems close and parallel, but the lower leaves usually quite persistent. Narrowest forms are those which are themselves surrounded and overtopped by other virgate plants, as Solidago migosa; or which occur in mixed thickets. Distinguished from similarly cespitose congeners as $A$. arcuatus by erect position, and from that and $A$. ulmarius by leaf-form.- On rocks or near them, in part shade of trees, N. Y. to Va., early in September.

\section{Examples:}

N. Y. vic., Yonkers, Bryn Mawr Park, Palmer Ave. rocks, Se. 17, '98, Se. 16, 1905, Bu. ; rocky woods, Se. 4, '98, Bi. ; Grassy Sprain Reservoir, Se. 4, '98, Bi. ; Hillview, Se. 13, '98, Bu. ; Lincoln Park, Se. I 904-5 ; Staten I., Clove L., Oc. $\mathbf{1} 7, ' 95$, late survivors.

N. J., Palisades, the most characteristic growths; Woodcliff, Se. I2, ' 98 ; Ft. Lee, Oc. I3, '98; Undercliff, Oc. 7, '98, late survivors.

Va., Potomac, Great Falls vic., Oc. I5, '9 I, late.

\section{Aster ulmarius sp. nov.}

Dark green dull plants with oblong-ovate crenate-serrate leaves, with narrow sinus, broad bracts, purplish-brown disks, and close-cespitose stems, inhabiting dark woods.

Name, L., "resembling the elm," from the form of the leaf.

FIg. 49, plant from Silver Cr., N. Y., Au. I7, ' 96 , in hb. $B u$. ; $b$, characteristic leaf ; $d$, cordated lower leaf; $e$, occasional radical.

Stems greenish-brown, generally acutely flexuous, growing in dense, erect clumps, consisting of many short, dull-green plants, I $\mathrm{I} / 2 \mathrm{ft}$. high or less.

Leaf-form oblong-ovate, with the deep sinus of the lower leaves soon disappearing upward. Teeth remote, rather small, of crenate-serrate type, sometimes almost obsolete. Form, color, serration and arrangement of leaves all combine to make each plant suggest a twig from an elm tree. Veins also somewhat elm-like, strongly marked, somewhat straight, about 5 or 6 pairs. Leaves much thicker than in many Divaricati, slightly roughish, somewhat puberulent beneath all over. Apex obtuse, acute or short-acuminate. Lower petioles narrow, 2 in. long or less, middle and upper ones chiefly strap-winged, I in. or less, usually half that length.

Larger leaves $3 \mathrm{~T} / 2 \times 2 \mathrm{I} / 2$; a few unusually luxuriant plants reach $2 \mathrm{ft}$. high, with about 6 large leaves $6 \times 3 \mathrm{I} / 2 \mathrm{in}$., and bearing as many as 20 heads; most plants hardly exceed I ft. 
Radicals, a few small ones seen, cordate-orbicular, with shallow sinus, $2 / 3$ in. across.

Heads $\frac{5}{8}$ in. broad, $\frac{2}{8}$ high. Inflorescence sometimes reduced to 3 or 4 subsessile heads in each of the uppermost axils.

Rays $1 / 4$ in. long or less.

Disks turning purple ; and the whole plant becoming deep crim-

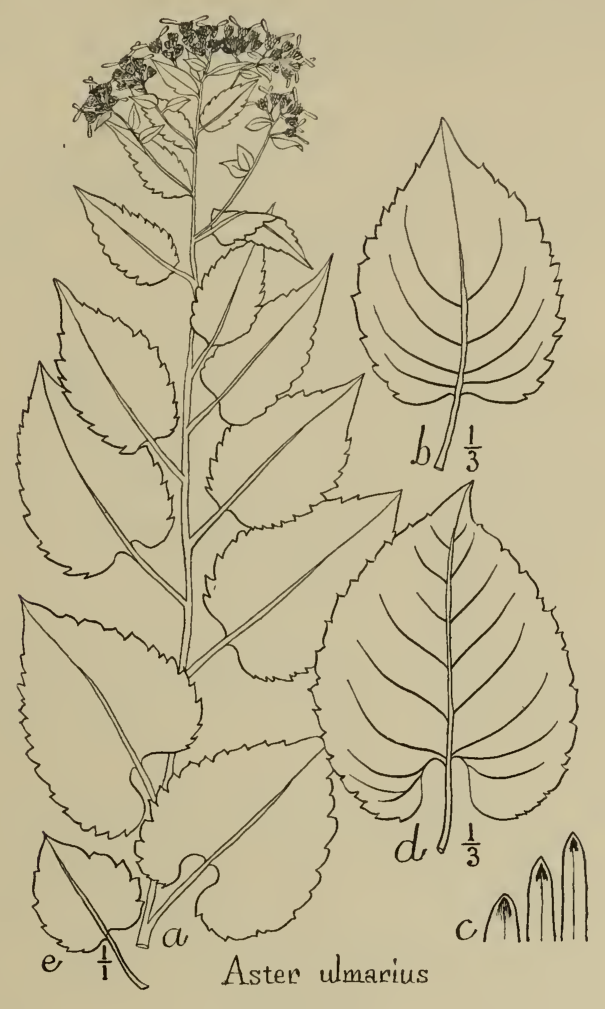

FIG. 49.

son or maroon in late autumn, with the veins darker and clouded, the whole leaf often beautifully marmorate.

Paths and dark banks of streams and moist cold woods, not owing its character to that situation alone, however, as it may be found surrounded by forms almost in contact with it which are tall, arcuate, decumbent, profuse-flowered, large flowered, smoothleaved, pale-leaved, solitary, or long-surculose ; to each of which characters $A$. ulmarius is the opposite. 


\section{Examples:}

Ms. Taconics, Mt. Ethel, paths in deciduous forest, at $\mathbf{I}, 6 \mathrm{co} \mathrm{ft} ., \mathrm{Se} ., \mathbf{1} 903$.

IV. N. Y., Silver Cr., Swift's Hill, Au. 15, '96; Aster-bank, numerous. Au. I 7, '96, Au., '98; Little Indian Cr., Au. 20, '96. Chautauqua, Assembly grounds, Au., ' 96.

D. C., Rock Cr., Blagden's Mill, in deep shades of laurels, Oc. I2, '88. Rock Cr., Oc. 9, '91, Oc. 24, '91.

Md., Potomac, near Great Falls, at Kirk's Mine, Oc. I I , '91.

Tenn., Knoxville, shaded hills, Oc. '94, A. Ruth in hb. Colu.

\section{Division E. FURCATE ASTERS.}

Small scattered leafy plants a foot high; bracts triangular-oblong, large and flattish. Species 38-39.

\section{Aster furcatus Burgess}

Small plants with long harsh ovate-triangular straight-acuminate leaves, little sinus or petiole, long straight teeth, triangularelongate bracts, and large remote turbinate heads with prolonged forking pedicels (whence the name).

FIG. 5o, top of plant of Oregon, Ills., M. B. Waite in hb. Bu., Au. '84: $b$, characteristic upper cauline: $d$, characteristic radical and lower cauline.

A. furcatus Burgess in Br. and Br. Ill. Fl. 3 : 358 (1898), with fig. 3738, and original description :

"Stem leafy, I I $/ 2 \mathrm{ft}$. high, or less, loosely forked above. Leaves hispid above, hispidulous beneath, firm, saliently cut-toothed, the lower ovate, short-petioled, with a small or shallow sinus, the upper sessile, with broad laciniate winged bases, often 5 in. long by $2 \mathrm{r} / 2$ wide, the uppermost elliptic-oblong, often $3 \mathrm{I} / 2 \mathrm{in}$. long; teeth long and low, sharp. Heads few $(5-20)$, slender-peduncled; involucre turbinate to campanulate, with a truncate or rounded base; rays 3-toothed; disk turning brown, the florets funnel-form with rather broad lobes; pappus long, straight; achenes pubescent, subangular, not constricted at the summit. - In woods, especially on shaded cliffs, Illinois and Missouri, Aug.-Oct."

Rootstock producing several strong reddened surculi at once.

Stem green, assurgent from a geniculate base, subangular, rough with minute short spreading hairs.

Leaf-surface above like shagreen with innumerable minute close spinescent bristles, or when very much shortened, with mucronate tubercles; margins not otherwise ciliate. Leaves beneath 
hispidulous, with a fine rough subappressed whitish pubescence, which becomes spreading on the veins. Texture firm, thickened. Color pale green, veins paler still. Petioles slender and $\mathrm{I} / 2 \mathrm{in}$. long or less, for the lowest cordate leaves ; for the middle leaves usually broadly winged, often $3 / 4$ in. broad and long, deeply gashed, contracted at the stem and again at the leaf, finally in the upper leaves merging gradually into the leaf. Teeth conspicuous, chiefly long, shallow, sharp, dorsally straight; occasionally curvescent, sometimes short, irregular and salient.

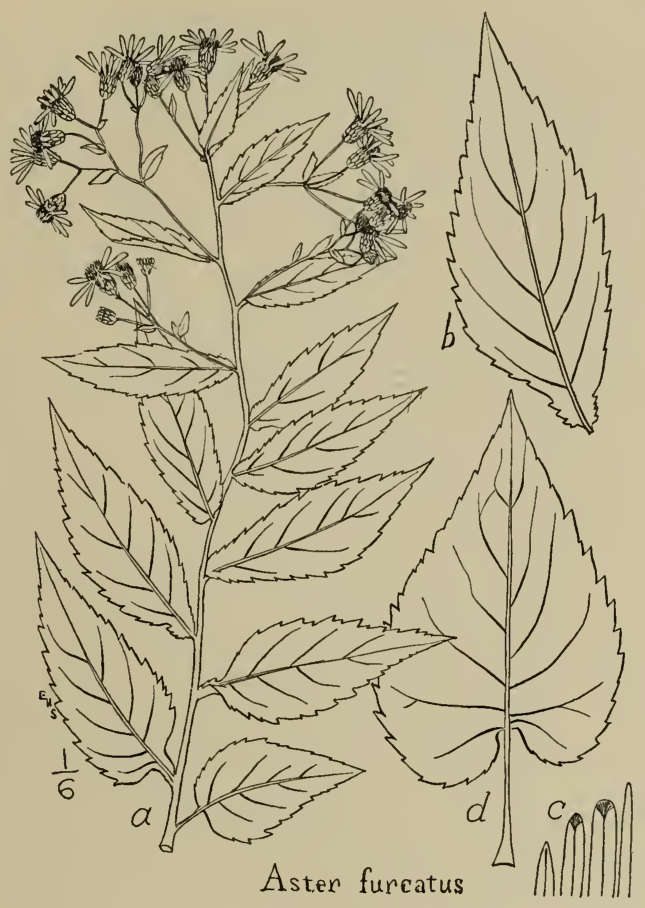

FIG. 50 .

Involucre chiefly turbinate with straight divergent sides from a small distinctly rounded base, conspicuously quincunx-chequered, little pubescent but with strong ciliation. Rays $1 / 2$ in. long, $\frac{1}{12}$ in. wide, when dry. Achenes sometimes still quite pubescent at maturity, covered with short upward-directed silky brown hairs especially on the angles and intermediate striae. Pappus golden-ferruginous in 10 years, ecru in 5 .

Plants long confused, vibrating in collections between " $A$. corymbosus" and $A$. macrophyllus, sometimes even appearing in the 
same herbarium under both names, sometimes first labelled $A$. corymbosus because white-rayed and sharp-toothed; and then relabelled A. macrophyllus because hispid and large-flowered; in reality highly unlike either. The plant also resembles $A$. conspicuus somewhat in aspect and leaf-form, in size of heads and rays, and in roughness; but differs in developing a cordate base (though such leaves are apt to be gone at flowering time).

Shaded cliffs and woods, of rare occurrence.

Examples:

Ill., Oregon, Ogle Co., woods, $M$. B. Waite in hb. Bu., Au., ' 84 ; a number of plants, the rays perhaps slightly purplish-tinged.

Ill., Fountaindale, Winnebago Co., M. S. Bebb in hb. Canby; with 6 subcordate leaves (instead of only one as usual); also, a larger plant almost $2 \mathrm{ft}$. high, from the same place. " $A$. corymbosus, ex hb. M. S. Bebb," now No. I4I893 in herb. U. S. Nat. Museum; also “ Bebb, Ills., No. I8gII," in same.

Ill. —, coll. Brendel in '73, no. I891 2 in hb. U. S. Nat. Mu.

Mo., "Shannon Co., shaded cliffs, rare, Oc. 21, '93, B. F. Bush" in hb. Colu., hb. Harv., hb. Bu. and hb. Mo. Bot. Gar.

Mo., "Jefferson Co., shady woods, banks of the Meramec R., Se. 6, I886, H. Eggert," in hb. Harv.; also, "banks of the Meramec R., Se., I886, H. Eggert," in hb. Harv., hb. Canby.

Mo., "St. Louis Co., shady cool places at Allenton, Se., '75," G. W. Letterman in hb. Engelmann, now in hb. Mo. Bot. Gar.

\section{Aster leptocaulis Burgess}

Plants resembling $A$. furcatus, but taller, and more leafy, the leaves oblong-acute or ovate-lanceolate, little roughened or nearly smooth, and dense-pubescent beneath, the bracts somewhat obtuse, the shining green stem very smooth (whence the name).

FJG. 5I, plant from Milwaukee, Wis., Dr. H. E. Hasse in hb. N. Y. Bot. Gar.; b, characteristic leaf-form of this and of plant of Milwaukee, Wis., $I$. $A$. Lapham, Au., 1842, in hb. Mo. Bot. Gar. description :

Aster leptocaulis Burgess, in Britton's Manual, 950 (I90I), with original

"Stem slender, smooth, $4 \mathrm{dm}$. high or more, the branches puberulent, erect-ascending, leafy to the inflorescence. Stemleaves lanceolate or the lower ovate-lanceolate, the large $1.5 \mathrm{dm}$. long, thin, slightly rough above, finely and densely pubescent beneath, long-acuminate, sharply serrate nearly or quite to the base, the upper sessile or very nearly so, the lower petioled and cordate or subcordate at the base, inflorescence corymbose, leafy ; peduncles slender, $\mathrm{I}-2.5 \mathrm{~cm}$. long; involucre turbinate-campanu- 
late, about $8 \mathrm{~mm}$. high, its bracts obtuse or obtusish, ciliate; heads about $2.5 \mathrm{~cm}$. broad. - Milwaukee, Wis., collected by Dr. H. E. Hasse."

\section{Subsection 2. CURVESCENTES.}

Radicals usual, numerous and large, forming conspicuous colonies ; involucre narrowly cylindrical or terete ; rays white, sometimes turning rose-color but not violet; disks turning brown or

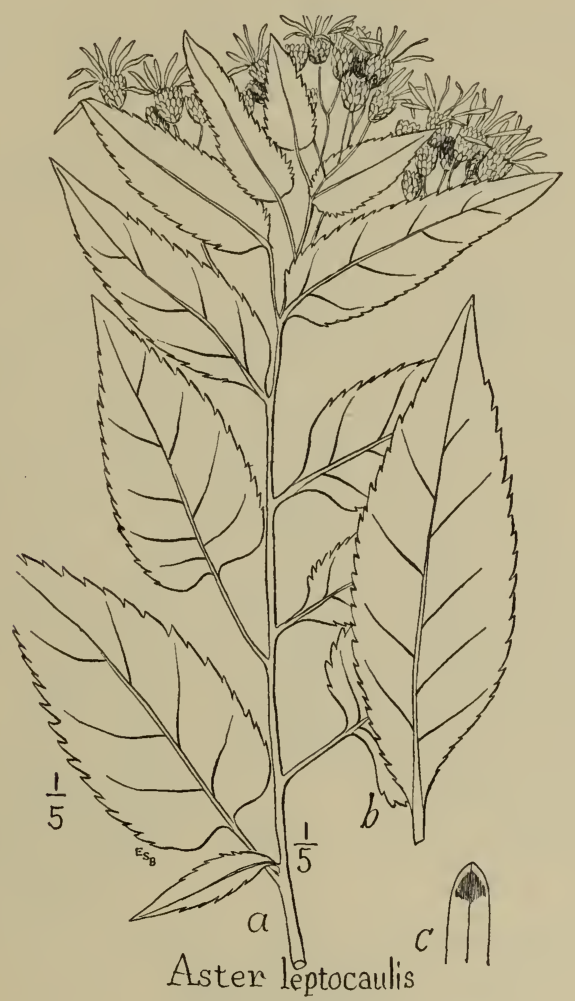

FIG. 5 I.

sienna, rather than crimson; pedicels not tomentulose all over (as in $A$. divaricatus) but bearing pubescence in lines; no glandular hair present. Includes Divisions A and $\mathrm{B}$, species 40-54.

\section{Division A. CURVESCENT ASTERS.}

Bracts chiefly scarious and pale, very narrow and attenuate, tapering-obtuse. Leaves large, thin. Rays narrow. 
Subdivision $A$. InNer BRacts without obvious midrib, COLOR OR HAIR, AND VERY THIN.

Species 40.

\section{Aster curvescens Burgess}

Deep green broad-leaved plants, with orbicular-cordate leafform, curvescent teeth, smooth narrow involucre, attenuate bracts, strong-linear rays; the small convex inflorescence flattening into a dome with divaricate branches; the whole plant outlined in flowing curves (whence the name).

FIG. 52, plate 9, plant from Lanier Heights Brook, Washington, D. C., Sept. 24, ' 88 , in hb. Bu. ; and plate Io its radicals, a single head, bracts and disk-flowers. A. curve cens Burgess in Br. and Br. Ill. Fl. 3 : 359 (1898) with fig. 3741, and original description :

"Dark green, chiefly glabrous; rootstocks often ı in. long; stem pale green, striate, delicate, $\mathrm{I} / 2$ to $2 \mathrm{ft}$. high. Basal leaves tufted, conspicuous, these and the lowest stem-leaves with a broad, shallow sinus tapering into a petiole $\mathrm{I}-2$ times as long as the blade, abruptly incurved-acuminate ; middle leaves ovate, short-petioled, rounded at the base, the upper lanceolate, slenderly acuminate, often falcate. Leaves firm, smoothish, the teeth broad, curved. Inflorescence small, convex, 3-5 in. broad, its short filiform naked branches widely ascending; heads 4 or 5 lines high; lower bracts short, obtuse, the others longer, nearly uniform, scarious, shining, linear, often acute, usually glabrous ; rays about 8, cream-white, about 5 lines long; disk becoming purple-brown; pappus early reddening ; achenes slender, glabrous.

"- In loose, moist shaded soil, New England and New York to Virginia. Aug.-Sept."

Rootstocks strong, rather slender, sometimes pulling up for IO to 20 in.

Young shoots bearing two small suborbicular primordial leaves, $1 / 3$ in. across, brownish-green, and nearly opposite (nearly ready to fall away, Apr. 2 I, at Washington, D. C.). Above these occurs a small deltoid-orbicular crenate leaf with truncate bracebase, which also soon perishes. Proper radicals follow, 2 or sometimes 3 , nearly alike in size and shape, 4 or $5 \times 4$ in., sometimes $6 \times 5$.

Leaf-form cordate-orbicular with broad and rounded base, incurved-acuminate, the brace-base sinus very broad and shallow, recurved conspicuously at the petiole. Petioles very long and slender, the radical 6-8 in., the lower cauline 2-3 in; middle cauline petioles often broadly winged and tapering upward. 


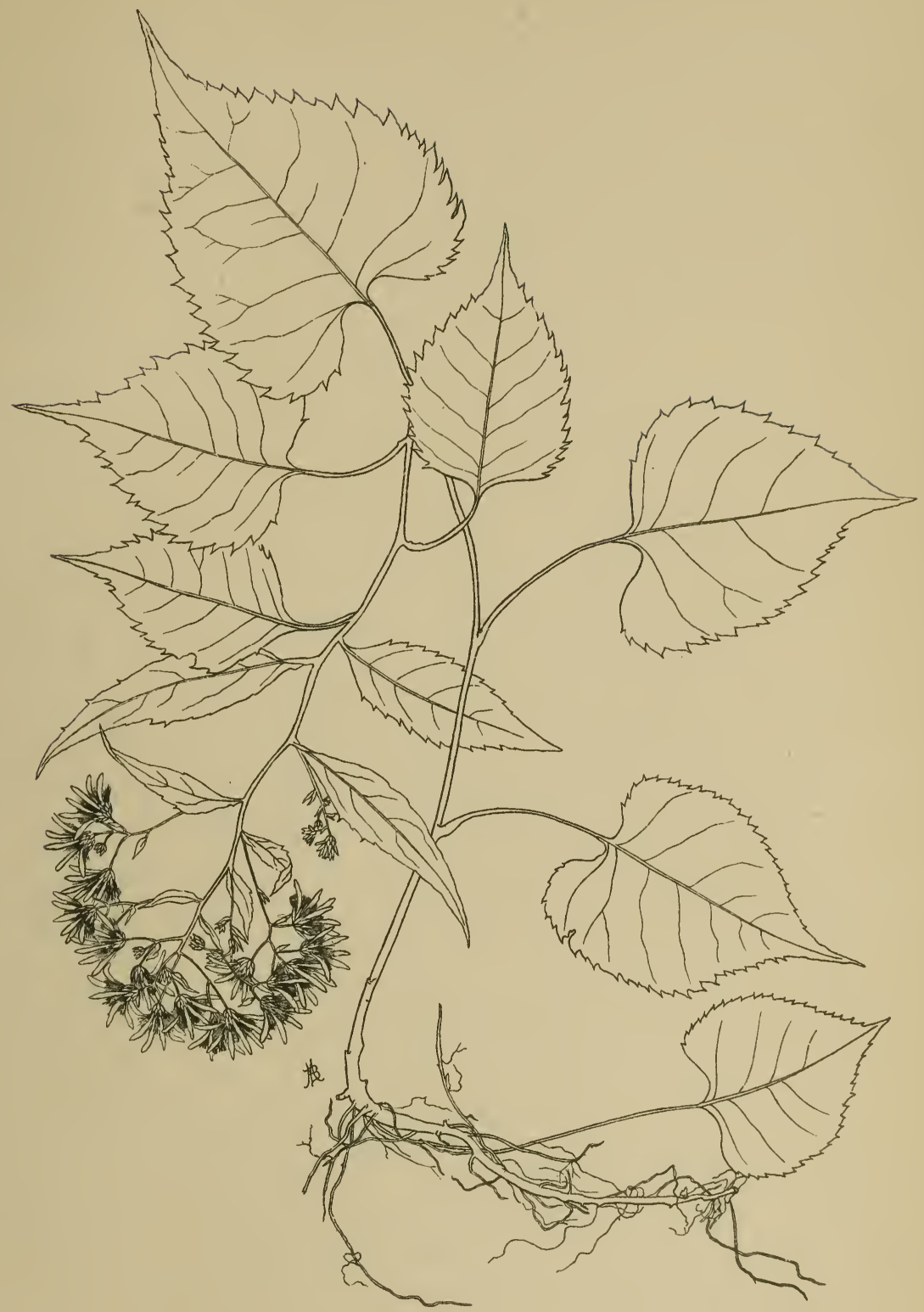

ASTER CURVESCENS 

Middle leaves ovate, remaining leaves to the inflorescence hardly at all shorter but progressively narrowed to lanceolate, serrulate. Axile leaves rapidly reduced in size and soon obsolescent ; the rameals few and minute, the inflorescence thus seeming naked.

Teeth even, rather close, on the radicals chiefly $1 / 4 \mathrm{in}$. long, projecting outward $1 / 8$ in. or less, much more shallow on the cauline leaves ; characteristic form curvescent, or slightly convex on the back, concave in front, tipped at the front projection with a long slender abrupt aculeus which is green and membrane margined.

Inflorescence usually semicircular on pressing, 3 in. across by 2 in. high, or less. Heads 25 or less, small ; branches widely patent, but not at right angles as in best-developed plants of $A$. glomeratus; pedicels $1 / 3$ in. long in flower, capillary, ninutely strigose in lines. Principal bracts very narrow, little seriate, slenderly linear-attenuate from base to acutish apex in most inner examples; most outer ones obtusish or seeming acute by infolding; all smooth or with mere trace of ciliation or hair, glume-like and scarious throughout, without midrib or green tip ; except in the few short inconspicuous outer bracts, which are ovate and thickened.

Rays bidentulate, quickly deciduous, persistently 8 , rarely Io or I 2 , disks about 20 , purple-brown or black when dry.

Achenes deep brown, smooth, the darker striae conspicuous but delicate, slender-fusiform, with conspicuous pale terminal annulus marked by short truncated grooves.

Habitat, loose, gravelly soil and steep banks, near streams, especially in narrow ravines, in shade, chiefly in the Middle States.

Examples:

N. H., Sullivan Co., Meriden woods, between Grantham Mt. and Connecticut R., Alphonso Wood, as A. corymbosus, in hb. Canby.

Ms., Taconics, Bashbish ravine and its branches, to $1600 \mathrm{ft}$. alt., I901, I903, 1904, Bu., and Sky Farm, Au. I903, 1904.

N. Y. vic.? in Torr. hb., early determined by Boott and Torrey as Biotia Schrebcri and by Gray as $A$. macrophyllus $\beta$.

N. V. vic.? in Gray hb., dating from Gray's studies with Torrey, at first labelled by Gray "intermediate between $A$. corymbosus and A. macrophyllus" by Gray again later as "thinnest $A$. mairophyllus."

N. Y., —, coll. Topting, '93, no. 2981 9 in U. S. Nat. Hb.

N. Y., Catskills, Colonel's Chair Mt., grove; to $1000^{\circ}$ alt., Se., '99, Bu.

" N. Y.," in hb. Buckley, as "A macrophyllus" (in hb. Mo. Bot. Gar.).

W. N. Y., Chautauqua Co., Stone Ledge, '73, Bu., Sheridan, Reed's Swamp,

Au. '97; Hanover, High Br., Au. 17, '96.

Pa., Huntingdon Co., Alexandria, I844? T. C. Porter in hb. Porter, and Mercersburg, '50? hb. Porter. 
Pa., Allegheny Co., Canonsburg, '63, Knipe in hb. Porter.

Pa., Bucks Co., Phoenixville, Au. 14, '96, W. K. Fisher in hb. Bu.

Pa., Lancaster Co., near Steelville, July 28, '9o, Jn. K. Small in hb. Porter; Octoraro, Small in hb. A. Brown.

$\mathrm{Pa}, \longrightarrow$, coll. T. C. Porter, '95, no. 236830 in U. S. Nat. Hb.

Del., Nezucastle, W. M. Canby, in hb. Canby.

Del., Mt. Cuba, Se. 24, '95, Joseph Crawford hb., in hb. N. Y. Bot. Gar.

D. C., streams; typical locality in present Zoological Park, near end of Lanier Hts. Brook, Se. 24, '88, etc., some plants still surviving Apr. 21, I90I, then just opening their first radicals and about to lose their primordials ; $B u$, in hb. $B u$, and in U. S. Nat. Hb.

D. C., Lobelia Run, near Rock Cr., July I2 and 19, '86, H. W. Henshaw, $\mathrm{i}_{\mathrm{n}}$ U.S. Nat. Hb.

D. C., near Washington, July 19, '86, L. F. Ward in hb. Bu.

Md., Cumberland, '94, coll. Frank Schriver in hb. N. Y. Bot. Gar.

Va., Potomac bank, near Spout Run, Bu.

Va., Stony Man Mt., Se. 4, I901, E. S. Steele in hb. N. Y. Bot. Gar.

$\mathrm{Ky}$., Lexington? from $C$. $W$. Short as " $A$. macrophyllus" in hb. Buckley, now in hb. Mo. Bot. Gar.

Ohio, Oberlin, '94, Richardson, no. 217620 in U. S. Nat. Hb.

S. C., Table Rock, Se., 1850, L. R. Gibbes, hb. N. Y. Bot. Gar.

History. Plants of this species were collected early in the I 9 th century and united by Boott with his specimens of $A$. Schreberi; were similarly classed by Torrey and Gray, together with $A$. Schreberi as A. macrophyllus $\beta$ (F1. N. Am.); fide Torrey herbarium; were so classed by Canby; and by others later were merely consigned to $A$. macrophyllus in general.

In I $88 \mathrm{I}$, Prof. L. F. Ward remarked of this species, under the name of $A$. macrophyllus, in his Flora of the District of Columbia, p. 88, "The form [A. curvescens $]$ found here differs from the northern from $[A$. macrophyllus $]$ in the size of the leaf and heads, and in the number of flowers in the heads, and seems to be intermediate between that and $A$. corymbosus."

Dr. Geo. Vasey said of this form to me in $\mathrm{I} 888$, "It surely is a different plant from $A$. macrophyllus, and intermediate on account of its smaller heads and form of inflorescence and different bracts."

I had myself regarded it as distinct since beginning its study in I 886 , but until I 898 deferred publishing it, in order to compare its development in other localities.

Variants:

$4 \mathrm{O}^{2}$ Rotundate form. Small plants differing in their conspicuous upper caulines which are broadly oval, and slender-petioled.

With the type, near Washington, D. C., Bu. 



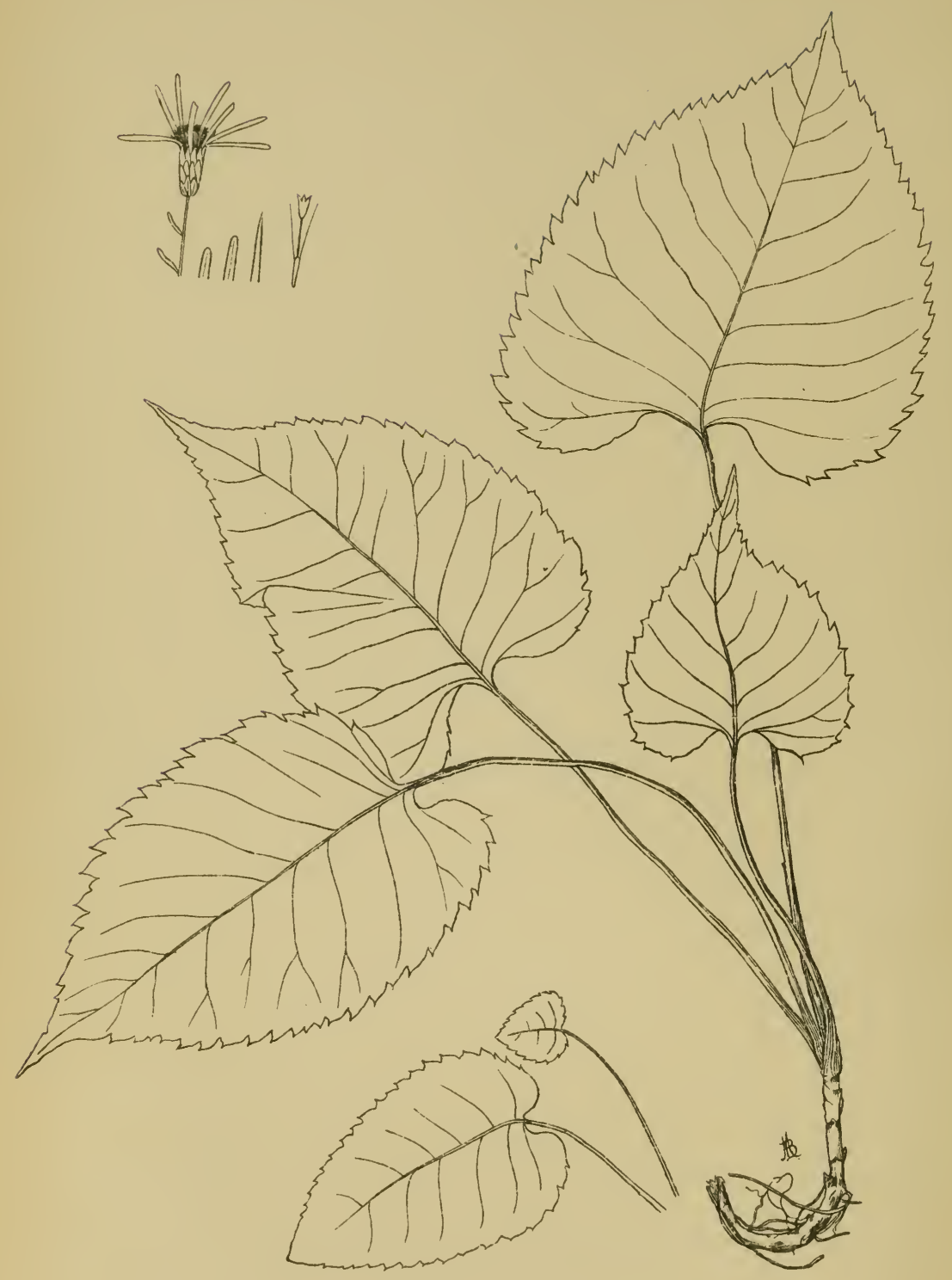

ASTER CURVESCENS AND VARIANT RADICALS 
$40^{3}$ Pedunculate. Tall stiff slender plants, differing in their numerous small ovate short-stalked upper caulines; by this arrest of leaf-size the upper part of the stem becoming a bracteose peduncle in appearance. Fisher, etc.

With the type, near Washington, D. C., Bu., Phoenixville, Pa., W. K.

$40^{4} A$. curvescens $\times A$. divaricatus, a probable hybrid; like the latter in its leafy-bracteate enlarged inflorescence, flexed stem, more salient teeth; otherwise chiefly like the preceding.

Va., Potomac bank, Spout Run, Oc. 9, '91, and Violet Rock, Oc. 17, '91, Bu.

$40^{5}$ A. curvescens $\times A$. macrophyllus, a probable hybrid, chiefly like the former parent, but with its thick hispidulous leaves, its bracts, inflorescence form and abundant large truncate rameals seeningly due to the latter.

At the localities of No. $40^{4}$.

Subdivision B. INNER BRACTS WITH OBVIOUS MIDRIB.

Species $4 \mathrm{I}-43$.

\section{I. Aster oviformis sp. nov.}

Slender plants with large, thin, dark, oval-acute leaves, closecrenate and with sharp sinus, and irregular flattish-topped inflorescence, linear-oblong rays and bracts.

Name, L., from the leaf-form, like an egg with one end gradually reduced.

Fig. 54, plant from Yonkers, N. Y., Au. 3, '99, hb. Bu., 1/8 natl. size. Characteristic leaf-form shown in radical group, $b$, and in lower and middle caulines. Aberrant radicals, $d$. hb. $B u$.

Fig. 53, plate Io, radicals and single head, etc., from Potomac R., '98, in

A. curvescens oviformis Burgess in Br. and Br. Ill. Fl., 3: 359 (I898), with original description :

"Stem about $2 \mathrm{~T} / 2 \mathrm{ft}$. high, leafy ; leaves dull green, not acuminate, very thin, but rough, ovate, cordate with a deep narrow sinus, 8 in. long by $4 \% / 4$ wide, or smaller; some of the bracts broader and green-tipped; inflorescence smaller and less [regularly] branched [than in A.curvescens]. Range of the preceding."

Teeth very shallow, crenate with stiff abrupt mucro.

Leaves extremely thin and tissue-like, lightly-pubescent on the veins beneath; the much-appressed bristles above, very slender, sharp and delicate; the sinus commonly overlapped. Leaf-development shows the unfolding leaves much narrower and much more 
acuminate than they remain; the hairs at first whiter, almost floccose on the midrib below.

In first development, a few thin triangular bracteose scales are succeeded by I or 2 little primordial leaves, these by about 3 suborbicular leaves respectively about $\mathrm{I}$ in., $2 \mathrm{I} / 2 \mathrm{in}$., and $4 \mathrm{in}$. across, the first subcordate, the second somewhat hastate at the deep

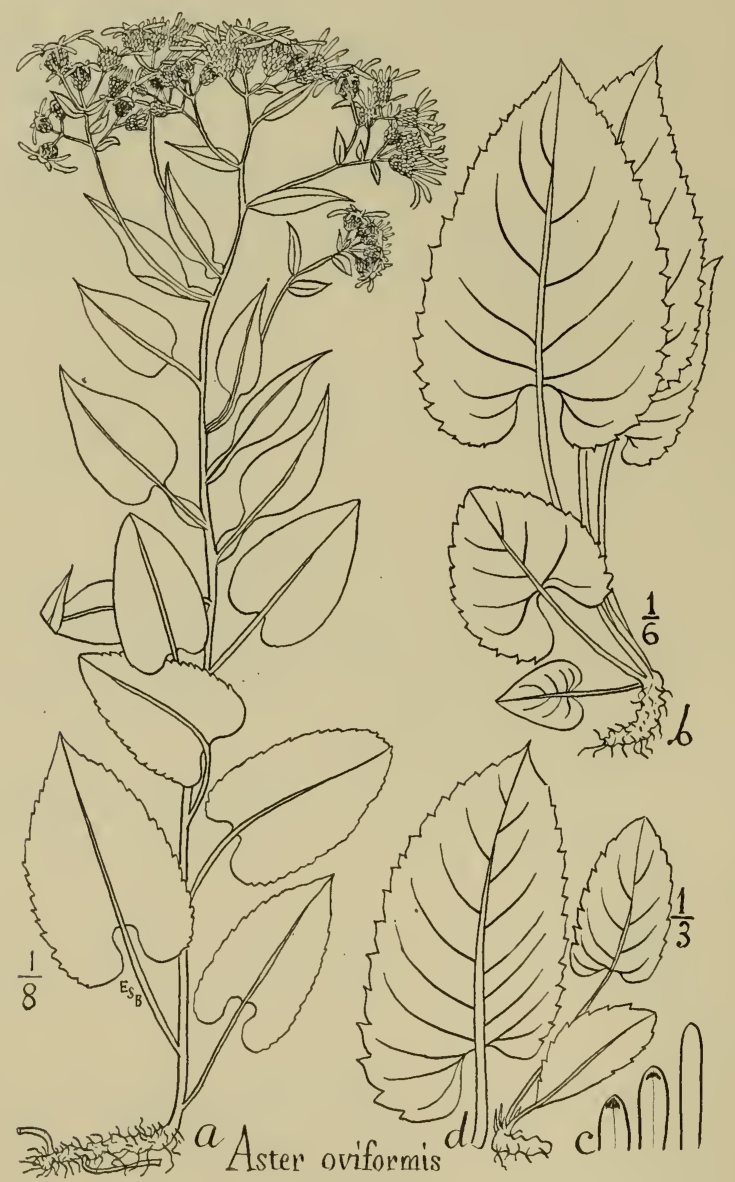

FIG. 54 .

narrow sinus, the third similar, but with the basal lobes thrown wide apart. The characteristic leaf-form, resembling an ostrichegg, is then assumed by about 3 leaves, and in diminished size by 2 or 3 more. Then follows the first axile leaf (often the ninth permanent leaf on the plant), this and 2 or 3 more being ovate- 
lanceolate and winged. Then follow 7 to Io lanceolate subentire axiles, I $\mathrm{I} / 4$ in. long or more.

Petioles long, narrow, delicate, 3 or only 2 in., the radical 7 in. or less.

Bracts linear-oblong, with the narrow obtuse apex slightly darkened. Pedicels slender, short and crowded.

Differs from $A$. curvescens especially in leaf-form, thinner substance and crenate teeth. Intermediate between $A$. currescens and A. Schreberi in its bracts.

Blooms in W. N. Y. from end of July through first week in August chiefly ; Sept. and Oct. collections on the Potomac representing late flowering colonies.

Examples:

N. Y. vic., Yonkers, McLean Av., Au. 3, '99; McLean's Pond, Au. 3, '99. Br., Au. 6,' '97.

W. N. Y., Silver Cr., Fern Glen, bank Walnut Cr., at summit; near High

Cattaraugus Resn., Indian cornfield corner, near Burning Spr., Au. 9, '97 ; Indian Twin, brook mouth, Au. 9, '97 ; Big Indian Cr. mouth, July 31, '96. Hanover, Rosebrook woods, Au. 27, 1900.

N. Y., Catskill, near Hunter, Au. I, '98, N. L. Britton, in hb. N. Y. Bot. Gar. I 8904 .

N. J., Millington, Morris Co., Au. 19, '92, G. V. Nash in U. S. Nat. Hb.,

Md., "Baltimore, Dr. Furman, A. macrophyllus," in U. S. Nat. Hb., No. 18916. Sugar Loaf Mt., Se. 23, '93, Bu., with the sinus often broad.

D. C., Rock Cr., Lanier Hts. Brook, Se. 24, '88, etc.; leaves just opening April 2 I ; full grown, May $2 \mathbf{I}$. Woodley Br., Oc. 22, '88.

Va., Potomac bank, west of Holtzman's, Oc. 26, '88, Oc. 22, '89.

\section{Variants:}

$4 \mathrm{I}^{2} A$. oviformis $\times A$. divaricatus; a probable hybrid, unlike the first parent in having irregular salient teeth, gashed and cut, a single tooth sometimes $1 \frac{1}{4}$ in. long, and projecting $\frac{1}{4}$ in. ; the leaves very thin and very large, reaching $10 \times 6$ in. or less.

N. Y. vic., Yonkers, Troublesome Brook, Oc. 28, '96, Bu.

D. C., Rock Cr., at Lobelia Run and at Pierce's Mill, '88, Bu.

$4 \mathrm{I}^{3} A$. oviformis $\times A$. glomeratus; probable hybrid, combining the leaves of the former and the inflorescence of the latter; bracts highly triseriate and with deep bright-green tips, near both parents.

W. N. Y., Cattaraugus Resn., on Cattaraugus Cr., Au. 3, '96; Silver Cr. ravine at Crenated Falls, two plants, Au. 17, '96.

$4 \mathrm{I}^{4} A$. oriformis $\times A$. macrophyllus; probable hybrid, chiefly like the former parent but with the upper leaves and minute glands of the latter; near both.

N. Y. vic., Yonkers, Troublesome Brook, Oc. 28, '96. 
$4 \mathrm{I}^{5}$ A. oviformis $>A$. curvescens; an intermediate in leaf-form, shorter and broader than the former, and not so dull green.

W. N. Y., Silver $\mathrm{Cr}$., near High Br., Au. 6, '97.

\section{Aster vittatus sp. nov.}

Small plants with ovate-acuminate leaves, close sharp teeth, broad shallow sinus below, loose-domed inflorescence, and longattenuate obtuse bracts with whitish scarious edges and upright green medial band (whence the name).

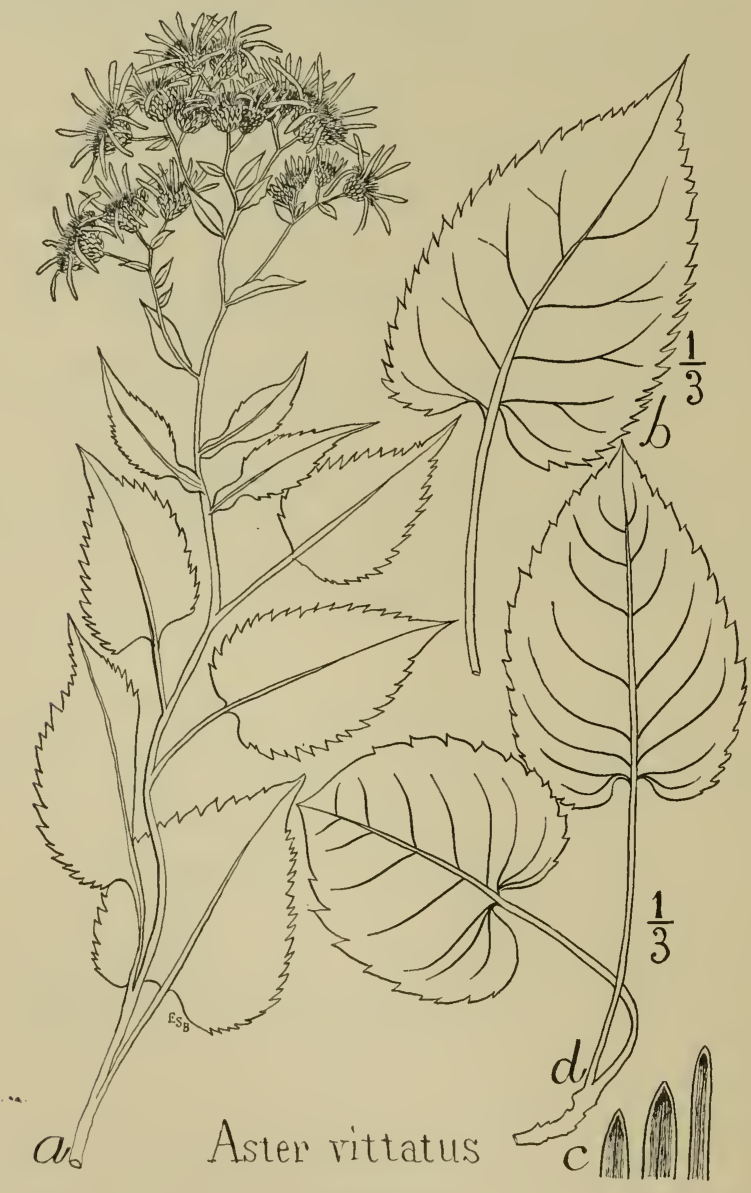

FIG. 55 .

FIG. 55, plant of Colonel's Chair Mt., Catskills, Se. 6, '99, in hb. Bu., 1/6 natl. size, with radicals $1 / 3 ; b$, characteristic leaf-form, radicals and lower caulines. 
Rootstock reddish-brown; finally black, with very short nodes.

Stem deep red, or green when under shade, smooth, continuously sinuous, about $\mathrm{I} \frac{1}{2} \mathrm{ft}$. high, finely striate when dry.

Leaves full green, firm, smoothish, continuously narrow-petioled, acuminate-serrate with very close slender teeth, and with broad shallow sinus. Radicals oblong-acute, with truncate base and straight sides; or sometimes cordate-triangular. Lower leaves characteristic, ovate-incurve-acuminate. Middle caulines ovate-acuminate rounding into a wing-petiole.

Inflorescence a loose dome, with branches upward-curved. Bracts of two kinds, the outer acutish or bevel-tipped, slightly ciliate; the middle and inner bracts very thin and smooth, nonciliate, very long-attenuate, with whitish margins and with a very characteristic long narrow green medial band continuing without enlargement, to the obtuse apex.

Habitat, grassy banks and lower mountain slopes, Schoharie Valley in the Catskills ; on Colonel's Chair Mt., Hunter, flowering the middle of August, passing out of flower Se. 5 .

Distinguished from the similarly domed $A$. curvescens by its more green-banded and less-attenuate bracts, looser upcurved inflorescence branches, usual red stem, smaller more ovate leafform, and different teeth.

Distinguished from $A$. ambiguns near which it grows, by its shorter non-cylindric simultaneous-flowered inflorescence, its darker red stem, and its narrower more sharp-serrate leaves.

Unlike $A$. Sclireberi in its curves of stem, leaf, inflorescence top and branches; also in its narrow green-banded bracts.

\section{Aster umbelliformis sp. nov.}

Large plants with smooth, orbicular ovate leaves, deep sinus, crenate-serrate margins, decompound inflorescence with tall subumbellate branches, and many bracts thickened and green-tipped.

Name, L., from the inflorescence-divisions, small corymbs with the pedicels brought nearly to a common base. hb. $B u$.

FIG. 56, plate II, plant from Hillview swamp, Yonkers, N. Y., July, '98, in

A. corymbosus (in part) Muhlenberg, Cat. ed. I ; $\mathbf{1} 8 \mathbf{1} 3$, fide traces in his herbarium ; and hence his statement of Juiy as blossoming time for "A corymbosus."

A. curvescens umbelliformis Burgess in Br. and Br. Ill. Fl. 3: 359 (I898), with original description :

"Stem very smooth, deep [green, or] red [in certain forms], robust, straight, sometimes $31 / 2 \mathrm{ft}$. tall; leaves apple-green, smooth when dry, sparingly toothed, inflorescence symmetrically 
umbelliform, decompound; sinus of the lower leaves rather deep and narrow. In grassy woods and thickets, Conn., and to Virginia."

Stem terete, non-flexuose. Radicals I, sometimes 2, with very long, erect petioles, twice the leaf-length, even $\mathrm{I} 2 \mathrm{in.long}$. Leaves thin, firm, light green, satiny, smooth and glabrous in growth, and remaining smooth when dry, except sometimes the very lowest leaves. Leaf-form cordate acuminate, or cordate with abruptly short caudate apex ; middle caulines large, ovate-acuminate with broad wing; upper caulines and axiles oblong-lanceolate, rounded into a short, broad wing. Rameals often large, $2 \times 1 / 2 \mathrm{in}$., or less, lance-oblong, sessile; in extreme cases about 3 such, an inch apart, crown the top of the long smooth branch, naked for 7 inches below.

Teeth of serrate type, fine and regular, shallow, nearly straight.

Inflorescence decomposite, its numerous branches each bearing an umbelliform cluster with radiating pedicels or in some clusters resuming the corymbose type by developing short internodes. The total inflorescence in small plants has a shallow convex top about 5 in. broad; in large plants a loose rounded dome, 10 in. or more across.

Pedicels very slender, often $\mathrm{x} / 2$ in. long; lateral buds of each cluster are apt to be sessile for some time, the pedicel often developing so much later as to make the whole cluster half-circular when fully in flower.

Rays 8 , tapering slightly to the 3 -toothed apex ; a little more so to the base. Disk-flowers about 25 , becoming purplish-brown, taper-funnelform, the short lobes forming not over 2 of the body. Achenes smooth and even, fusiform, dark greenish brown, with double striae, with a white terminal annulus which is decurrent on the striae and thus becomes triangularly denticulate downward. Receptacle foveolate, developing conical tubercles, on which the achenes were seated; but alveolae and fimbriae are obsolescent or absent.

Among allies which bear somewhat similarly umbelliform branches, $A$. ambiguus is smaller and more slender, $A$. Claytoni very much shorter; $A$. curvescens only produces similarly conspicuous colonies of broad radicals, and differs in darker, harsher leaves, more predominantly curvescent teeth, narrower rays, etc. A. limicola sometimes grows near, but differs in leaf-form, ciliate petioles, larger, rougher, thinner, more numerous radicals, crenate teeth and later blossoming.

Habitat, wet woods and river banks, Mass. and Ontario to Va. and Illinois, late July.

Examples:

Ms. Montague, July 25, '87, and Au. 6, '87, Walter Deane in hb.

Untario, Welland, July 12, I901, Macoun in hb. N. Y. Bot. Gar. 


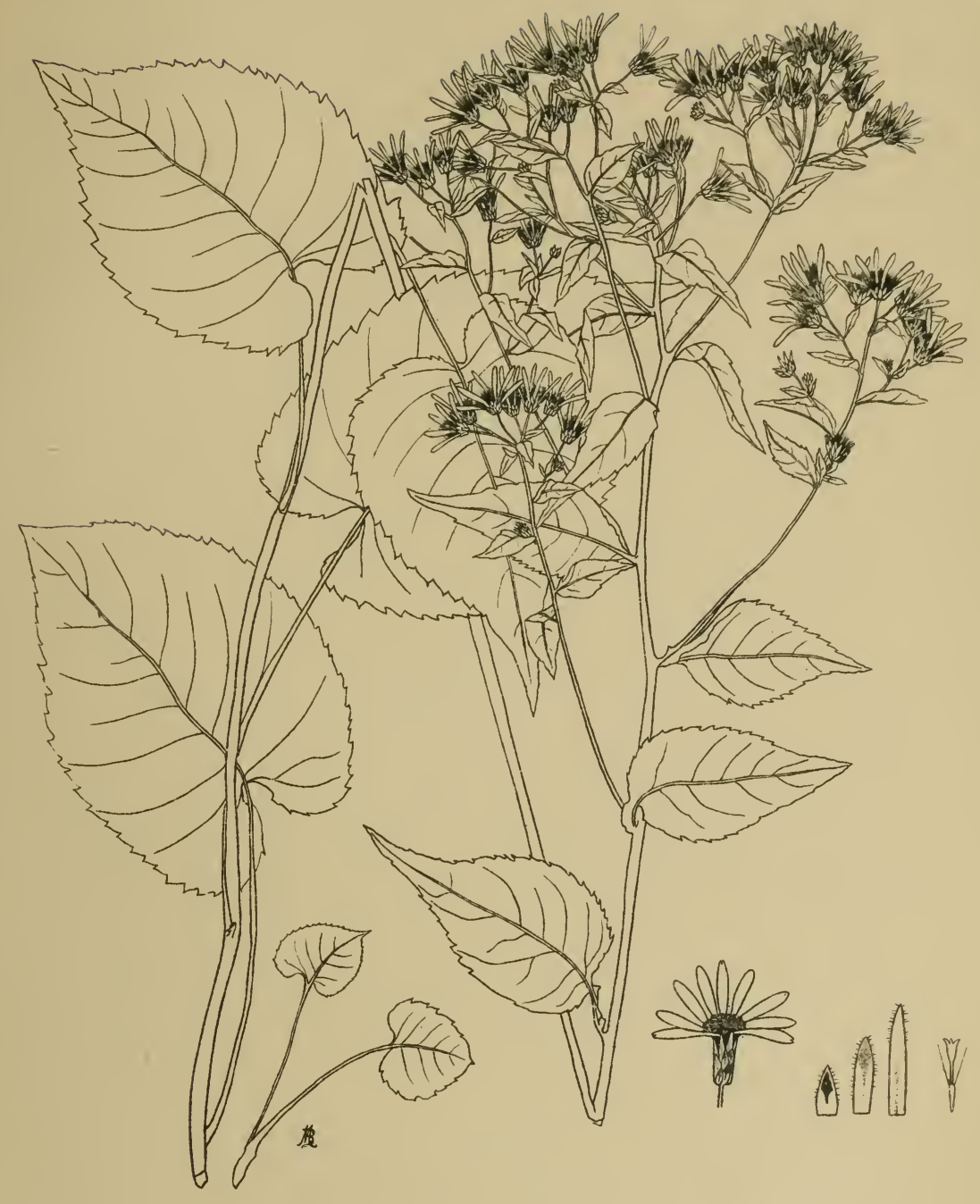

ASTER UMBELLIFORMIS

THE HELLOTYPE PRINTING CO, BOSTON. 

Conn., Southington, rich open woods, not common, Au. 20, '98, C. II. Bissell, in hb. N. Y. Bot. Gar.

Conn., C. Wright as A. corymbosus in hb. Gray.

Conn., Meriden at West Peak, Au. 27, '89, James Shepard in hb. Bu.

N. Y., Oneida L., at Oneida Falls on Oneida Cr., Au. 14 and Se. 1o, '99, Gerrit $S$. Miller, Jr., in his hb. S. Nat. Mus.

N. Y., Slocum's Pond, at Evans Mill, Au., '81, Mrs. L. F. Ward in hb. U.

N. Y. vic., Yonkers, Lincoln Park, Jul. 26, '96, Bi., Hillview, swamp, Jul., '97, Bu. ; Stanford Ave., spring, Jul., '97, '98, '99, 1900, 1901, 1902, 1903, 1904, 1905, Bu.

Ohio, Cincinnati, '8o, Lloyd, in hb. Mo. Bot. Gar.

Ills., "Peoria, shaly, rocky ravine, Au., '91 ; rare here," Frank E. McDonala in hb. W. Deane.

Minn., Sandy Lake copses, '91, Sandberg, no. 18908, in hb. U. S. Nat. Mus.

Del., Mt. Cuha, Se. 31, '96, Joseph Crawford in hb. U. S. Nat. Mus.

D. C., Washiniton, '86, H. M. Smith in hb. Bu. Nat. Mus.

D. C., "Washington, A. macrophyllus? '73," Vasey, no. 18915 , in U.S.

D. C., Lobelia Run, July 19, '86, H. W. Henshaw in hb. W. Deane.

Va., Potomac, bank, Violet Rock, Oc. 29, '88, Spout Run, Oc. 2, '88, Bu.

Va., Nick's Cr., Au. 5, '92, Jn. K. Small, in hb. Colu., hb. Porter, hb. W. Deane, etc.

W. Va., Upshur Co., near Bucklin, '92, coll. Pollock in hb. Mo. Bot. Gar.

Hb. Bernhardi as " $A$. macrophyllus" and mounted on sheet with a frag. ment of that species; in hb. Mo. Bot. Gar.

Hb. Bernhardi also, a plant labeled " $A$. Phila. Kin," and "A. niveus, no. 6," and as "Aster 1709 V[iget] July."

Hb. Berol., specimen reported by Dr. L. M. Underwood; the sheet endorsed in the hand of Willdenow " 288 . Aster corymbosus an etiam macrophyllus. Muhlenberg misit." To which Gray added when examining the sheet in 1880, "Forma intermedis sed ad macrophyllam nit."

$43^{2}$. Candelabriform plants accompany the umbelliform or typical plants and produce a more irregular inflorescence with strong branches directed outward and then upward. Conn., Yonkers, Potomac, etc.

$43^{3}$. Urceolate plants also accompany these, with the outcurved branches becoming incurved upward and recurved at the top.

$43^{4}$. Red-stemmed plants occur as late-flowering outliers in the sun, sometimes of very robust development and over 4 feet high ; as at Yonkers Ave. swamp, Oc. 3, '9 I, Bi.

$43^{5}$. A. umbelliformis $\times$ A. macrophyllus; probable hybrid, differing from preceding in having hispidulous lower leaves, pubescent branches, and stalked glands.

N. Y. vic., White Plains,' 87, Miss P. A. McCabe in hb. Torrey Bot. Club. $43^{6}$. A. umbelliformis $\times A$. divaricatus; probable hybrid, un- 
like the former parent in having sharper, stronger teeth, and upper caulines and large axiles resembling lanceolate leaves of the latter.

Va., Potomac bank, near Washington, Spout Run, Oc. 2, '88.

\section{Division B. GLOMERATE AND SCHREBERAN ASTERS.}

Bracts highly coriaceous, chiefly pale and obtuse, with green tip and midrib. Species 44-54.

\section{Subdivision A. Glomerate Asters.}

Inflorescence rather dense, quite regular, not very large. Radical colonies not very conspicuous. Species $44-47$.

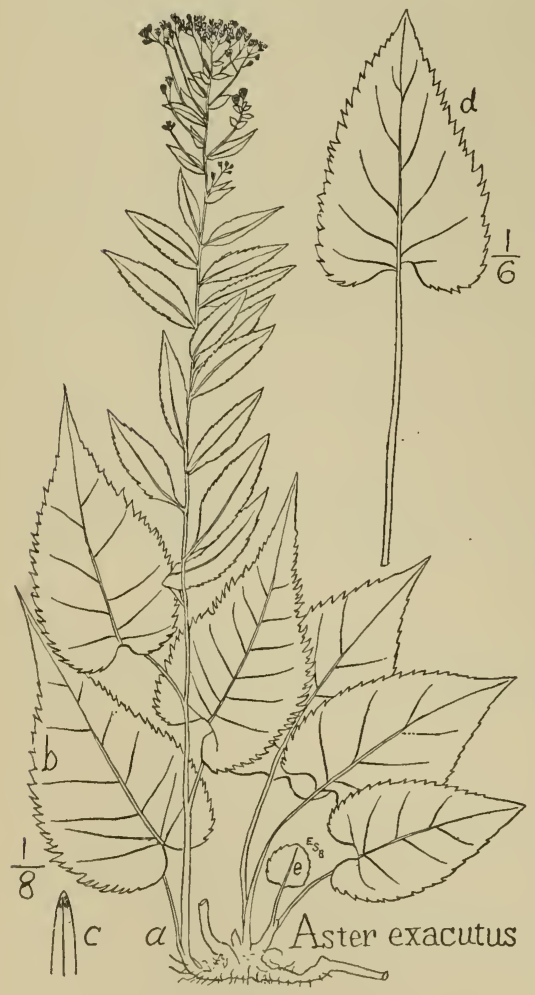

FIG. 57 .

* Bracts glabrate, but little ciliate, acutish or attenuate-obtuse, teeth close, sharp, outflung; leaves almost glabrate.

44. Aster exacutus sp. nov. Slender wand-like plants with about 3 triangular-ovate slit-margined radicals and as many similar lower leaves, followed by r 2-1 8 small elliptic-acute caulines and many small heads in a flat-topped corymb.

Name, L., = very much sharpened; from the very acute teeth and leaf-apices.

FIG. 57, from plant of dry wooded bank of the Hudson near Hast. ings, N. Y., coll. Bi. in hb. Bu., reduced to $1 / 8$ nat. size; rays omitted; $b$, characteristic leaf-form; $d$, common radical form; $e$, primordial leaf.

Stem about $2 \mathrm{ft}$. high, greenish-brown, smooth and terete, its nodes about 2 in. remote below, $1 / 2$ in. or less above.

Leaves deep green, of thin and dense texture, of two distinct types, the triangular-ovate radical and lower cauline 4 or 5 in. 
long, about 3 in. broad, with long slender petioles; their broad sinus open and shallow or closed by overlapping; the basal lobes elegantly rounded. Upper and lower caulines are typically ellipticacute or oblong-lanceolate, numerous and close, spreading and horizontal, nearly or quite sessile, $3 \times \mathrm{I}$ in. or becoming finally half that size, sharp-serrulate or finally subentire. Axiles steadily diminished from the last. Rameals small and inconspicuous, rather numerous, lanceolate or oval-oblong.

Teeth of slit-serrate type, remarkably uniform throughout the plant, very close, long-acuminate, directed outward on the best developed lower leaves, directed forward on the middle and upper caulines.

Leaves glabrous, their upper surface rough, the lower smooth. Petioles to the radicals exceed the leaf-length and are notably long and slender. Radicals of typical development are usually preceded by a small subcircular primordial, I in. or more broad, with crenate teeth or shallow sinus.

Inflorescence flat-topped, a typical compound corymb of highascending successively-lengthened branches, nearly simultaneous in flower, with small heads $1 / 4$ in. high.

Bracts coriaceous, rather thin, somewhat keeled along the midrib, somewhat short-ciliate, pale, but with small deep-green tips, all narrow, mostly linear-attenuate with obtuse apex. Rays narrow, creamy, about 8 . Pappus becoming ferruginous.

With $A$. Schreberi, from which it seems a very distinct offshoot.

N. Y., vic., Hastings, dry loose soil, wooded bank of Hudson R., July, '97, Bi. Ludlow, July, '97, Bi.

Va., near Marvin, Smyth Co., July, '92, Jn. K. Small.

\section{Aster Eriensis sp. nov.}

Small plants with smooth firm slit-serrate oval-acute leaves, conspicuous axiles, close convex inflorescence, with white or reddened rays and acutish lower bracts.

Name from occurrence, near the southern shore of L. Erie.

FIG. 58, plant from L. Erie, Rosebrook woods, Au. 2, I900, in hb. Bu., 1/4 natl. size; $b$, characteristic leaf-type; $d$ and $e$, radicals (Au. 14, '96). Rays omitted.

Stem low, I or $\mathrm{I} / 2 \mathrm{ft}$., reddish-brown, smooth and terete, widely and loosely branched above.

Leaf-form oval-acute, with continuous deep sinus, and finely slit-serrate margin, not large, about $3 \times 2$ in. or less, with conspicuously narrow-shouldered base. Texture dense and firm, smooth when fresh and almost so when dry.

Petioles rapidly diminished, narrow and weak, the lower ones 
longer than the leaves, the middle ones hardly as long as the leafbreadth, and ceasing with the axiles. Veins usually smooth beneath, pale above.

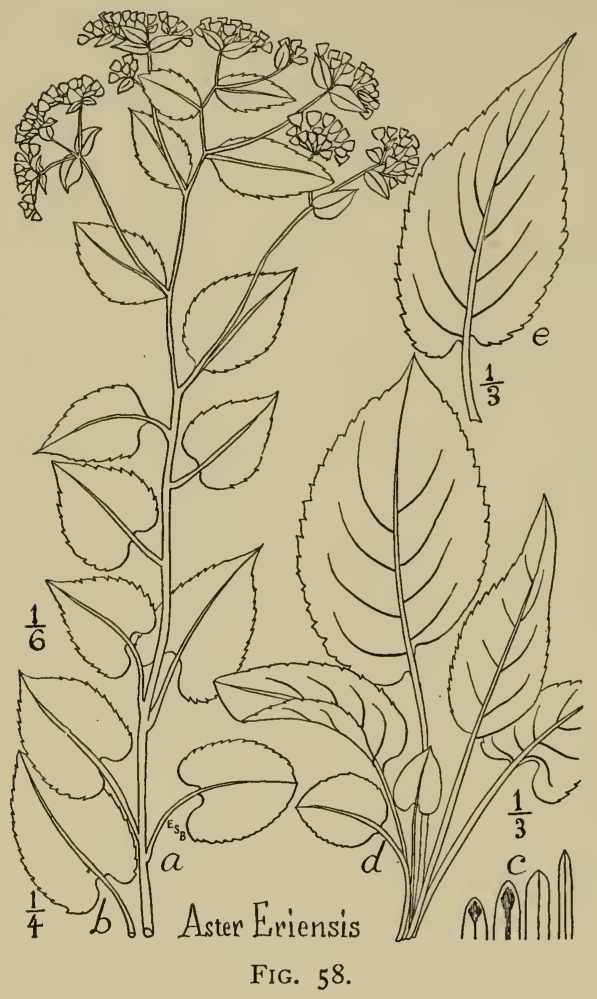

Sinus becoming finally shallow and broad in the upper caulines, which are deltoid or are lilac-like and soon apt to become shortacuminate and much reduced in size.

Hair almost absent, even from the bracts.

Inflorescence composed of a number, 3-6, of densely glomerate clusters, the whole pressing into a broken convex top, each cluster itself convex, and somewhat leafy-subtended, conspicuously so in large plants.

Heads small, subsessile; involucre $\frac{3}{16}$-in. high, bracts rigid, brownish, obtuse, or the lower acutish, chiefly with diamond-shaped green-tips.

Pappus copious, soon dark, tawny within three years.

Rays 6-8, but very often partly deficient, dull white, rounded at apex, often drooping, sometimes rose colored in the sun.

Habitat, low grounds in slight shade of thickets or thin trees, L. Erie shore in Chautauqua Co., N. Y.

\section{Examples:}

W. N. Y., Sheridan, Reed's swamp, Au. I, I900. Hanoter, Rosebrook woods, July $3 \mathbf{1}$ and Au. 2, I900. Silver Cr., Talcott's Brook, Au. 15, '96. Pomfret, Glasgow, Au. 14, '96. Cattaraugus Resn., Big Indian Cr., July 31, '96; Indian Twin brook, Au. 3, '96.

Differs from $A$. glomeratus which it most resembles, in its earlier blooming longer rays ; smoother leaves with almost no hair beneath, even on the veins; bracts more apt to be acutish, and almost wholly non-ciliate; axiles much larger; stem more reddened; teeth about twice as close, of slit-serrate type. Differs 
also in its growth more in the sun, and more inclined to form roundish clumps of many close stems.

** Bracts ciliate ; teeth of crenate-serrate type. Heads in a domed mass, quite compact; leaves of coarse heavy texture.

\section{Aster glomeratus Bernhardi in Nees.}

Small rigid plants with little firm rough roundish leaves, close crenate teeth, broad deep sinus, pilose veins or under-surface, short rays, subsessile heads, obtuse bracts, and wide-angled branching.

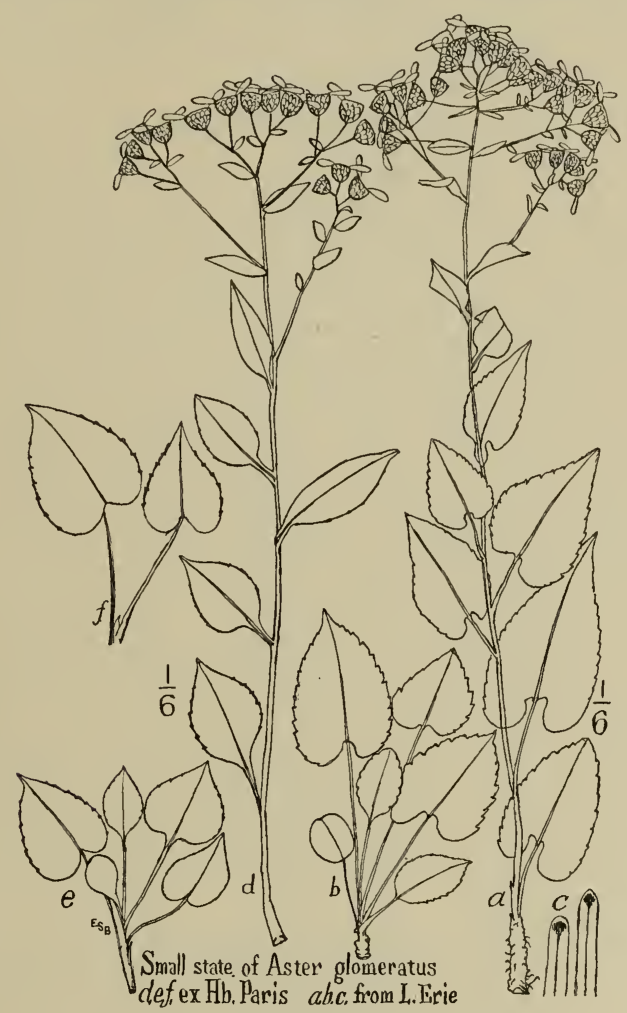

FIG. 59.

Name, L., from the inflorescence.

FIG. 59, small states; $d, e, f$, the ancient $A$. glomeratus specimen of the $\mathrm{Hb}$ Mus. Paris, as drawn in $\mathbf{1} 900$; and $a, b, c$, corresponding native examples from Can. adaway Cr., near L. Erie, Au. 10, '96, in hb. $B u$.

FIG. 6o, plant from L. Erie, Rosebrook woods, N. Y., Au. 31, '99, coll. Bu. in hb. $B u$; $b$, characteristic leaf-form, lower caulines; $b^{\prime}$, of middle caulines. One fifth natl. size. 
A. glomeratus Bernhardi in litt. ad Nees; cited, Nees, Gen. Ast. 139. 1832.

Eurybia glomerata Nees, Gen. Ast. 139. I832, with original description; see infra, p. 270.

Biotia glomerata D. C. Prodr., 5: 183. 1836.

Aster glutinosus Bernh. [fide D. C., Prodr., 5 : 250]. But perhaps this was by Bernhardi meant for a macrophyllus-form in young state and therefore with subsessile buds. Such a specimen of young subsessile $A$. macrophyllus was not long after this identified by Boott in N. Y. or N. England as Biotia glomerata; fide specimens so labelled in Torrey herbarium. Whether $A$. glutinosus Bernh. really represented one of the Macrophylli or was correctly relegated by DeCandolle to his giomeratus, the name was in any case invalidated, an Aster glutinosus of Cavanilles, J790-I80I (later becoming Grindelia glutinosa Willd.) already existing. Another Aster glutinosus, of Roxburgh, was by D. C. referred to Commidendron rugosum. See also $46^{6}$, infra.

A. glomeratus (Nees) Bernhardi; Burgess in Br. and Br. Ill. Fl. $3: 358$. I898, with fig. 3739 , and description as follows :

"Loosely clustered, dull green. Leaves not large, mostly short-pilose beneath, thickish, rough above; basal leaves present, these and the lower stem-leaves cordate with a deep narrow sinus, the teeth sharp, rather close and small; petioles slender, ciliate; upper leaves much smaller, ovate, truncate with a short broadly winged base, or the uppermost ovate to lanceolate, sessile, entire ; inflorescence compact, of many glomerate clusters, round-topped; heads about 4 lines high; bracts pubescent, obtuse, green, the inner twice as long as the outer; rays about 6 , cream-white, short, soon deciduous; disk turning brown. - In moist thickets or swamps, especially in ravines, N. Y. and Penn. July."

Small plants in loose colonies with a moderate development of radicals, which are chiefly 2 , and nearly equal, cordate or cordateoblong, with a deep full sinus, their size reaching about $4 \times 3$ in., or even $5 \times 4$; often with 2 or 3 additional smaller leaves, 2 in. long or less, elliptic, broad ovate or without any sinus. Occasionally a particularly strong rootstock will produce as many as 6 radicals and all without sinus. Their naked slender petioles equal the leaf-length. Usually a single subcircular primordial leaf persists, sometimes about I in. long, remotely toothed, with a narrow petiole about $I \frac{1}{2}$ in. long.

Lower caulines small, 4 or 5 , nearly alike, short rounded-cordate, $3 \times 2 \frac{1}{2}$ in. or less, short-acuminate or abruptly apiculate with obtuse apex, with a broad deep conspicuous sinus and slender naked ciliate petiole; chiefly with sharp crenate-serrate teeth.

Middle caulines diminished rapidly through subcordate or truncate-ovate to ovate, with short petioles equalling $1 / 2$ the leaf-length and distinctly winged.

Upper caulines ovate-lanceolate, often subentire, with a broad short wing.

Axiles oblong-lanceolate, prolonged, chiefly sessile, entire. 


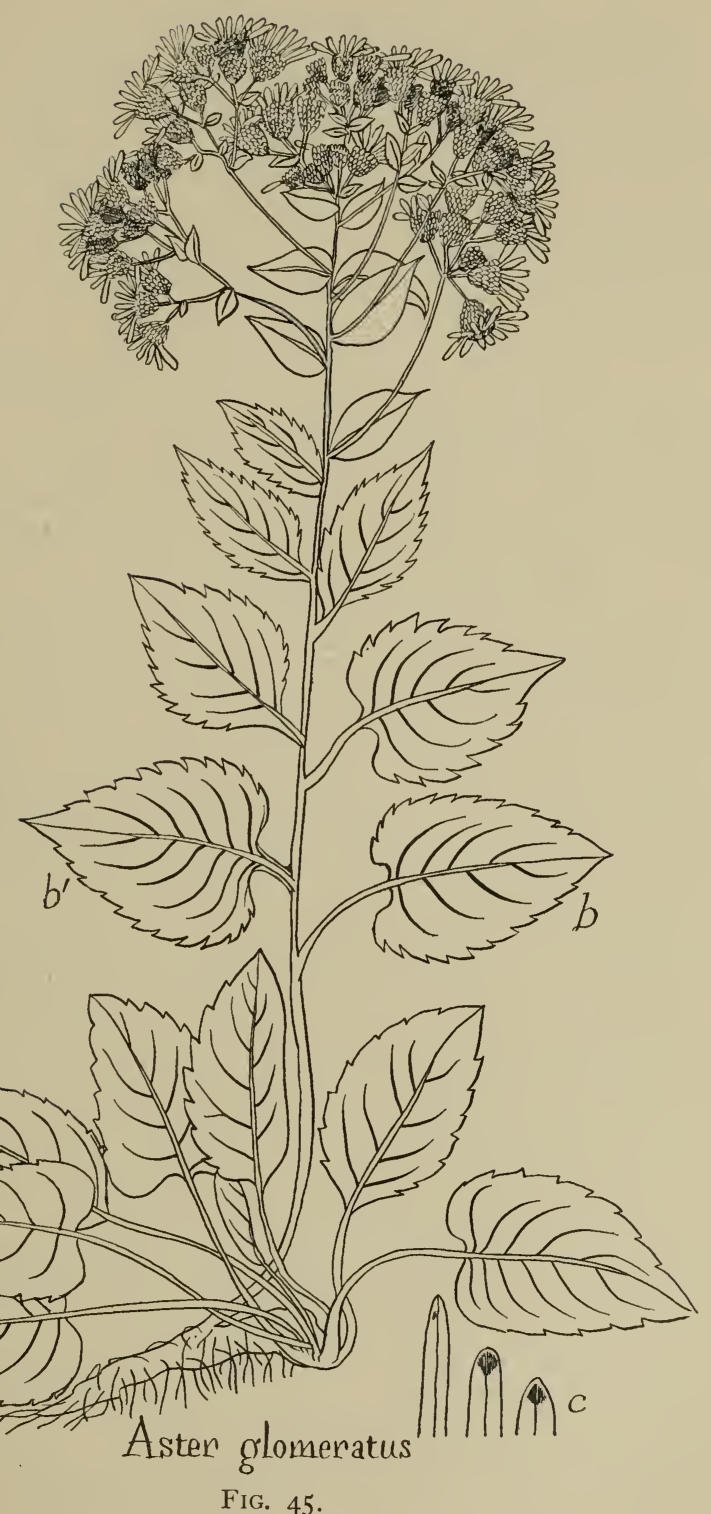


Rameals shorter but broader, developed only at the top of each branch.

Leaves all nearly symmetrical, apple-green. Texture thickish, firm, rough above while fresh, much more so on drying. Under surface obviously downy, at least on the chief veins, and throughout upon the lower leaves; in extreme cases bristly. Venation fine and close, the rather uniform areolation conspicuous beneath under a lens, because of the darker veinlets. Teeth subcrenate, finally of slit-serrulate type above ; the lower leaves with occasional aquiline, curvescent, or slit-serrate teeth intermixed.

Inflorescence convex and irregular, 3-5 in. across, compact and bunchy, with the $20-40$ small heads so numerous and close as to overlap thickly on pressing, in bud sessile and conical, then globose, finally with pedicel $1 / 3$ in. long or over.

Bracts pale, with heavy dark-green tips, strongly ciliate, smoothish-backed, suddenly obtuse; the lower broad, acutish or obtuse, the inner ones twice as long, narrowly oblong. Involucre greenish, close-imbricated, $1 / 4$ in. high.

Rays about 6 , sometimes Io, very short, very deciduous, cream-white, bidentate or acute. Disk-flowers about 20, yellow turning brown, short-bell-shaped, drying narrow-oblong. Achenes thick-fusiform, about I4-striate, usually well-covered with dense short tawny hair when ripe; more so perhaps than any other Biotian species. Annulus broad, pale, not decurrent.

Pappus whitish, ecru at end of flowering, soon faintly rufescent; the apex thickened.

Pubescence of three forms when fully developed:

I. Strigose pubescence, causing much roughness; long, stiff, sharp, pale, few-celled bristles, appressed and pointing forwards ; over the upper surfaces and along leaf-edges, and in some bristly plants occurring also over the under surfaces.

2. Scurfy pubesence, scattered beneath, and covering the midrib and principal veins thickly on the upper side.

3. Soft pubescence, making the under sides downy to touch when fresh; brown, spreading hairs, much longer, tangled when dry, commonly IO-2O (sometimes 40 ), cells long, constricting and twisting at the cell-ends, not beaded by any conspicuous condensation of cell-contents at the cell-bases. These are also abundant over bracts and pedicels. Such hairs also occur, but much reduced, in $A$. Schreberi.

Habitat, in grass and low districts with moist, loose soil, near streams or in swamps, especially in ravines. N. Y. and Ohio to Georgia. 


\section{Examples:}

N. Y., Catskills, Kaaterskill Junction, Se. 7, '99, Bu.

N. Y., Albany Co., Tivoli Pond, near Albany, in N. Y. State Hb., coll. 1870-8o by Prof. C. H. Peck as "A. macrophyllus with small petiolate leaves."

W. N. Y., Steuben Co., Rathboneville, on Conhocton R., in N. Y. State Hb., '93, C. H. Peck, as "A. macrophyllus, form approaching A. corymbosus."

W. N. Y., Cattaraugus Co., Persia, at Forty Hollow, near Gowanda, close to Cattaraugus Cr., Au. 29, '96, Bu., passing out of flower.

W. N. Y., Chautauqua Co., Silver Cr. at Wimer's Clearing, Au. 21, '97, in quantity, in full flower and passing out ; plants not found there since, though searched for, '99-1902. Hanover, Rosebrook woods, wide-branched plants standing erect and bushy, out of flower, Au. 31, '99. Pomfret, Darby Switch, full flower, Au. 1o, '96; some surviving ' 98 .

Penn., Phoenixville, Se., '96, W. K. Fisher.

Penn. ; perhaps it was from the Cove Valley, Perry Co., Pa., where Pöppig botanized 1824 , and whence he supplied plants to Bernhardi, that Bernhardi's original specimen came, published by Nees in 1332 . ?

Penn.; perhaps it was also from Penn. that Michaux's specimen came, now in the hb. Michaux (in hb. Paris) : the plant figured Fig. 59, d, e, f.

Ohio, near Sandusky, E. L. Moseley in hb. Mo. Bot. Gar.

Ga., Madison Springs, H. W. Ravenel in hb. Gray; considered by Gray at time of writing the Synoptic Flora, as "extreme form of $A$. macrophyllus, var. Schreberi" ; labelled by Ravenel "Biotia commixta? DC. Sept. Low grounds near Madison Springs, Ga., legit H.W. R." - Plant not A. commixtus, for it has no glands; has short hair on stem and leaves beneath, also on achenes; young heads subsessile, older with $1 / 2$ in. pedicels. Seems a loose-flowered, non-cordated plant of $A$. glomeratus, but has more slender inner bracts than are normal.

Ga., Beyrich, in hb. Bernhardi, now in hb. Mo. Bot. Gar.; original label "Aster corymbosus, Ait. Georgia, 1833, Beyrich." Plant similar to the last, with little ovate caulines, only one with slight cordation; the wing petioles conspicuous; very rough and coarse, but almost glabrate.

The usual occurrence of $A$. glomeratus is in small patches of 10 to 100 plants, their stems a foot apart or more, remarkably uniform in bloom, and of brief duration, the rays being quickly deciduous. The colonies themselves seem very short-lived compared with other Biotian species; I have repeatedly found a colony one year and returned to examine it another year only to find it obliterated; as if its flowering exhausted the vitality of its rootstocks. I have then repeatedly visited the spot to see if new growth from old rootstocks did not appear, and have found no trace for years together; although the land remained uncultivated and undisturbed.

Those who search for it will not find the glomerate character so marked in nature, it being best brought out in pressing. The original which suggested the name was itself a pressed specimen, now apparently lost, none under this name remaining in the herbarium of Bernhardi; nor in the herbarium of Nees as represented in the British Museum (Nat. Hist.), and in the Gray Herbarium. 
Allies. Its nearest affinity seems $A$. Eriensis, which differs in its glabrate leaves almost without hair on the veins, in its nonciliate bracts, its compound inflorescence of separated cymules, etc. A. Schreberi and the other Schreberan species differ in their larger and more numerous radicals. A. Julianus has a taller inflorescence, thinner leaves and less pubescence. Most typical plants of $A$. glomeratus are almost unique among Biotian asters in their small bristly crenate rounded-cordate apiculate lower caulines ; but numerous variants diverge from these toward the species abovenamed and toward $A$. divaricatus.

\section{Variants :}

$46^{2}$ Globular form, the extreme of condensation; branching flattening when pressed into an overlapping circle $2-4$ in. across, with $20-50$ heads, each branch itself also repeating this circle in miniature. With the type at Chautauqua, Cattaraugus and Albany county localities.

$46^{3}$ Expanded form; the opposite extreme; sometimes 200 heads, with inflorescence 8 in. across and 9 in. high; heads reaching $\frac{1}{2} \mathrm{in}$. high, rays 8 to $\mathrm{IO}$, the lamina $\frac{5}{16}$ in. long, $\frac{1}{16}$ broad. Localities in W. N. Y.

$46^{4}$ Pedunculate form; leaf-form not, as in all the preceding, diminished gradually to the top of the stem; but with the leafseries suddenly arrested after about 3 lower leaves, the numerous remaining leaves small and bractlike, I in. long or less, with very short winged petiole, all nearly of one size. Common with the type, W. N. Y.

$46^{5}$ Pomarial form, orchard-like plants resembling little looselyglobose apple-trees standing at little spaces apart with grass or radicals only between; smallest of the Curvescentes, I or sometimes I $\mathrm{r} / 2 \mathrm{ft}$. high. Radicals often 6 and all without sinus ; caulines all remarkably small. Leaf-form ovate-triangular, obtuse. Texture heavy, flabby, a little rough while fresh, hispidulous when dry above and bristly beneath. Teeth sharper but bracts more rounded than in type. Inflorescence a dome-like top quite large for the plant, 6-8 in. across; not densely flowered.

W. N. Y., Hanover, Rosebrook woods, Au. 3I, '99; the type growing near.

$46^{6}$ A glomeratus $\times A$. macrophyllus pinguifolius? a probable hybrid, both assumed parents growing in the vicinity. Leaves smooth, thick, flabby; upper caulines oblong, with truncate base and shallow teeth; lower caulines shallow-crenate; rootstock stout. Tends to glutinous hair and pedicelled glands, as in $A$. macrophyllus; but shows all the inflorescence-characters of $A$. glomeratus, and also its leaf-form. - Bernhardi's A. glutinosus, if it were recoverable, should be compared with this.

W. N. Y., bankside thicket near the mouth of Big Indian Cr., July 31, '96. 
$46^{7}$ A. glomeratus $\times$ A. macrophyllus; probable hybrid; both assumed parents growing in vicinity ; differs from $A$. glomeratus in showing upper leaves of $A$. macrophyllus.

W. N. Y., Indian Twin Brook, within a mile of $46^{6}$; Au. 3, '96.

$46^{8} A$. glomeratus $\times A$. divaricatus; probable hybrid; both assumed parents growing in the vicinity; differs from the former in its slenderer flexuous stem, larger, sharper, more salient teeth ; as in the latter species. Very thin smooth elliptic-lanceolate leaves predominant.

W. N. Y., with $46^{6}$; probable hybrids of the same species but with $A$. divaricatus prepotent, also occur; for another, A. oviformis $X$ A. glomeratus, see no. $4 \mathbf{I}^{3}$.

History. Bernhardi's Aster, Aster.glomeratus, was first so named by Bernhardi, of Erfurt, in letters written to his friend Nees between the dates of Nees' two monographs on the Asters, I 818 and I 832 , sending Nees a specimen with this name, and the assurance that numerous other examples of the same had arrived from different parts of North America, all very different from $A$. Schreberi, the nearest congener recognized by Nees.

Perhaps this original Erfurt plant of $A$. glomeratus was one of the Biotian Asters collected by Pöppig in Cove Valley, Perry Co., Pa., in 1824 ; specimens forwarded the next year to Dr. Radius, of Leipsic, presently finding their way into the herbaria of Bernhardi, Günther and Willdenow.

Johann Jakob Bernhardi was born in Erfurt, in Prussian Saxony, 7 Sept., I774, and died there I 3 Mar., I850; was professor of the medical faculty of the ancient University of Erfurt, director of its botanical garden, and an important author on the flora of Germany. He published a catalog of the Erfurt Garden, I799, an extensive descriptive flora of the Erfurt district, I 8 10, a general handbook of botany in 1804; he wrote on lichens and ferns, and gave much time to the more purely horticultural side of botany, till I 824 editing journals devoted to gardening, the Thuringisches Gartenzeitung and the Allgemeinen deutschen Garten magazin. It was doubtless largely due to him that Erfurt became a city famed as widely for its horticulture as it had once been as the temporary residence of Luther.

To the student of Asters, Bernhardi is of special interest as the source of very many of Nees' original specimens, as credited in the successive pages of Nees' Genera Asterearum. In his Synopsis Asterum, 1818, Nees had already expressed his great indebtedness to Bernhardi for information, adding that he had received specimens of most species from their native soil, and that Bernhardi was his special source. 
If Bernhardi travelled and collected in America himself, it might have been between I 806 and I 8 I 5, a period which forms a gap in Bernhardi's activity in publishing at Erfurt. Such an experience would account for the fact that Bernhardi was Nees' special informant respecting the experience and practice of American collectors, ${ }^{*}$ e. $g$. :

Nees' Gen. Ast., p. 77, Bernhardi tells Nees that American botanists knew as A. lanceolatus the species which Nees called $A$. obliquus.

P. I65, Bernhardi informs Nee's that "plant-lovers of the New World" call by the name $A$. hyssopifoizus the species which Nees called Galatella dracunculoides.

Bernhardi's own original aster species were four, and all fall close together in the Biotian group, $A$ glomeratus, $A$. subcymosus and $A$. ambiguus being Schreberan species and $A$. glutinosus probably a form or ally of $A$. macrophyllus. Of these $A$. glomeratus best commemorates Bernhardi, being the only one given specific rank by Nees in his monograph. Unfortunately no specimen bearing any of these names survives in the $\mathrm{Hb}$. Bernhardi as now preserved at the Missouri Botanical Garden.

Nees' original description of A. glomeratus, Gen. Ast. I 39, is as follows :

2. Eurybia glomerata Bernh.

E. foliis inferioribus sinu lato cordatis alate petiolatis, superioribus ovato-ellipticis subsessilibus, omnibus serratis supra in ambitu subtus ad costas scabris, caule glabro apice thyrsoideo, periclinii arcte imbricati foliolis ovatis obtusis, radio vix periclinium aequante.

Aster glomeratus Bernh. in litt.

Crescit in Pennsylvania (Bernhardi). Vidi exemplum spontaneum siccum, ab amiciss. Bernhardio traditum. Accedit ad Eurybiam Schreberi, a qua quidam inflorescentia compacta floribusque minoribus facile distinguitur. Caulis angulatus, glaber, purpurascens, simplex, solo apice divisus. Folia radicalia nostro exemplo desunt; caulina inferiora in petiolo unciali et longiori alato ciliato bipollicaria et longiora, $1 / 1 / 4-$ I $1 / 2$ pollices lata, cordata, acuminata, in medio mucronato-serrata, apice integerrima, supra in ambitu, subtus in nervis scabra, penninervia, neque nervata, reticulo interjecto subtilissimo; quae sequuntur folia in petiolo brevi latissimoque ovata acuminata, tum alia ovati basi contracta sessilia, suprema denique ovato-oblonga sessilia vel brevissimi petioli interjecti specie adnata, subserrata vel integerrima. Rami folia aequantes, vix pollicares, in apice caulis approximati, erecto-patuli, angulati, ad angulos pubescentiscabri, basi nuđ̃i, apice foliis unguicularibus ovatis integerrimis calathiişue subsessilibus agglomeratis praediti. Calathia quadrilinearia, 6 circiter lineas lata. Periclinium disco duplo brevius, ovatum, pubescens ; foliola arcte imbricata, obtusa ; inferiora ovata, medio viridula, margine membranacea et ciliata ; superiora vel intima duplo majora, oblongolinearia, tota membranacea, purpurascentia. Clinanthium planiusculum, alveolatum, marginibus alveolorum in dentes breves acutos solutis. Flosculi disci lutei, demum

* Still more frequently Bernhardi was Nees' authority for habitats; for Pennsylvania in case, p. 107, of $A$. ericoides - as well as for $A$. glomeratus; for New York in case, p. 88, of a form of $A$. eminens, p. I Io of $A$. divergens, p. I14, of $A$. pendulus ; for Virginia, p. 83 , of a form of $A$. luxurians, one of many specimens furnished by Bernhardi to the hb. Günther; for Carolina, p. 67 , for a short-branched form of $A$. puniceus in Bernhardi's herbarium; and p. 139, for North America as the source of $A$. Schreberi. 
fuscescentes, glabri, angusti ; tubus sensim in limbum transiens erectum, laciniis angustis obtusis. Antherae prominentes. Stigmata subulata, hirta. Radii ligulae paucae, oblongo-lanceolatae, vix periclinii longitudine, apice bidentulae, albae. Pappus pluriserialis, pallide rufescens, scaber. Achaenia linearia, glabra.

Adnot. Plurima sibi esse exemplo, e diversis Americae septentrionalis partibus allata, et ea tum inter se maxime congrua, tum ab Eurybiae Schreberi exemplis Americanis diversissima, per litteras me edocuit cl. Bernhardi.

Subsequent history. DeCandolle, Prodr., 5: 265, repeated parts from the above quoted description, adding (in Latin): "An aster in the garden of Paris 1818 , cultivated under the erroneous name of $A$. corymbosus, seems to belong here, but has ligules a little longer than the involucre, not shorter." Rays longer than the involucre seem the rule with native plants.

Dr. Wm. Boott, a careful student of the asters, and who worked about this time with a copy of Nees' recently published Genera Asterearum now preserved in the library of the Gray Herbarium - sought to identify native plants to correspond to Nees' descriptions. He came closer to it in A. Schreberi, but in $A$. glomeratus his identification proved to rest on a young subsessile state of $A$. macrophyllus, a species which, unlike $A$. glomeratus, is always glandular. The specimen, which is in the Torrey herbarium, still bears Dr. Gray's peremptory correction, "just the ordinary A. macrophyllus."

Boott's identification failing, Torrey and Gray seem to have concluded that no native plants were to occur, and remarking that the species $A$. glomeratus was apparently an accidental state, they omitted the species from the Flora of North America, I84I-3, since which it has remained unrecognized 'till my republication in Britton and Brown's Illustrated Flora in I 898.

I began searching for its native counterpart about the Potomac region in $\mathrm{I} 886$ and onward, but the allied form occurring there which possesses glomerate heads (A. curvescens), has very different bracts and much larger, broader more curving leaves than indicated in Nees' description; and I could never find a representative wholly satisfactory for the true A. glomeratus of Bernhardi until I 896 , when searching for Asters on the continental watershed close south of Lake Erie near the source of Canadaway Cr., when a score of fine plants suddenly looked out upon me from the grassy edge of bushes at the foot of a high bank of crumbling shale. Similar secluded ravines have often disclosed its presence since.

Various unrecognized collections of this species by Beyrich and Ravenel in Georgia, by Professor C. H. Peck in several places in New York state, etc., had meanwhile occurred, and probably it will yet be found throughout the intermediate Appalachian region.

*** Bracts ciliate; teeth of crenate-serrate type; heads in high-convex or cylindrical mass, loose; texture coarse and thin. 


\section{Aster Julianus sp. nov.}

Slender plants with thin, ovate-acute, subcrenate leaves, with broad, deep sinus, scanty hair, acute-angled branching and obtuse bracts.

Name, L., "belonging to July" ; its frequent flowering before the end of July being unusually early among asters.

FIG. 6I, from plant of Cattaraugus Cr., July 30, 1900, in hb. $B u$., 1/8 natl. size, with two radicals $1 / 4$; rays omitted; $b$, characteristic radical leaf-type; second cauline leaf figured shows the chief cauline type.

Stem smooth, terete, brown and straight, $3 \mathrm{I} / 2 \mathrm{ft}$. high or less. Rootstock for some distance slender and horizontal, and then

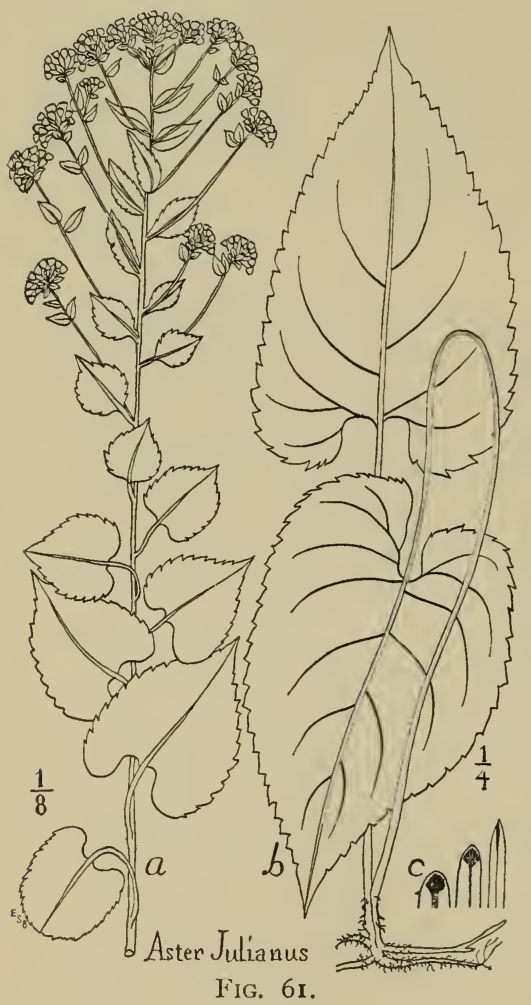
arising in a stout and vertical portion continuous with the stem.

Leaf-form cordate-ovate, acute, broadest slightly above the strong deep sinus, with rounded and somewhat semicircular basal lobes, curvescent teeth, and long, slender petioles. Leaves thinnish, but of coarse texture, smoothish (at least when fresh), dull green and paler beneath.

Radicals $5 \times 3$ in. or less, of scraggly and unkempt aspect, slightly roughened towards the margins, and with a very little hair on the veins beneath, their petioles ro in. long or less, terete and brittle, brownish green.

Caulines numerous, rather distant, the lower or typical leaves $4 \times 2 \mathrm{x} / 2$ or $3 \times 2$ in., with petioles of equal length. Middle caulines broader, with shallower, broader sinus, subcrenate, their slender petioles equalling half the leaf-breadth. Upper caulines becoming ovate-oblong with truncated or somewhat rounded base and short, broad wing. Axiles lance-oblong with short wing, finally lanceacuminate and sessile for the uppermost 4 or 5 inches, these remain- 
ing about $\mathrm{I} 1 / 2 \times 3 / 8$ in., either serrulate or somewhat crenulate. Rameals about 8 , or less, ovate-acuminate and sessile or narrower, all produced near the top of the slender branch, leaving about 4 in. below wholly naked.

Inflorescence obtusely conoid or somewhat cylindrical, becoming a high dome with flattish-convex top, its chief branches ascending, about 12 of nearly equal lengths, 5 or 6 inches long, I-2 in. apart down the stem, the whole inflorescence often $\mathrm{I} \mathrm{ft}$. high by $1 / 2$ foot broad. Each branch bears a somewhat umbelliform corymb about 2 in. broad, of $6-15$ heads.

Heads $3 / 8$ in. high or less, subsessile but becoming rather loosely pedicelled, very dissimilar in their time of flowering.

Bracts narrow, obtuse, pale and coriaceous, with moderate green tips, the inner quite acute. Rays about 8, narrow, acutish.

Hairs on veins beneath very slender, with about Io-cells, sometimes I 5, hardly enlarged at the base.

Habitat, wet soil of swamps or ravines, especially around decaying logs, forming small evanescent colonies intermixed with other weedy plants : Western New York, in Erie and Chautauqua counties, end of July.

Examples:

W. N. Y., Fredonia, Cascade Brook, July 30, '97; plantation destroyed by lumbermen next winter, only a few radicals remaining Au. 9, '98. Cattaraugus Resn., near Versailles bridge, in swamp on Halftown hill overlooking Cattaraugus Cr., July 30, I900, in its prime of blossom.

Allies. This species seems closely collateral with $A$. glomeratus and $A$. Eriensis, but is taller, slenderer, with taller, looser subcylindric inflorescence, different leaf-form, thinner smoother texture and sharper teeth.

\section{Subdivision B. Schreberan Asters.}

Inflorescence loose, more irregular, rather flattish-topped; texture firm. Species 48-54.

* Radical leaves large, in extensive colonies, thin, very broadly cordate. Species $48-54$.

+ Narrow petioles (the radical) long, ciliate; middle petioles winged; upper caulines broadly sessile. Radical leaves ovateorbicular, extremely large and thin, crenate, apple-green. Species 48.

\section{Aster limicola sp. nov.}

Plants with numerous large thin rough crenate-serrate radicals of ovate-orbicular type, with long ciliate petioles; with ovate and 
triangular caulines and winged petioles, short spreading branches and small heads.

Name, L., " mud-dweller," the plant preferring wet, muddy places in woods.

FIG. 62: $a$, from plant of Mosholu, N. Y. City, Se. 30, '96, in hb. Bu., reduced to $\frac{1}{9} ; b$, characteristic leaf-form, of lower caulines, $b^{\prime}$ of radicals ; $d$, radical group of May 18, $1 / 3$ natl. size, showing one primordial, $e$.

Stem green or pale, slender, $2 \mathrm{I} / 2 \mathrm{ft}$. high or less. Radicals large and very thin, apt to number 3 , sometimes 4 or 5 , seldom

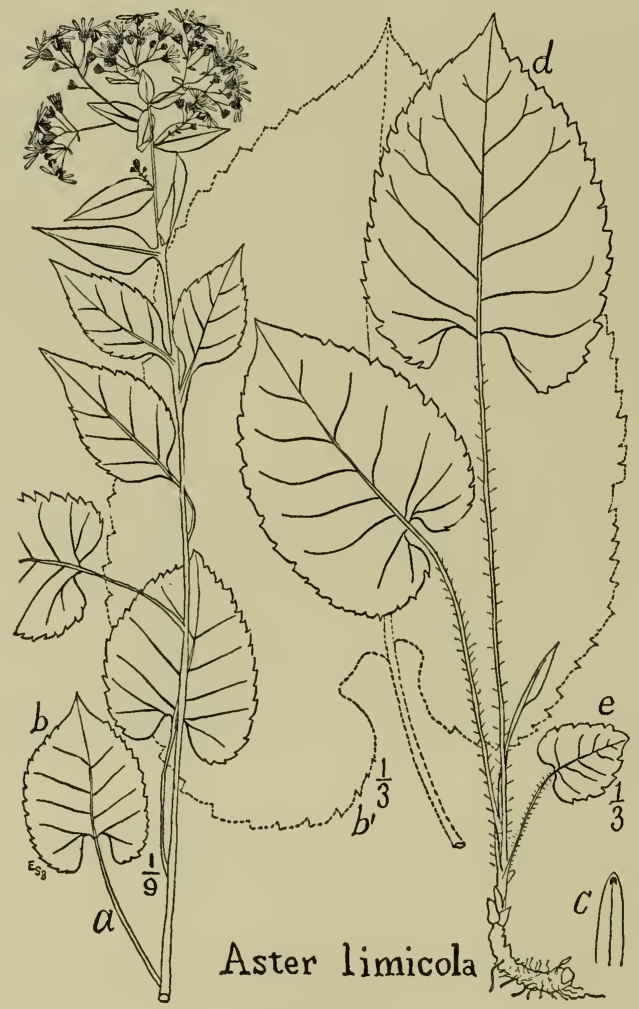

FIG. 62.

only 2 ; $10 \times 6$ inches or less ; their petioles ascending, 6-9 in. long, ciliate with two rows of long spreading remote but conspicuous multicellular hairs. Primordial cordate-triangular, acutish, about $3 / 4$ in. long and broad, with broad conspicuous curving sinus, and slender petiole twice its own length, soon perishing (yellowing by May i 8, N. Y. City). Rootstock short, dark and thick, with very short condensed nodes, ascending $\mathrm{I}$ or 2 in. from that of the previous year. 
Leaf-surface roughish from long weak scattered bristles. Leafform ovate-orbicular, broad well to the apex and toward the muchnarrowed base, usually asymmetrical. Teeth coarse and irregular, long or shallow, of crenate-serrate type, often $1 / 3$ or $2 / 3$ in. long on the radicals. Sinus deep and securiform, much enlarged within, usually with two strong reëntrant angles each side of the petiole, but in growth commonly overlapped by the basal lobes; rectangular and soon shallow in the lower caulines, and then quickly ceasing, the plant being remarkable for its large proportion of wing petioles or of subsessile leaves with truncate or rounded base.

Middle caulines ovate-acuminate, rounded into a short broad wing. Upper caulines and axiles sessile and lanceolate. Apex in lower caulines of apiculate type, very abrupt and acute, $1 / 2 \mathrm{in}$. long; in other leaves rather gradually straight-acute, not very long acuminate. Color full green or rather pale. Hair little, even beneath; but acicular appressed bristles occur remotely on the upper surface of the radicals, very slender and delicate and scarcely thickened at the base.

Inflorescence flattish, 4-5 in. broad, irregular and rather dense, or often scanty, the wide-spread branches very different in length but nearly simultaneous in flower.

Bracts rather narrow, linear, obtuse, the middle and inner ones quite tapering, almost scarious and acute.

- Grows sometimes in similar situations with $A$. umhelliformis and with similar large plantations of radicals; the leaves are much broader and coarser than in $A$. umbelliformis, the teeth broader and coarser, the petioles pilose, ciliate, the leaves more numerous to one radical shoot, often 4 or 5 or more, and a little longer in proportion to breadth.

Habitat, wet woods and banks.

N. Y. vic., Mosholu, Se. 30, '96, many in flower, large colony, continuing the next nine years with scanty blossoming or none, but abundant radicals ; in wet muddy levels in deep shade of small, close-growing, deciduous trees. - Also seldom-flowering, Yonkers, Vermilye's Ridge near Grassy Sprain L.; etc. Ludlow, Au. 27, '9I, Bi. Riverdale, July 26 , '93, Bi., in early flower.

N. J., Palisades, various places along the summit.

Va., Potomac bank, near Washington, July 27 , '77, L. F. Ward in hb. Bu.

$48^{2}$ Lilacifolial form, small dark green plant with little broadly ovate-deltoid leaves but without cordation, much like a lilac leaf in size and shape; allied in its wing-petioles to the above.

W. N. Y., Indian Twin brook, Oc. 20, '96.

†† Narrow petioles continuous up nearly or quite to the axils.

II Radical leaves reniform or deltoid-orbicular, larger, thickish, roughish. Species 49. 


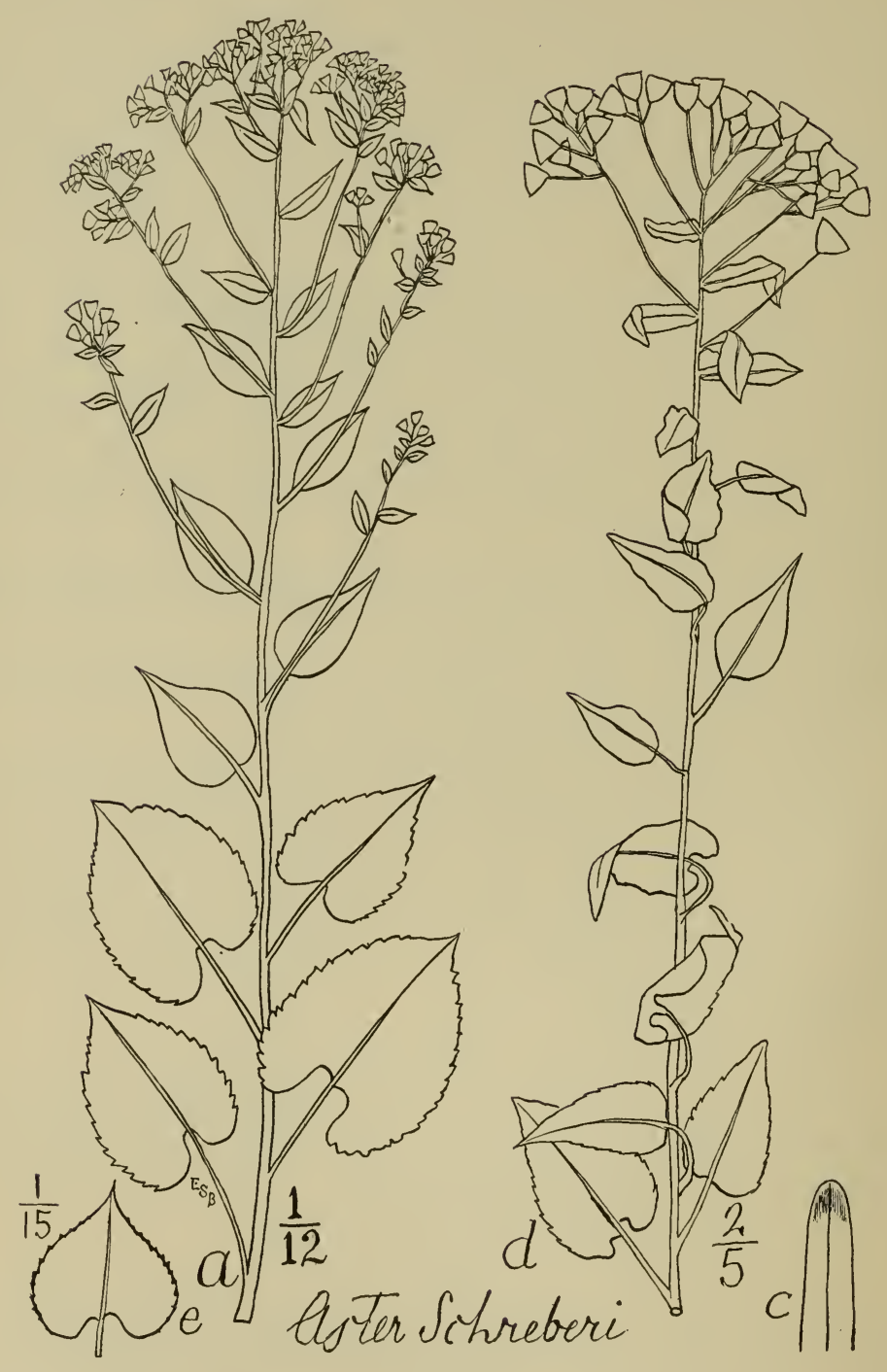

FIG. 63. 


\section{Aster Schreberi Nees.}

Large ample-leaved plants forming conspicuous colonies, with most radical and cauline leaves broadest near the base; with rounded curvescent-serrate margins, and broad or rectangular sinus, thick obtuse bracts and moderately large heads.

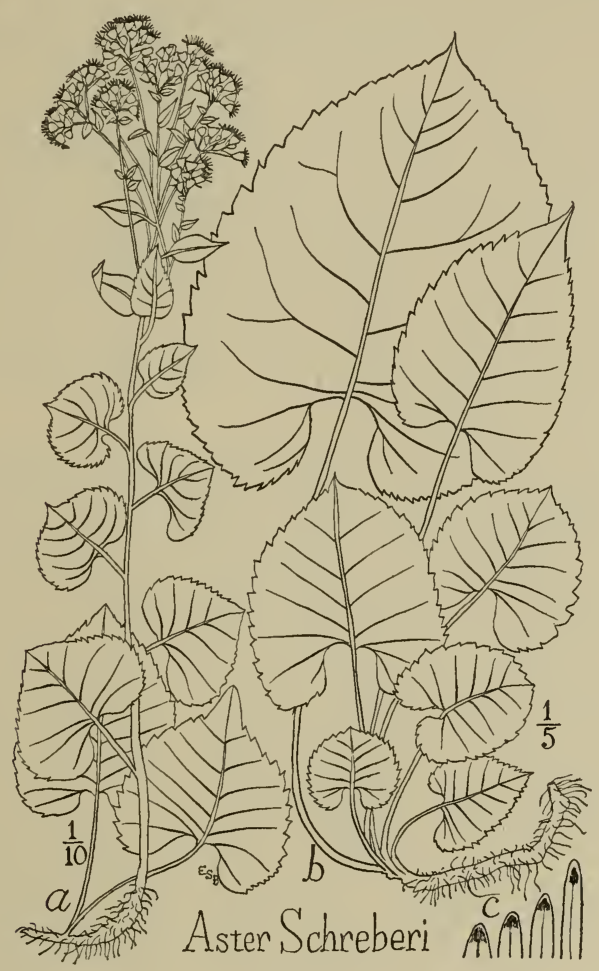

FIG. 64.

Name from the botanist von Schreber, Linnaean editor, professor and director of the botanical garden of Erlangen, who was the source of Nees' type specimen; see p. $28 \mathrm{I}$.

FIG. 63, with facsimile of the name Aster Schreberi as written in Nees' hand : $d$, the oldest known herbarium specimen, one of the Mus. of Paris of 1828 , hb. Gray, $\frac{2}{5}$ natl. size; $a$, the common native type corresponding, from Yonkers, N. Y., near Caryl, Au. 3, '99, reduced to $\frac{1}{12}$, with its radical $e$, $\frac{1}{15}$ natl. size. Rays omitted.

FIG. $64, b$, characteristic radicals, growth as reached on May 21 , ' 88 (Rock Cr., D. C. ), $\frac{1}{5}$ natl. size. $a$, All-reniform form, with typical radicals ; Schoharie Cr., Se. 7, ' 99 ; $\frac{1}{10}$ natl. size.

A. Schreberi Nees, Syn. Ast. 16. 1818, with brief description, see infra. 
Eurybia Schreberi Nees, Gen. and Syn. Ast. 137. 1832; with first full description, cited infra, p. $28 \mathbf{I}$ and 282.

Biotia Schreberi D. C., Prodr., 5 : 264. 1836.

Aster macrophyllus $\beta$, T. \& G., Fl. N. Am., 2 : 105. May, I84I.

Aster Schreberi Nees, Burgess in Br. and Br. Ill. Fl. 3: 359. 1898; with description as follows :

"Stem stout, 2-3 ft. high, with long internodes. Basal leaves often in extensive colonies, thin, dull green, firm, rough above, with scattered slender appressed bristles, pubescent beneath on the veins, reniform-cordate or cordate-triangular, often 7 in. long by 5 in. wide, the basal sinus when well developed rectangular, 2 in. across and I in. deep. Upper leaves ovate-oblong to lanceolate, with a short broad basal wing, or sessile. Petioles of the lower leaves long, conspicuously ciliate when young [in certain forms]. Inflorescence decompound, flattish, or irregularly convex, 6 to I 2 in. broad; heads about 5 lines high; bracts greenish, mostly obtuse, tips and midrib dark-green, ciliate; rays usually ı. In borders of woods and along fence-rows in partial shade, N. Y. to Mich. and Va. July-Aug."

Stem greenish or brown, nearly smooth. Radicals chiefly 3, thickish and firm, thicker than in preceding; thinner than the similar radicals of $A$. macrophyllus, and roughish above with flatter appressed pale remote bristles. Rootstocks brownish, strong but not very much thickened. Primordial rather large and persistent, suborbicular, 2 in. across, with long pendant lobes and narrow sinus.

Leaf-form reniform-cordate or deltoid. Sinus typically broader than in the last, closed by overlapping in growth, when flattened showing one straight line across within, and forming an oblong figure, not polygonal as in $A$. limicola.

Middle caulines still subreniform or deltoid, the sinus becoming broad, shallow and irregular. Upper caulines ovate-acute without sinus, with slender petiole. Axiles ovate-oblong, slightly tapered at the sessile or winged base; the upper axiles lanceolate, usually with short wing. Rameals also often all short-winged, short and oblong-ovate. Pubescence strong on veins beneath, almost lacking elsewhere.

Inflorescence a very irregular broad corymb of several sharply ascending branches different in length and rising therefore to various heights. Some lateral branches often surpassing the inner, but all nearly simultaneous in flower.

Heads about $\frac{7}{16}$ in. high, or including pappus, sometimes $\frac{8}{16}$ in. ; rays chiefly IO, sometimes 8 or $\mathrm{I} 2$, shorter, broader and less tapering than in $A$. curvescens.

Bracts greenish, ciliate, broad-oblong, with prolonged green tips, obtuse, only the innermost essentially more pale or narrow. 
Achenes coarsely striate, glabrate at maturity or wholly without hair, a little twisted and constricted at the summit. Pappus slow in reddening, about equally tinged in plants of I, 5 and 10 years, but deeply so in plants of presumably 70 years.

Habitat, in slight shade, among thickets and bushes, along fence-rows, brook-borders, rocky ledges or wood-openings, Middle States from the Hudson to Detroit and the Potomac.

Examples, usually originally labelled either $A$. corymbosus or A. macrophyllus or A. macrophyllus var.

N. Y., Catskills, Hunter, “A. macrophyllus, '81, Redfield," in hb. Mo. Bot. Gar.; also along the Schoharie Cr., Se. 5, 6, 7, '99, Bu., and at Kaaterskill Junction, Se. 7, '99: Quick's bridge on the Schoharie, Se. 7, '99 (with plants closest known to Nees' description), Colonel's Chair mountainside, Se. 6, '99.

N. Y., Selkirk in Aug., C. H. Peck in hb. N. Y. St.

N. Y., Turnwood, '9I, H. H. Rusby in hb. Colu., with very large heads.

N. Y. vic., Yonkers, Troublesome Brook, heads in seed, Oc. 28, '96; Bryn Mawr Park, Maple Av. rock ledge, Au. I, '98; Mott Farm, Au. I900; Hastings, I 905.

N. Y. vic., Torrey in hb. N. Y. State, I $8_{37-43 .}$

N. J., Palisades, '97.

Pa., Easton, T. C. Porter, '88, '92, '95, '96; Bushkill Gap, Tyler, '96; Bloomsburg, Heller, '89, in hb. Porter; Millvale, Allegheny Co., Curtiss, in hb. Porter.

Mich., Ft. Gratiot, I849, Dr. Pitcher in hb. Torrey (Biotia Schreberi, scripsit Boott).

D. C., Lobelia Run, July 16, '86, not yet in flower, H. W. Henshaze, Asarum Run, '85-'95, Bu. Broad Branch, "Au. 15, '96, a very late date," $H . W$. Henshaw, Lanier Hts., Brook, '88, Bu.

Va., Front Royal, Warren Co., dry bank near Cedar L., at 500, July 18 , '97, Gerrit S. Miller, Jr., in his hb.

Foreign specimens:

"Hortus Paris, I828; A. Schreheri, Nees," in Gray hb. to which Gray scripsit " A. macrophyllus." Gray hb.

Hortus Breslau? 1832? "Eurybia Schreberi, Nees," in Gray's hand, in

Hortus Erlangen? I 820? “A. Schreberi Nees," in hb. Bernhardi.

Hortus Breslau? I830-53, specimen of Nees' in British Museum.

\section{Variants :}

$49^{2}$ All-reniform form. Leaves all reniform to the branches or nearly so; instead of losing the reniform character after the base; some leaves nearly identical with those of $A$. violaris. With the type, of which this is an extremely accentuated state; Catskills, Quick's Bridge over the Schoharie, near the head of Stony Clove, Se. 7, '99. 
$49^{3}$ A. Sclireberi $\times$ A. macrophyllus; probable hybrid. Resembles the first-named parent in decomposite inflorescence, with long, stringy branches; and long, slim pedicels; and in general aspect. Resembles the second parent in thickness of the rough leaves, coarse heads and bracts, with some rays lavender and some glandular hair present on the pedicels.

D. C., Broad Branch, Au. 15, '86, H. W. Henshaw, in hb. Bu.

Hortus Berlin, I839, in Gray hb., labeled in Europe Biotia Schreberi D. C., and by Gray " $A$. macrophyllus $\beta$ T. \& G., Fl. N. Am.," and again by Gray, later, "A. macrophyllus Syn. Fl."

History. I762-6. The earliest specimen of $A$. Schreberi traced, was a plant, assignable to this species according to DeCandolle (Prodr. 5: 264), cultivated in the ancient botanic garden of Leyden as Aster macrophyllus var., and so labelled by the director, the elder Van Royen; doubtless soon after Linnaeus' publication, I762, of the name Aster macrophyllus; and presumably before I 766, when De la Roche, in whose herbarium the plant was preserved, published at Leyden the result of his studies there, in his Descriptiones.

The director, Adrian Van Royen, I705-1779, had already published in 1740 a Flora* of the Leyden Botanic Garden, one of a long series of publications emanating from that garden, which had begun as early as Paaw, I 59I. It had been from this garden that Hermann had described Aster Novi Belgii for the first time in his Paradisus, and that Linnaeus as a young man worked with Gronovius in editing Clayton's descriptions of Virginian plants in 1738 .

The other Leyden authority connected with A. Schreheri, Daniel de la Roche, was a young physician originally from Geneva, and only 23 years of age when he published his Descriptiones $t$ at Leyden.

- I783. The next to possess specimens of $A$. Schreberi may have been Lamarck, who had before 1783 some plants of this subsection, it would appear, referred to $\S$ by Lamarck under $A$. macrophyllus as varying in having a stem "quelquefois trés lisse," or "sometimes very smooth." Nees in I 832 assigned these smooth-stemmed plants to $A$. Schreberi, a determination rendered probable by Lamarck's color-description for A. macrophyllus as "white or very pale violet"; Lamarck's white plants belonging probably in part to $A$. Schreberi or to $A$. subcymosus.

* Floræ Leydinensis Prodromus, exhibens plantas quæ in horto acad. LugdunoBatavo aluntur. Lugd.-Bat. I740, 8 vo., 518 p., I tab.

$\dagger$ Descriptiones plantarum aliquot novarum. Lugd.-Bat. 1766, 4vo., 35 p., 5, tab. col.

\& Encyclopédie Méthodique, $1: 307 . \quad 1783$. 
-I783. Houttuyn, editing Linnaeus' Systema Vegetabilium, distinguished between white and blue components of the species A. macrophyllus. - Pfl. System, 39 I ( I783).

-I804. Willdenow in Berlin may have had A. Schreberi in cultivation and may have intended that by his variety described* I 804 under $A$. macrophyllus as

\section{" $\beta$, corollae radio albo,"}

adding below that this differs from the blue-rayed (genuine lilacrayed $A$. macrophyllus) in showing linear rays not oblong, and bracts oblong and obtuse; all of which distinctions point to $A$. Schreberi. Willdenow also added that the rays are longer than the involucre, which was probably the special cause of Nees' remark in 1832 that Willdenow had confused the characters of $A$. Schreberi and $A$. macrophyllus badly.

I 8IO-I8I8. Before I8IO, the time of his death, the director von Schreber $\uparrow$ of the botanical garden at Erlangen near Nuremberg, had brought there the type plant of this species, from some unknown source. The plant does not seem to have been noticed by Martius, who catalogued the garden in I 8 I 4 ; but C. G. Nees ab Esenbeck succeeding as director of the garden in 1818 , observed the plant, recognized it as distinct from $A$. macrophyllus, named it in honor of its first cultivator, and described it that same year as follows $\ddagger$ :

A. Schreberi, n. sp. Foliis reniformi-cordatis serratis, caulinis in petiolum alatum contractis glabris, caule decomposito-corymboso, calicibus arcte imbricatis. Hab. * * * In hortum acad. Erlangensem a beato Schrebero illatus est; frigus fert nostri coeli. Perenn. F1. med, albi.

I 826. Sprengel accepted the above and republished it in his edition of Linnaeus' Systema Vegetabilium, 3: 585, no. I 28.

I 832. Nees, publishing his Genera Asterearum, described the species anew, p. I37, as Eurybia Schreberi, with the following description :

I. Eurybia Schreberi N. ab E.

E. foliis reniformi-cordatis serratis, radicalibus trinervatis, caulinis in petio-

* Sp. pl. $3^{3}, 2037.1804$.

†Johann Christian Daniel von Schreber, b. in Weissensee, Jan. I6, I739; d. at Erlangen, Io Dec., I8Io; commemorated in the genus Schrebera Roxb. Schreber, celebrated Linnaean editor, had studied in youth under Linnaeus at Upsala, had become, at 30, professor of medicine and of botany at the Univ. of Erlangen and director of its botanical garden in 1769 . Schreber was author of botanical works, 1764-1792, writing, not on Asters, but on the Musci, the grasses, a Flora of Leipsic ; Icones and

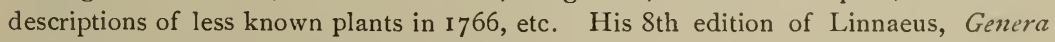
planlarum appeared at Frankfort, I789-1791.

$\ddagger$ Nees, Synopsis Asterum, 16. Erlangen, 1818. 
lum alatum contractis glabris supra in ambitu scabris, caule decomposito-corymboso glabro, periclinii arcte imbricati foliolis oblongis obtusis, radio periclinio longiore. (Characteres specierum in isto genere [Eurybia] paulo ampliores dedimus, scilicet ut iis quoque inserviant, quibus genus Eurybiae ab Asteribus sejunctum non probetur).

a. Foliis radicalibus reniformi-orbiculatis, radio elongato, pappo ferrugineo.

Aster Schreberi Synops. Ast., p. 16 [1818]. Spr. S. Veg., III., p. 535, n. I28.

[So far all applies to the original $A$. Schreberi Nees, of 1818 , which alone is retained under that name in this present monograph. Nees now, 1832 , adds a second variety, $\beta$, including at least two types which I restore to specific rank, $A$. subcymosus and $A$. ambiguus.]

$\beta$. Foliis radicalibus saepe ovato-orbiculatis, caulinis magis acuminatis, plerisque longe angusteque petiolatis, radio elongato, pappo albo, calathiis minoribus.

Aster subcymosus Bernh., in Herb. Günth. (Var. ramis apice cymosis.) [This $A$. subcymosus I recognize as a species, no. 54.]

Aster macrophyllus "quelquefois très lisse" Lam. Enc. méth., I., p. 307. [Same in fact with the preceding?]

Aster ambiguus Bernh. Horti Vratisl., ex Hort. Erfort. [For this see species 52.7

Aster discolor Hort. Hamb. [An uncertain form, which must remain a synonym of $A$. subcymosus in lack of evidence. Its name has been since used for Biotia discolor of Manchuria, so called from the contrast of the leaves above and beneath. What should in a Schreberan species have suggested the name discolor is not obvious; if it had such a contrast between the two leaf-surfaces, as to suggest the name, or if it had two colors as lavender and white in its rays, it would be sufficiently unlike other Schreberan species to call for separation. Perhaps it was a case like $A$. Eriensis in which the rays are occasionally part deep rose-color in the otherwise white head. If its name merely alluded to the rays and disk being of unlike colors, or to the disk changing from yellow to a perfectly new color later, all that would be true of any Aster.]

Crescit in America septentrionali. (Bernhardi.) Floret apud nos Septembre. Perennis. V. v. c. et sicc. spont. [I.e., Nees had seen his original A. Schreberi of 1818 cultivated at Erlangen during the year that he was director of its botanic garden. Now in 1832, at Breslau, he has A. ambiguus in cultivation and it blooms with him in September as it does with us in the Catskills. He had dried specimens he identified with $A$. Schreberi, sent from Bernhardi ? or referred to others seen by him in Breslau in the Günther herbarium sent from Pennsylvania by Pöppig.]

Caule glabro, foliis supra magis minusve scabris, sed praeterea glabris, tenuioribus, longe acuminatis, caulinis plerisque cordatis, inferioribus longe petiolatis, summis, ramos fulcientibus, parvis acuminatis, corymbi compositi ramis ramulisque tenuioribus, calathiis minoribus semper albis, achaeniis glabris laevibus aut subtilissime striatis a sequente specie facile distinguitur. [I.e., from $A$. glomeratus; the particulars above which really are strong contrasts both to Nees' description of $A$. glomeratus and to our native $A$. glomeratus specimens, are as follows: $A$. Schreberi has long-petioles predominant, instead of short; it has smoother leaves; it has more slender-acuminate axiles. ]

Folium primordiale pollicare, ovatum, subinaequale, acutum, glabriusculum, margine scabrum, in medio mucronato-serrulatum, petiolo trigono canaliculato purpureo sparsim ciliato; tum I-2 cordato-suborbicularia, 9-1o lin. longa, obtusa cum mucrone, dense incurvo-serrata, utrinque pubescentia, petiolo duplo longiore margine ciliato; reliqua per cordata lata pilosa in cordata angustiora glabriuscula vel glabra transeunt. 
Costa saepe hirta perstat. Basis trinervata in superioribus foliis. [So far applies fairly well to $A$. Schreberi as now mantained.] In varietate $\beta$ folia inferiora quandoque in ambitu hirta et petioli eorum longe ciliati deprehenduntur; post pauca autem folia diminuuntur isti pili ambitus et petiolorum evaduntque haé partes, extra folii margines, glabrae. [This quick loss of size, roughness and hair, is true of $A$. subcymosus as now maintained, and as representing $A$. Schreberi $\beta$.] - Periclinii foliola margine albida ciliata, dorso viridia, obtusa, inferiora ovata, media oblonga, intima lanceolata angusta tota membranacea. [This applies well to the bracts of $A$. subcymosus; by changing tota before membranacea to read saepe, or by reading "somewhat," it would apply to $A$. Schreberi. The character of whitish margins and greenish back is still more intensified in $A$. vittatus, a Sclireberan species which probably Nees never saw.]

Ligulae radii longitudine periclinii [speaking of $A$. subcymosus and $A$. Schreberi of 1818 both ? and meaning to say that the length of the rays surpasses the height of the involucre, as he had said in his general character for the species already, and as would be abundantly true for both species], anguste lanceolatae [apt for $A$. subcymosus and $A$. ambiguus], albae. Caulis saepe purpurascit [apt for $A$. ambiguus; not for the other species blended].

Adnot. In descriptione Asteris macrophylli apud Willdenovium Eurybia Schreberi et E. macrophylla promiscue traduntur [see infra, under sp. 55]."

I 836. DeCandolle, Prodr. 5: 264, describing the plant as Biotia Schreberi, appropriately mentioned the decompound-corymbose inflorescence, coarsely-serrate, leaves minutely roughened above, and the winged petioles; but then proceeded to describe the lower and radical leaves as non-cordate, apparently through misunderstanding the material from Nees, who had sent a living plant to DeCandolle. The plant may have been one of those occasional examples in most Biotian species which have passed into the lettuce-leaf stage, with a tuft of non-cordate leaves instead of the few normal cordate radicals. Or what Nees printed in I 832 may have been misinterpreted. Nees, Gen. Ast. I 37-8, had distinguished his two varieties of $A$. Schreberi by the characters

"Foliis radicalibus reniformi-orbiculatis," and

"Foliis radicalibus saepe ovato-orbiculatis."

By these expressions Nees meant general outline irrespective of sinus. He did not mean that cordation was lacking, for both varieties were comprehended under his preceding general character

"Foliis reniformi-cordatis."

But in some way missing this last statement, DeCandolle pronounced $A$. Schreberi to be non-cordate, and that mistake probably long prevented its identification with any native plant of the United States.

So the species $A$. Schreberi dropped out of further recognition until I 898, except as Boott identified plants as belonging to it 
here, and as Torrey and Gray mentioned it as an equivalent of their A. macrophyllus $\beta$ in $\mathrm{I} 84 \mathrm{I}$, in their Flora of North America. Most subsequent collections have appeared under the name $A$. corymbosus, but some as $A$. macrophyllus.

I 898. Revived as $A$. Schreberi, in Br. and Br., Ill. Fl.

Representation of $A$. Schreberi claimed for herbaria.

Hb. Nees; now in hb. Brit. Mus. (Nat. Hist.); heads about $\frac{8}{12}$ in. high; called Schreberi by Nees and by Schultz; $=A$. Schreberi.

Hb. Nees, now in hb. Gray; was from Bernhardi's type of A. ambiguus at Erfurt and Breslau; was by Nees labelled a variant of $A$. Schreberi and by Gray of $A$. macrophyllus; was given by Nees to Hohenacker, by him to Klatt, by him to Gray; heads small, $\frac{5}{16}$ in. high $;=A$. ambiguus.

Hb. Bernhardi, now in hb. Mo. Bot. Gar. originally labelled A. Schreberi; a red-stemmed plant with dense dome of heads; heads $\frac{5}{16}$ in. high $;=A$. ambiguus.

Hb. Bernhardi, a different species on same sheet, originally labelled $A$. cordatus, and then Eurybia Schreberi; heads remote, $\frac{10}{16} \mathrm{in.} \mathrm{high;=A.macrophyllus} \mathrm{pin-}$ guifolius.

"Hort. Paris, 1828," in hb. Gray, originally labelled Biotia Schreberi; = A. Schreberi.

" Hort. Berlin, I839," in hb. Gray, cult. in Berlin as Biotia Schreberi DC.; by Gray deemed $A$. macrophyllus $\beta ; 2$ glandular plants, perhaps hybrid and $=A$. Schreberi $\times$ macrophyllus.

Hb. Torrey, "Biotia Schreberi fide Boott," scr. Torrey ; from Dr. Pitcher at Ft. Gratiot, Detroit, I $829 ;=A$. Schreberi?

Hb. Torrey, "Biotia Schreberi fide Boott," scr. Torrey, apparently from near N. Y.; $=A$. curvescens.

|| || Radical leaves oblong-cordate, moderately large, of rather thick texture, with tall, stout stem. Species 50 and 5 I.

\section{Aster rectifolius sp. nov.}

Robust plants with some lower leaves large and with somewhat straight parallel sides, crenate margin, acute apex and deep, broad sinus; with winged axiles, small heads, pale oblong-acutish bracts and about Io rays.

Name, L., from the tendency to parallel sides in some lower leaves.

Fig. 65, from plant of Yonkers, N. Y., near Caryl, Au. 3, '99, in hb. Bu., reduced to $1 / 8$ natl. size; rays omitted; $b$, characteristic leaf-form, seen among both lower caulines and radicals; $d$, radical group ; $e, e^{\prime}$, primordials.

Stem smooth, purplish-brown or greenish, 2-3 ft. high or less, terete. Rootstocks and surculi strong and robust, with long internodes. Primordials ovate-cordate, $1 / 2$ in. or I in. long, aquilinecrenate. Radicals about 4 , quite uniform, $6 \times 4$ in. or less, strongly resembling those of $A$. macrophyllus (which is glandular, while this its counterpart is non-glandular), with short-acuminate 
abrupt apex, crenate-serrate margins, and deep, broad securiform sinus, the sinus overlapping in growth, with unequal pendant basal lobes of lop-side effect.

Leaf-form rather narrow, oblong-cordate, short-acuminate, with deep broad sinus, the sides parallel or somewhat so, in extreme cases parallel from the bottom at the basal lobes for two-thirds the length; or often with swelling sides not properly parallel, slightly curved from just above a more rounded base; the upper third of

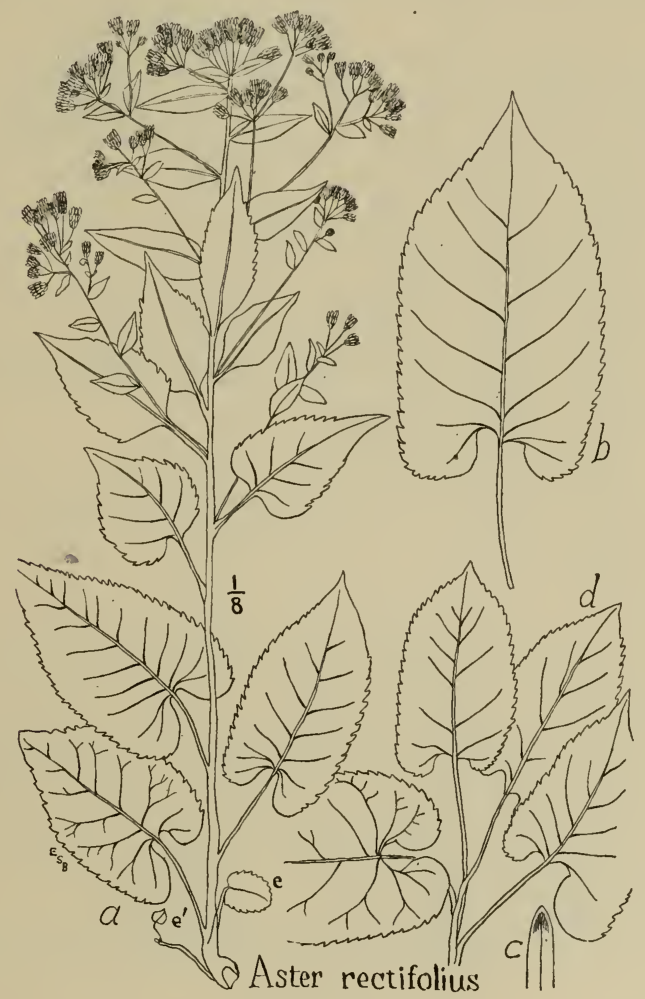

FIG. 65.

the last somewhat triangular and straight-acute. Some radicals and several similar lower caulines develop this form completely, others approximate it, passing soon into oblong-ovate and to cordate-triangular, still retaining a broad shallow base ; axiles oblonglanceolate, acuminate, closely low-serrate, thin, $4 \times 2$ in., or less, with truncate base and winged petiole I in. long; passing rapidly to ovate-lanceolate and lanceolate, with sessile taper base 2 or 3 in. by $2 / 3$ in. Rameals 3 or 4 , irregularly elliptic-lanceolate, serru- 
late, I $1 / 4 \times 3 / 8$ in., subterminal. Ramulars inconspicuous, ovalacute.

Leaves light green, firm, mostly smooth and but slightly thickened, but the lower ones much thickened and roughened, especially when in unusual sun; the leaves and whole plant glabrate or almost without minute hair even on the pedicels.

Petioles chiefly long and slender, the lower cauline and radical petioles not so long as the leaves, however; each base enlarged into a small close-clasping dilation extending two-thirds around the stem.

Veins of highly pinnate aspect, about 6 pairs, strongly outcurved, followed by several shorter upcurved pairs, darker than the leaf above, beneath paler and only very slightly projecting.

Inflorescence deep-branched and at an acute angle, a leafy corymb sometimes $\mathrm{I} 2$ in. high and 8 in. broad, centrally flattish, the lower branches much later in developing and not reaching the uniform level. Heads about $\frac{6}{16}$ to $\frac{7}{16}$ in. high.

Bracts rigid, pale or brownish, their green tips not very strongly developed, their straight parallel sides suddenly terminating in a short or bevelled acutish apex.

Pappus rufescent in 3 years.

Habitat, wood borders and grassy roadsides in slight shade, N. Y. to Virginia.

\section{Examples:}

N. Y. vic., Yonkers, Ludlow, Se. 24, '9I, late multicephalous plants, even with 300 heads, Bi. McLean Ave., Au. 3, '99, nos. II and 16, - also Se. 24, 1905. Bu.; Belmont, Au. 3, '99, under red oak; Troublesome Brook, thicket, '96; Hillview, Se. 22, '99, hickory. Bryn Mawr Park, rock ledge, Maple Ave., Au. I, ' 98 ; dense patch flowering only once in the years ' $97-1905$; its rootstocks after growing as leafless surculi 8 or 9 inches, produce a clump of radicals year after year for a least six years before flowering, each year adding about $1 / 3$ of an inch to the length or height of the upturned end of the rootstock.

N. Y., Catskills, Schoharie Creek, roadside near Quick's Br., Se. 7, '99.

W. N. Y., Cattaraugus Resn., opening above mouth of Indian Twin brook, Au. 9 , '97.

D. C., Zoological Park, Lanier Heights Brook, '87; early development by May 2I, '88, 15 in. high, with 4 large lower leaves full grown.

\section{I. Aster amnicola sp. nov.}

Tall virescent plants with narrow oblong acute leaves, curvescent teeth, narrow sinus, webby hair beneath, soft thin texture, acute thin and attenuate bracts and about i 2 prolonged narrow rays. 
Name, L., = river-diveller; from its occurrence at the stream-margin.

FIG. 66, from plant of Schoharie Cr., Se. 7, '99, of $\frac{1}{10}$ natl. size; $b$, characteristic cordate-quadrate cauline leaf-form; $d$, part of a radical group of 6 small leaves and 4 large, the one large leaf $\frac{1}{3}$ natl. size and showing the characteristic narrow leaf-type. Rays 12 or 14 , only 2 drawn.

Stem $3 \mathrm{ft}$. high or even more, greenish, rather slender, glabrate. Radicals several, or in vigorous plants as many as 6 large leaves reaching $6 \times 3 \frac{1}{2}$ inches, and as many others narrower and of half

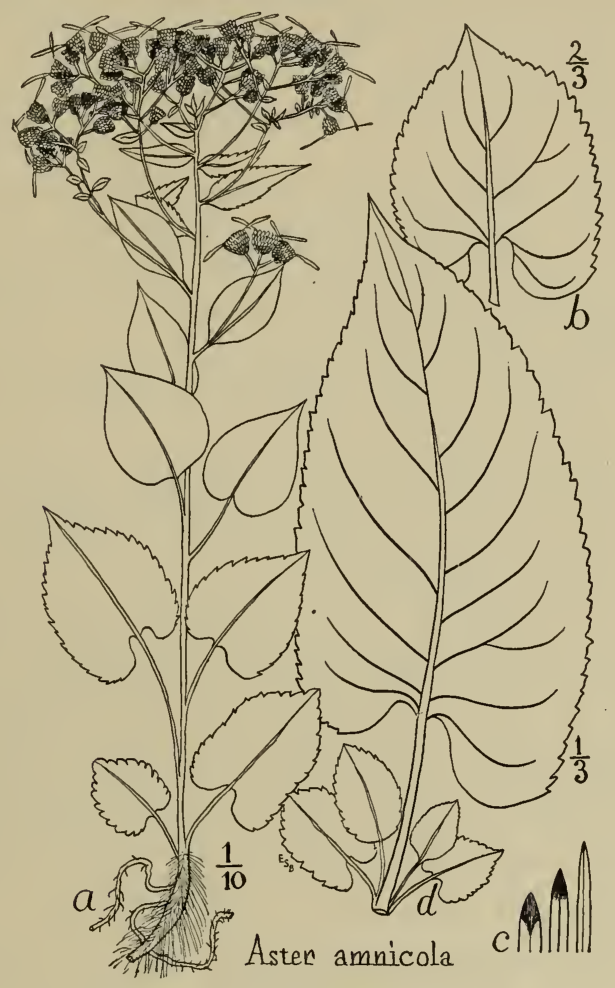

FIG. 66.

that length. Primordials not seen. Rootstocks stout, brown, very copiously fibrous.

Leaf-form narrow, asymmetrical and falcate, oblong-ovate, acute or short-acuminate, serrate, and with deep and rather narrow sinus; as seen in the large radicals and some lower caulines. Middle cauline type cordate-quadrate, still asymmetrical ; becoming cordate-ovate; upper caulines ovate with truncate base; axiles elliptic with winged base, finally lanceolate. Smaller radicals often oval-oblong, and non-cordate. 
Leaves very soft and thin, very quickly wilting, dull green, glabrate above, villous or webby-hairy beneath, firm when dry and the lowest somewhat roughened.

Teeth curvescent-serrate, long and coarse below, close and approaching the slit-serrate type on the middle leaves, slit-serrulate above.

Petioles pale green, slender, villous, being loosely covered with long webby hair but not ciliate; about the length of the leaf till the upper caulines are reached, then smooth and shorter.

Sinus very irregular, deep and enlarged within, narrow, but becoming broad and shallow in the middle caulines. Basal lobes highly unequal, narrow and rounded, overlapped, with strongly lop-side effect.

Veins about 7 pairs, strongly upcurved, dark above, pale below.

Inflorescence a flattish-convex corymb, about 8 in. high and broad or less, quite denuded, its slender longer branches elegantly upcurving and suberect, their bracteals very inconspicuous, lancelinear and long-acuminate.

Heads the largest of the Schreberan species, 7,8 or even 9 sixteenths of an inch high.

Bracts rather pale, the lowest triangular-oblong and acutish, the middle oblong and truncate or obtuse, the inner ones more conspicuous and numerous, attenuate and silvery-scarious. Green tips rather strongly developed.

Rays 12 or even I4, very long and narrow, greenish-white, nearly flat, recurving with age, with 4 narrow faint greenish longitudinal lines, and with 3 sharp teeth at the attenuate apex.

Disk-flowers about 40, pale yellow, soon virescent and becoming dark greenish or olivaceous-brown; the 5 linear lobes very long and divaricate, distinctly greenish like those of $A$. umbellatus. The long thread-form tube gradually enlarges, with a slight swelling just below the lobes. Achenes long, fusiform. Pappus rufescent in 3 years.

Habitat, stream-banks close to the water's edge among overshadowing bushes, seen at various places along the Schoharie in the Catskills; as

Hunter, east bridge, Se. 5, '99; central island, Se. 6, 99 ; near head of Stony Clove, near Quick's bridge, Se. 7, '99.

Allies. A. amnicola seems collaterally akin to $A$. rectifolius, from which it is distinguished by its villous hair on petioles, under surfaces and pedicels; its looser inflorescence, longer, more numerous rays, thinner narrower acuter bracts, tendency to virescence, to falcate-acute leaf-form, etc. Inner bracts resemble those 
of $A$. curvescens, and inflorescence-form that of $A$. umbelliformis, both not really very closely akin. A. vittatus is its intermediate to $A$. curvescens. A. sylvicola is its correlative, of mountain woodland depths. All of these are, however, markedly unlike A. amnicold in appearance and in many important minute characters.

When straying beyond its habitat of best development, under riverside bushes, into the open sun, $A$. amnicola produces truelliform thicker and more rigid leaves, smaller, but still palish green, and strigose beneath; remaining still unlike any other of the Curvescentes.

** Radical leaves smaller, ovate-cordate, thin but firm, dark green. Species 52-54.

\section{Aster sylvicola sp. nov.}

Upright plants of clearings in woods, with small dark subentire cordate leaves, square sinus, villous veins, shallow-chanfer bracts, and about io rather short rays.

Name, L., =forest-dweller; from its habitat, as opposed to A. amnicola, to which it is the correlative.

Fig. 67, plant from Hunter Mt., Catskills, Se. 6, '99, in hb. Bu., $\frac{1}{6}$ natl. size, with radical groups $\frac{1}{3}$. Only external rays indicated.

Stem erect, terete, brownish-green, $2 \mathrm{ft}$. high or less, smooth and glabrous. Radicals a violiform tuft, about 5, cordate, with deep narrow sinus, $3 \times 21 / 2$ in. or less.

Leaves all very dark green above, very pale or whitened beneath, of subentire aspect, but really low-serrate, with petioles at first much longer than the leaf, still as long as the leaf in the middle caulines.

Leaf-form cordate, elegantly and symmetrically curved, merely acute ; the upper caulines becoming reduced, passing from cordateovate, acuminate with broad shallow sinus or truncate-base, to lanceolate with winged base, or to short-oblong.

Inflorescence irregularly convex, loose, with long suberect branches, and inconspicuous or larger oval-elliptic axiles and rameals.

Heads not many, convex-topped, small and delicate, on very long tenuous upcurved pedicels, quincunx with very deep greentipped bracts, $\frac{5}{16}$ in. high.

Bracts more uniform and more sharply contrasting than in many allies, the pale portion being variegated by the long acute green-tip. Rays not so long as the last, $\frac{6}{8}$ in. or less. 
Habitat, in forest clearings.

Examples:

N. Y., Catskills, Hunter, in Mossy Glen, Se. 6, '99, in a mountain clearing, cut, it is said, Ioo years before.

N. Y. vic., Yonkers, along McLean Av., Au. 13, '99.

Allies. A. sylvicola seems to represent the descendants of the original Schreberan type after adaptations to mountain woodlands have become fixed, the best specimens occurring in a clearing, up a mountain wood-road of a century's use. As compared with all

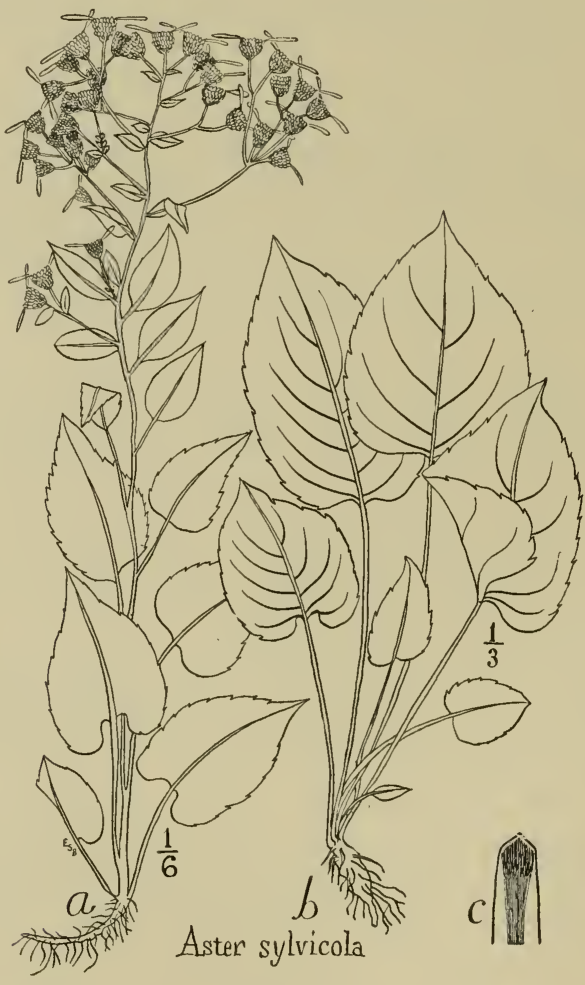

FIG. 67.

the many Schreberan types of the more open slopes and pastures, it is much darker; the teeth are almost obsolete; villous or downy hair is increased; its leaves are smaller and of a new shape, more typically cordate; its stem is straighter and slimmer, its bract-tips greener, its pedicels longer and fewer. Like $A$. Schreberi it is continuously petioled, even through the inflores- 
cence; and acumination is but little developed in its leaves. It is unlike any of the Curvescentes in its combining the following characters : leaves dark, small, cordate, subentire, little acuminate, villous beneath; bracts with abrupt shallow-chanfer apex; petioles persistent.

\section{Aster ambiguus Bernhardi in Nees.}

Slender smooth sparse-leaved plants with bright red stem, broad-cordate leaves, broad and persistent sinus, and heads successively developing laterally and downward into a cylindrical inflorescence of subequal umbelliform loose-flowered branches.

Name given by Bernhardi, doubtless from its then uncertain affinity, and originally, apparently, merely as a botanical garden label.

Fig. 68, $e, f, g, h$, the type-plant of Bernhardi and Nees as represented in hb. Gray ex hb. Nees ex hort. Breslau ex hort. Erfurt, there cultivated under the name A. ambiguus and originally perhaps from $\mathrm{Pa}$. in $1818-1820, e$, upper half of plant, $f$, young shoot, wilh scales, primordials and radicals, $g$, a lower cauline, $h$, a separated radical, rays omitted.

FIG. $68, a, b, c, d$, a similar native plant, from bankside fence-row above east bridge over Schoharie Cr. at Hunter, N. Y. Se., 5, '99; $d$, cluster of radials.

"A. ambiguus Bernhardi, Horti Vratisl. ex Horti Erfurt," Nees, Gen. Ast. 138. 1832 .

Stem I $\mathrm{r} / 2 \mathrm{ft}$. or less, or sometimes $2 \mathrm{ft}$, , very slender and erect, nearly straight, bright red, without obvious hair, with long internodes, especially upward, slightly striate, and glabrous except for minute hair in lines about the axils and on pedicels.

Leaves small, apple-green or paler, firm and slightly thickish, finely serrulate.

Leaf-form broad-cordate, obtuse or soon acutish, with the broad sinus at first deep but soon reduced; such leaves continuing (finally with narrowed sinus and short narrow petiole) characteristically to the inflorescence; or sometimes passing upward through a succession of cordate-acuminate, ovate, elliptic and oblong leaves with short winged petioles. Axiles lanceolate, entire and sessile, or the lower axiles truncate with short petiole. Rameals ovate-oblong, sessile, 2,3 or 4 , much reduced.

Inflorescence when fully developed in large plants, cylindricalconvex, composed of IO or I 2 subequal slender branches, the upper ones bearing heads in a dense convex mass or a high dome, with several nearly equal lateral branches below. In all branches the few heads are borne in a loose terminal cluster of subumbellate form, the central heads much earlier, and flowering while the surrounding lateral buds are yet very short-pedicelled or sessile. 


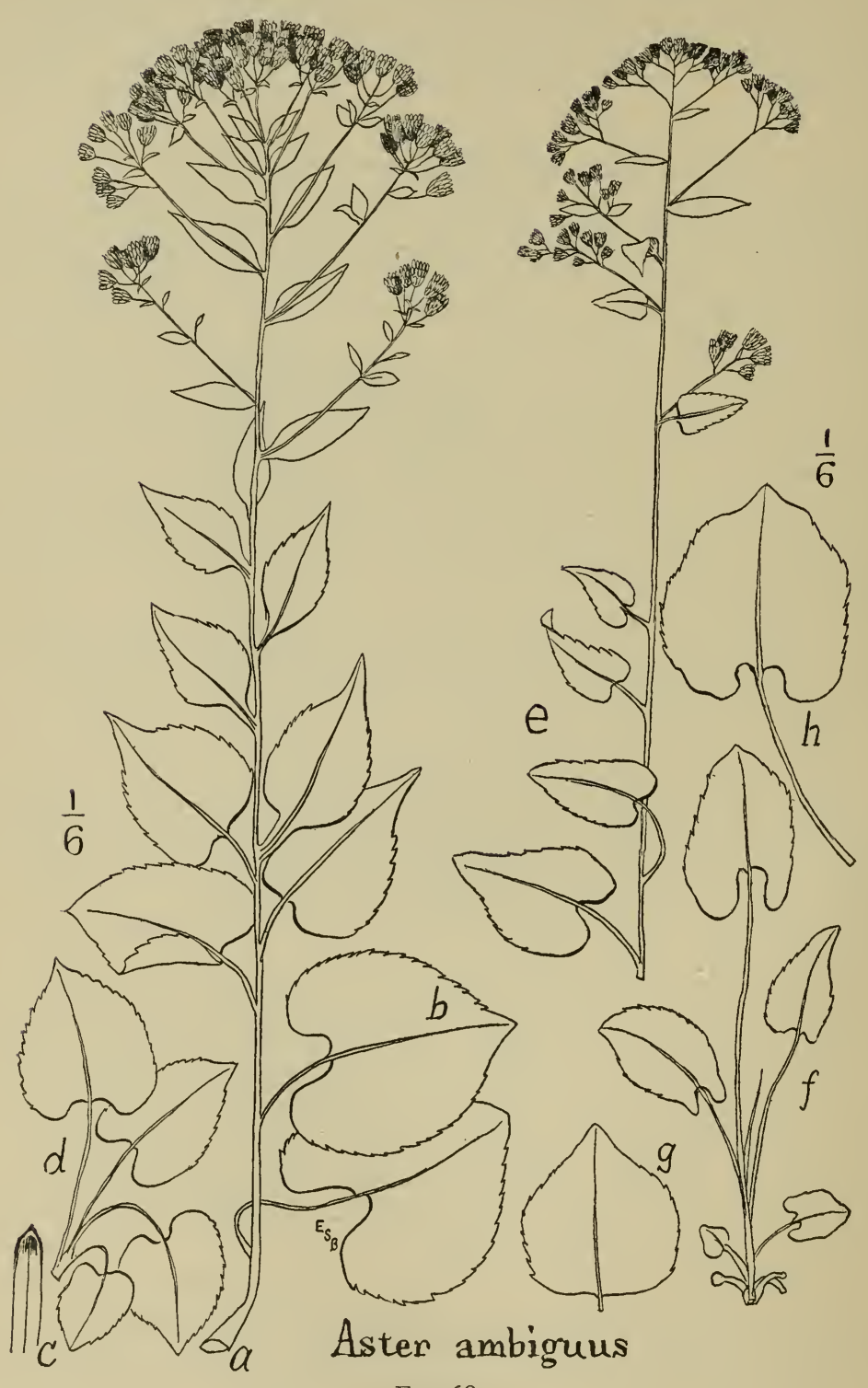

FIG. 68. 
Diversity of flowering-time is much more marked in the remoter lower branches, which therefore assume each more the proper form of a corymb.

Involucre pale, but the dark-green tips conspicuous. Bracts acutish at apex or broad-bevelled, broadly scarious along the margins, smooth-backed but retaining some ciliation along the margins.

The allied species $A$. vittatus resembles this in having also a smooth red stem. A. ambiguns differs in its broader leaves, different bracts, long upper internodes, straight stem, straight highangled branches, a sinus continuing $2 / 3$ the distance up the stem, not $1 / 3$; more ciliate-bracts, with broader scarious margins, and more determinate blossoming, many heads being but sessile buds when their central heads are in flower.

Small plants within thick woods may develop but a single convex tuft of heads, but retain the red stem and remoteness of the small upper leaves (Yonkers and Dunkirk).

Habitat, wood-borders and fence-rows, Catskills and L. Erie to the Potomac, chiefly in late July and in August.

Examples:

N. Y. vic., Yonkers, Diller rocks, in woods, July, '97, strangled by Amphicarpaea since; open crags near, 1903-5.

N. Y., Catskills, Hunter, bankside, fence-row, above east bridge over Schoharie Cr., Se. 5, '99; uplands of Colonel's Chair Mt., Se. 6, '99; near Kaaterskill Junction in head of Stony Clove, Se. 7, '99.

W. N. Y., Dunkirk, Pt. Gratiot, center of woods, July, '99. Cattaraugus Resn., Indian Twin Brook, Au. 3, '96.

Pa.? probably was the source (like many others of Bernhardi's plants) of the Erfurt-Breslau plant of I 818-1821 or earlier, from which came Nees' specimen in hb. Gray; see p. 294; and probably the existing Bernhardi specimen in hb. Mo. Bot. Gar. and the Turin plant of $\mathbf{I} 8 \mathbf{2} \mathbf{I}$.

D. C., near Washington, July 29, '79 and ' 80 ?, L. F. Ward as A. macrophyllus in hb. Bu.

History. The first knowledge of a specimen of Aster ambiguns leads us to the botanical garden of Erfurt, in Prussian Saxony, where the plant was cultivated by the director Bernhardi and was named by him Aster ambiguus, probably because of doubt as to its affinity. Probably the date was later than I808, or the plant would have appeared in the first part of the catalogue of the Erfurt garden that year. Perhaps its non-appearance in 1818 in the Synopsis Asterum of Bernhardi's friend Nees, indicates that it did not come to Bernhardi's observation before that year. It must, however, have been very soon after it, if not before, for Bernhardi's Aster am- 
biguus as well as his $A$. subcymosus appear* as cultivated in the garden of Turin in Capelli's catalog of $182 \mathrm{I}$; the source being probably cuttings from the Erfurt plants. The source in America of $A$. ambiguus may have been Pennsylvania, like so many of Bernhardi's plants; but the original collector cannot have been Pöppig, whose coming to Pennsylvania was in 1824 .

One specimen which may be referred to Bernhardi's $A$. ambiguus survives in his own herbarium as now preserved in the Hb. Mo. Bot. Gar., though under the label $A$. Schreberi, to which species Nees had asigned it.

In 1832, Nees (p. I 38 of his Genera et Species Asterearum), describing his new variety $\beta$ of his $A$. Schreberi, grouped under that variety four garden-names. The third of these citations was that of this Breslau specimen, derived from Bernhardi's plant of Erfurt, the citation reading

"Aster ambiguus Bernh. Horti Vratisl., ex Hort. Erfort." Probably it was the red stem of this plant, unlike the greenishbrown of most other Schreberan allies, which caused Nees now to add to his description of $A$. Schreberi, "Caulis saepe purpurascit."

In Jan., I 899, while working, through kindness of Dr. B. L. Robinson, over the Asters received by Asa Gray from Nees, now lodged in the Gray herbarium, I discovered among them a sheet representing this forgotten species, so labelled by Nees himself, and mounted apparently at a time between 18 I 8 when Nees published his $A$. Schreberi and 1825 when Cassini published its cognate A. macrophyllus as a species of Eurybia; under which genus Nees now newly labelled it.

Nees' label reads :

"Aster Schreberi, H [or]t. b[ot.] $\operatorname{Vr}$ [atislavensis], nomine A. ambigu $[u] s "$

with the addition above, of its new name,

"Eurybia Schrcberi."

Gray with his wonted broad-minded care for the personal relation of plants, noted on this label that these words were in Nees' own hand, and I find that they agree with other known examples of his writing.

Shortly before Nees' death, he gave this specimen, in 1856 , to Hohenacker; so Hohenacker wrote below the previous label, Gray continuing that it was "obtained by Klatt of Hohenacker, in I 870 [and] given to A. Gray, I 885 ."

* P. 12, of Catalogus stirpium quæ aluntur in regis horto Taurinensi. Augusta Taurinorum, 1821, 8vo, 67 p.-Carlo Capelli, 1763-1831, was physician to the Bourbon princes $\mathbf{1} 792-\mathbf{1} 8 \mathbf{1} \mathbf{I}$, professor of medical botany at Turin, 1815, collator of he Flore Sarde, and author of the above Catalog of the Turin Garden. 
Gray added that he himself classed the specimen as a "form of A.macrophyllus" - to which species he had long before united A. Schreberi and its allies.

By such a long series of steps, through life in Pennsylvania, Erfurt and Breslau, and through the hands of Bernhardi, Nees, Hohenacker, Klatt and Gray, descended this single frail specimen; a specimen which fortunately proves what it was which Bernhardi denominated $A$. ambiguns, and which by its coincidence of characters establishes the identity of a widely distributed ally of $A$. Schreberi which had long been clamoring in my herbarium for a name.

\section{Aster subcymosus Bernhardi in Nees.}

Plants with leaves broader in the middle, very fine-textured thin and smooth, with sharp curvescent or aquiline teeth, suddenly slender-acuminate, cordate-ovate; with heads about $\frac{5}{16}$ in. high.

Name, L., somewhat cyme-like, in application to its bearing a small segregate inflorescence of cymose development terminating each ascending branch (as also in $A$. Schreberi, A. rectifolius, and, with umbel-like radiation, in $A$. umbelliformis); fide Nees' remark that $A$. subcymosus varies from $A$. Schreberi in its branches cymose at the apex, "var. ramis apice cymosis," Gen. Ast., I 38 .

Fig. 69, from plant of Cattaraugus Resn., Indian Twin brook, Au. 9, '97, in hb. $B u$., $\frac{1}{6}$ nat. size; rays omitted; $b$, characteristic leaf-form, lower cauline, and $b^{\prime}$, radical ; $d$, frequent irregular radical form.

A. subcymosus Bernhardi in Capelli, Catal. hort. Taurinensium, 1821, fide DC. Prodr. $5: 264$.

A. subcymosus Bernhardi in hb. Günther, cited by Nees, Gen. Ast. 138. 1832.

A. discolor Hort. Hamb., in Nees, Gen. Ast. I38.

A. Schreberi $\beta$ in the main, Nees, Gen. Ast. $\mathrm{I}_{3} 8$.

Biotia latifolia DC., in part, at least as to non-glandular $B$. latifolia plants of hb. Mus. Paris, 1869 (in hb. Gray).

Stem terete, glabrate, greenish-brown, often $2 \mathrm{ft}$. high, sometimes 3. Radicals ovate-orbicular, thinner than in A. Schreberi, smooth except toward the margin, sometimes 8 by 4 or 5 inches. Caulines more long-acuminate, abruptly so ; sinus less rectangular, broad and shallow, and then broad and elegantly recurved, then obsolescent, next leaves (upper caulines) truncate and the next rounded-tapering, all having long slender petioles.

Leaf-form ovate-orbicular in radicals, cordate-ovate and incurved-acuminate in caulines, all with moderate sinus, unusually persistent petiole, coarse forward-directed teeth, and smoothish surface.

Heads smaller than in $A$. Schreberi, $\frac{5}{16}$, sometimes $\frac{6}{16}$ inch high, rather short pedicelled. Rays long, narrow.

Bracts of two very distinct types, the outer and middle oblong, pale, with distinct green tips, abruptly acutish and moderately 
coriaceous ; the inner long, attenuate, scarious, shining and straw color without green tip or midrib; much as in $A$. curvescens and A. amnicola.

Rays typically 8, rounded at the apex, broader than in its allies.

Habitat, wood borders and open thickets, Conn., N. Y., and southward; last of July and early August.

Ct., Neze Haven, '59, D. C. Eaton as "A. corymbosus" in hb. Mo. Bot. Gar.

W. N. Y., Hanover, Rosebrook woods, Au. 2, 1900, nos. 25, 26, 27, under Carpinus; a few remaining, $\mathbf{1 9 0} \mathbf{I}-4$.

W. N. Y., Cattaraugus resn., Indian Twin Brook mouth, July 31, ' 96 ; mostly out of flower and the rays fallen, Au. 3, '96, Bu. - Buffalo, C. F. P. in hb. Mo. Bot. Gar.

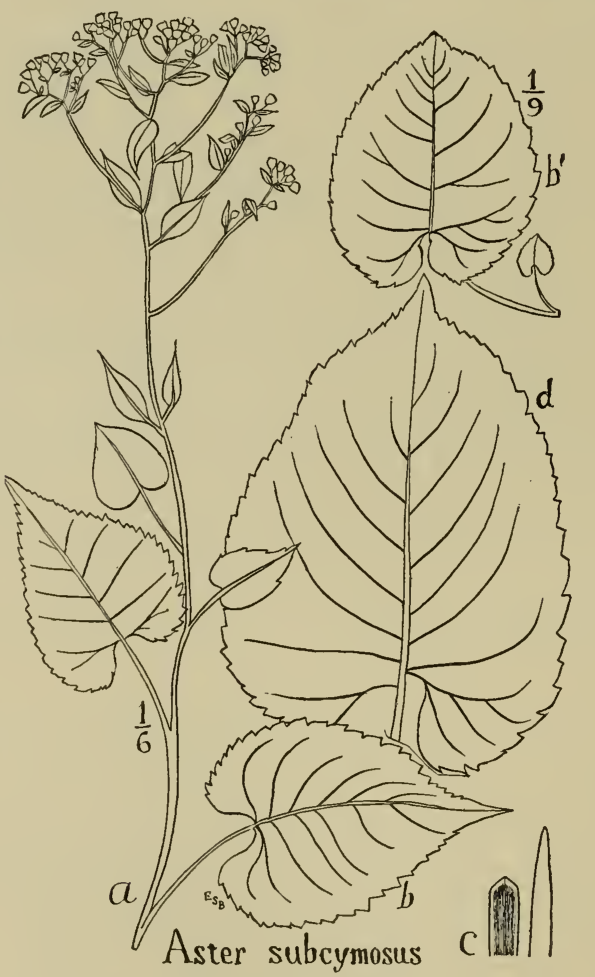

FIG. 69.

Pa., Bethlehem, Jacob Wolle, 1846, and Clinton Co., M. M. Minn, Jr., in the hb. Mo. Bot. Gar.; Delaware Co., no. I8914 in U. S. Nat. Hb.

Ohio, Richland Co., Au. 12, '92, E. Wilkinson in hb. Ohio St. Univ.

D. C., Washington, Vasey, '73, in U. S. Nat. Hb., no. 18917.

D. C., Washington, L. F. Ward in hb. Bu. 
Va., Potomac shore, near Washington, July $27, ' 77, L$. F. Ward in hb. Bu.

W. Va., Bucklin, '95, Pollock, no. 261326 in U. S. Nat. Hb.

"Hort. Paris, 1869, Biotia latifolia I)C," fide Hb. Mus. Paris label; plant in Hb. Gray, assigned by Gray to $A$. macrophyllus L. Other garden specimens purporting to be the $B$. latifolia of DC. appear to belong to the $A$. macrophyllus pinguifolius of the present monograph; but this one is without glands, and very different otherwise, and appears to belong to the $A$. Schreberi $\beta$ of Nees, the $A$. subcymosus of the present monograph.

$54^{2}$ Flexicaul form, dark-green, smaller, or equally tall but slenderer and more delicate, with curving flexuose stem and subsessile heads.

W. N. Y., Rosebrook woods, Au. 2, I900, and I90I-I904, with the preceding.

$54^{3}$ Lateral-bud form; long attenuate pedicels, the late lateral buds then still sessile; heads thus very diverse in development in flowering-time and the blossoming very uneven. Sinus very variable, broad and shallow, or deeper and overlapping. With the type.

Ct., Shuttle Meadorv, Se., '89, Jas. Shepard in hb. Bu.

W. N. Y., Cattaraugus Resn., Indian Twin brook, Au. 3, '96.

D. C., near Washington, July 29, '79, L. F. Ward in hb. Bu.

$54^{4}$ All-cordate form, even cordated to the inflorescence.

W. N. Y., Indian Twin, Au. 3, '96.

\section{SUBSECTION 3. MACROPHYLLI.}

Violet, lilac or lavender rays, pale or whitish in fading. Glandular hair present. Involucre larger, $3 / 8$ to $\mathrm{x} / 2$ inch high. Rays usually about I 3 , tridentate. Plants larger or coarser than the preceding (unless it be nos. $61,73,84$ ) in rootstock, stem, leaf and heads. Colonies of radicals extensive (even more so than in $A$. Schreberi). Texture often very thick, very rough or very rigid. Crenate teeth commonly predominant. Bracts less ciliate; tomentum of pedicels less crispate, not ranged in lines, either diffused or entirely absent. Disks soon purplish-red or maroon.

\section{Division A. LAVENDER MACROPHYLLI.}

Lilac rays slowly turning lavender or finally becoming pale, dull and whitish, at length brown. (Division B as a rule develops more strictly violet rays, changing to purer white; the color of the rays contains more blue in Division $\mathrm{B}$, more red in $\mathrm{A}$; but occassionally an equally violet head will be found in plants of Division A.) Radicals heavier and shorter stalked than in B, often less numerous, chiefly 3 , usually forming larger colonies. 


\section{Subdivision A.}

Thick heavy leaves, not firm but flabby. Teeth broad, crenate-serrate ; glandular hair chiefly confined to pedicels and bracts and upper part of stem.

Species $55-58$.

* Plants stout, rather tall, often $3 \mathrm{ft}$. tall, with sprangle-top inflorescence; bracts polymorphous.

Species 55 .

\section{Aster macrophyllus L.}

Stout rough-hairy August-flowering plants of extensive colonies on shaded banks, with coarse harsh flabby texture, cordate-oblong lower leaf-type, oblong-acuminate upper-cauline type with broad taper base, IO-I 3 lilac rays and broad triangular-acute principal bracts.

Name, L., from the large radicals.

Fig. 70, plant of Cattaraugus reservation, Au. I3, '98, in hb. Bu.; $b$, characteristic leaf type, seen in radicals and lower-caulines; $d$, characteristic upper-cauline type.

FIGS. 7 I, I-6, plant from Nees' herbarium, now in hb. Gray; with facsimile of its name in Nees' hand, Aster macrophyllus, written by Nees on the label probably before 1825 when Eurybia became its generic name to him; plant representing, fragmentarily, a part of Nees' conception of this species; 3,4 and 5 show radicals; 6 , a young radical shoot with 2 primitive scales and 2 intermediary scales.

FiGS. 7 I, 7-8, "A. macrophyllus" as understood by Bernhardi, fide labels of Bernhardi herbarium in hb. Mo. Bot. Gar. 8 is an arrest-form of frequent occurrence, with shortened stem and with the transitional leaves reduced or suppressed between the slender-petioled lower type and the wing-based upper type; two such arrest-form representatives occur in the Bernhardi hb.; and Engelmann's Hort. Salzwedel plant of 1825 is precisely similar.

Figs. 7 I, 9, I0, radical leaves of the "A. macrophyllus" of "Hort. Salz. zuedel, Frankfort, I825," in hb. Geo. Engelmann, now in hb. Mo. Bot. Gar.

$A$. canadensis, foliis imis amplioribus cordatis serratis. Vaillant, Act. $5^{8}$. $\quad \mathbf{I}_{722 .}$

A. Acadiensis, coronae solis folio, H. R. - i. e., "Aster from Acadia, with leaf resembling that of sunflower" [large, broad, subentire and somewhat ovate and coarse]; cultivated under this name in the Hortus Regius of Paris (and so named by its director Antoine de Jussieu, as far back as his activity there in 1718 ?). Cited as its Paris garden name, Lamarck, Encyc. méth., I : 307 ( I783); Lainarck frequently citing the garden-labels of Jussieu.

A. macrophyllus L., Sp. pl., ed. 2, 2: 1232 (I763); and continuously so of most subsequent authorities, as Lamarck, Aiton and Willdenow in part, Link, Persoon, Sprengel, Poiret, etc.; and of early American writers, Michaux, Pursh, etc.; and of Nees, Syst. Ast. 1818.

A. macrophyllus a, Willdenow, Sp. pl. $3^{3}: 2036$ (I804); not his var. $\beta$, which covered white-flowered forms. 
A. macrophyllus $\beta$, Aiton, Hort. Kew., ed. 2, $5: 57$ (1813); not his var. $a$, which covered white-flowered forms.

Eurybia macrophylla, Cassini in Dict. des sc. nat. $37: 487$ (1825); so Nees, Gen. Ast. I40. 1832 .

Biotia macrophylla DC., Prod. 5 : 265. 1836.

Aster macrophyllus L., of T. and G., Fl. N. Am., of Gray's manuals, of his Synoptic Flora. and of American botanists to $\mathbf{I} 898$; but in part only, being blended with many nonglandular white and glandular violet-rayed species.

A. Herveyi intermedia, C. H. Peck, Rept. N. Y. St. Botanist for 1892 , p. 46 (1893). Not $A$. intermedius Turcz., ex DC. Prod. $7: 272 . \quad$ I838-9.

A. macrophyllus L., in Br. and Br. Ill. Fl. 1898 , and works subsequent.

Names other than Latin; translation names, etc.

Grossblättrige Sternblume, Willd. Sp. pl. $3^{3}, 2037$. $\quad$ I804.

Great-leaved Starwort, Forster's Cat. of Plts. of N. Am. I $77 \mathbf{I}$.

Broad-leaved Blue Starwort, Martyn's edn. of Miller's Gardener's Dict. 1807.

Large-leaved Aster, Muhlenberg, Cat. of Plts, , I8I3; so, Bigelow, Fl. Boston, I814, etc.

Astere à grandes feuilles, Lam. I : 307 (1783); so Provancher, Fl. Canadienne (Quebec, 1862), adding, “it is known as

"Pétouane; its leaves dried are sometimes used as Tabac to smoke; from which without doubt the common name Pétouane, which is derived from petun." - The Indian name Petun for tobacco occurs as early as 1630 , when John Taylor wrote of "the hearb . . petun alias necocianum" ; it was the source of Jussieu's name of 1803 for the Petunia ; and is said to be still used in some parts of Canada for tobacco.

Figured (or an allied plant transitional to A. uniformis), Gard. and For. 4:89. 1891. Figured, Br. and Br. Ill. Fl. $f .3743$.

Stem stout, erect, brownish, glandular-hairy above, minutely roughened below by short strigose hairs or their remnant bases or finally becoming smooth below; about $2 \mathrm{x} / 2 \mathrm{ft}$. high ; with rather long internodes (often 2 in.); usually not quite straight, and with I or 2 flexures.

Rootstocks strong, dark brown, with long reddened surculi, forming large colonies sometimes confluent so as to cover thinly wooded banks for half a mile continuously, as on the Cattaraugus.

Leaf-type cordate-oblong, acute or very short-acuminate, with strong unequal basal lobes, deep strong asymmetrical sinus commonly overlapped, coarse crenate margin, and long robust narrow petiole; seen in most radicals and a few lower caulines. Texture thick, rough, coarse and flabby; variable on the same plant, but hardly firm in life; after drying, rigid and very rough. Strigose pubescence moderate, present at least on the veins beneath (and on the branches: usually on the upper part of the stem also). Leaf-color deep green, changing in fall to bronzed umber or russet; drying brownish-green or blackish.

Radical leaves usually 3 , not very dissimilar to each other, but only one of fully typical form; this the largest, $7 \times 5$ in. 


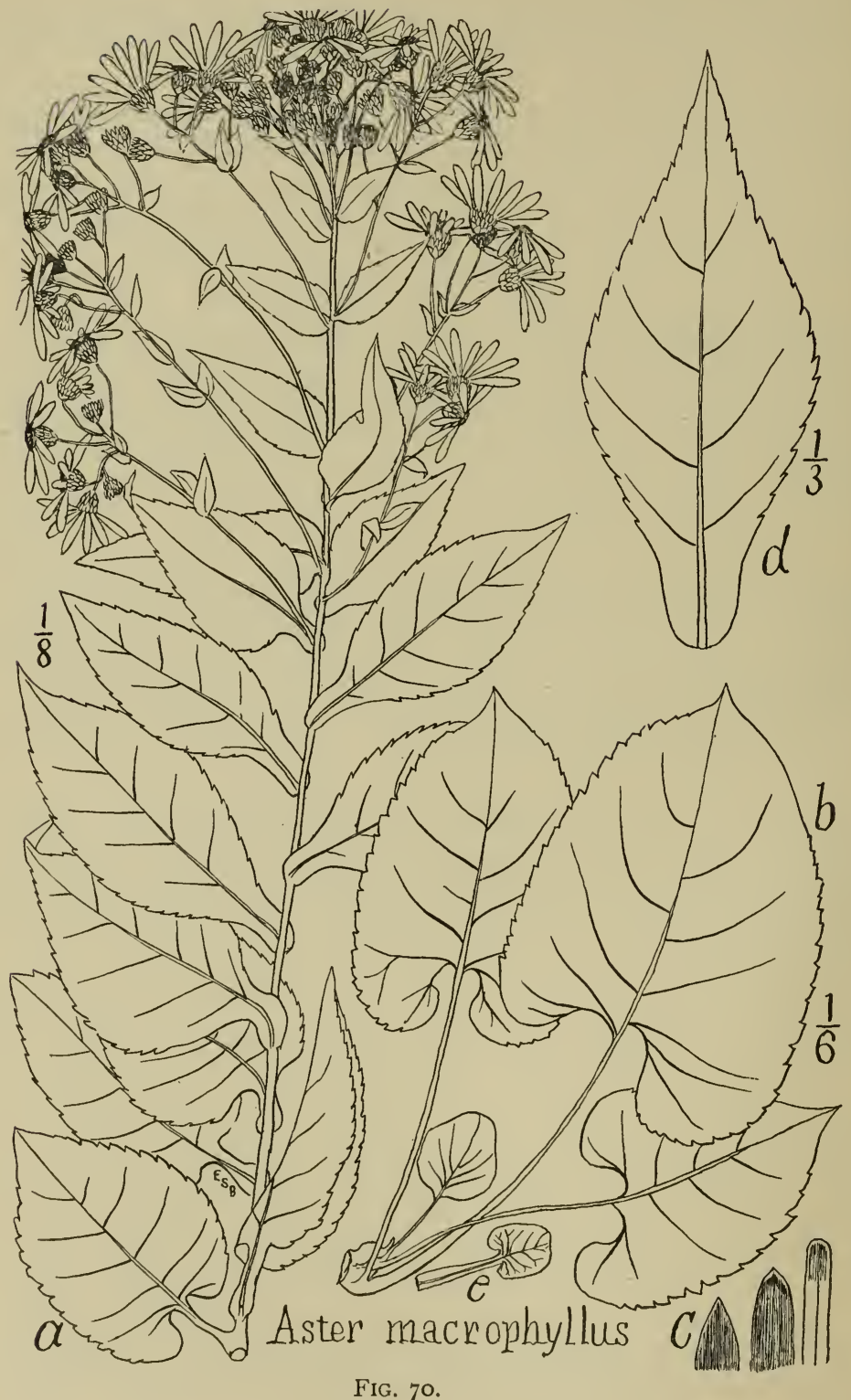

FIG. 70. 
or less ; another narrower and another shorter. With them sometimes I or 2 small broad subentire roundish additional leaves are interspersed, I in. long or less, with or without sinus; as shown in radical cluster $b$, Fig. 7o. Primordial leaf cordate-quadrate or reniform, very veiny, with broad-wing petiole, soon perishing; $e$, Fig. 70.

Lower caulines of typical form. Succeeding caulines slowly diminishing upwards, serrate or serrulate, $3 \times 2 \mathrm{I} / 2 \mathrm{in}$. and soon becoming narrower and with reduced sinus and receding roundbased lobes, the petioles still wingless and now shorter than the leaves. Middle caulines pass from broad-ovate to ovate-oblong, subelliptical, lance-oblong or ovate-lanceolate; the short narrowwinged petiole soon developing a basal dilation (undulatiform), then becoming uniformly dilated to the leaf (forming broad-winged petioles) and in the next leaves merging with the tapering base. Final upper cauline type quite characteristic, oblong-ovate, rather gradually and prominently acuminate, slowly contracted into a broad clasping basal portion; often $3 \times \mathrm{I} / 4 \mathrm{in}$.

Axiles oblong-ovate to lanceolate, sessile, clasping by a broad base, $2 \times 3 / 4 \mathrm{in}$. or less, acutely serrulate or nearly entire.

Rameals little developed except in cases of extensive inflorescence; then usually a subopposite pair about one-third below the first branchlet, sessile, chiefly triangular-ovate, acuminate, obsoletely serrulate ; those subtending the branchlets become narrowed, finally passing into narrow canaliculate investitures to the ultimate. pedicels, which are otherwise naked.

Veins not very conspicuous, about 4 pairs, not incurved nor greatly upcurved, lost toward the margins, and till then somewhat parallel and equidistant. General and minute venation quite inconspicuous. Trinervate bases resemble those of $A$. Schreberi.

Teeth low, broad, rather irregular, remotish, curvescent and crenate-serrate, with some shorter subdentate teeth intermixed. Predominant curvescent teeth are apt to be $10 \mathrm{~mm}$. long and $\frac{1}{5}$ as high. The aculeus terminating the tooth is little obvious, green, broad and flat, continuous with the leaf-membrane.

Sinus broad, irregular, rather deep, enlarged within, usually unequal and lop-sided, but commonly nearly closed in life by the assurgent basal lobes.

Hair of about 4 kinds; Ist, ciliation on the larger exposed bract-margins and tips ; 2 d, strigose hair over under surfaces and on the stem, slender, hardened but scarcely thickened, 8- to I2celled; 3d, stiff short sharp bristles occur over the upper surfaces of the leaves; these are pale, appressed, directed forward and outward, highly detentive to the touch when dry, about 2 times their own length apart, very slender and scarcely enlarged at the base; 


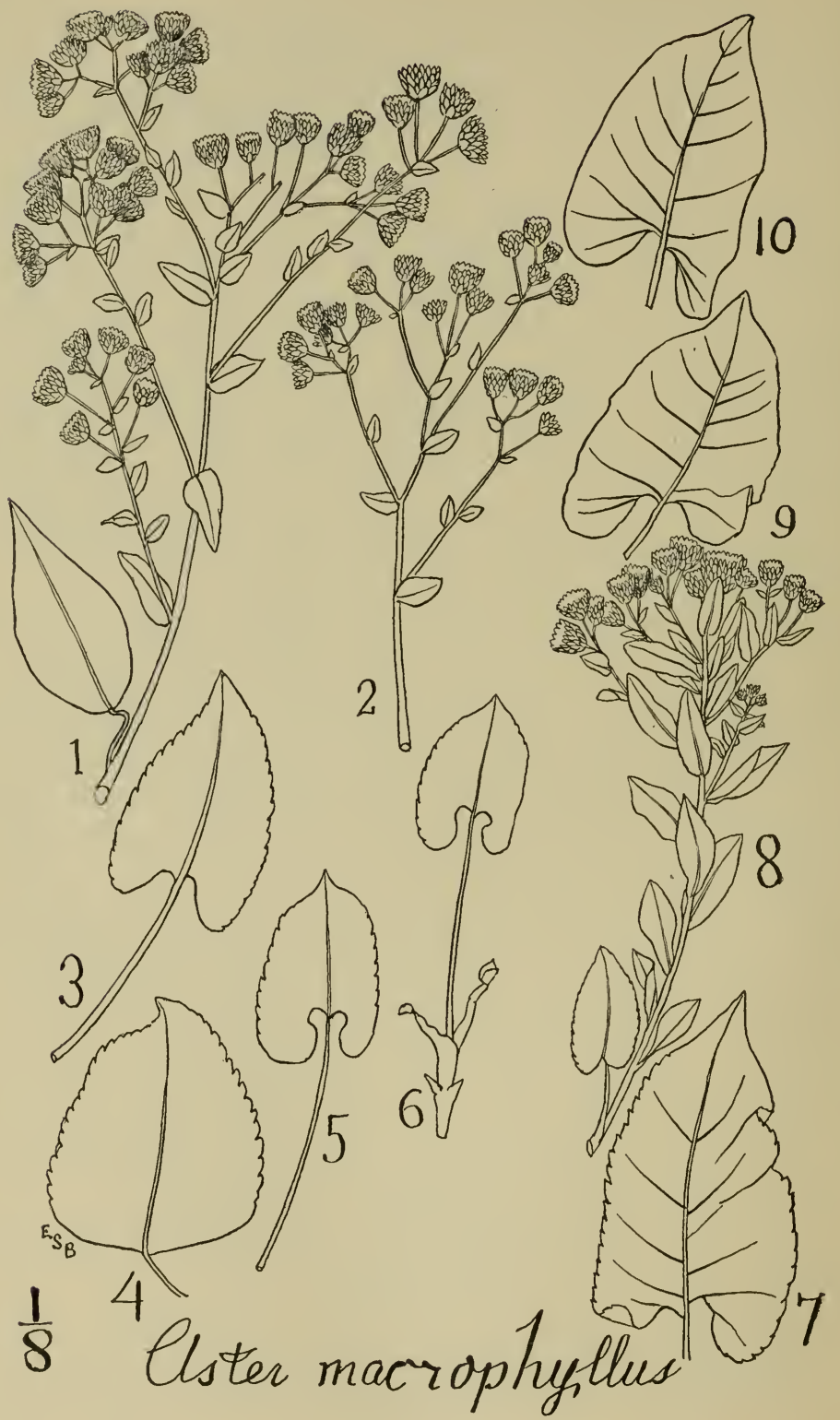

FIG. 71. 
4th, glandular capitate pubescence, mingled with the strigose hairs, much shorter but more extensively distributed, more abundant and persistent; best developed on the branches and branchlets, but continuing well-down the stem, typically to within 6 in. of its base. Glands quite odorous, subspherical, purplish,2-3times the breadth of their stalks, or less. Stalks one-celled, distinct, 4-6 times the length of the gland, straight, stiff and divaricate. Similar but shorter and closer glandular hair covers the exposed backs of bracts, sometimes, however, with but few glands remaining. On petioles and lower leaf-surfaces smaller paler shorter-stalked glands are scatteringly developed, at least when young; but much less so than in $A$. ianthinus and some other violet-rayed allies.

The preceding leaf-types all gradually pass into each other; only the lower and upper caulines are markedly characteristic; and the lower is often duplicated in the form in the non-glandular $A$. Schreberi and both the lower and the upper in $A$. subcymosus.

Inflorescence of vigorous plants a compound, uneven, deepbranched corymb rising to different levels, with stiff pedicels often I in. long, the plant bearing sometimes as many as 80 heads. Smaller and perhaps more common plants produce a broad flattish expanded corymb usually not large and with rather few remotish heads, I 5-20, on stiff stocky pedicels, $1 / 3$ in. long or more.

Pedicels and branches given off at about the same angle, about $40^{\circ}$, nearly straight or slightly upcurved at the base, and somewhat clavate or thickened toward their summits, terete. Their characteristic grouping is in 3's, making the branches seem trifurcate, additional subsessile lateral buds developing subsequently.

Heads about $\mathrm{I} / 2$ in. high and $\mathrm{I}$ in. broad, or slightly more. Involucre campanulate, broad-based, triseriately chequered, about $\frac{5}{16}$ in. high, subtended by a rather closely appressed bracteal which is cymbiform, oblong and obtuse, and usually deciduous.

Bracts stiffly coriaceous, broadly triangular-acute in aspect, pale, with somewhat oblong-triangular thickening at the green tip, the exposed surface densely covered with short stiff glandular hair. Bract-forms principally 3, changing gradually in breadth and shape and apex; Ist, basal bracts, acute, short-triangular, the lowest much broader than high; the next triangular-ovate, subciliate, brownish-green and close-puberulent all over; $2 \mathrm{~d}$, middle bracts, about two rows, oblong-ovate or broad-oblong, obtusish, more ciliate and green-tipped ; $3 \mathrm{~d}$, upper or inmost bracts, taperoblong or linear-oblong, obtuse, thinnish, subciliate, with little green or none.

Rays about 16 , or only 13 , about $\frac{6}{16}$ in. long, linear-oblong, not so broad or narrow as in various allies, tridentate at the 
slightly contracted apex, lilac-lavender, having more red in their composition than in the violet rays of the ianthine group, paling sornewhat and then turning brown.

Disk-flowers about 50, short-lobed, yellow turning reddishbrown, fragrant, soon forming a convex mass.

Pappus long, ecru, soon brownish (in one year) and later becoming highly rufescent, becoming first so in the buds.

Achenes smooth, dark brown, fusiform, slightly compressed, much smaller and slenderer than in the Curvescentes. Vertical striae faintly double, extending at the summit of the achene into an abrupt narrow brownish annulus which (unlike the conspicuous annulus of $A$. umbelliformis) is little whitened, is not double, and is not decurrent on the striae.

Odors include a bee-bread fragrance from the disk-flowers; and a nutty odor from the glands when rubbed, not so marked, however, as in the Ianthine group.

Typical native plants of the species as thus restricted are broad in all their lines; both radical and lower cauline leaves showing broad-cordate outline and a broad enlarged and curving sinus, the inflorescence broad and shallow, the teeth broad and crenate or curvescent, the middle and upper petioles widened into broad wings. This type seems to represent the species as first fully described by Nees and as preserved in the herbarium of Linnæus and as early cultivated in Kew. From this type are removed many extraneous elements at various times blended with it; on the one hand various white non-glandular representatives of the Curvescentes, and on the other hand, various violet-rayed highlyglandular plants of different leaf-form; members of both classes being joined with it by Willdenow and by Torrey and Gray.

Typical plants of $A$. macrophyllus, as now defined, do not show any distinct violet or predominant blue, as in the Ianthine group; no rays with rose, carmine, crimson or predominant red, as in some Divaricati, and in A. Alleghaniensis; no spongy or crumbly leafsubstance, as in $A$. biformis, $A$. orbicularis, etc. ; no very conspicuous prolonged or narrow or incurved acumination of leaf, as in so many Divaricati; no great jagged-edge teeth, as in $A$. viridis, A. ferox; no complete gradual transition from basal to axile leaves with little difference of size or petiole or shape, as in A. uniformis, A. Alleghaniensis; no such abundance of glandular secretion as to make all surfaces clammy to touch when young, as in $A$. roscidus; and 
after the bud-state, no close-bunching of mature subsessile heads, as in $A$. densatus and allies.

Habitat, in considerable shade, especially on the drier slopes of river banks and along their summits, widely through Canada to Manitoba, in the United States from Maine to Minnesota, and southward through the Appalachian region to North Carolina, but leaving the sea-coast at Staten Island. Its northern range was given by Hooker in $\mathrm{I} 840$ (Fl. Bor. Am. 2 : I4) as "from L. Huron, Dr. Todd, to Norway House on the Saskatchewan, Drummond,"

i. e., to L. Winnipeg.

Examples include :

Canada, Sandwich, July 27, I901, Macoun, in hb. N. Y. Bot. Gar. Southampton, L. Huron, Macoun, Au. 2I, I90r.

Nova Scotia, Vindsor, coll. Hozeard.

New Brunswick, "woods and borders of fields" ; Fowler's Cat.

Maine, Orono, Penobscot Co., recently burned clearings, Au. 24, '97, $M$. L. Fernald in hb. Bu. Sumner, Au. '86, J. C. Parlin in hb. Gray. Farmington, '96, C. H. Knozulton in hb. Bu. Mt. Desert, rocky woods at Seal Harbor, Au. 15, '87, Redfield in hb. Canby. Gardiner, Se. '99, coll. A. M. Richards, in hb. N. Y. Bot. Gar.

Vt., Monkton, '79, Pringle, no. 18922 in U. S. Nat. Hb.

Ct., Meriden, '59, D. C. Eaton in hb. Mo. Bot. Gar.

Ms., Taconics, Bashbish R., Au. 28, 1901, Au., I903; Guilder Hollow, Au. 22, 1903, Bu. $\quad N$. Bedford, Clark's Neck, Se. II, '97.

N. Y., Adirondacks, Au., '73, A. Brozen in hb. Canby; No. Elba, Au., '98, Horse-shoe Pond, Au., '9.3, and Sternbergs, Au., '93, C. H. Peck in N. Y. St. Hb. Blue Mtn. L., Aug., C. H. Peck, do.; Albany Co., Voorheesville, Steuben Co., Rathboneville and Catturaugus Co., Salamanca, C. H. Peck in N. Y. St. Hb.

N. Y. vic., Woodlawn Heights, Se. I8, '98, Bi. in hb. Bu. Tarrytown, Sleepy Hollow, east end, Se. 24, '98.

N. J., Palisades, Au. 8, '99, no. from Hottonia water; $N$. Brunswick, Se., I831, Torrey in hb. Torrey.

N. J., Montclair Hts., Au. 2I, '75, Ruger in hb. Canby.

W. N. Y., Niagai'a R., W'hirlpool woods, near brink of gorge, '96, '97, '98. Si,ver Cr., Swift's Hill, Au. I I ' '98-I904. Glenwood Cemetery, '96-I904. Rosebrook woods, Au. 3, '96, '97-1904; Clymer, '74; Panama, '73; Cattaraugus resn., Maybee road, Au. 9, '97; Indian-line road, Au. I3, '98, typical locality, '99-I902; Little Indian, Au. 24, '97; $B u$.

Pa., Susquehanna, Se. 20, '97, Jas. A. Graves.

W. Va., Aurora, alt. $3000 \mathrm{ft} .$, Au. 24, '98, E. S. Steele in hb. N. Y. Bot. Gar.

Wis., "Milwaukee," hb. Dr. H. E. Hasse, in hb. N. Y. Bot. Gar.

Minn., Amodar, Chisago Co., Au. I8, '92, coll. B. C. Taylor, now in U. S. Nat. Hb., no. 201952.

Hb. Bernhardi, one fragment of inflorescence with axiles, fairly typical ; its label, "Aster macrophyllus," seems to be in the handwriting of Nees. Now in hb. Mo. Bot. Gar., a half-sheet. 
Hb. Bernhardi, also now in hb. Mo. Bot. Gar., a whole sheet, with parts of two plants, and old labels "Aster cordifolius," "Aster macrophyllus" and "Aster macro. phyllus Hort. Hamb." See fig. $7 \mathbf{I}$.

Hb. Engelmann, now in hb. Mo. Bot. Gar. with Engelman's label " $A s^{\prime}$ er macrophyllus, Hort. Saltzzuedel, Frankfort, I825.", See fig. $7 \mathbf{1}$.

Hb. Nees, plant now in hb. Gray, and figured here, fig. $7 \mathbf{1}$. It bears a label "Aster macrophyllus" in Nees' hand, as attested by Gray. The fact that Nees named it Aster, not Eurybia, seems to indicate its date as before 1825, when Cassini published his genus Eurybia. The specimen was given by Nees to Schultz Bipontinus, who wrote a new label reading "Eurybia macrophylla Cassini ; Nees, Aster, p. I40," etc., adding " e herb. Neesii cum ejus autographo, Sz. Bip." Next it seems to have gone to Hohenacker, from him to Klatt, and from him, in $\mathbf{1} 885$, to Asa Gray, who at one time queried if the plant were not Biotia commixta, and again added that it " is the 'Eurybia commixta Hort. Petrop.' spec. Hb. Kezw," perhaps from consideration of the non-cordate radical on Nees' sheet; but non-cordate radicals occur occasionally in nature in $A$. macrophyllus as well as in $A$. commixtus and in all other Biotian species. Perhaps the well-known glandular character of Biotia commixta was the reasun for Gray's first comparing this specimen with it, the glandular character of Aster macrophyllus proper having been long overlooked. Nees' description, however, noted that Aster macrophyllus has short glandular and odorous hairs mixed with the longer strigose hairs, even as Jow down as the lowest radicals. So has his specimen, all over the younger parts, petioles, pedicels, under side of upper stem-leaves, and on the separate radicals both above and beneath. Nees' specimen is wholly unlike the Bernhardi plants of Aster commixtus (none of Nees' seem to have survived). It appears to be a proper specimen of $A$. macrophyllus, although in fragments and without the characteristic radicals and caulines. It agrees with the native plant which $I$ have considered to be $A$. macrophyilus and which is the nucleus of the $A$. macrophyllus representation in most Aınerican herbaria, in its abundant capitate glands, in their location, in its crenate-serrate and curvescent teeth, its large broad-triangular acute bracts, its large heads, and the form of its axiles.

Hb. Mus. Paris, in hb. Gray, obtained as representative of the Biotia macrophylla of the Paris garden, in 1869 . This plant is true to A. macrophyllus in its glandular and strigose hair on inflorescence and upper foot of stem, and on the leaves beneath; also in its bract form; but it is unlike A. macrophyllus in its rectangularly divaricate pedicels and close sharp teeth.

History of Aster macrophyllus. Being closely entangled in the past with $A$. divaricatus, and descending to us in lines parallel to it always, the outlines of their common annals are already given in tracing general Biotian history; page $62+$. In those pages I have mentioned the first European botanical traveller to notice A. macrophyllus as probably Sagard in $1624-6$, the first collector known to send it abroad as Sarrazin, before 1720 , the first to catalog it as Vaillant, writing I720, the first known to cultivate it as Philip Miller in or before I739, the first to give it proper description as Nees in 1832 . It remains to formulate here the successive steps of development of its description.

Appearing first in print as a polynomial, the Aster Canadensis, 
etc., of Vaillant in I 720,-who had his specimen from Sarrazin,it seems next to have been termed $A$. Acadiensis by Jussieu under whom it was so cultivated in the Paris garden, fide Lamarck's citation in 1783 . Meanwhile its first binomial description had appeared at the hands of Linnaeus, I763, and the successive increase of definiteness up to the full description of Nees in 1832 will be indicated by quotation ;

$$
\text { Linnaeus, } S p \text {. pl., ed. 2. } 2 \text { : } 1232 . \quad \text { i } 763 .
$$

[A.] macrophyllus. 34. Aster foliis serratis; radicalibus trinervatis cordatis maximis, caulinis ovatis sessilibus.

Aster canadensis, foliis imis amplioribus cordatis serratis, Vaill. act. 583 .

Habitat in America septentrionali. 21.

Folia Radicalia magna, petiolata, cordata, serrata, trinervata ut in Fetasitide. Ramea parva, ovata, sessilia, serrata. Pedunculi ad apicem conferti, sape trifidi.

[This description remained unchanged as far as 1784 , in the ed. I 4 of the Systema vegetabilium.]

LAMARCK, Encyc. meth., I : 307. I 783.

Astère à grandes feuilles.

A. foliis radicalibus petiolatis, cordatis, serratis; caulinis ovatis sessilibus; caule corymboso. $\quad N$ [obis].

A. Acadiensis, coronae solis folio. H. R.

A. Canadensis, foliis imis amplioribus cordatis serratis. Vaill. Act. 583 .

Lamarck, after his character and two synonyms as quoted above, added, in French, the following description :

"Its stem is about $2 \mathrm{ft}$. high, terete, pubescent, sometimes very smooth [such cases were by Nees deemed to be his $A$. Schreberi $\beta$, and were probably later included in part in De Candolle's $B$. latifolia] and furnished on its upper part with branches disposed in a corymb. Its radical leaves and those at the base of the stem are petioled, decidedly large, cordiform, pointed, toothed, hairy underneath ; and are not only 3 -nerved as says Linnaeus, but are furnished with many oblique nerves which proceed from each side of the midrib. [But Linnaeus knew this; his "trinervata" meant, having among its strong pinnate veins, two basal ones so much stronger than the rest as to give, with the midrib, a 3-nerved effect to the sinus.] Other leaves of the stem are oval-lanceolate, and sessile or almost amplexicaul. The flowers are terminal, white or a very pale violet, their involucre imbricated and close-ranked; and are in a corymb.-This plant is native of North America and is cultivated in the Jardin du Roi. Perennial, v. v."

$$
\text { Aiton, Hort. Kerv., 3: 207. I } 789 .
$$

A. foliis serratis oblongis, supremis ovatis sessilibus, caulinis cordatis petiolatis, petiolis superioribus alatis. 
Willdenow, Sp. pl, $3^{3}:$ 2037. I 804 [see p. 281]; what Willdenow says himself is as follows:

A. foliis ovatis petiolatis serratis, summis ovato-cordatis sessilibus, inferioribus cordatis petiolatis, petiolis submarginatis, caule ramoso diffuso, calycibus cylindricis, arcte imbricatis, W.

a. A. corollae radio caeruleo, W. [W. next citing Linnaeus' A. macrophyllus and Vaillant's $A$. Canadensis, etc., as synonyms $][=A$. macrophyllus $\mathrm{L}$. $]$.

$\beta$. A. corollae radio albo, W. $[=A$. Schreberi Nees $]$.

Variat foliis radicalibus ovato-cordatis et oblongo-cordatis, florum radio caeruleo et albo. In plantis radio caeruleo instructis, corollae radii sunt oblongae longitudine calycis, calycisque squamis ovatae acutiusculae; in plantis radio albo, corollae radii lineares calyce longiores, calycis squamae oblongae obtusae, W.

The Willdenovian herbarium still preserves 7 sheets labelled A. macrophyllus, as kindly examined for me by Dr. L. M. Underwood, of these nos. 3, 4, 6, may be A. macrophyllus L., nos. 7, 2, 5, A. iostemma, and no. I, A. umbelliformis; fide descriptions and drawings by L. M. U.

MaRTyn, in his edition of Miller's Gardener's Dict. (1807), quoting $A$. macrophyllus as described by Linnæus, adds as its English name, "Broad-leaved Blue-starwort," using " blue" for lavender, and showing that the plant then cultivated at Kew of which he speaks was not Willdenow's white variety but the var. $\alpha$. The Kew plant aside from the Linnaean herbarium, was doubtless the best representative of what Linnaeus' original $A$. murcrophyllus had been.

Martyn refers to L'Heritier, Stirpes nov. 2: t. 66 ( 1784-5), as a figure of $A$. macrophyllus; but the figure proves to be an Itea.

Schultes, Observationes Botanicae in Linnei Species plantarum ex editione C. L. Willdenow ; I 78 (I 809).

Def. Ait. Kew. optima. Folia scaberrima, sed in illo qui radiis albis est, non trinervia. [If the plant Schultes had was $A$. Schreberi, it may have failed to show radical leaves; otherwise his plant must have been some non-trinervate acutely-linearrayed white relative of $A$. Schreberi: like $A$. curzescens while young and unflattened.] Mira foliorum subcarnosorum vix describenda varietas. Petala linearia acuta. [The second sentence refers apparently to a plant of $A$. macrophyllus pinguifolius; and perhaps all three clauses do.]

NeEs, Synopsis Asterum (1818), though with but brief characters, first separated the white component of the $A$. macrophyllus of Willdenow, naming it $A$. Schreberi.

Cassin i in 1825 listed the species as Eurybia macrophylla, in Dict. des Scicnces nat., $37: 487$; having published his genus Eurybia (= broad-spreading), in 1818, Bull. philom. 166, and again, Dict. des Sciences nat. I6: 486. 
SPREngel in the I 6 th edition of Linnaeus' Systema Vegetabilium, 3: 532 (1826), described $A$. macrophyllus rather confusedly, but contributed to the growing mass of recognized characters, these that " the corymb-branches are rigid," and "the bracts appressed." He included both colors, saying "radius caeruleus seu albus"; although also recognizing $A$. Schreberi.

NeEs, Gen. Ast. I $40 . \quad$ I 832 .

3. Eurybia macrophylla Cass.

E. foliis cordatis ovatisve, radicalibus subtrinervatis, caulinis in petiolum alatum contractis serratis scabris subtus hirtis; caule hirto rariusve glabro patulo corymboso, ramulis rigidis, periclinii arcté imbricati foliolis oblongo-lanceolatis obtusis.

Variat: $a$. Foliis radicalibus cordato-subrotundis, caulinis inferioribus cordato-acuminatis petiolatis, superioribus cordato-ovatis amplectentibus (huc A. cordifolius Hb. Beilschm. ex Ht. Ber.). [Apparently Nees did not intend this var. $\alpha$ as the typical form of his species; when he did so intend, he frequently omitted any var. $\alpha$ beginning with $\beta$; but was not uniform, his typical or name-conferring form of a species sometimes seeming to be listed not as a first variety but as a third or fourth. - This present $a$ could agree with $A$. orbicularis sometimes, when the cordation continues even through the upper leaves.]

$\beta$. Foliis radicalibus cordato-ovatis acuminatis, caulinis omnibus ovatis acuminatis in basin amplexicaulem contractis. [= Small plants of $A$. excelsior? such often agree with this remarkable description; which involves a stem without a cordate leaf. Large plants of $A$. excelsior, like other Macrophyllan species, have some cordation in a few basal leaves.]

$\gamma$. Caule glabro, foliis caulinis plerisque cordatis longe petiolatis laxiusculis minus hirtis, summis ellipticis argute serratis basi attenuatis, corymbo terminali depauperato, ramis bi-unifloris. In umbrosis rupestribus Cove Valley, Pennsylvaniae. Aster corymbosus Fl. Pennsylv. in Herb. Günth.*

* The "Flora Pennsylvanica" was contained in the herbarium of Günther at Bres$\mathrm{l}_{\mathrm{au}}$ and in the Royal Herbarium at Berlin. Günther was an author of a Flora of Silesia, I824; and was "Medicinal Assessor" at Breslau, where he died, 1833, aged 64.

This "Flora Pennsylvanica" was often cited by Nees for his Asters, for species collected "in the woods of Tuscarora," "along hedges in Cove Valley," "in swamps of Lower Cove," "collected along Cove Cr.," " in Pennsylvanian thickets," or as in our exainple above, "growing on shaded rocks in Cove Valley." The specimens seem to have been collected in part by Pöppig, in part by Günther himself aud perhaps in part also by Bernhardi, who at least contributed specimens.

"Cove Valley" and "the woods of Tuscarora" seem to take us to Perry Co., central Pennsylvania, where are both the Cove Mts., a long range abutting on the Susquehanna just above the village of Marysville, and the Tuscarora Mts., the next long parallel range to the north, below which stretches for 30 miles or more the Tuscarora Valley, watered by Tuscarora Cr. forming the west half of Juniata Co., and now threaded by the Tuscarora Valley branch of the Pennsylvania R. R. To the south, beyond the Cove Mts., rises the Blue Ridge; before which one still finds the "Cove Station" and the "Cove Forge Station" on the Pennsylvania R. R.

This was doubtless the region where much of Günther's Flora Pennsylvanica was collected. Perhaps it was here that the original specimen of A. glomeratus had its 
Crescit [species macrophyllus] in sylvis umbrosis circa rupes per Canadan ad Virginiam usque. Floret a Septembre in Novembrem usque $\{i$. e., so reported probably by Pöppig to Nees, from imperfect observation of later-flowering forms and sprouts, and such Sept. and Oct. flowering species as $A$. curvescens]; apud nos saepe jam exeunte Augusto [indicating that Nees had our genuine August-flowering A. macrophyllus in cultivation]. Perennis. Vidi exempla culta et spontanea.

Similis Eurybia Schreberi, sed differt: caule plerumque hirto, foliis subtus, ad costas præcipue, hirtis, supra setis sparsis hirto-scabris; ramis rigidioribus paucifloris, foliis ovatis brevioribus acutiusculis vel etian obtusis, integerrimis; calathiis majoribus, radio plerumque lilacino, rarius albo [and when white, usually due to fading; sometimes to malnutrition]; achaeniis nervoso-striatis, in juventute pubescenti scabris, aetate glabris aut setulis sparsis; periclinii foliolis ovato-oblongis saepe acutiusculis, magis hirtulis ; clinanthii alveolis amplioribus, marginibus humilioribus repandis, neque evidenter dentatis.

Squamae [scales investing the growing upturned end of the young surculus] duae, latae, ovatae, aridae, suboppositae turionem germinantem cingunt ; sequuntur duae consimiles [phyllomes chiefly petiolar with small lamina imperfectly developed], purpureae, sursum angustiores et hac parte, ceu petiolo, laminam exiguam lineae longitudinis rotundam acutam ferentes; tum [primordial leaf] folium I $(-2)$ bi-trilineare, acutiusculum, serrulatum, orbiculare, in petiolum triplo longiorem basi squamatim vaginantem transiens. Quod proximum est folium [shorter radical], pollicare, in petiolo poll. $2 \frac{1}{2}$ longo, cordatum, obtusum cum mucrone, dense incumbenti-serratum, undique cum petiolo hirtum immixtis pilis brevioribus capitatis glandulosis odoris [the first mention of glands upon $A$. macrophyllus, an important character not emphasized till r 8981.

Reliqua folia [larger radicals and basals] circum cau'em inferiorem semper petiolata, reniformi-cordata, cordata, ovata, latiora vel angustiora, 4-6 pollices longa, 3-5 pollices lata, acuminata, crenato-serrata serraturis mucronatis, penninervia; quae reniformi-cordata, plerumque intra sinum trinervata ; rarius autem occurrunt inter haec, quam in Astere Schreberi, folia reniformia suborbiculataque; caulina infima [lower caulines] radicalibus similia sunt, similique ratione longe angusteque petiolata, reliqua pleraque [middle and upper caulines] sessilia invenies, alia basi ad speciem petioli latissimi contracta, alia et pleraque ovata vel ovato-oblonga, basi cuneiformia [the characteristic upper cauline type], superiora [axiles] denique ovata amplexicaulia, omnia acute serrata, serraturis sensim evanescentibus, usquedum folia ramorum [rameals] minora, acutiuscula vel obtusa, ovata, amplexicaulia, integerrima prodeunt. Ligulae radii longitudine periclinii, lineari-lanceolatae; discus periclinium adaequans, e flavo fusco-purpureus. Rami terminales saepe divaricati. Planta spontanea humilior est [a mistake due to the natural selection of small and more manageable plants as herbarium specimens], calathiisque paucioribus ornata, laxior quoque; caeterum cultae simillima.

Adnot. I. Asterem macrophyllım Lin. ob "folia caulina ovata sessilia" ad hanc adduxi speciem; reliqua autem definitionis etiam ad Eurybiam Schreberi, et majori

hirth; here certainly grew the third variety or Cove Valley form of Nees' Aste macrophyllus.

Cove Valley plants cited by Nees include his $A$. macrophyllus $\gamma$, in hb. Günther; Doellingeria cornifolia, furnished by Pöppig to hb. Günther; $A$. phlogifolius; $A$. prenanthoides; $A$. glabellus $\beta$ and $A$. cyancus $\beta$.

Other asters in the Hb. Günther include A. subcymosus, $A$ heterophyllus, $A$. luxurians $\beta, A$. ericoides, $A$. diffusus $\beta$, and about a dozen more, which Nees cites, many of them originally furnished by Bernhardi. 
fere jure, referri possent. 「At least 3 respects, however, may be noted in which Linnaeus' description applies better to Nees' $A$. macrophyllus than to his $A$. Schreberi; Ist, the ovate sessile serrate caulines; $2 \mathrm{~d}$, sacpe trifiai, said of the trifurcate peduncles ; 3d, the comparison to Petasites is suggested by the very aspect of $A$. macrophyllus but by $A$. Schreberi only after scrutiny.] Aster divaricatus Lin. Eurybiae macrophyllae, absque foliis radicalibus infimisque consideratae, praebet imaginem ; synonyma autem, eidem adscripta, pleraque ad Doellingeriam humilem pertinent.

Adnot. 2. Ante quadraginta annos hanc speciem in Horto botanico Jenensi Asteris divaricati sub nomine cultam vidi et exemplum ibidem lectum apud me servo. Folia radicalia, solo sicciore per aestatem pereuntia, humiliorem tum relinquunt caulem, pauciflorum, corymbo divaricato foliisque omnibus ovatis Linneanis characteribus ad verbum respondentem. [So Nees deemed his specimen of the $A$. divaricatus of Hort. Jena of about $\mathbf{1 7 9 2}$, to be a depauperate $A$. macrophyllus without radicals. Reading this may have helped to cause DeCandolle in 1836 to add his variety divaricata (infra) to the species macrophyllus.]

DeCandolle, Prodromus, $5: 265$ ( 1836 ), gave the following highly generalized description of Aster macrophyllus:

Biotia macrophylla, caule plùs minùs hirto apice patulo-corymboso, foliis radicalibus petiolatis cordatis, caulinis alato-petiolatis sessilibusve ovatis, omnibus subscabris serratis acuminatis, capitulis pedicellatis, invol. squamis arctè imbricatis oblongo-lanceolatis obtusis [only the inner ones are typically obtuse], ligulis elongatis. Perennis. In Amer. bor. umbrosis rupestribus à Canadâ ad Virginiam.-Ast. macrophyllus Linn. sp. I232. Michx. fl. bor. am. I 14. Eurybia macrophylla Cass. dict. 37. p. 487. Nees ast. 140. Desf.! hort. Par. ed. 3. p. 176. A. cordifolius hort. plur. Folia floralia acuta.- (v. v. et s.)

$\beta$ divaricata, foliis floralibus rotundatis. Perennis, in Amer. bor. (Linn.). Ast. divaricatus Linn. sp. I226. [So far this var. $\beta$ represents Linnaeus' description of $A$. divaricatus; the identity of which with the $A$. corymbosus of Aiton was unsuspected by DeCandolle.] Ast. macrophyllus carneus hort. angl. ex herb. Linn. obs. Lindl. in adn. mss. [Perhaps this carneus of which Lindley wrote was simply a designation for the typical $A$. macrophyllus of Nees as distinguished from 'the whitish-flowered Schreberan plants often confounded with it.]

- Since 1836 , and for some years before, the additions to description of $A$. macrophyllus $\mathrm{L}$., which require our consideration, are of American origin. Earlier writers on American plants had not noticed it, except that Forster catalogued it in $177 \mathrm{I}$, and Michaux, Fl. Bor. Am. 2: I I 4 (I803), described it as

A. macrophyllus L. Aster universe pubescens: foliis radicalibus imisque amplissime cordatis, petiolatis; omnibus arguto serratis asperis : corymbo floribus majusculis. Hab. in Canada.

Muhlenberg, Catalogus Pl. Am. Sept., 73 (I8I3; but written I809) listed it as "A. macrophyllus, alb. caer., perennis," the "large-leaved" Aster, flowering in Pennsylvania in "July."

Pursh, Fl. Am. Sept., 2: 552 (1814), repeating Willdenow's description, added 
In shady woods about rocks; Canada to Virginia. Perennis. Sept.-Nov. [misled in dates by confusing his own notes?] v. v. : v. s. in Herb. Banks et Lambert. A foot or two high; flowers above the middle size, rays white and sometimes blue.

Barton, Compendium Fl. Phila. 2: i I 5 (18 18), gave the first description in English, as follows :

17. A. macrophyllus. Leaves ovate, petiolate, serrate, rough; upper ones ovate, cordate [a mistake], sessile, lower ones cordate, petiolate; petioles submarginate; stem branched, diffuse; calices cylindric, narrowly imbricated; scales oblong, acute. Willd. and Pursh.

Large-leaved Aster, about $\mathbf{I} 2$ or $\mathbf{I} 5$ in. high. Flowers bluish [this suggests that his plants were of $A$. quiescens ], in the shady woods above the falls of Schuylkill, west side, abundant. Perennial, September.

Nuttall, Genera, I 8 I 8 , simply enumerates this species.

Torrey, "Cat. of Plants" for N. Y. City, 66 (I8 I9) lists it as "I 5, macrophyllus, Ait. Rocky shady woods, Bloomingdale [site long since destroyed by building]. Aug., white or pale-blue."

Bigelow, Fl. Bost., ed. 2, 3 I 4 (I 824), adds A. macrophyllus to the species he had described in the first edition, translates Willdenow's character, and adds :

The root-leaves are uncommonly large, heart-shaped, serrate and acute, rather smooth. Stem furrowed, scarcely rough. Upper leaves sessile, ovate, a little hearted at base [probably merely clasping the stem]. Scales of the calyx closely appressed. Ray pale blue. - Woods. - September. - Perennial. [Perhaps Bigelow's specimens were of $A$. ianthinus; typical-A. macrophyllus plants would not have been "rather smooth," nor "scarcely rough;", nor flowering in "September."]

Torrey, Compendium, 299 ( I 826), included A. macrophyllus, remarking of it, "white or pale blue ; scales oblong, acute."

Torrey and Gray, Fl. N. Am., 2 : IO5 (May, I 84 I) ; as follows, excluding synonyms :

A. macrophyllus (Linn.); stem stout, somewhat striate-angled, roughish-pubescent above, the corymbose branches also rigid; leaves thickish, scabrous, closely serrate, somewhat acuminate; the radical and lower ones (large) cordate, on slender petioles ; the upper sessile or on margined petioles ; heads in ample corymbs; involucre nearly the length of the disk; the exterior scales rigid, oblong or ovate-oblong; rays (white or purplish) I2-I 5 .

$\beta$. stem and leaves nearly smooth and glabrous; heads usually smaller. - Aster Schreberi Nees, synops. p. 16; Spreng. syst. 3. p. 535. Eurybia Schreberi, Nees! Ast. p. I38. Biotia Schreberi, DC.! l. c. (Varies, with the lieads somewhat glomerate on short pedicels, and the rays shorter; apparently an accidental state. Eurybia glomerata, Bernh. in Nees, Ast. l." c. Biotia glomerata DC.! l.c.)

$\gamma$. exterior scales of the involucre broadly ovate or roundish-oval; otherwise as in $\alpha$. [Cf. $55^{19}$.]

Woodlands, Canada! (from the Saskatchewan!) and Northern States! Aug.Sept. - Stem $1 \frac{1}{2}-3$ feet high, usually broadly corymbose ; the upper portion, as well 
as the pedicels and involucre, clothed with a close puberulence which appears glandular or viscid under a lens, often with roughish hairs intermixed; below, as also the petioles, either smooth or with a rough pubescence. Radical leaves 4-10 inches long and 3-6 in width, varying from roundish-cordate to cordate-oblong, serrate with broad and short mucronate teeth, often sparsely hirsute, and usually hairy on the midrib and strong veins beneath; the petioles 4-12 inches long; cauline leaves smaller, ovate or oblong; the upper closely sessile; the lower abruptly narrowed into a margined or winged petiole. Heads mostly large; the involucre about half an inch in diameter; the exterior rigid scales pubescent-ciliate, acutish or obtuse; the innermost much larger and membranaceous. Pappus tawny, or reddish. Achenia linear, obscurely striate, almost glabrous when mature. - There are certainly but two species of Biotia indigenous to the United States. B. (Eurybia, Nees) commixta, DC. is of doubtful origin; but perhaps it is only a form of this species.

Garden and Forest, 4: 88-89 (1 891), figured A. macrophyllus and added a brief description, stating, in substance: "Radicals sometimes 8 or Io by 4 or 5 inches, broad-ovate or reniform-cordate ; stem 3-4 ft. high, angled, bearing corymbose cymes. - Canada to Manitoba, to mountains of Carolina and Georgia." The figure and some features in the description seem drawn from a plant which would now be classed as $A$. uniformis, or as a transitional between $A$. macrophyllus and that species; as the description of the leaves as " sharply serrate."

- Since Torrey and Gray's Flora, Astcr macropliyllus had been accepted by American botanists for a body of forms, with white, lilac, lavender, or violet rays, but alike in producing colonies of large radicals; and under this name all the asters with large radicals were lumped together. Among the first to perceive that there was something wrong in this were Dr. L. F. Ward, Washington City, as indicated in remarks in his Flora of D. C., I88 I, and Dr. Geo. Vasey, as indicated verbally to the author in I 888 and to Dr. Ward earlier (vide p. 252); forms of $A$. curvescens and allies, with white rays and smaller heads, had aroused their suspicions and seemed to them separable. Meanwhile along the lower Hudson, Mr. E. P. Bicknell was perceiving cause for separation at the other extreme of "violet-rayed plants with camphoric odor" as labelled by him in the field, I 896, and Prof. C. H. Peck at Albany observing similar violet-rayed plants was at first inclined to class them in $A$. Herveyi (because that is a violet-rayed glandular species), leaving the body of white-rayed plants in $A$. macrophyllus. The true line of cleavage along the development of glands had yet to be made out by combination of careful field-study and comparison of herbaria. Meanwhile Prof. Peck, pp. 45, 46, of his Annual Report as State Botanist for I 892, published independently the following review of the situation as known to him (N. Y. St. Mus. Nat. Hist. Annual Repts. 46: 45, 46. I 893): 
A. Herveyi Gray. Borders of woods, Blue Mountain Lake [Adirondacks], and Voorheesville [Albany Co. ], August and September.

In the Manual this is indicated as an " ambiguous species," approaching $A$. macrophyllus. It is indeed liable to be mistaken for that species at least in some of its forms, if I rightly understand it. In the N. Y. specimen's, the branchlets and peduncles are glandular-hairy and the involucral scales are glandular and the rays are violet as in $A$. Herveyi, though in some instances the color is pale violet. On the other hand, the leaves are not always lanceolate, but are sometimes ovate and distinctly serrate. [So they should be understood to be in $A$. Herveyi, and also roughened]. They are also rough and rather thick as in $A$. macrophyllus. But this species [A. macrophyllus] as described in the N. Y. St. Flora, has a reddish-tawny pappus while in our violet-rayed specimens the pappus is white or whitish [because young], which is an additional reason for separating them from $A$. macrophyllus if this should prove to be a reliable character. It seems best, therefore, to consider them as a variety of $A$. Herveyi, and to indicate their character thus :

A. Herveyi Gray, var. intermedia Peck. Branchlets and peduncles glandular-hairy; heads large ; rays violet ; involucral scales glandular, erect, all or all except the longer and more pointed inner ones, green or with green tips ; pappus white or whitish ; leaves rather thick and rough, ovate or lanceolate, the lower on naked petioles and more or less cordate, the upper sessile, the radical leaves large, broadly ovate-cordate, rough, on long naked petioles. Apparently intermediate between typical $A$. Herveyi and [white] A. macrophyllus. With this it has probably been confused, but from it it may be separated by the larger heads, color of the rays and pappus and glandular peduncles.

All the foregoing derived its pertinence from the fact that the "lilacine" A. macrophyllus of early writers had fallen into obscurity and the whiter plants they had left associated with it had engrossed attention. Now that the wholly dissimilar white plants have been removed, forming the Curvescentes, the reason for Prof. Peck's var. intermedia disappears, and on conference later he agreed with the author that this variety is a synonym for typical A. macrophyllus.

Variants of A. macrophyllus.

$55^{2}$ Sprout-forms tend to develop flowers rather than foliage ; leaves more uniform, smaller, nearly alike in size, $2 \times \mathrm{I}$ in., sessile by a broad subcontracted base; or a few lower ones have a wingbase or short narrow petiole ; the leaves being mainly of the form which is typical of the axiles of the normal plant. In sprouts $2 \mathrm{ft}$. high, about $\mathrm{I} 2$ such leaves may be produced below the inflorescence, and are continued as axiles and rameals with little change except reduction in size and development of broader base and more tendency to conduplication; as would be expected from rameals on the normal plant. Heads not many, 20 or less, sometimes all much larger than in the type, and $\frac{13}{16} \mathrm{in}$. high instead of $\frac{8}{16}, 11 / 2 \mathrm{in}$. broad instead of I in. Compared with branch-forms, the lower leaves are apt to be broader, oval-acute to oblong-lanceolate, all sharp-serrate or serrulate. Common; examples include : 
Ct., Meriden Hills, Se. 28, '58, D. C. Eaton in hb. Mo. Bot. Gar.

N. Y., Plattsburg, L. Champlain shore, Au. 31, ' 97.

$55^{3}$ Branch-forms; where the branches are excessively developed from lower axils to replace a weak or deficient axis. Such branches usually show the rameal type of leaf, greatly enlarged, preceded by several small oblong-spatulate subentire leaves, 2 in. by $2 / 3$ in., or less, somewhat resembling Erigeron annuss; followed by larger more normal oblong-acuminate leaves, $5 \times \mathrm{I} \mathrm{I} / 2$ in., or more often $3 \times \mathrm{I} 1 / 2$.

$55^{4}$ Arrest-form, with little leaves. The 2 or 3 medium-sized basal leaves are followed abruptly by an arrest of leaf-producing vigor, the remaining nodes bearing a series of much smaller leaves, all much alike in size though differing in shape, petiole and base. Such plants may resemble $A$. biformis or arrested states of $A$. multiformis and other species; but are of the thick texture of $A$. macrophyllus, and often occur in patches of normal macrophyllus plants. They are unlike the similar arrest-forms of other species in their radicals or their strigose hair, roughness, glands, or inflorescence.

Very common, and seen in plants of early European cultivation, as of hb. Bernhardi, and of hort. Sallzwedel in Frankfort, 1825 ; see fig. 71 .

$55^{5}$ Other arrest forms; with certain middle nodes of the stem concentrated; occasional.

$55^{6}$ With axiles and rameals minute or absent; occasional.

$55^{7}$ Intercalary form. With one or two small middle caulines intercalated between ordinarily large leaves, occasionally; L. Champlain; L. Erie ; hort. Erfurt in hb. Bernhardi; etc.

$55^{8}$ Eccentric forms or sports; with gibbous or simular leaves among the normal ones; W. N. Y.

$55^{9}$ Trapezoidal middle caulines occurring; W. N. Y.

$55^{10}$ Glabrate form; mostly typical, with coarse flabby leaves, but with persistently smooth stem, minutely glandular above; roughness of leaves moderate; teeth more serrulate; middle bracts acuter. Transitional from $A$. macrophyllus $\mathrm{L}$. to the next form. Castine, Me.; L. Erie, very common.

$55^{11}$ Kid-finish form, transitional to $A$. $m$. pinguifolius in its smoother thinner firm leaves, of the texture of undressed kid when growing, but not greasy like pinguifolius; the same leaves becoming roughish usually on drying.

Unlike $A$. multiformis in its greater leaf-breadth, and usually a taller stronger plant, often $2 \mathrm{I} / 2 \mathrm{ft}$., but like it in dark-green leaves and violet rays.

N. Y. vic., Yonkers, Palmer Av., Se. 25, '96, Se. 13, '97, Au. and Se., '98, '99, 1900, I901, 1902, 1903, 1904, 1905. 
W. N. Y., Niagara, Whirlpool Woods, brink of gorge, radicals becoming even $12 \times 7$ in., the overlapped sinus $21 / 2$ in. deep; Au. 17, '96. Silver Cr. Cemetery, Au., '96, Au. 24, '97, Au. 12, '98, Au., '99-1904.

No sufficient explanation of this form is to be found in shade or in richness of soil, the type growing with it in the same conditions. Such variants may form the whole of a loose plantation; or be outliers from a colony of the type; or be stray individuals along a wood border; or stand as individual sports in the midst of a colony of the type; hence I do not separate this form as a subspecies but regard it as a transient manifestation of that tendency of the variable type which when much stronger in development produces the form pinguifolius, the ancient Biotia latifolia.

$55^{12}$ Hetchel form. Some pubescence; shapes very irregular but mainly as the type, of which it is but an extremely harsh form; leaves very rough in life, like sandpaper when dry; "rough as a hetchel," people call them; abundant in W. N. Y., etc.

$55^{13}$ Triangle-hetchs form. Lower leaves not large, triangular-cordate, rather obtuse, very thick and rough; leaves slowly diminished up the stem; stem glabrous, deep purple-red; inflorescence cylindric-convex, becoming $\mathrm{I} 2 \mathrm{in}$. high by 6 broad, or in smaller plants short-convex, apt to have their pedicels forking in 5's, instead of trifurcate. Some reniform lower caulines or radicals occur. Rays often full violet rather than lilac. Bracts chiefly rigid, brownish, acute, with little hair. - Appears intermediate between $A$. macroplyyllus and $A$. multiformis; and probably unstable. Highly developed plants appearing very distinct, led me to look for evidence subsequent years to determine whether or not it should rank as a separate species; but it seems sporadic.

W. N. Y., Sheridan, Herrick's woods, Au. 12, '96; Silver Cr., Swift's Hill Au., '96; gorge at Aster-bank, Au. 17, '96; Fredonia, Cascade brook, Au., '96; Perrysburg roadside, bronzed in the sun, Au. 29, '96; Cattaraugus resn., Little Indian Cr., bank, Au., '97, Au. 13, '98.

$55^{14}$ Tall-top form. With narrow tall inflorescence, its lateral branches late and much shorter; the distinct roughness of the broad-cordate leaves increased upward till the axiles are like shagreen. Inflorescence like the last in form, and in frequent 5 -forking umbelliform peduncles; but leaves and rays like $A$. macrophyllus. With the type.

W. N. Y., Cattaraugus resn., Big Indian Cr., prevailing form on steep bankside, in thickets and also on open gravel-flats, July $3 \mathbf{r}$, ' 96 .

Pa., Alexandria, open field, 1844, 7: C. Porter.

Minn., Chisago Co., Amodar, Au., '92, B. C. Tay'or in hb. Colu.

N. C., Swain Co., in Great Smoky Mts., Au., '91, Beardslee and Kofoid in hb. Gray. 
$55^{15}$ Aculeated form. Close-colony form with short rootstocks, very peculiar in aspect from the dark blackish-green leaves held stiffly outward at a straight slant continuous with the rigid blackish or purple petiole. Leaves very rough in life, and firm, somewhat triangular-cordate. Teeth long and coarse, often over $\frac{1}{2}$ in. long, sometimes even $\frac{3}{4}$ in., with $\frac{3}{16}$ projection, usually dorsally straight, though sometimes curvescent, with a strong aculeus which is very salient in life and points upward, giving the leaf its characteristic aspect. Radical petioles short, stout, succulent, enlarged at the base, not at all erect, but slanting at about $30^{\circ}$ instead of $75^{\circ}$ as usual. Radicals 3 , sometimes 4 , of which the 2 last are nearly equal, and the I or 2 first are very much smaller, a little more acuminate and asy mmetrical than in the type. Lower caulines 3, cordate-oblong, suddenly incurved-acuminate, sharp serrate. Stem smooth, blackish purple, its many leaves sometimes chiefly small, subentire, sessile and narrow oblong. Rracts short, more rounded than in type. Inflorescence rather small and dense.

W. N. Y., Silver $C r$., Au., under observation ' $97-1900$, then giving way to bushes and grass, and not reappearing $190 \mathbf{I}-2-3-4$.

$55^{16}$ Bunch-top form. Small leafy plants about $\mathrm{I} / 2 \mathrm{ft}$. high or less, with smooth stout ascending stem brownish and subsucculent in life, glabrate and reddish with age. Leaves not large, only moderately rough; radicals resemble those of $A$. multiformis, being 2, narrow-cordate, short-acuminate, rather symmetrical, aculeately forward-serrate. Some wing-based oblong-acuminate caulines are more as in typical A. macroplyyllus, as are the lilac rays, which however tend to assume a livid or slaty-lavender cast, and to fade whitish. Inflorescence small, densely convex. Bracts thinner, longer, and less puberulent than in typical A. macrophyllus, highly ciliate. Heads small, about $3 / 4$ in. broad, $3 / 8$ in. high. In small well-sunned colonies with grass between, under isolated trees; sometimes Ioo plants within $6 \mathrm{ft}$. with slanting stems about I 5 in. high, and with the radicals overtopped by intermixed grassblades.

Can., from Macoun, as A. macrophyllus, in hb. Mo. Bot. Gar.

N. Y., Plattshurg, Au. 31, '97.

N. J., Palisades, Oc. 17, '98.

W. N. Y., Pt. Gratiot, grassy edge near woodland, Au. 19, ' 98 , retaining similar characters six years under observation; showing in the outermost plants, most in light, a high-top or convex inflorescence, in the next a high broad-top, the inner more-shaded plants smaller and with denser inflorescence of more single-bunch type.

W. N. Y., Silver Cr., Talcott's Woods, by fence and by brook, Au. I 5, '98, to 1903. Cattaraugus resn., below skidway opening, Au. I3, '98 ; Little Indian Cr., Au. 24, ' 97 , with tough rootstock $\mathbf{I} \mathrm{ft}$. long, nodes $\mathbf{I}$ in. long, bearing very many heavy fibers; Maybee road, Au. 9, '97.

Also I888, H. H. Babcock in U. S. Nat. Hb. no. 18913. 
$55^{17}$ Dover form. Pubescent little-leaf plants with more dense flat-top inflorescence, and more uniform bracts. Glands abundant to base of stem. Villous hair clothes many leaves and petioles. Teeth small and close.

Me., Piscataquis Co., gravelly thicket at Dover, Au. 6, '95, M. L. Fernald, in U.S. Nat. Hb.

$55^{18}$ Denticulate form. Dark green plants with denticulate or subrepand oblong-acuminate lower leaves. Veins pale, about 6 pairs, forming gray lines across the leaf.

W. N. Y., Pt. Gratiot, Au. I I, '97, etc.

$55^{19}$ Round-bract form. Serrate rather than crenate. Heads close. Unlike type chiefly in its bracts which are chiefly rounded and very obtuse, even the outermost so; as in $A$. divaricatus $\mathrm{L}$. Perhaps as near to $A$. densatus, p. $34 \mathrm{I}$, as to $A$. macrophyllus; but with leaf-texture of the latter. Intermediate to $A$. roscidus. Rounded bract-tips occur also in Torrey and Gray's $A$. macrophyllus $\gamma$,- see supra, p. 3 I 2.

N. Y., Adirondacks, Horseshoe Pond, near Tupper's, St. Lawr. Co., August ; C. H. Peck in hb. N. Y. State.

W. Va., Aurora, Au. 24, '98, E. S. Steele, at $3000^{\circ}$, in hb. U. S. Nat. Mus.

$55^{20}$ Nigrescent form. Dark leaves; smooth green stem; texture thinner, smooth and slightly succulent in life, not harsh till dry; pedicels strict and elongated; rays violet, fading dingy white. Otherwise like $A$. macrophyllus type.

N. J., Palisade Park, Se. I4, I90o, very many plants with big radicals, $\mathrm{n}$. w. of Supt.'s house.

$55^{21}$ Refracted form. Branchlets greatly divaricated and refracted, on short distant branches in a high narrow inflorescence. Stem pale-green, smooth. Petioles continuous, soon narrowwinged, at the branches with broad short wings. Leaves applegreen, ovate-oblong, entire and smooth to the eye, actually irregularly denticulate. Sinus almost none even in basal leaves; bases chiefly truncate. Radicals small, deltoid-ovate, in small tufts. Bracts obtuse-rounded, oblong, ciliate. Rays I3-16, close together, violet, soon whitish, round-tipped with 2 or 3 excessively minute teeth. Disks golden, soon dull umber to maroon, finally a dingy greenish-brown. Glands very minute, whitish, capitate, continuous to base of stem.

N. J., Palisades, patch on clay-bank by Hottonia outlet, Se. 14, 1900. 


\section{5b. Aster macrophyllus apricensis Burgess}

Glabrate profusely-branched sprawling plants of sunny openings, with rough leaves, little or no cordation and long broad strap-like wings.

Name from L. apricum, a sunny opening.

Fig. 72, plant from near Cattaraugus Cr., N. Y., Au. 20, '96, in hb. $B u$. showing a stem with a few of its long branches.

A. macrophyllus apricensis Burgess in Br. and Br. Ill. Fl. $3: 360$. I898, with original description :

"Glabrate, branched from near the base, the branches numerous, often $18 \mathrm{in.} \mathrm{high;} \mathrm{heads} \mathrm{small,} \mathrm{numerous} \mathrm{;} \mathrm{rays} \mathrm{short,} \mathrm{pink-}$ ish lavender; leaves broad, oval to ovate, the teeth and sinus little developed; petioles often expanded into a long wing, sometimes 3 in. long and $1 / 2 \mathrm{in}$. wide; uppermost leaves short-oblong with a narrowed sessile base. In clearings and open gravelly or sandy places, N. Y. and Pa."

Stem and branches robust, pale, green or purplish, smooth to eye and touch, apt to become depressed, with about 5 broad ridges below, becoming multisulcate upward. Very peculiar in its branching habit, the short stem dividing not far above the ground into several or many long diverging branches, which are often $15-18$ in. long and bear each an abundant loose roundedcorymbose inflorescence. Leaf-type broad, ovate,

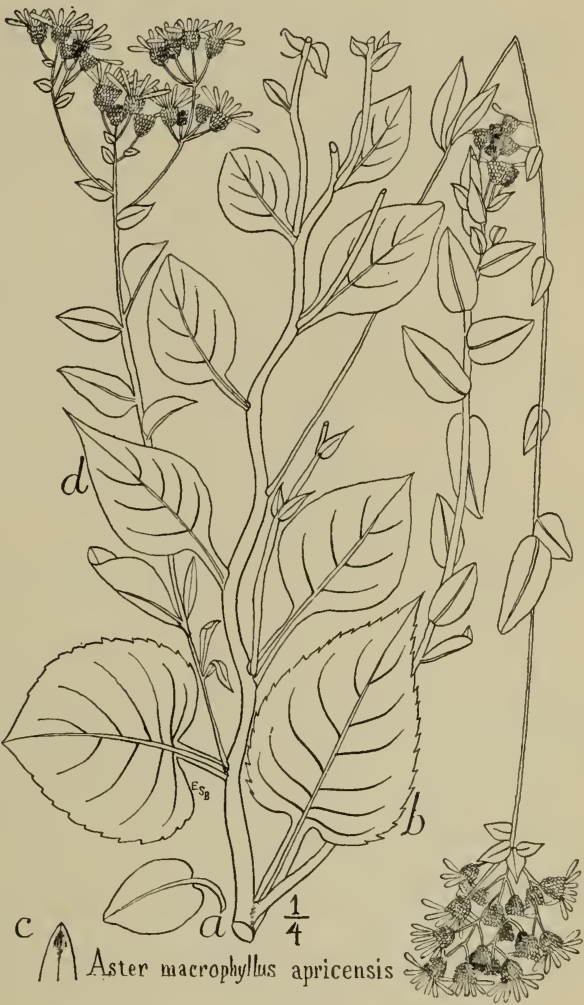

FIG. 72.

with little development of teeth or cordation. Axiles often the predominant leaves, large, oval or ovate, usually with rounded base and long strap-like amplexicaul petiole. Rameals numerous, sessile, somewhat oblong, often $2 \times 1$ in., sharply set, especially 
toward the apex, with broad shallow aculeate teeth directed forward; the apex either rounded or acute on the same branch. Leaves finely granular above, rough when dry. Minute downy and glandular hair on the upper six inches of branches and on the leaves beneath. Heads numerous and small with narrow impoverished rays; or fewer and larger, to $\frac{7}{16}$ in. high.

Examples:

Ms., Taconics, Mt. Ethel, Au., I90I, I903; Mt. Everett, Au., I90I ; Guilder Hollow, Au.. Igor, 1903.

IV. N. Y., Rathboneville, Steuben Co., Aug., Peck in N. Y. St. Hb. Cattaraugusresn., Little Indian Cr., Au. 20, '96, great hemispherical plant radiately branched from the ground; Maybee road, Au., '97; Indian-line road, Au. I3, '97, Au., '981903. Chautauqua Co., Silver Cr., July 31, '96.

Pa., Mercersburg, 1845, Dr. T. Green in hb. Porter, with many long branches I8 in. high; "Susquehanna, Au. 20, '95, and later; A. Herveyi," Jas. A. Ciraves in hb. Porter, some branches from very near the base reaching 18 in. length; Susquehanna, Kotz's newly cleared land, Se. 4, '96," Jas. A. Graves in hb. Forter (“A. macrophyllus, but peculiar," T. C. P.), with branches to 15 in. length. Susquehanna, same locality as the two last, Se. 10, '97, Jas. A. Graves in hb. $B u$.

\section{5c. Aster macrophyllus sejunctus Burgess}

More pubescent plants, subsolitary in grassy borders, with shorter broader more slowly-diminishing leaf-type.

Name, L., separated, from the subsolitary habit.

FIG. 73, plant from Perrysburg. N. Y., Au. 29, '96, in hb. $B u$; $b$, characteristic leaf; $d$, occasional acuminate leaf.

A. macrophyllus sejunctus Burgess in Br. and Br. Ill. Fl. $3: 360$. 1898 , with original description :

"Strigose-pubescent; glands numerous; leaves apple-green above, pale beneath, chiefly cordate-orbicular, abruptly shortacuminate, thick, spongy, commonly minutely-wrinkled; basal leaves few; bracts narrow, obtuse; peduncles slender; inflorescence dense, convex, 4-8 in. broad, not leafy; rays lilac. In open grassy places, Me. to Pa. and Wis."

Leaves soft, dry, becoming excessively brittle and even hispid after pressing. Sinus little developed. Long strap-like wings frequent. Upper caulines sessile. Few radicals seen.

Pubescence includes: First, minute surface-hairs, appressed, very short, whitish, all over the under surfaces. Second, long strigose hairs or weak bristles, spreading, slender, whitish, projecting in all directions from the veins beneath, multicellular and flexuous, making the leaves downy to the touch when fresh; some also on the stem. Third, stiff bristles; much appressed, 
forward-curved, set uniformly over the upper surface, one to each areolation, not more than their own length apart. Fourth, stout aculei or serrature-points, broad and yellowish, triangular, thick

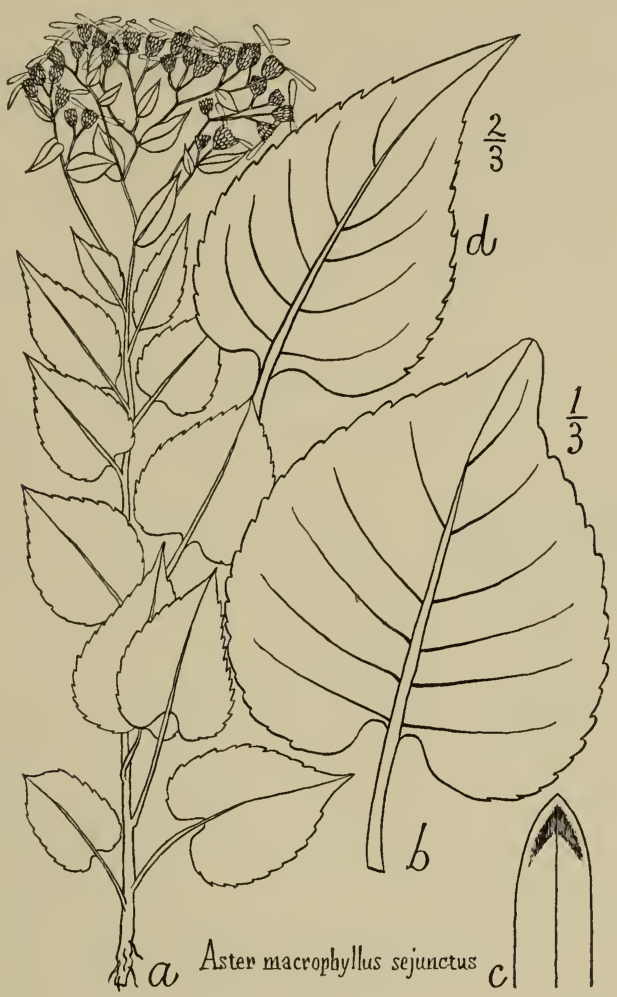

FIG. 73 .

and indurated, one terminating each tooth. Fifth, scurf, brownish and powdery over the chief veins above. Sixth, short stiff glandular hairs, rigidly projecting at right angles from the stem, and clothing it densely almost from its base, but almost imperceptible to the eye, increasing in length over the inflorescence, and there becoming mixed with short strigose hairs; the minute globose gland little thicker than its stalk.

Examples include:

Ms., Amherst, Se. '72, H. G. Jesup in hb. Canby.

N. Y., Hamilton Co., Blue Mtn. L., Au., and Steuben Co., Rathboneville, Au., C. H. Peck in N. I'. St. Hb.

W. N. Y., Niagara above gorge, Whirlpool woods, Se. 7, '96, '97, '98. Gowanda, Pt. Peter, Au. 29, '96. Perryshurghills, Au. 29, '96. Cattaraugus resn., Little Indian Cr., Au. 20, '96. 
Hanover, Gardner's Brook, Au. 19, '96. Dunkirk, Pt. Gratiot, Au. 29, '96. Pa., Bucks cio., T. C. Porter in hb. $P$.

Wis., Juneau Co., Cimp Doug!as, Se. 13, '90, Edyar A. Mearns in hb. Colu.

\section{5d. Aster macrophyllus velutinus Burgess}

Submontane plants with smaller firmer subtriangular shortacuminate leaves downy beneath.

Name, L., = velvety or downy.

FIG. 74, plant from Plattsburg, N. Y., Au. 31, '97, in hb. $B u$.; $b$, characteristic leaf-form ; $d$, frequent modification of $b$; $e$, radicals.

A. macrophyllus velutinus Burgess in Br. and Br. Ill. Fl. $3: 360$ (1898); with original description :

"Smaller; leaves small, ovate-triangular, slender-petioled, often truncate at the base, about $2 \mathrm{r} / 2 \mathrm{in}$. long by $2 \mathrm{in}$. wide, sometimes

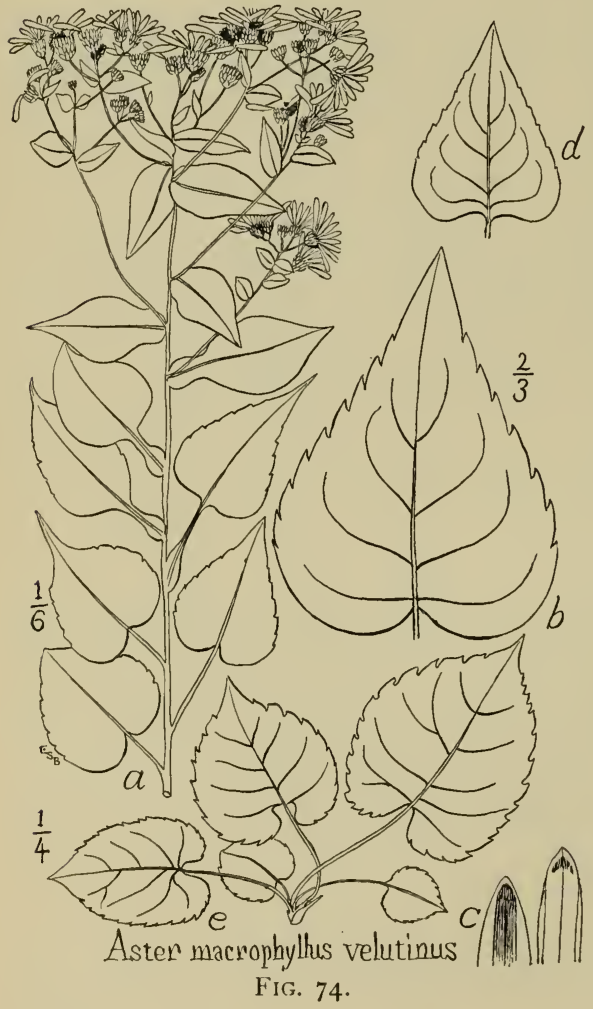
none of them cordate; glands fewer; pubescence subpilose or velvety; bracts broad, flat, green ; rays violet or blue. In grassy woods and thickets, especially in mountainous regions, Me. to Minn. and W. Va. Ascends to 2,400 $\mathrm{ft}$. in the Adirondacks."

Leaves quite uniform in size and shape ; teeth sharp, aculeate; axiles and rameals little developed. Pubescence abundant, pale and velvety, on all leaves beneath or on radicals or upper leaves only; often becoming rough and hispidulous in the herbarium.

Examples include:

Ontario, Nipigon, near mouth of Nipigon R., at L. Superior, Se. I2, '96; and Lake Nipissing, at North Bay, Au. 24, '95; Gerrit S. Miller, Jr., in his hb. Pt. Arthur, Se. 6,' $89, N$. L. Britton in hb. Colu.

Me., Orono, Se. 6, '93, M. L. Fernald in hb. Gray; Mt. Desert, '87, F'edfield in Gray hb., and Se. 8, '91, Theo. G. White in hb. Colu.; E. Livermore, '79, 
Kate Furbish in Gray hb.; Ft. Fairfield, near mouth of Aroostook R., on gravelly wooded slope, Se. 9, '96, M. L. Fernald in Gray hb.

N. H., Mt. Adams, Se. 24, '78, E. G. Knight in hb. N. Y. Bot. Gar.

N. Y., Adirondacks, Whiteface Mt., at 2,400 ft., Se. 9, '94, Britton in hb. Colu.; North Elha on Ausable R., C. H. Peck, Au., '97 and '98, in N. Y. State hb. Alder L., Au. 15, '91, Rusby in hb. Colu.; McKeever, on Beaver R., Au. 28, '97, and Plattsburg, Au. 31, '97, Bu. in hb. Bu.

Pa., Lackuwanna Co., "Moosic L., Au. 25, '84; flowers deep blue, pappus not tawny; A. macrophyllus var." ; T. C. Porter in hb. P.; in '97 its pappus had become deeply ferruginous; but some rays were still deep blue.

W. Va., Augusta Co., Mt. Rogers, 2,000 to 4,473 ft., Au. 9, '93, Helier in hb. Colu.

\section{5d. Aster macrophyllus pinguifolius Burgess}

Glabrate plants with large broad subsucculent or greasy leaves, wide-branched inflorescence and pale-lavender or whitish rays.

Name, L., from the frequent greasy leaf surface.

FIG. 75, I, 2, 3, from plant in Gray herbarium, derived from the Paris garden, cultivated as $\mathrm{A}$. latilolius in 1814 fide its label in $\mathrm{Hb}$. Gay; bought in 1870 by Hooker and later obtained by Dr. Asa Gray. Reduced to $\frac{1}{6} ; \mathbf{I}$ and 3 , separated radicals, 2 an inflorescence. Smooth fleshy blistered leaves; glands abundant.

FIG. 75, 4, from the specimen still existing in Hb. Mus. Paris, there labelled Biotia latifolia and said to date "from Michaux"; reduced to $\frac{1}{10}$ from drawings by Miss Ida L. Miner, Paris, 1900, by permission of the late Mons. Francke.

FIG. 75, $a, h, c$, native plant similar to preceding, from Bear L., Chautauqua Co., N. Y., '96, reduced to $\frac{1}{10}$ nat. size; in hb. $B u$.

A. latifolius Desf., Cat. Hort. Par., ed. 3, 176. 1829.

Biotia latifolia DC., Prodr. 5 : 264. $\quad$ I 836 , with first description:

"Caule glaberrimo apice corymboso, foliis glabris, radicalibus caulinisque infer. petiolatis cordatis, super. alato-petiolatis sessilibusve, omnibus seratis acuminatis, capitulis pedicellatis, invol. squamis arctè imbricatis oblongo-lanceolatis obtusis, ligulis elongatis. 24. In Amer. bor. (Desf.!) ad montes Alleghanys (Raf.!) et circa Bostoniam (Lindl.! herb.). Aster latifolius Desf.! cat. h. par. p. I76. Aster macrophylius Raf.! in litt. Eurybia macrophylla $\gamma$ Nees ast. I40? fortè suad. Lindley mera B. Schrebëri var. foliis cordatis donata? (v. s.).",

Not $A$. latifolius Mill. Gard. Dict., ed. 8 (1768).

A. mairophyllus pinyuifolius Burgess in Br. and Br. Ill. Fl. $3: 360$ (1898), with description :

"Stems stout, leafy, glabrous, about $2 \mathrm{ft}$. high; basal and lower leaves large, forming extensive patches, deep green above, very pale beneath, many of them appearing greasy, some roughening in drying; petioles fleshy, sometimes 9 in. long; inflorescence broad, flat-topped; heads large; rays lavender to almost white; only the upper leaves sessile. Borders of woods, Conn. and L. I. to Minn." 


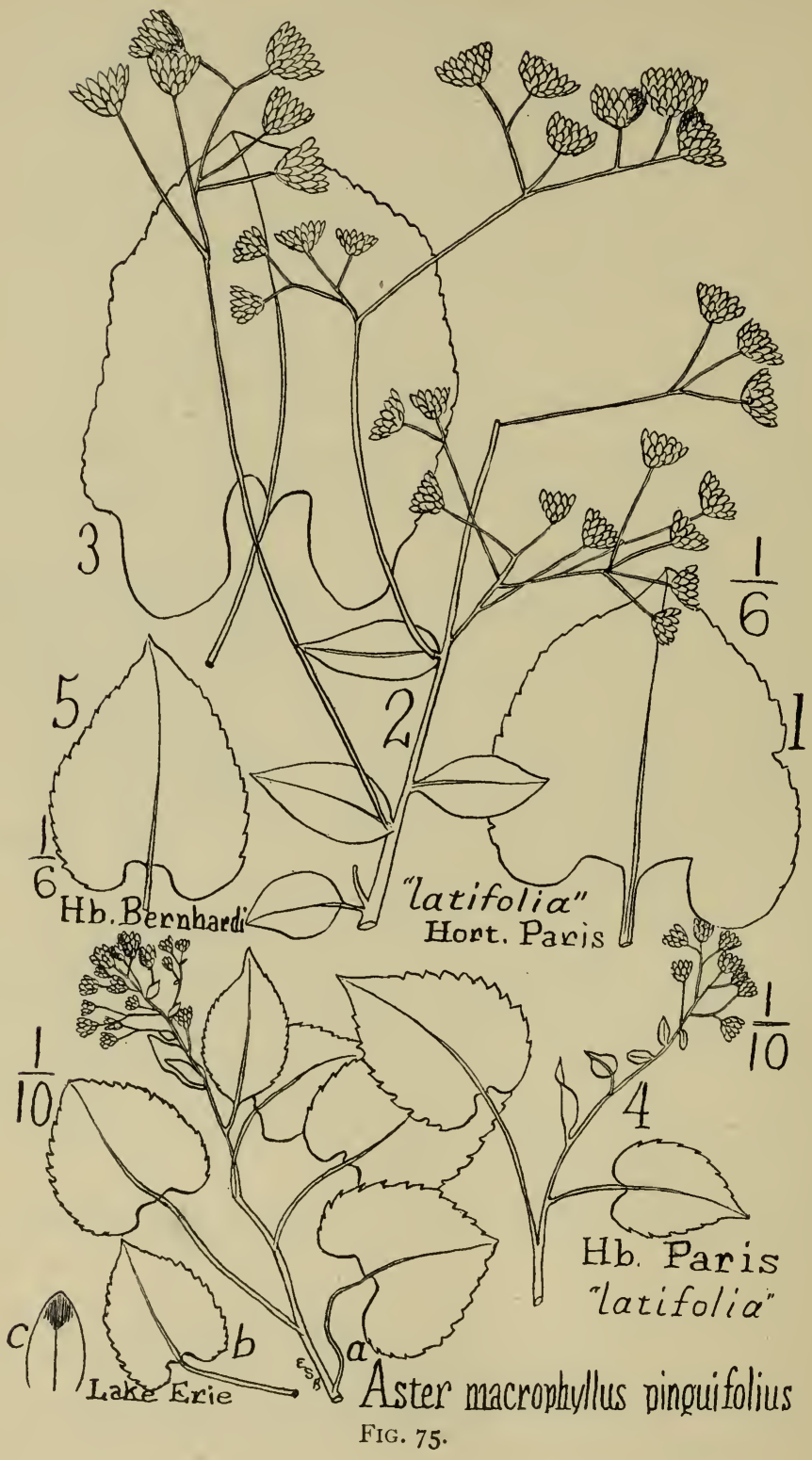


Stem brittle, pale green or brownish, leafy. Leaf-form cordateorbicular: sinus of characteristic radicals curving, broad, deep, recurvate in its center, with sloping sides, commonly closed by overlapping. Largest leaves seen (Niagara gorge) reach $12 \times 8$ in., subentire, with a very fleshy dark-green petiole of 9 in. More frequent size $6 \times 5$ in. Radicals often 4 , the ist small, reniformcordate, $21 / 2 \times 21 / 2$ or less, the rest nearly of one pattern, the sinus increasingly closed.

Texture that of undressed kid, with some portions unctuous and others finely granular. Sometimes all leaves of a plantation are unctuous and smooth; sometimes on the largest plants only; sometimes true of the surface on one side of a midrib while the other side is already roughish in life. Smooth and even greasy leaves often roughen in drying, especially if under but light pressure. Sometimes some plants of a smooth patch not different in other ways will be rough all over in life; but usually such plants are smaller-leaved. These differences in this variety seem independent of shade.

Inflorescence broad, rather level and wide-angled when fullgrown. Heads subsessile when young, some often still subsessile when most pedicels have attained an inch length. Heads rather larger; if numerous they are widely separated.

Rays pale lavender, quickly becoming very pale, and soon whitish ; perhaps in cultivation sometimes full white from the first, but usually at least a tinge of lavender shows at the base of the young ray while erect and involute before expansion.

Cultivation perhaps increases the leaf-breadth and size when in rich soil, and develops the unctuous tendency; the native plants which show these characters grow in richer soil than neighboring harsh A. macrophyllus plants. On extending into less favorable more open and more hard-baked soil, native plants become more condensed in inflorescence and develop only moderate leaves which are firm hard and minutely granular-roughened on drying; the heads forming subsessile clumps, widely bracteate by close subtending axiles: the rays pale lavender in bud, white on flattening. These bracteate plants (observed in one grassy woodroad for five years) owe their chief difference from the type to the suppression of pedicels, though that produces a great disguise; but some of them on obtaining more shade in later years proved to develop the typical characters.

-Development. Well-developed radical leaves May I 3 ('99), all very smooth or even unctuous; some petioles show slight 
glands; many petioles transiently villous, but the hair already passing. Strong short radical-bearing branches of the rootstock opposite, both now with 4 leaves, and a 5 th rolled in bud, the Ist leaf or primordial quadrate-orbicular with slight sinus, the others all rather large, cordate-orbicular with broad deep recurvate sinus and distinct short acumination. in hb. Gray.

Conn., " ^ eze Haven, 1858 , A. macrophyllus foliis laevibus," D. C. Eaton

L. I., Flushing, St. Ronan's Well, July, '86, Bisky in hb. Colu.

N. Y. vic., Yonkers, Troublesome Brook, thicket, out of flower, Oc. 28, '96 ; Bryn Mawr Park, old wood road, '97, '98, '99, 1900 ; Stony Lonesome, middle hollow, '97; Sunny Brook, '97.

N. Y., Indian R., Au. 6, '79, L. F. Ward in hb. U. S. Nat. Mus.

W. N. Y., Buffalo, in hb. Clinton; Niagara R., brink of Whirlpool-woods, Se. 7, '96, '97, '98; Devil's Hole, Au. 25, '96; Foster's Flat (Canada), Au. 29, '96, Se., '99; Chautauqua Co., Silver Cr., July 31, '96, Au., '97-1903 (and bracteate plants at Swift's Hill, Au. 11, '98-1903); Bear L., Au. 10, '96; Herrick's Cr., Au. 12, '96; Little Indian Cr., Au. 20, '96, Au. 13, '98; Pt. Gratiot, Au. 29, '96; Maybee road, Au. 9, '97 ; Wintergreen Gulf, Au., '96: Bu. Ithaca, late sprout, Oc. 7 , '84, F. $V$. Coville, no. 296234 in U.S. Nat. Hb.

Pa., Reading, at Monocacy Hill, in hb. Univ. of Penn., ex. hb. I. Burk.

Wis., Chipperva R., T. J. Hale, 1861, in hb. Mo. Bot. Gar.

Minn., St. Paul, Se., '68, in hb. Canby.

History. The flabbiness of leaf common in Aster macrophyllus L., seems to indicate a latent capability of developing the succulent petiole and unctuous leaf-surface of this subspecies pinguifolius. It may well be that cultivation will bring out this quality in certain plants still more than in nature. Richness of soil, in either native or cultivated plants seems to increase the leaves in breadth and in general size, and this coinciding with the development of succulence, brings into combination the characters which constitute this variety pinguifolius. When typically developed, they make the plant seem a wholly different species from $A$. macrophyllus; but probably it is quite unstable. This is indicated by the difficulty of finding the plant in successive years in the same place, and were it permanent it is probable that its history in European botanical gardens would not be so uncertain. My conclusion is that the form cannot be given more than subspecific rank, and that it will easily pass back again into the type.

The first recorded observation of this subspecies may have been that of Lamarck, I783, when he said of some of the plants at Paris accredited to $A$. macrophyllus, that, unlike the type, it was sometimes " tres lisse."

The first clear record of its pinguid tendency seems to be that 
of Schultes, I 809 [see citation, supra, p. 308] in the remark regarding certain plants assigned to $A$. macrophyllus L., "Mira foliorum subcarnosorum vix describenda varietas."

Its separation as a species, latifolius, early made in the Paris garden, appears in print first in Desfontaines' catalogue, in its third edition in I 829, based on a plant known only to have come from North America. DeCandolle's description, I 836, as Biotia latifolia, was founded on this as type.

The synonyms and the other localities quoted for Biotia latifolia by DeCandolle may belong in the main to this subspecies so far as appears; except the last two; Eurybia macrophylla $r$ seems to have no kinship with this but its smoothness; and Eurybia Schreberi $\beta$ is probably more complex.

Herbarium specimens credited to A. latifolius include the following :

Now in hb. Gray; plant originally labelled "Biotia latifolia DC. Cult. Paris I 814 " ; forming part of the herb. of J. Gray purchased by Hooker in I870; labelled A. macrophyllus by A. Gray. Figured, Fig. 75 ; 1, 2, 3. Plant fungus-blistered; highly-glandular glabrous fleshy-leaved representative of pinguifolius.

Now in hb. Gray; plant from Hort. Ware, 1861, near London; "cult. as Biotia latifolia DC. ; rays pure white; overlooked when [Synoptical] Fl, was written and printed " A. Gray scr. - This specimen may represent a very white and only slightlyglandular state of pinguifolius.

Now in hb. Gray; plant from Hb. Mus. Paris, labelled "Biotia latifolia DC., Hort. Paris I 869 " ; and by A. Gray, "A. macrophyllus I.." - This plant, having no glands, bearing bidentate white rays, smooth leaves, no obvious hair, except plentiful in lines along the pedicels, seems rather to belong to the Eurybia Schreberi $\beta$ of Nees, Aster subcymosus Bernhardi of the present monograph.

Now in Hb. Mus. Paris, in hb. Michaux, fide Monsr. Francke; small plant labelled "Biotia latifolic," which may have come from Desfontaines' plant? and seems a small plant of pinguifolius. Figured, Fig. 75, 4 .

Now in Hb. Mo. Bot. Gar. from Hb. Bernhardi; a plant perhaps assignable here, but in very battered condition, its old German label (Alyssum creticum) misplaced in mounting.

Now in Hb. Mo. Bot. Gar. from Hb. Bernhardi; a plant originally labelled $A$. speciosus.

** Plants taller, smooth and glabrous, with convex or diffuse infloresence; bracts lingual, acutish. Species 56 .

\section{Aster excelsior sp. nov.}

Smooth, tall, stout, purple-stemmed plants of shade with large thin narrow leaves, oblong-oval lower leaf-form, sessile-oblong cauline type, broad copious inflorescence, broad round-tipped lilac or violet rays, narrowish bracts, and little development of glands, sinus or teeth. 
Name, L., from its tall robust attitude.

Fig. 76, $a$, plant from Niagara gorge, Au. 27 , ' 96 , in hb. Bu.; $b$, charac teristic leaf-form ; $c$, leaf of its rumicial form of Se. 9, '99.

FIG. $76, d$, small plant of the common form away from Niagara gorge; plant from Cattaraugus Cr., N. Y., Au. 13, Is,oo, in hb. $B u$.

Eurybia macrophylla $\beta$ Nees?

A. macrophyllus excelsior Burgess in Br. and Br. Ill. Fl. $3: 360$ (1898), with original description :

"Stem robust, glabrous, often $4 \mathrm{ft}$. tall, purple or glaucous ; leaves mostly very smooth, 'pale, numerous, narrower, cordate,

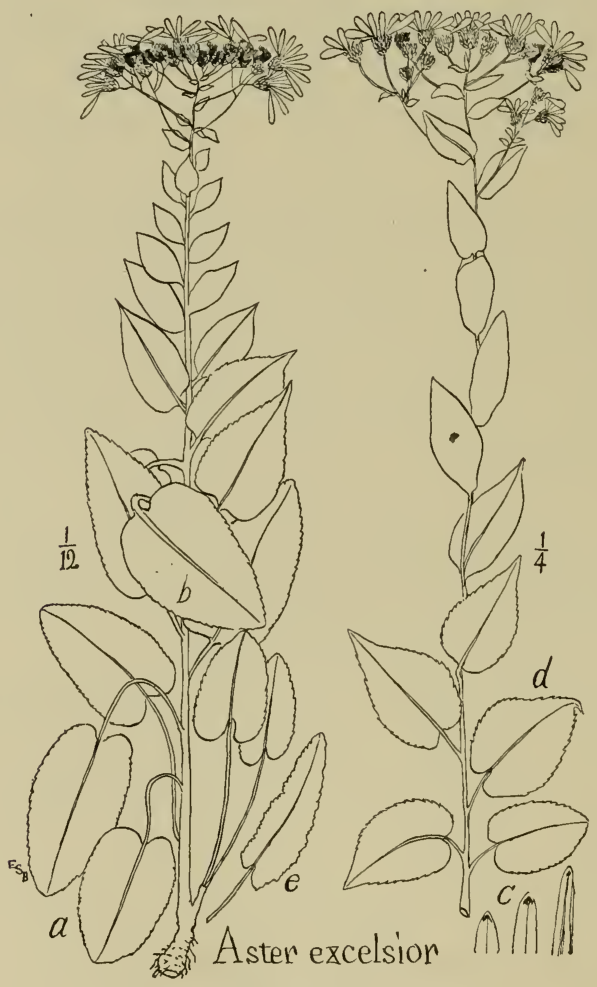

FIG. 76.

oblong to ovate-lanceolate, chiefly sessile; rays deep lilac to violet. Along paths and borders of rocky woods, Ontario and W. N. Y. to Mich."

Stem terete, glabrous and glaucous, stout but not rigid and, therefore, often decumbent, sometimes $4 \mathrm{r} / 2 \mathrm{ft}$. high. Radicals on long petioles, borne high upward, not forming flat patches; triangular-ovate or oblong-oval, with sudden short acumination, crenate- 
serrate. Cauline leaves gradually pass from this type to oblong and lanceolate-sessile, subserrulate or entire subclasping leaves, smooth or nearly so even after pressing. Upper leaves have a strong tendency to be erect, especially on young plants. Wingpetioles few.

Glands few, sometimes only on the back of a few bracts. Strigose hair little developed. Teeth slight and close, or none.

Bracts all narrow, merely subciliate, the lower triangular-acute, middle ones becoming ovate-obtuse, the inner ones oblong-obtuse; but not very unlike each other. Inflorescence a diffused dome, expansive or somewhat segregated in large plants. Rays about 13 , much narrowed toward the base, swelling into a rounded tip, from deep or pale reddish lilac to purplish-violet.

Occasionally a leaf develops a little roughness above or a little hair (under a lens) beneath.

Habitat, rich soil under half-shade or more, on shale, especially in gorges and rocky woods.

\section{Examples:}

Canada, Niagara gorge, Foster's Flat, there the prevailing form of Aster, in patches among thickets, abundant, Au. 25, 27, '96 ; less and less so, '97, '98, '99.

W. N. Y., Niagara, brink of Whirlpool woods, scattered and less developed, Au., '96, Devil's Hole, '96; Perrysburg hills, fence-row, Au. 29, '96. Sheridan, Herrick's Cr., Au. 12, '96; Talcott's woods at br., '93, Au. 15, '96, Au. 21, '97, Au. '98-1903; Silver Cr., Swift's Hill, '96-1903; Indian-line road, Au. 13, '98; Bear L., Au. го, '96.

Mich., Kezveenaw Co., rocky woods, Au., '89, O. A. Farwell in hb. Gray.

$5^{2}$ Drvarf form, resembles $A$. sabulosus but the leaves not granular-roughened and more usually sessile. Common with its type. Cattaraugus Reservation.

$56^{3}$ Rumicial form, low, with very narrow leaves; resembling Rumex crispus at least in some larger radicals of Niagara Glen, see fig. $76, e$.

$5^{4}$ Long-ovate form, leaves elongated ovate, not large; plants of moderate size, roughish, at least when dry ; intermediate to $A$. macrophyllus. Silver Cr., N. Y.

$56^{5}$ Sun-darkened form, bluer or violet rays, in grassy sunny openings, the great inflorescence wider and more deeply and irregularly branched. Silver Cr., N. Y.

*** Plants smaller, with compact bunch-top inflorescence; bracts lingual, obtusish. Species 57-58. 


\section{Aster orbicularis sp. nov.}

Low, purplish-stemmed plants with small spongy rugose leaves downy beneath, broad short leaf-form, subserrulate teeth, deep narrow sinus, pale-streak close-parallel wide-spreading veins, gradually transitional leaf-series with apiculate apex, short petioles; high-dome inflorescence, high-angled branching, and green ovate-oblong chief bracts.

Name, L., from the leaf-form, suborbicular or at least broad and short.

Fig. 77, from plant of L. Champlain bluff below Plattsburg, N. Y., Au. 3I, '97, in hb. Bu.; d, radicals from plant of Bar Harbor, Me., Au. 26, '99, coll. Bicknell, in hb. $B u$.

Stem terete, stout, brittle, glabrate below, above densely

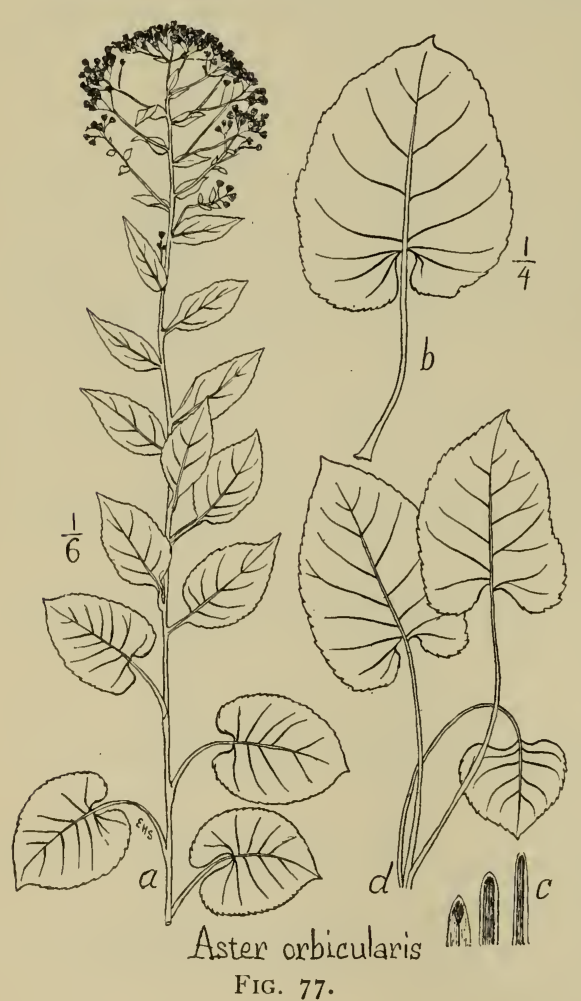
clothed with glandular tomentum or with the same much surpassed by downy and strigose hair.

Leaf-form orbicular or at least broad and short, small, 3 to $4 \frac{1}{2}$ in. long and broad, apiculate by a sudden obtuse or sometimes acute contraction, the sinus deep, narrow, somewhat overlapping, slightly or not at all enlarged within, its depth often $1 / 4$ the length of the leaf. Texture thick, dry and spongy; slightiy roughened above when dry and rough-bristly beneath.

Radicals either of the normal leaf-type or often with broad shallow sinus and deltoid-cordate outline ; others in more luxuriant growth are elliptical and non-cordate.

Veins remarkably pale, showing as pallid streaks on the apple-green leaf, very close together and directed from the mid rib strongly toward the margin. Glands dark, capitate on stalks 3-IO or even 15 times as long as the gland-breadth. 
Teeth small and inconspicuous, of subcrenulate or serrulate type, often doubly serrulate, on upper caulines becoming inconspicuously slit-serrulate.

Petioles of the radicals slender and much longer than the leaves; of the lower caulines hardly the leaf-length, and quickly diminishing into a long series of short strap-wings.

Middle caulines passing from orbicular-apiculate to ovateoblong; upper caulines and axiles oblong and sessile, these and the lanceolate rameals often amplexicaul and conduplicatelysheathing their branches.

Inflorescence rather close, broad and high-convex, its branches subequal, spreading upward at a high angle, $45^{\circ}$ or often more.

Bracts very much alike in shape, the outer acutish, and ovateoblong, and all over green, the middle similar but straight-sided and obtusish, the inner with broad whitish scarious sides and broad green medial band; all with sudden short triangular dark-green tip.

Rays still lilac or purplish.-Some plants of "A. macrophyllus" Hort. Berlin as represented by specimen of I 839 in hb. Gray (labelled by Gray as "fere $\beta$," i. e. nearly same as A. Schrcberi, because so smooth to touch) may have belonged here, having nearly orbicular lower caulines with deep narrow sinus, obtuse or with slight apiculation, subentire or faintly denticulate; with few glands and little hair.

Habitat, rocky shores and borders, in considerable sun; Maine to $\mathrm{L}$. Erie.

\section{Examples:}

Me., "Bar Harbor, dry thicket, Au. 26, '97," Bi., in hb. Bu., " with camphoric odor on sweeping the hand over the upper part of the plant; abundant in edge of woods and in grass near ; not forming plantations but separated." 3 I, '97.

N. Y., L. Champlain, open bluff-edge below Plattsburg, many plants, Au.

W. N. Y., Niagara gorge, Whirlpool woods, Se. 7, '96, Au. 27, '97. Hanover, Gardner's Brook, Au. I 7, '96. Indian-line road, Au., '97, Au., '98, Au., '99, Au., I900, Au., I90I, I902.

\section{Aster biformis sp. nov.}

Small stocky plants with thick roughish spongy leaves and dense convex corymb, growing in small sunlit grass-mixed patches, the few basal leaves cordate-oval and closely crenulate, an abrupt series of little ovate-oblong leaves following above.

Name, L., from this double leaf-type.

FIG. 78, $a$, typical plant of Whirlpool woods, above Niagara Gorge, Se. 7,' 96 ; $b$, its characteristic leaf; $d$, its petiole-flowered form (cf. that of $A$. multiformis, fig. 4). 
FIG. 79, plate 12, plant of Silver Cr., N. Y., Au. 17, '96, in hb. Bu.; unusual in its trifurcate habit.

A. macrophyllus biformis Burgess in $\mathrm{Br}$. and $\mathrm{Br}$. Ill. Fl. $3: 360$; with original description :

"Small, stocky, with 3 or 4 small oval closely crenate spongythickened lower leaves with long slender petioles, the sinus deep,

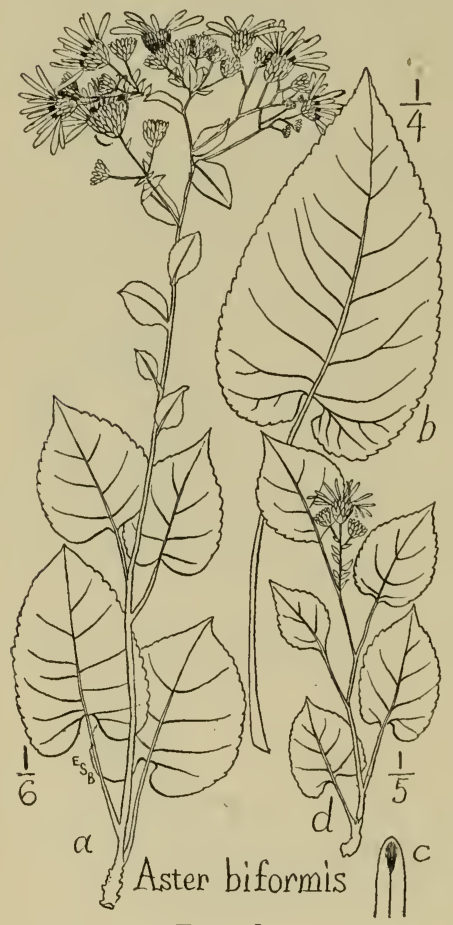

FIG. 78 . narrow, the teeth triangular to semicircular; stem-leaves crowded, much reduced, subentire, ovate-oblong, subsessile; inflorescence nearly naked, dense, convex, usually 4 in. broad; strigose pubescence little developed; rays lilac. - In open grassy sunny situations, forming small patches, Maine to Ontario and L. Erie."

Stem rigid, chiefly I ft. high, somewhat zigzag, reddened, glabrous below, covered above with short stiff glandular stubs.

Leaves apple-green, much reddened in fall, impressed-venulose beneath, rough above and hispidulous below, pubescent on the veins beneath under a lens. Leaf-form oval-acute with deep rather narrow sinus; these leaves 3 , or sometimes 2,4 or 5 , about $3 \times 2$ in. or less.

Petioles stiff, fleshy, naked, not widened below but continuing terete to the stem, all erect and successively shorter, the first much longer than its leaf; resulting in bringing the large leaves nearly on a level, just elevating them above the grass-sward. In plants not closely surrounded by grass the leaves are separated and spreading.

Little leaves 8-IO, sometimes 16 , crowded in small plants, remotish on well grown plants (occupying then 6-8 in.). On the less-usual branching individuals these little leaves continue on each branch.

Corymb dense, flat or convex; its stiff straight leading branches and their pedicels all given off at an angle of $50^{\circ}-60^{\circ}$.

Heads large for the plant, nearly $\mathrm{I}$ in. across ; involucre $\frac{5}{16}$ or $\frac{6}{16}$ in. high, minutely glandular.

Bracts narrow, somewhat lingual and uniform, reddened on the edges, whitish with a distinct narrow green median line but hardly 


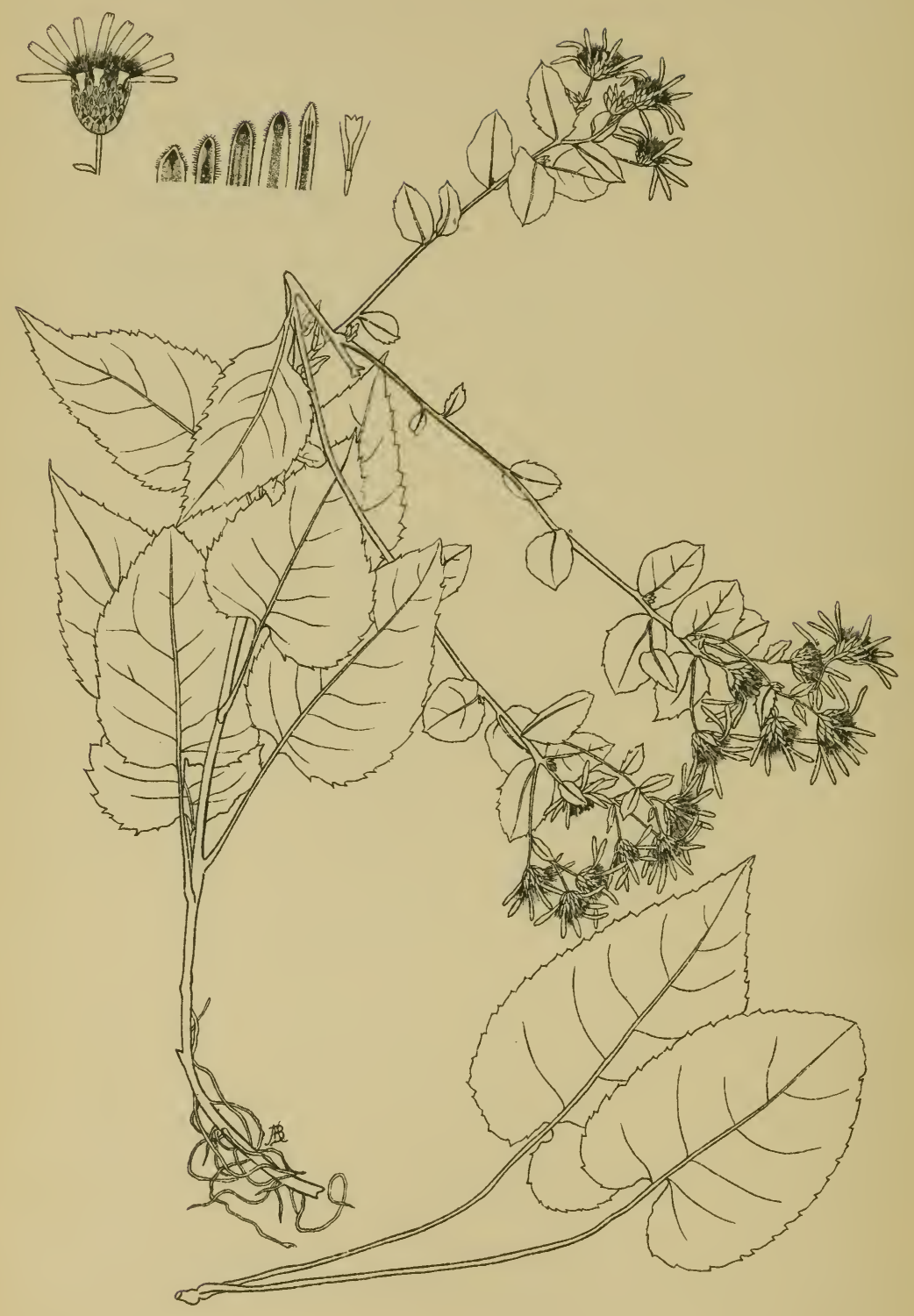

ASTER BIFORMIS 
green-tipped: the chief bracts oblong-obtuse ; the inmost, taperlinear; all with rounded subciliate apex.

Distinguished from arrest forms of A. macrophyllus, A. multiformis, $A$. roscidus, and other species, by its oval-acute leaf-form, narrow-sinus, crenulate margins, glabrate stem, bunch-top inflorescence, lilac rays and lingual bracts. Examples include :

Canada, Otlawe, '82, Fletiher in hb. Bu.

Me., Prospect Harbor, Se. 9, '89, H. M. Smith in hb. Bu.

N. Y., Steuben Co., Rathboneville, and Albany Co., Voorheesville, Sept., C. H. Peck in hb. N. Y. St., Greene Co., Catskills, Kaaterskill Mt., to 3,00o ft., Se. 7,'99, Bu.

W. N. Y., Niagara gorge, Whirlpool woods, Se. 7, '96, Se., '97, '98. Devil's Hole, Au. 25, '96; Canada side, at Wintergreen flat, on the brink of the prehistoric cataract, Au. 27, ' 96 ; and forming great piantations, thinner and nearly sterile, under slight shade on the Dufferin Is., Au. 27, '96.

W. N. Y., Perrysburg hills, Au. 29, '96; Dunkirk, Pt. Gratiot, Au. 29, '96; Silver $C r$., Au. 15 and 17 , '96; Lighthouse Pt., Se. 9, '96, beautifully red-marmorate; Rosebrook woods, ' 96.

Pa., Susquehanna, Se. 20, '97, Jas. A. Graves.

Variants. - In the type-locality, near DeVeaux College, Niagara Whirlpool, growing with $A$. azureus and $A$. ptarmicoides, the plant grew originally by the hundreds, not in large patches but in little families of a few plants each, in the open sun, at and near the brink of the gorge. A few rods away, at the woodborder, it becomes larger, taller, thinner, smoother and more leafy; but does not really extend into the woods. Dwarfs flowering at 6 in. are abundant; they do not omit the series of little leaves but simply reduce and crowd them. Average plants reach I ft. Maximum plants are stump-fed and occasional, reaching $2 \mathrm{I} / 2$ $\mathrm{ft}$., where enriched from a decaying stump ; also when forced upward to rise above neighboring low bushes.

\section{Subdivision $B$.}

Leaves firmer and less polymorphous than in Subdivision $A$; strong-serrate, but with teeth not very deep; stem strong but slender, with some strigose hair; plants usually glandular all over while young. Inflorescence dense, convex. Species 59-64.

* Plants not tall ; chief bracts acutish. Species 59-62.

\section{Aster uniformis sp. nov.}

Low, loosely-cespitose, apple-green, villous, fragrant plants, with elegantly-curved broad thin leaves, chiefly with falcate-acuminate apex and broad open sinus, the leaf-series very gradually diminished upwards, the bracts villous, thin, flat and broadly 
scarious-margined, white and green with purple edge, the rays lavender.

Name, L., from the persistence of the leaf-type far up the stem.

FIG. 80, plant from Randolph, N. H, Au. I2, I902; b, typical leaf; $c$, a modification of $b ; d$, radicals.

Plants little inclined to form large or sterile colonies, growing in small loose full-flowered masses in half-sun. Stems chiefly green, terete, glabrate or downy, $2 \mathrm{ft}$. high or less. General

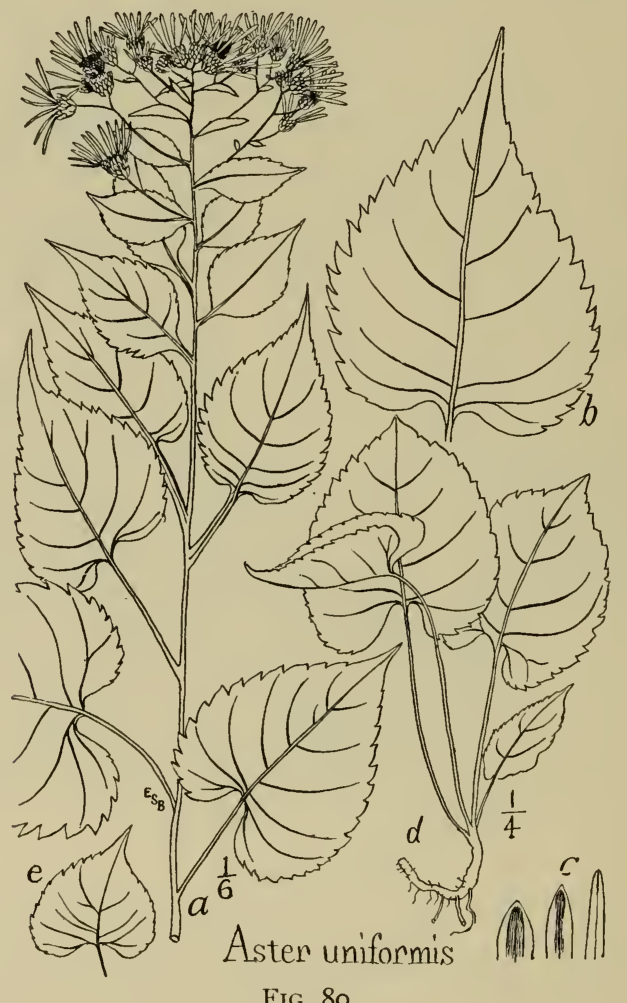

FIG. 80.

color a pale bright green. Texture thin and firm, soon limp on gathering, drying rough. Teeth of moderate size, acuminate, often falcately so.

Leaf-type cordate to orbicular-deltiform, with long and usually falcated acumination, with broad open sinus, upcurved slender veins, serrate or curvescent teeth, and long petioles.

Radicals less acuminate, about 3 , often $4 \times 3$ in., with upright slender petiole of $6-7$ in.; their sinus rather deep. 
Middle caulines slowly tapering into a longer acumination, often very elegantly falcate, with sweeping brace-base sinus.

Upper caulines resembling those of $A$. curvescens, being ellipticovate, incurved-falcate-acuminate, abruptly tapered into a broadwing petiole, finally elliptic-oblong with short cuneate-wing petiole.

Axiles few and inconspicuous, lanceolate, usually still petioled.

Petioles longer than the leaf, concavo-convex in section, set along the edge with bayonet-like bent hairs, and lined with shortstalked, dark-purple, minute, capitate glands with pale stalks.

Veins pale-green beneath, showing as narrow purple impressed lines above.

Inflorescence convex, about $5 \mathrm{in}$. broad, in its prime about $\mathrm{Au}$. I 5 , and then exhaling a delicate and delicious fragrance sometimes suggesting that of Linnaea rather than of an aster. The diskflowers exhale the different fragrance of bee-bread, as is common among the Compositae.

Bracts of 3-4 rows, uniform in shape, lightly ciliate with white hairs, obtusish, oblong-triangular or oblong with the sides slanted at the top, quite thin, green, downy and glandular all over; the inner with broad white scarious margins and narrow green median band, the inmost similar with addition of dark purple along the delicate white border. Involucre cylindrical.

Rays a beautiful low-violet, delicate, narrowly linear, broader forward and minutely 3 -toothed, about $\mathrm{I} 3$, sometimes only 9 , soon fading white. The rays open slowly, long remaining slightly channelled; they wilt quickly, hanging in limp curves.

Disks turn dull reddish-brown. Heads $1 / 2$ in. high.

Pedicels long, slender, terete, green or purpled, slightly enlarged upward, given off at a high angle.

Glandular hairs everywhere developed, over leaves beneath, and over the stem half way or wholly to the ground. They are short pale stubs, distinct below, but on the pedicels becoming very long, still pale, with the pale or whitish glands very slightly broader than the stalk.

Among glandular species this is a counterpart in superficial resemblance, to $A$. curvescens among the non-glandular.

Habitat, borders of woods, rivers and roadsides in the White Mtns. to 2,000 ft ; and northward.

Examples:

Me., Gilead, Au., 1904, Bu.: Mattawamkeag R., Penobscot Co., Au. 23, '97, 11. L. Fernald in hb.

N. H., Randolph, near Ravine House, Au. 12, 1902, 1904. Gorham, Au. 10, 1902, at the Androscoggin river-edge. Peabody R. valley and up Mt. Washington from the Glen along the road for the first mile, Au., 1902, 1904. Shelburne, Au., 
1902, I904; also coll. there by Walter Deane, Au. 7, '8 3 , hb. Deane; Franconia Notch, near Flume, Au., '99, Au., 1900. North Woodstock, near the Pemigewasset R., and Woodstock, Au., I 900.

\section{6o. Aster Alleghaniensis sp. nov.}

Low strict plants with small thick rugulose leaves, with broad base and ovate outline, few cordated, many erect and investing the stem; and with narrow densely branched lavender and pink inflorescence.

Name from the mountains on which specimens grew in Bedford Co., Pa.

FIG. 8I, plant from L. George, N. Y., Au. 31, I900, S. H. Burnham in hb. N. Y. Bot. Gar.

Stem strong, I to $\mathrm{I} / 2 \mathrm{ft}$., smooth, terete, pale reddish-brown

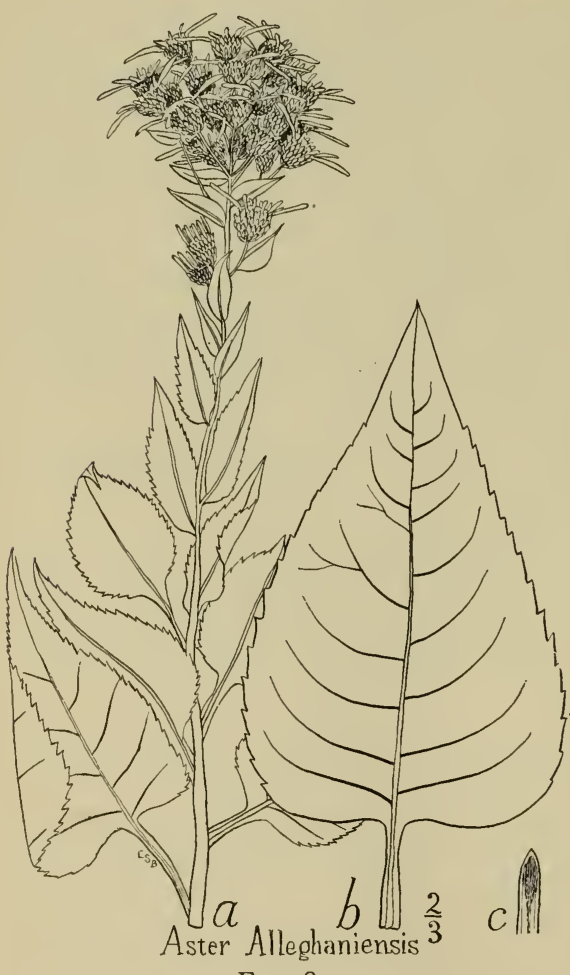

FIG. 8I. or with much purple-red like that characteristic of $A$. puniceus, in aspect very slender, subflexuously virgate.

Leaves sage-green, small, the lowest $3 \times 2$, the middle cauline reduced to $\mathrm{I} / 2 \times \mathrm{I}$ in. Lower leaves ovate with truncate-rounded base, serrate to dentate, sometimes with a strap-wing petiole, 2 in. long and $1 / 4$ in. broad. Upper caulines lanceolate with sessile tapered base, sharp-serrulate, nearly erect. Leaves thick, finely roughened. Teeth chiefly shortcurvescent.

Strigose hair on the veins beneath is long and spreading. Short stiff appressed scattered bristles occur over the leaves above. Short soft close hair covers the inflorescence-branches and the medial part of the bracts. Strigose ciliation occurs along the slender petioles, occasionally on the stem and slightly on the lower outer bracts.

Much purple-red (like that of $A$. puniceus) occurs on the full- 
grown stem, on the leaves and especially the veins beneath, and particularly on the bracts producing continuous broad purple margins. The pappus also becomes strongly reddened.

Inflorescence forming a dense club-like top. Rays about 13, $\mathrm{r} / 2$ in. long, lavender while young and while still of navicular form, turning white in flattening.

Bracts uniform in shape, lingual, in about 4 rows, not greatly thickened nor greened at the tip.

Capitate glands are abundant beneath the strigose hair on the pedicels, over the middle of the bracts, and down the stem for at least 8 or 9 in.

Habitat, mountains, N. Y. and Pa.

Examples include:

N. Y , L. George, summit of Black Mt., at 2,600 ft., Au. 31, 1900, S. H. Burnham in hb. N. Y. Bot. Gar.

Pa., Bedford Springs, Au. 6, '92 ; three plants in hb. Univ. of Penn., ex. hb. Aubrey H. Smilh.

N. C., Columbus, Polk Co., Oc., '97, R. C. Townsend in hb. U. S. Nat. Mus., no. 341510; about 12 short broad rays; no cordation.

\section{6r. Aster sabulosus sp. nov.}

Little-leaved smooth-stemmed plants with great rigidity of stem, leaf and pedicel, and much purple on stem and bracts, tending to produce ovate-acuminate uniform suberect leaves of extraordinary roughness, and a small loose flattish inflorescence.

Name, L., sabulum, a dry gravel spot; from the preference of the plant for dry open gravelly places.

FIG. 82, plant from Cattaraugus Cr., N. Y., Au. 13, '98, in hb. Bu.

Stem about I ft. high, dark purple or reddish-brown or at first paler, subangularly terete, glabrate but sometimes granuloseroughened. Growth in scattered or loose groups, with long slender rhizomes and profuse cord-like fibers from the base of the stem.

Radicals small, chiefly $3 \times 2 \mathrm{r} / 2$ in., asymmetrically cordateovate, crenate, with full deep sinus, a little apiculate.

Cauline leaves of very uniform shape and size, chiefly with straight-taper acumination, ovate-oblong leaf-form, cuneate-wing base, low-serrulate margin, and firm thick granular-roughened texture in growth, the upper surface like sand-paper when dry and almost spinulose.

Lower caulines spreading, with slight sharp sinus and narrow petiole, broad-cordate; usually only 2 such. Other caulines, 8-1 2 
of them, ascending or erect, soon subsessile. All leaves pale beneath, without obvious hair.

General foliage-color brownish-green, commonly profusely brown-maculate with circular fungus-spots, much more so than

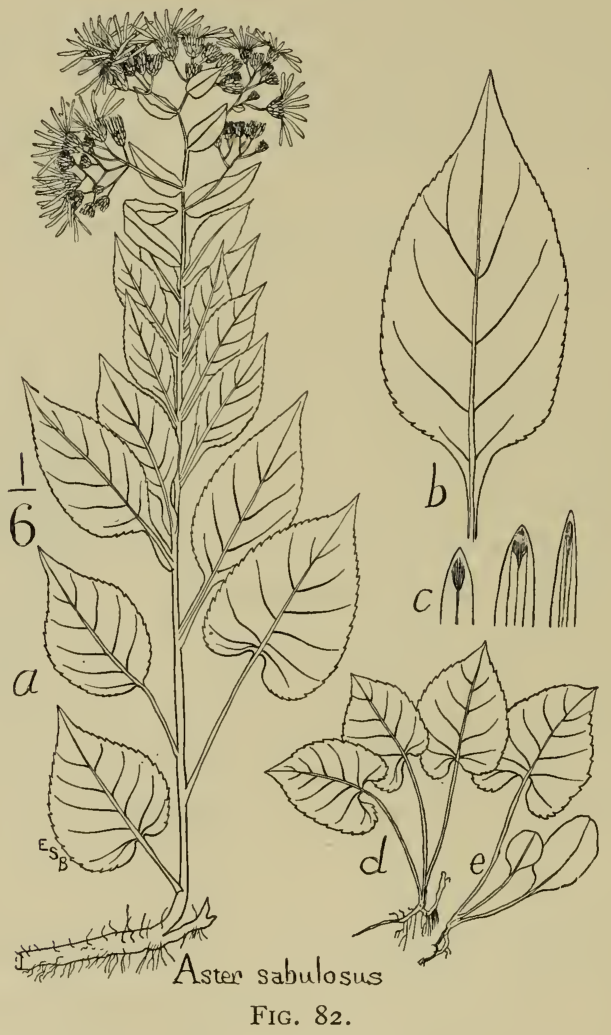

other allied species growing with it, in this and in its pale undersurfaces resembling $A$. elacagnius.

Inflorescence a shallow corymb, 3 or sometimes 4 in. across, forming a single irregular compact top or sometimes slightly separated and convex.

Bracts triform, subacute, a little narrower than in $A$. macrophyllus, quite green-tipped, the middle and inner broadly scariousmargined, the scarious portion pale or whitish with reddened edge.

Heads $\frac{6}{16}$ in. high, of which the involucre is two-thirds.

Rays lavender, of short duration.

Glands chiefly found on upper half of stem; resembling those of $A$. macrophyllus. 
Differs from $A$. macrophyllus not only in size, which taken alone might have suggested its rank as a dwarf of that species; but also in leaf-form, continuous leaf-series, erectish leaf-direction, and scarious bracts. Of forms of $A$. macroplyyllus most liable to be mistaken for it, sprout-forms are usually larger, leafier, fleshier and broader; branch-forms have obovate rameals; bunch-forms have more hair, less purple, paler rays, more regular and convex inflorescence, larger more spreading leaves; subsp. apricensis has oval leaves with long straight strap-wings; subsp. velutinus has more hair, more cordation, etc.

Differs from A. Alleghaniensis in its broad looser shallow inflorescence; from $A$. elaeagnius in its smaller suberect leaves and its lack of obvious hair; from both in its uniformity of leaf-type and its almost spinescent surface.

Differs from $A$. granulosus in its leaf-form, and small dense inflorescence.

Habitat, sunny gravel spots and sands, Maine to L. Superior. Examples:

Me., Orono, "recently burned clearing," Au. 24, '97, rays lavender, M. L. Fernald, in Gray hb.; Farmington, '96, C. H. Knowlton, in Gray hb.

Ms., Taconics, Mt. Ethel, clearing, Se. 5, 'o3.

W. N. Y., Cattaraugus resn., Little-Indian road, Au. 20, '96; path beyond straw-tree, Au. 24, '97; Indian-line road, Au. I3, '98, Au., '99, I900, I901, 1902.

Mich., Manitou I., Au., I840, Dr. Geo. Engelmann in hb. Mo. Bot. Gar.; Se., $1842, D r . B$. B. Brown in same hb.

Va., "Salt Pond Mt., A. macrophyllus var., Au. 25, '99," Pollard and Maxon, in hb. U.S. Nat. Mus.

\section{Aster quadratus sp. nov.}

Small plants with thickish large quadrate leaves with slight broad sinus, suborbicular radicals with deep sinus, triform bracts, and close domed heads with thin strap-like leaden-purple rays.

Name, L., from the lower cauline leaves.

FIG. 83, plant from Big Knob, N. Y., Au. 29, I900, N. L. Britton in hb. N. Y. Bot. Gar.

Stem stocky, I I $/ 2$ feet or less, green and glabrate, sinuously curved above and roughish, the lower part straight and merely minutely roughened.

Leaves much thinner and smoother than in the two last species, but still thickish and somewhat roughened. Smaller elliptic 
caulines with strap-wings soon succeed the few lower caulines of quadrate-orbicular type.

Leaves serrate with rather coarse teeth, firm, full-green, paler beneath.

Minute capitate glands occur close together all over, and occasional strigose hair also nearly to the base.

Inflorescence a rounded dome of close heads; rays very thin, much crinkled and purple or leaden-blue in drying, some remaining sky-blue; their form oblong and strap-like.

Bracts of three types, the outermost triangular-ovate-acute, the next outer resembling those of $A$. divaricatus in their rounded trun-

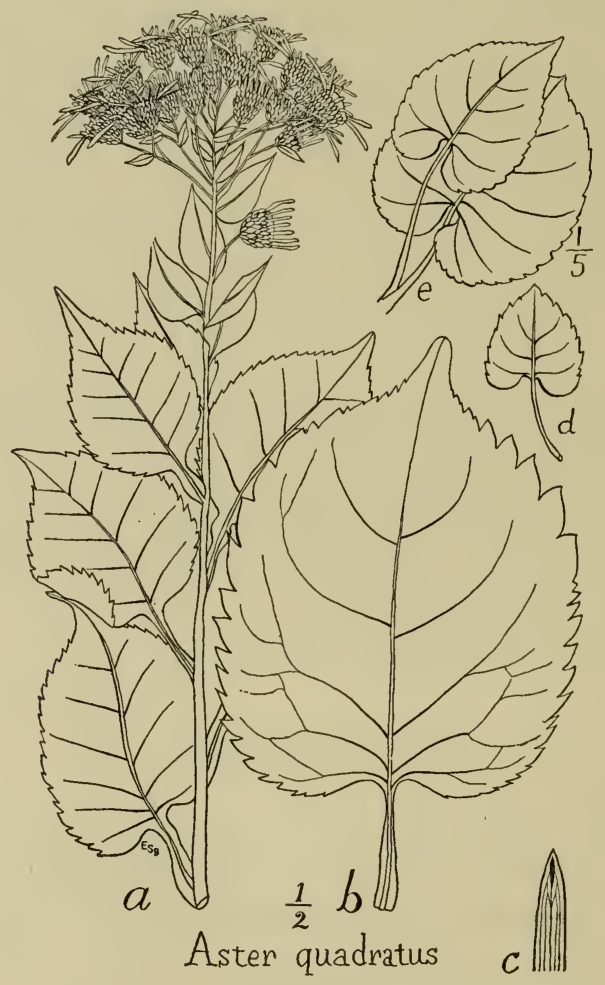

Fig. 83 .

cate apex and flat green backs. These both are narrowly scariousmargined, and the latter have the upper edges of the spatulate green-tip much darkened. Chief bracts follow, very much longer and thinner, oblong with taper-acute apex, with small dark linear green-tip pale-margined below, the brown midrib narrow and green-bordered, followed by a broad scarious portion, the inner 
part of which varies from cream to bluish-purple, the outer part pale or colorless; making three colored stripes each side of the narrow brown midrib, all changing to crimson at the tip.

N. Y., Adirondacks, Big Knob, at 5950 ft., Au. 29, I900, and Chilton L., Au. 28, 1900, Dr. N. L. Britton in hb. N. Y. Bot. Gar.,-"well distributed in the Mt. Marcy region in upper mountain clearings."

** Plants tall, with profuse glands throughout, and chief bracts lingual with rounded apex. Species 63,64 .

\section{Aster densatus sp. nov.}

Rough hairy plants with thin but firm texture, orbicular leaftype large and slowly diminished, coarse-dentate margins, dense rounded-convex inflorescence, rounded scarious-edged bracts and long curve-bordered green-tips.

Name, L., from the dense inflorescence.

FIG. 84, plant from N. Y. vic., in hb. Bu., E. P. Bicknell coll.; $b$, characteristic leaf; $d$ and $e$, radical groups.

A. macrophyllus $\gamma$, T. \& G., Fl. N. Am., $2: 184$, may be founded on this; its only character is that of rounded bracts.

Stem $3 \mathrm{ft}$. or less, finely roughened with remnants of close hair when mature, stout, erect and terete, greenish or brownish.

Leaf-type cordate-orbicular passing into broad cordate-deltoid. Sinus large, deep and securiform, in radicals sometimes 2 in. across and I in. deep ; or overlapped and polygonal, with proportions reversed, I in. broad and 2 in. deep. Teeth of dentate type, large and projecting, the longer ones becoming curvescent with long outward-directed aculeus, the shorter ones toward the leafbase often merely aquiline, or simply dentate or serrate, those toward the apex low-serrate, on upper leaves sharp-serrulate.

Color dull apple-green, pale or rusty beneath. Veins close, each straight-out and finally upcurved, projecting strongly beneath and conspicuously brown and strigose. Petioles of radicals about as long as the leaf, of the chief caulines about half their leaf-length and all slender, of the upper caulines reduced to short broad cuneate wings.

Radicals about $2,6 \times 6$ in. or more. Lower caulines remotish, abruptly short-acuminate. Upper caulines ovate-triangular with subcordate or finally truncate base, still short-petioled. Axiles sessile, triangular-lanceolate, soon inconspicuous. Rameals short-triangular-ovate, acuminate, squarrose, resembling those of $A$. triangularis. 
Inflorescence about 6 in. across, a compact dome, with a few remoter shorter lower branches added. Heads coarse and large.

Bracts with thin pale scarious margins and thick green back enlarged into a long curved-bordered green tip, nearly all alike.

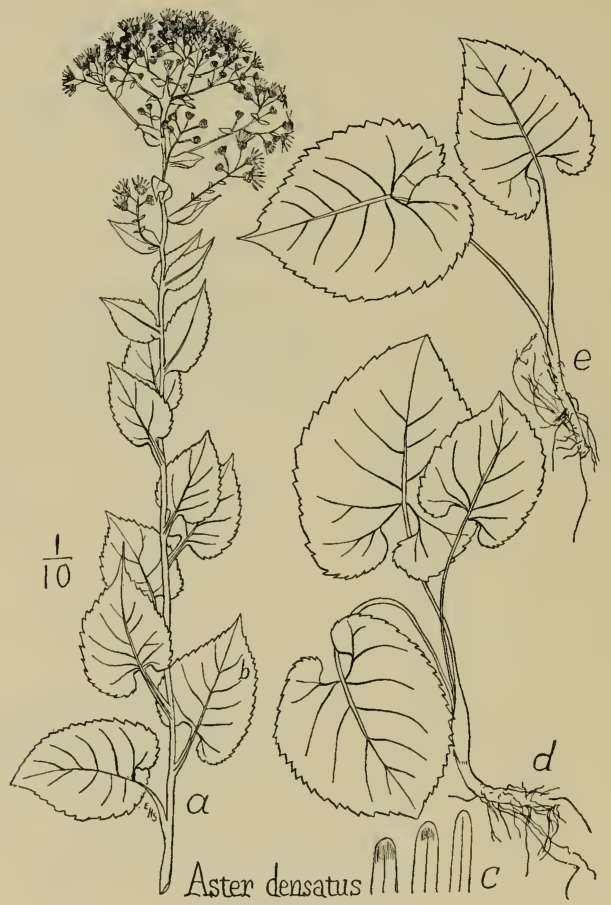

FIG. 84 .

Rays pale lavender, linear-oblong. Pappus soon deeply ferruginous, very long and full.

Resembles $A$. roscidus in broad outlines and wide diffusion of glands; but retains a dense inflorescence, lacks pendent leafbases, has a different sinus and much thinner, more dentate, more hairy leaves, the radicals of dissimilar more orbicular outline.

Examples include :

N. Y. vic., E. P. Bicknell.

Ohio, Kilbuck, Se. 14, '95, W. A. Kellerman, in hb. Ohio St. Univ., - a smoother sprout-plant but seemingly referable only here.

64. Aster roscidus Burgess.

Stout, odorous plants, densely viscid-glandular all over when young, with firm, thick, broad leaves, large and heavy dark-green 


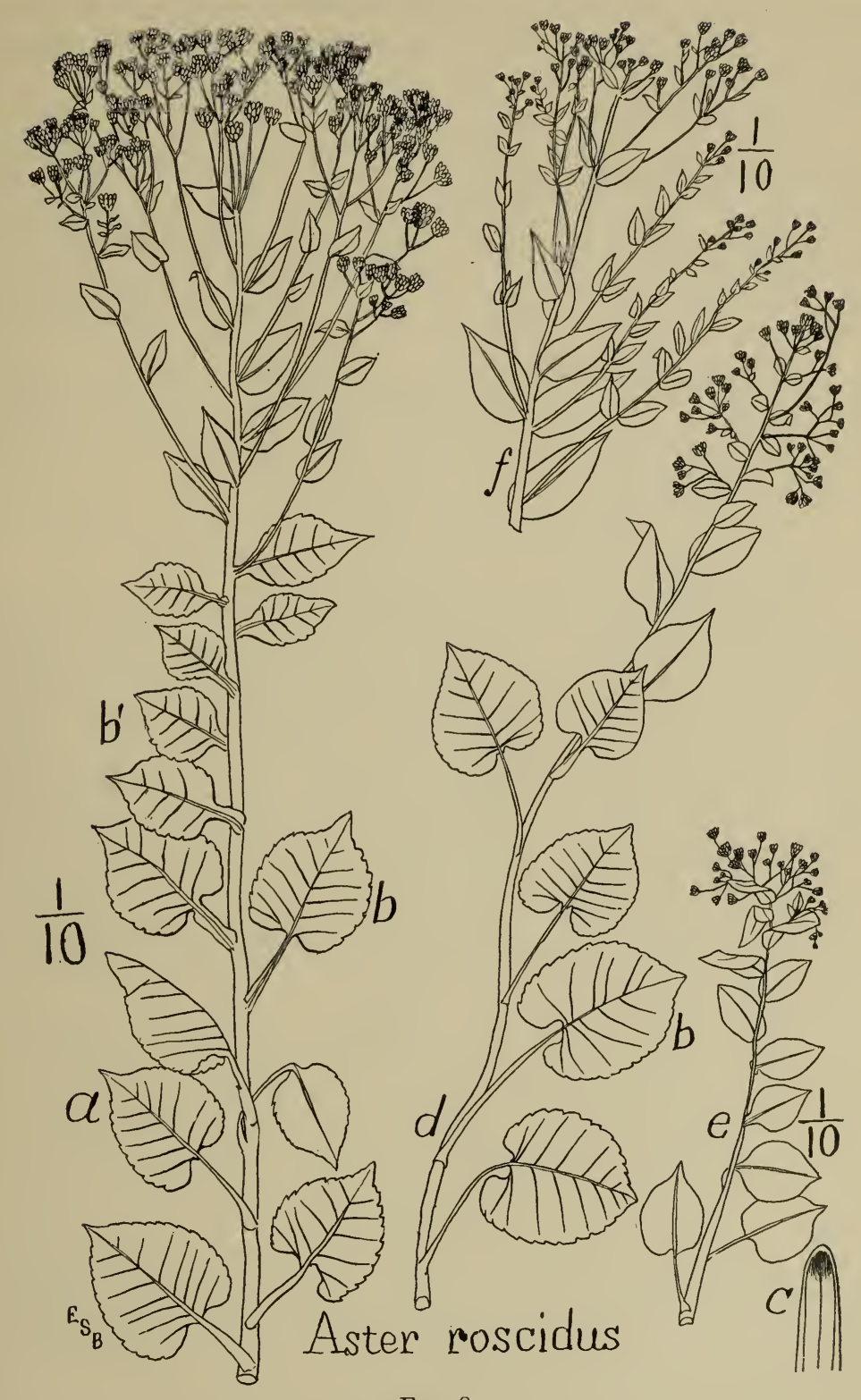

FIG. 85 . 
cordate-ovate, low-serrate radicals, caulines passing from shortcordate to orbicular-apiculate and oval, and large, wide-spread, lilacine inflorescence.

Naine, L., dewy, from the frequent covering of small glandular drops over the whole plant when young.

FIG. 85, a, plant from Bryn Mawr Park, N. Y. vic., Se. I4, '97, showing the usual full inflorescence; at the left some frequent 5 -headed or subumbellate branches; at $b$, characteristic leaf-form. Plant $d$, a small depressed and assurgent form with divergent inflorescence. Plant $e$, a dwarf. Plant $f$, showing the typical inflorescence in bud, July 20 , ' 98 .

FIG. 86 , rootstocks and radicals, from same place ; $A$, old woody rootstocks with primordials, May I $3 ; B$, three sets of radicals still connected by surculi, May I 3 ; $C$, usual radicals, well developed, May $30 ; D$, radical cluster of Nov. 8 , in lettuceleaf stage, with many non-cordate winter leaves recently grown, the cordate radicals of May now limp and depressed.

A. roscidus Burgess, in Br. and Br. Ill. Fl. $3: 360$. I898, with Fig. 3744 and original description :

"Clammy-hairy, odorous, copiously glandular when young, somewhat so at maturity. Stem $3 \mathrm{ft}$. high or less. Basal leaves in close colonies, coriaceous, the earlier ones cordate-quadrate, low-serrate, the sinus deep, narrow; the later or winter leaves elliptic, long-petioled, often prostrate, often 5 in. long. Stemleaves chiefly orbicular and not cordate, with short, broadly winged petioles, rarely slender-petioled. Inflorescence convex, sometimes irregular; involucre hemispheric, its bracts chiefly with rounded ciliate tips, rays $14-16$, broad, clear violet; disks at first golden-yeliow, soon turning red; pappus long, white, copious. - In slight shade and rich cleared woodlands, Me. to Penn. and Mich., Aug.-Sept."

Rootstocks black, thick and contorted, with short internodes. Surculi from them are long and vigorous; old ones are brown and comparatively slender, $\frac{8}{16}$ in. thick or less, pulling up for $\mathrm{I} 2 \mathrm{in}$. or less; young runners are white or slightly purplish, succulescent, growing 8 or 9 in. long in one season, with nodes about I in. long. Runners just forming, while only half an inch long, are sharply acuminate. Root-fibers also reach 8 or 9 in. long. When growing among rock-clefts the horizontal rootstock becomes deeply buried and slight, the principal part a thick vertical turion, rising I or 2 in., or sometimes even 5 in. above the soil, $\frac{5}{16}$ in. thick or less, fleshy and purplish.

Stem brown, terete, roughened till late with close remnantbases of short glandular and strigose hairs, deeply and profusely branched.

Leaf-type broad and short, low-serrate, full green, pale, 
brownish and slightly pubescent beneath, apiculate with an abrupt broad short obtuse projection, nearly orbicular otherwise, with rounded base and cuneate-wing petiole. Such leaf-form is best developed through the middle caulines. Lower caulines $31 / 2 \times 3$ in., with full deep sinus and narrow petiole almost as long as the leaf. Upper caulines oval-acute with broad-wing base. Axiles numerous and longer, elliptic-oblong, sessile, soon oblong-acute with truncate subamplexicaul base. Rameals progressively like

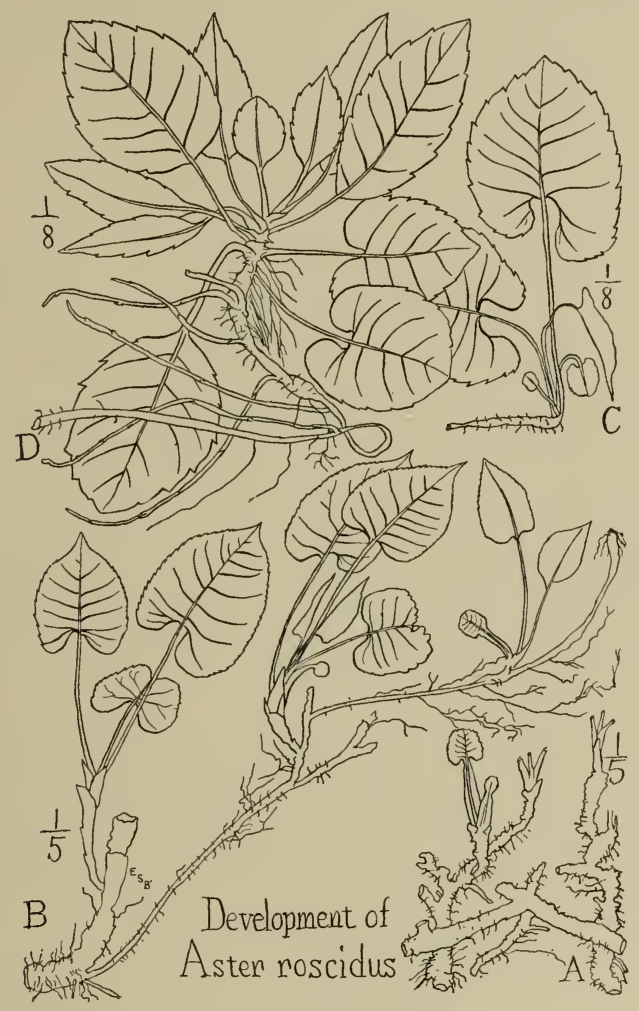

FIG. 86.

each axile type, but much reduced, less than half the axile length from the first, often in pairs, often 4 pairs on the middle and upper part of a branch before the inflorescence begins. These or the smaller similar ramulars sometimes all replaced by subcircular, entire shorter leaves, like those of the Mitchellian form of $A$. divaricatus L. or like those of Mitchella repens.

Leaf-texture soft till after maturity, somewhat resembling felt, the radicals finally leathery and rough. Middle and upper leaves 
a true green, the lower ones a deep dull green with a cabbage-blue tinge. Radical leaves very glutinous in May, little so by the middle of June; bracts then already glutinous and overspread with small capitate hairs, and beginning to show white margins.

Inflorescence copious, a widespread convex corymb 6-8 in. across in fairly-developed plants, in larger ones becoming high, diffused and irregular, often 14 in. across and 18 or 20 in. high, with sharply ascending branches at angle of $50^{\circ}$ to $70^{\circ}$; and heads of diverse development, each branch beginning as a reversed raceme with long-pedicelled buds down its sides below the terminal blossoming head, but later becoming highly irregular by the greater lengthening of occasional lower pedicels.

Heads of moderate size. $\frac{3}{16}$ inch high, I or $\mathrm{I} / \mathrm{s}$ in. broad or less. Involucre hemispheric or finally with truncate base, $\frac{7}{1^{6}}$ in. high. Pedicels long, when dry clavate-thickened to a marked degree, when fresh slender, $1 / 2$ to $I / 2$ in. or even 3 in., nude at the base, their subtending bracteals being very small, elliptic-ovate.

Bracts lingual and nearly alike in size, color and shape, nearly all-over greenish when dry, with increased thickness and green at the large spatulate green-tip, broadly ciliate all around, coriaceous, minutely puberulent except over the broad pale brownish margin. Occasional variant bracts are bevel-topped, and a few slightly acutish. Upper bracts are apt to show pinkish-purple margins; or often all are purpled throughout. At first flowering (July I, in '97), the 3 chief rows of bracts are nearly equal in length, and the outer bracts do not show midrib or green tip, but are increasingly thickened and fleshy to the obtuse incurved and somewhat hooded apex.

Rays broad-oblong with rounded apex, i 4 to 16 , beautiful clear lilac, by evening light amethystine, in age more purplish-violet, drying nearly blue. Young rays purplish-red, their color seen already strong in 1897 by June I9, but not expanding till the month following.

Disks broad and golden, soon full red.

Pappus extremely long and copious, becoming twice the disk, whitish or ecru in growth, rufescent within 3 years after drying. Achenes slender-fusiform, brownish, sparsely clothed with weak deciduous ascending bristles during growth.

Viscidity of the copious glandular hairs reaches its extreme among Biotian species here, all young and growing surfaces making the fingers sticky and odorous at a touch, such glands remaining still present though less viscid over nearly the whole stem and upper surface of leaves at maturity.

Odors present include a delicate fragrance from the flowers, a bee-bread odor from the disks, and, more conspicuous, a nutty 
odor resembling that of the black-walnut and that of Aster NovatAngliae, derived from the glands as in most other Macrophyili, but here intense enough to be perceived without touching. Odor of the broken stem, and less so of the broken leaf, resembles that of wild spikenard, Aralia raccmosa. Of the odor of black walnuts from the glands, one collector remarked "It smells as slippery-elm tastes, and a very soft elusive smell it is."

Pubescence of 4 principal kinds :

Ist. Strigose hairs, long, whitish and multicellular, forwardcurved, very slender, scattered under the midrib and chief veins, rising above a forest of short glandular hairs, perhaps I to 100 such. A few occur on the stem. Shorter upward-curved similar hairs make the leaf-edges ciliate.

2d. Cobwebby hairs, occasional long and still more slender ones, gluey from contact with capitate glands, over the upper surfaces, etc., ascending or deflexed or detached.

$3 \mathrm{~d}$. Indurated hairs, very short, thick and sharp, without green membrane. Such form the aculei terminating the teeth.

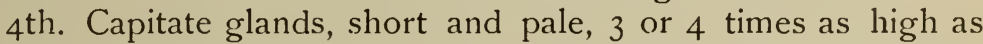
broad, standing so close as to touch and forming a short dense pile over the bracts, branches and veins; over $3 \mathrm{ft}$. or so of stem they stand about their own length apart; over the leaves, about $5-8$ to an areola, above and beneath, making the young leaves clammy.

Development; radicals full-grown by middle of May, or in late development, by end of May; these radicals chiefly 3, low-serrulate, full-green with pale close wide-spread veins, full broad deep sinus, long pendent rounded basal lobes, acute or short acuminate inconspicuous apex, 2 of cordate-ovate or cordate-quadrate outline, the other cordate-oblong, $5 \times 3$ in. or less. About 2 primordials precede these, quadrate or orbicular, with brace-base or simply truncate, with crenate margin and obtuse apex, $2 / 3$ in. long or less, with little or no green, but fuscous and downy; their flat smooth strap-wing petioles 2 in. long or more. About 2 phyllodial petioles precede these, with similar sheathing base and with slightly developed lamina.

Throughout the summer the 3 radicals remain notably of a dark bluish or finally blackish-green, losing pubescence and glands, increasing in stiffness and harsh surface, finally in late autumn pale or almost whitened underneath and roughened like shagreen above, their broad sinus now narrowed and deepened by the continued growth of the pendent basal lobes. Such rough brownish-green radicals sometimes remain as winter-leaves, made suborbicular by loss of the original apex, and lying nearly prostrate.

Plantain-leaf forms are assumed by the type on sudden access of light by timber-cutting; in which case numerous large 
elliptic radicals form a rosette, subtended by a few normal radicals. These elliptic radicals are alike acute at both ends, with remote low teeth, and harsh heavy texture very rough on drying; 8-IO such sometimes crown one rootstock, varying to oval and obtuse and to lance-oblong, reaching $5 \times 3$ inches. Only a few are produced the second season after such access of light has begun, and none the five following years where observed without further change of light conditions. When most characteristic these elliptic leaves are leathery and apple-green, radiating and semi-prostrate, remaining after the other radicals have decayed late in November.

Habitat, rich woodlands on or near rocks.

Examples include :

N. H., Meriden Ledge, A. Wood in hb.

N. Y., Fulton, Oswego Co., in hb. Clinton.

N. Y. vic, Yonkers, Split Rocks, July, Au. and Se., '97-1905, Bu.

Pa., Alexandria, " at Stryker's clearing, I844; A. macrophyllus No. 2," Porter in hb. Mercersburg, Au. 9, '50, Porter in hb.

Mich., "Flint, A. macrophyllus var., ex. coll. D. Clarke" in hb. Clinton.

Tenn., Gregory's Bald, Se., '98, Albert Ruth, no. 345785 in hb. U. S. Nat. Mus., seems to be a small form of this.

$64^{2}$ Sprout-forms. Leaves really rameal in origin and therefore following the rameal type, the sprout or sucker being a sprout-bud from the base of the primary stem and following the leaf-system of an inflorescence-branch; they are elliptic-oblong, sessile and amplexicaul, mouse-ear like, soft, thick, obtuse, and erect-ascending, $I \frac{3}{8} \times \frac{6}{8}$ in. or less, entire except for 3 or 4 little remote aculeate shallow teeth toward the apex. Late sprouts seen Nov. 3 , '96, were bearing $6-7$ heads each, lilac-colored and with a faint fragrance.

$64^{3}$ Peduncular form. An arrest-form where the upper caulines for 4 to io inches suffer an arrest of full growth, and are so small as to make this part of the stem seem a peduncle. Such leaves are narrowly oval, $\mathrm{I} / 4 \times 3 / 4$ in. or less, sessile or with sudden short narrow wing-base. With the type, N. Y. vic.

\section{Subdivision $C$.}

Leaves thinner, coarsely and saliently double-serrate.

Species 65 .

\section{Aster ferox sp. nov.}

Roughish apple-green plants with very large, fiercely-toothed, asymmetrical radicals, thin cordate-ovate, deep-serrate leaf-type, multiform sinus, short upturned branches and pale diffuse heads. 
Name, L., from the savage bristling aspect of the sharp cut leaves.

FIG. 87 , plant from Hastings, N. Y. vic., Se. 5, '98, in hb. Bu., coll. E. $P$.

Bicknell.

Stem $2 \mathrm{x} / 2 \mathrm{ft}$. high or less, greenish, terete, retaining, usually throughout, a minute roughness of glandular stubs and remnants of strigose hair.

Leaves rough above, villous on veins beneath, with scattered strigose hair elsewhere, with veins dark or brownish. Leaf-form

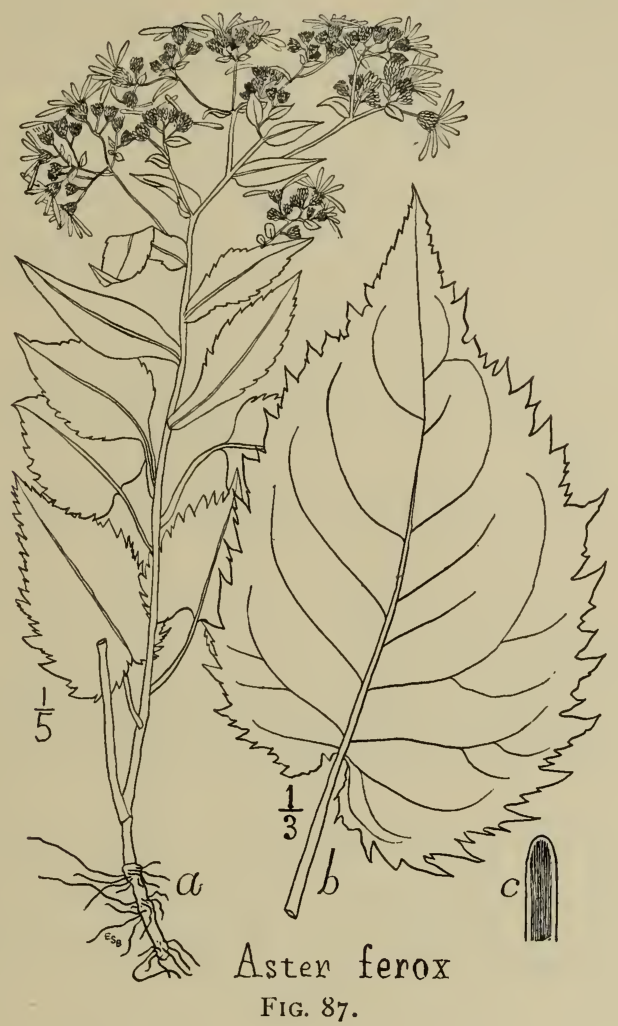

cordate-ovate, briefly but sharply incurved-acuminate, with deep sinus, broad or seeming narrow by overlapping assurgent lobes. Leaf-texture thin, firm, roughened minutely but decidedly.

Radicals 2, nearly alike, very large, two pairs of such sometimes reaching $8 \times 4$ in. on one branching rootstock, highly asymmetrical or falcate, their huge teeth still I in. long and of $3 / 8$ in. projection when dry, shorter teeth of buzz-saw type crowding the unequal basal lobes, low curvescent teeth lining the acumination. Petioles equalling the leaves, unusually slender. 
Lower caulines retaining the same leaf-type, or becoming symmetrical, gradually reduced and with greatly shortened narrow petioles. Middle and upper caulines ovate to lance-oblong, becoming long-acuminate, taper-wing based and serrulate. Axiles lanceolate, sessile, elongated. Rameals similar but abruptly smaller.

Inflorescence convex, dense or soon diffuse, its short rigid branches widely up-spreading.

Bracts somewhat lingual, much as in $A$. roscidus, but with more curving sides, tending to be ovate-oblong, obtuse below, the middle becoming bevel-tipped, the inner narrow-oblong with slightly tapered, rounding apex.

Rays pale lavender or soon white.

- Leaves and inflorescence suggest a hybrid origin from $A$. persaliens and $A$. densatus; but against this supposition is the fact of numerous plants so occurring, all alike, and all vigorous, and their radicals unique in size, margins and details.

From $A$. viridis, which it resembles in suggesting hybrid origin, it differs in much thinner, sharper-toothed leaves and wholly different inflorescence.

Habitat, dry openings along rocky woods, Maine to N. Y. Examples :

Maine, "North Berwick, York Co., rocky open woods, Se. 26, '97; rays white" ; M. L. Fernald in hb. Bu.

N. Y. vic., Hastings, "edge of woods opening on dry field, Se. 5, '98," Bicknell in hb. Bu., in thinly grassy soil, numerous plants, with lavender rays; also, Hastings, dry shaded bank near Amackassin, some virescent rays remaining, Oc. I7, 1905, Bu.

\section{Division B. IANTHINE MACROPHYLLI.}

Violet rays, turning pale or white. - Radicals apt to be smoother and longer-stalked than in the lilacine Macrophylli; or otherwise very numerous and very short-stalked. Colonies apt to be smaller than in $A$. macrophyllus (except in $A$. quiescens). Leaves seldom of extremely rough or of flabby type, chiefly moderately rough and firm; usually not very thick in comparison with $A$. macrophyllus and $A$. roscidus. Glandular hair mostly of stub-form and less broadly capitate, more abundant than in $A$. macrophyllus, less so than in $A$. roscidus.

\section{Subdivision $A$.}

Plants tall and robust, often $4 \mathrm{ft}$. or more; radicals large, 8 in. or less; glandular and strigose hair little developed below the inflorescence. Sp. 66-70. 
* Inflorescence somewhat deeply branched, rather regular and convex-topped. Sp. 66-69.

$\dagger$ Violet of the rays often almost blue, but evanescent and quickly becoming white; the same plant therefore often showing blue-violet heads and white heads at once. Sp. 66, 67.

\section{Aster iostemma sp. nov.}

Tall strong plants with smooth brown stem, granular-roughened elongate leaves, crenate-serrate or subentire margins, and prolonged cordate-oblong radicals; the characteristic caulines ovateacuminate with truncate and rounded base and taper-wing petiole, broad irregularly-compound high-angled inflorescence, the outside and lowermost heads successively flowering, the young dark blueviolet rays and the older white rays simultaneous in bloom side by side.

Name, Gr., = violet-crown, this species representing an extreme case of the dark violet rays found among some Ianthine asters.

Fig. 88, plant from Little-Indian Cr., N. Y., Au. 24, '98, in hb. Bu.; $b$, characteristic cauline leaf-form ; $c$, characteristic radicals ; $d$, less developed radicals.

Stem terete, erect but with continuous slight flexures, with long internodes, sometimes $4 \mathrm{~T} / 2 \mathrm{ft}$. tall.

Radicals 2 , 3, or often 4 , unusually long and narrow, glabrate and chiefly very smooth in life, still smooth or partly granularroughened when dry; cordate-oblong, and straight-sided, $9 \times 4$ 1/2 in. with equal petiole; or in less pronounced development much incurved toward the apex, short-scutiform and $5 \times 4$ in. or longscutiform and $8 \times 4$ in.; their teeth low-curvescent with but slight aculeus, but with their sinuses somewhat excavated. Petioles slender and smooth; even I 3 in. long sometimes. Surface sometimes almost as unctuous as in A. macrophyllus pinguifolius. Sinus broad and open, usually shallow and producing a recurving brace-base.

Caulines of ovate type, serrulate, at first with truncate bracebase; then rounded into a truncate base without cordation, and with short, cuneate wing, these being its most characteristic caulines. Axiles follow which are ovate-lanceolate, longer acuminate, with irregular wing, finally almost sessile.

Veins darker above than the full-green leaf, paler below than the pale-green tissue surrounding, few, strongly upcurved.

Leaf-substance firm, only moderately thick, highly roughened above, somewhat so beneath when dry. Weak pale strigose hairs cover the veins beneath. 
Inflorescence often I $\mathrm{ft}$. broad, I $\mathrm{I} / 2 \mathrm{ft}$. high, its angle of branching very high, apt to be $70^{\circ}$, its branches subequal, springing from remote nodes and bearing their loose corymbs at different levels. Involucre somewhat hemispherical, with straightish sides.

Bracts not very green nor very thick, narrow and of many rows, of 3 types, the outer curving, ovate-triangular, acutish, puberulent, the chief bracts (middle ones) oblong-lingual, becoming more narrowed and almost acutish. Bracts with green-banded

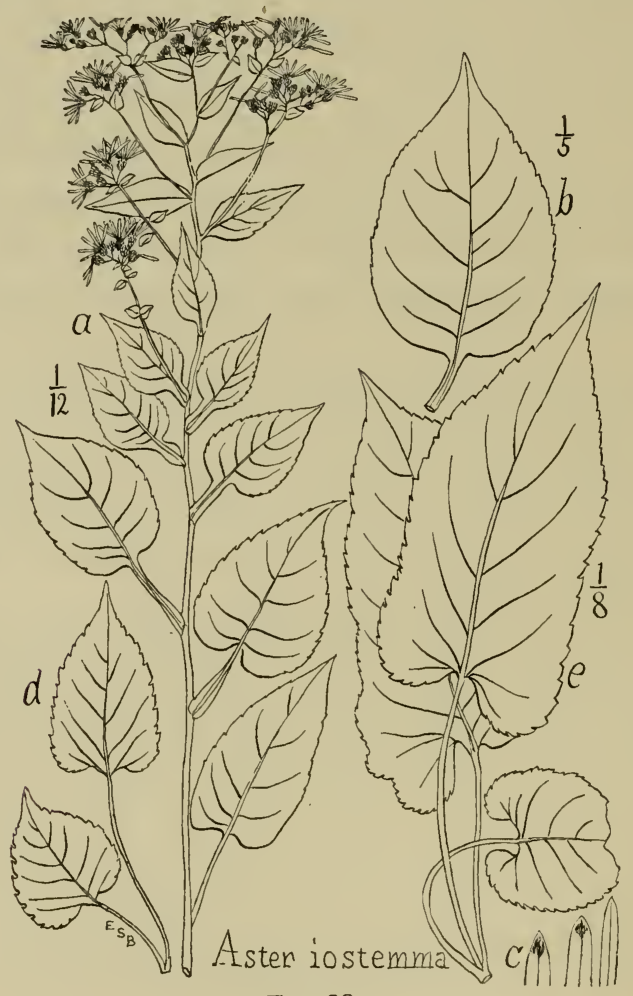

FIG. 88.

center, and thin, rigid, pale-brown, scarious border, the latter becoming progressively wider inward, till the inmost bracts are wholly scarious except the green-line of midrib. Ciliation moderate on outer and middle bracts, then disappearing.

Involucre $\frac{5}{16}$ high, or a little more.

Rays of medium breadth, oblong, with straight sides, broader than in the next.

But little hair on leaves, stem or inflorescence, though more than in the succeeding species. Glands abundant upward; on the stem toward the ground they become subsessile. 
- This species $A$. iostemma perhaps includes a part at least of the plants of which Gray remarks, under A. macrophyllus L., Syn. Fl. I75 :

"A robust form, with large heads, more glandular involucre and peduncles, upper leaves ovate and sessile, lower and petioled cauline leaves all rounded at base, and most of the radical ones little cordate (A. macrophyllus of Willd. herb. chiefly, the rays perhaps violet), comes near the next following." Of the 7 specimens labelled "A. macrophyllus" in the Willdenovian herbarium, kindly examined for me by Prof. L. M. Underwood, Nos. I, 2 and 5 may belong under A. iostemma; some others seem to belong to A. macrophyllus verus.

Of the "next following" group (A. mirabilis, A. Herveyi, A. spectabilis, etc.), $A$. Herveyi, the only one which could lead to confusion with $A$. iostemma, is much lower and more slender; its heads are fewer, broader, longer-pedicelled, more remote; its leaves are of a different duller green; its cordation is far more rare and slight, no well-defined brace-bases occurring.

Habitat, rich shaded banks, clearings and half-shaded roadsides, New Hampshire to N. Y. City and L. Erie.

Examples include:

N. H., Gorham, $900 \mathrm{ft}$. alt., near Shelburne line, at Q. Evans' farm, Androscoggin river, Au. 9, 1902, in early flower; obliterated in $\mathbf{1} 904$.

N. Y. vic., Woodlazon woods, cleared woodland, 4 and $41 / 2 \mathrm{ft}$. tall, in great profusion; " rays clear white and distinctly violet on the same plant, July $3 \mathbf{I}$, ' 98 ,' ' $E . P$. Bicknell in hb. Bu. Yonkers, Grassy Sprain L., in deep shade, Se. I7, '98, perhaps late sprouts of the same, thinner, smoother, darker green. Bryn Mawr Park, below Cohosh Bluff, mass of tall early plants with narrow rays, near woodroad nnw. of Maple Av., July, '98; well-developed long radicals May 13, '99; 40 plants in fine blossom, July 28, '99; a few plants I 900-I904; obliterated I905.

W. N. Y., Cattaraugus resn., 600-800 ft. alt. ; Little-Indian slopes to east and north of Straw tree, Au. 24, '98, many plants growing up out of leaf-mold covered yet with dead leaves; type locality. Silver $C r$., Swift's Hill, narrow-rayed narrow-radical plants, rather low. Salamanca, Au., C. H. Peck in hb. N. Y. St.

\section{Aster gremialis sp. nov.}

Tall robust plants with smooth green stem, broad roundish or orbicular-ovate sharp-serrate lower leaves, broad deep sinus, long taper-based lance-acuminate subentire broad-winged axiles, loose broad inflorescence, weak slender branches, and long dark narrow blue-violet rays. 
Name, L. = bosom-nourished, from its flourishing so remarkably when springing from the decay of a log or stump.

FIG. 89, a plant from Silver Cr., N. Y., Au. 2 I, '97, in hb. Bu.; $b$, its characteristic lower leaves; $d$, its radicals; $e$, its biculminate form, $f$, its fedian form.

Stem assurgent, nearly straight, often leaning forward out of thickets, often $4 \mathrm{ft}$. high.

Lower leaves large, orbicular and about $6 \times 6$ in., or orbicular-ovate and $6 \times 5$ in., their slender petioles much shorter, their

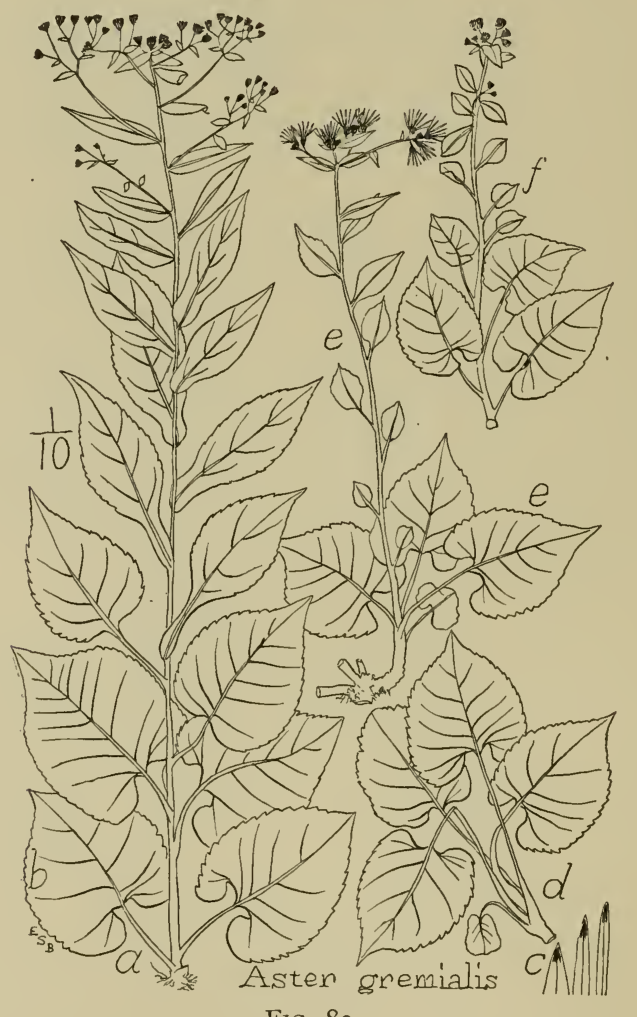

FiG. 89.

teeth large, sharp, of double-serrate or of aquiline-acuminate type (but occasionally inconspicuous); large examples $1 / 2$ to $2 / 3$ in. long. About 5 such radicals and about 4 such lower caulines are common. Their sinus is rectangular or deeply polygonal, their apex suddenly acuminate and entire.

Middle caulines ovate-acuminate, rapidly reduced from $6 \times 4$ to $4 \times 2$ inches, one or two with brace-base, others with roundedbase and taper-wing, becoming low-serrulate with forward-crouched teeth. 
Upper caulines and axiles highly characteristic, oblong-lanceolate, long-acuminate, slowly tapered into a very conspicuous broadwing base; the margins low-serrulate or subentire; $6 \times 2$ in. or less. Axiles similar, gradually reduced, all constricted or tapered suddenly at the sessile base, the upper ones still $2 \times 2 / 3$ in. and lance-acuminate.

Leaves very thin, very firm, deep green, smooth and glabrous in life, commonly granular-roughened when dry.

Veins narrow and inconspicuous, distant, each outcurved and soon upcurved, or after the lower leaves, directed upwards from the first.

Hair is found by lens on chief veins beneath, though scanty; slight glandular puberulence occurs in the lower bracts.

Inflorescence broadly convex at first, soon irregular, the lateral heads considerably later in growth and finally overtopping the central ones. Heads sometimes over $1 / 2 \mathrm{in}$. high, $1 \mathrm{I} / 3 \mathrm{in}$. broad, on pedicels often $\mathrm{I}$ in. long.

Bracts narrow, chiefly smooth and pale, the middle and inner ones scarious, the outer green and triangular-acutish, the middle oblong-acutish, the inner more taper and with only a narrow median line of green.

Rays long and narrow, almost acuminate, deep blue-violet, sometimes reaching the nearest to a full deep blue perhaps of any northeastern aster, fading whitish, sometimes becoming a peculiarly lustrous white. Disks early a deep red.

Glandular hairs often (or always ?) very few, often undiscoverable on the smooth bracts and pedicels when dry, though some viscidity is present in life.

Remarkable for the contrast between its lower sharp-serrate short broad leaves, and its upper subentire elongate taper-based leaves. A. nobilis, which resembles it, tends to reverse this contrast, having longer little-serrate lower leaves and shorter sharpserrate clasping or truncate upper ones.

Habitat, under shade among thickets or in damp levels ; springing from decaying logs and stumps; W. N. Y.

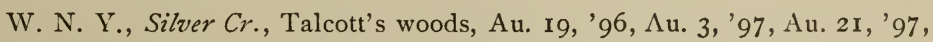
a few continuing, Au., '98-1904; Dunkirk, Pt. Gratiot, Au. I I, '97.

$67^{2}$ Biculminate form; an arrest-form where the size of leaf after sudden reduction at or below the middle-stem, reaches gradually a second (though much smaller) culmination, just below the inflorescence. See Fig. 89, $e$.

$67^{3}$ Fedian form; upper leaves and axiles short, entire, oblong-oval, contracted at base, resembling leaves of Fcdia or 
Valerianella. With the type; and with dwarf, interrupted, and biacuminate-leaved forms of the type. See Fig. 89, $f$.

t† Violet and subsequent white of the rays usually less pronounced. Sp. 68, 69 .

\section{Aster nobilis Burgess.}

Tall, robust, spreading plants with large cabbage-like subvillous radicals, cordate-ovate leaf-form, sharp or narrow sinus, crenate or subentire margins below, sharp-serrate above, lanceoblong broad-based axiles, deep high-angle branching, and proliferous inflorescence, long continuing to develop sessile closelylateral buds, all finally divergent and long-pedicelled.

Name, L., from the stately aspect.

FIG. 90, plant from Silver Cr., N. Y., Au. 15, '96, in hb. $B u$.; $b$, its basal leaf (unusually large), $c$, its radicals, $d$, a less-developed but frequent inflorescence.

A. nobilis Burgess in Br. and Br. Ill. Fl. 3: 361. 1898, with Fig. 3748, and original description :

"Tall, minutely glandular above, stem shining, bright green, 4 to $5 \mathrm{ft}$. high. Leaves thin but firm, smooth in growth, roughened in drying, minutely puberulent beneath, dark green; basal and lower leaves large, the blade often 9 in. long by 6 in. wide, about as long as the stout petiole, sharply toothed, the sinus deep, broad, or the lobes overlapping. Stem-leaves similar, the upper oblong-lanceolate, sessile, inflorescence irregularly cymosepaniculate, with small subulate recurved leaves. Bracts long, acute, green. Heads 6 lines high or less; rays I3-I 5, violet-blue or [more often] pale violet; disk-flowers not numerous, their corollas funnelform with a long capillary tube. - In leaf-mold, L. Champlain to L. Erie, Aug."

Stem bright green and shining or slightly browned in the sun, terete and smooth, stout and erect, 3 or 4 , sometimes nearly $5 \mathrm{ft}$. high.

Radicals usually 4, divergent, large and similar, often each $7 \times 5$ in., rising at an angle of $45^{\circ}$ on strong petioles at least equalling their own length, apple-green, cordate-ovate with subentire or indistinctly crenate margin, deep narrow or sharp sinus, the apex merely acute or suddenly short-acuminate.

Caulines, after a few of the preceding characteristic type, become chiefly oblong-ovate, strong-serrate, short-acuminate, truncate-based or finally rounded, with short irregular broad wing; spaced at regular intervals of 3 in., or in smaller plants 
about 2 ; measuring usually $7 \times 4$ in., or less, and gradually diminished upward.

Axiles oblong-lanceolate, broad to the sessile base, slit-serrate, often prominently and aculeately so, often conduplicate around the subtended branch, $4 \times \mathrm{I} 2 / 3$ in. or less.

Rameals few and remote below, I or 2 subopposite pairs a little below the heads, oblong-acuminate with sessile clasping base. Bracteals among the pedicels very peculiar, subulate-recurved,

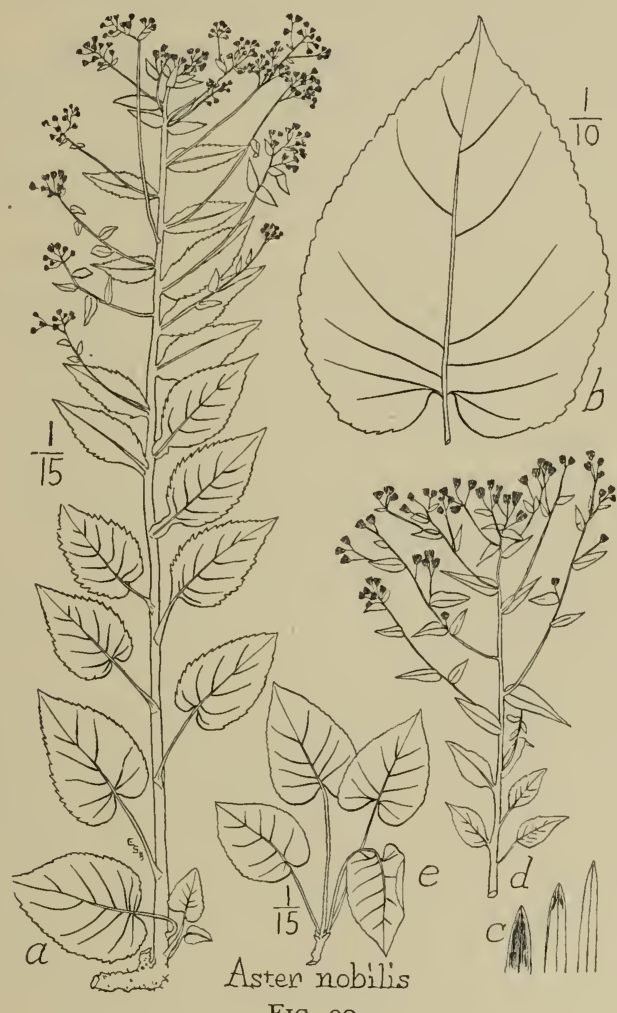

FIG. 90.

strongly conduplicate, triangular-acuminate, with an enlarged concave base and narrowed channeled recurved portion.

Villous hair weak and soft, confined to veins beneath or shorter and downy between them. Glandular hair sparse; subsessile glands occur over all midribs, and, though minute and few, on the pedicels and bracts.

Petioles green, fleshy, channelled, smooth and stout.

Inflorescence cymose-paniculate, when well developed very 
broad and very irregular, its I 2-I 5 long straggling branches smooth and green, mostly about 9 in. long, each breaking into an irregular compound cyme with divaricate or divergent branches and heads; these heads at first close-clustered, finally remote and long-pedicelled, the pedicels lengthening a half inch while the bud enlarges before flowering. Tendency strong to proliferous growth, side-branches and branchlets soon far surpassing their axis.

Involucre in the bud very green and smooth, globose or ovoid, becoming thick-urceolate in flower, and seeming hemispherical on pressing, not large, $\mathrm{x} / 4$ in. high.

Bracts all acutish, with indefinite broad-triangular green tips, otherwise chiefly pale and subscarious, flat and slightly ciliate in life.

Rays violet, I 3-1 5, oblong, elongated, closely set, not nearly so narrow as in the previous species, nor so blue.

Disks few, quickly becoming purple-red, by the time the rays are open, and becoming brownish as the rays reach full maturity.

Disk-flowers very slender, narrowly funnel-form, tapering into a long thread-like stalk, the stalk $\frac{3}{5}$, body $\frac{1}{5}$, and deep narrow lobes $\frac{1}{5}$, of the whole length ; the color of the stalk green, abruptly changing to yellow or purple at the bell. Achenes small, little longer than the disk-lobes. Pappus bright white, soft and copious, much overtopping the disk and already dingy by the end of flowering, rufous in two months after drying.

- Each plant apt to be isolated, or growing three or four together, such little groups occurring scattered widely through the woodlands in which they abound. Rootstalks little developed, pulling up for 2-3 inches, beyond which they are found decayed. Radicals and also basals usually lacking on flowering plants. Surfaces smooth while fresh, usually roughish on drying. All leaves thin, and the upper ones as thin as in A. divaricatus. Tendency strong to blasted buds, and in other cases to lose the ovaries, eaten out by larvæ before the bud has opened, causing the bud to become ovoid-conical and acute, and finally to wither on its stalk.

Habitat, among bushes in woodlands and clearings, then usually not over $3 \frac{1}{2}$ feet high; or in deeper shade on slight hummocks in wet woods, especially on soggy ground on a clay substratum over shale, then reaching almost $5 \mathrm{ft}$.; N. E. and Lake Champlain to L. Erie ; in neither case on the immediate lake-bluff, but in the heart of such woodlands as front on the bluffs. 
Examples:

N. H., Gorham, on Pt. I.ookout, at I,400 ft. alt., Au., I902. Mt. Washington, at $2000 \mathrm{ft}$., Au., 1902 ; Shelburne, Baldcap Mt., Au., 1904.

Mass., Taconics, Mt. Everett, Au., I90I. Mt. Ethel, Au., I90 I, I903.

Conn., Salisbury, Au. 18, I903.

N. Y., L. Champlain, bluffs below Plattsburg, Government woods, Au. 3 I, '97, Bu.: Catskills, '99, Sand Lake, Au., 99, C. H. Peck in hb. N. Y. St.

W. N. Y., Silver Cr., Talcott's woods, Au. 15, '96, Au. 3 and 21, '97, Au. '98-1904. Pt. Gratiot, Au. 29, '96, July 29, Au. II, Au. 21, '97; leaves only, '981904. Cattaraugus resn., Indian-line road, abundant, Au. I3, '97, Au. '98-1902.

Variants. Cabbage-like leaves with merely serrulate axiles seem to be developed best in loose gravelly soil. Smaller lower leaves and strongly aculeate-toothed axiles seem to be the result of moister more clayey soil ; the latter producing much more inflorescence and much longer branches.

\section{Aster ampliatus sp. nov.}

Large but weak and spreading plants with pale smooth fleshy stems, broad, polymorphous leaves with gradually dilated pendulous basal lobes, dentate or subentire margins, thin sleek leaf-substance, cordate-oblong radicals, elongated petioles, short ovateoblong upper caulines and axiles, close convex or irregularly profuse inflorescence, narrow-oblong rounded silvery-green scarious bracts, angular branches and long pale-violet rays.

Name, L., broadened, from the widened basal lobes of the larger leaves.

FIG. 9I, plant from Catskills, Kaaterskill Mt., Se. 7, ' $98, \frac{1}{10}$ nat. size, in hb. $B u . ; b$, its characteristic leaf-form with amplified lobes; $c$, occasional polymorphous radicals ; $d, \frac{1}{12}$ natl. size, its more usual radicals.

Stem green or brown, terete, $3 \mathrm{ft}$. or less, stout and succulescent, upper parts and branches becoming irregularly shrunken and angular in drying.

Leaf-form polymorphous; the most characteristic type being cordate-ovate-obtuse with sides increasingly broadened downward into expanded pendent basal lobes, and with the usually acute apex early lost, resulting in a liver-like shape.

Leaf-type large, thinnish, glabrate, asymmetrical, with irregularly crenate or dentate margin, unequal deep many-curved overlapped sinus, apple-green color and inconspicuous slender brown veins. Texture sleek in life, granular-roughened when dry. Weak pale strigose hair grows on all veins beneath, is permanent over the inflorescence, and early in the season occurs scatteringly 
over the whole stem, persistent remnants being visible by lens to the end. Glandular stubs clothe the whole stem and inflorescence, and all but the inmost bracts; they are just perceptible to touch, but leave the stem smooth to the eye. Recurved pale short slight glandular hairs occur quite closely over all leaf-surfaces beneath,

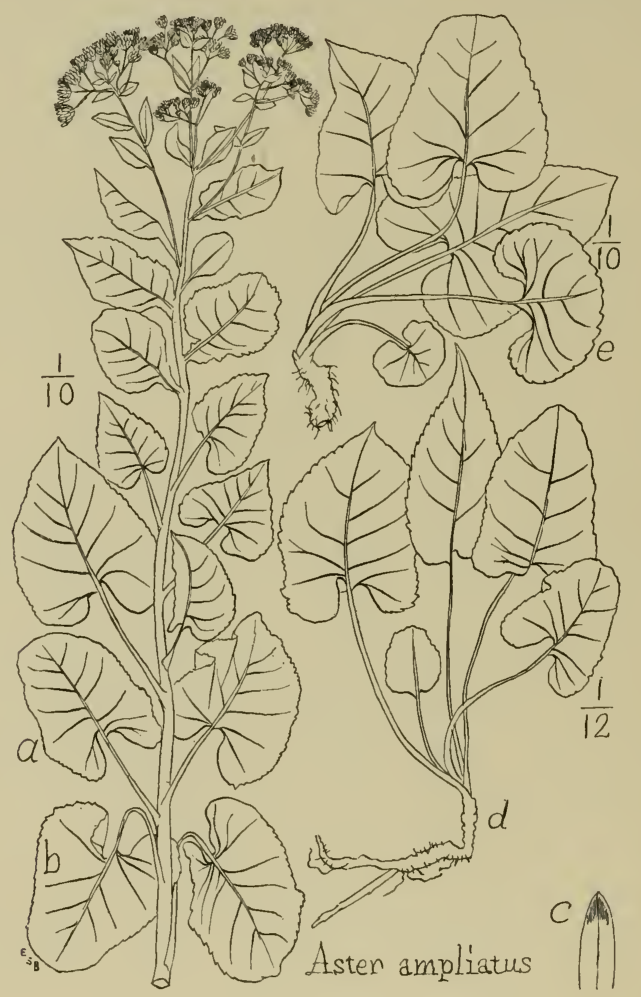

FIG. 9I.

with whitish glands not very readily seen by a hand-lens; as in other Ianthine species. Petioles, as well as sinus and leaf-form, are polymorphous.

Root-stock brown, thick, extensively assurgent.

Radicals apt to be 5 ; their very long weak assurgent smooth succulent petioles drying straw-like, much exceeding the large leaves, and reaching often 8, sometimes 16 inches long. Of 5 radicals, all may be nearly alike in size, 8 or 9 by 5 inches; or only one or two may be fully developed and the rest may be shallow-reniform with deep broad and elegantly-curved sinus and no distinct apex. Other radical shapes include cordate-quadrate (seen $7 \times 6$ in.), oblong-ovate $(9 \times 5$ in. $)$, oval-quadrate, truncate at 
ends $(3 \times 2 \mathrm{r} / 2$ in. $)$, cordate-acute $(6 \times 5$ in. $)$, cordate-oblong, acute $(5 \mathrm{r} / 2 \times 3 \mathrm{r} / 2$ in. $)$, etc.

Caulines begin with the characteristic obtuse and ampliate form in large size (to $7 \times 5$ in.), or with broadly cordate-acute leaves of similar size, all with long weak slender petioles, these shorter however than the leaf-length. Smaller plants sometimes show only narrower cordate-oblong lower caulines.

Middle and upper caulines oval-oblong, broad, irregular and asymmetrical, sharply dentate, with expansive broad-wing gashtoothed base (as often in $A$. divaricatus alatus) or in smaller leaves with an entire undulatiform wing (as in A. undulatus). Apex of these leaves obtuse retuse or acute.

Axiles like the last $\left(4 \times 2 \frac{1}{2}\right.$ in. $)$, or broad, biacuminate, serrulate $(3 \times \mathrm{I} / 2 \mathrm{in}$.$) , and sessile.$

Rameals often numerous and conspicuous, obovate or oblongovate, sessile by a broad base, acute, minutely slit-serrulate or subentire.

Inflorescence broad and irregular, of several or many leafystemmed, shallow corymbs, each convex-topped and composed of 8-40 loose heads, with slender, but rather short, pedicels.

Bracts lingual, rather narrow, rounded at apex, all nearly alike but progressively thinner, flatter, more scarious and more silvery-green toward the inmost series.

Rays rather thin, violet or pale-violet, involutely-wrinkled on drying.

Habitat, Catskills, at 2,500-3,000 ft. (Grand-View, E. front of Kaaterskill Mtn., Se. 7, ' 98 , in numbers, at several places).

** Inflorescence sympodially proliferous, very irregular, deep and narrow.

\section{Aster sympodialis sp. nov.}

Tall, robust, scattered plants, with thickish, ample, regular, low-crenate leaves, broad cordate-ovate leaf-type ; about 3 radicals ; numerous caulines, chiefly ovate-oblong with strap-wing or taper base; high-ascending or erect branches, each successively overtopping its axis, producing a straggling long-pedicelled inflorescence; and with numerous ( $14-20$ ) long, narrow, fragrant rays with obtuse apex and tapering or pedicelled base, violet fading white.

Name, L., from the strong tendency of lateral branches to surpass their axis.

FIG. 92, plant from Maple Ave. bank, near Yonkers, N. Y., Se. 6, '99, in hb. $B u$., $\frac{1}{10}$ nat. size; with narrow inflorescence; $b$, its characteristic radical and lower cauline form, $\frac{1}{6}$ nat. size; $d$, radical group, with primordial, $\frac{1}{10} ; e$, broader inflorescence, $\frac{1}{12} ; f-j$, sympodial developments, $\frac{1}{12}$ nat. size. 


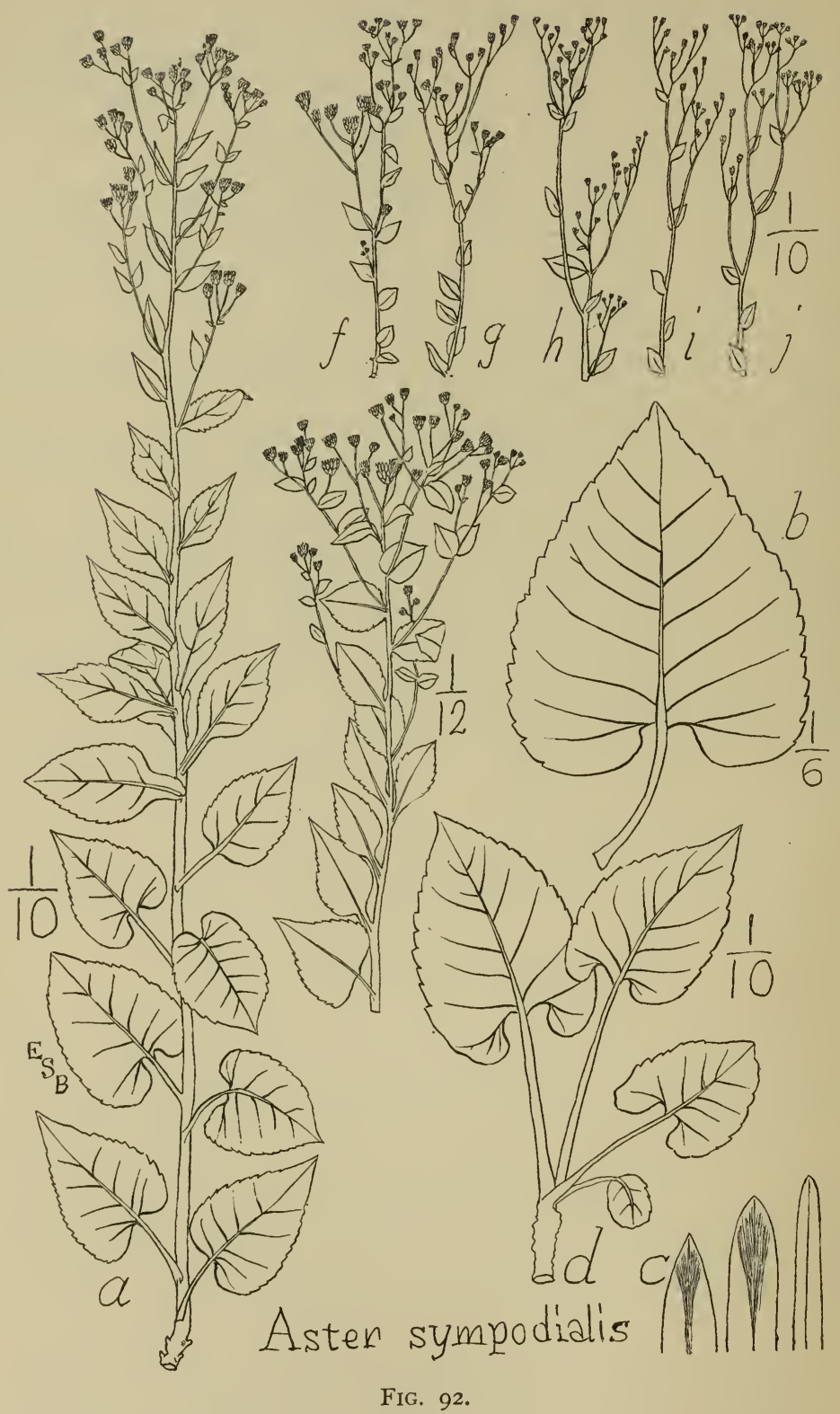


Stem 3 to $4 \mathrm{ft}$. tall, terete, pale or dark brown, glabrate, erect and leafy. Rootstock-runners become 9 in. long, $1 / 8$ in. thick, very uniform, of a dingy yellowish-brown, with nodes $3 / 8$ in. apart, bearing a crescentic scar halfway round. Ascending turionic branches of these rootstocks become $\frac{4}{8}$ in. thick, deeper brown, finally black, and bear larger and more numerous radicals with successive years.

Radicals usually 3, often 2, sometimes 5, crowning a very short, thick, black rootstock, which decays close to its assurgent end.

Leaf-type broad-cordate to cordate-ovate, $7 \times 5$ in., $6 \times 4$ or less, with low-curvescent margin, broad, deep, enlarged, squarish or many-curved sinus, and simply acute or very briefly-acuminate apex. Leaves thickish, somewhat succulent when young, full green above, very pale and glabrate beneath, with veins darker above and paler beneath than the surrounding tissue.

Radical petioles longer than the leaf, channelled, with dark glandular hairs within, ciliate and strigose-hairy without; as the veins beneath.

Fine close tomentum of brownish glandular stubs clothes the stem and infloresence, though worn away from the lower stem at flowering-time. No obvious hair anywhere then.

Lower caulines similar to the radicals or exceeding them. Middle caulines elliptic or ovate-acuminate with rounded or truncate base ; and a broad cuneate wing, I in. long or more. Upper caulines similar or oval, sessile; as the axiles, which with the rameals, become oblong-acuminate.

Inflorescence long-continuing, at first leafy and loose, forming a broad rounded corymb with violet rays ; later very proliferous, irregular and dingy-white. Lateral ascending branches alter its appearance altogether, clothing the upper foot-length of the stem with a succession of erect few-flowered corymbs of 4 to 6 heads each; or with repeated suppression of axis, the lateral branch overtopping its axis and its own summit overtopped in turn by one of its lateral buds, and so on repeatedly. Continuous lateral development of this kind is not usually balanced on both sides but tends to a sympodial form, with wholly one-sided overtopping; reaching an extreme in a stem 6 times suppressed and continued by an arising lateral branch at the left, within an inflorescence of 22 in. high.

Pedicels often over I or 2 in. long, very slender and threadlike but stiff and erect, as are the secondary peduncles, which may reach 3 or 4 in. long; both are subtended by inconspicuous suppressed subulate bracteals.

Heads large, $\mathrm{I} \frac{3}{16}$ in. broad or less, deliciously fragrant, the 
involucre bright green at base, cylindrical or urceolate in flower, broadly turbinate when pressed.

Bracts thickened, oblong to linear-attenuate, triseriately chequered, very unequal in length, obtuse and close-appressed, all green with pale edges and dark tips in life; the middle and inner ones silvery green and with mingled brown at the midrib when dry, now linear-acuminate but still obtuse, subciliate, and with very narrow scarious brownish margin; the very lowest bracts puberulent and ovate-acutish, all laterally-expanded at the concealed base.

Rays greatly tapered or pedicelled at the base, entire or but obscurely notched at the rounded apex, I 3-20 in number, repeatedly i 8 or 19 on central heads, changing from deep violet to whitish. Of five heads on one branch at once, the youngest was a beautiful full violet; the next pale violet, with reddish-brown disk; the next two with but the merest trace of violet, and beginning to recurve; the disks a pale reddish brown; the oldest was hung with collapsed flat drooping and curling rays, now white. with their disk pale brown. Old heads are remarkable for the diverse way in which each straggling ray projects and droops. Rays in the best developed cases reach $\frac{9}{16}$ in. long and $\frac{2}{16}$ in. broad, meeting each other or slipping under at base, all paler towards their base and at first making a perfectly flat pale halo within the violet (as in $A$. Novi-Belgii) around the perfectly flat yellow disk of the same level. Disk much elevated with age, but remarkable among its allies for attaining only a pale degree of the usual reddish-brown.

- Unlike $A$. iostemma in its sympodial tendency, silvery chief bracts, and details of leaf-form. Unlike $A$. nobilis in these particulars, with much more glandular hair and much less strigose hair. Unlike $A$. roscidus beside which it grows, in having rays narrower but more numerous and longer, heads $1 / 8$ to $1 / 4$ in. broader, but flowering later ; nutty odor and glandular viscidity comparatively slight even on young surfaces; rootstocks not stout nor woody nor closely-branched; radicals later in spring; teeth shallower; leaf-form, texture, and color, different and paler.

- Development. Young radicals well-developed, quite roscid, roughish to touch, and Io inches high by May I 3 ('99), and at that time with some hair under the leaves, and with petioles glandular and subciliate. Primordials remarkable for rounded ends, thick, still green or slightly browned, oblong or cordate-oval, about $I \times 3 / 4$ in., or half that size, finely denticulate-crenate. One 
radical group of this date had been producing radicals without flowering for 6 preceding years, fide its leaf-scars; and had made only 3 inches growth in that time.

Habitat, rich shaded banks, near Yonkers, N. Y.

Examples:

Bryn Mawr Park, scattered plants, north of sta., near railroad, Se. 5, '98, $B i$. in hb. Bu.; and bank above Mayflower-brook, near Maple Av., Se. 6, '99. Bu., typical locality; scattered plants, with radicals $5 \times 3 \frac{1}{2}$ in. by May 13 ; continuously in abundant bloom, '99-1 904 ; mostly destroyed by zealous gardening, 1905 .

\section{Subdivision $B$}

Plants smaller, chiefly $2 \mathrm{ft}$. or less; radicals fewer or smaller, mostly 3 , chiefly 5 in. long or less. Sp. 7 I -79 .

* Inflorescence with flattish top ; hair usually little developed; glands minute, less widely distributed; leaves firm, thinnish. Sp. $7 \mathrm{I}-73$.

† Inflorescence deeply V-shaped; with high and slender straight branches.

\section{I. Aster securiformis sp. nov.}

Plants of moderate height and breadth, with straight glabrate slender stem, long smooth slender petioles, cordate-acuminate leaf-form, firm thinnish roughish texture, close sharp teeth, broad deep sharply-recurved or securiform sinus, cordate petioled middle leaves, oblong-acute sessile upper leaves and axiles, and sharplyacute pale uniform bracts.

Name, L., = like a battle-axe, from the sinus.

FIG. 93, plant from Rock Cr., near Washington, D. C., Au. 25, '76, L. F. Ward in hb. Bu.; with characteristic leaf and radicals.

Stem $2 \mathrm{r} / 2 \mathrm{ft}$. often, pale brown or sometimes dark, from a long, stout, dark and very fibrous rootstock.

Radicals cordate-acute, sometimes $7 \times 5$ in., with sinus I in. broad and deep.

Leaf-type cordate-ovate, incurved-acuminate, with elegantlycurved symmetrical sides and diminished rounding bases, applegreen, thin but firm, glabrate but with strigose hair on the veins beneath, crenate or serrate with strong forward-directed aculeus. Sinus-type securiform, or bounded by three curves meeting at a sharp, reëntrant angle, an inch deep and broad or less, of square aspect or soon more shallow and open.

Lower caulines and middle ones typical or passing into ovate- 
acuminate leaves with merely rounded base. Upper caulines oblong-lanceolate with short wing-base. Axiles oblong-acute with broad sessile base.

Inflorescence broad and loose, heads broad and shallow, about

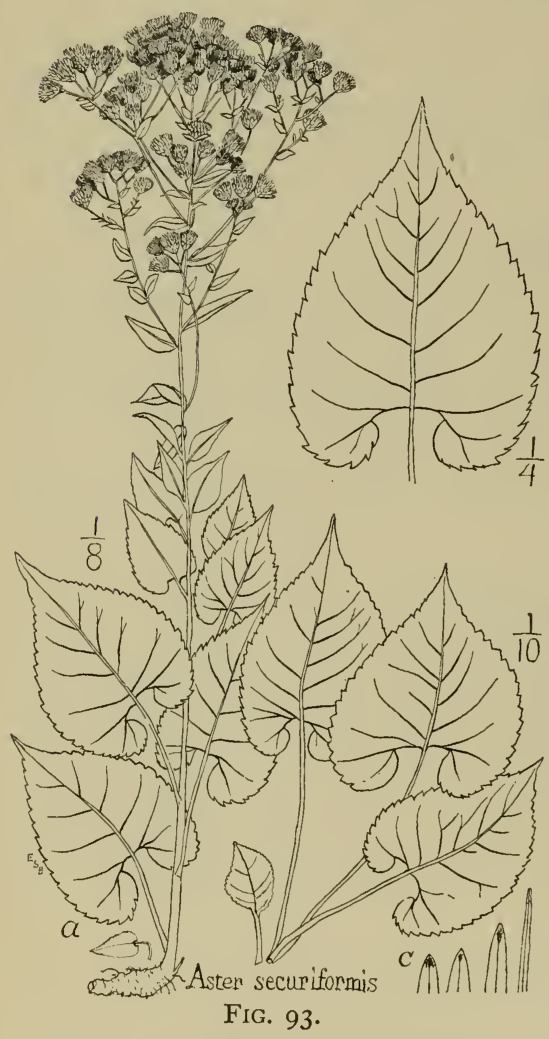
I in. broad and $3 / 8$ in. high; rays about $\mathrm{I} 5$, narrow, violet soon becoming whitish; or fewer, as I 2.

Bracts very uniform, pale, with triangular green-tips, smoothish, all acute, the lower triangular-acute, the others narrowly oblong with gradual taper to sharp apex. A few similar sharp bracts occur at the base of the involucre in $A$. macrophyllus; but to have all bracts acute is hardly true of any other near ally.

Glandular hairs stubby and minute, very numerous and slightly capitate on the inflorescence, and abundant but weaker and whiter on the leaves beneath.

Colonies of radicals not much seen ; colonies of flowering plants (as on Goat I., Niagara) form a straggling group of erectish stems rising among brush and weeds in gravelly openings in woods, with loose-topped whitish and dingy appearance.

Habitat, half-shade.

Examples include:

Mass., Ipswich, Oakes in hb. Torrey, "deep-colored," Oakes; "A. macrophyllus capit. magn." A. Gray scr.

N. Y., L. George, Dr. Vasey, Se. '82, no. I8921 in hb. U. S. Nat. Mus.

N. Y. vic., "Tuckahoc, dry woods, July 18 , '96; rays violet," $B i$. in hb. Bu.

N. J., Palisades, sprouts, Oc. 7 , '99.

W. N. Y., Pt. Gratiot, Au. 2, '96; Niagara, on Goat I., large colonies in full flower and now faded almost white, Au. 25, '96; "Buffalo, Aster — ," Clinton, in hb. Buff. Nat. Hist. Soc. Cattaraugus resn., Little Indian Cr., Au. 24, '97; Silver $C r$., Swift's Hill, Au. I2, '98. 
Va., Potomac, Rock Cr., Va., Au. 25, '96, L. F. Ward in hb Bu.

Mich., Grand Rapids, A. A. Crozier, no. 18920 in bh. U. S. Nat. Mus.

Minn., Au., '89, coll. F. F. Wood, no. 18919 in hb. U. S. Nat. Mus.

Wis., Devil's L., bluffs, Au. 5, '97, L. M. Umbach in hb. U. S. Nat. Mus., no. 339114 .

†† Inflorescence shallow-V-shaped, wide-spreading, plants low. Sp. 72 and 73 .

\section{Aster multiformis Burgess.}

Small deep-green plants with smooth slender stem, narrowcordate lower leaf-type, polymorphous caulines and bracts, serrate margins, deep and rather narrow sinus, firm texture rough when dry, glandular stubs above, strigose hair on the veins beneath, and about I 3 violet rays with rounded apex.

Name, L., from the many shapes of leaf usual on the stem.

Fig. 94, plant from Pt. Gratiot on L. Erie, July 29, '99, $\frac{1}{6}$ nat. size, in hb. $B u$.; $b$, its characteristic radicals ; $d$, radical development of May 1o; $e-h$, variants of Aug. $14, \frac{1}{12}$ nat. size; $e, f$, petiole-flowering form; $g, h$, dwarfs.

FIG. 95, plate I3, plant also from Pt. Gratiot, July 29, '99, with greater arrest of leaf-development.

A. multiformis Burgess in Br. and Br. Ill. Fl., 3 : 36I (1898) with Fig. 3747, and original description :

"Deep-green, minutely glandular. Stem erect, slender, I to $2 \mathrm{ft}$. high, angular-striate in drying. Basal leaves usually 2, large, thick, cordate-oblong, often accompanied by later smaller oblong ones; stem leaves very thin, sharply serrate, rough above, minutely puberulent beneath, the lower, ovate, acuminate, usually with a narrow sinus, the upper oval to ovate-lanceolate, petioled, the uppermost elliptic-lanceolate, serrulate, sessile or nearly so. Inflorescence small, its branches upwardly curved; heads about 7 lines high ; rays about $\mathrm{I} 3$, rounded and retuse at the apex; bracts green; glands few, almost hidden by the minutely strigose pubescence of the peduncles. - In moist shaded places, Me. to W. N. Y., Penn. and Md. - July-Aug."

Stem terete and succulescent when fresh, drying wrinkled and angular, usually ascending but seldom perfectly straight and erect, and often decumbent: color greenish with purpled base, or sometimes a bright purple red throughout.

Rootstock long and slender, finally becoming for a short distance thick, contorted and blackish; the whole cortex of stem and rootstock tending to peel off in a body.

Radicals quite characteristic, often but 2 (or 2 large and I very small and broader), oblong-acute, $7 \mathrm{I} / 2 \times 3$ in. often, with narrow or little-developed sinus, irregularly coarsely serrate or shallow- 


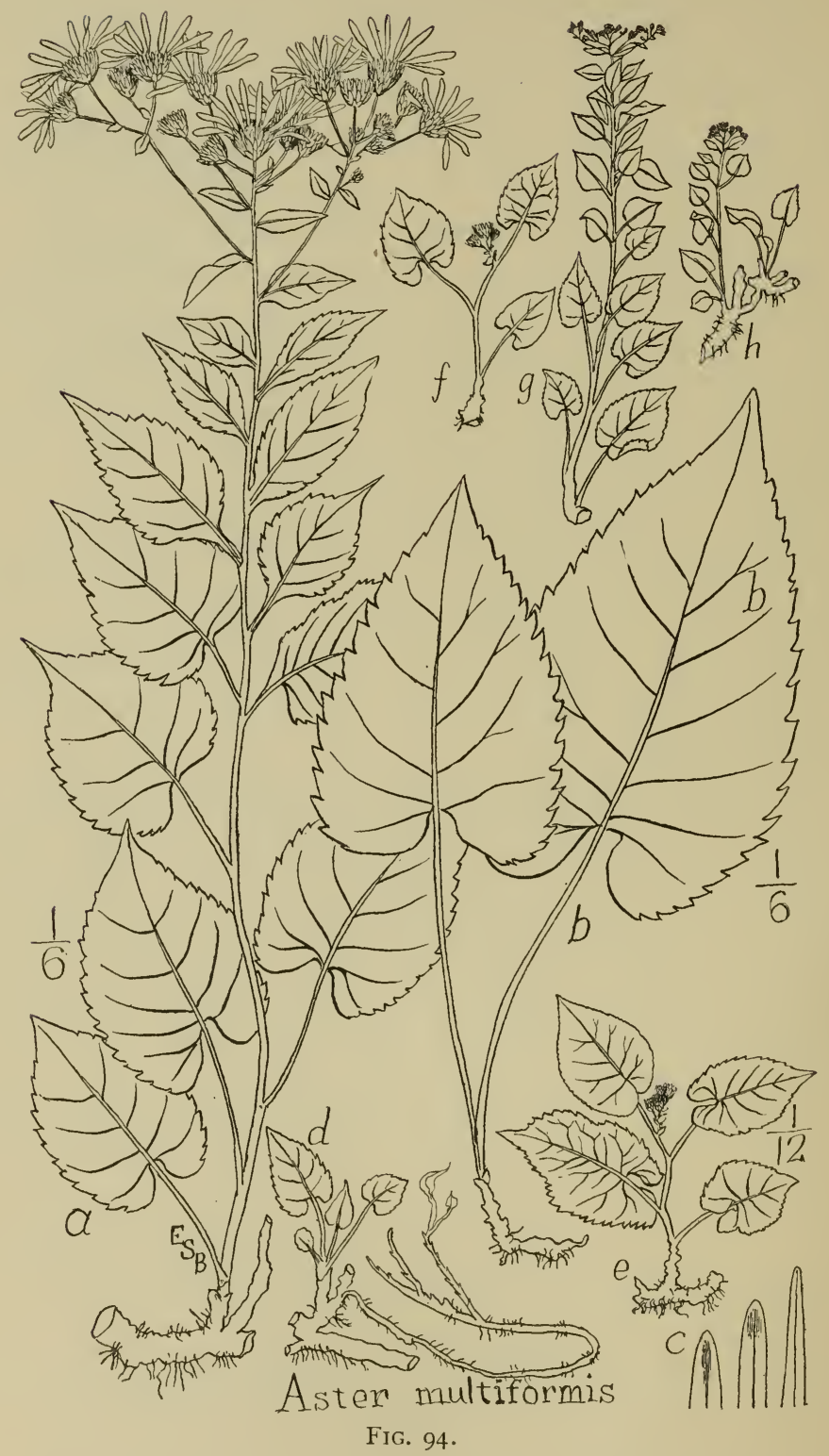





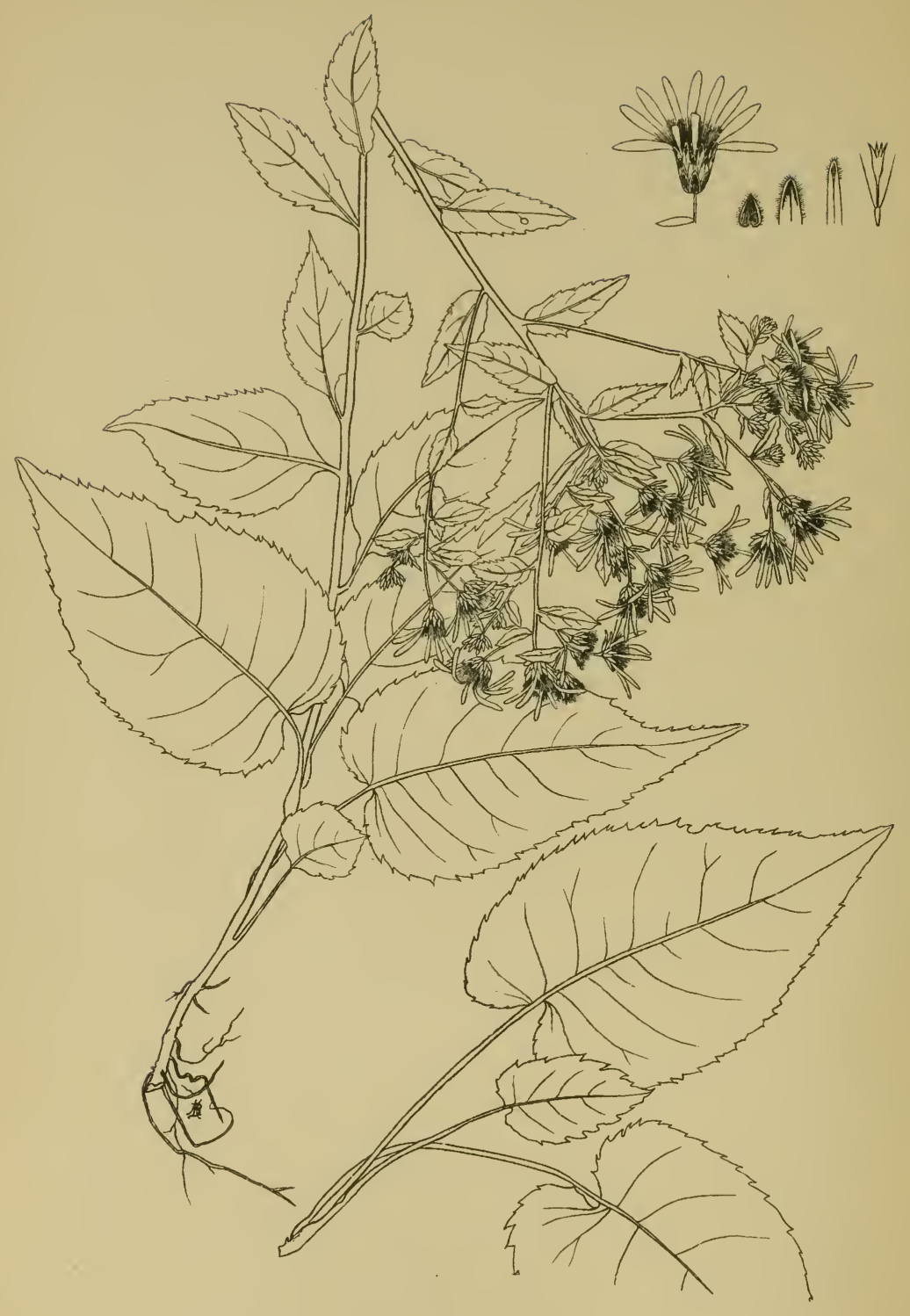

ASTER MULTIFORMIS 
serrate, thickish with clumpy and one-sided aspect, one basal lobe being much longer than the other and one leaf broader than the other. Upper surface rough with sharp appressed acicular bristles.

Between these larger radicals additional small subentire leaves are occasionally developed in luxuriant plants (the Lettuce-leaf stage of this species), of suboval or elliptical form, finally excavatetoothed or crenate-serrate.

Primordial leaf orbicular, crenate, green, $3 / 4$ in. long, with slight open sinus.

Leaf-form transitions when gradual include the following: Lower caulines sharp-serrate, with long slender petioles; typical forms (all these leaves sometimes replaced by oval leaves without sinus), -

I. Ovate-acuminate, cordated narrowly, often $5 \times 2$ in.; about 3 such.

2. Ovate-acuminate, subcordate with shallow open sinus.

3. Oval-acuminate, with rounded base.

Middle caulines sharp serrate, with short petiole: gradually or suddenly much smaller; types, -

4. Ovate-lanceolate, with short taper base; 2 or 3 such, often $3 \times \mathrm{I} \mathrm{I} / 2$ in.

5. Elliptic-lanceolate, with broad-wing base; a few.

Upper caulines sessile and serrulate ; typical shape, -

6. Oblong-lanceolate, sessile by a broad or a narrow base; several so; sometimes I 2 , half of them axiles.

Abrupt transitions of leaf-form or omission of some terms in the above series often occur.

Inflorescence flattish, shallow, loose, with its branches upcurved at a wide angle, in a somewhat candelabriform manner. Pedicels threadlike, greatly lengthened, often I in.

Heads usually $\frac{7}{16}$ in. high, about I in. broad. Involucre quite green in life; on drying and pressing remarkably acute and pale in aspect, triseriately chequered with large triangular green-tips.

Bracts triform, only the lower really acute, these triangularoblong, cymbiform, coriaceous, slightly puberulent. Middle and chief bracts oblong, diminished upward as if to form an acute apex but usually obtuse, with pale scarious margins. Inner bracts much more attenuate, but still obtusish, the green reduced to a narrow medial line.

Rays I I-I 7, usually about $\mathrm{I} 3$, narrow with rounded end and retuse or erose-toothed within a central notch ; about $\frac{6}{16} \mathrm{in}$. long, deep violet, becoming pale. Intensity of this deep violet is greatest in the first heads developed, or where in monocephalous shoots, a single head receives the strength of the plant. 
Pappus soon rufous, even within two months after drying.

Habitat, moist shade, thriving in wet woods along their borders or by woodroads, especially on drier spots among pools with a thin clay substratum resting on shale (L. Erie and L. Champlain).

Examples include:

Ct., Mount Riga, Au. I8, 1903.

N. Y., L. Minnewaska, Au., '99, C. H. Peck in hb. N. Y. St.

N. Y., L. Champlain, bluff near Plattsburg, Au. 31, '97, Bu. Ausable L., Au. Iо, '77, Addison Browen in his herb.; Westport, Se. 16, 1900, N. L. Britton in hb. N. Y. Bot. Gar.

N. Y., vic. Yonkers, Troublesome Brook, sprouts, Oc. 28, '96; Bryn Mawr Park, under chestnut near station, Se. 26, '96; group kept under observation Io years each spring, summer and fall; with little change of size or vigor and none of other characters; its environment also remaining unchanged; late flowers paling, Se. 24, 1905 .

N. J., Cluster, '77, Addison Brown in his herb.

W. N. Y., Dunkirk, Pt. Gratiot Park, typical locality, kept under observation 9 years, I896-1904, originally with hundreds of plants but finally much trampled out ; early bloom, July 21, '96, July 29, '97; profuse bloom, Au. I I-2I, '97; Au29, '96. Niagara, Goat I., Au. 25, '96 ; Fredonia, Marsh's Woods, Se. I, '96; Cas. sadaga, Fern I., Se. '96; Silver Cr., Talcott's Woods, Au. 15, '96; Rosebrook, Au. 3, '96 ; Little Indian sources, Au. 20, '96 ; Sheridan, Herrick's woods, Au. I2, '96; Perrysburg, hills, Au. 29, '96.

N. J., Palisades, Cliffside, near cattail swamp, sprouts, Oc. 23, '97 ; Undercliff, several spots near Hottonia brook, late pallid flowering, Se., '98, Woodridge, Bergen Co., July, '89, Geo. V. Nash in hb. N. Y. Bot. Gar.

Pa., Susquehanna, dry soil, open woods, Se. 10, '97, Jas. A. Graves, in hb. Bu. Allegheny mtns., Hyndman, Bedford Co., Au. 19-23, '90, Jn. K. Small in hb. $B u$. Blue Ridse, Sabillasville, on Md. line, I886, Tatnall in Gray hb., of which Gray wrote "A. macrophyllus, var. (violet rays) toward Herveyi," and again "why not corymbosus?"

Md., Cumberland, fall of '96, hb. J. K. Small.

E. Tenn., Mountain streams, Se., '97, A. Ruth in hb. N. Y. Bot. Gar.; Cocke Co., along Wolf Cr., Se. 2, '97, Thos. H. Kearney, Jr., no. 7 8o in hb. N. Y. Bot. Gar. Mtns. near Gregory Bald,'9e., '98, A. Ruth, no. 594 in hb. N. Y. Bot. Gar.

W. Va., Stony Man Mt., alt. 3400 ft., E. S. Steele in hb. N. Y. Bot. Gar.

Allies. Tall plants of $A$. multiformis connect with $A$. nobilis and $A$. ianthimus, though their proper types are very diverse. $A$. securiformis forms the intermediate term to A. macrophyllus: or, in the Adirondacks, such a transition is afforded by A. elaeagnius. $A$. riciniatus perhaps finally replaces $A$. multiformis in the mountains southward. Unlike $A$. multiformis, A. biformis has chiefly but one form of leaf, or at least but one reduced size, above the lower caulines; A. uniformis has less variety of form and has that masked under a continuance of large size up the stem ; A. riciniatus is paler, broader and dentate; $A$. quadratus broader and redder; 
$A$. elacagnius pale and scurfy beneath with more strigose hair, and more irregular in leaf-form and inflorescence; $A$. Masardiensis is much taller as well as downier, of different color and leaf-form. Other species of the Macrophylli are still more conspicuously different.

$72^{2}$ Arrest-forms. Arrest of leat development is very common in A. multiformis, the suddenly diminished little leaves above presenting quick transitions from slender-petioled and wing-petioled to broad sessile bases.

$72^{3}$ Petiole-flowered form. A peculiar arrest-form or a dwarf state, in which the few heads (or single head) seem to spring from the middle of the petiole of the upper leaf; that petiole continuing the direction and form of the stem exactly, while the real continued-stem breaks away from the petiole at an angle and with diminutive branch-like aspect, extending then for an inch or two and bearing 6-1 2 dwarfed little leaves (chiefly of form 3, or 5, p. 369. Similar development is occasional in A. biformis; see p. $33 \mathrm{I}$.

W. N. Y., Pt. Gratiot, '96-1904, every year, with the type.

$72^{4}$ Biculminate form. Large lower leaves are followed by little leaves which increase upward to the inflorescence, there forming a second culmination of foliage. The smallest leaves thus appear at the middle of the stem; they are usually oval or orbicular. Leaf-form as a whole broader than in the type.

W. N. Y., Pt. Gratiot, July 29, Au. 29, '96; July 29, Au. I I, 21, '97. Silver Cr., above Aster-bank, Au. I7, '96.

N. Y., L. Champlain, near Plattsburg, Au. 3I, 97.

N. Y., vic. Staten I., Erastina, with balloon-like obovate axiles, Se. 4, '9o, Hulst in hb. Colu.

$72^{5}$ Acutifolial form. Thin; most leaves incurved-acuminate into a straight caudation ; radicals various, large and long, broad and small, regular or lop-sided, their teeth big and remotish or very remote. Leaf-texture very thin, very rough, very hirsute to touch, not firm nor dense. Hair abundant, often obvious all over the stem and over the leaves beneath. Glands very few, mainly near the top. Bracts resemble those of $A$. divaricatus, being green and thin, roundish cuneate, with pale edges. Inflorescence composed of segregated clusters. Resembles $A$. divaricatus deltoideus and $A$. persaliens. A possible hybrid?

N. Y., vic. Woodlazon Woods, Au. 7, '98, Bi. ; Bronx Park, Se. Ir, '98.

$72^{6}$ Rubicund form. Intermediate to A. macrophyllus L., having greater thickness and roughness of leaf, broader outlines, and more red in rays and bracts, the erect tubular young rays continuing red till a brief duration of violet comes at expansion : in this redness agreeing with the next species. Dunkirk. 
$72^{7}$ Trapezinm-leaved state; some upper caulines resemble the leaf of Adiantum trapeziforme in size and figure. Silver $\mathrm{Cr}$.

$72^{8}$ Pallid-leaf form; both leaves and stem pale yellowishgreen, the leaves small and short, the stem erect and virgate. Rays narrow, this fact and the taller stem suggesting admixture with $A$. iosiemma, which sometimes grows near.

Mt. Ethel, Ms. (in Taconics), Se. 5, 1903; L. Champlain, Fort Henry, July 21, '78, hb. N. L. Britton in hb. N. Y. Bot. Gar. Silver Cr., N. Y., Au. I8961903 .

\section{Aster Riciniatus Burgess.}

Small plants with low-toned colors, dentate margins, pale glabrate leaves, reddened stem and bracts and rays, cordate-triangular leaf-form, few and quick-diminished caulines, narrow lingual bracts and small subsessile widely-diffused glands.

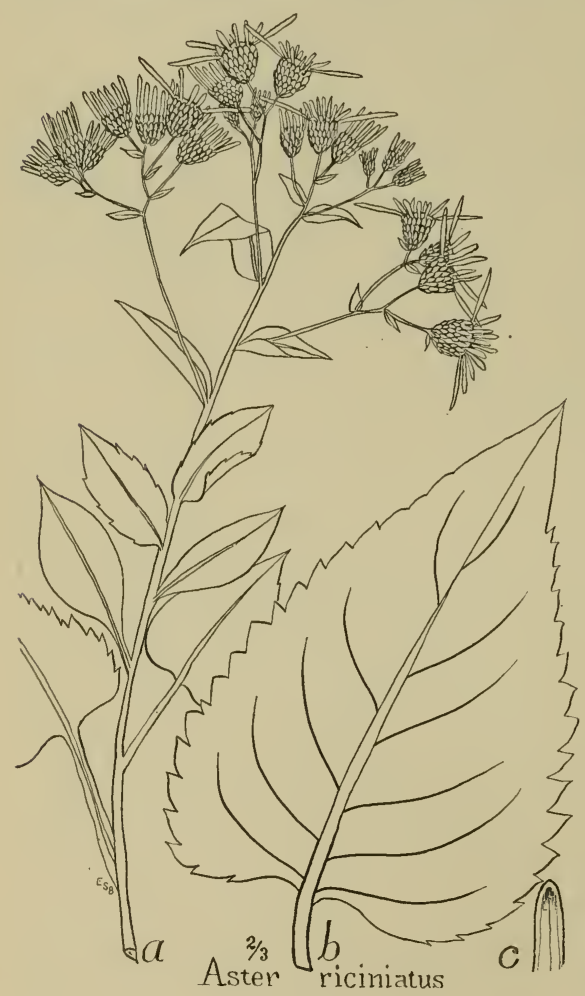

FIG. 96.

Name, L., = clad in a veil; from the subdued coloring of the plant when dry, its red and green both seeming as if seen through a veil or screened by a glazed surface.

FIG. 96, plant from Cedar Cliff Mt., N. C., Au. 24, '97, in hb. N. Y. Bot. Gar.

A. riciniatus Burgess in Small's S. E. Flora, I 2 I 2 (1903) with original description :

"Stem smooth, red, terete, often $3 \mathrm{dm}$. high; radical leaves usually two, unequal ; blades deltoidcordate or ovate-cordate, with long, low curvescent or crenate teeth; basal leaf smaller, the blade orbicular-ovate, without sinus; lower cauline leaves ovate in type, with slight broad open sinus; the others lanceolate or oblong, with sessile tapered base ; leaf-margins dentate below, becoming sharp-serrulate above; petioles slender, or with narrow, strap-like wings : inflorescence a small loose terminal tuft, with slender ascending pedicels ; bracts uniform, lingual ; rays rose- 
purplish and then transiently violet, soon turning whitish, linearbiacuminate. Plant very smooth and pale; much purplish-red occurs on stem and veins and especially along the bracts; glandular-pubescence very short, with small capitate glands, continuing down the stem to the base; strigose pubescence discoverable by lens on the upper leaves. Resembles $A$. multiformis; but the whole plant smoother and paler, with more red and less violet; leaves smaller, shorter, and often dentate; bracts narrower and more uniform; its colors neither sharp nor dull, but as if seen through a veil. - In moist mountain woods, N. C. Late summer. -Type [N. C., 'Cedar Cliff Mt., coll. Au. 24, I 897.'], Biltmore Herb., no. $44^{\mathrm{a}}$, in Herb. N. Y. B. G."

** Inflorescence more irregular or diffuse. Sp. 74-79.

$\dagger$ Leaves thicker, rougher; hair often villous or downy, or when dried, bristly. Sp. 74-76.

\section{Aster elaeagnius sp. nov.}

Small harsh dark-green plants with orbicular-ovate radicals, serrate margins, slight and open sinus, irregular tufted inflorescence, blue-violet rays, glumaceous and silvery inner bracts and woolly outer ones, large triangular green-tips, and polymorphous caulines with some leaves broad-deltiform and many elliptical, all pale and villous beneath, with gray or brown-scurfy aspect.

Name from the Elaeagnus as type of gray scurfy-backed leaves.

FIG. 97, plant from McKeever, N. Y., Au. 28, '97, in hb. Bu. ; b, characteristic leaf, the petiole broken off ; $d$, radicals.

Stem erect but not rigid or straight, slender and continuously slightly bent, pale above, deep purple-red below, sparsely villous, and overspread with short pale glandular stubs.

Rootstock black, of moderate thickness and length. Radicals usually 2, ovate-orbicular, acutish, crenate.

Leaf-type rather firm, harsh above, granular-roughened and hispidulous above when dry, dark dull green or brownish-green, serrate, with open or shallow recurvate sinus, continuously petioled, narrowly acuminate, villous and pale beneath with peculiar gray or brown-scurfy surface, due to long pale or ecru or straw-colored hairs and to brown veins and close veinlets, and often greatly increased by brown spots of cercospora or other fungus, the hairs in those cases brownish on these spots.

Lower leaves broadly deltiform-acute, or triangular-cordate, soon losing sinus and becoming truncate, longer than their slender petioles, not large, $5 \times 4$ in. or chiefly $3 \times 2$. 
Middle caulines quite characteristic and numerous, elliptic or oval, with truncate, rounded or finally tapered base, all incurved into a distinct narrow acumination, serrulate, and wing-petioled; the two ends of the leaf nearly alike.

Upper caulines oblong-lanceolate, tapering to the sessile base. Axiles similar but narrower; as are the rameals when developed.

Inflorescence a single terminal tuft of long erect pedicels ; or in well-developed plants, an irregularly branched paniculate corymb,

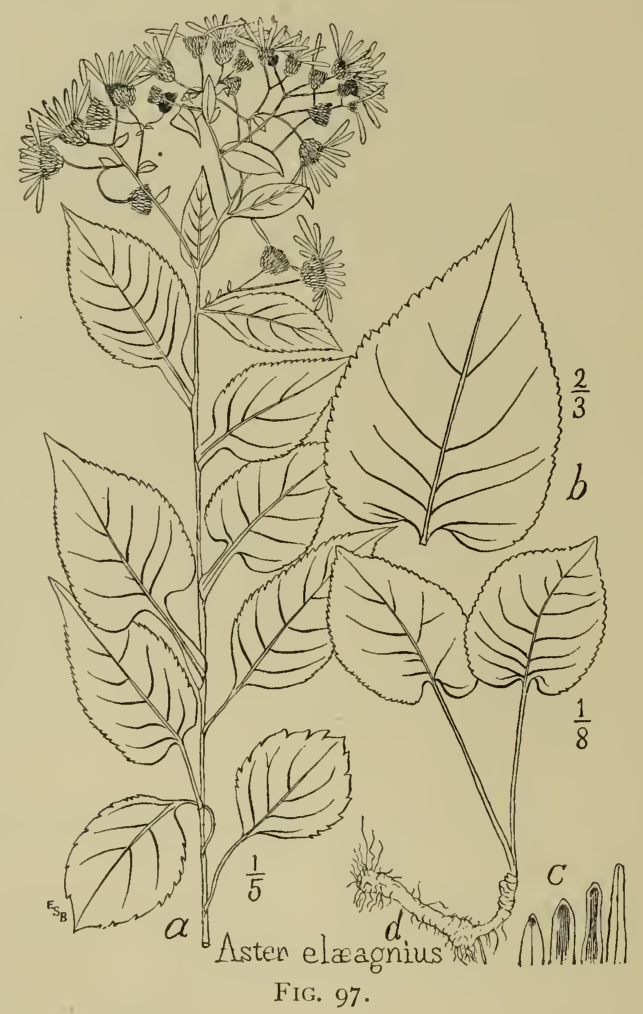

6 in. across or more, with scattered short branches from the lower axils.

Heads $\frac{7}{16}$ in. high, about $I$ in. broad. Involucre turbinate with broad base, triseriate-chequered with conspicuous dark-green tips, otherwise pale or silvery.

Bracts passing from ovate-oblong and acute to narrow-oblong and obtuse, finely downy with glands intermixed, the outer woolly and convex, the middle and inner ones partly scarious and flat, white or gray margined and often with additional red edge. 
Rays rather narrow, typically of a dull blue-violet before fading. Habitat, river thickets and wood-borders, Maine to Minnesota and northward.

Examples include : in hb. $B u$.

Maine, Orono, Penobscot Co., Se. 3, Se. 6, '93, low woods, M. L. Fernald

N. Y., L. Champlain, near Plattsburg, Au. 31, '97. Adirondacks, Beaver R., at McKeever, Au. 28, '97, type locality, and Clearwater, Au. 28, '97, Bu.; North Elba, Au. ' 98, C. H. Peck in hb. N. Y. St.

Minn., N. P. Junction, Se. I, '91, J. H. Sandberg, nos. 18906 and 18907 in hb. U. S. Nat. Mus.

Allies. A. elaeagnius resembles $A$. macrophyllus $\mathrm{L}$., but is apt to show these differences : radicals chiefly 2 ; leaves chiefly elliptic, gray-backed; stem apt to be deep red; inflorescence irregularlyflattish, scattered; bracts quite scarious-edged; rays blue-violet; texture spongy or brittle, but not flabby or subsucculent; teeth much closer, inconspicuous and crenulate. It resembles $A$. macrophyllus L. and differs from many other species, in having very rough harsh texture, acute bracts, dark dull-green leaf-surfaces above, and roughish stem.

Unlike $A$. macrophyllus velutimus in its larger form and leaves, fewer more separated heads, and larger non-triangular leaves.

Unlike $A$. multiformis in its more irregular inflorescence, more blue-violet in the rays and of a harder tint, and its broader bracts.

Unlike $A$. quadratus in its inflorescence, bract-form, bractmargins, and leaf-form ; in having obvious hair; and in its more scattering growth.

These five Adirondack forms seem well differentiated when the specimens are brought together.

\section{Aster Masardiensis sp. nov.}

Wandlike soft villous plants outlined in sweeping curves from greatly-thickened russet-brown rootstocks, with sharp slight sinus, sharp-serrate and aquiline margins, slender petioles, wing-base axials, large remotish heads, thin subscarious involucre, and triform type of leaves and bracts, the leaves successively cordate-acuminate, oval-acuminate and lanceolate, the bracts ovate-acute, linearobtuse, and then attenuate-acute.

Name from its type locality, Masardis, Me.

FIG. 98, plant from Masardis, Me., Se. 8, '97, in hb. Bu., coll. M. L. Fernald

Stem green or somewhat browned, $2 \mathrm{I} / 2$ feet high or less, sub- 
decumbent, rising in sinuous curves, roughish when dry, with long villous hair.

Rootstock long and finally becoming $3 / 8$ in. thick or more. Radicals (N. H. plants) large, with broad subtruncate base, the outline broad-oblong.

Lower leaves cordate-ovate, incurved-acuminate, with elegantly rounded symmetrical basal lobes and small sharp sinus, roughish

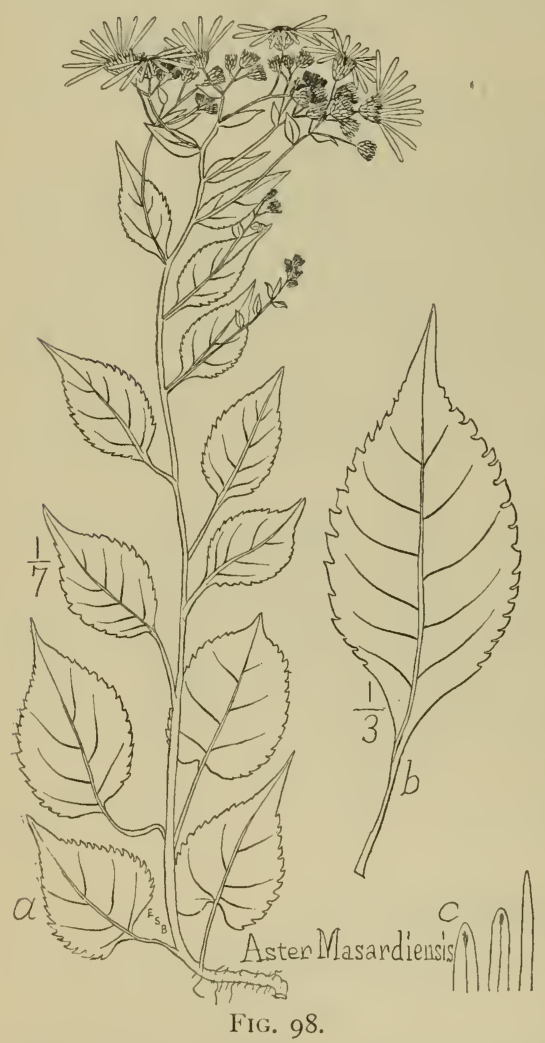
when dry, aculeately aquilineserrate, full-green, of firm thinnish texture, $4 \times 3$ in. or less.

Middle leaves the most characteristic, long and numerous, oval and incurved-acuminate, $5 \times 2 \mathrm{I} / 2$ in., with subtruncate or well-rounded base and short slender petiole. Teeth very inconspicuous and shallow, crenate-serrate, becoming very shallow and depressed.

Upper leaves and axiles ovate-lanceolate, lance-oblong and finally linear-lanceolate; their bases strap-winged, cuneate-winged and then sessile, $3 \times I \frac{I}{2}$ in. to $I \frac{1}{2} \times 1 / 2$ in. Rameals continuing the last type in more oblong and halfreduced pattern.

Leaves dark, thinnish, remarkably soft and downy to touch when fresh.

Inflorescence fragrant, a loose flattish or convex corymb, 8 in. across or less, with high-ascending curving branches at an angle of $60^{\circ}$ or more. Heads rather large, $1 / 2 \mathrm{in}$. high, over an inch wide. Involucre hemispherical, ciliate, rather pale, the exteriors green and glandular puberulent, minutely downy, the interior portions scarious, pale and silvery, with purpled margins, or with bluish margins goldenbrown at the edges in large examples. Pedicels $\mathrm{I}$ to 2 in. long.

Rays beautiful clear violet (or lavender), long and narrowly linear, ro or more, paling into an olivaceous tint.

Disks full and broad.

Habitat, northern thickets, Maine, New Hampshire and Quebec. 


\section{Examples :}

Quebec, Gatineau R., Se. 3, '94; Macoun in hb. Mo. Bot. Gar.

N. H., Gorham, near Androscoggin R., Au. 9, 1902.

Maine, Masardis, Aroostook Co., wooded river bank; rays lavender; M. L. Fernald, Se. 8, '97, in hb. Bu.; Orono, Penobscot Co., low woods, Se. 6, '93, do.

W. N. Y., Cattaraugus resn., Au. 31, '99; plant seemingly referable to this species ; or a sport of $A$. iostemma.

\section{Aster ianthinus Burgess.}

Tall wandlike plants with smooth pale brownish-green stems, broad suborbicular leaf-form, firm roughened texture, downy or villous under-surfaces, ubiquitous minute glands, conspicuous wingbases, close convex inflorescence, oblong and rounded bracts, and violet rays soon turning to dingy white.

Name, L., violet-colored, the violet of the rays being sometimes transiently extraordinarily clear and deep.

Fig. 99, plant from Silver Cr., N. Y., Au. I7, '96, in hb. Bu.; b, characteristic radical or lower cauline leaf; $c$, bract; $d$, radical group, $e$, primordial of May I O, ' 98 .

A. ianthinus Burgess in Br. and Br. Ill. Fl., $3: 360$ (1898) with Fig. 3745 and original description :

"Glandular, dark green, slightly strigose pubescent. Stem erect or decumbent, $2-3 \mathrm{ft}$. tall, leaves thinnish, rough, the lower and basal ones orbicular to oblong, 5 in. long or less, abruptly acuminate, low-serrate or crenate; the sinus broad, open, shallow; upper leaves sessile by a narrowed base, crenate-serrate. Inflorescence open, nearly naked; peduncles slender, divergent; heads large; rays IO-I 3 , long, very deep violet or sometimes pale, 4 to 6 lines long; bracts green-tipped, little pubescent. - On shaded banks and along woodland paths, Me. to L. Erie and W. Va. July-Oct."

Stem stout but not strong, often decurved, or if erect, arising in long undulatory curves.

Radicals chiefly 3 , one cordate-deltoid and rather narrow, $4 \mathrm{I} / 2 \times$ 3 in. or less, with broad shallow sinus somewhat as in $A$. violaris; the others large and equal, $7 \times 6$ in. or less, of the typical form, granular-roughened when first mature, nearly orbicular, abruptly short-acuminate, with conspicuous broad rectangular sinus, and serrate dentate or crenate margin. Often an earlier smaller orbicular leaf is present, crenate with perfectly-curved even teeth.

Lower caulines similar to the last or sometimes to the first, somewhat remote.

Middle caulines very characteristic, oval-biacuminate, the cen- 
tral part nearly orbicular and abruptly rounded into each tapering end, serrate, the short broad winged petiole of strap, cuneate or undulatiform shape. These pass above through elliptic-biacuminate and sessile to oblong-acute forms.

Axiles oblong-subulate, canaliculate and enwrapping round the branch, falcately decurved at apex.

Teeth include crenate-serrate, dentate and excavated-serrate as

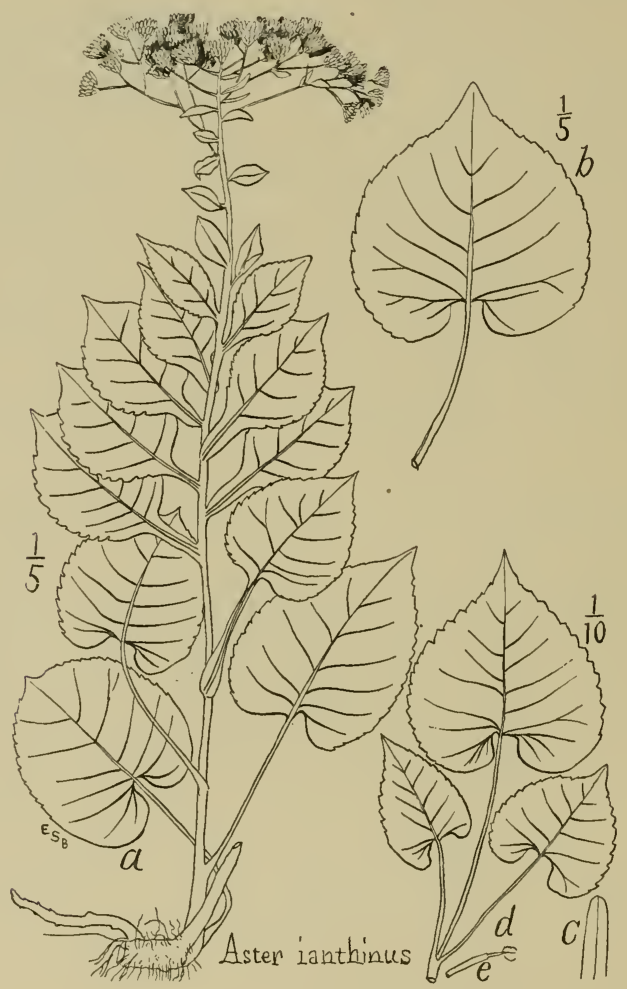

Fig. 99.

the prominent forms, aquiline-serrate or entire toward the petiole, denticulate often, and sometimes with a few curvescent teeth intermixed.

Veins numerous, and close, widely outcurved, pale brown beneath and villous, the surface between usually downy or subvillous, and with numerous minute pale weak-stalked odorous glands.

Inflorescence remarkably open and nude, with widespreading short close branches, at angle of $45^{\circ}$ to $30^{\circ}$, these branches covered very densely with a short glandular plush. 
Bracts coriaceous, oblong or lingual with rounded apex, nearly all alike, with little pubescence or ciliation.

Rays long, full clear violet, becoming pale and soon whitish. Disks turning purplish brown.

General leaf-color deep full green, the radicals often paler and yellowing early in fall.

Habitat, wood roads and borders, New England and Ontario to Alabama and Tennessee.

\section{Examples:}

Mass., Great Barrington, on Great Hill, near waterworks, Se. 20, '94, Addison Brown, in his herb.

Mass., Winchendon, Se. 3, '95, in hb. U. S. Nat. Mus., Wilbraham, Au., '99, Prof. J. Gillet.

Mass., Midalesex Fells, top of rocks under thin trees, Au., '98.

N. Y., L. George, '95, Mrs. Watrous in hb. Colu.; L. Champlain near Plattsburg, Au. 3I, '97.

N. Y. vic., Yonkers, Bryn Mawr Park, flat stones, Se. 13, '97, Se., '9S-1905 ; opposite first house, Se. I 8 , '97; by path, Se. 26 , '96.

N. J., Palisades, Undercliff, Se., '97.

W. N. Y., Silver Cr., Aster-bank, Au. 17, '96, in first deep violet bloom, a dense patch without radicals; heads $11 / 4$ in. across; type locality; in faded whitish bloom, Au. 24, '97; Niagara, Goat I., Au. '96; Buffulo, Clinton in hb. Buff. Nat. Hist. Soc.; Dunkirk, Pt. Cratiot Pk., July 21, '96, Au. 29, '96, July 29, '97, Au. I I, '97 ; Cassadaga, Se. 4, '96 ; Pomfret, Marsh's Woods, Se. I, '96.

Pa., Pocono Summit, Au. 6, '91, T. C. Porter in hb. P. ; Susquehanna, Se. 20, '97, Jas. A. Graves in hb. Bu.

IV. Va., Mt. Rogers, A. A. Heller, in hb. Porter.

Tenn., Wolf Cr., Cocke Co., Se. 2, '97, T. H. Kearney, Jr., in hb. U. S. Nat. Mus., no. 313088 .

Ala., Auburn, Lee Co., Se. 18, '97, Earle and Baker, in hb. Colu. ; very few glands, only on the bracts.

$76^{2}$ Refined form. Delicate plants with slender, glabrate, rather weak greenish stems I I/2 ft. high; small, broad, deep green leaves smoothish in life; and few-flowered, long-pedicelled, small inflorescence, fragrant and with long, deep violet rays of surprising beauty; in depths of cool woods. No radicals or few. Repeatedly observed isolated, a single plant in a place, with little slender rootstocks, perhaps seedlings from the ianthinus type and made glabrate from sylvanism; but perhaps not properly assigned here. Stems in shade with hardly any hair, and leaves smooth to touch, but rough in a few seen at the wood-borders.

Examples include:

Ontario, Pt. Abino, L. Erie, by swamp back of the Pines, heads even $11 / 2$ in. across, Au. 28, '96; Niagara, Foster's Flat, a few plants, Au. 27, '96.

IV. N. Y., Hanover, Aster-bank brink, and below, above and below the type-locality; also in edge of open "slashing," Au. 17, '96. Fredonia, Se. I, '96; Cassadaga, Se. 4, '96; Cattaraugus resn. near Big Indian Cr., Au. '96. 
$\dagger+$ Leaves thickish, with peculiar granular-roughened surface, but with little hair. Sp. 77-79.

\section{Aster viol.aris Burgess.}

Small, broad-leaved, dark-green plants with numerous reniform-apiculate radicals, these radicals sharp-serrate, with broad shallow sinus and long slender petioles; with pale violet rays, deep, short-branched, leafy inflorescence, rounded bract-tips, and oblong-oval, slender-petioled middle caulines.

Name, L., = having the leaf of the violet; from the shape.

FIG. I00, plant from Palisades, N. J., Se. 24, ' 97 , in hb. Bu.; $b$, a charac. teristic radical leaf; $d$, radicals, with primordials and phyllodial, as developed May Io.

A. violaris Burgess in Br. and Br. Ill. Fl., $3: 361$ (1898), with Fig. 3746 and original description;

"Caudex thick, fleshy; plant glabrate, bluish-green, minutely glandular. Stem slender, erect, or assurgent, $2 \mathrm{ft}$. high or less; basal and lower leaves broadly reniform, abruptly acuminate or apiculate, often 3 in. long by 4 in. wide, their slender petioles 6 to 8 in. long, the sinus very broad and shallow; middle stem-leaves similar, not cordate; the upper numerous, long-elliptic, chiefly with narrowed bases, all thin, firm, rough above. Inflorescence leafy, small, loose, rather narrow and high, paniculate corymbose, nearly level-topped, its slender branches with nearly opposite, oblong leaves; heads 6 lines high, or more; rays I2-I 3 , pale violet, narrow. - In shaded moist places, sometimes in leaf-mold among rocks, N. Y. from the Hudson to L. Erie. Sept.-Oct."

Stems slender, greenish, $2 \mathrm{ft}$. high or less, from a thick black contorted rootstock; in very old vigorous examples the rootstock sometimes reaches I in. thick, with numerous short parallel upright offshoots; each of which produces 2, 3, 4 or more leaves, making sometimes a dozen or more radicals in a close cluster.

Radicals exhibit the typical leaf-form, being singularly violetlike or violarial, very broadly reniform-apiculate, sharply and doubly serrate, or closely aquiline-toothed, rather small, $4 \times 4$ in. or less, very commonly $3 \times 3$, broad shallow examples sometimes 2 in. long by $3 \frac{1}{4}$ broad, thin, dull bluish-green and opaque, with about 5 pairs of close wide-spread but much up-curved brown veins. Sinus broad, open and shallow, recurvate conspicuously down the petiole. Apex abruptly and notably apiculate with a long narrow entire acumination which becomes successively longer as new radicals develop; becoming $\mathrm{I}$ in. long. Teeth also acuminate, with forward or outward-directed aculeus, sometimes incised curvescent, sometimes of excavate denticulate or pure cre- 
nate type. Petioles 9 in. long often and very slender; smooth and glabrate, as is usually true of the whole leaf. Veins shallow-depressed, soon blackening or filling with dust-particles adherent to the blackish glands.

Occasional variant radicals are longer than broad but otherwise similar. Sometimes oval-acute non-cordate leaves occur between ; these are smaller and on shorter petioles. The caulines repeat these types regularly in the order mentioned, the basal violarial,

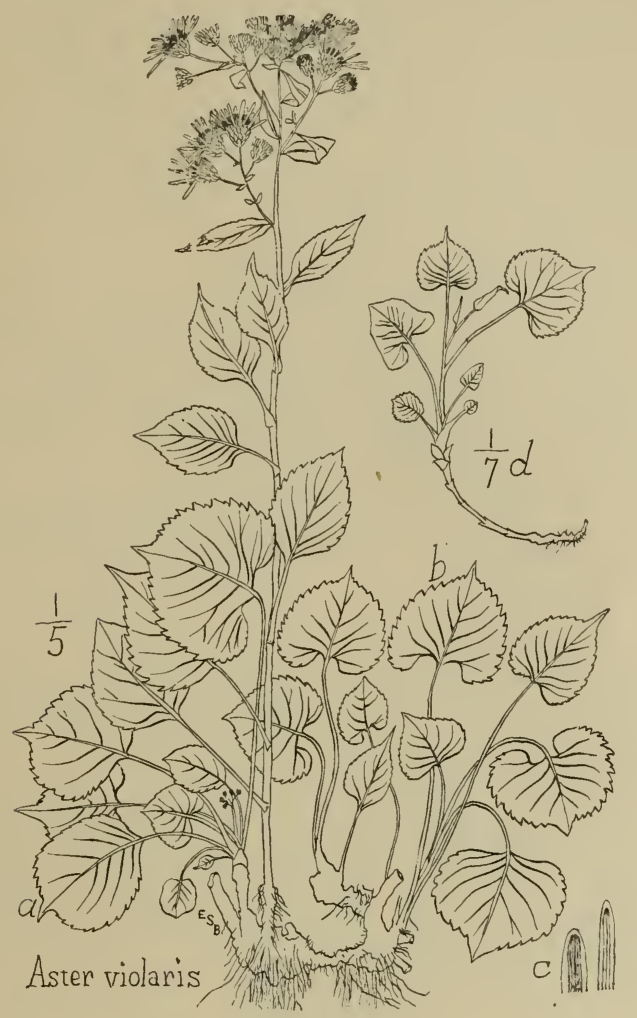

FIG. 100.

then similar but longer, the next losing cordation and becoming oval-acute, all these on narrow petioles of about the leaf-length.

Upper caulines oblong-acuminate with short narrow-winged petioles. Axiles similar, narrower, sessile. Rameals, when developed, shorter and broader, sharply acute.

Primordials two, similar, small and suborbicular, $1 / 2 \mathrm{in.} \mathrm{long}$ or less, yellowing and ready to fall by middle of May. A larger cordate-quadrate leaf of intermediate character, finely downy and 
aquiline-toothed, occurs above these, followed by the proper radicals, which by that time have attained about $\mathrm{I} / 2 \mathrm{z}$ in. square.

Surface smooth when dry occasionally, hispid-roughened usually.

Inflorescence 4 or 5 in. across, sometimes 8, leafy in aspect from the large axiles, and sometimes from the rameals, much deeper than broad, with stiff branches arising at an angle of about $65^{\circ}$. Heads $1 / 2$ in. high or more; pedicels twice as long or less.

Bracts rather uniform and pale, narrow and linear-obtuse, in life, acute by infolding of scarious-edges when dry, somewhat ciliate.

Rays I 2-I 5, narrow and remotish, pale violet or lavender, $\frac{10}{16}$ in. long or less, entire or with 2 or 3 minute teeth.

Disk-flowers funnel-form with very long capillary stalk, three times the length of the body which is itself $3-4$ times the length of the short erect lobes.

Pappus long-exserted, soon rufescent.

Glandular hairs short, at first colorless and clavate, becoming black and capitate, developed from the translucent veinlets of the minutest reticulation; such cover the leaves beneath ; similar glands but nearly sessile, occur on the upper surfaces ; similar and blacker in the midrib and channelled petiole.

Habitat, moist flat places in rich soil, in considerable shade or edge of woods, sometimes in deep leaf-mold between stones.

Examples include :

Ct., Salisbury, Au. 18; 1903 .

N. Y. vic., Hastings, late flowers faded, Oc. 17, 1905; Yonkers, Bryn Mawr Park, path ; Palmer Av., roadside, Se., '97, woodpath, near depot, Se. 26, '96, Se. 25, 97, colony'persistent but seldom flowering at all, '98-1905. L. I., Flushing, St. Ronan's Well, Farley in hb. Canby, July, ' 87.

N. J., Palisades, Undercliff, old trolley-bend, Se. 24, '97, '98, colony persisting but reduced and flowerless, '99-190I, then destroyed by parking.

N. J., Palisades, Bicknell, "Se. 6, '92, approaching A. Herveyi," from the violet rays and elliptical upper leaves which suggest those of $A$. spectabilis.

N. Y., "Steuben Co., Rathboneville, Au.," C. H. Peck, in hb. N. Y. St.

W. N. Y., Niagara, Goat I., Au. 25, '96. Cattaraugus resn., Little Indian Cr., Au. ' 98.

\section{Aster quiescens sp. nov.}

Low plants of tough, heavy texture, subsucculent in life, very rough when dry, with dark green, cordate-oval, pendent-lobed leaf-type, crenate margin, deep sharp sinus, irregular, scanty inflorescence, acute bracts and pale lavender rays.

Name, L., from the long time during which large colonies remain without flowering. 
FIG. IOI, plants from Palisades, N. J., in hb. Bu.; e, ordinary quiescent plant, a radical cluster, Se., ' 97 ; $a$, a flowering stem arisen late from such cluster, Nov. I ; $g$, early development, May Io, with one primordial ; $d$, such a radical cluster as developed June $30 ; f$, young leafy shoot of June Io, such as might flower in August, with inflorescence like $a$, but with more heads.

Stem low, I I $/ 2 \mathrm{ft}$. often, glabrate, pale green, angular in drying. Leaf-type heavy, strong and tough, pinguid and smoothish or roughish in life, very rough when dry, dark green or apple green,

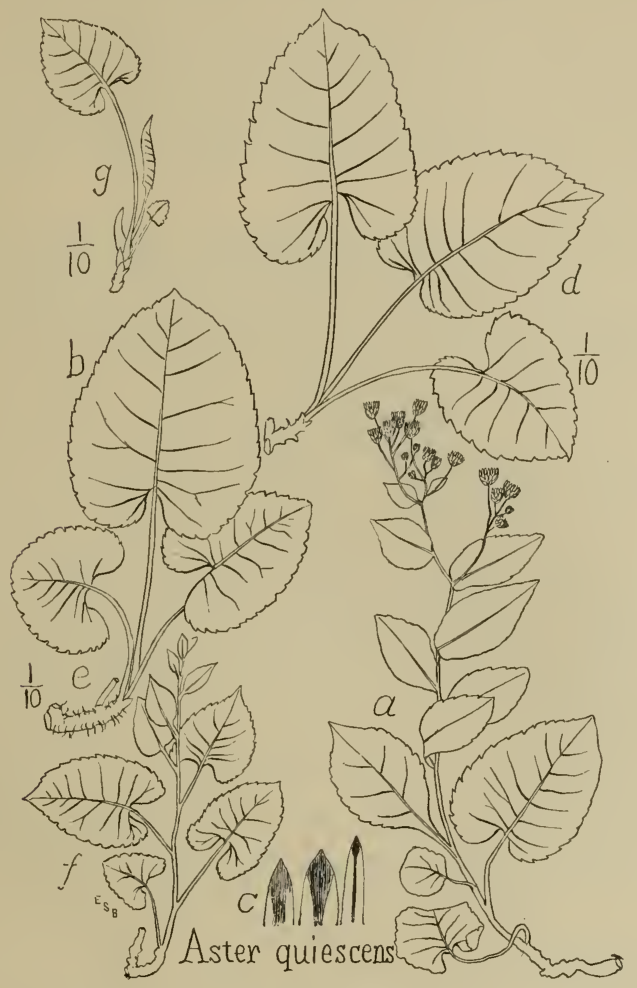

FIG. IOI.

glabrate and thickish, with excavated-curvescent or shallow-crenate teeth; outline cordate oval with apiculate apex soon obtuse by breaking, and tending to produce dilated pendent basal lobes, conspicuous deep narrow sinus, often closed by overlapping, but enlarged within.

Radicals commonly 3, the first one of violarial form ; or triangular with large sinus and larger pendent lobes ; or orbicular-cordate ; or reniform-apiculate with pendent lobes, or reniform and pointless.

The two following radicals are commonly of the typical leaf- 
form (as one or two lower cauline), broad cordate-oval, and rather large, often 6 or 7 by 4 or $5 \mathrm{r} / 2$ inches.

Primordial triangular-acute, or half an ellipse with truncate base, excavate-crenate, long-petioled, preceded by 2 or 3 phyllodials with long broad petiole and little roundish lamina.

Caulines, the lowest commonly of the radical form, others chiefly long scutiform, with long slender petioles; upper caulines oblong-lanceolate, finally wing-based and serrulate. Axiles similar, narrower and sessile. Rameals minute, somewhat subulate.

Inflorescence small, irregularly paniculate-corymbed, or reduced to a mere tuft. Heads moderate, involucre $\frac{5}{18}$ in. high.

Bracts narrow-oblong, obtuse, rounded or bevelled at apex, pale and with narrow spatulate green tips, the lower spreading or reflexed in drying.

Rays lavender, soon turning dingy-white, and in larger more diffused plants seemingly dingy-white from the first, but in outliers and occasional few-flowered sprouts, deep-violet.

Disk turning reddish-brown. Pappus ecru still after four or five years.

Development: Charles River plants, May 7 ('99), 5 in. high, covered (leaves and petioles) with obvious villous upright hairs, which are viscid but tapering: with pale or amber glands between, subsessile over the leaves beneath, more stalked above; spots of viscid smear occur on the leaves beneath also. Some rootstocks $2 \mathrm{ft}$. long. Earliest growth shows 3 -scales; then a little quadrate primordial, $1 / 3$ in. ; 2 radicals follow, with petioles of 5 in., themselves $2 \times$ I $3 / 4$ and $\mathrm{I} / 2 \times 2$ in. long. - Palisades, plants $6-8$ in. high, on May Io, '99.

Habitat, woods near water, forming large flowerless dense colonies sometimes for several rods and finally flowering scantily around the edges (after 5 years in one case). - Mass., N. Y. and Penn.

Examples include:

Mass., Charles R., in Weston, Au., '98, radicals fully up May 9, '99; in flower Au., I 900 .

N. Y. vic., Yonkers, Dunwoody, Seminary grounds, Au., '98-1905; a few late sprouts in pale flower, Se. 14, 1905; Woodlazm, '98.

N. J., Palisades above Undercliff, hundreds of plants in luxuriant condition '97-1901, till destroyed by parking.

Pa., near Pinila., in hb. Canby'.

Pa., Willow Grove, Montgomery Co., Oc. 14, '94, J. Bernard Brinton, M.D., in hb. Phila. Bot. Club.

$78^{2}$ Sprout-form. Lower leaves slender petioled or winged or cuneate-based, these or the next above them small and orbicular 
or oval. Other caulines and axiles sessile, obovate or short-ovate, clumpy shallow crenate or subentire. Palisades, Dunwoody, etc. $78^{3}$ Stump-fed form. Similar to last but all foliage very large and luxuriant and rays dark. Palisades, decaying stump.

\section{Aster granulosus sp. nov.}

Little-leaved granular-roughened brownish-green glabrate plants with short winged or narrowed petioles, small sharp sinus, low-crenate margins, diminished lobes, obtuse acumination, brittle stem, widely diffused and forking inflorescence, narrow lavender rays, bevel-tipped bracts, broad short radicals and small scattered rootstocks.

Name, L., from the strong tendency to granular roughness, chiefly on the upper surfaces, and also on lower surfaces and stem.

FIG. I02, from Palisades, N.\&J., Oc. 7 , '99, in hb. $B u$; $a$, normal plant, $b$, its characteristic leaf, $c$, its bracts, $d$, its radicals as seen Oc. 7 ; $e$, as developed May Io, with one primordial ; $f$, sprout form ; $h$, dwarf, with its radicals, winter-leaves, $j$; $g$, little-leaf form, tall plant with all leaves alike small.

Stem brown or greenish, terete, slender and brittle, with short close internodes.

Radicals 3 , or in luxuriant plants even 5 large ones, $5 \times 3 \mathrm{x} / 2$ in. or less, with 3 small ones of similar shape, I in. long or so, and 4 little non-cordate elliptic or obovate ones, still smaller.

Leaf-type polymorphous, the caulines prevailingly narrow, the radicals broad and short; substance thin, firm, opaque dull green, as in $A$. quiescens, soon brownish-green. Veins pale and almost white beneath, up-curved from the first. Teeth mostly excavatecrenate (with single dorsal curve only) or excavate-curvescent (with double curve), shallow and inconspicuous. Petiole short, half the leaf-breadth usually, narrowly margined or becoming cuneate-winged above. Sinus sharp, narrow and short, soon becoming shallow, broad and recurvate. Apex taper-acuminate with obtuse end or soon becoming so by breaking. Surfaces granular, roughened or hispidulous, more highly and extendedly so than in such allies (A. quiescens, etc.) as also partake the granular surface.

Primordial quadrate-oblong, excavate-Cl vescent, very obtuse, minutely cordated, with much red above and along margins, with narrow-margined petiole twice its length, somewhat ciliate and with 5 or 6 pairs of uniform, straight, parallel, opposite veins, all at an angle of $65^{\circ}$ to the midrib, yellowing by middle of May, $\frac{4}{8} \times \frac{3}{8} \mathrm{in}$.

A second similar but larger primordial may reach $2 \frac{3}{8} \times 1 \frac{3}{8} \mathrm{in}$, become green and serve as a radical foliage-leaf by May I 5 . 


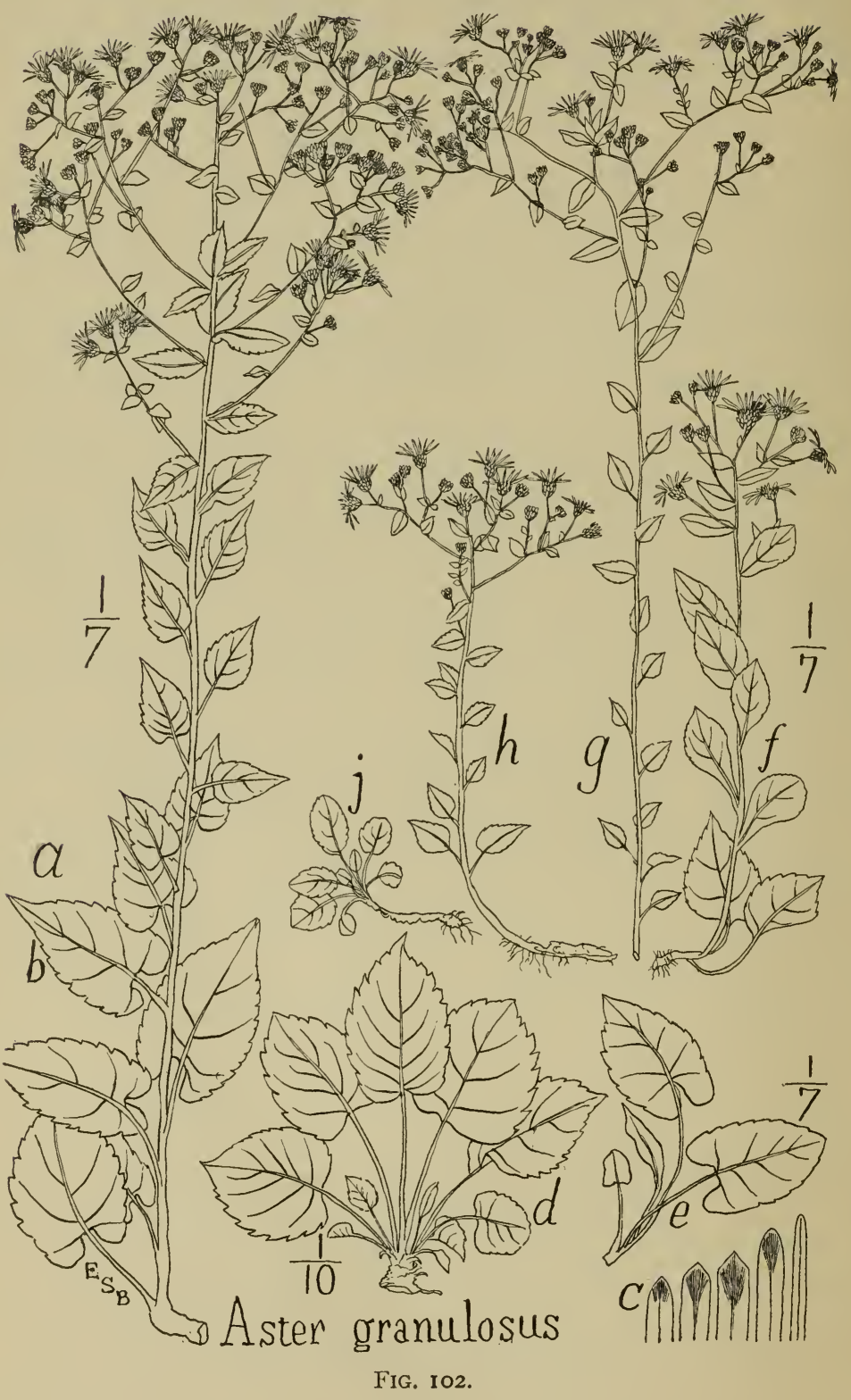


Radical primary type (and in lower caulines) ovate-lanceolate with narrow, deep, sharp or overlapping sinus, as if cut out of the diminished ovate base, much as in A. excavatus among Divaricati; $4 \times 21 / 2$ in. or less; the veins spreading, alternate, 6 pairs, but of widely diverse direction; 2 or 3 such leaves, their bases tardily unrolling from the involute shallop-like bud.

Radical secondary type, seemingly predominant in radicals of later start or of forced growth, broad and short with sharp, small, slight sinus, closed and appearing sharp by overlapping, with coarser but similar teeth and veins, with somewhat oval-acute or triangular-short-ovate leaf-form and larger size, $4 \mathrm{r} / 2 \times 3 \mathrm{r} / 2$ or $2 \mathrm{I} / 2 \times 2 \mathrm{I} / 2$ in., and slender petiole slightly longer; 4 such and as many small ones occurring from one rootstock, and becoming highly detentive-hispidulous on both surfaces.

Lowest caulines like the primary or secondary radicals, but much smaller, as in plants with the 6 lowest leaves all only $2 \times I$ in.

Middle caulines elliptic-acuminate, abruptly tapered into a short cuneate-wing base; $3 \times 2$ in. or in smallest leaved plants all $\mathrm{I} / 2 \times 7 / 8$ in.

Upper caulines and axiles sessile, oblong-ovate or ellipticbiacuminate or oblong-lanceolate.

Rameals sessile, oval-acute or ovate, with truncate base, or smaller and obovate.

Inflorescence very wide-spread, remotely-forked and diffuse, becoming I $\mathrm{ft}$. high and as broad, the long slim pedicels often I or $\mathrm{I} \mathrm{I} / 2 \mathrm{in}$. long, all nearly simultaneous in flower, often forked 3 from a node, more often 2. Involucre pale, sub-turbinate or hemispherical.

Bracts polymorphous, oblong, the lowest seemingly obtuse with an acutish centre, the next and most numerous bevel-tipped and acute, the inner oblong-lingual and decidedly obtuse; the inmost linear-tapering and still obtuse.

Affinity, apparently a mutation from $A$. quiescens, but with very unlike aspect and without transitional forms.

Habitat, dry rocky woods, Conn. to Penn.

Examples:

Conn., Meriden Hills, Se. $25,{ }^{\prime} 58$, coll. D. C. Eaton, in hb. Mo. Bot. Gar. (Sprout form.)

Conn., Groton, "dryish rocky woods, w. of Cedar Swamp, Au. 28, '99," C. B. Graves in hb. Bu.

N. Y., Yonkers, Seminary corner, Se. 14, 1905.

N. J., Palisudes, Undercliff, 1897, ' 98 , ' 99 , 1900, type locality, and with abundant sprout forms, Oc. 7, '99; obliterated by parking, I9or.

Pa., Nockamixon, Bucks Co., rocks, Oc., '78, a late growth, then in young and abundant blossom, T. C. Porter in hb. Bu. 
Sprout-forms show chiefly obovate cuneate-winged caulines and oblong-acute sessile axiles, with larger heads.

Druarf-forms often I foot high, with 20 heads, and perhaps I 8 little leaves uniformly I $+1 / 2$ in. [see FIG. IO2], their radicals similarly small, oval and noncordate. - Palisades and Dunwoody.

\section{Subdivision $C$.}

Plants of moderate height, often $3 \mathrm{ft}$; radicals moderate, 5 in. or less; many non-cordate radicals and caulines; glands abundant nearly all over; leaves not extremely rough nor very thick; diskflowers funnel-form and deep-slit ; violet of the rays well-developed. Sp. $80-82$.

\section{8o. Aster Jussiei (Cassini) Burgess.}

Slender dark-green plants with multiform radicals, lanceolate sharp-serrate long-acuminate leaf-type, some lower ones and radicals lanceolate with narrow sinus, all leaves thin glabrate and roughish, the inflorescence very irregular, a deep-branched corymb becoming proliferously panicled, with narrow tapering rays and acutish bracts.

Name from A. L. de Jussieu, in whose herbarium Cassini found the original specimen.

FIG. I03, $a$, reduced to $\frac{1}{1} \frac{1}{2}$ th nat. size, plant from Cattaraugus reservation, Au. $\mathbf{1}_{3}$, ' 98 ; $b$, characteristic leaf from same; $d, \frac{1}{10}$ nat. size, smaller broader proliferous state, plant from Pt. Gratiot, $\Lambda$ u. 21, '97.

Stem green or brown, slender and terete, erect and nearly straight, glabrate and very smooth to touch even when dry, $3 \mathrm{ft}$. high or less.

Leaf-type characteristically lanceolate-acuminate with distinct short petiole, sharp aculeate-serrate, some with short sinus, all thin, smooth in life, roughish or almost smooth when dry, apt to stand suberect.

Radicals and lowest caulines erect or spreading, either lanceolate ovate or oblong-cordate with deep narrow sinus, usually a few leaves of each form on each plant, $4 \times 2,6 \times 3 \mathrm{r} / 2$ or $7 \times 3 \mathrm{r} / 2$ in. or less.

Middle caulines suberect, lanceolate and prolonged-acuminate, the base successively truncated, rounded, or tapered, the short petiole narrow-margined or cuneate-winged; $4 \times \mathrm{I} \mathrm{I} / 2$ to $2 \times \mathrm{I}$ in.

Axiles similar, narrower; rameals oblong-lanceolate, subsessile only, the short petiole being unusually persistent.

Inflorescence at maximum reaching $\mathrm{I} f \mathrm{ft}$. across and $2 \mathrm{ft}$. deep, some lower branches I 5 in. long, outer branches very slender, 
ascending at a rather high angle, usualfy greatly overtopping the central corymb and finally forming an irregular loosely-paniculatedecompound tangle, most confused in plants of moderate size.

Heads $3 / 8$ in. high or the central ones $1 / 2$ in., their pedicels slender, straight, thickened at the summit, developing during flowering to $\mathrm{I}$ in. long or more.

Bracts conspicuously triseriate with prominent large lancetriangular green-tips, all alike at the acutish or almost obtuse apex, the outer ovateoblong, others oblong-subulate or linear, mostly with thin scarious reddened margins.

Rays long, narrow, I 5-20, often 18 , linear and tapered to an entire apex (so often, but occasionally 3 -toothed), deep purplish-violet.

Disk-flowers with long narrow linear acutish lobes (all equal and alike, so far as observed), the lobes twice as long in proportion as is usual in the Macrophylli; body funnelform; stalk long, greenish ; lobes form $1 / 2$ to $2 / 3$ the length of the bell.

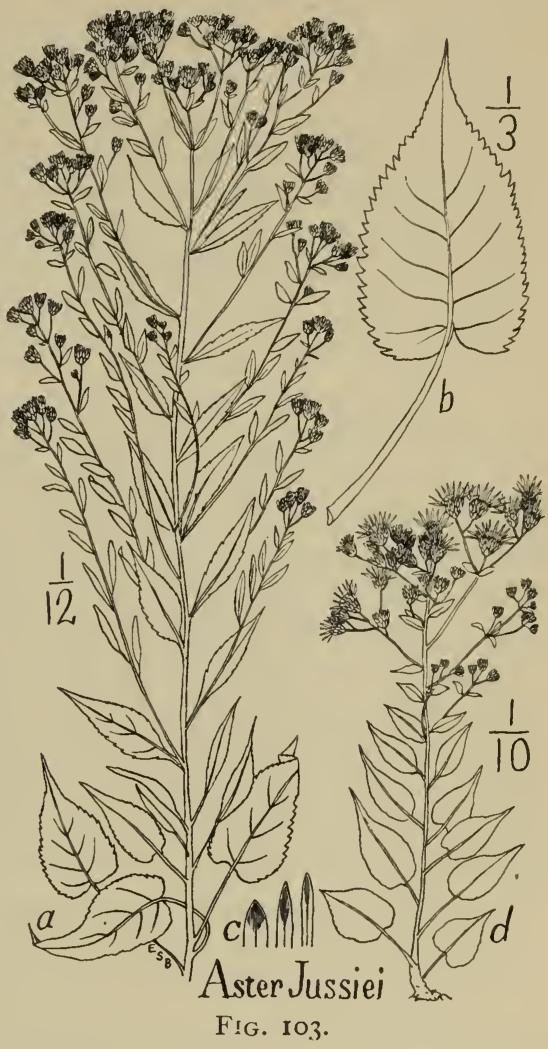

Glandular pubescence minute, sometimes almost absent from the stem; other pubescence little developed, scantily on leaves beneath while young.

Halitat, rich woods and abandoned clearings, Western N. Y. Examples:

W. N. Y., Cattaraugus resn., Indian-line road, Little Indian Cr., near last cornfield, Au. 13, '98. Dunkirk, Pt. Cratiot, Au. 29, 96, Au. 21, '97, Au. I I, '97 ; Fredonia, Marsh's woods, Se. I, '96; Silver Cr., Aster-bank, Au. I 7, '96; Talcott's woods, no. of railroad, 10 or 12 radicals without sinus on one plant; one with 36 heads I $\frac{1}{4}$ in. broad, $\frac{7}{16}$ in. high, Au. 15, '96; Swift's Hill, Au. 15, '96.

Canada, Niagara, at Foster's Flat, Au. 25, '96.

Allies. Unlike $A$. commixtus in being taller, slender, thinnerleaved, lanceolate rather than oblong oval in predominant leaf 
type, much more sharply serrate, much less viscid, with larger, narrower rays, and more tendency to proliferous inflorescence.

Unlike $A$. Herveyi, which in its cordated leaves tends to ovate form and subentire margin.

Unlike both in its strictly-erect appressed bracts.

Unlike $A$. decapliyllus in being thinner, narrower, taller, etc.

Variants.

$80^{2}$ Lingulate form. Decumbent often, with long weak green stem, the upper leaves or axiles lingulate or prolonged oblongacute, sessile and very dark green, with low serrate teeth aculeately acuminate and with the aculeus upturned as well as forward-turned.

Pt. Gratiot Pk., Au. 29, '96, not again developed '97-1903, its locality much interfered with by parking.

$80^{3}$ Biculminate form. Corresponding in leaf development to the biculminate form of $A$. multiformis, q. $\mathrm{v}$.

History. This species rests originally on an unnamed specimen found by $\mathrm{H}$. Cassini in the herbarium of A. L. de Jussieu (1748I 836), of unknown origin but doubtless from the northern Atlantic States. Cassini thought it remarkable, among other reasons, on account of its elongated cordate-lanceolate leaves, panicled inflorescence, long narrow taper-point rays, and deep-slit disk-flowers. He therefore described it as a new species, in the Dict. des sciences naturelles, $37: 487$, in 1825 , in which he was then incorporating his botanical observations ; giving to the plant the name of Jussieu, and placing it in his genus Eurybia, which included our Biotian Asters. His description is as follows; with accompanying remarks :

Nous avons trouves, parmi les plantes innommées de l'herbier de M. de Jussieu, une nouvelle espéce d'Eurybia, que nous pouvons signaler ainsi.

Eurybia Jussiei H. Cass. Feuilles longuement pétiolées, ovales-oblongues, presque lanceolées, échancrées en coeur à la base, aiguës au sommet, grossièrement dentées en scie, glabriuscules: calathides disposées en panicule: péricline égal aux fleurs du disque, formé de squames régulièrement imbriquées, appliquées, obtusiuscules, uninervées, subcoriaces, épaissies au sommet: les extérieures ovales, les interieures linéaires; clinanthe alvéolé ; couronne à languettes tres-longues, rubanaires, étrécies supérieurement, non dentées au sommet, disque jaune, à corolles divisées par des incisions inégales et très-profondes en cinq lanières très-longues, linéaires.

Cette espéce, assez remarquable par la longueur des divisions des corolles du disque, est très-analogue aux Aster macrophyllus et corymbosus, qui sunt aussi de Eurybia. Il faut en core rapporter au même genre l'Aster liratus (Bot. mag.) et l'Aster argophyllus, Labill.; ce dernier a, comme l'Eurybia Jussiei, les corolles de disque divisées, presque jusqu' a la base du limbe, en cinq lanières; les filets de l'aigrette ont le sommet épaissi et comme barbelle, c'est-a-dire tres courtement plumeux; le disque est composé d'environ cinq fleurs blanches, tridentées, le clinanthe est petit, nu; le pericline est étroit et tres-inferieur aux fleurs du disque.

In genre Eurybia se trouve ainsi, quant, à présent, composé de neuf espèces, nommées, quercifolia, fulvida, viscosa, microphylla, Jussiei, macrophylia, corymbosa lirata, argophylla. 
Nees, Gen. Asterearum (1832) cites Cassini's Eurybia Jussiei as similar to Nees' own Eurybia commixta but probably distinct notwithstanding. Nees' cites Cassini's description in the form of a Latin summary, as follows :

Eurybia Jussiei, probabiliter diversa a nostra specie [E. commixta Nees], hoc loco saltem debet intrare; cuius descriptionem auctoris verbis hic addimus. Folia longe petiolata, ovali-oblonga, fere lanceolata, basi cordata, apice acuta, grosse serrata, glabriuscula. Calathia paniculata. Periclinium discum aquans, foliolis concinne imbricatis appressis obtusiusculis uninerviis subcoriaceis apice incrassatis, quorum exterioribus ovalibus, interioribus linearibus. Clinanthium alveolatum. Radii ligulae longissimae, lineares, apicem versus angustiores apiceque integerrimae. Disci flosculi lutei, limbo profunde quinquefido, laciniis inaequalibus linearibus longis. - Species haec, laciniarum flosculorum discoidalium longitudine distincta, maxime affinis est Asteribus macrophyllo et corymboso, qui et ipsi Eurybiae sunt.

The original specimen seeming to have disappeared,* and none other to have been hitherto discovered, the species rests on Cassini's description, which was rightly interpreted by Nees as suggesting a somewhat different plant from the latter's commixta. Lanceolate leaves with sinus are rare in Aster, or indeed in other genera. Paniculate inflorescence is also unusual in the Biotian group. Long narrow disk-lobes are much less common than short ones. Entire tapering terminations ending narrow rays are still rarest of all among the Macroplyylli. This is the combination of four unusual characters presented by Cassini's description, the counterpart of which I have sought in nature through various parts of the Middle and New England States for eight or nine years. I find very few Biotian forms which show any of the four characters, and the one form which I do find, which shows them all, I have described above as the representative in nature of Cassini's plant.

\section{I. Aster decaphyllus sp. nov.}

Dark deep-branched paniculate-corymbed ascending or decumbent plants with rosettes of thick, coarse-serrate oval radicals, reddish-brown stems, cordate-ovate, reniform and elliptic-acuminate leaf-series, taper-based caulines, oblong-lanceolate axiles, deep violet-rays, deep-slit disks, and oblong-acute white-edged bracts.

Name, L. from Gr. = ten-leaved, from the frequency of rosettes of about ten leaves.

Fig. I04, plants from Little-Indian Cr., N. Y., Au. I3, '98, reduced to $\frac{1}{6}$ nat. size; $a$, small half-grown plant; $b$, characteristic stem-leaf; $d$, another radical cluster.

* Search for it was kindly made in my behalf in ' 99 by Mons. A. Franchét, of the Laboratoire de Botanique, Jardin des Plantes. 
Stem profusely branched from near the base, terete and stout, undulately-ascending or often partially decumbent, glabrate and smooth, often 2 or 3 from one root-cluster, subsucculent like the leaves, $3 \mathrm{ft}$. or less.

Surculi pale or purplish, long and stout, with scales which are themselves often $1 / 3$ or $1 / 2$ in. long and $I \frac{1}{2} \mathrm{in}$. apart.

Radical clusters of lettuce-like aspect when strongly developed, then of about IO or I 2 leaves, of about 3 types; Ist, I to 4 cor-

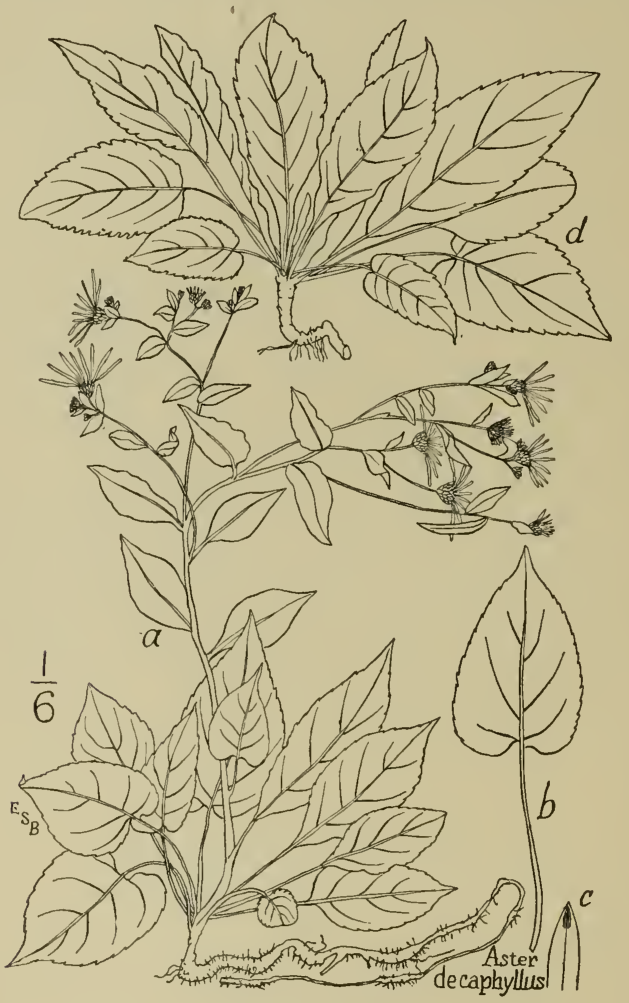

FIG. 104.

dated ovate or oblong acute leaves, $4 \times 21 / 2,3 \times 1 \mathrm{x} / 2$, etc., with small sharp sinus; $2 \mathrm{~d}$, I or 2 violarial leaves, $3 \times 2 \frac{1}{2}$ in. or less, broad and reniform, apiculate or obtuse, with shallow brace-base sinus; these sometimes not developed, or replaced by little orbicular forms; $3 \mathrm{~d}$, about io non-cordate oval or elliptic-oblong longer more-conspicuous leaves, $5 \times 2$ in. often, or oval and $4 \times 3$, the latest ones apt to be oblanceolate with long cuneatestrap petiole, often $6 \times 2$ in., including 2 in. of petiole; the other radicals slender-petioled. - Sometimes the radical rosette is borne 
an inch or two up the flowering stem as if grafted on; but usually it crowns the rootstock closely, not to be followed by the flowering-stem till another year.

Leaf-type thick, firm, subsucculent, glabrate, very dark green, very rough above when dry, very smooth when fresh, minutely rugulose with impressed veinlets, and thus closely areolate above, each areola having 2 or 3 whitish papillae and many pale scurflike dots.

Glands scattered over the leaves beneath are minute, spherical, subsessile, colorless or amber-like; such granule-glands continue over the involucres, branches and upper stem, on the pedicels mixed with scanty minute puberulence.

Lower caulines include some sharp-cordated ovate-acuminate or lanceolate leaves with narrow petiole ; and a non-cordate roundbased oval or ovate-lanceolate type with long undulatiform petiole.

Middle or chief caulines oblong-elliptic or ovate-oblong, acuminate, close-serrulate, $3 \mathrm{I} / 2 \times 1 \mathrm{I} / 2$ in., with a taper strap-wing often forming an additional inch.

Upper caulines and rameals oblong-lanceolate, with contracted sessile base.

Teeth closely aquiline-serrate in Ist and $2 \mathrm{~d}$ radical forms, long straight-serrate or coarsely crenate-serrate in chief radicals, obscurely serrulate in caulines.

No obvious hair present.

Inflorescence branches given off at a high angle, $70^{\circ}-80^{\circ}$, prolonged and leafy, seldom rising to a uniform level.

Bracts oblong-lingual, quite uniform, with acuted apex but obtusish at its termination, with green or reddened medial band and pale or white thin scarious margins.

Rays oblong, of a beautiful dark-violet or blue-violet, paling slowly; of nearly uniform breadth, about $1 / 2$ in. long, slightly upraised along the edges, appearing entire at the rounded end, but minutely tridentate under a lens.

Disk-flowers composed $2 / 3$ by the filiform, greenish tube, rather gradually swelling into the upper $1 / 3$, which forms a narrow purplebrown bell with its lobes $1 / 2$ or even $2 / 3$ of its depth; as in $A$. Jussici.

Achene cylindrical, faintly about ro-striate.

Pappus rufous in 5 years.

Habitat, rich openings and clearings in deciduous forests, Maine and the Taconics to L. Erie.

Examples:

Maine, Cumberland, Se. 15, '85, J. Blake in hb. T. C. Porter.

Mass., Taronics, Mt. Ethel, oak-clearing, near Melius' corner, Au. 15-Se. 5, I 903 ; flowering-stems without radicals ; abundant radical rosettes set for next year's flowering; but not visible yet May I, 1904 . 
Canada, Kingston, dry woods, Se. 23, I901 ; Toronto Junction, Se., Iç05, A. B. Kiugh in hb. Bu.

W. N. Y., Cattaraugus resn., toward Little Indian Falls in basswood-clearing, Au. I3, '98, filling the woodland; most of these plants failed to flower again the August following.

\section{Aster Herveyi Gray.}

Slender, glabrate, remote-flowered plants, with thin, ovate roughened leaves, little sinus or acumination, the radicals about 4 , large, low-crenate and long petioled, the caulines ovate to lanceoblong and sessile; with upcurved lengthened pedicels, long narrow blue-violet rays, and thin flat bracts, with broad, obtuse viscid green-tips, the inner pale, scarious and shining, and some of them subsquarrose or spreading.

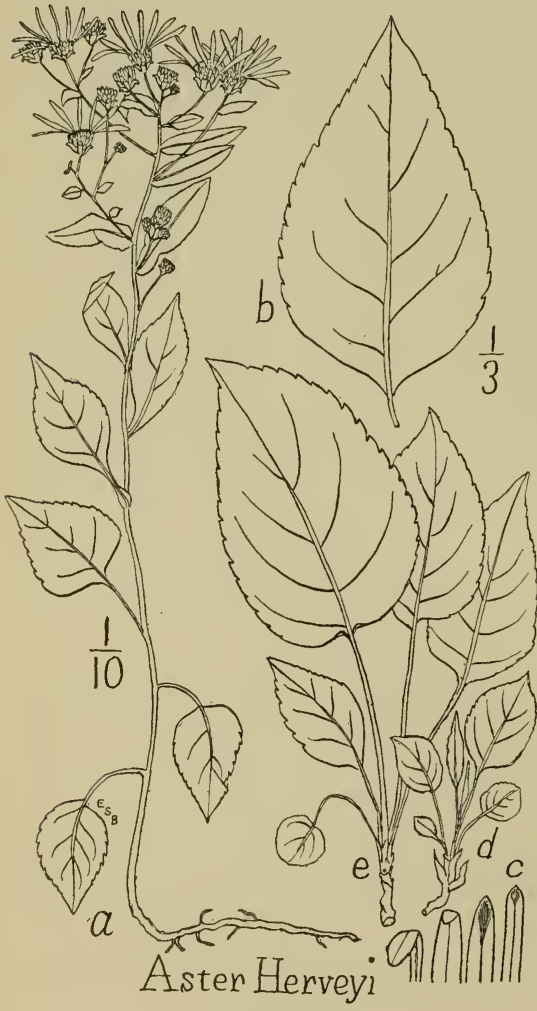

Fig. 105.

Name from the discoverer, Mr. E. Williams Hervey, of New Bedford, Mass., who sent the first specimens to Dr. Asa Gray in $\mathbf{1 8 6 6 , \text { and }}$ who still could point out the original colony to me at the glen on Clark's Neck, New Bedford, in 1897.

FIG. I05, plant from original type locality, Se. II, '97, in much shade, $\frac{1}{10}$ nat. size; $b$, characteristic leaf-form, radical or lower cauline; $d$, young radicals, as developed May 6 ; $e$, radicals as developed Se. II, '97.

FIG. 106, plant from thinner shade, $1 / 8$ nat. size; $d, e$, its radicals ; $f$, plant from sunny roadside; all of $\mathrm{N}$. Bedford, Se. I1, '97.

Figured also, no. $3784 ; \mathrm{Br}$. and Br. Ill. Fl. $\mathbf{3}: 374$, and in Garden and Forest, $2: 473$ (1889).

Stem $2 \mathrm{r} / 2 \mathrm{ft}$. high or less, green and terete, slender, erect from a long slim rootstock of half-inch internodes.

Radicals ovate, $6 \times 3 \mathrm{I} / 2$, $5 \times 3$ in. or less; about 3 such and an elliptical earlier one about $3 \times 2$ in., form the usual radical cluster. All or some of these have a slightly overlapped, asymmetrical rounded base, with or without slight sharp sinus: their margins low- 
crenate, their veins inconspicuous, remote, upslanted from their base, their petioles very long and slender, sparsely villous, pale green. Primordial suborbicular.

Caulines ovate or with rounded base and strong slender petiole, soon ovate-triangular, then lance-triangular and obtusely acuminate and with taper-wing petiole, then lanceolate and sessile. Axiles lance-oblong, sessile by a broad clasping subentire base; rameals similar but only half-length or less.

Leaf-type thin, membranous, full deep green, pale beneath, glabrate, but much roughened above when dry.

Inflorescence sparse but showy, the wide-spreading branches forking once or twice into long stiff upcurved pedicels, I in. or $\mathrm{I} I / 2$ in. or even 2 in. long. Heads hemispherical, $\mathrm{I} / 2 \mathrm{in}$. high, I $1 / 4$ in. or even I $1 / 2$ in. broad, apt to be closely subtended by an obovate recurving bracteal.

Bracts thin, pale below, the outer with broad conspicuous deep green tips, very obtuse and rounded, at least the upper tips often spreading or decidedly squarrose. Inner bracts scarious, pale and shining, linear-attenuate but obtuse.

Rays long, narrow, remotish, about I4, deep blue-violet, soon decurved and paling.

Achenes long, slender, fusiform, nearly smooth and brown.

Spring development as seen in Cambr. Bot. Gar. May 2, '99: very roscid-glandular; leaves I $\mathrm{I} / 2$ and even 2 in. long, about 3 to a shoot and this now 3 in. high; two-thirds of the radicals show cordation in a slight or a definite notch. Leaves dark green, leaving the fingers odorous.

Habitat, thickets and half-shade, wood-borders near the coast, southern New England.

\section{Examples:}

Mass., N. Bedford, glen on Clark's Neck, original type-locality, E. Williams Hervey, there discovered by him 1866, still flowering there substantially unchanged Se. II, '97; specimens in hb. Gray, hb. Colu., hb. Bu., '86, etc. Also at "Wall-place" locality, now within the city, some blocks from the other station, in thinner shade, with more truncate-based caulines, more leaves slightly cordate, total aspect more like other Macrophylli; see Fig. ro6. Se. I I, '97.

Mass., Blue Hills, Milton, Se. I8, '94, /. R. Churchill in hb. Gray', etc.; West l'oxbury, Oc. 15, '85. E. Faxon in hb. W. Deane and hb. Gray; Brookline, E. Faxon, Au. I9, '90, in hb. Gray' and hb. Colu., and Se. 9, '99, in hb. W. Deane; Muddy Pond Woods, Boston, Se. 20, '87, E. Faxon in hb. Gray; Brookline, at Puttenham, Se. 12, '84, E. Faxon in hb. Gray.

Ct., N. London, '97, E. Williams Herzey', in his hb.

Allies. A. Herveyi as here recognized is unlike $A$. commixtus in having obtuse, not acute, bracts; unlike $A$. decapliyllus and $A$. Jussiei in having thinner texture, and wholly different bracts and 
branching. Gray described $A$. Herveyi as having erect bracts, relying on the dried specimen, which would have been an important distinction from $A$. commixtus, described by Nees as having squarrose bracts. But I find $A$. Herveyi has many bracts squarrose when growing, on examining them in the field, though most of

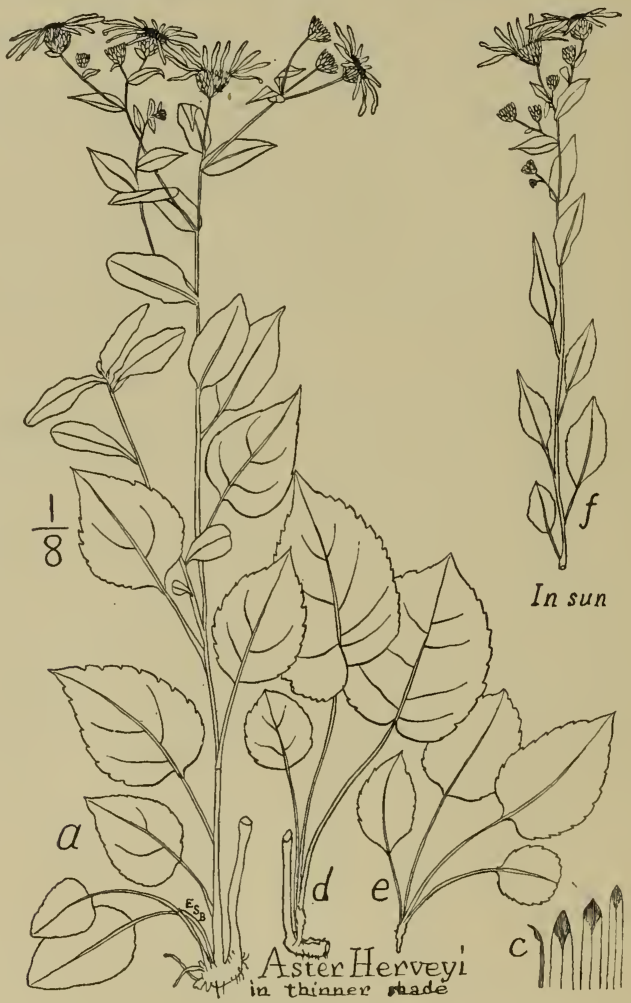

FIG. 106.

them seem to flatten on pressing, as do many of those of $A$. commixtus.

Variants:

$82^{2}$ A. Herveyi $\times$ A. spectabilis? Thicker-leaved small plant growing near both parents Se. I I, '98, at New Bedford, with biacuminate leaves, elliptical to ovate-lanceolate; leaf-form and size more as in the latter species; texture more of $A$. macrophyllus L., which also grew near; leaves much thicker than the forms of A. Herveyi following. Figured, Fig. $106 \mathrm{f}$. A form of $A$. Herveyi collected by Sargent at Tiverton, R. I. (with other forms), seems the same as this supposed hybrid. 
$82^{3}$ A. Herveyi $\times$ A. spectabilis? Oblong-leaved plant, another intermediate, or a probable hybrid, much narrower and slighter in all its parts than the last, but with a wide-forking, paniculate corymb; the small, narrow leaves more oblong, very similar to the oblong leaves of a narrow form of $A$. spectabilis which grew with it, but the lower ones with slender petioles and broadened bases, as in $A$. Herveyi; with pale green stems, glabrate; leaves rough when dry; some bracts somewhat squarrose. Glen, New Bedford, Ms., Se. i I, '98.

$82^{4}$ Lance-leaved form, perhaps also a hybrid; smaller and slenderer than the type; its radical, lower and middle cauline leaves chiefly ovate-lanceolate, no broader than occasional in $A$. spectabilis, $i$. e., I inch, but more toothed; the upper cauline oplong, strap-like, usually toothed toward the apex, and continuing broad to the sessile base, instead of entire and tapering to base and apex, as in true $A$. spectabilis. Grows with the type at the New Bedford, Milton and West Roxbury localities, and more abundant if we may trust herbarium material. Specimens also include :

Mass., Readville, Neponset R., Au. I3, '93, J. R. Churchill, in hb. W. Deane; Hyde Park, Muddy Pond woods and hills, C. E. Faxon, Se. 26, '87, and Oc. 12, '87, in hb. Colu. ; Oc. 10, '85, and Oc. 9, '88, in hb. Gray. Blue Hill, rocky woods near summit, Se. II, '85, E. Faxon in hb. Gray. Bract tips enlarged and squarrose.

R. I., Tiverton, C. S. Sargent, Au. I 7, '79, in hb. Gray and hb. Canby.

History. First described by Asa Gray, Manual, ed. 5: 229 (I 867) as follows :

A. Herveyi, n. sp. Stem slender, $\mathrm{I}-2 \mathrm{ft}$. high, nearly smooth, the summit and peduncles of the several corymbose heads minutely glandular-pubescent; leaves thinnish, roughish, obscurely serrate, oblong-lanceolate, very acute, all but the uppermost taper-pointed, and also tapering below into a narrowed base or winged petiole; heads small (less than $1 / 2$ in. long, exclusive of the narrow rays); involucre between bellshaped and top-shaped; the scales obscurely glandular, linear, or the short outer ones oblong, with greenish appressed tips; achenia linear, slightly pubescent. - Borders of oak woods, in rather moist soil, New Bedford, Mass., E. W. Hervey', Sept. to Au. An ambiguous member, and the smallest-flowered, of the section [Calliastrum]. Pappus whitish, finer than that of the preceding.

\section{Gray, Synoptical Flora :}

Slightly scabrous, the corymbose branches and short peduncles glandular-puberulent; leaves minutely or obscurely serrate; radical and lowest ćauline ovate on slender naked petioles; upper lanceolate; heads loosely corymbiform-cymose ; involucral bracts all erect [chiefly so in most pressed specimens, all so in some, but many bracts squarrose in the field, as the discoverer remarked to me before I verified it, N. Bedford, I 898] and with less distinct close tips, pulverulent-glandular; the short outer oblong. linear; rays 15 to 24 , narrow, half-inch long, lilac or violet. - Man. ed. 5, 2.30 . 
Eurybia commixta, Nees, Ast. 143. Biotia commixta, DC. Prodr. 5:265 (excl. syn.?), is a robust cultivated form of this, which has long been in the gardens, of unknown origin. - Borders of oak woods, E. Mas : and R. I., near the coast, Hervey, Sargent, etc. Grows in company with $A$. macrophyllus and $A$. spectabilis, evidently most related to the former, both in foliage and involucre; fl. Au., Sept.

Br. and Br. Ill. Fl. 3 : 374 (I898), with fig. 3784 :

Stem roughish, at least above, slender, simple or corymbosely branched, rarely paniculate, I-3 ft. high, the branches glandular-puberulent. Leaves firm, rough above, pubescent on the veins beneath, the basal and lower ones on slender naked petioles, ovate, dentate with low, usually distant teeth, acute at the apex, narrowed, rounded or rarely cordate at the base, $2-6$ in. long, $\mathbf{I}-3$ in. wide; upper leaves sessile, or narrowed into winged petioles, smaller, entire or nearly so ; heads $\mathbf{I}$ to $\mathbf{I} 1 / 2 \mathrm{in}$. broad; involucre turbinate or campanulate, its bracts appressed, or sometimes spreading, densely glandular, oblong or spatulate, obtuse or mucronulate ; rays 15-25, violet, 5 to 7 lines long; achenes minutely pubescent, striate ; pappus nearly white. - In dry soil, eastern Mass. and R. I. Apparently hybridizes with A. spectabilis. Au.-Oc.

\section{Subdivision $D$.}

Plants usually I $1 / 2$ or $2 \mathrm{ft}$. high; lower leaves 3 in. or less; traces of cordation almost absent ; bracts very squarrose ; leaves thick and extremely rough. Sp. 83 and 84 .

* Glands abundant; bracts narrow, acute or acuminate.

\section{Aster commixtus (Nees) Kuntze.}

Small plants with oblong-acute or ovate leaves, paniculatecorymbed, wide-spread inflorescence, small heads, narrow, acute principal bracts, the inner ones subulate-acuminate, some lower or inner ones subsquarrose or recurved.

Name from the appearance as if of hybrid origin.

FIG. I07; $\frac{1}{6}$ nat. size, $a$, specimen (the top of plant only) the most complete of the two plants in the hb. Bernhardi labelled (in Bernhardi's own hand?) Aster commixtus; $c$, its bract-form; $d$, a radical purporting to belong with it; $e$, a lower cauline from young plant labelled by A. Braun as "Eurybia commixta, Nees, hort. Carlsr. I843"; all these now in hb. Mo. Bot. Gar.

Eurybia commixta Nees, Gen. Ast. I42. I832.

Aster ornatus Hort. Anglic. fide DC. Prodr. 5 : 265.

Biota commixta DC. Prodr. 5 : 265.

Aster commixtus Kuntze, Rev. Gen., $189 \mathbf{I}$, and so written by Nees before I 825 ? but not published; so written by Bernhardi in his herbarium; so published, Burgess in Small's S. E. Flora (page I 212), with description :

"Stem 5-6 dm. high, rather robust, glandular-pubescent over the upper half and strigose above. Leaf-blades rough, thick, dull green, paler beneath, ovate-acute in type, low-serrate or with curvescent teeth, and with slender petioles; only the basal leaves, if any, slightly cordate; upper leaves diminished, finally lanceolate 
and sessile; bracteals oval, small and few. Inflorescence loosely corymbose, with long-ascending pedicels; bracts narrow and acute or subulate, ciliate and minutely puberulent, the apex squarrosely recurved; rays pale violet becoming white: disk becoming copper-brown. From its congeners $A$. mirabilis and the northern $A$. Herveyi, this is distinguished by the long acumination of its squarrose bracts; and from $A$. mirabilis by its capitate glands. - In dry woods, Georgia and Alabama. Late summer and fall."

\section{Known specimens :}

I. Ga., "Upson Co., dry woods, at the base of Pine Mt., Au. 28, Igor," R. M. Harper in hb. $N$. Y. Bot. Gar.

2. Ala., "Osanippa Cr., Lee Co., dry ground, S.e. 6, '99," F. S. Earle, no. 2206.

3. Hort. Bonn, Nees' original specimen, doubtless originally from the Atlantic coast of the U. S., "brought to Bonn without a name" remarks Nees, perhaps before 1825? Were Bernhardi's specimens taken from this? No specimens from the herbarium of Nees are known to me.

4. Hb. Mo. Bot. Gar. et hb. Bernhardi, two sheets each with similar specimen (top of plant) original labels reading "Aster commixtus." Each has a second specimen accompanying it which appeared to belong to $A$. macrophyllus verus; and the best developed plant has also two oval-acute coarse serrate non-cordate overlapped radicals

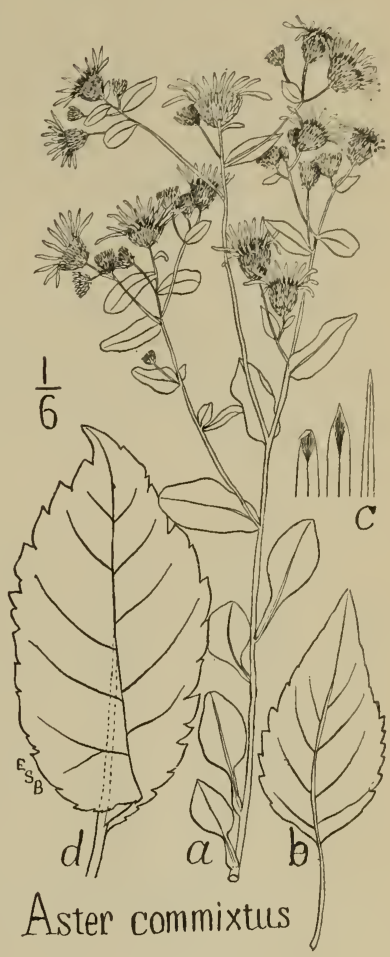

FIG. 107. which purport to belong to it; see figure 107, $a, c, d$.

5. Hb. Mo. Bot. Gar. ex hb. A. Braun, a young plant coming into flower without radicals, labelled "Eurybia commixta Nees, hort. Carlsr[uhe], 1943, $A$. Braun." Fig. 107, e represents its lower cauline leaf-type.

6 ex Hort. Paris, there cult. as Biotia commixta, and brought to Bot. Gar. of Harv. Univ. I $87 \mathrm{I}$; so wrote A. Gray on its label in hb. Gray.

7. ex hb. Mus. Paris, ex hort. Paris, "B. commixta D.C.," 1869 , in. hb. Gray.

8. ex hb. Nees, as Eurybia commixta, cult. in hort. Breslau; given to Schultz Bipontinus ; in hb. Gray.

History. Nees' original description was based on a plant of the botanical garden of Bonn, where he was director, I819-1830; a plant which, he remarks, was "brought there without a name." He may have found it there on his accession in I819. Perhaps he named it in the garden and in his herbarium Aster commixtus, and transmitted specimens under that name to his friend Bern- 
hardi. If so, this would account for the old label "Aster commixtus" on both of Bernhardi's specimens (now in hb. Mo. Bot. Gar.). If Nees gave the name to the plant at first in this form, Aster, etc., it may have been before 1825, when Cassini's genus Eurybia appeared; at all events, when Nees came to publish his new species it was as Eurybia commixta, and with allusion in comparison with Cassini's E. Jussiei which Nees thought similar but probably distinct, as its characters, smoothish leaves rather than rough, sublanceolate-cordate lower leaves, appressed obtusish bracts, etc., indicated. Nees' description of his commixtus is as follows :

4. Eurybia commixta N. ab E.

E. foliis ovatis, caulinis superioribus oblongo-lanceolatis sessilibus serratis viscidoscabris, caule patulo-corymboso, periclinii foliolis imbricatis squarrosis acutis.

Eurybia Jussiei Cass. in Dict. des sc. nat. XXXVII, p. 487? [but see supra, p. 390].

Crescit . . . In Hortum Bonnensem illata est, absque nomine. Floret Septembri. Perennis. V. v. c.

Caulis pedalis circiter, teres, inferne glaber, superne pubescenti-scaber, subviscidus. Folia radicalia petiolata, ovata, acutiuscula, appresso-serrata, utrinque scabra. Petioli angusti. Caulina inferiora pariter petiolata, oblongo-ovata, serrata, petiolo angusto; superiora oblongo-lanceolata amplexicaulia; ramea quoque his similia, sed breviora magisque amplectentia; haec cuncta scabra, subviscida, odoris singularis, haud ingrati [the same nutty odor doubtless which is found in all such Macrophylli as have profuse glands]. Apex caulis abit in corymbo compositum; rami patuli, 5-8-flori, ramulis simplicibus, rarius 2-3-flori, foliis aliquot lanceolatis patentibus subserratis bracteati. Calathium fere Eurybiae macrophyllae. Periclinium ovatum, foliolis imbricatis oblongo-lanceolatis ciliatis scabriusculis apice acuto viridi squarroso-patulis. Radius angustus linearis, lilacinus, periclinio parum longior. Discus periclinium nonnihil superans, primum luteus, dein cupreo-fuscus. Clinanthium alveolatum, alveolis acute dentatis. Achaenia lineari-cuneiformia, nervoso- (IO)-striata, setulis exiguis scabra. Pappus pallidus.

Differt a binis praecedentibus [A. glomeratus and $A$. macrophyllus $]$ : foliis radicalibus augustioribus, rameis serratis, corymbo magis composito, periclinio-squarroso, pube glutinosa. [The last word does not imply that Nees thought of $A$. macrophyllus as non glandular; for he had already said, p. I4I, that its leaves are glandular-hairy all over.]

DeCandolle's description adds only the suggestion that probably it was of North American origin; and that he had seen it formerly cultivated in England under the name $A$. ornatus. DeCandolle seems to have had no specimen; his description, which was condensed from Nees, is as follows:

" 5 . B[IOTIA] сомміхтA, caule infernè glabro supernè pubescenti-scabro patulocorymboso, foliis ovatis serratis, radic. petiolatis, caulinis super. oblongo-lanceolatis sessilibus viscido scabris, capitulis pedicellatis, invol. squamis imbricatis subsquarrosis acutis, ligulis elongatis. Perennis: patr. ign. verisim. Amer. bor. Eurybia com- 
mixta Nees ast. 142. An E. Jussicei Cass. dict. 37, p. 487? Ligulæ lilacinæ. (v. s. c. olim in hort. angl. sub nom. A. ornati.)

Other botanical gardens began to cultivate somewhat similar plants under the name of commixta, as that of St. Petersburg, a specimen from which at Kew, "Eurybia commixta, Hort. Petrop," was seen by Gray and likened by him to his representative (figured supra, p. '302) from Nees' herbarium of A. macrophyllus; probably on account of the widespread branching, coarse rough texture and a non-cordate radical ; Gray at one time also querying if this particular macrophyllus specimen of Nees was not the same with DeCandolle's Biotia commixta, at a later time on publishing the Synoptical Flora, definitely adopting this conclusion (though afterward reconsidering it), and also making this commixta a synonym for his $A$. Herveyi. Gray's treatment as printed Syn. Fl. I 75, is in the following words under A. Herveyi:

"Biotia commixta DC. Prodr. v. 265 (excl. syn. ?) is a robust cultivated form of this, which has long been in the gardens, of unknown origin."

Probably Gray's union of Biotia commixta DC. with his $A$. Herveyi (which should have invalidated his name $A$. Herveyi, had it been substantiated) was largely due to Gray's field acquaintance with $A$. Herveyi as a noncordate species, and as the only noncordate Aster species of Biotian affinity which he recognized. So he sought to identify with it the European Biotian plants with the non-cordate character. But $A$. Herveyi was thin, extremely so, and the European plants were thick-leaved and broader; hence his designating them as a form with " robust" habit.

Taking either Nees' description or Bernhardi's specimens of A. commixtus, several distinctions appear which abundantly separate it from $A$. Herveyi, although the spreading inflorescence has much similarity; distinctions including these; $A$. commixtus has much thicker leaves, much coarser teeth, much rougher surface, much acuter bracts, etc.

Confusion was early increased by the cultivation of a dissimilar broad-leaved "southern form" of $A$. radula Ait. in the Berlin Garden in I 839 as Biotia commixta var. stricta; as noted by Gray, Syn. Fl., I 76.

Perhaps the original $A$. commixtus of Nees' garden at Bonn was itself a southern form; for one specimen according well with Nees' character was discovered by Roland M. Harper in Georgia in 1901 .

Native plants of this obscure species should be searched for further in that region.

** Glands nearly or quite absent; bracts broad, subtruncate. 


\section{Aster mirabilis T. \& G.}

\section{Small plants with oval crenate leaf-form, hispid on both sur-} faces and sometimes spinulosely so above, with loosely subremote heads, and strongly squarrose broad-tipped lingual green bracts.

Name, unexplained; probably from its uniting squarrose bracts like those of A. spectabilis with Biotian leaf-characters.

FIG. I08, original type collected by Prof. Lewis Reeve Gibbes at Columbia, S. C., 1835 , now in the Gibbes herb. at N. Y. Bot. Gard.; $b$, a radical preserved on same sheet.

A. mirabilis Torr. and Gray, in Fl. N. Am., $2: \mathbf{I} 65$ ( $184 \mathbf{I}$ ), with original description : (with the prefatory remark that the species reached the authors too late for insertion in its proper place, which should stand as the first species " in section Calliastrum, before $A$. radula" ") :

I30. A. mirabilis: pubescent-scabrous; stem simple, sparingly corymbosepaniculate at the summit ; leaves ovate, strigose-scabrous above; the lowest (and radical?) abruptly narrowed into a petiole ; the others sessile, rather acute; those of the branches small, roundish; involucre hemispherical, shorter than the disk; the scales regularly imbricated in 4-5 unequal series, oblong-linear, with conspicuous squarroserecurved obtuse herbaceous tips; rays (about 20) elongated; achenia linear, scarcely compressed, nearly glabrous (minutely hairy under a lens when young), striate.

Columbia, S. C. (probably in dry soil), Professor Gibbes! Sept.

- Stem I-2 ft. or more in height, apparently simple, clothed with a close and rather rough pubescence, which is scarcely if at all viscid, sparingly branched towards the summit; the branches bearing solitary or $2-3$ scattered heads, or sometimes 4 or 5 heads, somewhat crowded at the summit. Leaves thickish when old, rather strongly pinnately veined and more or less reticulated, all serrate from the base to the apex with close and short mucronate teeth ; the lower surface less scabrous and more pubescent than the upper, often somewhat hoary; the cauline $\mathbf{I}-3$ in. long, uniformly ovate, but the upper gradually diminishing in size, all but the lowermost closely sessile, not clasping; those of the branches similar but much smaller, obtuse, and nearly round; the lowest cauline abruptly narrowed into a margined petiole, or rarely almost cordate; the proper radical leaves wanting. Heads nearly as large as in A. spectabilis, subglobose. Involucre minutely pubescent; the scales between chartaceous and coriaceous in texture, whitish, closely imbricated, with rather short, but conspicuous, squarrose or reflexed herbaceous tips. Rays large, thrice the length of the involucre, blue or violet. Achenia narrow and slender, many-striate, somewhat shorter than the rather rigid (brownish or ferruginous) unequal pappus; the innermost bristles of which are manifestly thickened towards the apex. Appendages of the style subulate-lanceolate, and at length recurved or reflexed, as in Biotia [within which seems its proper position].

- This very interesting species furnishes additional evidence of the propriety of reuniting Piotia with Aster; being exactly intermediate in character and appearance between that group and our subgenus Calliastrum. We have received it only from Professor Gibbes of Charleston, South Carolina, who collected it at Columbia in the year 1835 .

The Bioita commixta, a plant of unknown origin cultivated in the European gardens, which is said to have a squarrose involucre, has (fide descr. Nees) oblonglanceolate and partly clasping upper leaves, a very compound corymb, glutinous pubes- 


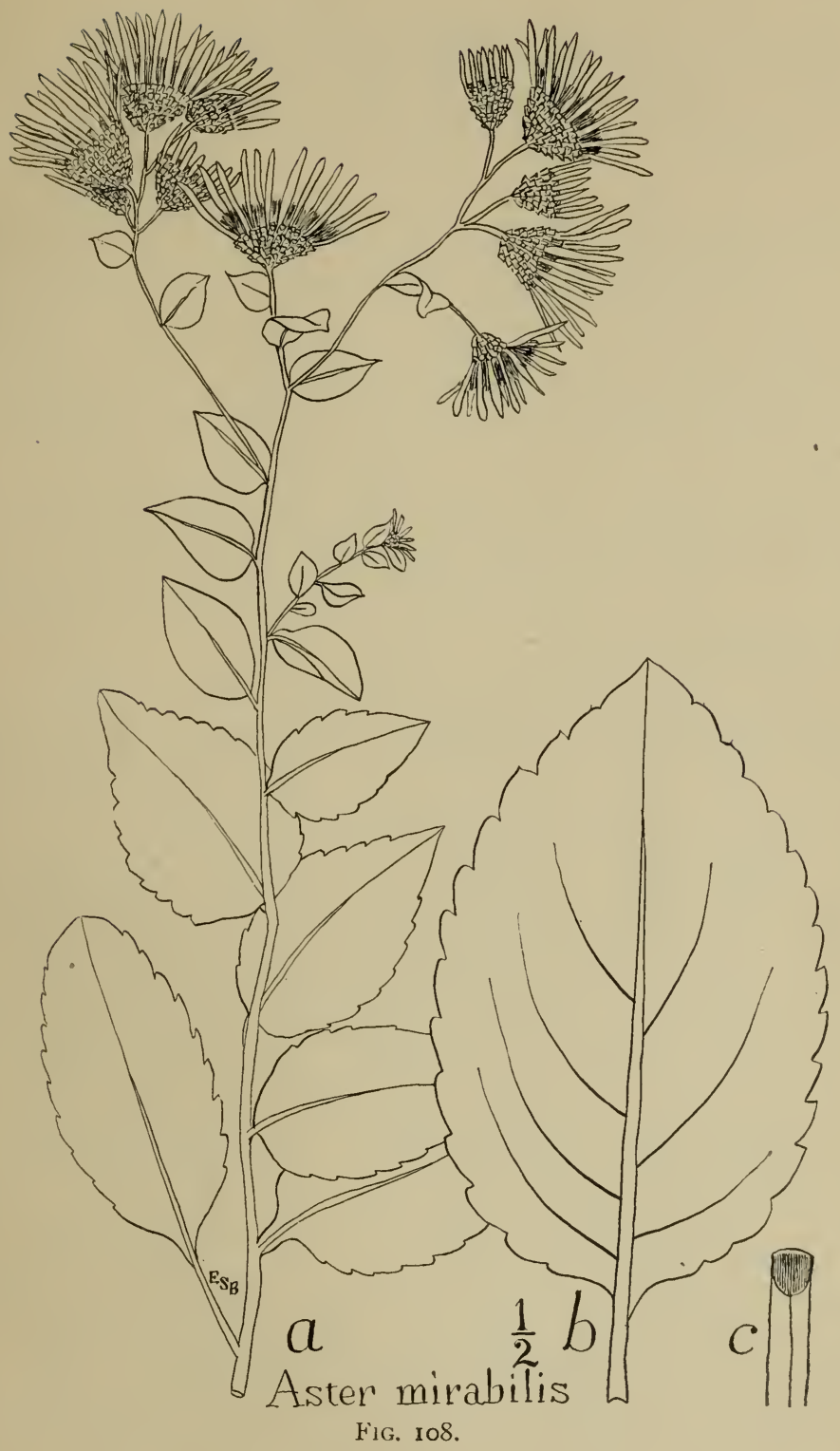


cence, and an involucre resembling Aster macrophyllus, as long as the disk ; the scales oblong-lanceolate, acute, etc.

The species remained without additional knowledge till the acquisition of Prof. Gibbes' herbarium by the N. Y. Bot. Garden brought to light the original and much larger specimen, followed by my description in Small's Southeastern Flora, p. I 2 I 3 (I9O2), viz :

"I3. Aster mirabilis T. and G. Stem 3-7 dm. tall, sparingly branched above, manifestly pubescent, the branches and especially the branchlets closely and finely pubescent : leaves various, the basal and lower cauline little known, the upper cauline rather remote; blades ovate to oblong ovate, $2.5-9 \mathrm{~cm}$. long, or those on the branchlets smaller, mostly acute, firm, serrate with appressed subcrenate teeth, mainly sessile, rough-pubescent, with appressed scattered hairs, those of the upper surface fewer, shorter, often spinescent: heads solitary or few in terminal clusters : involucres 8-10 $\mathrm{mm}$. high ; bracts firm, linear-oblong to linear, pubescent without and ciliate, the recurved herbaceous broadly-obtuse tips pubescent on both sides: ray-flowers about 20 ; ligules violet, $\mathbf{I} .5-3 \mathrm{~cm}$. long : achenes about $3.5 \mathrm{~mm}$. long, glabrous or rearly so, shorter than the tawny pappus whose inner bristles are thickened at the apex. Resembles A. multiformis Burgess, but the bracts squarrose and leaves hispidulous above ; cordation seems wanting but will probably yet be found on some basal leaves. - Near Columbia, S. C. Fall."

- The original specimen or specimens of $A$. mirabilis were found by Prof. Lewis R. Gibbes, of Charleston, S. C., at Columbia, S. C., Se. 20, I835. He sent a small fragment to Torrey and Gray which is in the Torrey herbarium in N. Y. Later, Prof. Gibbes divided his own specimen with Gray, Nov. 23, '83, fide Gray's notes; thus furnishing the fragment in the Gray herbarium. The remaining part was found in Prof. Gibbes' own herbarium, I 898, on its purchase from his daughter, by the N. Y. Botanical Garden. This proved to be much the better representative, showing a radical leaf of strong Biotian aspect though without cordation, the leaf-curve at the base having just stopped short of an actual sinus. Probably when further specimens are found, slight cordation will sometimes show. The chief reason for hesitancy in placing this species within the limits of the Biotian group (instead of exactly halfway between $A$. macropleyllus and $A$. spectabilis as Gray placed it in I 843 , or on the spectabilis side of the line as he placed it in I884) is the apparent absence of glands. Gray was however not quite sure that glandular viscidity was altogether absent from his plant when examining it in 1843 ; and perhaps when fresh specimens are found, glandular viscidity will show itself. If the species actually has none, it will be exceptional among the Macrophylli, although $A$. excelsior and $A$. multiformis and $A$. nobilis lead up to it in this particular, their glands being sometimes so few as to require much searching. 


\title{
SINGLE-LINE INDEX-KEY TO THE BIOTIAN ASTERS.
}

\author{
For fuller Conspectus or Analytic Key see pp. 89-100.
}

Abbreviations occurring below include : acum. acuminate, apic. apiculate, $b r$. bracts, char. characteristic, chf. chief, hds. heads, lanceo. lanceolate, lvs. leaves, $l r$. lower, nar. narrow, oblg. oblong, ped. pedicels, ov. ovate, pet. petioles, rad. radical leaves, ser. serrate, si. sinus, $t$. teeth of the leaf-margins, triang. triangular.

White rays; no glands; rays usually under I 2 . Sp. I-54.

Subsections I and 2, DIVARICATI and CURVESCENTES.

Subsection I. DIVARICATI. Radicals few, small, seldom seen ; exc. I $\ell$ and 2.

Div. A. DIVARICATE ASTERS proper. Thin long smoothish polymorphous leaves; reddish-brown disks. Broad-tip bracts. Salient teeth.

Subdiv. A. Stem assurgent, repeatedly flexuous, brittle.

a. Chief leaves prolonged ovate-lanceo., incurved-acum.

I. A. divaricatus: coarse t.; br. ciliate, and truncate, chanfer, or rounded.

p. 102

b. Chief leaves diverse, much shorter.

I $a$. A. d. alatus: large lvs. \& t.; wings ; br. less obtuse.

Ib. A. d. cymulosus: lvs., t. \& rays reduced; heads crowded. I 30

Ic. A. d. curtifolius: small rounded lvs.; close sharp t. $\quad$ I 32

I $d$. A. d. deltoideus: small deltoid-acute lvs.; remotish t. I 33

I e. A. d. fontinalis: tufts of large thin radicals, oval-acute, etc.

2. A. viridis: tufts of large thick radicals, cordate-oblong, etc.

3. A. arenicola: lvs., t. \& sinus small; br. nar.-oblong. I 38

c. Chief leaves long-attenuate, but unlike $A$. divaricatus.

* Bracts obtuse or chanfer, linear; sharp out-flung teeth; sinus broad. Virgate.

4. A. persaliens: lance-lvs., taper-based; remote couchant t. 140

5. A. atrovirens: chf. lvs. triangular-acum.; close slender t. $\quad \mathrm{I} 45$

6. A. erectus: lance-acum. lvs.; couchant t.; suberect rays. 147 
7. A. fimbriatus : larger t.; broader bracts ; many slit rays. I 50 ** Bracts truncate and rounded, scarious edged with white or pink ; teeth small, sharp.

8. A. fragrans: lvs. lanceolate from a broad base; si. shallow.

9. A. excavatus : lvs. oblong-lanceo.; si. enlarged, nar., deep. I 56 *** Bracts more uniform; teeth obsolescent above.

I O. A. subinteger: lvs. lance-triangular; hds. few, divergent. 159 **** Bracts triangular-acutish; teeth slit-serrate.

I I. A. sextilis: lvs. oblong-lanceo., caudate; si. slight. Early. I6 I

Subdiv. B. Stem weak or decumbent.

I2. A. stilettiformis: lvs. nar., straight-acum., slit-serrulate. $\quad$ 63

I 3. A. Parthianus: lvs. lance-ovate, deflexing, serrul.; pet. short, narrow.

I 66

I4. A. camptilis: lvs. oblong-acum., serrate; many wings. I68

I 5. A. Boykinii : lvs. obl.- or ovate-acum.; ser.; si. strong ; Southern.

170

I6. A. flexilis : lvs. ovate-acute, subcrenate; si. slight; Southern.

I 7 I

Div. B. CARMESINE ASTERS. Erect. Thinnish, firmer, shorter lvs. Disks deep red.

Subdiv. A. Lower bracts acutish.

I7. A. arcifolius: lvs. short-ovate ; brace si.; wide-branching.

I 8. A. capillaris : lvs. oval-acute; fair si.; high capillary ped.

Subdiv. B. Chief bracts obtuse or chanfer, diverse.

19. A. virgularis: lvs. ovate-acum.; sharp si.; close sharp t. $\quad$ I 77

20. A. rupicola: lvs. broader, shorter, rougher; broad si.; spike-t.

21. A. circularis: lvs. small, roundish, acute; close curved t.

Subdiv. C. Bracts rounded, lingual, more uniform.

22. A. argillarius: lvs. tiny, ovate-acute, slight si. \& t.; rough when dry. 
23. A. aucuparius: chf. lvs. oval-acum. with rounded base, pet. narrow.

24. A. listriformis: chf. lvs. obtuse, crenate, spade-like; wings.

25. A. carmesinus: Ivs. oval-acute, crenate-serrate, pet. nar. 197 Div. C. TENEBROSIAN ASTERS. Thinnest, smoothest leaves. Disks hardly red.

Subdiv. A. Bracts obtuse, very narrow. Cymules remote. 26. A. castaneus: chf. lvs. ovate-lanceo., slit-ser., taper-based.

27. A. olivaceus: lvs. ovate-acum., coarse-ser.; si. strong. 204 Subdiv. B. Bracts acute, very broad-triang.; exc. inner. 28. A. tenébrosus: lvs. obl.-ov., large, coarse-ser., axiles long. 207

Subdiv. C. Bracts rounded, short and broad, scale-like.

29. A. chlorolepis : lvs. like last, but si. sharp; disk more red. 2 I I Div. D. CLAYTONIAN ASTERS. Thickened firmer lvs., roughish when dry, not large. Disks high, soon brown. Lvs. chiefly ovate-acuminate.

Subdiv. A. Bracts narrow, oblong; lvs. smooth, fresh; veins cord-like beneath.

30. A. Claytoni: lvs. short-acum.; t. strong; axis percurrent. 2 I 2 30b. A. Cl. crispicans: lvs. caudate; teeth close, nar., crispicant.

Subdiv. B. Bracts lingual (exc. 34); lvs. thicker; veins cordlike ; hds. narrow.

3I. A. ebeneus : lvs. oblg., rough, dark, crenate-ser.; stem dark.

32. A. mollescens: lvs. ov., alm. fleshy, little ser.; disk, lvs. and stem pale.

33. A. ardens: lvs. triang.-ov.; t. sharp; disk and stem bright red.

232

34. A. scutiformis: 1r. lvs. scutiform, ser.; disk and stem dull.

Subdiv. C. Bracts broad. Texture dense, firm. Plants in stools.

35. A. arcuatus: low-ser.; lvs. \& si. broad, subtruncate; stem decurved. 
36. A. sociabilis: lvs. ov.-acum.; t. close, salient; si. strong. 242

37. A. ulmarius: lvs. oblong-ov., crenate-ser.; si. nar. 244

Div. E. FURCATE ASTERS. Bracts acutish, large, flattish. Plants small, scattered.

38. A. furcatus: lvs. ov.-triang., hispidulous both sides; hds. remote.

246

39. A. leptocaulis: lvs. oblong-acute, little rough, dense hair ben.

Subsection 2. CURVESCENTES. Radicals usual, in conspicuous colonies; white rays, at times pink but not violet; disk sienna, not red; pedicels with lines of hair, not all-over tomentulose; no glands.

Div. A. CURVESCENT ASTERS proper. Rays narrow. Chf. bracts thin, pale, attenuate, taper-obtuse.

Subdiv. A. Inner bracts all-scarious, without obvious midrib or hair.

40. A. curvescens: lvs, orbicular-cordate; curvescent; rays 8 .

Subdiv. B. Inner bracts with obvious midrib.

4I. A. oviformis: lvs. oval-acute, close-crenate, thin; si. sharp.

42. A. vittatus: lvs. ov.-acum., sharp-ser., firm, br. striped; si. shallow.

43. A. umbelliformis : lvs. orbic.-ovate, subcrenate, large; si. deep.

257

Div. B. Bracts highly coriaceous, pale, obtuse, with green tip and midrib.

Subdiv. A. GLOMERATE ASTERS. Hds. close, radical-colonies not very large.

* Bracts glabrate, little ciliate, acutish or taperobtuse; teeth close, sharp, firm.

44. A. exacutus: fastigiate; lr. lvs. larger, few ; many elliptic, entire.

260

45. A. Eriensis: low-convex; lvs. oval-acute, glabrate, small. 26 I

** Bracts ciliate; teeth subcrenate; texture coarse and heavy; sinus large.

46. A. glomeratus: domed; lvs. orbic.-acute, small, pilose ben. 
$* * *$ Bracts ciliate; teeth subcrenate; texture coarse and thin ; sinus large.

47. A. Julianus: high-convex; lvs. ovate-acute; hair scanty. 272 Subdiv. B. SCHREBERAN ASTERS. Heads in looser, uneven masses; radical colonies usually very extensive and plants much larger.

* Radical lvs. large, thin, firm, very broadly cordate.

+ Narrow petioles (of radicals) long, ciliate, few ; middle lvs. winged, upper sessile.

II Radicals ovate-orbic., large, thin, crenate.

48. A. limicola : chf. stem-lvs. ovate, winged; hds. small, close.

$\dagger \dagger$ Narrow petioles continuous up the stem.

II Radicals reniform or deltoid-orbicular, large, thick, rough.

49. A. Schreberi: chf. stem-lvs. broad-based; hds. large, $1 / 2 \mathrm{in}$. high.

|| || Radicals oblong-cordate, large; stem tall, robust.

50. A. rectifolius: some lr. lvs. straight-sided, rough; hds. small. 284

5 1. A. amnicola : chf. lvs. slant-sided, soft, webby ben.; rays long. 286

** Radical lvs. ovate-cordate, smaller, thin but firm, dark green.

52. A. sylvicola : lvs. cordate, subentire, villous ben.; si. square.

53. A. ambiguns: lvs. broad-cordate, glabrate; si. shallow; late. 29 I

54. A. subcymosus: larger; lvs. cordate-ovate, glabrate, thin; t. sharp.

Subsection 3. MACROPHYLLI. Violet rays. Glands. Involucre larger, broader than in 2. Pedicels tomentulose or at least not hairy in lines. Bracts but little ciliate. Radicals conspicuous. Sp. 55-84.

Div. A. LAVENDER MACROPHYLLI. Lilac rays first turning lavender and then pale; seldom full violet.

Subdiv. A. Thick, heavy, flabby lvs., rough when dry; crenate-serrate teeth.

* Stout ; branching irregular; bracts polymorphous. 
55. A. macrophyllus: lr. lvs. oblong-ov., acute, harsh; si. large. 298

55b. A. m. apricensis: branched; lvs. oval-acute, strap-winged.

55c. A. m. sejunctus: lr. lvs. cordate-ov., soft-hairy, bristly dry. 320

$5 \Xi d$. A.m. velutinus: lvs. smaller, subtriang.; close short hair ben. 322

55e. A. m. pinguifolius: whitish; broad-cordate, greasy, glabrate.

** Plants taller, glabrous; bracts lingual; acutish; inflorescence convex or diffuse; sinus broad.

56. A. excelsior: 1r. lvs. cordate-oblong, large ; stem purple-red.

*** Plants smaller; bracts lingual, obtusish ; inflorescence bunchy, compact; sinus narrow.

57. A. orbicularis: hairy; lr. lvs. cordate-suborbic.; sinus narrow.

58. A. biformis : 1r. lvs. few, cordate-oval, acute, crenulate, glabrate.

33 I

Subdiv. B. Lvs. firmer, less polymorphous; strong-stem; serrate; very glandular.

* Not tall ; lavender rays ; chf. br. acutish ; inflor. convex.

59. A. uniformis: lvs. broad-deltiform, abruptly acum.; downy.

6o. A. Alleghaniensis: lvs, ovate, thicker; few cordated; strict. 336

6I. A. sabulosus: lvs. still thicker, rougher, ov.-acum., suberect. 337

62. A. quadratus: lr. lvs. subquadrate, si. shallow; radical si. deep.

** Tall ; lilacine rays ; chf. bracts lingual, rounded at apex.

63. A. densatus: lvs. thin, suborbic., quite uniform, rough-hairy. 34 I

64. A. roscidus: lvs. thick, subquadrate or rounded, apiculate.

Subdiv. C. Lvs, thinner, savagely double-serrate; plant low, strigose; radicals large, asymmetrical. 
65. A. ferox: caulines soon small, subentire; heads pale, diffuse.

Div. B. IANTHINE MACROPHYLLI. Violet rays turning white ; glandular hair chiefly not broad-capitate, mostly reduced to stubs.

Subdiv. A. Tall, robust, often $4 \mathrm{ft}$; radicals 4 or 5 , large, often 8 in. long; glabrate.

* Inflorescence somewhat deep-branched, rather regular.

+ Violet of the rays often almost blue, but soon white; upper leaves narrow-based.

66. A. iostemma: char. rad. oblong; cauline ov.-acum., subcrenate.

67. A. gremialis: char. rad. orbic.-cordate; cauline oblg., subentire.

t† Violet and subsequent white of the rays usually less pronounced; upper leaves broad-based.

68. A. nobilis : char. rad. cordate-ov., downy ben., cauline lanceoblg.

69. A. ampliatus: 1r. lvs. dilated at basal lobes, often dentate. 359 ** Inflor. irregular, deep, narrow, sympodially proliferous.

70. A. sympodialis: lr. lvs. thick, broadly cordate-ov., crenate.

Subdiv. B. Plants smaller, often $2 \mathrm{ft}$; radicals few, smaller. * Inflor. flattish ; glabrate; glands minute; lvs. firm, thinnish.

† Inflor. high-branched; sinus securiform.

7I. A. securiformis : radicals cordate-acum. ; teeth close, sharp.

†† Inflor. low-branched; plants low; rad. about 2.

72. A. multiformis : rad. cordate-oblg., ser., rough; si. nar.

73. A. riciniatus : rad. cordate-triang., dentate; sinus broad.

** Inflor. more irregular or diffuse.

† Lvs. thicker, rougher; hair downy, when dry bristly.

74. A. elaeagnius: dark; gray ben.; lr. lvs. orbic.-ov.; some triang.

75. A. Masardiensis : pale; some lvs. elliptic, abrupt-biacuminate. 
76. A. ianthinus: often blue-green; 1r. lvs. suborbic., firm, low serrate.

†† Lvs. thickish, granular-roughened, with little hair.

77. A. violaris : 1r. lvs. reniform-apic., sharp-ser.; si. shallow.

78. A. quiescens: 1r. lvs. oval-acute, heavy, crenate, dark; si. deep. 382

79. A. granulosus : lr. lvs. ov:-oblg., others ov.-acum., all small. 385

Subdiv. C. Many non-cordate lr. lvs. and radicals ; disk-flowers deep-slit, funnel-form; glands abundant.

80. A. Jussiei : char. radicals oblg.-lance., ser., with nar. sinus.

8 I. A. decapinyllus : oval radicals, often Io; char. lr. lvs. cordate-ov. 39 I

82. A. Herveyi : lvs. ov., thin., subentire ; many bracts squarrose. 394

Subdiv. D. Cordation almost absent ; bracts very squarrose. * Glands abundant ; bracts narrow, acute, or subulate.

83. A. commixtus: lvs. oblg.-acute or ov. ; si. rare, sharp. 398 ** Glands obsolescent ; bracts broad, subtruncate.

84. A. mirabilis : lvs, oval, crenate, hispid above and beneath. 


\section{GENERAL INDEX}

\section{EXPLANATIONS}

All classes of entries are here ranked in one alphabetical series - as in index to Part I. of these Aster Studies - observing the following distinctions :

Subjects and miscellaneous entries are in Roman type ; also English plant-names, English names of forms, etc. (with abbreviation f. for form).

Species and higher group-names are in italics.

Names of authors are in small capitals.

Page-numbers first cited refer to more detailed treatment, if of higher rank than the number following; e.g., in the reference Aster orbicularis 330, 77, 97, the species will be found described in full at page 330 , but there may be only a mere mention at 77 .

Abbreviations, 86

Aculeated f. of A. macrophyllus, 317, 96

Acutifolial f. of A. multiformis, $37 \mathrm{I}$ Adanson, 52, 61 Agathaea, $5 \mathrm{I}$

Aiton, 54, 57, 62, 63, 108, 307

All-cordate $\mathrm{f}$. of $A$. carmesinus, 200 ; of $A$. divaricatus, I 7

Allion I, 57

All-reniform f. of A. Schreberi, 279, 95

Alternate-decurrent f. of $A$. castaneus, 204

Amellus, 52

ANGUillara, 56

Angulate f. of $A$. rupicola, 183, 92

Aster, generic character, Ioo; species. characters, 102-402; geographical distribution, 3 ; specific limits, 4; specific names, II, I2; sports, II4, 20 ; hybrids, Iо ; subspecies or varieties, 8 , 9, го, II; forms or minor variants, 4, 5, 6, 9, 84, III, etc. ; sections or subgenera, II, 59 ; 10cality-lists, 86; localities under continued observation, 20 ; explanations of treatment adopted, 9,83 ; terminology adopted, 83 ; coincident leaf-forms, I2; consecutive leafforms, I3; seedlings, I8; comparative variability of colony- characters, 22, I9; color-characters, 24 ; pubescence, $3 \mathrm{I}, 320,347$; glands, 31 ; fragrance, 33 ; size, 35 ; stemcharacters, 36 ; leaf-margins, 37,85 ; texture, 38 ; veins, 39 ; wings, 39,85 ; bracts, 40 ; inflorescence-development, 42 ; primordial leaves, 45

Aster Alleghaniensis, 336, 97

Aster ambiguus, 291, 64, 65, 96, 282

Aster amnicola, 286, 95

Aster ampliatus, 359, 98

Aster arcifolius, I73, 9I

Aster arcuatus, 240, 94

Aster ardens, 232, 93

Aster arenicola, I38, 90

Aster argillarius, 186, 92

Aster atrovirens, 145, 90

Aster aucuparius, 190, 92

Aster biformis, 331, 97

Aster Boykinii, I70, 91

Aster camptilis, I68, $9 \mathrm{I}$

Aster capillaris, I76, $9 \mathrm{I}$

Aster carmesinus, 197, 92

Aster castaneus, 201, 92

Aster chlorolepis, $21 \mathrm{I}, 93$

Aster circularis, 184,92

Aster Claytoni, 212, 93

Aster Claytoni crispicans, 225, 93

Aster cummixtus, 398, 66, 99, 306

Aster curvescens, 250, 94

Aster decaphyllus, 391, 99 
Aster densatus, 34I, 97

Aster divaricatus, I02, 62, 63, 90

Aster divaricatus alätus, 127, 66, 77, 90

Aster divaricatus curtifolius, I32, 90

Aster divaricatus cymulosus, I30, 90

Aster divaricatus deltoideus, I33, 90

Aster divaricatus fontinalis, I34, 90

Aster ebeneus, 227, 93, IIo

Aster elaeagnius, 373, 99

Aster erectus, I47, 9I

Aster Eriensis, 26I, 95

Aster exacutus, 26o, 95

Aster excavatus, I56, 9 I

Aster excelsior, 327, 97

Aster ferox, 348, 97

Aster fimbriatus, I50, 9 I

Aster flexilis, I 7 I, 9I

Aster fragrans, I 53, 9 I

Aster furcatus, 246, 94

Aster glomeratus, 263, 64, 65, 95

Aster granulosus, 385, 99

Aster gremialis, 353,98

Aster Herveyi, 394, 68, 99

Aster ianthinus, 377, 77, 99

Aster iostemma, 35 I, 98

Aster Julianus, 272, 95

Aster Jussiei, 388, 65, 99

Aster leptocaulis, 248, 94

Aster limicola, 273, 95

Aster listriformis, 193, 92

Aster macrophyllus, 298, 62, 63, 67,

$69,72,96$

Aster macrophyllus apricensis, 319, 96 Aster macrophyllus pinguifolius, 323,

66, 97

Aster macrophyllus sejunctus, 320, 97

Aster macrophyllus velutinus, 322, 97

Aster Masardiensis, 375, 99

Aster mirabilis, 402, 78, 99

Aster mollescens, 229, 93

Aster multiformis, 367,98

Aster nobilis, 356, 98

Aster olivaceus, 204, 92

Aster orbicularis, 330, 77, 97

Aster oviformis, 253, 94

Aster Parthianus, I66, 9 I

Aster persaliens, I 40, 90

Aster quadratus, 339, 97

Aster quiescens, 382, 20, 99
Aster rectifolius, 284,95

Aster riciniatus, 372, 65, 77, 98

Aster roscidus, 342, 97

Aster rupicola, I80, 91

Aster sabulosus, 337, 97

Aster Schreberi, 277, 64, 65, 95

Aster scutiformis, 237, 94

Aster securiformis, 365, 77, 98

Aster sextilis, .I6I, 9I

Aster sociabilis, 242, 94

Aster stilettiformis, I63, 91, I I

Aster subcymosus, 295, 64, 65, 96, 282

Aster subinteger, I59, 9 I

Aster sylvicola, 289, 96

Aster sympodialis, 361, 98

Aster tenebrosus, 207, 92

Aster ulmarius, 244, 94

Aster umbelliformis, 257, 77, 95

Aster uniformis, 333, 97

Aster violaris, 380,99

Aster virgularis, I77, 9 I

Aster viridis, I35, 90

Aster vittatus, 256, 94

Aster Synonyms :

A. Acadiensis, 73

A. Canadensis, etc., 62

A. corymbosus, 62,63

A. corymbosus alatus, I29, 64, I 27

A. curvescens oviformis, 253

A. curvescens umbelliformis, 257

A. discolor, 282, 65

A. divaricatus, $102, \mathrm{I}_{0} 3$

A. divaricatus persaliens, I 40

A. elatus, 63

A. glutinosus, $26_{4}, 65$

A. Herveyi intermedia, 299, 3 I4, 68

A. infirmus, 107

A. latifolius, $65,323,327$

A. macrophyllus biformis, 332

A. macrophyllus carneus, 3 II

A. macrophyllus excelsior, 328

A. ornatus, 398

Astereae, 75

Asterinae, 75

Asteriscus, 52, 77

Asteromoea, 52

Attenuate f. of $A$. divaricatus, II9

Axilliferous f. of A. Claytcni, 216; 
of A. divaricatus, I23; of $A$. fra- Broad-ray f. of $A$. carmesinus, 200 ; grans, 156 ; of $A$. persaliens, 143

Barton, Benjamin S., I 28

BARTON, W. P. C., I29, 55, 57, 64, 7I, $77,108,312$

BAUHin, C., 56

BaUHin, J., 56

Beech-twig f. of $A$. divaricatus, I 21

BERN HARDI, 269, 59, 64, 293

Bertero, 63

BEYRICH, $27 \mathrm{I}$

Bicknell, 59, 79, 3 I 3

Biculminate $\mathrm{f}$. of $A$. gremialis, 355 ; of A. Jussiei, $390 ;$ A. multiformis, $37 \mathrm{I}$

Bigelow, 54, 57, 64, 65, 108, 31 2

Bindera, 52

Bгот, 61

Biotia, 59, 52, 61, 66; first collectors of, 69 ; first cultivation, 72 ; first detailed study, 73 ; description, Ior ; pseudo-Biotian species, 66, 67

Biotia commixta, 398, 66

Biotia corymbosa, 66

Biotia corymbosa alata, I 27, 66

Biotia crenata, 66

Biotia discolor, 66

Biotia glomerata, 264, 66

Biotia Japonica, 66

Biotia latifolia, 295, 323, 66

Biotia macrophylla, 299, 3II, 66

Biotia macrophylla divaricata, 311, 66

Biotia Schreberi, 278, 283, 66

Biotia viscosa, $6 \mathrm{I}$

BoerifaAve, 54, 57

Boltonia, 52, 75

Bоотт, Wм., 78, 71, 271

Brachyactis, 53

Brachyconle, 5I, 75

Branch-forms, II2, etc.

of $A$. divaricatus, 124

Brown-top f. of A. Claytoni, 217, 93

Brush-top f. of A. Claytoni, 216, 93

Bunch-leaf $\mathrm{f}$. of $A$. divaricatus, I I 2

Bunch-top f. of A. macrophyllus, 3I7, 96

Burnish-leaf f. of $A$. divaricatus, I 20

Calimeris, 51, 52

Callistephus, $5 \mathrm{I}$

Canaliculate $\mathrm{f}$. of $A$. divaricatus, I 24

Candelabriform f. of A. umbelliformis, 259

Capelli, 294

Cassini, 51, 55, 59, 61, 65, 308, 390

Catesby, 76

Catskill f. of A. Claytoni, 21 8, 93

Cesalpino, 56

Chapman, 55, 58, IIO

Charieis, $5 \mathrm{I}$

Chiliotrichum, $5 \mathrm{I}$

Circaean f. of $A$. divaricatus, I 20, 90

Clayton, 222, 57, 62, 71

Cliff-clinging f. of A. Claytoni, 218, 93

Clusius, 56

Colden, 76

Collinson, 76

Colonna, 56

Color-characters, 22, 19, 86

Conduplicate $\mathrm{f}$. of $A$. divaricatus, II 8

CoRdus, 56

Cornut, 54, 56, 76

Crimson-tassel f. of $A$. virgularis, I79, 9 I

Cupreous f. of $A$ divaricatus, I 24, 90

Curvescentes, 89, 94, 249

Cutler, 76, 54, 57, 71, 76

Dalechamps, 56

Darlington, 55,57

Branchy-base f. of A. Claytoni, 216, 93

BRERETON, 57

BRICKELL, 76

De Candolle, 52, 55, 58, 61, 66, 109, $283,3 \mathrm{II}, 400$

Denticulate f. of $A$. macrophyllus, 318. 96

Bright-eye f. of A. Claytoni, 216, 93

Britton, 55, 58, 68

Britton AND Brown, 55, 58, 68, III

Broad-bush f. of $A$. ardens, 236, 93

Dentifolial f. of A. stilettiformis, 165 , 9 I

Desfontaines, 65

Broad-heart f. of $A$. divaricatus, 120

Detridium, 52 
Dieteria, 52

Dillenius, 54

Diminished states of $A$. divaricatus, I 5

DiosCoRIDEs, 56

Diplactis, 52

Diplostephium, 52

Divaricati, 89, 102

Dodecalis, 77

Dodoens, 56

Doellingeria, $52,53,66,75,107,223$, 225

Dover f. of A. macrophyllus, $3 \mathrm{I} 8$

EAton, Amos, 55, 58

EDDY, C. W., 54, 57

ElliotT, 55, 57, 65, 7 I

Engler and Prantl, 60, -75

Erigeron, 75

Etiolated state of $A$. divaricatus, II 7 ; of A. Claytoni, 218

Eucephalus, 52, 53

Eurybia, 51, 60, 61, 65

Eurybia commixta, 398, 400, 66

Eurybia corymbosa, 65, 66

Eurybia glomerata, 264, 270, 65

Eurybia Jussiei, 390, 65

Eurybia macrophylla, 299, 309, 65

Eurybia Schreberi, 278, 281, 65

Expanded f. of $A$. glomeratus, 268

Explanations of treatment, 9, 83

Fedian f. of A. gremialis, 355, 98

Felicia, 51, 75

Few-flowered f. of $A$. persaliens, 144

Fimbriated rays, I5 I

Fimbristima, 52

Five-ray f. of $A$. divaricatus, 124

Flabellate f. of $A$. divaricatus, 122,90

Flagelliform f. of $A$. Claytoni, 2 I9, 93

Flexicaul f. of $A$. subcymosus, 297

Forster, J. R., 224, 54, 57, 62

Fragrance, 33

Galatella, $5 \mathrm{I}$

GARIDEL, 57

Gash-winged f. of $A$. divaricatus alatus, I 28

GERARDE, 56

Gesner, 56
Gibbes, 71, 78, 404

Glabrate f. of A. macrophyllus, 315, 96

Globular f. of A. glomeratus, 268

Gray, Asa, 55, 58, 68, I Io, 397

Green-áwl f. of $A$. carmesinus, 200, 92

Green-disk f. of $A$. divaricatus, I25, 90

Greene, E. L., 53

Gronovius, 54, 57, 62

Gunther, 309, 72, 75

Gymnostephium, $5 \mathrm{I}$

Heleastrum, 52, 53

Helioscopian f. of $A$. listriformis, I95, 92

Henricia, 5 I

Herman , 54, 57

Hervey, E. W., 78, 394

Hesperastrum, 60

Hetchel f. of $A$. macrophyllus, 316,96

HofFMAN , 6o, 75

Hooker, W. J., 55, 58

Houttuyn, 62, I08, 28I

Hybrids, Io

A. arcuatus $\times A$. aucuparius, 242

$A$. ardens $\times A$. axillaris, 237

A. ardens $\times A$. roscidus, 237

A. Claytoni $\times A$. lateriflorus, $22 \mathrm{I}$

A. Claytoni crispicans $\times A$. glomeratus, 227

A. curvescens $\times A$. divaricatus, 253

A. curvescens $\times A$. macrophyllus, 253

A. glomeratus $\times A$. divaricatus, 269

A. glomeratus $\times A$. macrophyllus, 269

A. glomeratus $\times$ A. macrophyllus pinguifolius, 268

A. Herveyi $\times$ A. spectabilis, 396 , 397

A. oviformis $\times A$. divaricatus, 255

A. oviformis $\times A$. glomeratus, 255

$A$. oviformis $\times A$. macrophyllus, 255

A. persaliens $\times A$. excavatus, 144

$A$. persaliens $\times A$. umbelliformis, I 44

A. Schreberi $\times$ A. macrophyllus, 280

A. tenebrosus $\times$ A. glomeratus, 2 II 
A. umbelliformis $\times$ A. divaricatus, Machaeranthera, 52, 53, 75 259

Macrophylli, 89, 96, 297

A. umbelliformis $\times$ A. macrophyl- Madia, 6I lus, 259

Mairia, 52

MARTYN, 54, 308

Inflorescence-development, 42

Matthioli, 56

Inflorescence-stages, I 6

Michaux, 54, 57,63,7I, 76

Intercalary f. of $A$. macrophyllus, $3^{15}$

Ionactis, 53, 223

Miller, P. 54, 57, 72

Mitchellian f. of $A$. divaricatus, I 26, 90

Mixed-leaf f. of $A$. divaricatus, I I 2,90

Jag-edge $\mathrm{f}$. of $A$. stilettiformis, I66, $9 \mathrm{I}$

MonaRdes, 76

Jagged-leaf f. of $A$. persaliens, I44, 90

JosSELyn, 76

Monocephalous f. of $A$. divaricatus, i 6

Morison, 54, 57

MuhlenberG, $54,57,63,71,77,129$,

Keys, 89, 405 3 I I

Kidfinish f. of $A$. macrophyllus, 31 5, 96

Kuntze, 53

Munychia, $5 \mathrm{I}$

Myctanthes, 52

LAMARCK, 54, 57, 62, 28o, 307

NECKER, 52

Lance-leaved f. of $A$. Herveyi, 397

LAPHAM, 72

Lateral-bud f. of $A$. subcymosus, 297

Leaf-forms, I 2, I 3, 36

Leaf-margins, 37,85

LE Conte, J. E., 54, 57

Leiachenis, 52, 77

Leptocoma, $5 \mathrm{I}$

LESSING, 5 I

Leucelene, 53

Leucosyris, 53

Lilacifolial f. of $A$. limicola, 275, 95

Limp-leaf f. of $A$. divaricatus, I 20

LiNDLEY, 109

Linear-oblong f. of $A$. virgularis, I79, $9 \mathrm{I}$

Lingulate f. of $A$. Jussiei, 390

NEES, 73, 51. 55, 57, 64, 65, 109, 28 I, $308,309,39 \mathrm{I}, 400$

Nigrescent f. of $A$ macrophyllus, 3 I 8 Non-cordate f. of $A$. divaricatus, I 77

Nuttall, 52, 64, 31 2

OAKES, $7 \mathrm{I}, 78$

Oblong-leaf f. of $A$. divaricatus, II 7

Oblong-ovate f. of $A$. divaricatus, I 8

Obolarian f. of $A$. divaricatus, I I 3,90

Olearia, 52, 75

Oreastrum, 53

PAAW, 280

Pale-disk f. of $A$. argillarius, 189,92

Pallid-leaf f. of A. multiformis, 372

Paquerina, 51, 75

Linnaea-leaved $\mathrm{f}$. of $A$. argillarius, 189 , 92

Linnaeus, 54, 57, 62, $107,3^{\text {r }} 7$

Little-head state of $A$. divaricatus, I I 5

Little-leaf state of $A$. divaricatus, I 15

Little-spade f. of $A$. listriformis, I96, 92

LOBEI, 56

Parchment-leaf f. of $A$. carmesinus,

200, 92

PARKINSON, 54, 56

Pauciflore state of $A$. divaricatus, II 6

Peck, C. H.. 79, 68, I3 I, 27 I, 31 3

Pedunculate forms, 112 , etc.

Petiole-flowered f. of $A$. multiformis, $37 \mathrm{I}$

Localities under continued observation, 20

Long-ovate f. of $A$. excelsior, 329

Long-pedicelled $\mathrm{f}$. of $A$. persaliens, $\mathrm{I} 43$

Loose-flowered f. of $A$. divaricatus, I 26

Luxuriant states of $A$. divaricatus, I I 5

Petouane, 67, 68, 70, 299

Pinardia, 52

Pinnated f. of $A$. argillarius, I89, 92

Plukenet, 54, 57

Pluridentate f. of $A$. rupicola, I83, 92

Polyarrhena, 5 I 
Pomarial f. of $A$. glomeratus, 268

Pöppig, 72, 309

Primordial leaves, 45

Printzia, $5 \mathrm{I}$

Provancher, 67, 299

Prune-stem $\mathrm{f}$. of $A$. dizaricatus, I $2 \mathrm{I}, 90$

Pubescence, 31, 320, 347

Purple-pappus f. of $A$. divaricatus, I 26

PURSh, 55, 57,63, 7I, 3II

Radius, J. W. M., 72

Rafinesque，52，55，7I，76

RAVENEL, $27 \mathrm{I}$

RAY, 54, 57

Red-stemmed state of $A$. umbelliformis, 259

Refined f. of $A$. ianthinus, 379

Refracted f. of $A$. ardens, 237 ; of $A$. listriformis, 195, 92; of A. macrophyllus, 318

Reniform f. of A. mollescens, 230, 93 Rhinactina, $5 \mathrm{I}$

Roche, Daniel De LA, 280

Rock-cleft f. of A. Claytoni, 2 19, 93

Rock-dwarf f. of $A$. rupicola, I 84, 92

Rock-seam f. of $A$, argillarius, I90, 92

Rose-ray f. of A. Claytoni crispicans, 227

Rosette f. of $A$. divaricatus, II I

Rotundate f. of $A$. curvescens, 252

Round-bract f. of A. macrophyllus, 318,96

Round-leaf f. of $A$. listriformis, 196, 92

Rounded-base f. of $A$. persaliens, I 44, 90

Royen, 280, 54

Rubicund f. of $A$. multiformis, $37 \mathrm{I}$

Rumicial f. of $A$. excelsior, 329

Russet-tuft f. of $A$. diz'aricatus, I i 8, 90

SAGard, 69

SARRASIN, 70

SCHREBER, 28I

Schultes, 308

Scorpioid f. of $A$. fragrans, I 56

Sea-swept state of $A$. divaricatus, II 5

SERAPION, 56

Sericocarpus, 52, 53, 75
Sessilifolial f. of A. scutiformis, 239 , 94

Short-leaf f. of $A$. fragrans, I 56

Shuttle f. of $A$. listriformis, 196, 92

SHutTleworth, 71, 225

Slant-stem state of $A$. divaricatus, I 6

Sleek-leaf f. of $A$. divaricatus, I 20

S MALl, 55, 58, 68

Small-tangle f. of $A$. ardens, 236, 94

Specific limits, 4

SPRENGEL, 28I, 309

Stalk-leaf f. of $A$. divaricatus, II 9

Stellarian f. of $A$. divaricatus, I 25, 90

Subscandent state of $A$. divaricatus,

I 17

Sunburnt state of $A$. divaricatus, II 5

Sunburnt f. of $A$. fragrans, 155

Sun-darkened f. of $A$. excelsior, 329

Symphyotrichum, 52, 75

Syncopate f. of $A$. mollescens, 230

Syncopated f. of $A$. carmesimus, 200, 92

TABernaemontanus, 56

Tall-top f. of A. macrophyllus, 316, 96

Tangle-tuft f. of $A$. virgularis, I79, 9 I

Terminology, 83

Tetramolopium, 52

Thevet, 76

Thin-leaf f. of A. Claytoni, 219

Tilli, 57

Three-ray f. of $A$. divaricatus, I 24

Tobyhanna f. of $A$. divaricatus, I23, 90

TORREY, 55, 57,64,65,67, 31 2

Torrey ANd Gray, 52, 55, 58, 60, 67, I IO, 3 I 2

TOURNEFORT, 54,57

Trapezium-leaved f. of $A$. multiformis, 372

Trapezoidal f. of $A$. macrophyllus, 3 I 5

Triangle-hetchel f. of $A$. macrophyllus, 316, 96

Tripolium, 52, 53

Trowel-leaf f. of $A$. listriformis, 196, 92

Truncate-base f. of $A$. aucuparius, 192, 92

Tuberous f. of $A$. divaricatus, II 2, 90

Tubular f. of $A$. excavatus, 159 
Turbine-wheel f. of $A$. virguiaris, I79, Walter, 54, 57, 76 9 I

WARD, L. F., 79, 31 3

Urceolate state of $A$. umbelliformis, 259

White-disk f. of $A$. divaricatus, 125

White-saucer f. of $A$. fragrans, 156

Willdenow, 54, 57,63, 79, 108, 281, 308

Vaillant $, 54,57,62,70$

Xylorhiza, 52

Venatris, 52

Verticillate f. of A. Claytoni, 219, 93

Virescent f. of A. listriformis, 195, 92 Zyrphelis, 51

Virgulus, 52 




